UNIVERSIDADE DE SÃo PAULO

FACUldade DE Filosofia, LETRAS E CiÊNCIAS Humanas

DEPARTAMENTO DE HISTÓRIA

Pós-graduação - História Social

\title{
AS LUTAS ANTI-RACISTAS DE AFRO-DESCENDENTES SOB VIGILÂNCIA DO DEOPS/SP \\ (1964-1983)
}

Dissertação de mestrado entregue como parte da avaliação para obtenção do título de Mestre, sob orientação da Prof ${ }^{a}$. Dr ${ }^{\mathrm{a}}$. Leila Maria Gonçalves Leite Hernandez.

Karin Sant' Anna Kössling

$n^{0}$ USP: 3112661

São Paulo, 2007 


\section{SUMÁRIO}

RESUMO

AGRADECIMENTOS

ABREVIAÇÕES

INTRODUÇÃO

I - LUTAS ANTI-RACISTAS SOB O OLHAR DO DEOPS/SP

1.1) Aspectos dos Aparatos Repressivos

1.2) Repressão e vigilância aos movimentos negros brasileiros

II - OS DISCURSOS POLICIAL E MILITAR

2.1) Os discursos sobre o negro: estigmas e estereótipos

2.2) Os discursos sobre os movimentos de independência africanos

2.3) Os discursos sobre os movimentos negros dos Estados Unidos

III - MOVIMENTOS NEGROS E SEUS PRINCIPAIS DEBATES

3.1) Afro-marxismo

3.2) Críticas as estruturas do regime militar

3.3) Negritude e Pan-africanismo

3.4) África: o colonialismo e o racismo

3.5) Os conflitos raciais nos Estados Unidos

3.6) Construção do herói: Zumbi e o Dia da Consciência Negra

IV - CARACTERÍSTICAS DOS MOVIMENTOS NEGROS BRASILEIROS

4.1) Diálogo com outros movimentos

4.2) A visão do MUCDR e MNU

4.3) Divergências e Unidade

4.4) Os partidos políticos e as "comissões de negros"

V - CONSIDERAÇÕES FINAIS

VI. Fontes

VI. Bibliografia

VIII. Anexos 


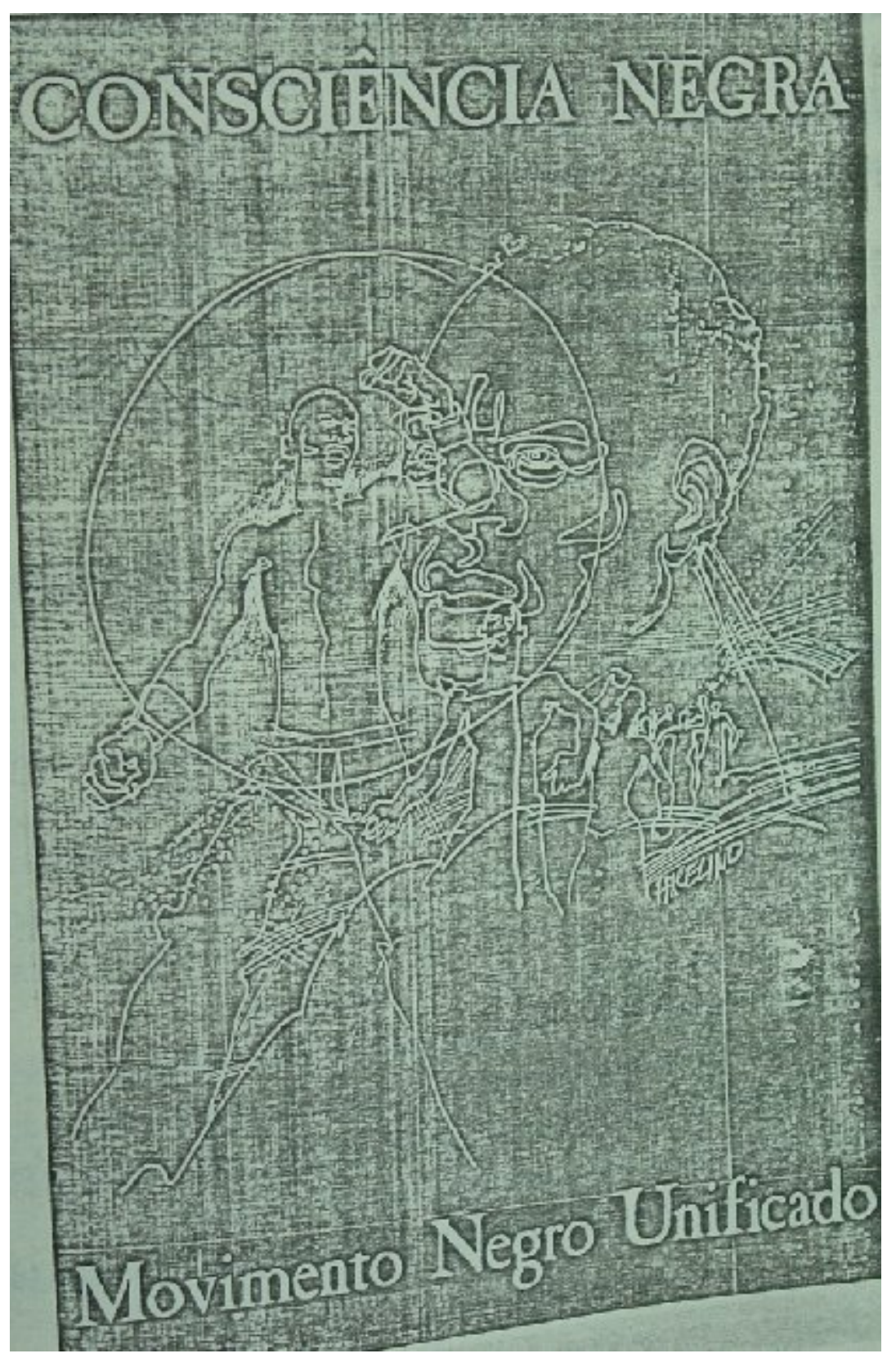

Dedico essa dissertação a todos aqueles que sofreram perseguições políticas

\footnotetext{
${ }^{1}$ Xérox do cartaz do MNU de divulgação do seu III Congresso, de 1982. In Sumário Semanal de Informações do CODIN/COSEG, do período entre 26/3 a 1/4/1982, de 2/4/1982, fl. 14. Dossiê 50-H-84- 5457. DEOPS/SP, DAESP.
} 


\title{
RESUMO
}

O tema principal desta dissertação é a vigilância e a repressão do regime militar brasileiro as lutas anti-racistas no período de 1964 a 1983, por meio da documentação do DEOPS/SP. Buscamos compreender as lógicas por de trás da vigilância policial, investigando, em especial, o preconceito e a persistência de estigmas e estereótipos raciais no discurso sustentado pela polícia política.

Ao mesmo tempo, ao pesquisar as noções e classificações policiais sobre os movimentos negros também obtivemos parte dos discursos empregados pelos ativistas destes movimentos. Assim, visamos compreender as contraposições entre os discursos e ações sustentados pelos aparatos policiais envolvidos no regime militar e os apresentados pelas lutas anti-racistas dos afro-descendentes no Brasil.

\begin{abstract}
The central theme of this dissertation is the vigilance and the repression from the brazilian military regime on the subject of the anti racist fights at the period of 1964 at 1983, through the documentation from the DEOPS/SP. To embrace the logic behind the police alertness we inquired, particularly, the bias and the persistence of racial stigmas and stereotipies at the discourse supported by the policy police.

At the same time, on seeking the police ideas and classifications about blacks movements as well we got some of the discourses employed by the militants of these movements. In this manner, we aim to understand the counterpoints among the discourses and the actions suffered by the police display involved at the military regime and the presented by the afro-descendants anti-racist fights in Brazil.
\end{abstract}

\section{PALAVRAS-CHAVES}

Movimento Negro, Regime Militar, Racismo, DEOPS, Polícia Política 


\section{AGRADECIMENTOS}

Aos meus pais, Ivan Padilha Kössling e Vera Terezinha Sant' Anna Kössling, por todo suporte emocional, financeiro, estrutural, educacional, etc etc. Por tudo de bom que vocês proporcionaram na minha criação e que com muito orgulho formou e influenciou quem eu sou e que me possibilitou chegar até aqui.

Aos professores de todos os níveis educacionais pelo qual eu passei, e com quem tive o prazer de aprender a gostar de aprender, ou seja, ter o gosto pelos estudos. Em uma época que a docência parece cada vez ter menor valor em nossa sociedade quero aqui reafirmar a importância que cada professor teve em minha formação. Em especial, agradeço a duas importantes professoras que marcaram minha trajetória de pesquisadora: A Prof ${ }^{\mathrm{a}}$. $\operatorname{Dr}^{\mathrm{a}}$. Maria Luiza Tucci Carneiro, que me orientou na iniciação científica durante a graduação em História; e a Prof ${ }^{\mathrm{a}}$. Dr ${ }^{\mathrm{a}}$. Leila Maria Gonçalves Leite Hernandez, que orientou a presente pesquisa sempre com muita generosidade, atenção e zelo.

Aos meus queridos alunos que me ensinaram a ser professora. Aos colegas de magistério que com seu companheirismo sempre apoiaram a realização deste mestrado.

Ao Marcos Aurélio Nogueira Lourenço que durante a pesquisa me auxiliou com sua amizade e companheirismo. Além de ouvir todas minhas angústias decorrentes do processo de pesquisa, ele esteve intimamente ligado a este e outros trabalhos lendo-os e fazendo gratuitamente a revisão.

Ao Marcos Antonio Veiga Lopes por sua infinita amizade, um grande amigo e um grande exemplo de pesquisador e historiador. Colega de faculdade, de pesquisas, de dúvidas, de angústias, de metodologias, teorias, etc.

Ao Márcio Macedo (Kibe) por sempre fornecer auxílio nessa minha jornada pelos movimentos negros, desde a graduação até o mestrado. Além de ser um excepcional pesquisador sobre os movimentos negros, com dissertação de mestrado que trouxe uma grande contribuição no assunto.

Aos diversos amigos e colegas que fizeram parte dessa dissertação, seja de forma direta ou indireta. Valeu pela compreensão das várias vezes que tive que dizer não. Maya Tamie Nakahara, Vania Vaitieka, Kelly Jardim, Érika Cunha, Leandro de Almeida, Karina Alves Teixeira, Dayane Nogueira e tantos outros. 
Aos colegas do PROIN, projeto coordenado pelos professores Dr. Boris Kossoy Dr ${ }^{\mathrm{a}}$. Maria Luiza Tucci Carneiro, que fizeram presente nas minhas pesquisas desde a graduação.

Aos colegas do grupo de alunos orientados pela $\operatorname{Prof}^{\mathrm{a}}$. Dr ${ }^{\mathrm{a}}$. Leila Maria Gonçalves Leite Hernandez: Regiane, Gabriela, Joceley, Paulo Manoel, entre outros. Especialmente a Marly Spacadieri que sempre nos auxiliou na logística desse processo.

Aos funcionários do Arquivo do Estado de São Paulo que auxiliaram a adentrar neste universo documental.

Aos Profs. Dr. Antônio Sérgio Alfredo Guimarães e Dr ${ }^{\mathrm{a}}$. Maria Luiza Tucci Carneiro pelas contribuições de grande valia na qualificação deste trabalho.

Ao CAPES pelo apoio financeiro, concedendo bolsa de estudos.

E por fim a todas as entidades espirituais que me acompanham, estas afiaram minha intuição para a localização dos documentos que compõe essa pesquisa. A minha fé nessas entidades também fez com que eu tivesse forças para enfrentar todos os obstáculos que se apresentaram no processo. Salve! 


\section{ABREVIAÇÕES}

$\mathrm{AI}$ - Ato Institucional

ASI - Assessorias de Segurança e Informações

CEABAR - Centro de Estudos Afro-brasileiro "André Rebouças"

CENIMAR - Centro de Informações da Marinha

CIA - Agência de Inteligência dos Estados Unidos

CIDAC - Centro de Informação e Documentação Anti-colonial

CIE - Centro de Informações do Exército

CISA - Centro de Informações de Segurança da Aeronáutica

$\mathrm{CN}$ - Cadernos Negros

CODI - Centros de Operações de Defesa Interna

CS - Convergência Socialista

DEOPS - Departamento Estadual de Ordem Política e Social

DGS - Direção Geral de Segurança

DOI - Destacamentos de Operações de Informações

ESG - Escola Superior de Guerra

EsNI - Escola Nacional de Informações

EUA - Estados Unidos

FBI - Federal Bureau of Investigation - Polícia Federal dos Estados Unidos

FGV - Fundação Getúlio Vargas

FNLA - Frente Nacional de Libertação de Angola

FRELIMO - Frente de Libertação de Moçambique

FRENAPO - Frente Negra para a Ação Política de Oposição

GRAE - Governo Revolucionário de Angola no Exílio

IBGE - Instituto Brasileiro de Geografia e Estatística

IPM - Inquérito policial militar

KGB - Serviço Secreto da União Soviética

LSN - Lei de Segurança Nacional

MNUCDR - Movimento Negro Unificado contra a Discriminação Racial

MNU - Movimento Negro Unificado 
MUCDR- Movimento Unificado contra a Discriminação Racial MPLA - Movimento pela Libertação de Angola

MR 8 - Movimento Revolucionário 8 de outubro

OBAN - Operação Bandeirante

ONU - Organização das Nações Unidas

OP - Ordem Política

OS - Ordem Social

PAIG - Partido Africano da Independência de Guiné e Cabo Verde

PCB - Partido Comunista Brasileiro

PIDE - Polícia política portuguesa

PM - Polícia Militar

PT - Partido dos Trabalhadores

PUC/SP - Pontifícia Universidade Católica de São Paulo

SACHAC - Sociedade Habitacional de Carapicuíba

SNI - Serviço Nacional de Informação

SISNI - Sistema nacional de informações

SISSEGIN - Sistema nacional de segurança

SWAPO - Organização do Povo do Sudoeste Africano

UMES - União Metropolitana dos Estudantes Secundaristas

UNITA - União Nacional para a Independência Total de Angola

URSS - União das Repúblicas Socialistas Soviéticas

USP - Universidade de São Paulo 


\section{INTRODUÇÃO}

“Ébano

(Luis Melodia)

Canta Luis Melodia

Meu nome é Ébano/Venho te felicitar tua atitude/ Espero te encontrar com mais saúde / Me chamam Ébano / O novo peregrino sábio dos enganos / Seu ato dura pouco tempo se estragando / Eu grito Ébano / O coro que cobre a carne não tem planos / A sombra da neurose te persegue há muitos anos / Do Rio de Janeiro estou te sacando / Do centro da cidade vou te assemelhando / No núcleo do seu crânio eu mostrei meu jogo / Tem a quem te amando / Pessoal passando / E só eu ficando" ${ }^{2}$

O objetivo central dessa pesquisa de mestrado foi analisar como se desenvolveu a ação vigilante e repressiva aos movimentos negros pelo regime militar de 1964 a 1983, investigando o preconceito e a persistência de estigmas raciais no discurso sustentado pela polícia política, o DEOPS/SP, órgão repressor do Estado que forma a principal fonte documental investigada.

Nesse sentido, o recorte cronológico de 1964 a 1983, tem seu início com o Golpe de 1964 e se encerra com o desativamento oficial do DEOPS/SP, em 1983. Esta instituição tinha como dever atribuído pelo Estado coibir o crime político, tornando-se um sistema de repressão que procurou controlar a disseminação de idéias contestatórias e reprimir a atuação política da sociedade. A preocupação em manter o controle social levou os militares a organizarem vários órgãos, formando um complexo aparato repressivo por meio da atuação do Serviço Nacional de Informação, das Seções das Forças Armadas, dos COI/CODI e dos DOPS estaduais que integravam a comunidade de informações e segurança.

É preciso ressaltar que a vigilância aos movimentos negros por parte do DEOPS/SP não foi iniciada com o regime militar. Desde a década de 1930, em geral, ocorreu uma atuação repressiva às associações afro-descendentes, sustentada por uma visão policial que classificava essas associações como "introdutoras" da questão racial no Brasil e, por conseqüência, geradora de conflitos que poderiam desestabilizar a "democracia racial brasileira". ${ }^{3}$ Haroldo Costa, em sua obra Fala Crioulo alerta que: "cada vez que há um

\footnotetext{
${ }^{2}$ Dossiê 50-Z-138- 806. DEOPS/SP, DAESP.

${ }^{3}$ Estudo realizado por mim em Iniciação Científica, financiado pela FAPESP e orientado pela Prof ${ }^{\mathrm{a}}$. Dra . Maria Luiza Tucci Carneiro, com a documentação do DEOPS: Movimentos Negros: Identidade étnica, Identidade politica (1924-1950). A ser publicado na Série Inventários do Arquivo do Estado de São Paulo.
} 
endurecimento, um fechamento político, o negro é atingido diretamente porque todas as suas reivindicações particulares, a exposição de suas ânsias, a valorização de sua história, desde que não sejam feitas segundo os ditames oficiais, cheiram à contestação subversiva. "4 Esta constante vigilância e repressão aos movimentos negros ao longo do século XX, sobretudo entre 1964-1983, é o principal eixo deste trabalho.

Historicamente esta repressão se traduz em violências e mecanismos de legitimação do uso da força contra os "inimigos". Importante salientar que a violência não se limita a uma simples oposição à pacificação de um mundo equilibrado e homogêneo, que pressupõe uma ordem social. "Violência é uma palavra carregada de conteúdos negativos. Na linguagem ordinária, jornalística ou jurídica, a qualificação de um ato como sendo violento comporta uma condenação." 5 No entanto, a pacificação não é um processo unidirecional e muito menos a paz é um valor absoluto, a paz também se impõe pela força, estados de paz são, em geral, temporários e frágeis. Assim, a violência é a utilização da força física na regulação das relações sociais e, violência política é o uso da força em situações públicas, em relações sociais compreendidas pelos agentes sociais como próprio do mundo da política. ${ }^{6}$ Desta forma, o uso da força situa-se no tempo e no espaço social e é relativo a posições e pontos de vista, de forma que o que é legítimo ou justo em um momento ou para um grupo social, em outro momento ou para outro grupo pode não o ser.

Sob essa perspectiva, investigamos o projeto político envolvido na construção do pensamento autoritário do regime militar acerca da identificação e da perseguição dos adjetivados como "inimigos" do regime. Nesse sentido, visamos compreender as condições sociais e os motivos que levaram os militares a legitimar o uso da força para fazer política e impor seus ideais de sociedade. Priorizamos os consensos presentes nos projetos políticos dos militares no poder. No entanto, essa política não pode ser pensada como um bloco monolítico, uma vez que apresentou especificidades nas suas lutas e em seus embates, o consenso sobre determina e impede a existência de dissenso.

O período histórico que estudamos possibilitava espaço para que certos setores sociais fossem classificados como aliados ou inimigos pelos grupos de poder. O golpe militar de

\footnotetext{
${ }^{4}$ COSTA, Haroldo. Fala Crioulo. Rio de Janeiro: Record, 1982, s/ n. pg.

${ }^{5}$ NEIBURG, F. "O naciocentrismo das ciências sociais e as formas de conceituar a violência política e os processos de politização da vida social” In NEIBURG, F. [et al]e WAIZBORT, L. (org) Dossiê Nobert Elias. São Paulo: Editora da Universidade de São Paulo, 1999, p. 41.

${ }^{6}$ NEIBURG, F. Op. Cit., p. 44.
} 
1964, gênese do regime militar no Brasil marcou a construção de um projeto político dos militares. Assim, no primeiro capítulo tratamos das dimensões históricas das instituições envolvidas na vigilância e na repressão da sociedade, salientando a atuação da comunidade de informações e de segurança, na qual o DEOPS/SP se inseriu e que estava a cargo de por em prática o projeto político de controle social.

No segundo capítulo, buscamos compreender a prática dos aparatos repressivos em relação aos movimentos negros. $\mathrm{O}$ material privilegiado para apreensão deste tema foram os discursos produzidos pela comunidade de informações e segurança. Para transcender uma análise puramente interna e formal desses discursos, tornou-se importante articulá-los às práticas sociais desenvolvidas pelos aparatos repressivos. Em outros termos, as relações entre idéias e ações políticas só podem ser recuperadas se estabelecida uma relação de oposição complexa entre ambas em um contexto histórico determinado. Assim, os sistemas de pensamento são "processos dinâmicos nos quais as experiências concretas são integradas à ordem dos conceitos e discursos." 7 O discurso é uma leitura da realidade social, mas que não nasce por si só, exprimindo também uma relação com outros discursos. É com o diálogo e o confronto de idéias que se estabelecem novos discursos. Nesta abordagem, a tradição também é importante no caso específico deste trabalho de pesquisa, notamos essa questão ao identificar relações intrínsecas entre os discursos da polícia política sobre os movimentos negros no período do regime militar e a "tradição" construída pelo DEOPS/SP ao longo do século XX. Nesse sentido, as publicações da teoria policial, por exemplo, a Revista Arquivos produzida pela polícia civil paulista e de circulação interna policial, constituíram parte importante da documentação para compreensão dos pensamentos envolvidos na prática policial.

Nesta pesquisa de mestrado buscamos mais especificamente compreender o pensamento policial acerca dos movimentos anti-racistas de afro-descendentes no Brasil e por quê foram classificados como "subversivos", sendo dignos de vigilância da sua atuação. Para tal, documentos do DEOPS/SP, publicações militares e policiais tornaram possível identificar e compreender quais eram as idéias, as noções, os estigmas ${ }^{8}$, os estereótipos ${ }^{9}$ e

\footnotetext{
${ }^{7}$ BARBOSA, L. e SILVA, P. O pensamento negro em educação no Brasil. São Carlos: Editora da UFSCar, 1997, p. 10.

${ }^{8}$ Estigma é qualquer marca ou sinal físico que é considerado indigno e desonroso. In HOUAISS, A. Dicionário Houaiss de Língua Portuguesa. Rio de Janeiro, Objetiva, 2001. (versão eletrônica)
} 
as formulações sobre os afro-descendentes e sobre as suas mobilizações sócio-políticas. É necessário destacar que as informações contidas na documentação do Fundo DEOPS/SP configuraram "uma rede intertextual produtora de eficazes efeitos de sentido e de convicção." 10 Desta forma, procurou-se recuperar o campo do confronto político do qual emergiram os discursos e projetos políticos presentes nas instituições de repressão do regime militar. Essa ação policial esteve envolvida em termos relacionados ao campo do preconceito, discriminação e racismo. Importante compreendermos as diferenças desses termos: Preconceito é uma idéia, uma opinião ou um sentimento desfavorável formado $a$ priori, sem maior conhecimento, ponderação ou razão sobre um grupo social. O racismo é conjunto de teorias e crenças que estabelecem uma hierarquia entre as raças, entre as etnias. Enquanto a discriminação é um ato de separar, segregar, pôr à parte alguém por causa de características pessoais. ${ }^{11}$

Por sua vez, o terceiro capítulo buscou compreender quais as idéias em circulação nos movimentos negros e o quarto capítulo, apresentar algumas características marcantes dessa mobilização. As práticas políticas apresentaram-se multifacetadas, voltando-se para organizar e disciplinar de forma burocrática as massas, além de promover a despolitização da sociedade civil. ${ }^{12}$ Ainda assim, alguns segmentos sociais reagiram, buscando combater o regime de feições ditatoriais, um deles foram os movimentos negros, que formularam estratégias de luta, que buscamos ressaltar nestes dois capítulos.

Enquanto movimentos sociais, os movimentos negros constituem "um processo coletivo e comunicativo de protesto, conduzido por indivíduos, contra relações sociais existentes, e que afetam a um grande número de pessoas (que não precisam estar necessariamente organizadas)." 13 Assim sendo, apresentam um conjunto de valores, que

\footnotetext{
${ }^{9}$ Estereótipo é algo que se adequa a um padrão fixo ou geral, esse próprio padrão, formado de idéias preconcebidas e alimentado pela falta de conhecimento real sobre o assunto ou pessoas em questão. Ou seja, idéia ou convicção classificatória preconcebida sobre alguém ou algo, resultante de expectativa, hábitos de julgamento ou falsas generalizações. In HOUAISS, A. Op. Cit. "O uso de estereótipos contribui para o que é apresentado como uma distinção precisa entre os indivíduos classificados, aos quais é atribuída uma série de características positivas e negativas que dependem da raça.” In GUIBERNAU, M. Nacionalismos: o estado nacional e o nacionalismo no século XX. Rio de Janeiro: Jorge Zahar Ed., 1997, p. 97.

${ }^{10}$ FICO, C. Como eles agiam. Os subterrâneos da Ditadura Militar: espionagem e polícia política. Rio de Janeiro: Record, 2001, p. 21.

${ }^{11}$ HOUAISS, A. Idem.

12 ARENT, H. Origens do totalitarismo. São Paulo: Cia das Letras, 1989.

${ }^{13}$ KÄRNER, Hartmut. "Movimentos sociais: revolução no cotidiano." In WARREN, I. e KRISCHKE, P. Uma Revolução no Cotidiano? São Paulo: Brasiliense, 1987, p.24.
} 
permeiam seus objetivos e projetos para definir formas de ação social voltados para transformar a sociedade, questionando parcial ou totalmente as estruturas de dominação. ${ }^{14}$ Além disso, a atuação política dos movimentos negros desenvolveu-se não só ao questionar os detentores do poder de governo buscando influir nos processos decisórios, mas também na prática cotidiana de sua ação social transformadora junto a sua comunidade, como parte de uma sociedade civil que "se movimentava num momento em que parecia submersa numa normatividade tecnocrática e repressora que despolitizava e privatizava a vida social." 15

\footnotetext{
${ }^{14}$ Bobbio, N. e MATteuCCI, N. e PASQUinO, G. Dicionário de Política. Brasília: UnB, 1999, p. 787. CAMACHO, Daniel. "Movimentos sociais: algumas discussões conceituais" In WARREN, I. e KRISCHKE, P. Uma Revolução no Cotidiano? São Paulo: Brasiliense, 1987, p. 216.

${ }^{15}$ TELLES, Vera da Silva. "Movimentos sociais: reflexões sobre a experiência dos anos 70" In WARREN, I. e KRISCHKE, P. Op. Cit., p. 55.
} 


\section{I - LUTAS ANTI-RACISTAS SOB O OLHAR DO DEOPS/SP}

\section{1) Aspectos dos Aparatos Repressivos}

Desde a década de 1940 os movimentos negros ${ }^{16}$ foram sistematicamente vigiados e reprimidos pelo DEOPS, uma vez que a polícia política entendia esses movimentos como subversivos e que levariam a uma crise que poderia gerar conflitos raciais a "democracia racial" brasileira. O que levou a proibição de ação de algumas das associações afrobrasileiras, por exemplo, a Organização de Cultura e Beneficência "Jabaquara" na década de 1940. ${ }^{17}$ No entanto, as análises dos movimentos de resistência a ditadura não costumam analisar os movimentos negros que também sofreram com a repressão e a censura dos "anos de chumbo". Decorre daí uma lacuna historiográfica sobre a resistência dos afrobrasileiros não só em relação ao regime militar, mas ao longo de todo o século XX.

A documentação do DEOPS/SP é uma fonte riquíssima para a reconstrução desse quadro. Porém, como qualquer outra fonte, apresenta limites. Uma característica peculiar dessa fonte é que ela narra uma "estória" construída pelos policiais e militares envolvidos nos órgãos produtores dos diversos documentos presentes nos prontuários e dossiês por meio da reunião de "provas" do crime, relatórios, informações, entre outros documentos. Faz-se necessário levar em conta a finalidade por trás dos documentos, que certamente no nosso caso tiveram como objetivo maior a de identificar "crimes políticos", o qual era classificado como um crime contra o Estado. ${ }^{18}$. Ou seja, um crime contra a ordem vigente. Esse tipo de crime começou a ser definido a partir de 1935, quando surgiu a $1^{\text {a }}$ lei, como uma legislação especial para regular o crime político, que definia os crimes contra a "ordem política e social". Assim, "a forma pela qual o enredo é contado se relaciona perfeitamente com o mesmo. Forma e conteúdo fazem parte de um mesmo conjunto

\footnotetext{
${ }^{16}$ Constatamos que o movimento negro é "representado por um conjunto de organizações que formulam discursos anti-racistas, com avaliações nem sempre coincidentes sobre o lugar da questão racial na sociedade brasileira" In MENDONÇA, L. Movimento Negro: Da Marca da Inferioridade Racial a Construção da Identidade Étnica. Dissertação de Mestrado. São Paulo: FFLCH/USP, 1996, p.2. Essa constatação nos fez adotar a categoria "movimentos negros", por assim abarcar a multiplicidade de projetos político-ideológicos envolvidos na luta anti-racista e suas diversas estratégias.

${ }^{17}$ Dossiê 50-J-46-8. DEOPS/SP, DAESP.

${ }^{18}$ In MARTINS, R. Segurança Nacional. São Paulo: Brasiliense, 1986, p. 59.
} 
inseparável de intenções. "19 No caso da polícia política era recolher o máximo de informações dos que eram classificados como "subversivos".

Estas informações eram resguardadas de forma sigilosa: a série dossiês foi organizada pelo Arquivo Geral do DEOPS/SP com códigos alfa-numérico, num esforço criptográfico, que "tinha por certo o objetivo de limitar ou impedir o acesso às informações armazenadas e ao conhecimento pleno das atividades do órgão, por pessoas estranhas ao quadro." 20 Como parte de valorização da informação enquanto ponto estratégico, o armazenamento era sigiloso a pessoas estranhas ao serviço do DEOPS. Ao mesmo tempo, em que era acessível às autoridades policiais com intuito de fornecer subsídios e informações sobre o maior número de pessoas, segundo a lógica de que todos eram suspeitos a priori.

Praticamente toda a documentação consultada no Fundo DEOPS/SP possuía carimbos de "confidencial", "reservado" e "secreto", mas a maior parte da documentação foi classificada como "confidencial", sendo raros os documentos da comunidade de informações e de segurança não classificados. A norma geral era classificar os documentos, no mínimo, como "confidencial”. ${ }^{21}$ A difusão da informação era decisão importante e da competência do comandante, uma vez que: "O ato de informar acarreta inarredável parcela de responsabilidade quanto aos graus de confiabilidade e credibilidade." 22

A série dossiês compõe a maior parte do corpus documental desta pesquisa. É necessário ressaltar que "os relatórios de agentes infiltrados são o produto-base gerador da série Dossiês, que se caracteriza por armazenar o material produzido pelo Serviço Secreto (data da década de 40), posteriormente denominado Serviço de Informações (final dos anos 60 e início da década de 70) e, finalmente, Divisão de Informações (a partir de 1975 até o término do órgão em 1983). Esses organismos, dentro do DEOPS/SP, produzem, prioritariamente, esses relatórios, com base na vigilância exercida por seus agentes. Evidentemente, encontram-se muitos outros materiais dentro da série Dossiês que,

\footnotetext{
${ }^{19}$ AQUINO, M. A. "Um certo olhar” In TELES, Janaína. (org) Mortos de desaparecidos políticos: reparação ou impunidade? São Paulo: Humanitas/ FFLCH-USP, 2001, p. 239.

${ }^{20}$ LEITÃO, A. "Estudo sobre os códigos da série Dossiês do Fundo DEOPS-SP" In Informativo Associação dos Arquivistas de São Paulo. São Paulo: Arquivo do Estado, junho de 2000, n. 2, p. 7.

${ }^{21}$ FICO, C. Como eles agiam. Os subterrâneos da Ditadura Militar: espionagem e polícia política. Rio de Janeiro: Record, 2001, p. 27.

${ }^{22}$ Memória de Gustavo Moraes Rego Reis In D' ARAÚJO, M. e SOARES, G. e CASTRO, C.. Os anos de chumbo: a memória militar sobre a repressão. Rio de Janeiro: Relume - Dumará, 1994, p. 163.
} 
aliás, caracteriza-se pelo armazenamento de material diverso." ${ }^{23}$ Nesse sentido, a produção da maior parte dos documentos, base dessa pesquisa, derivaram das espionagens realizadas pelos agentes do DEOPS/SP, com o objetivo de desvendar as idéias e ações dos movimentos negros.

Com o regime militar, desde 1964, “as investigações [dos dossiês] tornaram-se mais amplas e detalhadas, e os dossiês passaram a conter extensos relatórios sobre vários segmentos sociais e assuntos. ${ }^{24}$ De modo geral, observam-se mudanças na organização da informação nos documentos do Fundo DEOPS/SP pós-golpe de 1964, sendo que a informação passa a ser cada vez mais privilegiada, alimentando os aparatos repressivos regionais e nacionais. ${ }^{25}$ "Documentos sobre investigações de politicos, estudantes, trabalhadores e diversas manifestações sociais de oposição ao governo - movimentos negro, feminista, estudantil, sindical, de luta pela anistia, etc. -, antes dispostos em vários dossiês especificos e individuais, passaram a ser arquivados num mesmo dossiê.,"26 Espalhados por diversas pastas organizadas por fichas remissivas que se referiam aos temas e pessoas investigadas. $\mathrm{O}$ trabalho do arquivo policial foi caracterizado por um grande volume de documentação. A "obsessão" por informações demandava que o arquivo apresentasse o maior número possível de dados aos investigadores ou analistas que consultassem o seu acervo.

\section{Regime Militar}

Durante 21 anos do regime militar, o Brasil passou pelo controle político das Forças Armadas, respaldado em um aparato de informações e segurança, que compõe nossa principal fonte documental. Com o golpe de 1964, houve uma intervenção militar inédita no país, ao lado da manutenção de algumas instituições consagradas como democráticas, ainda que dentro de limites estabelecidos, o que permite considerar a: "especificidade do regime militar brasileiro no que tange ao seu aspecto ambíguo de construção de um

\footnotetext{
${ }^{23}$ AQUINO, M. e MORAES, M. e MATTOS, M. e SWENSSON JR., W. (orgs). O Dissecar da estrutura administrativa do DEOPS/SP - o Anticomunismo: Doença do aparato repressivo brasileiro. São Paulo: Arquivo do Estado, 2002, p. 15.

${ }^{24}$ AQUINO, M. e MORAES, M. e MATTOS, M. e SWENSSON JR., W. (orgs). A constância do olhar vigilante: a preocupação com o crime político. São Paulo: Arquivo do Estado, 2002, p. 55.

${ }^{25}$ AQUINO, M. e LESITER FILHO, A. e MATTOS, M. e SWENSSON JR., W. (orgs). A Alimentação do Leviatã nos planos regional e nacional: mudanças no DEOPS/SP no pós-1964. São Paulo: Arquivo do Estado, 2002, p. 17.

${ }^{26}$ AQUiNO, M. e MORAES, M. e MATTOS, M. e SWENSSON JR., W. (orgs). A constância do olhar vigilante: a preocupação com o crime político. São Paulo: Arquivo do Estado, 2002, p. 56.
} 
regime autoritário, sempre caracterizado, por seus dirigentes em suas proclamações públicas, como dotado de caráter democrático." 27

Também nota-se como particular ao regime militar brasileiro de 1964 a 1983: a longevidade do regime; um processo de abertura longa (entre 1974, com o início do governo Geisel a 1990, ano de eleição direta para presidente da República); atos institucionais que legislavam o regime; o congresso funcionando a maior parte do tempo, apesar de 3 fechamentos (1964, 1968 e 1976), ou seja, com limitações às suas competências e à liberdade de palavra de seus membros; o rodízio de poder entre os militares, escolhidos de forma indireta por um Colégio Eleitoral; a manutenção de 2 partidos, um de "situação" e outro de "oposição"; e o funcionamento de uma justiça militar que tinha também a atribuição de julgar o "crime político". Além disso, houve a manutenção de um calendário eleitoral, ainda que restrito, pois não era possível a escolha direta para presidente, governadores, prefeitos das capitais e áreas de segurança nacional. Desse modo, evidenciase um regime híbrido se revestido de liberalismo sob uma aparência de legalidade ${ }^{28}$, ao mesmo tempo em que exercia uma prática autoritária. ${ }^{29}$ "Todos os governantes do regime militar abriram e fecharam seus governos com discursos falando em nome da democracia." ${ }^{30}$, assim, a democracia tornava-se um ideal retórico, como observamos nas memórias de alguns militares: "No movimento de 64, a ideologia política foi puramente a de preservar o regime democrático. Essa foi a grande mola que conduziu o movimento." 31 Mas, de qual democracia tratamos aqui? ${ }^{32}$

A legislação federal, de 1965, revela de qual "democracia" os militares estavam tratando: "Democracia supõe liberdade, mas não exclui responsabilidade nem importa em licença para contrariar a própria vocação política da Nação. Não se pode desconstituir a

\footnotetext{
${ }^{27}$ AQUINO, M. "A especificidade do regime militar brasileiro: abordagem teórica e exercício empírico" In REIS FILHO, D. A.(org) Intelectuais, História e Política (século XIX e XX) Rio de Janeiro: 7Letras, 2000, p. 272.

28 "Na linguagem política, entende-se por Legalidade um atributo e um requisito do poder, dai dizer-se que um poder é legal ou age legalmente ou tem o timbre da Legalidade quando é exercido no âmbito ou de conformidade com leis estabelecidas ou pelo menos aceita." In BOBBIO, N. e MATTEUCCI, N. e PASQUINO, G. Dicionário de Política. Brasília: UnB, 1999, p. 674.

29 SOARES, G. e D' ARAÚJO, M. 21 anos de regime militar: balanços e perspectivas. Rio de Janeiro: Editora da Fundação Getulio Vargas, 1994, p. 128.

${ }^{30}$ AQUINO, M. e LONGHI, C. e MATTOS, M. e SWENSSON JR., W. (orgs). O DEOPS/SP Em busca do crime político. São Paulo: Arquivo do Estado, 2002, p. 53.

${ }^{31}$ Memória de Antonio Bandeira In D' ARAÚJO, M. e SOARES, G. e CASTRO, C. (orgs). Visões do golpe: a memória militar sobre 1964. Rio de Janeiro: Relume - Dumará, 1994, p. 225.

${ }^{32}$ Alusão ao título do trabalho: WEFFORT, F. Qual Democracia? São Paulo: Companhia das Letras, 1992.
} 
Revolução, implantada para restabelecer a paz, promover o bem-estar do povo e preservar a honra nacional." 33 Percebe-se que o pensamento militar conferia um caráter instrumental à democracia, restringindo-a a "vocação política da nação" e a "revolução" de 1964. A democracia como elemento discursivo, no contexto da Guerra Fria, apresentou-se como oposto ao "comunismo". "Nesse ambiente, para o mundo ocidental, os conceitos democracia e comunismo foram carregados de significados opostos." ${ }^{34}$ Ao falar em nome da "democracia", tratava-se de uma afirmação de busca de legitimidade ${ }^{35}$, e do próprio combate aos "comunistas", principal propósito do aparato repressor que aqui analisamos.

As pesquisas realizadas pelos integrantes do Centro de Pesquisa e Documentação da Fundação Getúlio Vargas (CPDOC) apresentaram como razões para o golpe, segundo a análise dos depoimentos dos militares ${ }^{36}$, destacando: o anti-comunismo; e a percepção de caos, a baderna e a desordem ${ }^{37}$ presentes na sociedade brasileira; fatores do contexto político externo e fatores da crise econômica no país. Necessário levar em conta que o pensamento autoritário, presente no regime militar, "teme o novo e o inédito e esforça-se para retraí-los até às fronteiras do já sabido. Incapaz de pensar a diferença, tanto no espaço quanto no tempo, precisa sentir-se autorizado antes de impor-se; vive sob o signo da repetição. „38

A ordem era o ponto central do projeto social e político dos militares: "A desordem, o caos e a anarquia, em contraposição à ordem, à estabilidade, à segurança e à tranqüilidade, ocupam posição central nas análises da situação política feitas por

\footnotetext{
33 Legislação Federal n. 1523 de 1965 Apud VECCHIO, A. Impasses do Regime Militar Brasileiro: Construção de Potência, Institucionalização e Estabilização Política (1964-1979). Tese de doutorado. São Paulo: FFLCH/USP, 1998, p. 97.

${ }^{34}$ REZNIK, L. Democracia e Segurança Nacional. A Polícia Política no pós-guerra. Rio de Janeiro: Editora FGV, 2004, p. 19.

${ }^{35}$ REZENDE, M. A ditadura militar no Brasil: repressão e pretensão de legitimidade (1964-1984). Tese de Doutorado. São Paulo: FFLCH/USP, 1996, p. 6.

${ }^{36}$ D' ARAÚJO, M. e SOARES, G. e CASTRO, C. (orgs). Visões do golpe: a memória militar sobre 1964. Rio de Janeiro: Relume - Dumará, 1994; Os anos de chumbo: a memória militar sobre a repressão. Rio de Janeiro: Relume - Dumará, 1994 e A volta aos quartéis: a memória militar sobre a abertura. Rio de Janeiro: Relume - Dumará, 1995.

${ }^{37}$ Faz-se necessário lembrar que "Desordem, em verdade, é apenas um nome: é o nome dado à ordem não desejada, não querida, não procurada. Ou o nome dado à ordem que não deve ser desejada, nem querida, nem procurada. É o nome da ordem que desagrada, desgosta, decepciona, prejudica, infelicita, desola. Às vezes, é o nome da ordem que causa arrependimento. Mas a desordem é sempre uma ordem..." TELLES JÚNIOR, G. "Meditações sobre a desordem" In Revista Imaginário, n. 3. São Paulo: LABI-NIME, 2002. (In http://www.imaginario.com.br/artigo/a0031_a0060/a0049.shtml).

${ }^{38}$ CHAUÍ, M. Ideologia e mobilização popular. São Paulo: Paz e Terra: Cedec, 1978, p. 38.
} 
militares." 39 Os militares apresentavam uma oposição maniqueísta entre "ordem” e "desordem", avaliando que a desordem geraria o caos, a guerra e a convulsão social. Em síntese: "O caos, real ou percebido, é um conceito politicamente relevante, sobretudo para entender a participação política dos militares, que são particularmente sensíveis à desordem. Além de um bem em si, os responsáveis pelo regime militar consideravam a ordem um pré-requisito para o crescimento econômico. A ampliação e a elaboração da ordem levaram ao conceito de segurança nacional, que integra o binômio doutrinário que regeu boa parte da política pós-64 - desenvolvimento e segurança." ${ }^{40}$ Nesse pensamento, entendia-se que o subdesenvolvimento brasileiro ameaçaria o país e, o próprio Ocidente, uma vez que os tornaria "vulneráveis" ao comunismo. ${ }^{41}$

Os militares valorizavam a ordem como um elemento fundamental para organização da sociedade, conforme nota-se no manual da ESG: "Manifestação essencial da cultura política é a Ordem, por ela gerada, e que corresponde a um modelo de organização social decorrente do respeito a obediência a normas que se estabelecem naturalmente à medida que os participantes do grupo adotam os valores culturais e admitem como obrigatórios os usos e costumes vigentes. A Ordem apresenta-se como um complexo de normas e constitui o substrato essencial e básico de toda atividade social. Ela específica os grupos humanos, distinguindo-os uns nos outros." 42 Tratava-se do valor da "ordem" sob a perspectiva da obediência plena das normas sociais que o regime buscava implementar e "salvaguardar" seus valores. Assim, a contestação dos movimentos negros à "democracia racial”, tornavase "desordem" sob a perspectiva do regime militar.

Durante o regime militar houve a sustentação de um "discurso 'ético-moral que deita raízes na larga tradição do pensamento autoritário brasileiro." ${ }^{43}$ Percebemos que alguns aspectos autoritários na sociedade brasileira tem raízes históricas: "Não podemos esquecer que o Brasil é um país que conviveu três séculos com a escravidão. Ora, um país que

\footnotetext{
39 SOARES, Gláucio Ary Dillon e D' ARAÚJO, Maria Celina. 21 anos de regime militar: balanços e perspectivas. Rio de Janeiro: Editora da Fundação Getulio Vargas, 1994, p. 23.

${ }^{40}$ SOARES, Gláucio Ary Dillon e D’ ARAÚJO, Maria Celina. Op. Cit., p. 24.

${ }^{41}$ SILVA, G. Conjuntura Nacional - O Poder Executivo. Geopolítica do Brasil. Rio de Janeiro: José Olympio, 1981, p. 247.

${ }^{42}$ Manual ESG, "Seção I - Expressão política do poder nacional (poder político)", "3- Fatores" Apud ROCHA, M. A Evolução dos conceitos da doutrina da Escola Superior de Guerra nos anos 70. Dissertação de Mestrado. São Paulo: FFLH/USP, 1996. ANEXO 12, p. 119/120.

${ }^{43}$ FICO, C. Como eles agiam. Os subterrâneos da Ditadura Militar: espionagem e polícia política. Rio de Janeiro: Record, 2001, p. 112.
} 
aceitou que um povo, por diferença de cor, fosse escravizado, tem uma herança muito forte da presença do autoritarismo. Esta é apenas uma marca, e aos poucos outras marcas vão sendo acumuladas. " $44 \mathrm{O}$ autoritarismo decorre do princípio de ordem social, caracterizado pelo busca por obediência, empregado por meios coercitivos.

O regime militar visando formar uma "consciência nacional" pretendia propagar uma idéia de nação, permeada de valores moralistas e autoritários, como "ordem", "disciplina" e "hierarquia". Formulada pela ESG, a idéia de nação ${ }^{45}$ como termo intercambiável de Pátria ${ }^{46}$, numa concepção desta como um todo homogêneo sem dissensos. Dessa idéia decorriam os "objetivos nacionais", definidos pelo Conselho de Segurança Nacional.

Os militares se auto-atribuíam representantes da vontade da nação, como consta no AI1: "A revolução se distingue de outros movimentos armados pelo fato de que nela se traduz, não o interesse e a vontade de um grupo, mas o interesse e a vontade da Nação." 47 Nesta perspectiva, o Estado era concebido como "uma entidade supostamente capaz de representar os interesses da nação como um todo, cuja vontade se supõe única $e$ unificada." 48 Quanto às Forças Armadas se propunham "a fortalecer o Estado, a neutralizar as tensões sociais, a suprimir o dissenso político e a alcançar um elevado crescimento econômico." 49 Este conjunto de atribuições próprias dos militares requeriam alto grau de patriotismo, de conhecimento da realidade brasileira e uma retidão moral inquestionável. Construiu-se, assim a "utopia autoritária", projeto político-social dos militares para o Brasil. ${ }^{50}$

\footnotetext{
${ }^{44}$ AQUINO, M. "História e Autoritarismo". Entrevista In Informe: edição especial 1999-2001. São Paulo: SDI/FFLCH/USP, 2002, pp. 105-107, p. 106.

${ }^{45}$ Segundo dicionário etimológico nação seria um "agrupamento de seres, geralmente fixos num território, ligados por origem, tradições, costumes comuns e, em geral, por uma língua.” In CUNHA, A. Dicionário etimológico. Nova Fronteira da língua portuguesa. Rio de Janeiro: Nova Fronteira, 1982. (2ª edição, 1986), p. 543.

${ }^{46}$ MARTINS, R. Segurança Nacional. São Paulo: Brasiliense, 1986, p. 32.

47 "Ato Institucional" Apud FICO, C. Além do golpe: a tomada do poder em 31 de março de 1964 e a ditadura militar. Rio de Janeiro: Record, 2004, p. 339.

${ }^{48}$ LEITE, R. A dupla face do nacionalismo no Brasil: Kubitschek e Médici. Dissertação de Mestrado. Recife: CFCH/UFPE, 1992, p. 164.

${ }^{49}$ DREIFUSS, R. e DULCI, O. "As forças armadas e a política" In SORJ, B. e ALMEIDA, M. (orgs) Sociedade e política no Brasil pós-64. São Paulo: Brasiliense, 1984, p. 96.

${ }^{50}$ D' ARAÚJO, M e SOARES, G e CASTRO, C. (orgs). Visões do golpe: a memória militar sobre 1964. Rio de Janeiro: Relume - Dumará, 1994, p. 9.
} 
Policiais e militares sustentavam um discurso no qual defendiam uma cruzada em defesa da "democracia"51 e de "instituições nacionais", defendendo a "ordem e o progresso". Para tanto consideravam necessário conter o "comunismo internacional" que agiria no país por meio do "aliciamento" de militantes que se contrapunham às "instituições nacionais", como os movimentos negros que contestavam a "harmonia racial", considerada pelo regime militar.

O general Carlos de Meira Mattos, em 1969, descreveu serem os "objetivos nacionais" "52: a "independência", a "soberania", a "integridade territorial", o "prestígio internacional", a "integração nacional”, a "democracia", a "preservação dos valores morais e espirituais da nacionalidade" e a "paz social". Ainda segundo Mattos, esses objetivos, que poderiam ser resumidos em "integração" e "prosperidade" nacional, deveriam ser conquistados "a todo custo e a curto prazo." ${ }^{53}$ Nesta perspectiva, os movimentos negros que nesse período articulavam protestos contra o racismo tornar-se-iam obstáculos à “integração nacional" e ameaçariam a "paz social", ao desnudar a "desintegração" da sociedade brasileira.

Na Lei de Segurança de 29/09/1969, que considerava crime "ofender moralmente quem exerça autoridade, por motivos de faccionismo ou inconformismo político-social, ofender a honra e a dignidade do Presidente da República, do vice-presidente e outros dignitários; incitar à guerra, à subversão, à desobediência às leis coletivas, à animosidade entre as Forças Armadas ou entre estas e as classes sociais ou instituições civis; à luta de classes, à paralisação de serviços ou atividades essenciais, ao ódio ou à discriminação

\footnotetext{
${ }^{51}$ A idéia de "democracia" era em moldes bem limitados. Segundo o dicionário Aurélio, define, por meio da ciência política, a idéia de uma "democracia autoritária" como um "Sistema de governo surgido após a $1^{a}$ Guerra Mundial, em geral anticomunista, firmado na supremacia do poder executivo em relação aos demais poderes." In FERREIRA, A. Dicionário Aurélio Século XXI. Rio de Janeiro: Nova Fronteira; Lexikon, 1999. CD-ROM.

${ }^{52}$ Os objetivos nacionais "exprimem os desejos da Nação; entre eles, os Objetivos Nacionais Permanentes constituem a expressão dos anseios duradouros da nacionalidade." In Manual ESG, "Seção II", "5 Objetivos Nacionais Permanentes Brasileiros" Apud ROCHA, M. A Evolução dos conceitos da doutrina da Escola Superior de Guerra nos anos 70. Dissertação de Mestrado. São Paulo: FFLH/USP, 1996. ANEXO 8, p. 57. Nessa ótica, a nação deve manter os seus valores tradicionais, gerando conservação, equilíbrio e ordem, segundo o conceito de segurança. In Manual ESG, "Objetivo Nacionais", "2- Interesses, Aspirações e Objetivos" Apud ROCHA, M. Op. Cit. ANEXO 9, p. 29.

${ }_{53}$ MATTOS, C. "Ensaio sobre a Doutrina Política da Revolução" In ASSESSORIA ESPECIAL DE RELAÇÕES PÚBLICAS. O Processo Revolucionário Brasileiro. Brasília, 1969. Apud LEITE, R. A dupla face do nacionalismo no Brasil: Kubitschek e Médici. Dissertação de Mestrado. Recife: CFCH/UFPE, 1992, p. 163.
} 
racial." 54 Assim, a "questão racial" integrava as temáticas consideradas como "crimes" pela legislação do regime militar. ${ }^{55}$

O regime militar pautou-se numa fundamentação teórica básica: a doutrina de Segurança Nacional ${ }^{56}$, elaborada na $\mathrm{ESG}^{57}$, tinha como objetivo projetar o fortalecimento do poder nacional e planejar o desenvolvimento econômico-social do país. "Ou ainda, por outras palavras, a Doutrina de Segurança Nacional era uma doutrina de guerra." ${ }^{\circ 8}$ Em tempos de um mundo bipolarizado e em constante tensão gerada pela Guerra Fria, o projeto de Segurança Nacional visava, nas palavras de Golbery de Couto e Silva (o mais importante ideólogo do regime), "salvaguardar a consecução dos objetivos vitais permanentes da Nação, contra quaisquer antagonismos tanto externos quanto internos, de modo a evitar a guerra se possível for e empreendê-la, caso necessário, com as maiores probabilidades de êxito." 59

A ESG sustentou o aporte teórico para a política de segurança nacional do regime militar, contribuindo a formação do pensamento da polícia civil paulista no combate à “subversão", como podemos observar no artigo "O poder de polícia, o desenvolvimento e a segurança nacional”, na Revista Arquivos da Polícia Civil de São Paulo. ${ }^{60}$ Desta forma, a "ESG consolidou, assim, uma rede militar-civil que institucionalizou e disseminou a Doutrina de Segurança Nacional e Desenvolvimento. Esta rede, organizada na Associação dos Diplomados da Escola Superior de Guerra (ADESG $\left.{ }^{61}\right)$, promovia conferências,

\footnotetext{
${ }^{54}$ ALVES, M. H. Estado e Oposição no Brasil (1964-1984). Petrópolis: Vozes, 1985, pp. 158/159.

${ }^{55}$ Esta questão será retomada no capítulo II.

${ }^{56}$ O termo "segurança nacional" remonta a década de 1930, e ao longo da década de 1950 foi sendo reelaborada na ESG. Em outubro de 1954, Golbery proferiu a conferência: "Planejamento e a Segurança Nacional", em que desenvolveu os conceitos de "guerra subversiva" e "guerra total", desenvolvendo as principais idéias de uma política de Segurança Nacional que por fim levou a formulação da Doutrina de Segurança Nacional. In GASPARI, E. A ditadura derrotada. O sacerdote e o feiticeiro. São Paulo: Companhia das Letras, 2003, p. 135.

${ }^{57}$ A Escola Superior de Guerra (ESG), fundada em 1949, com a assistência de consultores franceses e norteamericanos, visou treinamento de pessoal para a direção e planejamento da segurança nacional. In ALVES, M. H. Op. Cit., p 24.

${ }^{58}$ MIYAMOTO, S. e GONÇALVES, W. A Politica Externa Brasileira e o Regime Militar: 1964-1984. Campinas: IFCH/ UNICAMP, 1991, p. 12.

59 SILVA, G. Planejamento Estratégico. Brasília: UNB, 1981, p. 22. Apud MIYAMOTO, S. e GONÇALVES, W. Op. Cit., p. 12.

${ }^{60}$ MEIRELLES, H. "O poder de polícia, o desenvolvimento e a segurança nacional” In Arquivos, vol. XXVII. São Paulo: Polícia Civil de São Paulo, $1^{\circ}$ semestre 1976, pp. 27-37.

${ }^{61}$ A ADESG foi organizada por ex-alunos da ESG, a partir de 1951, sua tarefa era a de promover cursos e atividades com o objetivo de discutir problemas de cada Estado ou região e difundir a Doutrina de Segurança Nacional. In ROCHA, M. A Evolução dos conceitos da doutrina da Escola Superior de Guerra nos anos 70. Dissertação de Mestrado. São Paulo: FFLH/USP, 1996, p. 39.
} 
seminários, debates e cursos por todo o país, levando os princípios e doutrinas da ESG a outros protagonistas políticos civis e militares." ${ }^{62}$ As idéias gestadas pela ESG foram importantes para a formação da mentalidade do regime militar. ${ }^{63}$ Uma mentalidade que não se formou a partir do golpe de 1964, mas que foi sendo desenvolvida desde as leis de Segurança Nacional do governo Vargas (1930 a 1945) e, posteriormente com a fundação da ESG, em 1949, que foram compondo um universo de contenção social ao longo do século $\mathrm{XX} .{ }^{64}$

O pensamento sobre a segurança nacional esteve atrelado ao anti-comunismo e as idéias de geopolítica em voga no período, como "Brasil Potência", em que o Brasil teria uma "vocação" para ser uma grande potência pela a sua localização geográfica privilegiada e um porte continental. Calcado no binômio "segurança e desenvolvimento", cuja viabilidade não se relacionava direta e tão somente com os militares no poder, constituiu um pensamento que integrava um projeto para o Brasil. ${ }^{65}$ A ESG pautou-se, principalmente, na geopolítica, desenvolvendo um conjunto de definições e formulações, como os Objetivos Nacionais Atuais e Permanentes, o Poder Nacional e a Segurança Nacional, formulando uma Doutrina de Segurança Nacional, que visava reger as políticas interna e externa do Brasil. Nota-se que as noções desenvolvidas pelo discurso esguiano ganharam uma forma "marcadamente circular e maniqueísta, cujo ponto de partida e de chegada fundamentam-se em critérios próprios, permitindo a distinção entre falso $e$ verdadeiro, natureza e cultura, ordem e subversão, Óbices e Aspirações Nacionais, sempre em nome dos legítimos anseios da Nação." 66

Dessa forma, a idéia de segurança nacional era compreendida como garantia da consecução dos "objetivos nacionais" contra os "antagonismos" internos e externos. ${ }^{67}$ Segurança e desenvolvimento formavam o binômio da Lei de Segurança Nacional (LSN),

\footnotetext{
${ }^{62}$ ALVES, M. H. Idem., p 34.

${ }^{63}$ Vale ressaltar a definição do conceito de mentalidade: "conjunto de idéias, crenças, valores, nem sempre conscientes, subjacentes aos costumes, práticas, hábitos de uma sociedade ou grupo social, caracterizando sua maneira de agir, seus sentimentos, sua produção cultural." In JAPIASSU, H. e MARCONDES, D. Dicionário Básico de Filosofia. Rio de Janeiro: Jorge Zahar Editor, 1989, p. 164.

${ }^{64}$ A Lei de Segurança Nacional do governo Vargas data de 1935, que definiu pela primeira vez o "crime político" por meio de uma lei nacional. Além disso, houve no mesmo ano a criação do Tribunal de Segurança Nacional (TSN), um tribunal de exceção.

${ }^{65}$ ROCHA, M. S. A Evolução dos conceitos da doutrina da Escola Superior de Guerra nos anos 70. Dissertação de Mestrado. São Paulo: FFLH/USP, 1996, p. 54.

${ }^{66}$ ROCHA, M. S. Op. Cit., p. 52.

${ }^{67}$ AQUINO, M. Mudanças e permanências: ambigüidades do Estado Autoritário brasileiro pós-64, p. 25.
} 
na qual o "lema 'Ordem e Progresso', caro aos positivistas que ajudaram a fundar a República, atualizava-se na idéia de Segurança e Desenvolvimento. " 68.

Segundo os pesquisadores do CPDOC, o regime militar sustentava a idéia de que "via controle policial e militar, a sociedade poderia ser moldada de uma forma estática e desideologizada." ${ }^{69}$ Procurava-se, dessa forma, o "saneamento ideológico", como se fosse possível haver uma única e verdadeira forma de entender o mundo. Assim, consideravam que era "essencial reprimir. Não posso discutir o método de repressão, se foi adequado, se foi o melhor que se podia adotar. O fato é que a subversão acabou." 70 Essa foi a mentalidade fortemente ideológica que esteve presente ao longo dos 21 anos de regime militar brasileiro sustentando e justificando a constituição e o funcionamento de todo um aparato repressivo, adjetivado como "soldado de guerra".

\section{A comunidade de informações e segurança}

A principal fonte desta pesquisa constitui-se do Fundo DEOPS/SP, que possui uma documentação não só produzida por esse órgão como também por outras instituições pertencentes à comunidade de informações e segurança. Reúne o "conjunto de órgãos encarregados de fazer espionagem e reprimir os brasileiros considerados 'subversivos', „71 Esse corpus documental é extremamente rico com origem diversa, de comunicação com os outros órgãos ou de materiais pertencentes aos investigados que foram anexados às pastas policiais.

O Departamento Estadual de Ordem Política e Social (DEOPS) foi criado em 1924, pela lei n. 2034, e extinto em 30/12/1983, pelo decreto n. 20728. ${ }^{72}$ Órgão de identificação, vigilância e repressão ${ }^{73}$, foi criado "com o objetivo de afastar o perigo para o regime representado pela proliferação das chamadas idéias estrangeiras (o Anarquismo e o Comunismo num primeiro momento, e o Nazismo e o fascismo, posteriormente) e também

\footnotetext{
${ }^{68}$ DREIFUSS, R. e DULCI, O. "As forças armadas e a política” In SORJ, B. e ALMEIDA, M. (orgs) Sociedade e política no Brasil pós-64. São Paulo: Brasiliense, 1984, p. 91.

${ }^{69}$ ARAÚJO, M. e SOARES, G. e CASTRO, C. Os anos de chumbo: a memória militar sobre a repressão. Rio de Janeiro: Relume - Dumará, 1994, p. 24.

${ }^{70}$ ARAÚJO, M. e CASTRO, C. (orgs) Ernesto Geisel. Rio de Janeiro: Editora FGV, 1997, p. 223-4.

${ }^{71}$ FICO, C. Como eles agiam. Os subterrâneos da Ditadura Militar: espionagem e polícia política. Rio de Janeiro: Record, 2001, p. 18.

${ }_{72}$ AQUINO, M. e MORAES, M. e MATTOS, M. e SWENSSON JR., W. (orgs). O Dissecar da estrutura administrativa do DEOPS/SP - o Anticomunismo: Doença do aparato repressivo brasileiro. São Paulo: Arquivo do Estado, 2002, p. 20.

73 AQUINO, M. e LONGHI, C. e MATTOS, M. e SWENSSON JR., W. (orgs). O DEOPS/SP Em busca do crime político. São Paulo: Arquivo do Estado, 2002, p. 15.
} 
pelas manifestações sociais contrárias à ordem vigente." ${ }^{74}$ Tinha por dever coibir o crime político, um crime essencialmente ligado às idéias e às práticas políticas. "Um dos principais objetivos deste órgão - parte integrante do projeto político do Estado - era o de bloquear a heterogeneidade de pensamento procurando silenciar aqueles que eram considerados como 'potencialmente perigosos.," 75 O DEOPS visava o controle de idéias, baseado num pensamento de que "quem maneja e comanda os foguetes são as idéias." 76

Por sua vez, as polícias políticas estaduais, os DEOPS, integraram o sistema de segurança e informação do regime militar, aproveitando a experiência da atuação repressiva dos delegados e investigadores da polícia civil. ${ }^{77} \mathrm{O}$ sistema aproveitou essas estruturas que já estavam montadas para desenvolver medidas políticas "saneadoras" da sociedade brasileira. Neste sistema, a "ordem político-social é a razão de ser de uma Nação" 78 , e a polícia política teria por função "a profilaxia social, purificando as coletividades $e$ livrando-as do 'virus' nefasto dos agentes de toda a espécie, que pretendem a subversão da ordem pública. [...] os fins da Polícia Política devem ser amplos, dentro do principio da garantia e da salvaguarda das instituições. " 79 Desta forma, foram centrais no conjunto da organização policial, sendo que seus quadros e colaboradores eram considerados "sentinelas avançadas da ordem pública. Suas missões, conquanto árduas, são como um ideal a realizar e seus efeitos se concentram no equilibrio social." 80

Segundo o Manual de Polícia Politica e Social, a polícia política seria "a Polícia do Estado, que tem por finalidade máxima exercer atividades preventivas, indagando $e$ combatendo os fatores da desordem social, a bem da ordem. Visa ela, especialmente, os movimentos políticos e sociais de caráter internacionalista. [...] Dentro do País zela pela manutenção da ordem político-social, pela segurança das instituições, da forma de governo e da segurança da autoridade, prevenindo e reprimindo as greves, atentados,

\footnotetext{
${ }^{74}$ LEITÃO, A. "Estudo sobre os códigos da série Dossiês do Fundo DEOPS-SP" In Informativo Associação dos Arquivistas de São Paulo. São Paulo: Arquivo do Estado, junho de 2000, n. 2, p. 6.

${ }^{75}$ CARNEIRO, M. L. T. "Os arquivos da Polícia Política Brasileira- uma alternativa para os estudos de História do Brasil Contemporâneo" Comunicação apresentada no II Congresso Internacional Historia a Debate. Santiago de Compostella, Espanha, julho de 1999, p. 2.

${ }^{76}$ BAFFA, A. Nos porões do SNI. O retrato do monstro de cabeça oca. Rio de Janeiro: Editora Objetiva, 1989, p. 55.

${ }^{77}$ FICO, C. Como eles agiam. Os subterrâneos da Ditadura Militar: espionagem e polícia politica. Rio de Janeiro: Record, 2001, p. 128.

${ }^{78}$ TERRA, S. e CORD, P. Polícia, lei e cultura. Rio de Janeiro: Gráfica Guarany, 1939, p. 139.

${ }^{79}$ TERRA, S. e CORD, P. Op. Cit., p. 139.

${ }^{80}$ TERRA, S. e CORD, P. Idem, p. 140.
} 
agitações, conspirações, conjurações, revoluções, a propaganda e a disseminação das ideologias subversivas e dissolventes. " 81 Os órgãos de informação e segurança buscavam o maior conhecimento possível do grande "inimigo", que ao longo do século XX foi o "comunista". ${ }^{82}$ Mas, o manual também enumerava como crime contra a ordem política e social definido pela lei número 1802, de 5 de janeiro de 1953: "Fazer publicamente propaganda [...] de ódio de raça, de religião ou de classe." ${ }^{83}$ Ao definir quais as propagandas criminosas, o "inimigo número um” era apresentado com facetas que ampliavam a noção de subversivo. Assim, ao tornar público o "ódio de raça, de religião ou de classe" apresentava-se como ameaças à "harmonia" da nação. O regime militar, ainda que de forma difusa, deixava entrever as diferenças e desigualdades sociais, objetivando evitar conflitos de qualquer ordem mascarava essas diferenças e desigualdades.

Com o regime militar, houve um "aperfeiçoamento do aparato repressivo resultante da aplicação da Doutrina de Segurança Nacional, desenvolvida pela Escola Superior de Guerra (ESG), que, após o golpe de 1964, passou a ditar as normas da atuação da polícia política. ${ }^{" 84} \mathrm{O}$ sistema repressivo ampliou-se e ganhou maior complexidade com novos órgãos, a reformulação dos já existentes e, sua posterior integração, reforçando a atuação voltada para a vigilância, controle e repressão aos que se engajaram em qualquer forma de oposição ao regime. ${ }^{85}$ A grande novidade do sistema de repressão organizado no regime militar foi o envolvimento direto das Forças Armadas na repressão política.

O exército comprometido com a "segurança interna" foi a força principal a coordenar as ações. A repressão política não atingiu apenas a luta armada, como a Guerrilha do Araguaia, na década de 1970, mas também alguns dos militantes e lideranças políticas que operavam em estruturas legalmente constituídas, como os ativistas afro-descendentes. " $O$ 'sistema', a comunidade de informações fazem parte de um bem articulado plano que

\footnotetext{
${ }^{81}$ APOLlONIO, L. Manual de polícia política e social. São Paulo: Escola de Polícia de São Paulo, 1963. ( $3^{\mathrm{a}}$ Edição), p. 318.

${ }^{82}$ Dessa forma, diversos livros, artigos de revistas policiais e militares buscavam traçar o perfil do comunismo. Como exemplo temos CARVALHO, F. "Por que devemos lutar contra o comunismo" e POZZOBON, Z. "Guerrilha Urbana" In A Defesa Nacional, Ano 59, n. 647. Rio de Janeiro: Ministério da Guerra, jan/fev 1973. e SALMON, H. "O fascismo de hoje, o comunismo de ontem” In Arquivos, vol. XXVIII. São Paulo: Polícia Civil de São Paulo, 1976, pp. 69-83.

${ }^{83}$ APOLLONIO, L. Op. Cit., p. 319.

${ }^{84}$ AQUiNO, M. e MORAES, M. e MATTOS, M. e SWENSSON JR., W. (orgs). A constância do olhar vigilante: a preocupação com o crime político. São Paulo: Arquivo do Estado, 2002, p. 56.

${ }^{85}$ AQUINO, M. e MATTOS, M. e SWENSSON JR., W. (orgs); ARAÚJO, L. e NETO, O . (co-orgs). No coração das trevas: o DEOPS/SP visto por dentro. São Paulo: Arquivo do Estado, 2001, p. 24.
} 
procurou não só controlar a oposição armada mas também controlar e direcionar a própria sociedade." ${ }^{86}$ Desse modo, o regime militar para além da repressão a setores sociais específicos realizou uma ampla campanha de intimidação da sociedade civil, como um todo. ${ }^{87}$

O "poder de polícia" foi tema de Manual da ESG, ressaltando que em prol do “combate a subversão" deveriam ser utilizados todos os aparatos possíveis e, sobretudo, o pensamento e a experiência, da polícia que, ao longo do século XX, combatiam o "crime político". 88 "O poder de polícia se exerce tendo por finalidade assegurar a liberdade individual e promover o bem-estar da coletividade." ${ }^{89}$ É notório que o pensamento policial tratou, por meio da expressão "poder de polícia", de legitimar o emprego da força, como mecanismo de limitação social necessária ao convívio coletivo. ${ }^{90}$ "No desempenho de sua relevante missão de preservar a ordem e segurança pública, a polícia necessita, com freqüência, de exercer um poder discricionário sobre as pessoas e coisas, poder esse especial, cujos limites não podem ser geralmente estabelecidos em lei, pois são imprevisíveis." 91 O discurso apresentado pelo pensamento policial apresentava aspectos que podiam levar a um abuso de poder como apresentado na citação anterior que justificava um poder policial acima da lei.

No debate em torno do "poder de polícia" esteve presente também a questão da Segurança Nacional. No artigo "O poder de polícia, o desenvolvimento e a segurança nacional”, da Revista Arquivos, o "poder de polícia” foi definido como "a faculdade de que dispõe a Administração Pública para condicionar e restringir o uso e gozo de bens, atividades e direitos individuais, em beneficio da coletividade ou do próprio Estado." 92

\footnotetext{
${ }^{86}$ ARAÚJO, M. e SOARES, G. e CASTRO, C. Os anos de chumbo: a memória militar sobre a repressão. Rio de Janeiro: Relume - Dumará, 1994, p. 18.

${ }^{87}$ MATTOS, M. Em nome da segurança nacional: os processos da Justiça Militar contra a Ação Libertadora Nacional (ALN), 1969-1979. Dissertação de Mestrado. São Paulo: FFLCH/USP, 2002, p. 23.

${ }^{88}$ Manual ESG, "Seção I - Expressão Política do Poder Nacional (Poder Político)", "5- Órgãos e Funções" no sub-item "5.1.1- Poder de Polícia" Apud ROCHA, M. A Evolução dos conceitos da doutrina da Escola Superior de Guerra nos anos 70. Dissertação de Mestrado. São Paulo: FFLH/USP, 1996. ANEXO 12, p. 128.

${ }^{89}$ ALONSO, A. Poder de Policia, 1954, p. 6.

${ }^{90}$ Ver também PESTANA, J. Manual de Organização Policial do Estado de São Paulo. (2a edição). São Paulo: Escola de Polícia de São Paulo, 1957, pp. 45- 50. e ALVES, L. "Poder de polícia" In Arquivos, vol. XXVI. São Paulo: Polícia Civil de São Paulo, $2^{\circ}$ semestre 1975, pp. 171-178. e SILVA, O. "Poder de Polícia" In Arquivos, vol. 42. São Paulo: Polícia Civil de São Paulo, $2^{\circ}$ semestre de 1984, pp. 41-43.

${ }^{91}$ PESTANA, J. Op. Cit., p. 46.

${ }^{92}$ MEIRELLES, H. "O poder de polícia, o desenvolvimento e a segurança nacional" In Arquivos, vol. XXVII. São Paulo: Polícia Civil de São Paulo, $1^{\circ}$ semestre 1976, pp. 27-37, p. 28.
} 
Assim sendo, o "poder de polícia" trata de mecanismos de contenção da Administração Pública da restrição do direito individual que se revelasse contrário, nocivo ou inconveniente ao bem-estar social, ao desenvolvimento e a segurança nacional, ameaçando a ordem estabelecida. ${ }^{93} \mathrm{O}$ referido artigo demonstra uma total integração com a Doutrina de Segurança Nacional e Desenvolvimento, chegando a citar o Manual Básico da ESG, e concluiu que "O desenvolvimento requer, pois, segurança." 94

Era responsabilidade da Segurança Nacional naquela conjuntura histórica utilizar todos os quadros policiais e militares, incluindo também “os órgãos policiais comuns civis e militares - que prestam colaboração em todos os assuntos e ações de interesse da Segurança Nacional, em decorrência de suas atribuições gerais de polícia”. "95 Desta forma, "poder de polícia" abrangeria "desde a proteção à moral e aos bons costumes, a preservação da saúde pública, a censura de filmes e espetáculos públicos, o controle de publicações, a segurança das construções e dos transportes, até a segurança nacional em particular." 96 Neste quadro, segurança nacional era importante para a consecução dos “objetivos” do cidadão e da Nação em geral. ${ }^{97} \mathrm{Na}$ esteira desse pensamento, a polícia visava evitar: "eventuais desequilíbrios, desagregação ou desajustamentos possam empecer o desenvolvimento do Estado, naqueles objetivos visados no interesse da coletividade nacional." 98 Ou seja, a ação da vigilância e a penalidade teriam como finalidade impor moral e materialmente o poder da norma. ${ }^{99}$

Para efetivar a impertinente restrição individual e proteger a coletividade, o Estado se utilizava do poder discricionário, o que constituiria o "poder de polícia”, argumentando que “Existem, sempre, os 'inconformismos'. As normas são violadas, praticam-se atos que não correspondem ao padrão ocorrem atos ilícitos praticam-se crimes. Daí a necessidade de se

\footnotetext{
${ }^{93}$ MEIRELLES, H. Op. Cit., p. 28.

${ }^{94}$ MEIRELLES, H. Idem, pp. 34-35.

${ }_{95}$ MEIRELLES, H. Ibdem, p. 35.

${ }^{96}$ MEIRELLES, H. Idem, Ibdem, p. 30.

${ }^{97}$ MEIRELLES, H. Ibdem., p. 31.

98 ALVES, L. "Poder de polícia" In Arquivos, vol. XXVI. São Paulo: Polícia Civil de São Paulo, $2^{\circ}$ semestre 1975, pp. 171-178, p. 174.

${ }^{99}$ CHÂTELET, F., DUHAMEL, O. e PISIER-KOUCHNER, E. História das Idéias Políticas. Rio de Janeiro: Jorge Zahar Editor, 1982, p. 376.
} 
estabelecer a coerção social, os padrões inerentes ao 'Dever Ser' se tornam obrigatórios, são impostos pela autoridade." 100

Sob essa ótica, a polícia acreditava estar zelando "com ardor patriótico, como é do seu dever, os tesouros morais que as gerações transmitem umas às outras. " ${ }^{101}$ Assim, por trás dessas formulações, havia uma visão de que o criminoso, seja lá qual fosse o crime, era um "desajustado", o que bastava para identificá-lo como “inimigo' não como alguém que tinha outros planos para seu país, mas como um 'desajustado', incapaz de perceber os beneficios da nova era." ${ }^{102}$ Esta era mais uma faceta do pensamento autoritário utilizado como justificativa da ação repressora e saneadora, na qual a representação do "desajustado" reforça o poder do Estado para regular a sociedade segundo um modelo de ordem social fundado na paz, na harmonia e no desenvolvimento.

No intuito de munir todos os aparatos de segurança (policiais e militares), garantindo sintonia entre eles, as idéias básicas do pensamento da polícia civil, como a valorização de ações preventivas, a produção e o controle da informação, também integravam o pensamento militar. $\mathrm{O}$ esforço policial esteve concentrado de modo prioritário na repressão à dissidência política ${ }^{103}$ e apesar da existência de uma oposição consentida no período do regime militar, o Movimento Democrático Brasileiro (MDB), este encontrava sua atuação limitada, circunscrita e sob físcalização dos aparatos de repressão. As polícias, ao longo do século XX, "têm sido também o braço armado das forças sociais hegemônicas na defesa do seu status quo, o que no Brasil se traduziu na lógica do inimigo interno e no uso indiscriminado da violência contra a população. "104 Portanto, as ações policial e militar mesclaram prevenção e punição, ou seja, o inimigo seria neutralizado, ou pela segunda forma de ação, ele seria eliminado.

\footnotetext{
${ }^{100}$ Manual ESG, "Seção I - Expressão Política do Poder Nacional (Poder Político)", "3- Fatores" Apud ROCHA, M. A Evolução dos conceitos da doutrina da Escola Superior de Guerra nos anos 70. Dissertação de Mestrado. São Paulo: FFLH/USP, 1996. ANEXO 12, p. 120.

${ }^{101}$ DIAS, B. "O dia da polícia” In Arquivos, vol. XXIX. São Paulo: Polícia Civil de São Paulo, $1^{\circ}$ semestre de 1977 , pp. 7-12, p. 7.

${ }^{102}$ FICO, C. Reinventando o otimismo. Ditadura, propaganda e imaginário social no Brasil. Rio de Janeiro: Editora Fundação Getulio Vargas, 1997, p. 125.

${ }^{103}$ NEVES, P. (org) Polícia e Democracia: desafios à educação em direitos humanos. Recife: Edições Bagaço, 2002, p. 9.

${ }^{104}$ NEVES, P. (org) Op. Cit., p. 14.
} 


\section{2) Repressão e vigilância aos movimentos negros brasileiros}

"Apurar e apresentar a verdade, essência do trabalho policial”, 105

Parte da cúpula de poder do regime militar acreditava que: “o problema da repressão contra os movimentos sediciosos, que eram principalmente da área comunista - das diferentes facções da área comunista -, tinha diminuído depois da eliminação daquela operação Xambioá, da guerrilha em Xambioá, a atividade subversiva da esquerda tinha diminuido sensivelmente." 106 No entanto, foi justamente a partir da década de 1970, quando a luta armada já estava "aniquilada", que os órgãos de repressão passaram a dispensar uma maior vigilância aos movimentos negros. No Governo Geisel (1974-1978), a repressão voltou-se para os grupos de oposição, reais ou imaginados. A repressão não alcançou somente a luta armada e aos que almejavam lutar pelas revoluções nacional e social, mas também atingiu a todos os que articulavam reivindicações sociais ou que apenas faziam oposição política, como os diversos movimentos anti-racistas no Brasil.

A própria historiografia, em geral, aponta como "alvos" do regime militar os comunistas, isto é, os estudantes, os operários, os políticos e uma parte dos padres da Igreja Católica. "Os limites da tolerância geralmente foram demarcados pela aversão ao comunismo e ao que ele poderia significar entre os movimentos sociais e politicos." 107 Mas é necessário ressaltar que muitos outros setores foram alvos de vigilância e repressão pelos sistemas de segurança e informação, embora careçam ser estudados. ${ }^{108}$ Os movimentos negros fazem parte de temas pouco estudados pela historiografia especializada do período. Como, ao longo do século XX, o principal inimigo dos órgãos de repressão política foi o "comunismo", outras frentes de possível instabilidade, como a questão racial brasileira e as lutas anti-racistas, acabou encoberta.

\footnotetext{
105 Informação da Divisão de Informação do DEOPS sobre IBEA. Dossiê 50-Z-0- 14617. DEOPS/SP, DAESP.

${ }^{106}$ Memória de Ernesto Geisel In COUTO, R. Memória viva do regime militar - Brasil: 1964-1985. Rio de Janeiro: Record, 1999, p. 208.

${ }^{107}$ REZNIK, L. Democracia e Segurança Nacional. A Polícia Política no pós-guerra. Rio de Janeiro: Editora FGV, 2004, p. 25.

108 O "guia bibliográfico" a respeito do regime militar apresentado por Carlos Fico em sua obra Além do Golpe, no item "Movimento operário e movimentos sociais urbanos", apresenta entre 59 artigos, livros, teses e dissertações apenas um artigo que faz menção aos movimentos negros: MOORE, Z. "Out of the shadown: black and brown struggles for recognition and dignity in Brazil, 1964-1985." Journal of Black Studies, v. 19, n. 4, pp. 394-410. In FICO, C. Além do golpe: a tomada do poder em 31 de março de 1964 e a ditadura militar. Rio de Janeiro: Record, 2004, pp. 149-153.
} 
A vigilância se dava a quaisquer segmentos que ameaçassem ou se opusessem à ordem instaurada, segundo determinados critérios. Assim, tentaremos nesse capítulo identificar questões que levaram à vigilância e à repressão dos movimentos negros.

O processo de abertura, entre 1979 a 1985, proporcionou uma progressiva mobilização de vários segmentos sociais que foram organizados em uma grande frente de oposição. Por outro lado, o período do governo Geisel caracterizou-se pela contradição entre a política oficial de liberalização do projeto de abertura e a ação contínua dos aparatos da repressão política. "Por um lado, a política oficial de distensão deu aos setores de oposição mais espaço para se organizar e maior possibilidade de êxito. Por outro, as pressões coordenadas por melhoria das condições de vida, fim da censura à imprensa e revogação da legislação repressiva intensificaram os temores dos setores mais estreitamente identificados com a Doutrina de Segurança Interna. A medida que se fortalecia o movimento de defesa dos direitos humanos, aumentavam no Estado de Segurança Nacional as pressões e contradições internas com respeito às políticas de repressão. " 109

Com o governo de João Baptista Figueiredo (1979-1985) houve a revogação em 1979 do AI-5 e da Legislação de Segurança Nacional. Com o clima de "abertura política", houve novas possibilidades legais para os movimentos sociais e políticos o que, sem dúvida, foi aproveitado também pelos movimentos negros que intensificaram suas campanhas. Além disso, também em 1979, o governo Figueiredo promoveu a volta do pluripartidarismo e a reforma partidária, o que tornou acessível novos canais de luta, inclusive a anti-racista, por exemplo, a constituição das comissões de negros nos recém inaugurados partidos, PT e PDT. Foi justamente na "abertura política", em que as lutas anti-racistas ganharam maior ação com o Movimento Negro Contra a Discriminação Racial (MNCDR) e, em seguida, com o Movimento Negro Unificado (MNU). Ao mesmo tempo, houve uma maior vigilância da comunidade de informações e segurança do regime militar voltado para o controle dos movimentos negros.

Esse processo de abertura deu ensejo a intensas negociações entre os militares e as oposições. ${ }^{110}$ Porém havia uma corrente mais conservadora entre os militares que acreditava que era necessário conter a oposição para dirigir a "abertura", tendo a sob

\footnotetext{
${ }^{109}$ ALVES, M. H. Estado e Oposição no Brasil (1964-1984). Petrópolis: Vozes, 1985, p. 200.

110 MATTOS, M. Em nome da segurança nacional: os processos da Justiça Militar contra a Ação Libertadora Nacional (ALN), 1969-1979. Dissertação de Mestrado. São Paulo: FFLCH/USP, 2002, p. 31.
} 
controle. Afinal, o regime buscou, ao longo de sua existência, aniquilar qualquer manifestação que lhe fosse contrária, buscando uma sociedade sem conflitos. O que explica a intensificação da vigilância aos movimentos sociais.

Assim, no período da abertura política o foco da repressão ampliou sua atuação, tornando o "inimigo interno" todo e qualquer grupo que desviasse do projeto político-social que os militares almejavam para o país. Tornando um período contraditório para os movimentos negros, que viam na perspectiva da abertura um contexto que possibilitasse uma atuação política, ao mesmo tempo em que a comunidade de informações e segurança voltava sua vigilância de forma mais efetiva para esses setores sociais.

\section{Anti-comunismo}

Como é sabido, parte do pensamento militar esteve fundamentado em um ideário fortemente anti-comunista. $\mathrm{O}$ anti-comunismo inseriu-se no contexto internacional da guerra fria, que perdurou de 1947 a 1989. Nele, o golpe de 1964 foi considerado pelo regime militar como mais um episódio da guerra ideológica entre o comunismo e o capitalismo. Desse modo, 1964 foi apresentado por alguns militares como um "contragolpe" ao "potencial" golpe dos comunistas. ${ }^{111}$ Interessante notar que o mesmo evento, o golpe de 1964, foi tratado com denominações diferentes, nomeado por seus agentes sociais como "contra-golpe" ou como uma "revolução". Essas denominações aparecem, dependendo do destaque que se pretende dar ao evento. Para enfatizar a ação anticomunista utilizou-se a denominação "contra-golpe", enquanto para ressaltar uma "nova" rearticulação entre Estado e Nação foi utilizado o termo "revolução". Com freqüência, o golpe de 1964 apresentava-se na documentação do DEOPS/SP, estampada com carimbo a frase: "A Revolução de 64 é irreversível e consolidará a Democracia no Brasil”. 112

\footnotetext{
${ }^{111}$ D’ ARAÚJO, M. e SOARES, G. e CASTRO, C. (orgs). Visões do golpe: a memória militar sobre 1964. Rio de Janeiro: Relume - Dumará, 1994, p. 12.

${ }^{112}$ A documentação produzida ou recebida pelo DEOPS/SP no período do regime militar apresenta estampada por diversos carimbos com frases de efeito que louvavam o próprio regime. Nota-se que foi necessário para o regime reafirmar e glorificar a "revolução" ao longo de seus governos, até mesmo para os funcionários da repressão. A documentação policial que apresentava esse carimbo se revertia a comunicação interna, e demarcava a "revolução" como um "mito fundador" do regime e, visava relatar o primórdio, a criação, o começou: "Os mitos de criação e a elaboração da memória histórica constituem os rudimentos de legitimação, reafirmação do destino comum de uma nação.” In MIR, L. Guerra Civil: estado e trauma. São Paulo: Geração Editorial, 2004, p. 69.

Ao mesmo tempo, se faz necessário ressaltar que a remissão ao termo "revolução" passou a ser um aspecto que "codificava objetivos do próprio Estado. Por isso mesmo, os servidores públicos, civis e militares, deveriam conduzir sua atividade de acordo com os 'objetivos da Revolução," In VECCHIO, A. Impasses do
} 
Violências física e simbólica combinaram-se no regime militar contra os seus “inimigos", em especial, o comunismo. O anti-comunismo deu origem à constituição de um imaginário composto de imagens dedicadas a representar o "comunismo" e os "comunistas".

O imaginário "opera através de séries de oposições que estruturam as forças afetivas que agem sobre a vida coletiva, unindo-as, por meio de uma rede de significações, às dimensões intelectuais dessa vida coletiva: legitimar/invalidar; justificar/acusar; tranqüilizar/perturbar; mobilizar/desencorajar; incluir/excluir." 113 Essas oposições maniqueístas apresentaram-se entre os detratores do "comunismo", que o entendiam como a representação do "mal", do "caos" e da "desordem". Nesse sentido, representações mentais ${ }^{114}$ integram o processo de construção de idéias, signos ou imagens por meio das quais as pessoas interpretam e conferem sentidos à realidade. As representações baseiam-se em fatos sociais, ainda que sejam construções que possam, por vezes, produzir versões caricaturais e até mesmo deformadas do "real" ${ }^{115}$, "as representações se utilizam dos fatos e alegam que são fatos; os fatos são reconhecidos e organizados de acordo com as

Regime Militar Brasileiro: Construção de Potência, Institucionalização e Estabilização Política (1964-1979). Tese de doutorado. São Paulo: FFLCH/USP, 1998, p. 99.

A comunidade de informações e segurança como a "voz autorizada" do regime militar se situava como a "guardiã dos fundamentos da 'Revolução'. A frenética troca de papéis secretos que empreendia tinha por objetivo não apenas municiar as autoridades de informações, mas constituir uma espécie de narrativa legitimadora dos atos repressivos." In FICO, C. Além do golpe: a tomada do poder em 31 de março de 1964 e a ditadura militar. Rio de Janeiro: Record, 2004, pp. 92-93.

Da mesma forma, em um discurso legitimador da "revolução" de 1964, o artigo intitulado Contrainformação, diferenciando golpe e revolução, afirmava o caráter "revolucionário" de março de 1964. In NASCIMENTO, F. "Contra-informação” In Arquivos, vol. XXXI. São Paulo: Polícia Civil de São Paulo, $1^{\circ}$ e $2^{\circ}$ semestre de 1978, pp. 57-62.

A noção de "revolução", com representações positivas sobre a atuação do regime militar a partir do golpe, visava obter legitimidade. "A fim de impregnar as mentalidades com novos valores e fortalecer a sua legitimidade, o poder tem designadamente de institucionalizar um simbolismo e um ritual novos." In BACZKO, B. "Imaginação Social” In Enciclopédia Einaud, vol 5. Lisboa: Imprensa Nacional e Casa da Moeda, 1985, p. 302.

${ }_{113}$ BACZKO, B. Op. Cit., p. 312.

${ }^{114}$ Segundo Chartier as representações se referem as "classificações, divisões e delimitações que organizam a apreensão do mundo social como categorias fundamentais de percepção e de apreciação do real." CHARTIER, R. A História Cultural. Entre práticas e representações. Lisboa: Difel, 1990, p. 17.

${ }^{115}$ MOTTA, R. Em guarda contra o perigo vermelho. O anti-comunismo no Brasil (1917-1964). São Paulo: Editora Perspectiva, 2002, p. XXV. 
representações; tanto fatos quanto representações convergem na subjetividade dos seres humanos e são envoltos em sua linguagem." 116

As representações se apresentam de forma bastante intensificada em momentos de “crise". A própria noção de crise torna-se elemento mobilizador, servindo para opor uma “ordem" ideal a uma "desordem" empírica; ou seja, a crise e o desvio pressupõem um “dever-ser" contrariado pelo acontecer, mas que poderá ser restaurado justamente porque é um dever ser. A idéia de crise trás um sentimento de perigo que aglutina a sociedade em torno da superação da crise. "A crise serve, assim, para dissolver todas as diferenças $e$ contradições, empenhando todos os agentes sociais na tarefa da reorganização da Nação. "117

Desde a Revolução Russa de 1917, até a crise do socialismo real, por volta de 1989, o comunismo foi o centro das atenções de diferentes governos brasileiros. Assim, " $O$ comunismo despertou paixões intensas e opostas: de um lado, o dos defensores, encaravam-no como revolução libertadora e humanitária, que abriria acesso ao progresso econômico e social; de outro, o dos detratores, que o encaravam como uma desgraça total, se acreditava que ele traria a destruição da boa sociedade e a emergência do caos social e do terror político. " 118

Com o contexto de bipolaridade na Guerra Fria, o mundo encontrava-se diante da disputa entre os blocos comandados pelas duas superpotências os Estados Unidos e a União Soviética. "A idéia de superpotência está associada ao fato de emergência de Estados que se tornam referências para os demais, a partir do conceito de área de influência e da sua capacitação para a ação militar. A hegemonia como projeto, e a mediação pelo poderio bélico são expressões das superpotências." 119 O Brasil diante desse quadro se posicionou alinhado ao bloco capitalista.

No Brasil, o anti-comunista foi marcado por imagens, que povoaram o imaginário sobre práticas conspiratórias externas, com a presença de agentes estrangeiros enviados por Moscou (URSS), como o que teria acontecido na "Intentona Comunista", de 1935, ou

\footnotetext{
${ }^{116}$ PORTELLI, A. “ O massacre de Civitella Val di Chiana (Toscana, 29 de junho de 1944): mito, política, luto e senso comum" In FERREIRA, M. e AMADO, J. (coords.) Usos e abusos da história oral. Rio de Janeiro: Fundação Getulio Vargas, 1996, p. 111.

${ }^{117}$ CHAUÍ, M. Ideologia e mobilização popular. Rio de Janeiro: Paz e Terra: Cedec, 1978, p. 130.

${ }^{118}$ MOTTA, R. Op. Cit., p. XX.

${ }^{119}$ RIBEIRO, W. "Guerra e geopolítica após a Segunda Guerra Mundial” In COGGIOLA, O. (org.) Segunda Guerra Mundial: um balanço histórico. São Paulo: Xamã e FFLCH/USP, 1995, p. 457.
} 
mesmo o "Plano Cohen", em 1936. ${ }^{120}$ Há uma "sólida tradição anti-comunista na sociedade brasileira, reproduzida ao longo das décadas seguintes através da ação do Estado, de organismos sociais e mesmo de indivíduos, cujo zelo militante levou à constituição de um conjunto de representações sobre o comunismo, um verdadeiro imaginário anti-comunista." 121 Esse imaginário fundamentou práticas políticas de "segurança nacional" contra a "ameaça comunista", que culminaram com golpes políticos tanto em 1937 quanto em 1964. A documentação do DEOPS/SP revela que, desde sua fundação em 1924, esse órgão esteve engajado na empreitada da identificação, vigilância e repressão do "crime político" representado, principalmente, pelo "comunismo".

As representações sobre os "comunistas" estiveram associadas à imagem do "mal", com uma gama de adjetivos que atribuía a estes qualidades negativas. A ação dos “comunistas" traria como conseqüência, segundo esse imaginário, a fome, a miséria, a violência e o pecado, entre outros males próprios da ação do "demônio". Também ganhava um caráter polissêmico, quando associado a agentes patológicos e a doenças, dando ênfase a uma infiltração que destrói um organismo por dentro. A ameaça estrangeira como uma doença ou um corpo estranho, levaria ao crime, à corrupção, e para atos imorais ou amorais. "As representações anti-comunistas mantiveram a tradição de divulgar uma imagem deformada dos revolucionários, apresentados como seres violentos e imorais, em uma palavra malignos. ",122

No regime militar certamente houve especificidades e novos elementos do anticomunismo, próprios daquela conjuntura histórica, referentes a produção ideológica da Doutrina de Segurança e Desenvolvimento. Mas, nota-se "uma forte tendência à regularidade, ou seja, à permanência ao longo do tempo de imagens, idéias, mitos etc. Muitas das representações sobre o 'inimigo' comunista foram reproduzidas durante décadas, repetindo temas elaborados no primórdios. Diversos elementos do imaginário anti-comunista construido entre as décadas de 1920 e 1930 ainda eram utilizados na década de 1980, por exemplo." 123

\footnotetext{
${ }^{120}$ CARNEIRO, M. L. T. "Força, Medo, Liberdade: algumas coisas não combinam entre si..." in Cidadania, Verso e Reverso (vários autores). São Paulo: Imprensa Oficial, 1997/1998, p. 59.

${ }^{121}$ MOTTA, R. Em guarda contra o perigo vermelho. O anti-comunismo no Brasil (1917-1964). São Paulo: Editora Perspectiva, 2002, p. XXII.

${ }^{122}$ MOTTA, R. Op. Cit., p. 276.

${ }^{123}$ MOTTA, R. Idem, p. XXVI.
} 
Essa regularidade decorra da característica própria do pensamento autoritário, que "tem a peculiaridade de precisar recorrer a certezas decretadas antes do pensamento e fora dele para que possa entrar em atividade. Seria ilusório supor que o pensamento autoritário desemboque numa exigência de obediência, pois esta é seu próprio ponto de partida: precisa de certezas prévias para poder efetuar-se e vai buscá-las tanto em 'fatos' quanto em 'teorias'., 124

A Revista Arquivos da Polícia Civil do Estado de São Paulo ressaltava o "perigo do comunismo" em um de seus artigos: "Porque, então, o Comunismo se torna perigoso? Talvez, e justamente, por ser uma 'doutrina', para a maior parte dos seus adeptos. Doutrina que promete mudanças e que as explica, o que as torna, aparentemente, de fácil execução." 125 A mudança apresenta-se como algo inesperado e causa temor, pois o novo é uma incógnita, dando ensejo para que aparecesse e se desenvolviam medos coletivos, dos quais para o regime militar, o comunismo era, sem equívocos, o maior de todos.

O imaginário anti-comunista alimentado por diversos preconceitos construiu, no regime militar, um arcabouço discursivo para legitimar ações cada vez mais belicistas no combate dos inimigos "comunistas" ${ }^{126}$ De tal modo, "se definiu, de maneira geral, como sendo comunismo todas manifestações de oposição ao regime militar e de livre pensamento." ${ }^{127}$ Assim, os movimentos negros, independente das estratégias adotadas, eram compreendidos como mais um elemento da ação comunista no país.

Utilizando-se de "um medo que se demonstrou tão ou mais mobilizador do que suas convicções políticas.". ${ }^{128}$ Formulando a idéia de que: "Ainda que oculto ou mesmo desconhecido, o inimigo é citado cotidianamente como sempre pronto a atacar. A linguagem empregada para designá-lo (perigoso, fanático, terrorista, etc.) desperta, por sua vez, sentimentos paranóicos na sociedade, o que provoca em muitos a disposição à violência." ${ }^{129}$ Portanto, na esteira desse pensamento não se tratava de um problema apenas de ordem política, mas, essencialmente "moral": "É no campo moral e espiritual que reside

\footnotetext{
${ }^{124}$ CHAUÍ, M. Ideologia e mobilização popular. São Paulo: Paz e Terra: Cedec, 1978, p. 37.

${ }^{125}$ SALMON, H. "O fascismo de hoje, o comunismo de ontem” In Arquivos, vol. XXVIII. São Paulo: Polícia Civil de São Paulo, 1976, pp. 69-83, p. 78.

${ }^{126}$ ARAÚJO, M. e SOARES, G. e CASTRO, C. Os anos de chumbo: a memória militar sobre a repressão. Rio de Janeiro: Relume - Dumará, 1994, p. 20.

${ }^{127}$ ARAÚJO, M. e SOARES, G. e CASTRO, C. Op. Cit., p. 30.

${ }^{128}$ MAGALHÃES, M. “A lógica da suspeição: sobre os aparelhos repressivos à época da ditadura militar no Brasil.” In Revista Brasileira de História. São Paulo: ANPUH/Humanitas, vol. 17, n. 34, 1997, p. 217.

${ }^{129}$ MAGALHÃES, M. Op. Cit., p. 211.
} 
a mais profunda crise do mundo contemporâneo, razão maior da Insegurança generalizada entre as nações e dentro das próprias comunidades nacionais. " 130

$\mathrm{O}$ mito ${ }^{131}$ da conspiração "comunista" alimentado pelo anti-comunismo, enquanto elemento político-ideológico central dos governos militares, considerava qualquer manifestação dissidente e crítica como parte de uma conspiração, o que, por conseqüência, justificava uma vigilância constante do Estado em relação a esfera pública. Como o mito se organiza em uma dinâmica de imagens ${ }^{132}$, é possível, portanto, considerar que o regime militar construía imagens de um perigo constante da "ameaça comunista", identificadas como verdadeiros "complôs maléficos". Para tal, utilizavam-se imagens que se confundiam com a figura do "mal" e com os medos coletivos.

\section{Vigilância aos movimentos negros}

Apesar de nem todos os movimentos negros debaterem idéias marxistas, todos foram alvos de uma intensa vigilância. Houve uma multiplicidade de estratégias da mobilização afro-descendente, que foi adotada conforme os contextos históricos, mas a polícia política não esteve atenta às diferenças entre as estratégias dos movimentos negros. Mesmo com uma tendência "integracionista" ${ }^{133}$ dos movimentos negros brasileiros, principalmente, até a década de 1960, a comunidade de informações e segurança preocupava-se com o discurso afro-descendente que em outras regiões do mundo, como nos EUA e em países africanos, apresentavam uma ação de ruptura. Em especial, desde os anos de 1960, foi crescente o debate dos movimentos negros acerca de temas próprios do marxismo-leninismo em particular, em relação às propostas revolucionárias, próprias dos movimentos de

\footnotetext{
${ }^{130}$ Manual ESG, "Seção I - Segurança Nacional”, "2- Razões de Insegurança” Apud ROCHA, M. A Evolução dos conceitos da doutrina da Escola Superior de Guerra nos anos 70. Dissertação de Mestrado. São Paulo: FFLH/USP, 1996. ANEXO 20, p. 231.

${ }^{131} \mathrm{O}$ mito tem função explicativa e mobilizadora, uma vez que organiza imagens que evocam sentimentos na sociedade ou grupo social. O mito, segundo Raoul Girardet, é o impulso psicológico, a inspiração ideal, que pode conduzir os homens. Os mitos possuem uma função explicativa da realidade social desde a sua gênese atuando na história e não apenas exprimindo-a. GIRARDET, R. Mitos e Mitologias Políticas. São Paulo: Cia. Letras, 1987.

${ }^{132}$ GIRARDET, R. Op. Cit., p. 14.

133 KOSSLING, K. Movimentos Negros: Identidade étnica, Identidade política (1924-1954). Iniciação Científica. São Paulo: FAPESP, 2003. (a ser publicado). A "tendência integracionista" significava uma política de integração social e a não ruptura radical com a ordem vigente. Entre outros autores que discutem as tendências de "integração" dos movimentos negros no Brasil, ver Kabengele Munanga.
} 
independência em Angola e Moçambique e a luta armada dos Panteras Negras, nos Estados Unidos. ${ }^{134}$

Os movimentos negros ao questionarem, como tantos outros movimentos sociais da época, a opressão e o autoritarismo, também entravam para o rol das entidades "subversivas" segundo as instituições repressoras do regime. A participação e o diálogo dos movimentos negros com a oposição e a resistência, por exemplo, a proposta de aliança do MNU aos "setores progressistas" do país, conforme expressão utilizada no III Congresso Nacional do referido movimento ${ }^{135}$, posicionando-se de forma contrária à política social, econômica e repressiva do regime militar. Estas posições levaram a comunidade de informações e segurança a ter maior desconfiança para com a mobilização afrodescendente, classificando-a de "subversiva". ${ }^{136}$ Houve um processo de criminalização dos movimentos sociais, envolto em uma mentalidade de que estes se tornavam "ameaças" à estabilidade política.

As reivindicações próprias do discurso dos movimentos negros referentes as carestias sociais que a população afro-descendente enfrentava apresentava-se como subversão aos olhos da polícia política. Não obstante, os aparatos repressivos consideravam qualquer crítica contra as autoridades constituídas como um crime contra a segurança do Estado, o que justificava a repressão. A ação dos movimentos negros por meio de atos públicos e manifestações contrárias ao preconceito, à discriminação e ao racismo, ou mesmo, pela imprensa alternativa que denunciava os problemas sociais brasileiros, também chamava a

\footnotetext{
${ }^{134}$ Necessário diferenciar "contestação" e "resistência", o primeiro refere-se à crítica que põe em questão a ordem, mas não necessariamente em crise, ou seja, é um discurso crítico; já a resistência é ruptura, põe o sistema em crise ou em revolução. Desse modo, entendemos que o discurso desenvolvido pela maioria dos movimentos negros brasileiros estaria num nível contestatório.

135 Informe n. 89/Conseg/82 de Belo Horizonte de 19/04/1982, fl. 1. Ordem Social 1157 pasta 218 C. DEOPS/SP, DAESP.

${ }^{136}$ Como exemplos de documentos que expressam essa classificação claramente: Sumário Semanal n. 39, entre 11 a 17/12/1981, de 18/12/1981, do CODIN/CONSEG da Coordenação de Informação da Secretaria de Estado da Segurança Pública de MG, fl. 7. Dossiê 50-H-84- 5104. DEOPS/SP, DAESP. E no Sumário Semanal n. 5, entre 24/01 a 4/2/1982, de 5/02/1982, do CODIN/CONSEG da Coordenação de Informação da Secretaria de Estado da Segurança Pública de MG, fl. 5. Dossiê 50-H-84- 5139. DEOPS/SP, DAESP. Sumário Semanal n. 27, entre 18 a 24/9/1981, de 25/9/1981, do CODIN/CONSEG da Coordenação de Informação da Secretaria de Estado da Segurança Pública de MG, fl. 7. Dossiê 50-H-84- 4850. DEOPS/SP, DAESP. Relatório diário n. 1330 da Divisão de Informações do DEOPS, período 7 a 8/8/1980, fl. 3. Dossiê 21-Z-14- 9502. DEOPS/SP, DAESP. Relatório diário n. 1505, entre 25 e 26/5/1981, da Divisão de Informações do DEOPS, fl. 2. Dossiê 21-Z-14-11366. DEOPS/SP, DAESP. Relatório diário n. 1310 da Divisão de Informações do DEOPS. Dossiê 21-Z-14- 9362. DEOPS/SP, DAESP. Relatório diário n. 1364 da Divisão de Informações do DEOPS, fl. 4. DEOPS/SP, DAESP. Relatório diário n. 1366 da Divisão de Informações do DEOPS. Dossiê 21-Z-14- 15183. DEOPS/SP, DAESP.
} 
atenção dos aparatos da repressão. Importante lembrar que as manifestações públicas eram controladas e algumas vedadas pela LSN. Como afirmou coronel Rubem Ludwig, porta voz da presidência da República: "O governo tem o direito de estabelecer onde pode ocorrer, onde não pode, e a que horas, esse tipo de manifestação." 137

A imprensa alternativa, buscava "dar voz" aos grupos sociais que não tinham espaço nos outros canais de informação, com o compromisso de publicar matérias que abordassem temas e questões não postas na grande imprensa. Segundo documentação do Ministério da Marinha, a imprensa "nanica" ou alternativa: “ [...] surgiu, aparentemente, na busca de mercado de trabalho, face à carência de colocação adequada nos órgãos da imprensa tradicional. No entanto, o que ocorreu, na realidade, foi o aparecimento de uma verdadeira 'cadeia' de pequenos jornais, correndo paralelamente aos órgãos da chamada grande imprensa e quase totalmente controlada pelos contestadores do regime vigente.". Segundo o estudo militar dos jornais da imprensa alternativa, citava alguns representantes da imprensa negra: Sinba, Jornegro e Versus (Coluna Afro-Latino-América), apresentando seus conteúdos como "marxista" e "subversivo". 138

Os movimentos negros obtiveram espaço na imprensa alternativa como a coluna Afro-América-Latina, do jornal Versus, editado entre 1976 a 1979, ou mesmo com a confecção de seus próprios periódicos. Por exemplo, o Jornegro, editado pelas Entidades Afro-brasileiras do Estado de São Paulo, que foi junto com os responsáveis pela sua publicação, foi identificado pelo DEOPS como pertencente a "imprensa alternativa" ou "nanica". 139

Importantes segmentos dos movimentos negros se expressaram por meio da chamada "Imprensa Alternativa", buscando orientar e incentivar a população afro-brasileira. Com um caráter de denúncia e propaganda de suas idéias, estes jornais eram confiscados e anexados à documentação do DEOPS como "provas materiais" da "subversão" desses movimentos. Destes depreende-se o tema central de reivindicação dos diversos movimentos negros que buscavam a garantia de direitos sociais, uma sociedade igualitária e os direitos à

\footnotetext{
137،"Ludwig admite rever proibição a concentrações” In Folha de S. Paulo, 29/08/1978. OP 0654 Atos Públicos. DEOPS/SP, DAESP.

${ }^{138}$ Encaminhamento n. 0393/78 do Ministério da Marinha. Dossiê 50-Z-0- 14928. DEOPS/SP, DAESP.

${ }^{139}$ Anexo A e B- Encaminhamento n. 0393/78 do Ministério da Marinha. Dossiê 50-Z-0- 14920. DEOPS/SP, DAESP
} 
cidadania para todos os negros no mundo, aspectos esses que envolvem a politização da sociedade e a democratização do Estado.

Para as estruturas repressivas essas temáticas eram um incomodo e foi objeto de vigilância, especialmente a bandeira do combate à violência policial, a qual o setor de informação do DEOPS compôs uma pasta sobre as notícias veiculadas na grande imprensa a cerca das denúncias dos movimentos negros à violência policial. ${ }^{140} \mathrm{O}$ regime militar classificava essas diversas campanhas como subversão e reprimiu com a detenção alguns de seus participantes. ${ }^{141}$ As campanhas contra a violência policial eram compreendidas pela polícia política como apenas uma tática para “[...] desmoralizar as autoridades constituidas, principalmente as Policiais. " 142

Os diversos artigos e manuais policiais que qualquer debate social era considerado uma “tática camuflada" da ação "comunista". "Toda atenção, portanto, deve ser voltada para essas falsas atividades, desde o momento em que elas surjam no cenário nacional ou estadual." ${ }^{143}$ Nessa perspectiva, a explicação para o descontentamento popular era de que "os conflitos sociais não decorrem da exploração e da opressão em que vivem as massas populares. Por trás de cada reivindicação, de cada greve, de cada luta social, está sempre $o$ dedo do 'comunismo internacional'." 144 A associação de reivindicações com conspirações ideológicas levou a que se criasse em meio ao contexto internacional de guerra ideológica um círculo vicioso em que qualquer ato de contestação fosse utilizado como justificativa para a vigilância policial, identificando a insubordinação social como ação "comunista". Encontramos exemplos significativos da paranóia anti-comunista dos EUA: “Assim, durante a década de 60, a violência dos guetos em cidades americanas foi largamente atribuída a uma conspiração comunista, ao invés de se culpar a raiva a

\footnotetext{
${ }^{140}$ Ordem Política 1184, Violência Policial, vol. 2. DEOPS/SP, DAESP.

${ }^{141}$ Exemplo da ação repressiva a esses movimentos ver sobre o Movimento contra o custo de vida, jornada contra a carestia. Dossiê 50-C-22-11166. DEOPS/SP, DAESP. Outro exemplo é do militante Moisés José Soares, participante do MNU de MG, que foi detido por envolver-se em movimento por melhoria do transporte. In Sumário Semanal de Informações n. 28 do CODIN/COSEG, período entre 9 a 15/7/1982, de 16/7/1982. Dossiê 50-H-84- 5741. DEOPS/SP, DAEPS.

${ }^{142}$ Relatório sobre Ato Público Contra o Racismo, da Divisão de Informações do DEOPS, de 6/7/1978. Dossiê 50-Z-0- 14623. DEOPS/SP, DAESP.

${ }^{143}$ APOLLONIO, L. Manual de polícia política e social. São Paulo: Escola de Polícia de São Paulo, 1963. (3 Edição), p. 330.

${ }^{144}$ MARTINS, R. Segurança Nacional. São Paulo: Brasiliense, 1986, p. 29.
} 
discriminação e condições miseráveis de vida. As idéias podem, de fato, germinar violência, mas a violência nem sempre é motivada ideologicamente." 145

Os militares entendiam que dentre as estratégias para a "comunização" da sociedade brasileira realizada pelos ativistas "comunistas", uma delas era chamar a atenção para os "antagonismos sociais" do Brasil. Dessa maneira, entendiam que os militantes afrodescendentes eram "cooptados" pelos comunistas, e classificavam a sua ação como própria de "comunistas". 146

No entanto, percebemos que a vigilância e a repressão desenvolvidas contra os movimentos negros também se devem a uma mentalidade que remonta a década de 1940, de que os movimentos negros introduziam uma "falsa problemática" na "democracia racial" brasileira: o conflito e a desigualdade racial. Essa questão se apresenta na própria legislação do regime militar: a Lei de Segurança Nacional, de 11/03/1967, em seu artigo n. 33, no item VI assinalava como crime incitar publicamente "ao ódio ou à discriminação racial”. ${ }^{147}$ Esta lei previa pena de detenção de 1 a 3 anos, podendo ser aumentada se o "crime" fosse praticado por meio de imprensa, panfleto ou escritos e de qualquer natureza, radiodifusão ou televisão. Da mesma forma, a Lei de Imprensa de 9/2/1967 no parágrafo $1^{\circ}$ do art. 1, apontava que: "não será tolerada a propaganda de guerra, de processos de subversão da ordem politica e social ou de preconceitos de raça ou classe." 148

Este conjunto de leis revela a preocupação que o regime militar desenvolveu em relação às lutas anti-racistas e seu potencial de contestação política. A partir desta legislação e do pensamento policial e militar, analisado por meio das publicações da Polícia Civil de São Paulo, dos manuais da Escola Superior de Guerra, das publicações militares e dos documentos do DEOPS/SP, nota-se que os movimentos negros ao contestarem o mito da democracia racial e o "congregamento racial" harmônico no Brasil, tornaram-se alvo de vigilância e repressão.

\footnotetext{
145 BAYLEY, D. Padrões de Policiamento: Uma Análise Internacional Comparativa. São Paulo: Editora da Universidade de São Paulo, 2001, p. 223.

${ }^{146}$ Para ampliar essa questão ver FICO, C. Como eles agiam. Os subterrâneos da Ditadura Militar: espionagem e polícia política. Rio de Janeiro: Record, 2001, pp. 183/184.

${ }^{147}$ Lei de Segurança Nacional de 11/3/1967 Apud FICO, C. Além do golpe: a tomada do poder em 31 de março de 1964 e a ditadura militar. Rio de Janeiro: Record, 2004, p. 367. Ver também ALVES, M. H. Estado e Oposição no Brasil (1964-1984). Petrópolis: Vozes, 1985, p. 159.

${ }^{148}$ Lei de Imprensa de 9/2/1967. Apud FICO, C. Op. Cit., p. 371.
} 
Nesse sentido, havia também uma preocupação com a "propaganda adversa", a Lei de Segurança, de 11/3/1967 que no artigo n. 14, apontava como crime: "Divulgar, por qualquer meio de publicidade, notícias falsas, tendenciosas ou deturpadas, de modo a por em perigo o bom nome, a autoridade, o crédito ou o prestígio do Brasil." ${ }^{149}$ Sob a ótica do regime militar, os movimentos negros ao tornarem público o racismo brasileiro para o resto do mundo, a discriminação racial e a violência policial no Brasil fariam uma "propaganda adversa" do situação racial no país. Esta propaganda era entendida pelos militares como um discurso que agredia "os valores espirituais, morais e sociais da nação ou que contestasse os fundamentos da organização atual do Estado. ${ }^{150}$ Esse aspecto aliava-se ao temor que os movimentos negros desencadeassem um processo de conflito, o que se tornaria "pernicioso à nação": “Justificava-se, assim, a repressão a determinados grupos que se negavam a identificar-se com o regime em vigor. Portanto, tudo o que estava fora dos limites desta relação de identificação em quaisquer campos (objetivos e/ou subjetivos) estava sujeito ao controle, rechaçamento e até eliminação. O regime só admitia, então, aquilo que estava absolutamente integrado ao seu controle num processo de geração contínua de uma ampla consonância com seus propósitos nas diversas esferas da vida social." 151

Visando sustentar o discurso de harmonia racial e social no Brasil, a política exterior do regime militar em relação à África explorava retoricamente que o Brasil era uma "democracia racial" e exaltava as origens africanas da cultura brasileira. ${ }^{152}$ Desta forma, as críticas dos movimentos poderiam ser identificadas pelos aparatos de informação e repressão como "guerra psicológica adversa", uma vez que divulgavam uma imagem considerada "negativa" do país para o exterior. Conforme o $2^{\circ}$ parágrafo do $1^{\circ}$ capítulo da Lei de Segurança Nacional de 11/03/1967: “A guerra psicológica adversa é o emprego da propaganda, da contrapropaganda e de ações nos campos político, econômico, psicossocial e militar, com a finalidade de influenciar ou provocar opiniões, emoções,

\footnotetext{
${ }^{149}$ Apud FICO, C. Idem, p. 356.

150 BAFFA, A. Nos porões do SNI. O retrato do monstro de cabeça oca. Rio de Janeiro: Editora Objetiva, 1989, p. 24.

${ }^{151}$ REZENDE, M. A ditadura militar no Brasil: repressão e pretensão de legitimidade (1964-1984). Tese de Doutorado. São Paulo: FFLCH/USP, 1996, p. 7.

${ }^{152}$ GUIMARÃES, A. Classes, Raças e Democracia. São Paulo: Ed. 34, 2002, p. 158.
} 
atitudes e comportamentos de grupos estrangeiros, inimigos, neutros ou amigos, contra a consecução dos objetivos nacionais." 153

Em manual da ESG temos a conceituação de fatores "adversos", "antagonismos" e "pressões", os quais nos auxiliam a compreensão da visão policial e militar sobre os movimentos negros:

"Fatores Adversos são óbices de toda ordem, internos ou externos, que se interpõem aos esforços da comunidade nacional para alcançar ou manter os Objetivos Nacionais. Quando tais obstáculos passem a ser criados pela vontade humana e assumem uma forma de contestação aos atos, ideais e esforços da comunidade que visam à consecução dos Objetivos Nacionais, imprimindo à sua manifestação uma atitude deliberadamente impeditiva, denominam-se Antagonismos, conceituados da seguinte forma: Antagonismos são óbices de modalidade peculiar, por manifestarem atividade deliberada, intencional e contestatória à consecução ou manutenção dos Objetivos Nacionais. Se o antagonismo dispuser de poder, isto é, se à vontade deliberada de se opor aos esforços da comunidade somar-se alguma capacidade de obter efeitos através de algum meio (força, ameaça, logro, etc.), qualifica-se como pressão. As pressões podem manifestar-se de forma direta ou indireta, apresentar uma caracteristica formal ou latente e significar um perigo atual ou potencial. Em suma, podem ser existentes ou potenciais. Pressões são óbices de grau extremo em que a vontade contestatória se manifesta com capacidade de se opor ao Poder Nacional." 154

Dessa forma, os movimentos negros eram entendidos como "fatores adversos", ao impedir que a "harmonia racial", um dos objetivos nacionais, fosse "preservada". A ação contestatória dos movimentos negros também poderia ser identificada como um “antagonismo". Analisando o Movimento Nacional dos Blacks, a mobilização afrobrasileira em torno das idéias do black power ou poder negro dos movimentos negros nos EUA, a Polícia Federal afirmava que "Esses movimentos revelam o incremento das tentativas subversivas de exploração de antagonismos raciais em nosso País, merecendo uma observação acurada das infiltrações no Movimento 'black', tendo em vista que se por ventura houver incitação de ódio ou racismo entre o povo, caberá Lei de Segurança Nacional." 155

Os movimentos negros não chegaram a ser caracterizados como "pressão" (fator esguiano de classificação dos movimentos subversivos), uma vez que a ação repressiva aos movimentos negros esteve mais ligada a uma vigilância e repressão indiretas, do que

\footnotetext{
${ }^{153}$ Apud FICO, C. Além do golpe: a tomada do poder em 31 de março de 1964 e a ditadura militar. Rio de Janeiro: Record, 2004, p. 364.

${ }_{154}$ Manual ESG, "Seção IV - Política Nacional", "4- Fatores Adversos, Antagonismos e Pressões" Apud ROCHA, M. A Evolução dos conceitos da doutrina da Escola Superior de Guerra nos anos 70. Dissertação de Mestrado. São Paulo: FFLH/USP, 1996. ANEXO 16, p. 86.

${ }^{155}$ Informe n. 318 confidencial do Centro de Informação da Polícia Federal, de 14/08/1978. Dossiê 50-E-332153. DEOPS/SP, DAESP.
} 
propriamente ligada a prisões e processos na Justiça Militar. Diferente de outros movimentos sociais, os movimentos negros foram alvos de poucas prisões, contando muito mais com uma "repressão preventiva", por meio de uma vigilância constante, do que propriamente judiciária, não sofrendo a ação policial repressiva a ponto de haver abertura de processos judiciais.

Em geral, militantes negros foram alvo de processos quando envolvidos ou aparentemente envolvidos com outros movimentos, e não apenas pela mobilização afrodescendente. Como exemplo, temos a detenção de Milton Barbosa por distribuir panfletos de uma campanha contra a violência policial, que não se relacionava apenas aos movimentos negros, mas era tema caro a esses. ${ }^{156}$ Isso se insere numa política de parte da polícia de que é necessário: "investigar para prender e nunca prender para investigar. "157

A ação vigilante do regime militar contou com infiltrações, perseguições aos movimentos investigados, ação que por vezes era documentada com fotografias ou com relatórios, muitas vezes, diários das atividades dos movimentos sociais. ${ }^{158}$ Como nesta fotografia de um grupo de militantes da Convergência Socialista na reunião da Convenção Nacional da Convergência Socialista, em 19 de agosto de 1978, em São Paulo, na qual nota-se a ação de "campana" realizada pelo investigador. ${ }^{159}$ Os movimentos negros empreenderam relações com a Convergência Socialista e, nesta reunião esteve presente o militante afro-descendente Paulo Roberto França, identificado como o número 3, pertencia

\footnotetext{
${ }^{156}$ Informação da Divisão de Ordem Política, de 3 de setembro de 1982. Dossiê 20-C-43- 4878. DEOPS/SP, DAESP.

${ }^{157}$ APOLlONIO, L. Manual de polícia política e social. São Paulo: Escola de Polícia de São Paulo, 1963. (3ª Edição), p. 334.

${ }^{158}$ Quanto aos relatórios diários temos os exemplos dos documentos: relatório diário n. 1710 referente a observação do Grupo Negro da PUC, em 13/05/1982. Dossiê 21-Z-14- 13576. DEOPS/SP, DAESP; relatório diário n. 1711 referente a espionagem na Assembléia Legislativa em que Adalberto Camargo foi citado, entre 13/05/1982 a 14/05/1982. Dossiê 21-Z-14- 13595. DEOPS/SP, DAESP. Relatório diário n. 1734 referente a observação a Ato de Solidariedade ao povo de Angola e a Nelson Mandela realizado em auditório da PUC dia 16 de junho de 1982. Dossiê 21-Z-14- 13873. DEOPS/SP, DAESP. Relatório diário n. 1737 referente a observação ao" ato público pelo fim do genocídio e da agressão israelense no sul do Líbano e ao povo palestino" apoiado pelo MNU, em 22/6/1982. Dossiê 21-Z-14- 13907. DEOPS/SP, DAESP. Relatório diário n. 1741 referente a distribuição de panfletos do movimento negro em Mogi das Cruzes. Dossiê 21-Z-1413944. DEOPS/SP, DAESP. Relatório 1767 e 1773 sobre denúncia de racismo por deputado no GAP. Dossiê 21--Z-14- 14188. DEOPS/SP, DAESP. Relatório diário 1780 sobre observação do III Congresso de Cultura Negra das Américas, realizado em 24/8/1982 na PUC-SP. Dossiê 21-Z-14- 14278. DEOPS/SP, DAESP. Relatório diário n. 1402 sobre o grupo Bologum do MNU, entre 22/11/1980 - 25/11/1980. Dossiê 21-Z-1410278. DEOPS/SP, DAESP. Relatório n. 1782 sobre observação ato publico da comunidade negra brasileira, em frente a Consulado Geral da África. Dossiê 21-Z-14-14304. DEOPS/SP, DAESP.

${ }^{159}$ OS 1157, pasta 218C. DEOPS/SP, DAESP.
} 
a Convergência Socialista e ao PST, tendo ação também no movimento estudantil e nos movimentos negros. Nesta foto ele aparece acompanhado de Antonio Maria de Sá Leal, número 1, português da Fração Bolchevique do Secretariado Unificado da IV Internacional e de Halley Margon Vaz Júnior (número 2).

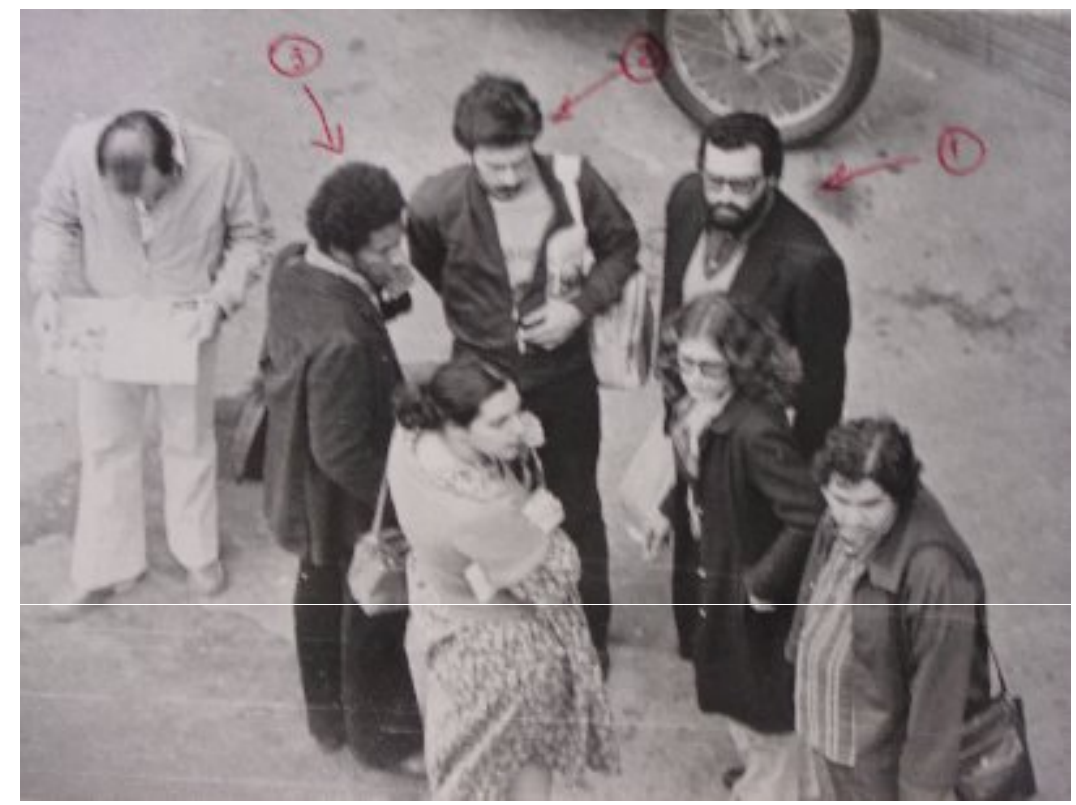

Fotografia de um grupo na reunião da Convenção Nacional da Convergência Socialista, em 19 de agosto de 1978, em São Paulo.

Encontram-se relatórios de debates, reuniões, eventos, etc. dos movimentos negros em que os investigadores interagiam com os investigados de forma disfarçada. Em fotografias que acompanham informação de uma reunião do $\mathrm{MNUCDR}^{161}$ nota-se pela postura dos fotografados de forma não posada a ação do investigador infiltrado, em meio aos militantes, na qual este, até mesmo tirava, fotografias de forma secreta, podendo posteriormente identificar e fichar os participantes desse movimento.

\footnotetext{
${ }^{160}$ Dossiê 50-H-84- 2711 e 50-H-84- 2813. DEOPS/SP, DAESP. Informações da Reunião da Convergência, em 20/8/1978. Informe n. 089/78 LS, confidencial, do II Exército para DOPS, de 21/09/1978. Dossiê 50-Z-042618. DEOPS/SP, DAESP.

161 Informação da Divisão de Informações do DEOPS, 22/10/1979. Dossiê 20-C-44- 6306. DEOPS/SP, DAESP.
} 


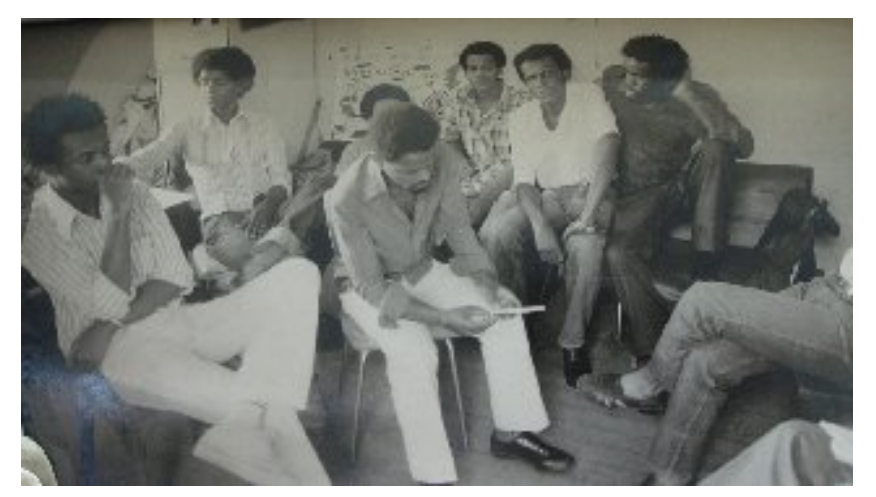

\section{Fotografia de reunião de militantes do MNUCDR, em 1979.}

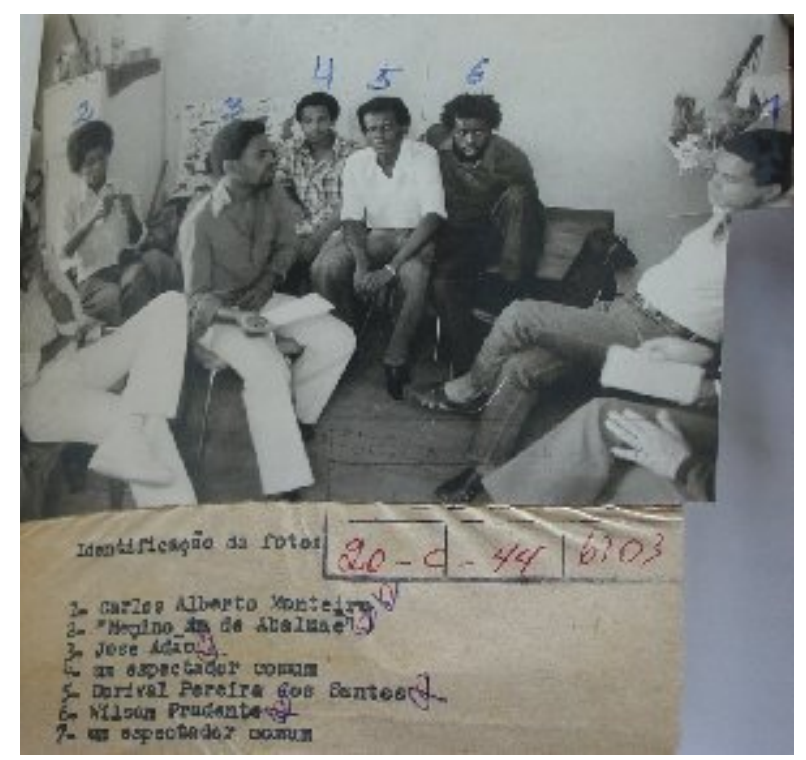

Fotografia de reunião de militantes do MNUCDR com identificação dos militantes pela polícia, em 1979 .

\footnotetext{
${ }^{162}$ Fotografia de grupo em reunião do MNUCDR, em 1979, sem número de documento. Referente a reunião da Informação da Divisão de Informações do DEOPS, 22/10/1979, fl. 2. Dossiê 20-C-44- 6305. DEOPS/SP, DAESP.

${ }^{163}$ Fotografia de grupo em reunião do MNUCDR, em 1979. Dossiê 20-C-44- 6303. Referente a reunião da Informação da Divisão de Informações do DEOPS, 22/10/1979, fl. 2. Dossiê 20-C-44- 6305. DEOPS/SP, DAESP.
} 
Uma das estratégias militares para aumentar as informações sobre os possíveis “inimigos" era a "infiltração" nos movimentos sociais realizada, via de regra, por sargentos, uns poucos oficiais e civis, e alguns informantes. Para alguns militares: "O sargento era o melhor infiltrado, porque era um profissional. E não era preciso pagar extra: ele estava ali executando uma missão. Infiltrar um civil significa pagar um agente. Eu tenho um pouco de receio disso, não sou partidário de pagar freguês de caderninho. Sou partidário de comprar a informação, como compro uma mercadoria qualquer. Eu vejo: se é boa, pago tanto; se não é boa, não quero." ${ }^{164}$ Nota-se, a partir de um conjunto de indícios ${ }^{165}$, que alguns relatórios e informações policiais provinham da ação de elementos infiltrados nas reuniões, atos e ações dos movimentos negros. ${ }^{166}$

A técnica de infiltração consistia, em princípio, em suspeitar de todos, daí a necessidade de coletar e arquivar quaisquer dados obtidos no processo de investigação. "Além de aumentar a eficiência do processo repressivo, os informes obtidos podiam também assumir um papel preventivo, uma vez que instruíam os poderes sobre as tendências, em cada microconjuntura, dos movimentos de oposição." 167 A infiltração, nessa lógica, talvez pudesse dispensar prisões e torturas, por exemplo, pois mantinha o aparato repressivo ciente de dados que pudessem limitar a atuação dos opositores. Por isso mesmo, um dos setores mais importantes da polícia política era aquele incumbido de, sob formas secretas ou reservadas, conseguir informações em torno das atividades dos possíveis “conspiradores". O "Seu dever é infiltrar-se nos meios conspirativos, colher informações, acompanhar o desenvolvimento da ação revolucionaria a fim de que, quando possível, prevenir o crime político ou social, ou fornecer elementos seguros aos órgãos repressivos para uma ação adequada, de acordo com as Leis em vigor." 168

A atuação reservada apresentava-se no meio estudantil em eventos, seminários e debates, dentre os quais, os organizados pelos movimentos negros, que divulgavam suas

${ }^{164}$ D' ARAÚJO, M. e SOARES, G. e CASTRO, C. Os anos de chumbo: a memória militar sobre a repressão. Rio de Janeiro: Relume - Dumará, 1994, pp. 39/40.

${ }^{165}$ GINZBURG, C. Mitos, Emblemas, Sinais. São Paulo: Cia das Letras, 1989.

166 Por exemplo, o informe n. 89/CONSEG/82 refere-se ao III Congresso Nacional do Movimento Negro Unificado. Nota-se que o informante (de classificação "B") estava fazendo parte deste congresso. Ordem Social 1157 pasta 218C. DEOPS/SP, DAESP.

${ }^{167}$ MAGALHÃES, M. "A lógica da suspeição: sobre os aparelhos repressivos à época da ditadura militar no Brasil.” In Revista Brasileira de História. São Paulo: ANPUH/Humanitas, vol. 17, n. 34, 1997, p. 207.

${ }^{168}$ APOLLONIO, L. Manual de polícia política e social. São Paulo: Escola de Polícia de São Paulo, 1963. (3ª Edição), pp. 320/321. 
propostas nas principais universidades, como no campus da USP e da PUC-SP. Essa infiltração resultou em relatórios diários com suas escalas de observação junto às diversas unidades. 169

As informações eram recolhidas nas atividades cotidianas dos investigadores do DEOPS, do SNI ou dos órgãos de espionagem do Exército, no exercício da vigilância, nas buscas e nas apreensões de materiais diversos, que eram anexados nos relatórios desses investigadores. Constituiu-se uma vigilância cerrada a tudo que acontecia nas universidades, com inúmeros informes feitos pelos agentes que descreviam a rotina acadêmica, como a circulação de panfletos, cartazes pregados nos prédios, realização de seminários e debates. O Decreto-Lei n. 477 de 26 de fevereiro de 1969 enquadrava alunos, professores e funcionários do ensino público e particular, proibindo que: "pratique atos destinados à organização de movimentos subversivos, passeatas, desfiles ou comícios não autorizados, ou dele participe" ou "conduza ou realize, confeccione, imprima, tenha em depósito, distribua material subversivo de qualquer natureza." ${ }^{170}$ Exatamente as estratégias utilizadas pelos movimentos negros para divulgação de seus debates, idéias, atos, reuniões e etc.

A vigilância ao MNU em Minas Gerais contava com infiltrados que acompanhavam de perto os debates, reuniões e decisões deste movimento, apresentados por meio de comunicação com sumários semanais, produzidos pela coordenação de informações da Secretaria de Segurança Pública de Minas Gerais. Aspecto primordial da rede de informação e segurança do regime militar que primava pela circulação de toda e qualquer informação.

As infiltrações eram técnicas que permitiam um conhecimento maior não só das idéias que circulavam nos movimentos, mas também em identificar os seus participantes. Sendo assim, encontramos por diversas vezes referências às pessoas presentes nos eventos vigiados. Por exemplo, na informação acerca da manifestação promovida pelo MNUCDR para o Dia Nacional da Consciência Negra, 20 de novembro, de 1981, foram listados, entre

\footnotetext{
${ }^{169}$ Como exemplos dos relatórios diários sobre as universidades vistos por nossa pesquisa: Na PUC-SP, Dossiê 21-Z-14- 13873. DEOPS/SP, DAESP. Na PUC-SP, Dossiê 21-Z-14- 14278. DEOPS/SP, DAESP. Na USP, Dossiê 21-Z-14- 14270. DEOPS/SP, DAESP. Na USP, Dossiê 40-Z-10-1882. DEOPS/SP, DAESP. Na USP, Dossiê 50-C-0- 5920. DEOPS/SP, DAESP. Na USP, Dossiê 50-C-22- 12591. DEOPS/SP, DAESP.

${ }^{170}$ Apud VECCHIO, A. Impasses do Regime Militar Brasileiro: Construção de Potência, Institucionalização e Estabilização Política (1964-1979). Tese de doutorado. São Paulo: FFLCH/USP, 1998, pp. 142-143.
} 
os presentes, os principais militantes ${ }^{171}$, como também na reunião do MNU, de 28/11/1981. ${ }^{172}$

Encontramos por trás dessa vigilância e repressão um pensamento de que a diversidade de idéias, ao invés de constituir a democracia, era considerada como algo "maléfico" a ela: "Não estando em parte alguma, a oposição pode estar em toda parte. É aí que começa o papel estratégico dos serviços de inteligência. Dada a necessidade de controle universal para aumentar a previsibilidade social, e a ausência de instituições políticas que canalizem quaisquer dissensões que possam ocorrer, o governo é compelido a confiar na espionagem, na censura e em outros mecanismos para detectar e impedir a irrupção do conflito." 173 Esse tipo de pensamento que só aceita a si próprio como verdadeiro justificou a existência de órgãos de informação e segurança que empreenderam a vigilância e repressão a sociedade brasileira. Desde 1939 o pensamento policial valorizava a ação de agentes disfarçados que deveriam "infiltrar-se" ou fazer "campana": "uma das qualidades essenciais num policial é saber 'acampanar' corretamente, porque ela é necessária em quase todos os ramos da atividade do detetive ou investigador." 174

No processo de vigilância aos movimentos negros buscava-se, por meio dos infiltrados, além de desvendar temáticas debatidas, contatos, dirigentes, também buscavam ter conhecimento da estrutura organizativa. Nesse sentido, um investigador em MG apresentou em seus relatórios o organograma da estrutura do MNU:

171 Sumário Semanal de Informação confidencial n. 36, entre 20/11 a 26/11/1981, de 27/11/1981, CODIN/CONSEG da Coordenação de Informações da Secretaria de Estado da Segurança Pública de MG, 27/11/1981, fl 36. Dossiê 50-H-84- 5048. DEOPS/SP, DAESP.

172 Sumário Semanal de Informação confidencial n. 37, entre 27/11 a 3/12/1981, de 4/12/1981, CODIN/CONSEG da Coordenação de Informações da Secretaria de Estado da Segurança Pública de MG, 4/12/1981, fl 48. Dossiê 50-H-84- 5069. DEOPS/SP, DAESP.

${ }^{173}$ SANTOS, W. Paradoxos do liberalismo: teoria e história. São Paulo: Vértice / Revista dos Tribunais, 1988, p. 124. In REZNIK, L. Democracia e Segurança Nacional. A Polícia Politica no pós-guerra. Rio de Janeiro: Editora FGV, 2004, p. 24.

174 TERRA, S. e CORD, P. Polícia, lei e cultura. Rio de Janeiro: Gráfica Guarany, 1939, p. 141. 


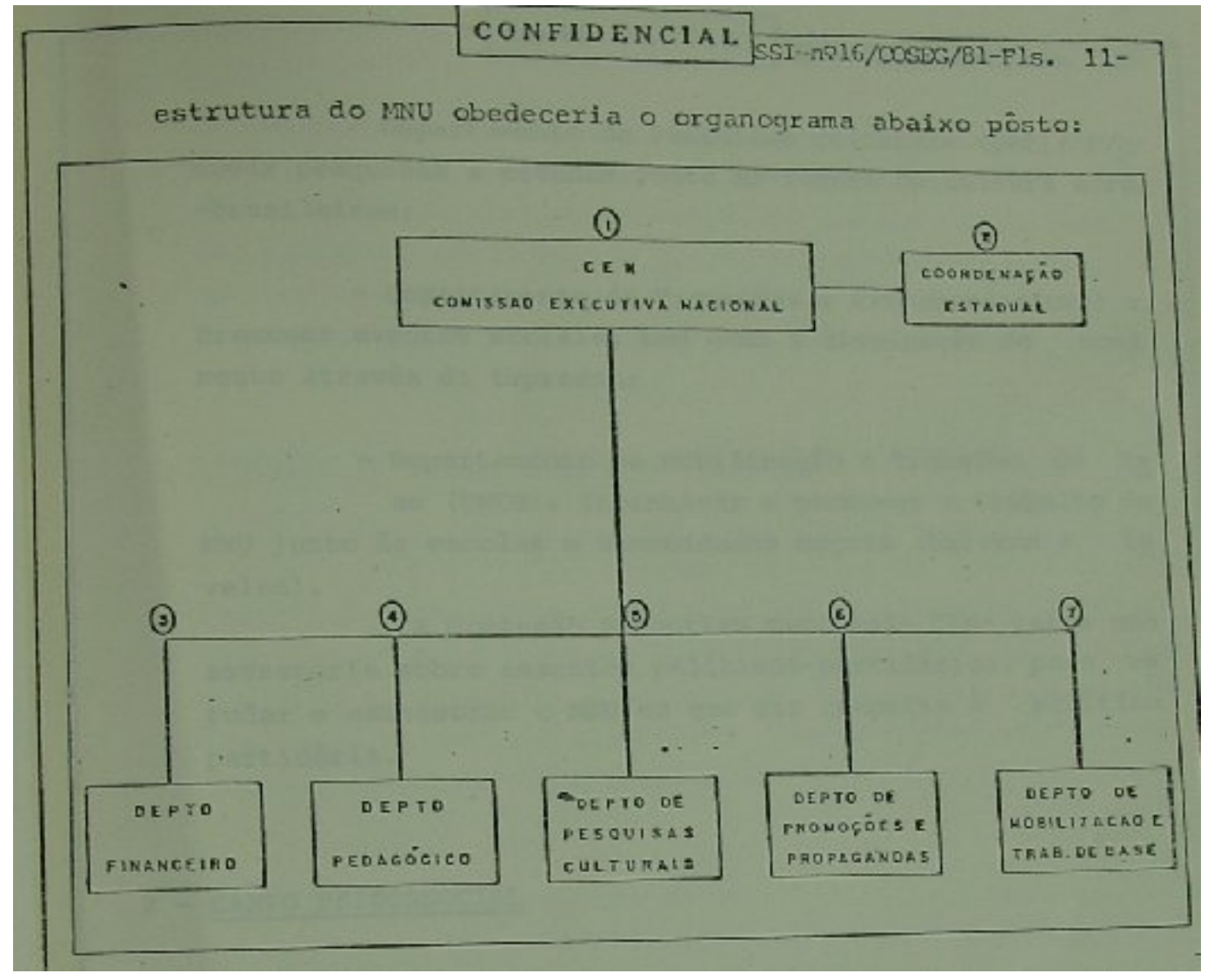

\section{Organograma do Movimento Negro Unificado (MNU), 1981.}

Alguns militares entendiam que o movimento de 1964 foi " uma contra-revolução preventiva face ao quadro de perturbações da ordem, de comprometimento da disciplina e da hierarquia e, principalmente, de deterioração do governo e de sua autoridade legal. "176 Deve-se atentar para alguns termos chave nessa declaração. A questão da "ação preventiva" foi básica na formação do pensamento da polícia civil e dos militares diante da possibilidade de uma ação "revolucionária", sendo que o mito do complô estava presente, inclusive, na afirmação do militar Gustavo Moraes Rego como fundamento para a ação golpista de 1964.

\footnotetext{
175 Sumário Semanal de Informações n. 16, CODIN/CONSEG, entre 3 a 9/7/1981, de 10/7/1981, fl. 11. Dossiê 50-H-84- 4422. DEOPS/SP, DAESP.

${ }^{176}$ Memória de Gustavo Moraes Rego In D’ ARAÚJO, M. e SOARES, G. e CASTRO, C. (orgs). Visões do golpe: a memória militar sobre 1964. Rio de Janeiro: Relume - Dumará, 1994, p. 38.
} 
Desta forma, se lançou mão de diversas armas de combate ao inimigo, uma vez que os militares entendiam estar num contexto de "guerra", utilizando-se de espionagens, delações e da construção de uma verdadeira rede de informação e repressão que visava controlar a sociedade civil. O regime militar construiu um discurso legitimador sobre sua ação como um "contra-complô" em que seria necessário utilizar-se de meios escusos, infiltrações e manipulações que, nessa lógica, seriam os meios utilizados pelos "subversivos", adjetivados como "imorais" e sem ética: "conclui-se que cada comunista é um agente de espionagem." ${ }^{177}$ Nesse sentido, é importante lembrar a observação feita por Girardet que ao analisar a mitologia da conspiração questiona se esta não revelaria uma projeção negativa das aspirações do acusador e que o poder atribuído ao inimigo poderia revelar o poder que o acusador deseja possuir. ${ }^{178}$ Dessa forma, reiteramos que a vigilância foi a base da atuação da polícia política.

A idéia de complô no imaginário político se articulou a imagem da organização dos "inimigos internos", que a polícia política visava desvendar e destruir, como fica evidente nos interrogatórios do DOI/CODI, presentes no Fundo DEOPS/SP. ${ }^{179}$ Estes interrogatórios, muitas vezes, apresentavam organogramas das organizações consideradas "subversivas", para que as autoridades policiais e militares pudessem agir com efetividade na destruição das mesmas, interferindo no funcionamento de suas diversas divisões, por meio de informações obtidas em depoimentos extorquidos com violência física e psicológica. ${ }^{180}$ Este objetivo era sustentado pela idéia de que “os inimigos só se tinham tornado visiveis porque foram desmascarados, descobertos. Os processos são concebidos como o espetáculo em que as máscaras caem por fim e só então os inimigos mostram a sua verdadeira cara." 181

A vigilância sobre a sociedade se processava também por meio dos jornais, utilizados pela polícia política como fonte de informações. ${ }^{182}$ Os artigos selecionados tornavam-se “informações úteis sobre pessoas, grupos elou instituições, [...] a segunda é efetuar um

\footnotetext{
${ }^{177}$ APOLLONIO, L. Manual de polícia política e social. São Paulo: Escola de Polícia de São Paulo, 1958. (2a Edição), p. 181.

${ }^{178}$ GIRARDET, R. Mitos e Mitologias Políticas. São Paulo: Cia. Letras, 1987, p. 62

${ }^{179}$ GIRARDET, R. Op. Cit., p. 34.

${ }^{180}$ BACZKO, B. "Imaginação Social” In Enciclopédia Einaud, vol 5. Lisboa: Imprensa Nacional e Casa da Moeda, 1985, p. 327.

${ }^{181}$ BACZKO, B. Op. Cit., p. 328.

${ }^{182}$ AQUINO, M. e LONGHI, C. e MATTOS, M. e SWENSSON JR., W. (orgs). O DEOPS/SP Em busca do crime político. São Paulo: Arquivo do Estado, 2002, p. 59.
} 
raio $X$ sobre a sociedade, aprofundando o conhecimento sobre seus passos e suas discussões e a última, complementando o aspecto anterior, perceber as tendências expostas nos principais jornais, possibilitando, segundo os próprios militares, uma avaliação do que chamam de opinião pública." ${ }^{183}$ Desse modo, diversos recortes de jornais que discutiam ou divulgavam a ação dos movimentos negros apresentavam-se anexos aos documentos policiais.

No monopólio da violência do Estado houve a formação de aparatos reguladores da sociedade, tornou-se necessário a construção de provas e contraprovas para a acusação de um crime, tornando essencial o cuidado na produção das provas e critérios para todo o procedimento policial e judiciário. ${ }^{184}$ Nesse sentido, o material "subversivo" apreendido pelos aparatos repressivos do regime militar apresentava-se sob a leitura e as apropriações policiais ou militares, com intenção prévia de constatar uma contravenção, um crime de idéias. O processo de investigação policial significava, em última instância, a busca de provas de crimes. Além disso, nota-se que alguns relatórios visavam também "doutrinar" os funcionários públicos envolvidos na repressão, divulgando uma determinada visão sobre o Brasil, como o objetivo de "extirpar" os "baderneiros ideológicos, criadores de rebeliões perigosas" que impediriam a "evolução" e desenvolvimento do país. ${ }^{185}$

Todo "esse arcabouço repressivo era parte de um projeto social que tinha como cerne uma concepção autoritária de sociedade." ${ }^{186}$, com um discurso monocórdio que rejeitava a possibilidade de oposição e crítica livres. Dessa forma, os planos dos militares de "intervir e controlar todas as esferas da vida social, foram dados pela combinação de um processo altamente repressivo com uma contínua pretensão de legitimidade. O próprio regime, desde o imediato pós-golpe, insistia em que através de suas estratégias econômica,

\footnotetext{
${ }^{183}$ AQUINO, M. e LONGHI, C. e MATTOS, M. e SWENSSON JR., W. (orgs). O DEOPS/SP Em busca do crime político. São Paulo: Arquivo do Estado, 2002, p. 85.

${ }^{184}$ NEVES, P. (org) Polícia e Democracia: desafios à educação em direitos humanos. Recife: Edições Bagaço, 2002, pp. 7/8.

${ }^{185}$ Relatório de inquérito de 1970 Apud MATTOS, M. Em nome da segurança nacional: os processos da Justiça Militar contra a Ação Libertadora Nacional (ALN), 1969-1979. Dissertação de Mestrado. São Paulo: FFLCH/USP, 2002, p. 57/58.

${ }^{186}$ AQUINO, M. e LONGHI, C. e MATTOS, M. e SWENSSON JR., W. (orgs). Op. Cit., p. 93.
} 
política, militar e psicossocial iria moldar a sociedade brasileira aos seus desígnios e ações." 187

A disciplina militar pretendia enquadrar e castigar os "desvios", ou seja, os que não se adequavam às regras estabelecidas, numa visão de que a ordem se relacionava a: "por em linha, sem choques, sem superposições." 188 Os documentos policiais representam construções ideológicas sobre os cidadãos suspeitos sob a lógica da desconfiança. Mesmo a documentação apreendida e anexada encontra-se de forma a compor uma "estória" narrada pelas autoridades policiais visando a "criminalização" do indivíduo ou entidade investigada. Toda e qualquer informação era considerada pelas estruturas de informação e repressão do regime militar, como o recorte de jornal com a matéria "Grupo negro faz presépio ao vivo na Igreja do Paiçandu" de 18/12/1981, que retrata uma encenação teatral religiosa de atores afro-descendentes não profissionais, dirigida por Miroel Silveira. Por certo essa informação não apresentava nenhum crime político, mas os contatos dos afrodescendentes e sua mobilização eram de interesse da comunidade de informações e segurança.

A rede, mais que de informações, também era de espionagem, visando se proteger dos "perigos" da mobilização do "comunismo". Dados sobre contatos sociais, vida pessoal, assim como julgamentos de "imoralidade" sobre os investigados, integravam um conjunto de informações que poderiam servir, no caso de um julgamento formal, para o "agravamento" da situação do julgado. ${ }^{189}$ Deste modo, era mantido um quadro de vigilância constante e cerrada aos identificados como opositores ou possíveis opositores do regime.

Ayrton Baffa, ao analisar a documentação do SNI, chamou a atenção para os dados "irrelevantes" que o SNI levantava sobre os investigados, como os aspectos banais da vida pessoal: "Não na época não era exigido mapa astrológico do espionado",190, ou "cansativo

\footnotetext{
${ }^{187}$ REZENDE, M. A ditadura militar no Brasil: repressão e pretensão de legitimidade (1964-1984). Tese de Doutorado. São Paulo: FFLCH/USP, 1996, p. resumo.

${ }^{188}$ PESTANA, J. Manual de Organização Policial do Estado de São Paulo. (2 a edição). São Paulo: Escola de Polícia de São Paulo, 1957, p. 51.

${ }^{189}$ FICO, C. Como eles agiam. Os subterrâneos da Ditadura Militar: espionagem e polícia politica. Rio de Janeiro: Record, 2001, p. 101.

${ }_{190}$ BAFFA, A. Nos poróes do SNI. O retrato do monstro de cabeça oca. Rio de Janeiro: Editora Objetiva, 1989, p. 39.
} 
seria enumerar aqui tanto mexerico, tanta falta do que fazer dos besouros do SNI" ${ }^{191}$ Isto levou ao autor, diversas vezes, a denominar os informes de "mexericos". 192 Caberia indagar o porque da vigilância cotidiana e pessoal, ou qual a mentalidade dos funcionários desse órgão e quais as funções do uso desses dados pessoais. Afinal, se estes dados constam da documentação, em algum momento, foram considerados importantes, o que retiraria a adjetivação de "irrelevantes".

Há de se ressaltar que para policiais e militares: "numa investigação, tudo interessa; por menor importância que possa aparentar uma ação, o modo de vida do investigado, mesmo de caráter privado, ele pode fornecer meios de ligação com o fato principal a ser apurado. "193 Mesmo porque, por tradição, no pensamento policial, em particular com o advento da Antropologia Criminal, era importante o estudo do "criminoso" para a compreensão dos perfis "psico-biológicos" envoltos na criminalidade, incluindo o "estudo da vida pregressa", que era considerado, em um inquérito policial, uma prova complementar 194: "O Código de Processo Penal, em seu artigo $6^{\circ}$, inciso IX, estabelece ser atribuição da autoridade policial, logo após a prática de uma infração penal 'indagar da vida pregressa do indiciado, sob o ponto de vista individual, familiar e social, sua condição econômica, sua atitude e quaisquer outros elementos que contribuírem para a apreciação de seu temperamento e caráter." 195

Essa documentação não trás apenas "mexericos", e é sim reveladora das visões e diretrizes sobre temáticas diversas, como os modelos de espionagem e investigação dos órgãos de informação e segurança e a própria visão de mundo dos seus funcionários. De todo modo, os "mexericos" revelam apenas uma faceta da mentalidade presente no SNI. Salienta Carlos Fico: "alguns trabalhos jornalísticos têm chamado a atenção para o lado grotesco da comunidade de informações, aludindo a avaliações equivocadas, a erros de interpretação e a coisas do gênero. Isso de fato existiu. Porém, ao longo dos anos, o Serviço Nacional de Informações (SNI) constitui-se em fonte bastante profissional de informações para os generais-presidentes, permanecendo quase sempre nos níveis

\footnotetext{
${ }^{191}$ BAFFA, A. Op. Cit., p. 111.

192 BAFFA, A. Idem, p. 118.

${ }^{193}$ APOLLONIO, L. Manual de polícia política e social. São Paulo: Escola de Polícia de São Paulo, 1954. (1 ${ }^{\text {a }}$ Edição), p. 156.

${ }^{194}$ NOGUEIRA, C. Manual de Investigação Policial. São Paulo: Escola de Polícia de São Paulo, 1965, p. 23.

${ }^{195}$ FERREIRA, H. "Do Exame Criminológico na Fase Policial” In Arquivos, vol. XXV. São Paulo: Polícia Civil de São Paulo, $1^{\circ}$ semestre 1975, pp. 58-72, p. 59.
} 
subalternos as avaliações equivocadas, filtradas que eram, naturalmente, pelos escalões superiores e mais habilitados. Desse modo, a comunidade de informações gerou situações muito sérias, com conseqüências gravíssimas para a sociedade brasileira. É necessário, portanto, compreendê-la em profundidade, pois o folclore sobre as 'trapalhadas' pode ocultar a verdadeira dimensão do problema.". 196

Os dados da vida pessoal de algum espionado, por certo não eram úteis como informações para as decisões governamentais, função primeira do SNI, mas eram tidos como essenciais para as atividades de repressão do sistema, que poderia lançar mão desses dados para "desqualificar o inimigo" 197 ou pressioná-lo num interrogatório. Desse modo, interessava aos órgãos de vigilância e repressão não só os antecedentes, mas também os dados biográficos da pessoa, construindo um acervo sobre a sua vida pessoal, política e social. Portanto, esses dados arquivados com cuidado, mais tarde poderiam ser utilizados em uma possível "afronta à segurança nacional", ou mesmo ser elemento de acusação de "imoralidade" do investigado pelos órgãos de segurança. Nesse sentido, os órgãos de informação encaravam essa tarefa como uma ação "preventiva".

Como exemplo, o pedido de busca n. 2494/115, de 24 de agosto de 1982, o SNI agência de São Paulo para o DOPS solicitava dados biográficos e os antecedentes de Milton Barbosa $^{198}$, militante afro-descendente, devido a uma investigação procedida sobre os candidatos à Câmara Federal, no pleito de 1982, pelo Partido dos Trabalhadores (PT). Na resposta, consta sua participação em uma campanha contra a violência policial, o que poderia ser utilizado contra ele para uma eventual desqualificação da sua candidatura. ${ }^{199}$

O objetivo de registrar o maior número possível de informações sem a possibilidade de descarte revela o pensar dessas instituições: “A investigação resolvia tudo. Você ia atrás do passado do indivíduo, da ficha policial, se tivesse, acompanhava a sua atuação em vários setores de atividade, colhia o testemunho de pessoas que trabalhavam ou que tinham

\footnotetext{
${ }^{196}$ FICO, C. Como eles agiam. Os subterrâneos da Ditadura Militar: espionagem e polícia politica. São Paulo: Record, 2001, pp. 74/75.

${ }^{197}$ FICO, C. Op. Cit., p. 76.

${ }^{198}$ Milton foi um dos fundadores do MNU, em 1978. Participou do Centro Acadêmico da FEA/USP e da diretoria da AEMESP (Associação dos Empregados do Metropolitano do Estado de São Paulo). Foi um dos fundadores do Diretório Bela Vista do PT, em 1981, participando do diretório estadual do PT na gestão de 1984. OLIVEIRA, E. Quem é quem na negritude brasileira. São Paulo: Congresso Nacional Afro-Brasileiro, 1998, p. 204.

${ }^{199}$ Dossiês 20-C-43- 4880 a 4878. DEOPS/SP, DAESP.
} 
trabalhado com ele... É a única maneira de se fazer uma investigação desse tipo." 200 Dessa forma, segundo o general Golbery, "Ficha não se limpa. Informações não se apagam, superpõem-se, como camadas geológicas.” ${ }^{201}$ A lógica do máximo de informações inseria-se numa visão de que para combater o inimigo seria necessário conhecê-lo a fundo. Além disso, a visão de que toda informação poderia tornar-se necessária, provinha da própria experiência do DEOPS, apresentada no manual de polícia política e social, em 1954. ${ }^{202}$ O pensamento policial do século XX girou em torno da proposição de prevenção do crime ${ }^{203}$, em que "todos eram convidados a participar da Comunidade de Informações, suspeitando de tudo e de todos que os cercassem, como que movidos por um sentimento de ameaça permanente." ${ }^{204}$ Esta idéia de prevenção se refere ao embate, no pós II Guerra Mundial, entre democracia e totalitarismos.

Outro exemplo do raciocínio de que o inimigo pode estar em toda parte, até um convite para uma festa de "cultura negra", a festa "Black Power" em homenagem a "Nêga Zula", em São Paulo, a qual foi alvo de investigações pelo Serviço de Informações do Ministério da Aeronáutica, gerando, em 18 de maio de 1972, um informe ao DEOPS/SP, com o convite anexado. ${ }^{205}$ Levando-se em consideração que a festa pode ser um espaço de conscientização e reafirmação de identidade, sendo uma estratégia de socialização cultural que pode levar a mobilização política por meio da circulação de idéias, a polícia política teria motivos para vigiar essa festa. ${ }^{206}$ Além disso, nesse quadro, a cultura negra, "black", também estava sob vigilância, já que poderia divulgar valores de movimentos internacionais como a afirmação étnica que "incitasse" o conflito racial.

\footnotetext{
${ }^{200}$ Memória de José Luiz Coelho Netto In ARAÚJO, M. e SOARES, G. e CASTRO, C. Os anos de chumbo: a memória militar sobre a repressão. Rio de Janeiro: Relume - Dumará, 1994, p. 231.

${ }^{201}$ GASPARI, E., HOLLANDA, H. e VENTURA, Z. 70/80 Cultura em Trânsito. Da Repressão à Abertura. Rio de Janeiro: Aeroplano, 2000, p. 328.

${ }^{202}$ APOLLONIO, L. Manual de polícia política e social. São Paulo: Escola de Polícia de São Paulo, 1954. (1ª Edição), p. 149 e 152.

${ }^{203}$ Para uma noção a cerca da teoria policial sobre a questão da prevenção ver Anexo 2 - Controle preventivo do Estado.

${ }^{204}$ MAGALHÃES, M. “A lógica da suspeição: sobre os aparelhos repressivos à época da ditadura militar no Brasil.” In Revista Brasileira de História. São Paulo: ANPUH/Humanitas, vol. 17, n. 34, 1997, p. 212.

${ }^{205}$ Dossiê 50-D-26- 3806 e 50-D-26- 3806 A.

${ }^{206}$ Sobre as estratégias culturais e políticas e sua relação ver: CUNHA, O. "Depois da festa: movimentos negros e 'políticas de identidade' no Brasil”' In ALVAREZ, S. e DAGNINO, E. e ESCOBAR, A. Cultura e politica nos movimentos sociais latino-americanos: novas leituras. Belo Horizonte: Ed UFMG, 2000, p. 350.
} 


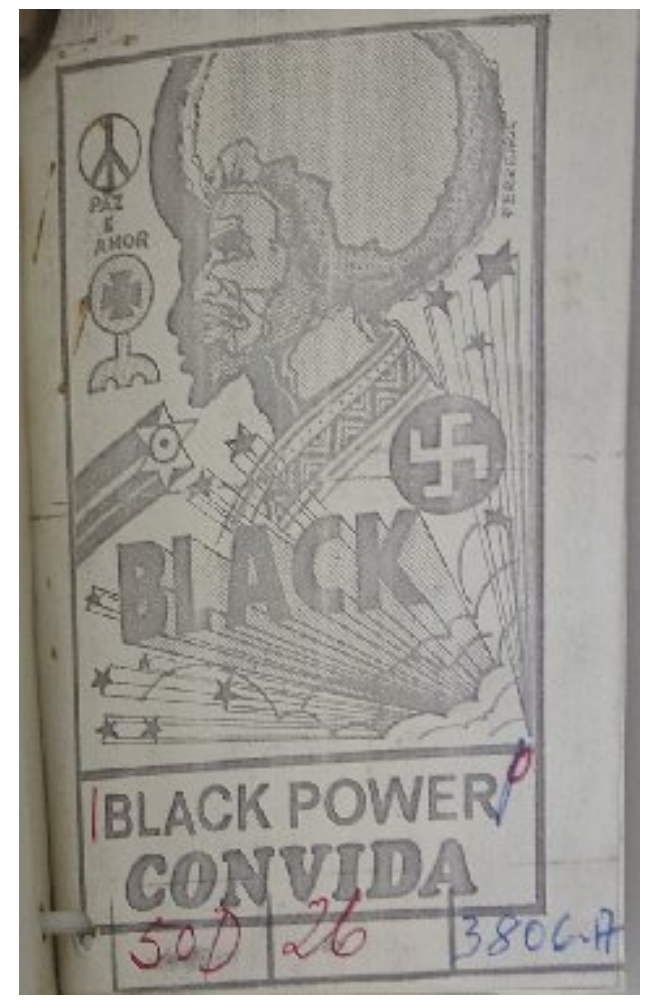

\section{Convite da festa "Black Power", de 1972.}

A divulgação do discurso de solidariedade entre os afro-descendentes esteve presente também nos debates dos diversos movimentos negros brasileiros, o que sem dúvida, visava reforçar a identidade negra assentada na ascendência africana. Por certo o debate dessas idéias de solidariedade "internacional" reforçava o cuidado vigilante do aparato repressivo brasileiro aos movimentos negros no Brasil, investigando quais poderiam ser as influências, as idéias, os financiadores ou os contatos internacionais dos movimentos brasileiros. Como exemplo, temos a solicitação de dados sobre o CEBA (Centro de Estudos Brasil - África) que requisitava os seguintes dados: "Nomes e dirigentes, estatutos, locais de reuniões, ligações estaduais, nacionais e internacionais. b. Fontes de recursos, número de associado, apoio recebido de órgãos públicos, autárquicos, regionais e federais. " 208

\footnotetext{
${ }^{207}$ Convite festa "Black Power". Dossiê 50-D-26- 3806 A. DEOPS/SP, DAESP.

${ }^{208}$ Pedido de Busca confidencial n. 418/76 do CIE para DOPS/SP, de 22/11/1976. Dossiê 50-J-0-4866. DEOPS/SP, DAESP.
} 
Temas relacionados à situação dos negros na África e nos EUA, foram centrais em importantes debates para a formação da "consciência negra", norteando as lutas antiracistas brasileiras. Este processo foi favorecido pelo desenvolvimento da mídia, com suas novas tecnologias que levava a uma maior divulgação do que estava acontecendo no exterior. ${ }^{209}$ A soul music e o estilo de comportamento black power ou poder negro, provinda dos EUA, foram também fonte de preocupação da comunidade de informações e segurança, uma vez que identificavam um estilo de comportamento e uma ação de subversão por sua característica contestatória da hegemonia dos brancos no poder.

Parte dos movimentos negros propunha a "luta pela libertação integral do povo negro, combatendo o racismo e todas as formas de opressão." ${ }^{210}$, utilizavam de elementos do discurso marxista-leninista na sua linguagem e na sua abordagem, como a noção de "libertação", que se encontrava em voga também na África, com os movimentos de independência entre 1945 a 1975, tendo como marco principal a década de 1960. Nesse sentido, a semelhança dos discursos era captada pela comunidade de informações e segurança como um elemento de subversão.

O intenso e constante debate dos militantes negros sobre a situação africana, seja sobre o jugo colonialista ou sobre o apartheid na África do Sul, levava esses movimentos a contestarem também as relações externas do Brasil com a África do Sul, o que ampliava a desconfiança dos aparatos de repressão do regime militar em relação aos movimentos negros brasileiros. ${ }^{211}$ As reivindicações anti-racistas brasileiras que se manifestavam contra o apartheid se tornavam inconvenientes para a política externa brasileira ao divulgarem uma imagem negativa ao exterior e, ao mesmo tempo, no campo interno com o receio da aproximação dos movimentos brasileiros das lutas africanas, classificadas pelo regime militar como "terroristas". Presente nesta desconfiança a "imagem do Inimigo, força diabólica, escondida e omnipresente, que age tanto no interior como no exterior do país." ${ }^{212}$, formando no fim das contas, um só "inimigo", os “comunistas" ou "terroristas". O "terror produz sentimentos generalizados de insegurança, impotência e suspeita que

\footnotetext{
${ }^{209}$ SILVA, N. Consciência Negra em cartaz. Brasília: Editora Universidade de Brasília, 2001, p. 38.

${ }^{210}$ Manifesto do MNU sobre o Dia Nacional da Consciência Negra assinado pela Comissão Executiva Nacional do MNU. Dossiê 20-C-44-14605. DEOPS/SP, DAESP.

${ }^{211}$ Essa questão será melhor tratada no item "IV. Movimentos Negros e seus principais debates", no subitem "África, o colonialismo e o racismo" e "O apartheid".

212 BACZKO, B. "Imaginação Social" In Enciclopédia Einaud, vol 5. Lisboa: Imprensa Nacional e Casa da Moeda, 1985, p. 329.
} 
impregnam toda a vida quotidiana." 213 que estiveram intensamente presentes na mentalidade militar a cerca dos movimentos sociais no Brasil e até mesmo em outros contextos fora do país em meio a Guerra Fria.

Os contextos interno e externo do Brasil estiveram presentes no debate da comunidade de informações e segurança. Os documentos produzidos pelo $\mathrm{SNI}^{214}$ na década de 1960 predominaram uma preocupação maior com a situação política interna, no entanto, na década seguinte, o foco se dirigiu a situação política externa, que obteve espaço importante nessa documentação pela produção dos "Sumários de Informações" sobre o “comunismo internacional”. Nesta documentação, nos interessam, em particular, as análises desse órgão sobre os movimentos de independência africanos e o racismo nos Estados Unidos. ${ }^{215}$ Em sua preocupação com a repressão ao "comunismo", a rede de informações e segurança brasileira mantinha-se atenta à mobilização do "comunismo internacional", uma vez que as políticas interna e externa eram entendidas como indissolúveis, pois se tratava de uma guerra contra o "comunismo" em qualquer parte do Ocidente. Como apresenta o documento a seguir, os Sumários do SNI circulavam pelos diversos setores da comunidade de informações e segurança que estudavam a ação comunista pelo mundo.

\footnotetext{
${ }^{213}$ BACZKO, B. Op. Cit., p. 329.

${ }^{214}$ Por meio das pastas 20-C-43, que reúnem uma serie de documentos do SNI, do Fundo DEOPS/SP, DAESP.

${ }^{215}$ Questões abordadas nos próximos itens desse capítulo.
} 


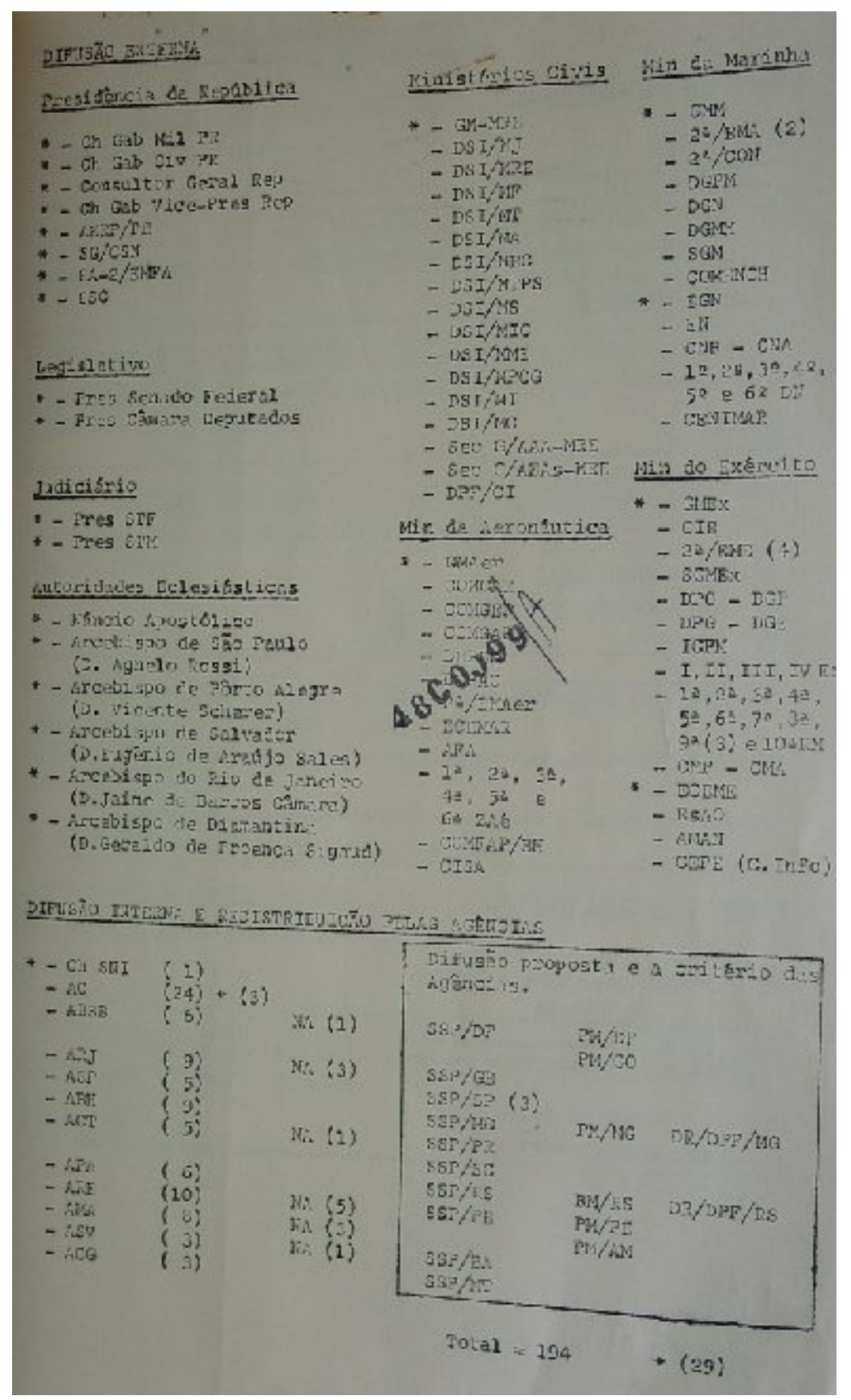

Difusão do Sumário de Informações sobre o Comunismo Internacional, p. 12.

${ }^{216}$ Sumário de Informações sobre Comunismo Internacional, parte da difusão do documento na página 1. Dossiê 20-C-43-2489. DEOPS/SP, DAESP. 
Por exemplo, notícias acerca de Portugal e o ultramar, de 25/04/1974, eram transcritas pelos órgãos de informação e segurança visando compreender a atuação do comunismo internacional, em particular na África, pela ligação de grande parte dos movimentos de independência com a URSS. ${ }^{217}$ Mas os órgãos de informação e segurança preocupavam-se também com a vinda dos militantes dos movimentos de independência para o Brasil, com a situação política de Portugal e de suas colônias, estes poderiam se refugiar no Brasil devido à proximidade lingüística e cultural. ${ }^{218}$

Por sua vez, havia também uma preocupação com a infiltração das idéias externas nos movimentos brasileiros. A Polícia Federal na Bahia proibiu que o bloco afro Ilê Aiyê fosse registrado como "poder negro", alegando que possuía conotações negativas e "alienígenas", devido as referências a situação racial norte-americana. Assim, a "imprensa baiana, à época, apoiou e incentivou a proibição, apontando possiveis e inconcebiveis intenções 'subversivas' de vincular a situação do negro brasileiro à do negro norte-americano." 219 A apreensão dos possíveis diálogos dos movimentos negros com os contextos políticosociais internacionais apresentava-se também na vigilância aos Congressos de Cultura Negra das Américas, no qual os movimentos negros trocavam idéias com diversos movimentos no continente americano e ampliavam laços de solidariedade. ${ }^{220}$

Dessa forma, o contato com o exterior parece que não foi apenas um receio da comunidade de informação e segurança do regime militar, mas que de fato ocorria. Na III Assembléia Nacional do MNU o militante Márcio, de São Paulo - que leva a crer tratar-se de Marcio Barboza - afirmou que mantinha contato com “ [...] movimento racista no exterior, no sentido de que os mesmos dêm (sic) apoio ao movimento brasileiro." ${ }^{221}$ Clovis

\footnotetext{
${ }^{217}$ Dossiê 50-E-29-113, fl. 3. DEOPS/SP, DAESP.

${ }^{218}$ Dossiê 50-E-29-113, fl. 13. DEOPS/SP, DAESP.

${ }^{219}$ Periódico Nêgo, n. 3, p. 2, n. 14, p. 7 Apud SOUZA, F. Afro-descendência em Cadernos Negros e Jornal do $M N U$. Belo Horizonte: Autêntica, 2005, p. 217.

${ }^{220}$ Segundo informação confidencial, sobre o III Congresso de Cultura Negra das Américas, identificou os grupos participantes desse evento no Brasil, que foi organizado pela Coordenação Estadual das Entidades Negras do Estado de São Paulo. Sua primeira edição havia sido realizada na Colômbia, em 1977 e a segunda edição foi no Panamá, em 1980. Informação n. 1258B sobre III Congresso de Cultura Negra das Américas, 19/08/1982. Dossiê 20-C-44- 26130. DEOPS/SP, DAESP. Panfleto "III Congresso de Cultura Negra das Américas: Participar ou Não?" da Coordenação Estadual de Entidades Negras do Estado de São Paulo recolhido na PUC-SP, 18/08/1982. Dossiê 20-C-44- 26129. DEOPS/SP, DAESP.

${ }^{221}$ Informação n. 350 confidencial, da $2^{\text {a }}$ Seção da Aeronáutica, de 15/12/1978, fl. 2. Dossiê 50-D-26- 5922. DEOPS/SP, DAESP.
} 
Moura $^{222}$, segundo a polícia política, manteria contato com elementos do MPLA, em Angola. ${ }^{223}$

\section{Legalidade e ilegalidade dos movimentos negros}

As relações entre os movimentos negros e as autoridades policiais foram complexas no que se refere a legalidade de sua atuação. Por vezes, os movimentos negros buscavam encaminhar seu protesto de forma legal. Para manter uma atuação legalizada alguns movimentos informavam os seus eventos às estruturas de repressão, como o Club 220 que mandava solicitações para realizar passeatas comemorativas. Por exemplo, no caso dos festejos da Abolição da Escravatura, em 1973, no qual constando em seu convite o nome de autoridades presentes, como Alfredo Buzaid, Ministro da Justiça, e o General Humberto de Souza Mello, comandante do II Exército. ${ }^{224}$ Essas relações complexas e ambíguas se desenvolveram por parte dos movimentos negros buscarem obter meios legais de atuarem na sociedade brasileira. Havia divisões de interesses entre os movimentos negros também e, certamente setores que não tinham críticas ao regime militar existiram.

Ao mesmo tempo, a polícia obtinha cautela em relação a sua ação repressiva sobre esses movimentos. Para alcançar o desarticulamento desses movimentos, por diversas vezes, sua ação era de forma oculta, sem que fosse por meios repressivos diretos. Por exemplo, em relação ao III Assembléia Nacional do MNU que desagradou as autoridades policiais baianas, para evitar que esse evento acontecesse determinaram o fechamento dos locais que haviam sido programados para a realização do evento. Transferido de local, a polícia decidiu apenas monitorar o evento e não coibir, para não provocar repercussões nos meios de comunicação. ${ }^{225}$

\footnotetext{
${ }^{222}$ Clóvis Steiger de Assis Moura nascido em 1925 e falecido em 2004. Foi um importante militante e intelectual negro. Ao mesmo tempo, militou no Partido Comunista Brasileiro, em Salvador, participou do jornal O Momento, do PCB e foi eleito duputado em 1947 pelo PCB. Dessa forma, seu pensamento sobre a questão racial esteve imbricada ao pensamento marxista. Concomitantemente a profissão de jornalista pesquisava sobre a questão social do negro no Brasil. MESQUITA, Érika. "Clóvis Moura e a sociologia da práxis" In Estudos Afro-Asiátiacos, v. 25, n. 3. Rio de Janeiro:Centro de Estudos Afro-asiático Universidade Candido Mendes 2003. In http://www.scielo.br/scielo.php?pid=S0101546X2003000300007\&script=sci_arttext

${ }^{223}$ Informação confidencial sobre Clovis Moura, fl. 2. Dossiê 50-Z-0- 14615. DEOPS/SP, DAESP.

${ }^{224}$ Prontuário n. 97352, Club 220. DEOPS/SP, DAESP.

${ }^{225}$ Informação n. 350 confidencial, da $2^{\text {a }}$ Seção da Aeronáutica, de 15/12/1978, fl. 2. Dossiê 50-D-26- 5922. DEOPS/SP, DAESP.
} 
Segundo relatório do investigador reservado "Fox 9", de 1 de outubro de 1980, acerca do levantamento junto ao MNU para levantar seu estatuto, conforme solicitado pela ordem de serviço n. 54/80, o investigador tentou aproximar-se desse movimento em sua sede. Sem encontrá-la aberta, intimou um dos diretores desse movimento, Milton Barbosa, a comparecer ao DEOPS para prestar declarações. Milton compareceu em 29/9/1980 garantindo ser da Comissão Executiva coordenadora do MNU, comprometendo-se a apresentar posteriormente os estatutos ao DEOPS. ${ }^{226}$ Assim, em tempos de repressão a expressão de reivindicação ou protesto, agir legalmente era uma estratégia de sobrevivência do movimento.

Além disso, esse documento esclarecedor mostra as táticas adotadas pela polícia política na vigilância e repressão às mobilizações da sociedade brasileira, apresentando uma abordagem de infiltração nos movimentos, entre outras razões, para investigação das lideranças, estatutos e objetivos. Numa segunda etapa, eram convocados os investigados para prestar esclarecimentos da sua atuação política ou social, como foi Milton Barbosa. Porém, a vigilância não se encerrava apenas na primeira abordagem, que se manteve de forma constante em todas as ações dos movimentos negros.

O nascedouro do MUCDR por meio de um ato público, em 7/7/1978 em frente ao Teatro Municipal de São Paulo foi acompanhado de perto pela polícia política. ${ }^{227}$ Também na Bahia, a ação do MUCDR era de interesse do DEOPS/SP, que resumia toda a sua atuação onde ela ocorresse. A distribuição de panfleto dessa entidade foi relata, assim como as pessoas que o distribuíam foram identificadas, Durval Souza Carvalhal, Lele C. Crescencio dos Santos, Valmir Santos de Araújo e Aida Carmen Santos de Araújo. ${ }^{228}$ Do mesmo modo, a distribuição da carta de princípios do MNUCDR nas ruas de Salvador foi informada ao DEOPS paulista, além do conteúdo deste que "discorre sobre o convencimento do negro da existência de discrepâncias de atitudes contra a raça, enquanto conclama os representantes da raça negra a lutar em 'defesa do povo negro em

\footnotetext{
${ }^{226}$ OS 1157 p. 218 C. DEOPS/SP, DAESP.

${ }^{227}$ Informação Confidencial sobre o Movimento Negro Unificado Contra a Discriminação Racial. OS 1157 p. 218 C. DEOPS/SP, DAESP.

${ }^{228}$ Informação Confidencial sobre o Movimento Negro Unificado Contra a Discriminação Racial. OS 1157 p. 218 C. DEOPS/SP, DAESP.
} 
todos os aspectos políticos, econômicos e sociais.." ${ }^{229}$ A atuação no Rio de Janeiro também apresentava-se nas informações levantadas pelo DEOPS, de 9/10/1978, da qual constava o programa de Ação do MNU, em Assembléia Nacional, e uma detalhada comunicação de todos os passos dos movimentos negros devidamente vigiados nos estados em que atuavam. ${ }^{230}$

Os movimentos negros figuravam entre os movimentos contestatórios do período, como o MNUCDR: “É sabido que várias Entidades, legais ou mesmo paralegais, na maioria das vezes, desvirtuando a natureza e os objetivos aos quais se propuseram, patrocinam e apoiam (sic) Campanhas de contestação, tanto ao Governo como também ao Regime. [...] $\mathrm{Na}$ maioria das vezes, tais entidades, patrocinando, apoiando ou simplesmente participando de eventos totalmente desprovidos de cunho ideológico, aproveitam-se, subrepticiamente ou mesmo ostensivamente, utilizando-se do temário em debate, para traçar paralelos e promover polêmicas e debates, aguçando e aflorando assuntos que propiciem doutrinações tendenciosas elou contestatórias." ${ }^{231}$ Os temas próximos dessas entidades, de origem diversas, e eram vistos com suspeição pelas estruturas de segurança: a carestia, o desemprego, a anistia, as arbitrariedades policiais, entre outros. Presentes também nos movimentos negros, eram compreendidos não como reivindicações sociais e sim como forma de desmoralizar as autoridades constituídas, o que tanto como a crítica ao regime militar tornava os movimentos negros alvo de vigilância e repressão pelo DEOPS/SP. ${ }^{232} \mathrm{O}$ envolvimento com assuntos políticos não ligados de forma direta à questão racial também levaram a afro-descendentes à prisão, como, 2 afro-descendentes detidos, em 1979, com material de propaganda da campanha de anistia. ${ }^{233}$

A ação panfletária foi um dos principais motivos para as detenções contra os militantes negros. A apreensão do panfleto "Enterro da Lei Afonso Arinos", em poder de Celso Luiz

\footnotetext{
${ }^{229}$ Informação Confidencial sobre o Movimento Negro Unificado Contra a Discriminação Racial. OS 1157 p. 218 C. DEOPS/SP, DAESP.

${ }^{230}$ Informação Confidencial sobre o Movimento Negro Unificado Contra a Discriminação Racial. OS 1157 p. 218 C. DEOPS/SP, DAESP.

${ }^{231}$ Sumário Semanal de Informações n. 30, entre 9 a 15/10/1981, CODIN/CONSEG da Coordenação de Informações da Secretaria de Estado da Segurança Pública de MG, 16/10/1981, fl. 7. Dossiê 50-H-84- 4970. DEOPS/SP, DAESP.

${ }^{232}$ Exemplo dessa crítica, ato público contra o racismo do MNCDR: Relatório de observação da Divisão de Informações do DEOPS, de 17/10/1979. Dossiê 21-Z-14- 7947. DEOPS/SP, DAESP.

${ }^{233}$ Oficio n. 1127/79, do $5^{\circ}$ Distrito Policial - Aclimação, 9/8/1979. Dossiê 50-Z-0- 15313. DEOPS/SP, DAESP.
} 
Prudente $^{234}$ e Wilson Roberto Prudente ${ }^{235}$, em 1979, além de um cartão de identificação destes como representantes do periódico Versus, mais os cartões de um advogado e de uma gráfica, chamaram a atenção do delegado Wilson Tamer. ${ }^{236} \mathrm{O}$ panfleto, encaminhado ao DOPS por ofício, denunciava o arquivamento do processo judicial apresentado pela advogada negra Nair Silveira, alvo de discriminação racial. O panfleto observava que as leis anti-racistas eram ineficientes e denunciava que: "Esse arquivamento, mais uma vez, demonstra com que naturalidade as autoridades brasileiras recebem, aprovam $e$ participam das violências sofridas pela comunidade negra em todo o Território Nacional. ${ }^{, 237}$

Torna-se evidente que qualquer interesse particular próprio do discurso político era transformado em interesse geral. Assim, este discurso se legitimava ao mesmo tempo em que deslegitimava o discurso do que era identificado como adversário, fosse este de qualquer forca qualificada como de oposição.

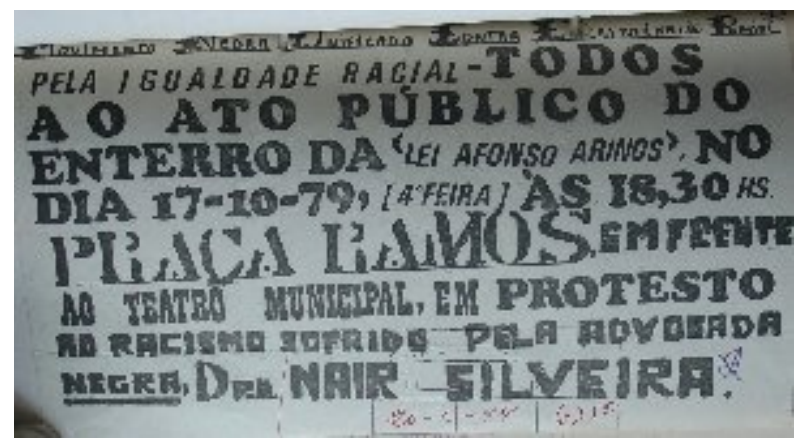

Panfleto do MNUCDR divulgando ato público "Enterro da lei Afonso Arinos", de 1979.

\footnotetext{
${ }^{234}$ Celso Prudente além de ter uma militância importante junto ao MNU auxiliando em sua fundação, é um importante acadêmico, com produção científica ligada ao cinema e ao negro. Ver OLIVEIRA, E.. Quem é quem na negritude brasileira. São Paulo: Congresso Nacional Afro-Brasileiro, 1998, p. 62.

${ }^{235}$ Wilson Prudente foi fundador e presidente do MNU, como apresenta a Mensagem do Sumário de Informações n. 035/4 sobre ato público do MNU, de 13 de maio de 1981. Dossiê 50-D-18- 2850. DEOPS/SP, DAESP. Foi um dos coordenadores do SOS Racismo, do Instituto de Pesquisa da Cultura Negra (IPCN) no Rio de Janeiro. Faz parte do Tribunal Regional do Trabalho, possuindo uma atuação importante no combate a escravidão na atualidade. Ver OLIVEIRA, E. Op. Cit., p. 280.

${ }^{236}$ Ofício n. 2291/79 do Primeiro Distrito Policial da Sé para o DOPS, 16/10/1979. Dossiê 50-E-38- 833. DEOPS/SP, DAESP.

${ }^{237}$ Panfleto do MNUCDR "Enterro da Lei "Afonso Arinos"”. Dossiê 50-E-38- sem número. DEOPS/SP, DAESP.
} 
Por isso o ato público divulgado pelo panfleto do MNUCDR fora comunicado ao II Exército, ao SNI, à IV Comar e à Comissão Naval pelo delegado de polícia, chefe do DOPS/SP, Romeu Tuma, em 17/10/1979. Por meio de telegrama ressaltava que neste protesto houve vários militantes que criticavam não só o regime como o preconceito racial. $^{239}$

As atividades permaneciam sob vigilância acirrada. Analisando o Boletim do Grupo Negro da PUC-SP ${ }^{240}$ consta uma sessão de Atividades do período de junho de 1982 a junho de 1983 que apresenta um cronograma dos movimentos negros, abrangendo o II Encontro Estadual das Entidades Negras, um ato público contra o apartheid, o Encontro Nacional Afro-brasileiro, o Congresso de Cultura Negra das Américas, um baile, do Burro Negro, o XI Congresso de Comunicadores Sociais, um debate sobre "mulher negra e a libertação política do negro", o Festival Comunitário Negro Zumbi (FECONEZU), debates e trabalhos do ciclo básico da PUC-SP, semana do calouro PUC-SP, com exibição do filme “O negro da senzala ao soul”, de Gabriel Priori Neto, manifestação do Dia do Trabalho, ato público pelo Dia Nacional de Denúncia Contra o Racismo, e debates em escola públicas. ${ }^{241}$ Interessante notarmos que essas atividades destacadas pelo Grupo Negro da PUC-SP, na sua maioria foram registradas nos documentos do DEOPS/SP.

Por visar combater o discurso e ação política dos movimentos negros, um outro mecanismo utilizado foi o de levantar suspeitas de ligações do MNU com o PCB. Como no informe da II Seção do II Exército, de 2/7/1981, acerca de reunião (em casa alugada por José Antonio Souza Pinto Neto, professor de tênis e fotógrafo) para planejamento de uma operação de coordenação entre o PCB e o MNU para assalto conjunto. Portanto, ao inimigo do conflito principal soma-se um outro inimigo que poderia fortalecer a luta "comunista". Essa ligação encontraria articulações inter-estaduais, nesta reunião deveriam comparecer

\footnotetext{
${ }^{238}$ Panfleto do MNUCDR de divulgação de ato público. Dossiê 20-C-44- 6250. DEOPS/SP, DAESP.

${ }^{239}$ Telegrama n. 9324/79. Dossiê 20-C-44- sem número. DEOPS/SP, DAESP.

${ }^{240}$ O Grupo Negro da PUC-SP nasceu dos estudantes afro-descendentes dessa instituição ao constatarem a pequena parcela de estudantes negros e buscarem resgatar as "raízes culturais" que acreditavam que se perderiam na formação acadêmica e atuarem na comunidade afro-brasileira. Panfleto "Negros", de 5/5/1979, em manuscrito. Dossiê 21-Z-14- 6825. DEOPS/SP, DAESP.

${ }^{241}$ Boletim III do Grupo Negro da PUC-SP, p. 30. Pasta Movimento Negro. CEDIC/PUC-SP.
} 
Murilo da Costa Ferreira (do Rio de Janeiro) e o angolano Tierno Gueye (que também morava no Rio de Janeiro), constante em São Paulo. ${ }^{242}$

A proposta dos militantes do MNU formarem um partido político, como Celso Prudente, certamente preocupava os aparelhos repressivos do regime militar, ainda mais que esta acompanhava claramente um objetivo revolucionário marxista. Um partido com uma bandeira racial já havia sido monitorado pelo DEOPS/SP na década de 1930, a Frente Negra Brasileira, o que gerou preocupação sobre sua ação, embora de curta duração, já que foi fechado com o golpe de 1937 junto com os outros partidos vigentes naquela época. ${ }^{243}$ Por outro lado, a comunidade de informações e segurança diante dessa nova proposta partidária na década de 1970, apreciou a como inócua, por estes militantes afrodescendentes serem uma minoria dentro do MNU, demonstrando divergências internas. ${ }^{244}$

Um segundo exemplo foi o da Frente Negra para a Ação Política de Oposição (FRENAPO) e de suas possibilidades de uma atuação político-partidária, questão que a tornava subversiva aos olhos da polícia política. ${ }^{245}$ Sobre a FRENAPO, um relatório confidencial revelava que "Seu posicionamento quanto aos negros africanos indica vínculos e orientações internacionais." 246 A proposta do vereador Nilton Santos, da FRENAPO, a criação de uma Frente Nacional Livre que fosse partidária do "poder negro" brasileiro, apresentava proximidade com discurso do "black power" dos movimentos afroamericanos, classificados como "subversivos" pelo regime militar.

Da mesma forma, Hamilton Bernardes, pertencente ao Núcleo Negro Socialista e redator do periódico Versus, apresentava em discurso no Ato Público contra o racismo, organizado pelo MNCDR, em 1979, a proposta de que o Núcleo Negro deveria lutar pelo

\footnotetext{
${ }^{242}$ Informe da II Seção do II Exército, de 2/7/1981, assunto plano de assalto conjunto : subversivos e marginais. Dossiê 30-C-1- 24941. DEOPS/SP, DAESP.

${ }^{243}$ KOSSLING, K. Movimentos Negros: Identidade Política, Identidade Étnica (1924-1954). Iniciação Científica São Paulo: Fapesp, 2004.

${ }^{244}$ Relatório de investigações n. 501 de investigador estagiário da Divisão de Ordem Política do DEOPS/SP para delegado titular, de 7/8/1980. Dossiê 20-C-44- 11939. DEOPS/SP, DAESP. Relatório de investigações n. 498 de investigador estagiário da Divisão de Ordem Política para delegado titular, de 6/8/1980. Dossiê 21-Z14- 9490. DEOPS/SP, DAESP. 245

Relatório confidencial sobre a FRENAPO, de 18/7/1980. Dossiê 50-Z-130- 3803. DEOPS/SP, DAESP.

${ }^{246}$ Relatório confidencial sobre a FRENAPO, de 18/7/1980. Dossiê 50-Z-130- 3802. DEOPS/SP, DAESP.
} 
poder, tendo sua atuação política constantemente cerceada pelas estruturas repressivas do DEOPS/SP nos diversos governos a que esse órgão prestou seus serviços. ${ }^{247}$

Mas essas propostas parecem ter sido minoria entre os movimentos negros que, em geral, não propunham idéias de rompimento social. É possível observar que a deputada Theodosina Rosário Ribeiro, do PDS, em discurso proferido na Assembléia Legislativa, em 13 de abril de 1981, apresentou a noção de integração racial: "na qualidade de representante que somos, nesta Casa, da comunidade afro-brasileira, que vem emprestando nossos esforços para o soerguimento de uma sociedade forte e próspera que se aproximará do ideal, à medida da realização de uma completa integração racial em seu bojo..." 248 Da mesma forma, nos documentos do MNU encontramos formulações similares: "Somos integrantes desta sociedade e queremos transformá-la. E começamos por combater o racismo e a discriminação social, a exploração e exclusão sócioeconômica, desta sociedade, onde a divisão de classes, corresponde a uma divisão e discriminação racial." ${ }^{249}$ Comprovando que os movimentos negros, em sua maioria, não pretendiam um rompimento radical com as estruturas vigentes o MUCDR enviou ao diretor do DEOPS, em 4/7/1978, carta repudiando atos de violência e discriminação racial, buscando garantir ação legal de seu protesto. ${ }^{250}$

Ao recuperar a visão dos movimentos negros torna-se evidente que eles não apresentavam um objeto constante. Aspecto que levou aos investigadores do DEOPS em seus relatórios os qualificarem de desorganizados e atribuir aos seus debates classificação de precário. O que por certo colaborou para uma repressão mais branda sem prisões e processos judiciais diretamente relacionados aos movimentos negros. ${ }^{251}$

Porém, seria arbitrário estabelecer uma relação mecânica (e repetitiva) entre prática e os discursos que a engendram. Consta de um outro Relatório de investigações que: "De maneira geral todos os grupos negros acima mencionados contam com apoio direto ou indireto de um grupo de base, este mais bem estruturado e com elementos gabaritados,

\footnotetext{
${ }^{247}$ Relatório de observação da Divisão de Informações do DEOPS, de 17/10/1979. Dossiê 21-Z-14- 7947. DEOPS/SP, DAESP.

${ }^{248}$ Discurso proferido na Assembléia Legislativa a deputada Theodosina Rosário Ribeiro, do PDS, em 13 de abril de 1981, p. 2. Dossiê 20-C-44-23971. DEOPS/SP, DAESP.

${ }_{249}$ Manifesto Nacional. Dia Nacional da Consciência Negra, MNU. Dossiê 20-C-44- 14605. DEOPS/SP, DAESP.

${ }^{250}$ Juntada de informações sobre o MNUCDR ou MUCDR. Dossiê 52-Z-0- 28559. DEOPS/SP, DAESP.

${ }^{251}$ Relatório de investigador não identificado da Ordem Política para delegado titular, de 5/8/1980, fl. 2. Dossiê 20-C-44- 11829. DEOPS/SP, DAESP.
} 
bastante conhecido no meio negro paulista [...]" ${ }^{252}$ Neste caso, a vigilância cerrada a esses movimentos era considerada necessária.

Vale chamar atenção, em particular, para a forma pela qual o embate políticoideológico ocorria naquela conjuntura. Buscando impor uma concepção particular de como a realidade brasileira é em sua essência, os aparelhos repressores buscavam o controle total. A espionagem realizada pelos investigadores acompanhava todos os passos dos participantes dos eventos, como no ato público organizado pelo MNU, em 13 de maio de 1981, controlado por um tenente coronel da PM que anotou os nomes de oradores, suas palavras, trajetos, entidades participantes, palavras de ordem da multidão, panfletos distribuídos, carros em trânsito, além de outros dados. ${ }^{253}$ Tudo era observado em minúcia, minuto a minuto, e relatado pelo investigador aos seus superiores, delegados do seu setor. Estes por sua vez retransmitiam o que entendiam ser mais importante para as autoridades de outros órgãos. ${ }^{254}$

A vigilância era constante e os investigadores do DEOPS permaneciam atentos a todas as formas de divulgação dos movimentos sociais fossem jornais, impressos ou televisivos. Por exemplo, o jornal do Canal "13", de 21 de novembro de 1979, que apresentava uma notícia sobre o dia Nacional da Consciência Negra e as manifestações do MNU, foi notificada pelo analista do setor de documentação eletrônica da Divisão de Informações do DEOPS. $^{255}$

Ao analisar a vigilância e a repressão policial e militar, ao longo do século XX, notamos que, em geral, os afro-descendentes foram passíveis de intolerância política e exclusão social. Quanto aos movimentos negros que se mobilizaram contra o racismo, eram alvos de condenação (por existirem) e de repressão (por suas atuações).

\footnotetext{
${ }^{252}$ Relatório de investigações n. 501 de investigador estagiário da Divisão de Ordem Política do DEOPS/SP para delegado titular, de 7/8/1980, fl 2. Dossiê 20-C-44- 11938. DEOPS/SP, DAESP.

${ }^{253}$ A PM também participava das ações coordenadas pelos setores de informação e segurança do regime militar.

${ }^{254}$ Mensagem sobre Sumário de Informações n. 035/4 sobre Ato Público do MNU, de 13 de maio de 1981. Dossiê 50-D-18- 2850. DEOPS/SP, DAESP.

${ }^{255}$ Relatório do plantão do dia 21/11/1979 para o delegado titular, fl 1. Dossiê 40-Z-13- 2956. DEOPS/SP, DAESP.
} 


\section{II - OS DISCURSOS POLICIAL E MILITAR}

\section{1) Os discursos sobre o negro: estigmas e estereótipos}

"Certa vez Sartre escreveu sobre a questão negra. Ali, ele falava uma coisa inesquecivel, e que eu vou citar de memória... 'O que vocês esperavam ouvir quando estas bocas negras se vissem livres das mordaças? Que gritassem frases doces, amenas?' Será que estas 'mordaças' estão sendo arrancadas no Brasil? Sim, então. Foi o que vimos em São Paulo, numa noite histórica. Bocas negras gritando contra a injustiça e a opressão. Punhos erguidos, no lusco-fusco daquele momento em que, numa grande cidade, os homens cansados vão para casa. Não se ouviram frases amenas -e é bom que tenha sido assim. À humilhação de séculos, só o duro estômago do povo poderia resistir." ${ }^{256}$

Por meio da documentação policial e militar pudemos conhecer a visão das instituições de vigilância e repressão brasileiras sobre as mobilizações dos afrodescendentes. Neste item procuramos tratar das construções do pensamento policial e militar acerca do afro-descendente, identificando estigmas e estereótipos que influíram na ação repressiva.

Segundo Castoriadis as sociedades constroem seu universo por meio da relação entre o histórico e o imaginário. ${ }^{257}$ Nesse sentido, a herança das relações assimétricas provindas da escravidão produziu um histórico e um imaginário sobre as representações simbólicas dos negros na sociedade brasileira. O imaginário torna-se "uma peça efetiva e eficaz do dispositivo de controle da vida coletiva e, em especial, do exercício da autoridade e do poder. Ao mesmo tempo, ele torna-se o lugar e o objeto dos conflitos sociais.” 258

Esse conceito tem relevância para nosso estudo, uma vez que o racismo presente na sociedade brasileira construiu, ao longo de séculos de uma convivência hierarquizada e violenta, seja físico ou simbólico, um imaginário negativo sobre os afro-descendentes. Nesta perspectiva, é necessário considerar desde as violências físicas dos tempos da escravidão (como os castigos corporais), até a violência policial sobre os afro-descendentes

\footnotetext{
${ }^{256}$ FAERMAN, Marcos. "Histórias" In Versus, n. 23, julho e agosto de 1978, p. 1. Dossiê 50-K-6- sem número doc. DEOPS/SP, DAESP.

257 “O imaginário de que falo não é imagem de. É criação incessante e essencialmente indeterminada (socialhistórica e psíquica) de figuras/formas/imagens, a partir das quais somente é possível falar-se de 'alguma coisa'. Aquilo que denominamos 'realidade' e 'racionalidade' são seus produtos.” In CASTORIADIS, C. $A$ Instituição imaginária da sociedade. Rio de Janeiro: Paz e Terra, 1982, p. 13. Desse modo, o imaginário organiza a visão de mundo de determinada sociedade, uma vez que se constitui enquanto um "mundo" de significações.

${ }^{258}$ BACZKO, B. "Imaginação Social” In Enciclopédia Einaud, vol 5. Lisboa: Imprensa Nacional e Casa da Moeda, 1985, p. 310.
} 
identificados a priori como suspeitos e, portanto, sujeitos a tratamentos desiguais, afetando-os física e moralmente. Além disso, toda uma gama de representações que se configuram em injúrias no cotidiano acerca dos afro-descendentes, como "macaco" ou "vagabundo", que derivam desse imaginário que se constrói por meio de estereótipos e estigmas, demarcando fronteiras sociais. ${ }^{259}$

Houve um caráter elitista e autoritário na produção das Forças Armadas, sendo que este elitismo e autoritarismo se fazem presente em todo o pensamento político brasileiro desde o Império. O receio à mobilização e à reunião de afro-descendentes em associações de solidariedade étnica, por exemplo, remonta a segunda metade do século XIX. E, espantoso constatar que o discurso sustentado pelas instituições de informação e repressão envolvidas no regime militar apresentou idéias similares as do Conselho do Brasil Imperial. ${ }^{260}$ As imagens estereotipadas sobre essa população penetraram de forma diversificada ao longo do tempo e também se apresentaram na prática das autoridades envolvidas com a repressão política do DEOPS/SP.

Além disso, nem a vigilância aos movimentos negros brasileiros, por parte do DEOPS/SP, foi iniciada com o período militar. A atuação vigilante e repressiva às associações negras ocorreu, em geral, desde a década de 1930 e era sustentada por uma mentalidade policial que definia essas associações como "introdutoras" da questão racial no Brasil e, por conseqüência, geradora de conflitos que poderiam desestabilizar a “democracia racial brasileira." ${ }^{261}$ Nesse quadro social, nota-se que o imaginário fornece "um sistema de orientações expressivas e afetivas que correspondem a outros tantos estereótipos oferecidos aos agentes sociais: ao individuo relativamente ao seu grupo

259 GUIMARÃES, A. "O insulto racial: as ofensas verbais registradas em queixas de discriminação" In Estudos afro-asiáticos, n. 38. Rio de Janeiro: Centro de Estudos afro-asiáticos, dezembro de 2000, pp. 3148.

${ }^{260}$ No ano de 1875 , conforme o autor Flávio Gomes relata a rejeição do Conselho de Estado do Império ao estatuto da Associação Beneficente Socorro Mútuo dos Homens de Cor justificava que: "Os homens de cor, livres, são no Império cidadãos que não formam classe separada, e quando escravos não têm direito a associar-se. A Sociedade especial é pois dispensável e pode trazer os inconvenientes da criação do antagonismo social e político: dispensável, porque os homens de cor devem ter e de fato têm admissão nas Associações Nacionais, com é seu direito e muito convém à harmonia e boas relações entre os brasileiros." GOMES, F. Negros e política (1888-1937). Rio de Janeiro: Jorge Zahar, 2005, p. 9.

${ }^{261}$ Estudo foi realizado por mim em Iniciação Científica (financiado pela FAPESP e orientado pela Prof ${ }^{a}$. Dr ${ }^{\mathrm{a}}$. Maria Luiza Tucci Carneiro) com a documentação do DEOPS: Movimentos Negros: Identidade étnica, Identidade política (1924-1950) In Série Inventários, organizada pela Prof ${ }^{\mathrm{a}}$. Dr ${ }^{\mathrm{a}}$. Maria Luiza Tucci Carneiro. (no prelo) 
social; aos grupos sociais relativamente à sociedade global, às suas hierarquias e relações de dominação" 262

Com a Frente Negra Brasileira, fundada em 1931, "com o ideal de União PolíticoSocial da Raça" 263, um movimento de repercussão nacional que em 1936 se inscreveu como partido político e extinta com o golpe de 1937 de $\operatorname{Vargas}^{264}$ - o receio aos "conflitos raciais" aumentou na atuação da polícia política. A preocupação com possíveis "conflitos raciais" como os encontrados em outros países, como nos Estados Unidos, levou as elites exaltarem o processo de miscigenação, visando "anular a superioridade numérica do negro e ao alienar seus descendentes mestiços graças à ideologia de branqueamento, ia evitar os prováveis conflitos raciais conhecidos em outros países, de um lado, e, por outro, garantir o comando do País ao segmento branco, evitando a sua 'haitinização'., 265

O sociólogo norte-americano Franklin Frazier observou, em visita ao Brasil, após a II Guerra Mundial, que "Parece haver um entendimento não expresso entre todos os elementos da população para não discutir a situação racial, pelo menos como fenômeno contemporâneo." ${ }^{266}$ Ao generalizar para "toda a população", notamos que essa questão preocupante no período do regime militar, cresceu justamente quando os movimentos negros "quebraram" com o silêncio sobre as desigualdades presentes na sociedade brasileira e, assim, foram considerados subversivos.

Da mesma forma, o pesquisador norte-americano Smith apresentou alguns princípios presentes na questão racial brasileira: "1) Não deve ser admitido, em nenhuma circunstância, que existe discriminação racial no Brasil; e 2) qualquer expressão que possa surgir de uma discriminação racial deve ser atacada como não-brasileira." ${ }^{267} \mathrm{E}$

\footnotetext{
${ }^{262}$ BACZKO, B. "Imaginação Social” In Enciclopédia Einaud, vol 5. Lisboa: Imprensa Nacional e Casa da Moeda, 1985, p. 311.

${ }^{263}$ Marcos Rodrigues dos Santos "O que pretendem os frente-negrinos brasileiros com o nome Frente Negra Brasileira", A Voz da Raça 3/2/1937. Microfilmes Jornais Negros Brasileiros, IEB/USP.

${ }^{264}$ KOSSLING, K. Movimentos Negros: Identidade étnica e Identidade política (1924-1954). Iniciação Científica: FAPESP, 2001-2003.

${ }^{265}$ MUNANGA, K. Rediscutindo a mestiçagem no Brasil: identidade nacional versus identidade negra. Belo Horizonte: Autêntica, 2004, p. 87. Lembramos que o autor se refere ao Haiti onde se realizou uma das maiores revoltas dos escravos negros, acarretando a expulsão dos brancos. O exemplo do Haiti constitui-se em verdadeiro pavor para os senhores de escravos no Brasil.

${ }^{266}$ NOGUEIRA, O. Tanto preto quanto branco: estudos de relações raciais. São Paulo: T.A. Queiroz, 1985, p. 42.

${ }^{267}$ NOGUEIRA, O. Tanto preto quanto branco: estudos de relações raciais. São Paulo: T.A. Queiroz, 1985, p. 42.
} 
exatamente o que observamos na documentação policial, ao ser referir a atuação dos movimentos negros como introdutores de uma questão "alienígena" ao país.

Com o "protesto negro" apresentando reivindicações sociais, houve a formação de um imaginário de um crescente "perigo" de conflitos raciais que se disseminou entre as elites e as instituições de repressão política do Estado. Além disso, os movimentos negros ao recusarem valores e idéias do regime militar para afirmar valores de uma cultura de resistência negra apresentaram conflitos tanto nas práticas sociais e políticas, como no campo das representações. ${ }^{268}$

Assim, "ao produzir um sistema de representações que simultaneamente traduz e legitima a sua ordem, qualquer sociedade instala também 'guardiães' do sistema que dispõem de uma certa técnica de manejo das representações e símbolos." ${ }^{269} \mathrm{Com}$ isso, o discurso sobre o negro foi construído por imagens, formando um imaginário sobre o que é "ser negro" na sociedade brasileira. O que esteve na base da construção de um poder simbólico ${ }^{270}$ que alimentou contínuas violências em relação aos afro-descendentes ao apresentá-los como “inferiores”. O imaginário possui funções múltiplas e complexas na vida coletiva e no exercício do poder, em particular, no poder político que é exercido servindo-se de representações coletivas, entrelaçadas a um conjunto de manifestações simbólicas. ${ }^{271}$ Essas representações apresentam-se de forma mais clara no emprego de palavras e frases estereotipadas que se transformam "em dado indicativo a de uma situação que, neste caso, comprova a persistência de uma mentalidade racista." 272 Ao mesmo tempo, a polícia política tornava-se "guardiã" do sistema, utilizando-se dessas representações para construção de um projeto de nação brasileira.

\section{"Democracia Racial"}

Historiadores ao descreverem o mito da "democracia racial" preferem usar o termo "mito do paraíso racial" referindo-se a utopia que o termo visa apresentar, uma vez que

\footnotetext{
${ }^{268}$ CAPELATO, M. e DUTRA, E. "Representação política: reconhecimento de um conceito na historiografia brasileira", p. 250.

${ }^{269}$ BACZKO, B. “Imaginação Social” In Enciclopédia Einaud, vol 5. Lisboa: Imprensa Nacional e Casa da Moeda, 1985, p. 299.

${ }^{270}$ Para Baczko o poder simbólico consiste em duplicar e reforçar a dominação efetiva pela apropriação dos símbolos e garantir a obediência pela conjugação das relações de sentido e poderio. BACZKO, B. "Op. Cit., p. 299.

${ }^{271}$ BACZKO, B. Op. Cit., p. 297.

${ }^{272}$ CARNEIRO, M. L. T. "O discurso da Intolerância - fontes para o estudo do racismo" In Fontes Históricas: Abordagens e Métodos. Assis/ SP: Faculdade de Ciências e Letras UNESP, 1996, p. 23.
} 
“democracia racial" se encontra envolto em significados específicos em diferentes períodos históricos. ${ }^{273}$ No entanto, utilizamos aqui "democracia racial", visando mapear a sua construção e utilização ao longo do regime militar, uma vez que este termo, de forma diversa, esteve presente tanto nos discursos do regime como nos movimentos negros.

No quadro de debate da questão racial brasileira, a mestiçagem foi questão importante para os pensadores, desde o século XIX até a década de 1930. O discurso da mestiçagem, particularmente na década de 1930, na América Latina, visava responder as formulações européias do racismo científico que entendiam a mestiçagem como degeneração. ${ }^{274}$ Assim, o resgate da mestiçagem como um valor positivo serviu para a construção de uma nacionalidade que poderia dar certo, contrariando as visões dos teóricos europeus. Gilberto Freyre, no Brasil, foi o grande expoente dessa tendência e consolidou uma visão acerca das relações raciais brasileiras, destacando uma formação "harmônica" dessa mistura, no âmbito da "fábula das 3 raças". ${ }^{275}$ Freyre fez um elogio à colonização portuguesa, ressaltando o caráter original, multirracial da sociedade brasileira, visualizando no processo de colonização do Brasil contribuições sócio-culturais de todos os matizes raciais que formaram a cultura brasileira. Freyre apresentava o "mundo que o português criou" como "harmônico", "equilibrado" e "democrático". ${ }^{276}$

O mito da "democracia racial" integrou o imaginário sobre a sociedade brasileira e, de alguma forma, auxiliou a manter a mentalidade racista ${ }^{277}$ camuflada por trás desse discurso, ao mesmo tempo que auxiliava a garantir a ordem racial desigual no pós-abolição. ${ }^{278}$ "Democracia racial" foi uma importante representação social que fez parte da própria

\footnotetext{
${ }^{273}$ GUIMARÃES, A. Classes, Raças e Democracia. São Paulo: Ed. 34, 2002, p. 140.

${ }^{274}$ APPELBAUM, N.; MACPHERSON, A. e ROSEMBLATT, K. Race \& Nation in Modern Latin America. North Carolina: The University of North Carolina Press, p. 7.

${ }^{275}$ DA MATTA, R. Relativizando: Uma Introdução à Antropologia Social. Rio de Janeiro: Rocco, 2000.

${ }^{276}$ Freyre, entre agosto de 1951 e fevereiro de 1952, realizou viagem por Portugal e pela maioria das suas colônias, no período do regime salazarista, proferindo discursos e conferências, exaltando as características peculiares da colonização portuguesa. RAMPINELLI, W. As duas faces da moeda: as contribuições de JKe Gilberto Freyre ao colonialismo português. Florianópolis: Editora da UFSC, 2004.

${ }^{277}$ Utilizamos mentalidade racista para definir um conjunto de idéias que defenderam a superioridade e a inferioridade entre os homens, podendo ser de natureza preconceituosa ou discriminatória, em relação a indivíduos considerados racialmente distintos.

278 "while Freyre focused on how those ties underscored a consensual national order, his national myth could also be read as reinscribing racial hierarchy by equating it with gender hierarchy (and vice versa)" In APPELBAUM, N.; MACPHERSON, A. e ROSEMBLATT, K. Op. Cit., p. 16.
} 
identidade brasileira e, como um mito é "um conjunto de idéias e valores poderosos que fazem com que o Brasil seja o 'Brasil'(...), 279

Houve uma "gilbertização" 280 , isto é, a absorção dos cânones explicativos da obra Casa Grande \& Senzala pelo grupo no poder no pós-30. “Ante a necessidade de redefinir valores sociais, que, no pós-30, já não mais poderiam estar fundados nas doutrinas racistas anteriores, Casa grande \& senzala promove uma re-significação dos negros e mestiços, valorizando essa mão de obra e possibilitando sua utilização, num quadro menos conflituoso, pelo novo capitalismo brasileiro." ${ }^{281}$ Apresentando uma sociedade isenta de conflitos raciais e ressaltando a exuberância natural da formação social brasileira, organizaram-se idéias em contraponto às leituras preconceituosas sobre a formação racial da população brasileira. ${ }^{282}$ Deste modo, formou-se um mito fundador e fundamental a própria essência da "brasilidade". Os mitos nacionais são produtos de operações de seleção e transposição de fatos e traços escolhidos conforme os projetos de legitimação política.

Sobre o termo "democracia racial", Antônio Sérgio Guimarães adverte que " $a$ expressão, atribuida a Gilberto Freyre, não ser encontrada em suas obras mais importantes e de não aparecer na literatura especializada a não ser tardiamente, nos anos 50. " 283 Este termo, segundo Guimarães, foi cunhado por Roger Bastide, a partir da leitura de Freyre, em artigo para o Diário de São Paulo, em 31/3/1944. Porém, o próprio Freyre em suas conferências na Universidade da Bahia, desde 1943, usava a expressão “democracia étnica" para referir-se a uma suposta "tradição democrática brasileira". ${ }^{284}$

Gilberto Freyre, em conferência proferida em Lisboa, no ano de 1937, tratou dos "Aspectos da influência da mestiçagem sobre relações sociais e de cultura entre portugueses e luso-descendentes", destacando a existência de um "legado democrático" da civilização luso-brasileira utilizando-se da expressão: "democracia social através da

\footnotetext{
${ }^{279}$ FRY, P. "O que a cinderela negra tem a dizer sobre a 'política racial' no Brasil” In Revista USP. São Paulo: Coordenadoria de Comunicação Social USP, 1989, pp. 122-135, p. 134.

280 Expressão cunhada por Carlos Guilherme Mota In FICO, C. Reinventando o otimismo. Ditadura, propaganda e imaginário social no Brasil. Rio de Janeiro: Editora Fundação Getulio Vargas, 1997, p. 34.

${ }^{281}$ FICO, C. Reinventando o otimismo. Ditadura, propaganda e imaginário social no Brasil. Rio de Janeiro: Editora Fundação Getulio Vargas, 1997, pp. 34/35.

${ }^{282}$ FICO, C. Op. Cit., p. 78.

${ }^{283}$ GUIMARÃES, A. "Democracia racial” In OLIVEIRA, I. (org.) Relações raciais e educação: temas contemporâneos. Niterói: EdUFF, 2002, p. 35.

${ }^{284}$ GUIMARÃES, A. Op. Cit., p. 35.
} 
mistura de raças. ${ }^{, 285}$ Porém, Freyre somente fez uso do termo "democracia racial", em 1962, quando defendeu o colonialismo português na África, apresentando as suas idéias acerca do "luso-topicalismo". ${ }^{286}$ Dessa forma, também investiu contra "o que ele considerava como influência estrangeira sobre os negros brasileiros, particularmente o conceito de 'negritude'., 287

Perante as lutas de independência na África e o aumento de mobilização de afrodescendentes no Brasil, centrado no debate da "negritude", Gilberto Freyre manifestou-se não somente favorável à cultura "luso-tropical”, mas também contrário a "negritude": "Que afinidade com esses afroracistas, cruamente hostis ao mais precioso valor democrático que vem sendo desenvolvido pela gente brasileira - a democracia racial - pode haver da parte do Brasil? [...] Nós, brasileiros, não podemos ser, como brasileiros, senão um povo por excelência anti-segregacionista: quer o segregacionismo siga a mística da 'branquitude', quer siga o mito da 'negritude'. Ou o da 'amarelitude'., 288

Mesmo sem ter cunhado a expressão "democracia racial" as idéias de Freyre sempre foram associadas a ela, pois Freyre foi fortemente apontado como responsável pela legitimação científica da afirmação da inexistência de preconceitos e discriminações raciais no Brasil. 289 “O mito da democracia racial não nasceu em 1933, com a publicação de

\footnotetext{
${ }^{285}$ GUIMARÃES, A. Idem, p. 38.

${ }^{286}$ Luso-tropicalismo foi uma teoria de Gilberto Freyre, apresentada na obra $O$ mundo que o português criou (FREYRE, Gilberto. O Mundo que o Português criou: aspectos das relações sociais e de cultura do Brasil com Portugal e as colonias portuguesas. Rio de Janeiro: José Olympio, 1940), no qual exaltava a miscigenação promovida pelos portugueses em suas colônias como um dos principais traços da presença lusa nos trópicos, aliada a fatores "inerentes" dos portugueses que lhes conferia uma melhor adaptação ao clima e ao meio físico tropicais. O luso-tropicalismo constituiu um importante elemento no imaginário nacional português sobre a sua experiência colonial. A partir de 1950, Freyre escreveu dois livros, nos quais utilizou pela primeira vez a noção de luso-tropicalismo, e o estudo de sua obra foi introduzido no mundo acadêmico lusitano, especialmente no Instituto Superior de Ciências Sociais e Políticas, criado com vistas a formar quadros para administrarem as colônias. O luso-tropicalismo tornou-se uma interpretação da presença portuguesa em territórios tropicais que legitimava a continuidade do poder colonial português. RAMPINELLI, W. As duas faces da moeda: as contribuições de JK e Gilberto Freyre ao colonialismo português. Florianópolis: Editora da UFSC, 2004. e SANTOS, G. A invenção do "ser negro": um percurso das idéias que naturalizaram a inferioridade dos negros. São Paulo: Educ/ Fapesp; Rio de Janeiro: Pallas, 2002, p. 153.

${ }^{287}$ GUIMARÃES, A. Ibdem, p. 41.

${ }^{288}$ GUIMARÃES, A. Idem, Ibdem, p. 47.

289 GUIMARÃES, A. "Democracia racial" In OLIVEIRA, I. (org.) Relações raciais e educação: temas contemporâneos. Niterói: EdUFF, 2002, p. 46.
} 
Casa-Grande \& Senzala, mas ganhou, através dessa obra, sistematização e status científico - para os critérios de cientificidade da época." 290

As idéias de Freyre, mais tarde conhecidas sob o rótulo de "mito da democracia racial", eram sínteses do pensamento de toda uma época. Freyre ao valorizar a mestiçagem auxiliou na construção de uma identidade brasileira fundada na mestiçagem biológica e cultural. A este se associou o mito da "democracia racial", ressaltando que a mestiçagem teria ocorrido de forma harmônica, minimizando os conflitos raciais das relações desenvolvidas ao longo da escravidão no país e, por conseqüência, do pós-abolição. ${ }^{291}$ Necessário ressaltar que os mitos também marcam as contradições sociais e, no nosso caso, visou escamotear as diferenças sociais decorrentes da escravidão.

O mito político apresenta-se como polimorfo o que significa que "uma mesma série de imagens oníricas pode encontrar-se veiculada por mitos aparentemente os mais diversos; é preciso igualmente entender que um mesmo mito é suscetivel de oferecer múltiplas ressonâncias e não menos numerosas significações. ${ }^{292}$ Os mitos constituem respostas dadas pelas sociedades aos seus desequilíbrios, às tensões no interior da estruturas sociais. ${ }^{293}$ Desta forma, o mito da "democracia racial" visou conter as tensões decorrentes da nova situação pós-abolição e se propagou ao longo do século XX nas estruturas de poder. No regime militar, especificamente, também foi importante visando conter o protesto negro e possíveis conflitos raciais.

A mestiçagem também foi um valor importante para a identidade nacional que o regime militar valorizava e queria exaltar. O nacionalismo brasileiro de cunho autoritário ${ }^{294}$

\footnotetext{
${ }^{290}$ BERNARDINO, J. “Ação Afirmativa e a Rediscussão do Mito da Democracia Racial no Brasil” In Estudo Afro-asiático, v. 24, n. 2. Rio de Janeiro: Centro de Estudos Afro-asiático, 2002, p. 250.

${ }^{291}$ MUNANGA, K. Rediscutindo a mestiçagem no Brasil: identidade nacional versus identidade negra. Belo Horizonte: Autêntica, 2004, pp. 88-89.

${ }^{292}$ GIRARDET, R. Mitos e Mitologias Políticas. São Paulo: Cia. Letras, 1987, p. 15.

${ }^{293}$ BACZKO, B. "Imaginação Social” In Enciclopédia Einaud, vol 5. Lisboa: Imprensa Nacional e Casa da Moeda, 1985, p. 308.

${ }^{294}$ O nacionalismo visando a integração social e a formação de "consenso": "privilegia pontos em comum intenta, através deste, minimizar outros aspectos que estariam normalmente numa esfera conflitante e até irreconciliável." (In LEITE, R. A dupla face do nacionalismo no Brasil: Kubitschek e Médici. Dissertação de Mestrado. Recife: CFCH/UFPE, 1992, p. 88.) Assim, o nacionalismo seria um princípio que sustenta a unidade política e social. Os "vários nacionalismos diferem segundo as idéias e tradições políticas que representam." (In KONH, H. A Era do Nacionalismo. Rio de Janeiro, Fundo de Cultura, 1963, p. 24.) Encontramos no regime militar um nacionalismo pautado na identificação com o Estado-nação, ou seja, a nação como um Estado territorial, segundo formulação de Hobsbawm. (Hobsbawm, E. Nações $e$
} 
pautou-se na formulação do discurso de um povo mestiço e harmônico, visando mobilizar a população em torno da sua concepção sobre o país e homogeneizar em torno dos "interesses nacionais". Notamos que o nacionalismo, em seu caráter político, "defende a noção de que estado e nação devem estar em harmonia; e sua capacidade de ser um provedor de identidade para indivíduos cônscios de constituir um grupo baseado numa cultura, passado e projeto para o futuro comuns, bem como na fixação a um território concreto. $O$ poder do nacionalismo emana de sua habilidade para engendrar os sentimentos em torno de pertencer a uma comunidade especifica." 295

$\mathrm{O}$ nacionalismo brasileiro, nos moldes conservadores presentes no regime militar, apresentava a nação como um conjunto orgânico, uma unidade acima de qualquer conflito social. Esse nacionalismo enfatizava a defesa da ordem, da tradição, da integração e da centralização contra as forças da "desordem”. Dentro desse quadro, a nação seria intocável, envolta numa aura de objeto sagrado que deveria ser protegida das divisões do "corpo nacional". Apresentava-se uma concepção de nação "una e indivisível". ${ }^{296}$ Com uma mentalidade que não aceitava: "o povo dividido em classes, em regiões, em raças, em crenças, em grupos, em partidos, insuflado de ódios e preconceitos, mas o povo uno e indivisível, de uma só alma, uma só vontade -, integrado na comunhão da lei, da língua e da liberdade." 297

\footnotetext{
Nacionalismo desde 1780. Rio de Janeiro: Paz e Terra, 1990, p. 90.) Sobrepondo o Estado à Nação, configura-se como Montserrat Guibernau categorizou um "nacionalismo de estado". (In GUIBERNAU, M. Nacionalismos: o estado nacional e o nacionalismo no século XX. Rio de Janeiro: Jorge Zahar, 1997, p. 12.) O nacionalismo de cunho autoritário do regime militar apoiava-se num discurso de convivência pacífica para fortalecer a "unidade nacional" em prol de supostos "interesses da nação" ou "objetivos nacionais" e desse modo auto-afirmando o próprio regime como construtor desses interesses. Ao mesmo tempo, esse discurso nacionalista tinha uma intenção de mobilizar a sociedade para os projetos do regime de desenvolvimento calcado pela Doutrina de Segurança e Desenvolvimento visando alcançar o "Brasil - potência". O apelo à "unidade nacional" acabava por retirar do foco as desigualdades e os conflitos sociais do país, ressaltando que os conceitos de "nação" e "nacionalidade" para alguns militares eram entendidos como: Nação: "envolve tradicionalmente o elemento humano que habita determinada porção de terra, e o complexo de crenças, idéias e costumes, que se harmonizam e sistematizam, determinando os traços peculiares de cada grupo 'nacional'." (In MORAES FILHO, B. "Elementos básicos da nacionalidade: as instituições" In Segurança e Desenvolvimento, Ano XVII, n. 130. Rio de Janeiro: Associação dos Diplomados da Escola Superior de Guerra, 1968, pp. 50-60, p. 50.) Enquanto, que a nacionalidade traduziria "mais o espírito da nação, o conjunto dos valores éticos, que cumpre preservar em cada povo, não apenas como um complexo de princípios adotados e seguidos pelos integrantes do grupo, mas como a própria psicologia viva dos que formam a nação." (In MORAES FILHO, B. Op. Cit., p. 50.)

${ }^{295}$ GUIBERNAU, M. Op. Cit., p. 11.

${ }^{296}$ MOTTA, R. Em guarda contra o perigo vermelho. O anti-comunismo no Brasil (1917-1964). São Paulo: Editora Perspectiva, 2002, pp. 29/30.

${ }^{297}$ COSTA, O. Compreensão da Revolução Brasileira. Apud MOTTA, R. Op. Cit., p. 30.
} 
Visando alcançar a unidade nacional, o regime militar exaltava a mestiçagem como um elemento essencial da formação da sociedade brasileira. "O nacionalismo invoca um passado comum, e tanto seleciona como interpreta certos acontecimentos, para aumentar um sentido de coerência entre os membros de um dado grupo. O passado, o presente e o futuro se fundem para conferir à comunidade uma sensação de continuidade sobre a qual se funda o caráter transcendente da nação." ${ }^{298} \mathrm{O}$ patriotismo do regime militar reforçava os sentimentos e símbolos da "comunidade imaginária" brasileira em torno das idéias de mestiçagem e "democracia racial". ${ }^{299}$ Articulava sentimentos e símbolos que visam reforçar os laços por meio dessas idéias, ou seja, utiliza-se de representações sobre a nação. A formação mestiça da população e o mito da "democracia racial" formaram as representações próprias da identidade do que é "ser brasileiro".

O regime militar procurava consolidar uma definição de nação, entendida como "pátria" 300 , colocando-a em prática por meio de um projeto político de vigilância dos movimentos negros e propaganda de um Brasil harmônico, também racialmente. Percebe-se que para o regime a "Nação é uma vontade única, um projeto único." 301 Sob essa perspectiva, almejava-se uma nação homogênea, um todo sem conflitos. Os movimentos sociais tornavam-se "impertinentes", pois se sustentava "a idéia de que a identidade nacional é essencial para a estabilidade politica e implica em lealdade para com as instituições e práticas consuetudinárias do que se entende como nação. [...] A decorrência disso é que será considerado como algo desestabilizador o influxo e existência de grupos populacionais não comprometidos com essas instituições e que tenham como prioridade projetos como: a redistribuição de renda, o exercício do poder político e econômico, a deferência à diversidade étnica e cultural, a composição de uma nação multiétnica, etc. "302

Como destacava o manual da ESG, citando frase de Médici: "Segurança de uma comunidade não prospera na desigualdade entre os homens, na floração de privilégios, na

\footnotetext{
${ }^{298}$ GUIBERNAU, M. Nacionalismos: o estado nacional e o nacionalismo no século XX. Rio de Janeiro: Jorge Zahar Ed., 1997, p. 137.

${ }^{299}$ HOBSBAWM, E. Nações e Nacionalismo desde 1780. Rio de Janeiro: Paz e Terra, 1990, p. 111.

${ }^{300}$ MARTINS, R. Segurança Nacional. São Paulo: Brasiliense, 1986, p. 32.

${ }^{301}$ MARTINS, R. Op. Cit., p. 18.

${ }^{302}$ MIR, L. Guerra Civil: estado e trauma. São Paulo: Geração Editorial, 2004, p. 63.
} 
injustiça social, nem na desagregação entre raças e gerações" 303 Tornava a "democracia racial”, na feliz expressão de Antônio Sérgio Guimarães, em um "dogma” dos governos militares, visando evitar a "desagregação entre as raças". ${ }^{304}$ Sustentado na idéia de "unidade nacional" o regime militar desenvolveu também "um processo continuado $e$ violento de unificação política por meio de supressão das identidades étnicas discrepantes $e$ de opressão e repressão das tendências virtualmente separatistas, inclusive dos movimentos sociais que lutavam para edificar uma sociedade mais aberta e solidária." 305

O mito da "democracia racial" compôs o universo das idéias políticas no Brasil e foi elemento chave para o pensamento sobre o país, também no regime militar. "A partir de uma rápida alusão a Benedict Anderson (1983), poderíamos dizer que a comunidade que denominamos Brasil se imagina, entre outras coisas, a partir dos referidos ideais.” 306 Nesse sentido, o mito da democracia racial gerou uma "grande dificuldade da população negra no Brasil [...] justamente a questão do preconceito não ser considerado um problema.", 307

Por outro lado, a "democracia racial" tornou-se, em especial a partir da década de $1970^{308}$, em um "rótulo político" referente às idéias de Freyre, que as militâncias afrodescendentes combateram reivindicando a ampliação das liberdades civis. Parte dos movimentos negros, desde a década de 1970, tinha como uma das principais bandeiras o desmascarar da "democracia racial", que era vista como um empecilho à organização das lutas anti-racistas. ${ }^{309}$ Já outra parcela dos movimentos negros utilizava a "democracia racial" como uma bandeira de luta, um ideal, para que houvesse realmente uma efetivação dessa democracia.

\footnotetext{
303 Manual ESG, "Seção I - Segurança Nacional", "7- Conclusões" Apud ROCHA, M. A Evolução dos conceitos da doutrina da Escola Superior de Guerra nos anos 70. Dissertação de Mestrado. São Paulo: FFLH/USP, 1996. ANEXO 20, p. 239.

${ }^{304}$ Expressão utilizada por GUIMARÃES, A. Classes, Raças e Democracia. São Paulo: Ed. 34, 2002, p. 98.

${ }^{305}$ MUNANGA, K. Rediscutindo a mestiçagem no Brasil: identidade nacional versus identidade negra. Belo Horizonte: Autêntica, 2004, p. 108.

${ }^{306}$ BERNARDINO, J. “Ação Afirmativa e a Rediscussão do Mito da Democracia Racial no Brasil” In Estudo Afro-asiático, v. 24, n. 2. Rio de Janeiro: Centro de Estudos Afro-asiático, 2002, p. 252.

${ }^{307}$ GUIMARÃES, A. "O problema do racismo à brasileira". Entrevista In Informe: edição especial 19992001. São Paulo: SDI/FFLCH/USP, 2002, pp. 147-151.

${ }^{308}$ Em especial após a defesa de tese para titular da cadeira de Sociologia de Florestan Fernandes, em 1964, na USP.

${ }^{309}$ GUIMARÃES, A. Classes, Raças e Democracia. São Paulo: Ed. 34, 2002, p. 158.
} 


\section{"Democracia racial" versus a denúncia das lutas anti-racistas}

Relações de poder são disseminadas nas relações sociais, constituindo relações de força, que no domínio do imaginário coletivo sobre o contexto racial brasileiro fizeram-se presentes no embate entre os movimentos negros e o regime militar. Encontramos, a partir da década de 1970, uma luta simbólica e discursiva entre a aspiração de uma verdadeira “democracia racial” proposta pelos movimentos negros, utilizando ou não esse termo, como se apresenta na documentação policial de vigilância ao III Congresso Nacional do Movimento Negro Unificado: “o objetivo principal do Congresso Nacional era o de unificação real do Movimento, para levá-lo a lutar pela verdadeira 'democracia racial'..." 310, questão presente desde a fundação do MUCDR em 1978, por uma "autêntica democracia racial”. ${ }^{311}$ Em contraposição a defesa do regime militar da idéia de uma “democracia racial” supostamente já consolidada.

Os movimentos negros procuravam construir uma imagem positiva do afrodescendente, denunciando os mecanismos de racismo difuso presentes na sociedade brasileira, além de reivindicarem melhores condições sociais, visando garantir uma identidade "afro" no âmbito de uma sociedade plural.

Enquanto o discurso pautado no mito da "democracia racial" em conjunto com outros mitos, como a "exuberância natural", o "congraçamento social”, a "harmônica integração nacional", a "cordialidade" e a "festividade" do povo brasileiro, foram apropriados e resignificados pela propaganda do regime militar, em nome da idéia de unidade nacional. Não é demais reiterar que os governos militares utilizaram-se de "um discurso ético-moral com estrutura, teóricos e militantes que se apropriaram - via golpe(s) de Estado(s), não nos esqueçamos - do poder de conceituar o que era 'nacionalidade'. 'democracia', 'sociedade brasileira', 'cultura brasileira', 'economia brasileira' e assim por diante.", 312 Desta forma, procurou-se construir uma imagem positiva do Brasil, valorizando o que se consideravam as grandes "potencialidades" brasileiras. Nesta perspectiva, o “congraçamento racial” e a "integração nacional” foram temas caros à propaganda do

\footnotetext{
${ }^{310}$ Informe n. 89/Conseg/82 de Belo Horizonte de 19/04/1982, fl. 1. Ordem Social 1157 pasta 218 C. DEOPS/SP, DAESP.

${ }^{311}$ Carta aberta à população "Contra o Racismo", distribuída no Ato Público contra o Racismo, em 7/7/1978. Dossiê 50-Z-0- 14629. DEOPS/SP, DAESP.

312 Prefácio de Carlos Guilherme Mota In FICO, C. Reinventando o otimismo. Ditadura, propaganda e imaginário social no Brasil. Rio de Janeiro: Editora Fundação Getulio Vargas, 1997, pp. 11/12.
} 
regime militar, constitutivos do imaginário sobre o Brasil. ${ }^{313}$ Como podemos também observar na expressão de alguns militares, ressaltando uma "índole brasileira" para garantir o projeto de "Brasil potência": "A nossa índole, o nosso jeito tem de viger plenamente para fazermos desse país um país grande. "314

A propaganda política, as publicações e os discursos empregados pelo regime militar, além de serem a visão da realidade que o regime pretendia propagar, denotavam a percepção que o próprio poder tinha de si mesmo. ${ }^{315}$ Afinal, o imaginário intervém na esfera do poder, "exercer um poder simbólico não consiste meramente em acrescentar o ilusório a uma potência 'real', mas sim em duplicar e reforçar a dominação efetiva pela apropriação dos símbolos e garantir a obediência pela conjugação das relações de sentido e poderio." 316

Reiteramos que Baczko, em Imaginação Social, estudou o imaginário imbricado na política e no poder, constatando que o imaginário é também objeto de disputa de poder. Assim, se politiza o imaginário sustentando que o imaginário fornece sentidos à realidade social, legitimando o poder e também podendo se tornar um terreno de conflito. Por meio "dos seus imaginários sociais, uma coletividade designa a sua identidade; elabora uma certa representação de si; estabelece a distribuição dos papéis e das posições sociais; exprime e impõe crenças comuns; constrói uma espécie de código de 'bom comportamento', designadamente através da instalação de modelos formadores. "317 $\mathrm{O}$ imaginário sobre a sociedade brasileira construído pelo regime militar entrava em choque com as aspirações e o imaginário construído pelos militantes afro-descendentes.

As políticas nacionalistas desenvolvidas pelo regime militar desconsideravam a possibilidade da afirmação de uma identidade afro-brasileira nos moldes propostos pelos movimentos negros daquele período. O "protesto negro" nesse contexto político-social trazia à tona a desigualdade racial, pondo em xeque a massificação presente nos projetos políticos dos órgãos governamentais. Assim, a denúncia do racismo, a articulação de

\footnotetext{
${ }^{313}$ FICO, C. Reinventando o otimismo. Ditadura, propaganda e imaginário social no Brasil. Rio de Janeiro: Editora Fundação Getulio Vargas, 1997, pp. 17 e 127.

${ }^{314}$ Memória de Leônidas Pires Gonçalves In ARAÚJO, M. e SOARES, G. e CASTRO, C. Os anos de chumbo: a memória militar sobre a repressão. Rio de Janeiro: Relume - Dumará, 1994, p. 256.

${ }^{315}$ FICO, C. Op. Cit., p. 20.

316 BACZKO, B. "Imaginação Social" In Enciclopédia Einaud, vol 5. Lisboa: Imprensa Nacional e Casa da Moeda, 1985, pp. 298/299.

${ }^{317}$ BACZKO, B. Op. Cit., p. 309.
} 
gestos, músicas, visuais, comportamentos, religiosidades, enfim, o cultivo de formas de representações próprias, ligadas à ascendência africana, levava a formulação de uma cultura de resistência fundada em signos e símbolos identitários afro-brasileiros que ganharam ares subversivos para as autoridades policiais e militares.

As lutas de representações no caso desta pesquisa, apresentam duas posições que se opõem, reivindicando para si, cada uma delas, as representações sobre as relações sociais brasileiras, que se traduzem no poder de estabelecer visões e sentidos à organização social As lutas de representações formam estratégias de força pela definição imaginária da sociedade, com diferentes projetos sociais. Desse modo, apresentam concorrências em termos de poder e dominação, em que um grupo busca impor sua concepção de mundo, os seus valores, enfim, a hegemonia do seu pensamento. O que está em jogo nas lutas de representações é a ordenação, ou seja, a hierarquização da estrutura social. ${ }^{318} \mathrm{~A}$ identidade afro-descendente que se desenvolveu a partir de 1960 concorreu e se contrapôs a identidade que o regime militar sustentava, do Brasil "harmônico" e "racialmente igualitário". Por outro lado o regime militar negava uma identidade "afro-centrada", com uma formulação de poder e apropriação simbólica sobre o "ser negro" e o "ser brasileiro". Concorria a atribuição de uma identificação pelo regime militar versus uma identificação dos grupos afro-brasileiros.

Durante o regime militar a preocupação com a identidade nacional constituiu-se num dos pilares da política dos governos militares que visava identificar os "valores brasileiros". ${ }^{319}$ A formulação da identidade se dava com base numa idéia de "missão civilizadora" que os militares se viam imbuídos e que "se expressou, portanto, através da firme convicção de estarem construindo um novo patamar econômico, político e moral para o Brasil." 320

Qualquer divisão ou dissenso era visto de forma negativa e o mito da "democracia racial" foi utilizado em alguns documentos do regime militar para afastar a divisão na qual, os militares e policiais acreditavam ser a "congregação racial" brasileira. Como exemplo, a formulação numa publicação militar:

\footnotetext{
${ }^{318}$ CHARTIER, R. A História Cultural. Entre práticas e representações. Lisboa: Difel, 1990, p. 23.

${ }^{319}$ FICO, C. Reinventando o otimismo. Ditadura, propaganda e imaginário social no Brasil. Rio de Janeiro: Editora Fundação Getulio Vargas, 1997, p. 36.

${ }^{320}$ FICO, C. Op. Cit., p. 41.
} 
"psicologia brasileira que preside o caldeamento das raças em nosso País: a ausência de um verdadeiro preconceito racial, de que só encontramos paralelo em Cuba, antes do regime do ditador Castro. Com um orgulho racial muito reduzido o brasileiro gloria-se antes de não possuir um vero (sic) preconceito de raças. As distinções sociais derivam ainda de um remanescente espirito de nobreza, caracterizado hoje pelas diferenças de poder econômico, e pelo nível de educação, de mais fortemente distingue pessoas o grupo no Brasil. Mas a isto não se pode chamar 'preconceito racial", ${ }^{321}$

A "inexistência" do preconceito racial seria, na mentalidade do regime, parte do "caráter nacional". Estimulando a idéia de que "somos todos brasileiros", de forma similar ao que se articulou com o slogan "Brasil, ame-o ou deixe-o", o nacionalismo do regime visava reforçar a "união" e a "harmonia" do país. ${ }^{322}$ Numa preocupação de reiterar a "tendência" brasileira à "tolerância" em relação às diferenças raciais, exaltava-se um "Brasil mestiço", no qual "não existiria" e "nem poderia existir" a discriminação racial. ${ }^{323}$ Esse tipo de pensamento foi a base que norteou os procedimentos dos governos militares perante as lutas anti-racistas.

Por outro lado, “os movimentos políticos negros no Brasil, depois de 1978, ressurgem a partir da reelaboração da tradição de resistência negra inscrita internacionalmente no pan-africanismo de DuBois, no afro-centrismo de Diop, no anti-colonialismo de Fanon e no quilombismo de Abdias do Nascimento. Durante toda a década de 1980, o 'mito da democracia racial' será denunciado sistematicamente como um dogma da 'supremacia branca' no Brasil." ${ }^{324}$ Ainda que nesse período houvesse discursos de movimentos negros que defendiam a luta por uma "autêntica" ou "verdadeira" "democracia racial" como um ideal a ser alcançado ${ }^{325}$, gradativamente os movimentos negros passaram a denunciar o

321 MORAES FILHO, B. "Elementos básicos da nacionalidade as instituições" In Segurança e Desenvolvimento, Ano XVII, n. 130. Rio de Janeiro: Associação dos Diplomados da Escola Superior de Guerra, 1968, pp. 50-60, p. 53.

322 "Objetivando reforçar a imagem do Brasil como nação próspera e forte. Os conhecidos slogans 'Para frente Brasil', 'Ninguém Segura Mais Este País' ou 'Ame-o ou deixe-o'são, no entanto, apenas ilustrações de um complexo esquema de propaganda que objetivava difundir as diretrizes políticas do Governo, orientadas pela Doutrina da Segurança Nacional." In LEITE, R. A dupla face do nacionalismo no Brasil: Kubitschek e Médici. Dissertação de Mestrado. Recife: CFCH/UFPE, 1992, p. 165.

${ }^{323}$ SANTOS, J. "Ações afirmativas e ditadura militar: imagens e propostas" In evento The Cultures of Dictatorship: Historical Reflections on the Brazilian Golpe of 1964, University of Maryand, 14-16 de outubro de 2004. (html/www.history.umd.edu/Historycenter/2004-05/conf/Brazil64/program), p. 33.

${ }^{324}$ GUIMARÃES, A. "Democracia racial" In OLIVEIRA, I. (org.) Relações raciais e educação: temas contemporâneos. Niterói: EdUFF, 2002, p. 50.

${ }^{325}$ Entre outros exemplos de documentos que se referem a luta por uma "real democracia racial" temos o panfleto redigido pela Convergência Socialista que entre outras pautas defendia "Pela democracia racial pelos direitos dos trabalhadores negros". OS 1061. DEOPS/SP, DAESP. E o informe policial que relata o III Congresso Nacional do MNU, de abril de 1982, em que Dalmir Francisco da Costa, segundo a documentação do CONSEG/MG, abriu o congresso afirmando ser o objetivo principal deste a "unificação real do 
mito e a combatê-lo de forma mais veemente, como, por exemplo, o Grupo Negro da PUCSP, que via de forma crítica a "democracia racial": "ideologia dos dominadores que tentam sustentar o mito da 'democracia racial' e esconder os mecanismos racistas que exploram a maioria da população brasileira, o negro." ${ }^{326}$ Por sua vez, em outro trecho: "não é contraditório que o governo brade a quatro cantos a harmonia racial e nada faça contra a reprodução de situações racistas vivenciadas cotidianamente pela comunidade negra." 327 O Grupo Negro da PUC-SP identificava a "democracia racial" como uma ideologia ${ }^{328}$ e denunciava uma "política racial demagógica" do governo, que "pretende adormecer a identidade cultural de homens e mulheres negras desmobilizando-os.", 329

Outro exemplo de contestação encontra-se em panfleto de 1982 no qual a “democracia racial" passa a ser contestada com a analise de dados do IBGE sobre a exclusão dos negros do mercado de trabalho: “[...] fica comprovado oficialmente que esta

Movimento, para levá-lo a lutar pela verdadeira 'democracia racial'...” In Informe n. 89/CONSEG/82. OS 1157, pasta 218C. DEOPS/SP, DAESP. Presente também em documento do MNU "Um balanço crítico de nossa atuação" In Sumário Semanal de Informações n. 15 da CODIN/COSEG, do período entre 9 a 15/4/1982, de 16/4/1982, fl. 17. Dossiê 50-H-84- 5498. DEOPS/SP, DAESP. Em fala de Dalmir Francisco Costa em congresso do MNU, em 1982. Relatório de avaliação de 20/9/1981 do MNU de MG. In Sumário Semanal de Informações n. 15 da CODIN/COSEG, do período entre 9 a 15/4/1982, de 16/4/1982, fl. 43. Dossiê 50-H-84-5497. DEOPS/SP, DAESP. No programa de ação do MNU apresenta-se como slogan de luta: "Por uma autêntica democracia racial". In Programa de Ação do MNU, p. 14. Dossiê 20-C-44- 17289. DEOPS/SP, DAESP. O programa fora coletado por ocasião do Io Encontro em Defesa da Raça Negra, realizado em 23/5/1981, na PUC-SP. Relatório diário n. 1505, entre 25 e 26/5/1981, da Divisão de Informações do DEOPS, fl. 2. Dossiê 21-Z-14-11366. DEOPS/SP, DAESP. Percebendo as diferentes formas de se utilizar o mito da "democracia racial", Oracy Nogueira ressaltou que: "Assim, de um lado, o mito ou a ideologia da democracia racial brasileira tem um sentido negativo na medida em que é empregado simplesmente como um argumento justificador ou legitimador do status quo, como se este correspondesse ao melhor dos mundos no que diz respeito às relações raciais; porém, de outro lado, tem um sentido positivo, quando tomado como a proclamação de um ideal ou valor em contraste com o qual ou inspirado no qual se pode criticar a realidade e tentar melhorá-la, estabelecendo maior coerência entre esta e aquele." In NOGUEIRA, O. Tanto preto quanto branco: estudos de relações raciais. São Paulo: T.A. Queiroz, 1985, p. 26. Este mito compunha o discurso do MNU como um ideal a ser alcançado, como afirmava Eduardo de Oliveira, coordenador nacional do MNU: "para que haja, efetivamente, uma autêntica democracia racial" In "Negros fazem ato público" In O Estado de S. Paulo, 14/05/1980, p. 13. OP 0654 Atos Públicos. DEOPS/SP, DAESP. O argumento de luta por uma verdadeira "democracia racial" também se apresentou na coluna AfroLatino-América. Versus, n. 23, de julho-agosto de 1978, p. 33. Dossiê 50-K-6- 280. DEOPS/SP, DAESP. Versus, n. 23, de julho-agosto de 1978, p. 33. Dossiê 50-K-6- 280. DEOPS/SP, DAESP. O mito tem função explicativa e mobilizadora, uma vez que organiza imagens que evocam sentimentos na sociedade ou grupo social. O mito, segundo Raoul Girardet, é o impulso psicológico, a inspiração ideal, que pode conduzir os homens. Os mitos possuem uma função explicativa da realidade social desde a sua gênese atuando na história e não apenas exprimindo-a. GIRARDET, R. Mitos e Mitologias Políticas. São Paulo: Cia. Letras, 1987.

${ }_{326}$ Boletim III do Grupo Negro da PUC-SP, p. 9. Pasta Movimento Negro. CEDIC/PUC-SP.

${ }^{327}$ Boletim III do Grupo Negro da PUC-SP, p.12. Pasta Movimento Negro. CEDIC/PUC-SP.

${ }^{328}$ Boletim III do Grupo Negro da PUC-SP, p. 12. Pasta Movimento Negro. CEDIC/PUC-SP.

${ }^{329}$ Boletim III do Grupo Negro da PUC-SP, p. 13. Pasta Movimento Negro. CEDIC/PUC-SP. 
abolição nada solucionou e que a democracia racial tão preconizada nunca existiu." 330 Da mesma forma no manifesto nacional pelo dia nacional da consciência negra, ressaltava que o racismo brasileiro era disfarçado pela "democracia racial". 331

Com as reivindicações dos movimentos negros travou-se também uma luta de representações sobre o "ser negro", pela sua valorização e pelo rompimento de estigmas e estereótipos, denunciando a existência cotidiana da discriminação racial. As "lutas pela definição de 'identidade regional' e 'identidade étnica', assinala que essas só podem ser compreendidas se efetuada a ultrapassagem da oposição entre a representação e a realidade, e à condição de incluir no real a representação do real, ou mais exatamente a luta de representações. Representações entendidas como imagens mentais, mas também como manifestações sociais destinadas a manipular as imagens mentais." 332

Podemos perceber essa luta de representações nos exemplos de discursos dos afrodescendentes e das estruturas envolvidas no regime militar: O discurso do Movimento Negro Unificado (MNU) destacava que a sociedade brasileira: "procura silenciar os oprimidos, pela violência e repressão, em nome da 'ordem social' e pelo racismo, disfarçado de 'democracia racial'. Não há harmonia entre classes, nem democracia racial, numa sociedade onde a maioria negra tem o seu direito ao trabalho, ao salário condigno e a segurança social, negados pela força e é submetida a cruéis condições de vida, confinada nas favelas e alagados, humilhada pela violência policial e militar, terror cotidiano exercido contra negros e oprimidos, com a finalidade de intimidar e destruir a resistência moral frente a opressão." 333

Enquanto o regime militar sustentava um discurso pautado no mito da "democracia racial", ao mesmo tempo, classificava as denúncias de discriminação racial como casos excepcionais. O Jornal do Brasil, em 1976, denunciou um caso de discriminação racial em Salvador, o que levou o presidente Ernesto Geisel (1974-1979) a recomendar a apuração do caso ao Ministro da Justiça. Como resposta, o governador da Bahia, Roberto Santos, afirmara que este era um caso excepcional, pois seu estado era um dos lugares de maior

\footnotetext{
${ }^{330}$ Panfleto "13 de maio: dia nacional de denúncia contra o racismo". Dossiê 20-C-44- 23944. DEOPS/SP, DAESP.

${ }^{331}$ Dossiê 20-C-44- 14605. DEOPS/SP, DAESP.

${ }^{332}$ CAPELATO, M. e DUTRA, E. "Representação política: reconhecimento de um conceito na historiografia brasileira", p. 235.

${ }^{333}$ Manifesto Nacional do MNU sobre o Dia Nacional da Consciência Negra. Dossiê 21-Z-14- 10268. DEOPS/SP, DAESP.
} 
"democracia racial”, com a sua grande miscigenação. ${ }^{334}$ A apuração do caso de discriminação tornava-se uma medida governamental que faziam parte estratégica da exaltação do mito da "democracia racial", com uma condenação oficial e formal da discriminação racial. Não nos esqueçamos que a lei n. 1390, de 30 de julho de 1951, a lei “Afonso Arinos", no governo de Castelo Branco (1964 - 1967), foi transportada para o texto constitucional de 1967.

Do mesmo modo, o Parque Histórico de Zumbi, projetado a partir de 1980, com o I Encontro Nacional do Parque Histórico de Zumbi, fez parte da política governamental que com a criação de um parque histórico, na área onde existiu o Quilombo dos Palmares, poderia contornar parte das reivindicações de lideranças afro-brasileiras. "A possibilidade de fazer desse Parque uma referência de nossa nacionalidade era uma resposta àqueles que estavam a fazer do Quilombo dos Palmares um espaço próprio de referência exclusivamente negra. Ao referendar a criação de um Parque Histórico naquela área, o Estado regulava algo que tinha sido, desde o período do Estado Novo, um tema considerado inoportuno." 335

Não obstante, o governo ansiava que as medidas restritivas pusessem limites aos movimentos anti-racistas, ao mesmo tempo em que exaltava a "democracia racial" e a importância da cultura afro-brasileira. Deste modo, mesclava-se tensão e apropriação política. ${ }^{336} \mathrm{O}$ parque significou um espaço de luta material e simbólica sobre esse patrimônio cultural ${ }^{337}$, no qual regime militar e movimentos negros projetavam enfoques diferenciados. O governo buscava uma atração turística sobre um signo histórico brasileiro, enquanto os movimentos negros um memorial da história dos afro-brasileiros. ${ }^{338}$

Este conjunto de aspectos possibilita afirmar que no regime militar houve o desenvolvimento de políticas culturais, produzindo uma identidade nacional simpática ao

\footnotetext{
${ }^{334}$ HASENBALG, C. "Excepcionalidade do corriqueiro: as notícias sobre descriminação racial na imprensa" In Revista de Cultura Contemporânea, 1978, p. 86. Apud SANTOS, J. "Ações afirmativas e ditadura militar: imagens e propostas" In evento The Cultures of Dictatorship: Historical Reflections on the Brazilian Golpe of 1964, University of Maryand, 14-16 de outubro de 2004. (html/www.history.umd.edu/Historycenter/200405/conf/Brazil64/program), p. 22.

${ }^{335}$ SANTOS, J. Op. Cit., p. 23.

${ }^{336}$ SANTOS, J. Idem, p. 25.

${ }^{337}$ CANCLINI, N. Culturas Hibridas: Estratégias para entrar e sair da Modernidade. São Paulo: EDUSP, 1997.

338 "Memorial Zumbi" do Grupo Negro da PUC-SP In Porandubas, jornal da comunidade universitária da PUC-SP, Ano VI, n. 49, de 1 de junho de 1982, fl. 2. Dossiê 20-C-44- 24430. DEOPS/SP, DAESP.
} 
regime e à sua moral. Ao exaltar a unidade nacional e a presença do Estado e de seus dirigentes, ao mesmo tempo em que buscava apagar as contradições sociais: "Os negros $e$ indios, na política republicana, são apropriados como objetos culturais, símbolos e marcos fundadores de uma civilização brasileira, mas têm negado o direito a uma existência singular plena como membros de grupos étnicos. Estes são marcos da fronteira da civilização brasileira, remanescentes dos antepassados que criaram a nação, restos e vestígios das origens." 339

A declaração do ministro do trabalho Júlio Barata, conforme matéria do jornal $A$ Tarde, em 16 de junho de $1971^{340}$, retratava a base do pensamento dos governos militares, que sustentava que as denúncias de discriminação racial faziam parte de "elementos interessados na desmoralização do Brasil levantavam o problema da discriminação racial". ${ }^{341}$ Constituíam, assim, em conflito interno e propaganda adversa do país para o resto do mundo.

O mito da unidade esteve presente nas políticas adotadas pelo regime militar, valorizado pelo discurso que considerava a origem do "mal" decorrente da divisão social, enquanto o "bem" se desenvolveria por meio da unidade. Assim, toda representação ou reivindicação social que apresentasse diversidade de opinião era, de alguma forma, combatida. Os afro-descendentes que buscavam, a partir da década de 1960, resgatarem elementos da cultura africana e exigir a sua cidadania, tornaram-se alvo de controle para os órgãos de informação e segurança. Para governos que rejeitavam a diversidade de opinião e de comportamentos e tinha como projeto uma sociedade estática e sem conflitos, o protesto dos movimentos negros apresentava-se, no mínimo, como um "inconveniente" que devia ser neutralizado. Por isso, a partir da década de 1970, os ativistas e movimentos, como Movimento Negro Unificado, Grupo União e Consciência Negra, Grupo Afro-latino América, Grupo Negro Universitário, eram constantemente vigiados por "arapongas”, isto é, investigadores disfarçados que relatavam o cotidiano destes por meio de infindáveis relatórios guardados no Fundo DEOPS/SP. ${ }^{342}$ Nesse contexto, um dos objetivos básicos do

\footnotetext{
${ }^{339}$ GUIMARÃES, A. Classes, Raças e Democracia. São Paulo: Ed. 34, 2002, p. 121.

340 SANTOS, J. "Ações afirmativas e ditadura militar: imagens e propostas" In evento The Cultures of Dictatorship: Historical Reflections on the Brazilian Golpe of 1964, University of Maryand, 14-16 de outubro de 2004. (html/www.history.umd.edu/Historycenter/2004-05/conf/Brazil64/program), p. 41.

${ }^{341}$ SANTOS, J. Op. Cit., p. 41.

${ }^{342}$ Movimentos como:, entre outros foram vigiados pelos diversos órgãos de repressão.
} 
governo era eliminar "os riscos de contradição interna, de cisma ou de dissidência, de fato é o advento de total coesão. "„43 Tornando-se uma verdadeira obsessão, tratava-se: “de assegurar para sempre a vitória das forças centrifugas sobre os fatores contrários de rompimento ou de divergência; de prevenir e de rechaçar as ameaças sempre presentes de ruptura e de discórdia." 344

As imagens propagandeadas eram de harmonia, de equilíbrio, de fusão, de unidade, de uma sociedade indivisível e homogênea, um verdadeiro bloco sem fissura, características que os governos militares acreditavam implantar, com governo forte e centralizador. A idéia de integração nacional forjado pela doutrina de Segurança Nacional procurava, no nível do discurso e da prática, resolver as diferenças regionais e a diversidade na sociedade brasileira. "A noção de integração, trabalhada pelo pensamento autoritário, serve assim de premissa a toda uma política que procura coordenar as diferenças, submetendo-as aos chamados Objetivos Nacionais." 345

$\mathrm{Na}$ definição da unidade e da identidade nacional o regime exaltava "o elemento da mestiçagem contém justamente os traços que naturalmente definem a identidade brasileira: unidade na diversidade." ${ }^{446}$ A "diversidade" nesse contexto encobre um pensamento de harmonia pautada no mito da unidade. Nesse quadro, as lutas anti-racistas significavam para os militares, a oposição, a proximidade com o debate marxista e o "potencial de conflito".

Segundo Maria Selma Rocha, a análise dos manuais da ESG permite compreender que a diferença social apresentava-se "ao mesmo tempo negada e reconhecida como realidade social. O discurso doutrinário reconhece a existência de diferentes grupos ocupacionais, étnicos, religiosos e culturais, o que seria positivo na medida em que cada um desses grupos, por suas 'funções' específicas no 'sistema social', criaria relações de complementaridade entre si, assegurando, dessa forma, a sobrevivência e a evolução do todo social. Entretanto, o discurso omite tanto as diferenças intragrupos - étnicos, religiosos, culturais e econômicos - como as relativas às classes sociais. Ao fazê-lo, a ESG pretendia eliminar duas idéias-chave: o conflito e a contradição, entendidos como

\footnotetext{
${ }^{343}$ GIRARDET, R. Mitos e Mitologias Politicas. São Paulo: Cia. Letras, 1987, p. 148.

${ }^{344}$ GIRARDET, R. Op. Cit., pp. 163/164.

${ }^{345}$ ORTIZ, R. Cultura Brasileira \& Identidade Nacional. São Paulo: Brasiliense, 2003, p. 82.

${ }^{346}$ ORTIZ, R. Op. Cit., p. 93.
} 
desagregadores da sociedade; e, assim, pretende afirmar e difundir a perspectiva de integração e harmonização das classes como alternativas de esvaziamento dos conflitos e prováveis enfrentamentos. " 347

Nesse sentido, a ESG sustentava que "a miscigenação criou zonas de confraternização entre as raças e as culturas, democratizando, dessa forma, a sociedade patriarcal e aumentando a mobilidade social." ${ }^{448}$ A ESG entendia que estava nessa formação social brasileira o "caráter do povo", pautado em idéias como "adaptabilidade", "cordialidade" e "vocação pacifista". A idéia de unidade nacional era interligada à noção presente sobre a formação social brasileira: "fruto maravilhoso desse caldeamento e do sincretismo cultural, de tão variadas procedências, é esse sentimento de unidade nacional, tão facilmente identificável em muitos exemplos da vida social brasileira." ${ }^{349}$ Nesse quadro, o regime propagava a imagem de que mesmo com as diferenças regionais, culturais e sociais "verifica-se um forte sentimento nacional, que constitui o laço mais sólido de nossa unidade." 350

Os movimentos negros, ao ressaltarem a diferença social, não "celebravam" a unidade nacional que os excluía. Uma vez que o regime militar tinha como base de seu pensamento que no Brasil "a cordialidade é a regra e o conflito é a exceção." ${ }^{351}$, gerava as condições para que se formasse a idéia de que a discriminação racial estava presente em uns "poucos casos isolados" e, portanto, que as reivindicações dos afro-descendentes eram "indevidas".

Entretanto, por certo o "sentimento de querer-se negro não exclui as outras possíveis afirmações identitárias como querer-se brasileiro e latino-americano, homem ou mulher, etc." ${ }^{352}$ Destas identidades, a polícia política e o regime militar percebiam a identidade negra como ameaçadora à identidade brasileira.

No item "vocação pacifista", o manual da ESG indicava que a vida política brasileira "foi sempre orientada pelas idéias de paz e harmonia e caracterizada pelo desejo de

\footnotetext{
${ }^{347}$ ROCHA, M. S. A Evolução dos conceitos da doutrina da Escola Superior de Guerra nos anos 70. Dissertação de Mestrado. São Paulo: FFLH/USP, 1996, p. 78.

${ }^{348}$ ROCHA, M. S. Op. Cit., p. 79.

349 MORAES FILHO, B. "Elementos básicos da nacionalidade as instituições" In Segurança e Desenvolvimento, Ano XVII, n. 130. Rio de Janeiro: Associação dos Diplomados da Escola Superior de Guerra, 1968, pp. 50-60, p. 53.

${ }^{350}$ MORAES FILHO, B. Op. Cit., p. 53.

${ }^{351}$ MOTTA FILHO, C. Idem, p. 70.

352 BERND, Z. O que é negritude. São Paulo: Brasiliense, 1988, p. 42.
} 
conciliação." 353 Já sobre a cordialidade, o manual salientava que "estes sentimentos apuram-se com a formação cristã do povo e com a fusão das raças, especialmente pela contribuição do negro, que segundo Gilberto Freyre, 'deu nos a revelação de uma bondade maior que a dos brancos, de uma ternura como não a conhecem igual os cristãos'. Daí a sensibilidade ao sofrimento alheio, a facilidade em esquecer e perdoar, a indulgência nas repressões, a eliminação das distâncias sociais e conseqüente abolição das distinções de classes e de raças, e de todo um elenco de manifestações afetivas." ${ }^{354} \mathrm{O}$ manual trabalhava com estereótipos sobre o negro, adjetivando-o como "passivo", além de negar as distinções sociais entre brancos e negros.

Ao tratar da temática "Objetivos Nacionais Permanentes Brasileiros", no subitem "paz social", para ilustrar a "vocação" para tal, o manual refere-se como herança dos tempos coloniais e da escravidão "aspectos típicos, figuras históricas, como a mãe-preta, a amade-leite, a mucama e os moleques, praticamente componentes da família. A integração racial é facilitada pela ausência de preconceito racial, herança benéfica do caldeamento racial português." 355 Utiliza-se de uma visão da escravidão como "pacífica" e "sem conflitos", valorizando o "mundo que o português criou", como, mais tarde se tornariam dominantes as formulações do lusotropicalismo de Gilberto Freyre. ${ }^{356}$

Em artigo da revista Segurança e Desenvolvimento, afirmava-se que quanto ao homem brasileiro: "não basta explicá-lo pela dinâmica criadora da raça branca, de mistura com os ingredientes de passividade e conformismo das raças vermelha e preta.",357 Ressaltava a permanência de preconceitos, em que o branco era visto como "criador", enquanto negros e índios eram entendidos como "passivos", corroborando com a idéia uma

\footnotetext{
${ }^{353}$ Manual ESG, "Seção II”, “4.2- Atributos do Caráter Nacional Brasileiro” Apud ROCHA, M. A Evolução dos conceitos da doutrina da Escola Superior de Guerra nos anos 70. Dissertação de Mestrado. São Paulo: FFLH/USP, 1996. ANEXO 8, p. 46.

${ }^{354}$ Manual ESG, "Seção II", "4.2- Atributos do Caráter Nacional Brasileiro" Apud ROCHA, M. Op. Cit., p. 46.

${ }^{355}$ Manual ESG, "Seção II", "5 - Objetivos Nacionais Permanentes Brasileiros" Apud ROCHA, M. Idem, p. 63.

${ }^{356}$ FREYRE, Gilberto. O Mundo que o Português criou: aspectos das relações sociais e de cultura do Brasil com Portugal e as colônias portuguesas. Rio de Janeiro: José Olympio, 1940.

${ }^{357}$ MOTTA FILHO, C. "Elementos básicos da nacionalidade - o homem" In Segurança e Desenvolvimento, Ano XVII, n. 130. Rio de Janeiro: Associação dos Diplomados da Escola Superior de Guerra, 1968, pp. 6178, p. 67.
} 
sociedade sem conflitos. Deste modo, idealizava-se o brasileiro como "um tipo ideal, aquele que significa a alma do Novo Mundo, libertada dos preconceitos europeus." 358

Ainda na revista Segurança e Desenvolvimento, apresentava-se uma visão atenuada da escravidão: "Uma velha anedota, do tempo da escravidão, muito embora reconheça a existência social de hierarquia, ao mesmo tempo que despreza qualquer preconceito de classe ou de raça, pode ter sido verdade em qualquer ponto do país:-Um viajante, batendo estrada com seu guia, pergunta a este, ao encontrar um negro a cavalo, bem posto em sua farda vistosa: - 'Quem é esse negro?' Ao que o guia responde: 'Não é negro, é um capitão.' Negro não é homem de cor, porque o que prevalece é sua condição, muito embora ainda se considerasse, na oportunidade da anedota, aquele homem marcado pela escravidão. Mas quem o visse, já em outra condição, deixava, espontaneamente de lado a idéia de qualquer inferioridade. O negro de farda não é visto como tal. 'Não é negro, é capitão. ", 359 A anedota revela os padrões sociais brasileiros que negam a cor do indivíduo em uma situação de ascensão social e a associação do negro à "escravidão", ao "trabalho braçal" e à "pobreza", ou seja, à "inferioridade". Nesses parâmetros, um negro que como exceção chegasse a capitão, "deixaria” de ser negro.

A temática da abolição constitui outro exemplo usado pelo Manual da ESG para ressaltar a "vocação pacífica" da sociedade brasileira: "A luta pela Abolição integrou povo e governo, embora a elite dirigente percebesse que sua decretação, pura e simples, poderia abalar os alicerces da economia e provocar a queda da Monarquia. Apesar dessas perspectivas, a Princesa Regente não titubeou em correr o risco." ${ }^{360} \mathrm{O}$ ponto de partida foi, portanto, a idéia de que a abolição foi "dada" pela monarquia, além de ser um evento que teria contado com uma "união da nacionalidade" e, mesmo com os "riscos" de afetar a economia, a princesa Isabel realizou a abolição em prol da "nacionalidade".

Assim, essa "aspiração natural" pela paz social, teria levado a uma "evolução histórica praticamente livre das grandes convulsões que o problema causou em outros países." 361

\footnotetext{
${ }^{358}$ MOTTA FILHO, C. Op. Cit., p. 67.

${ }^{359}$ MOTTA FILHO, C. Idem, p. 72.

${ }^{360}$ Manual ESG, "Objetivo Nacionais", "5- Objetivos Nacionais Permanentes Brasileiros" Subitem "5.2.5 Paz Social" Apud ROCHA, M. A Evolução dos conceitos da doutrina da Escola Superior de Guerra nos anos 70. Dissertação de Mestrado. São Paulo: FFLH/USP, 1996. ANEXO 9, p. 48.

${ }^{361}$ Manual ESG, "Seção II", "5 - Objetivos Nacionais Permanentes Brasileiros" Apud ROCHA, M. Op. Cit., p. 64.
} 
Tornavam-se, então, parte dos "objetivos nacionais permanentes" a integração nacional e a paz social. Com a "integração nacional", visava-se a consolidação da "comunidade nacional": "língua, ascensão moral, miscigenação e supressão de desníveis sociais e regionais." 362 Sob essa perspectiva, torna-se claro o pensamento do regime militar sobre a ação "perniciosa" dos movimentos negros brasileiros que desestabilizariam a "integração nacional" apresentando uma divisão social "inexistente".

A visão de que os movimentos negros eram introdutores de conflitos raciais externos e “inexistentes" na "democracia racial" brasileira apresentou-se a partir da década de 1930 na mentalidade de algumas autoridades policiais do DEOPS/SP. ${ }^{363}$ No período do regime militar essa visão se manteve e foi acirrada com a classificação dessas manifestações como "racistas". Desse modo, "Não poucos acabam por revelar, nas entrelinhas, diversos preconceitos, dentre os quais o mais destacado é o racial. O subversivo, quando [...] o negro, desordeiro. E os estrangeiros, em geral, são qualificados como portadores de idéias estranhas ao sistema." 364 . Como exemplo, temos o "Pedido de busca do Ministério do Exército Assunto: Racismo Negro”, de 26 de abril de 1977:

"2. Dados Solicitados:

a. Confirmar a veracidade do item la dos dados conhecidos.

b. Acompanhar e informar sobre o desenvolvimento do encontro caso o mesmo se realiza (líderes, constituição de delegações, temas abordados, conferencistas e origem dos recursos).

Outros dados julgados úteis capazes de caracterizar subversão ou estímulo ao racismo e participação dos sociólogos FLORESTAN FERNANDES, OCTAVIO IANNI e FERNANDO HENRIQUE CARDOSO." "365

Neste documento, além da preocupação com os "comunistas", principalmente representados pelos sociólogos que estudaram a questão racial brasileira sob uma interpretação marxista, também há uma preocupação com o "racismo negro", no qual as autoridades entendiam o protesto dos movimentos negros como elemento desestabilizador da sociedade brasileira que estimularia o "racismo negro". Desta forma, o mito político da

362 Manual ESG, "Seção II", “5 - Objetivos Nacionais Permanentes Brasileiros”, sub-item "5.2Caracterização dos Objetivos Nacionais Permanentes Brasileiros” Apud ROCHA, M. Idem, p. 55.

${ }^{363}$ Refiro-me, entre outras, a documentação do dossiê 50-J-46-8 com relatório sobre a Organização de Cultura e Beneficência Jabaquara. DEOPS/SP, DAESP. A esse aspecto escrevi o artigo "O discurso policial sobre o afro-descendente: estigmas e estereótipos" na Revista Histórica, n. 15 editada pelo Arquivo do Estado de São Paulo, julho/agosto/setembro de 2004. Esse artigo parte do estudo de iniciação científica Movimentos Negros: Identidade étnica, identidade política (1924-1954), com bolsa FAPESP e orientação da Prof ${ }^{\mathrm{a}}$. Dr ${ }^{\mathrm{a}}$. Maria Luiza Tucci Carneiro.

${ }^{364}$ MAGALHÃES, M. “A lógica da suspeição: sobre os aparelhos repressivos à época da ditadura militar no Brasil.” In Revista Brasileira de História. São Paulo: ANPUH/Humanitas, vol. 17, n. 34, 1997, p. 216.

${ }^{365}$ Dossiê 50-Z-138-1019. DEOPS/SP, DAESP. 
"democracia racial" foi alimentado, re-significado e recriado. Nessa perspectiva, são os negros tidos como racistas, pois eles ameaçariam a unidade e a ordem social estabelecida em que cada um possuiria um lugar social estabelecido. ${ }^{366}$

Ao analisar a expressão "racismo negro" utilizado no pedido de busca, devemos levar em conta que "a escolha de determinadas palavras e formas de se expressar informa sobre a visão de mundo e o campo de possibilidades aberto àquele indivíduo, em razão de sua experiência de vida, sua formação, seu meio, etc. Se ele escolhe determinadas palavras, $e$ não outras, é porque é daquela forma que ele percebe o sentido dos acontecimentos ou das situações sobre os quais está falando." ${ }^{367}$ Sob essa perspectiva, a expressão utilizada trás indícios do pensamento policial e militar, envolvida na vigilância e na repressão às lutas anti-racistas no Brasil entre 1964 a 1983.

Nesse discurso há também inserida uma visão de que os movimentos negros eram “facilmente manipuláveis" pelos "comunistas", prestando-se a "inocentes úteis" a serem cooptados pelo discurso dos "antagonismos sociais", como forma de ganhar interlocutores para sua "ideologia", incitando ao "ódio racial". O "movimento negro, que igualmente surgia no Brasil, era visto como objeto de manipulações por parte dos comunistas, que, através dele, pretenderiam 'reavivar e agravar tensões sociais, no caso, valendo-se da questão racial'," 368 Os movimentos negros eram considerados como elemento da propaganda comunista, apresentando-se como mais uma "temática", conforme o Boletim Informativo do SNI, de maio de 1972, “Racismo e 'sexismo', temas da propaganda vermelha - a Teoria Classista de Marx e sua falsidade." 369

O DEOPS/SP apresentava uma visão da relação dos movimentos negros com os movimentos de esquerda com alguns elementos de estereótipos sobre o negro: "Tem sido observados que a Convergência Socialista alegando lutar pelas classes oprimidas, estando neste caso o negro brasileiro, desde o início incita jovens negros universitários à participarem do Movimento pela Convergência Socialista. Prova disto é que compareceu ao 'Ato Público contra o Racismo' através de um representante que discorreu sobre o

\footnotetext{
${ }^{366}$ Sobre a questão dos "lugares sociais pré-estabelecidos" DA MATTA, R. Relativizando: Uma Introdução à Antropologia Social. Rio de Janeiro: Rocco. 2000.

367 ALBERTI, Verena. "Histórias dentro da História" In PINSKY, C. (org.) Fontes Históricas. São Paulo: Contexto, 2005, p. 185.

${ }^{368}$ FICO, C. Como eles agiam. Os subterrâneos da Ditadura Militar: espionagem e polícia política. Rio de Janeiro: Record, 2001, p. 188.

${ }^{369}$ Boletim Informativo produzido pelo SNI, maio de 1972. Dossiê 20-C-43- 32. DEOPS/SP, DAESP.
} 
problema do negro brasileiro e sua conscientização do problema social e o papel do Movimento Negro pela Discriminação Racial. O Movimento pela Convergência Socialista - desta maneira tenta engodar (sic) os incautos, fingindo identificar-se com o Movimento Unificado Contra a Discriminação Racial., 370

Nesta perspectiva, o negro era apresentado como o "ingênuo" que caia nas armadilhas dos "sagazes comunistas" que "enganavam", visando arregimentar mais pessoas para suas fileiras, parte do complô dos "comunistas" contra os governos militares.

Sobre a realização do ato público, o investigador advertia que tratava-se mais do que um simples protesto contra injustiças: “[...] esconde no fundo, um movimento que observamos de longa data, através de conhecidos militantes esquerdistas como FLORESTAN FERNANDES e CLOVIS MOURA, membros do Instituto Brasileiro de Estudos Africanistas [...]" ${ }^{371}$ Nesse sentido, o investigador notava que a esquerda avançava em meio aos movimentos negros, estabelecendo entidades em torno da Frente Socialista em formação, como o grupo Afro-Latino-América que propunha a "libertação e organização do negro no Brasil". ${ }^{372}$ Por meio do jornal Versus, da Convergência Socialista, matérias divulgavam as idéias "[...] que tentam agitar a questão com um movimento de emancipação de cunho socialista, inspirado nos 'Panteras Negras', grupo que nos Estados Unidos, tem se notabilizado pelas ações radicais e violentas." 373 O receio da implementação de guerrilhas pelos movimentos negros brasileiros a exemplo da ação dos Panteras Negras fez presente na apreciação desses movimentos pelo DEOPS.

A realização deste ato público respeitou as leis vigentes, enviando ao Delegado de Polícia do Estado de São Paulo, Tácito Pinheiro de Machado, solicitação por meio de documento do MUCDR assinado por Eduardo de Oliveira, Marcio Barboza além de conter uma terceira assinatura ilegível. ${ }^{374}$ No entanto, mesmo apresentando interesse em permanecer na legalidade a visão acerca dessa ação dos movimentos negros é a de subversão.

\footnotetext{
${ }^{370}$ Relatório sobre Ato Público Contra o Racismo, da Divisão de Informações do DEOPS, de 7/7/1978, fl. 2. Dossiê 14632A. DEOPS/SP, DAESP.

${ }^{371}$ Relatório sobre Ato Público Contra o Racismo, da Divisão de Informações do DEOPS, de 6/7/1978. Dossiê 50-Z-0- 14623. DEOPS/SP, DAESP.

372 Relatório sobre Ato Público Contra o Racismo, da Divisão de Informações do DEOPS, de 6/7/1978. Dossiê 50-Z-0- 14623. DEOPS/SP, DAESP.

${ }^{373}$ Relatório sobre Ato Público Contra o Racismo, da Divisão de Informações do DEOPS, de 6/7/1978. Dossiê 50-Z-0- 14623. DEOPS/SP, DAESP.

${ }^{374}$ Dossiê 50-Z-14621. DEOPS/SP, DAESP.
} 
O relatório policial confidencial, de 15 de maio de 1978, relativo aos protestos de 13 de maio, destacou a matéria "Negro tem que ir pro pau", no Folhetim de 14 de maio de 1978, que tratava do episódio da morte de Robson Silveira Luz. ${ }^{375}$ Nesse quadro, o autor do relatório ressaltava que esse caso era usado pelos militantes socialistas para sua causa por meio da Convergência Socialista. ${ }^{376}$ Ressaltava também o papel de Clovis Moura e Florestan Fernandes, que “observamos de longa data que 'africanistas' (estudiosos da cultura e raça negra de origem africana) como Clovis Moura e Florestan Fernandes, entre outros, tentam, usando da dialética, 'acordar' a cultura negra 'ainda adormecida na escravidão' para um movimento de emancipação de cunho socialista, inspirado nos 'Panteras Negras', grupo norte-americano conhecido pelas ações radicais e violentas. (Jornal Versus, n. 19, página 39).” Dessa forma, o caso da morte de Robson era vista como uma repercussão "maior" do que a esperada com a incitação dos setores esquerdistas, representados pelos sociólogos marxistas citados.

Para alguns participantes da repressão o protesto dos movimentos negros à discriminação racial era conseqüência do incitamento das idéias esquerdistas, gerando o "racismo no negro". Como representante da Convergência Socialista o grupo Afro-LatinoAmérica era visto pela polícia política como "revanchista", que procurava incutir o "racismo no negro" e distorceria a miséria como algo "privativo ao negro". 377

Interessante notarmos que Clovis Moura ${ }^{378}$ era classificado como "branco" pelo investigador da Divisão de Ordem Política do DEOPS/SP, quando acompanhava o Ciclo de Debates sobre a marginalização social do negro e a violência policial, organizado pelo

\footnotetext{
${ }^{375}$ Xerox da matéria encontra-se anexo ao dossiê 50-Z-0- 14618. DEOPS/SP, DAESP.

${ }^{376}$ Segundo informe confidencial n. 671/09 do Serviço de Informações da Polícia Federal, de 19 de setembro de 1980, sobre a Convergência Socialista: "depois de uma análise da situação internacional (Vietnam, África, Grécia, Espanha, América Latina, América Central e Brasil) 'se construiu e tem toda a sua trajetória intimamente ligada à luta feroz contra o governo, pelas liberdades democráticas, e ao lado das lutas dos trabalhadores e estudantes'. Em princípio de 1978, aproveitando o espaço aberto pelas mobilizações anteriores, foi lançada publicamente. No mesmo ano realizou duas reuniões nacionais, divulgadas abertamente, consolidando sua 'legalidade de fato', e concentrou sua atividade no $A B C[. .$.$] A CS 'se$ constrói nos marcos do internacionalismo proletário e apóia as posições politicas do COMITÊ PARITÁRIO e FRAÇÃO BOLCHEVIQUE. ’’. DEOPS/SP, DAESP.

${ }^{377}$ Relatório confidencial da Divisão de Informação do DEOPS, de 15 de maio de 1978. Dossiê 50-Z-014619. DEOPS/SP, DAESP.

${ }^{378}$ Clovis Moura, segundo informação do DEOPS, era conhecido deste órgão desde 1952 por ter sido diretor de uma revista comunista, Flama, de Araraquara. Desde a década de 1950, Clovis Moura fora constantemente monitorado pelos órgãos de informação e segurança, tendo correspondências examinadas. In Informação confidencial sobre Clovis Moura, fl. 1. Dossiê 50-Z-0- 14615. DEOPS/SP, DAESP.
} 
MNU. ${ }^{379}$ O que ressaltava sua opção política marxista, retirando o foco da questão racial propriamente dito.

Os nomes de Clovis Moura e de Florestan Fernandes apresentam-se em conjunto devido a proximidade com o IBEA. ${ }^{380}$ Clovis presidindo este instituto de pesquisa e Florestan, palestrando nesta sobre suas pesquisas acadêmicas. Por exemplo, no curso de extensão cultural "Uma visão dinâmica do negro no Brasil", no qual Florestan apresentou “A situação do negro no Brasil”. ${ }^{381}$ Em informação acerca das ações políticas sociais de Florestan, a polícia destacava que o jornal Última Hora apresentava o como "[...] um dos pucos (sic) cientistas que estuda e luta pela raça negra, e fala dos problemas do negro de hoje." 382

A mobilização do "I ${ }^{0}$ Congresso de la Cultura Negra de las Américas", entre 24 a 28 de agosto de 1977, em Cali, na Colômbia, foi alvo de vigilância da repressão brasileira, em especial quanto ao negro no Brasil, conforme documentação confidencial proveniente da reitoria da USP encaminhada para o DEOPS. ${ }^{383}$ A representação brasileira para o congresso era o Instituto Brasileiro de Estudos Africanistas (IBEA), grupos do interior de São Paulo, Gran-Quilombo e a Sociedade de Estudos Brasil-África, ambos do Rio de Janeiro. Informavam ainda da projeção na imprensa sobre a "Quinzena do Negro" organizado por Eduardo de Oliveira e Oliveira ${ }^{384}$ com apoio financeiro da Secretaria Estadual de Cultura, entre 28 de maio a 8 de junho, constando de estudos na própria USP. 385 Além de notícias sobre Abdias Nascimento ${ }^{386}$ no jornal The Brazilians nos EUA, de maio de 1977. ${ }^{387}$

\footnotetext{
${ }^{379}$ Relatório investigador não identificado da Divisão de Ordem Política ao delegado titular, de 5/8/1980. Dossiê 20-C-44- 11830. DEOPS/SP, DAESP.

${ }^{380} \mathrm{O}$ Instituto Brasileiro de Estudos Africanistas (IBEA), que realizava pesquisas sobre a influência das culturas negras no Brasil, tinha seus eventos monitorados pelos aparelhos de informação e segurança desde 1975. In Informação da Divisão de Informações do DEOPS. Dossiê 50-Z-0- 14617. DEOPS/SP, DAESP.

${ }^{381}$ Informação reservada sobre Florestan Fernandes, fl. 6. Dossiê 50-Z-0- 14616. DEOPS/SP, DAESP.

${ }^{382}$ Informação reservada sobre Florestan Fernandes, fl 8. Dossiê 50-Z-0- 14616. DEOPS/SP, DAESP.

${ }^{383}$ Informação n. 230, São Paulo, 5 de julho de 1977. Dossiê 50-J-0- 5373. DEOPS/SP, DAESP.

${ }^{384}$ Eduardo, além de militante era sociólogo, obtendo uma ação militante e acadêmica. Faleceu em 1980. Ver OLIVEIRA, E. Quem é quem na negritude brasileira. São Paulo: Congresso Nacional Afro-Brasileiro, 1998, p. 94.

${ }_{385}$ Dossiê 50-J-0- 5372 e 50-J-0- 5365. DEOPS/SP, DAESP.

${ }^{386}$ Abdias teve uma importante atuação ativista desde a década de 1930, participando da FNB, do TEM, do MNU. Esteve presente nos 3 Congressos de Cultura Negra das Américas, fundou o IPEAFRO (Instituto de Pesquisas e Estudos Afro-brasileiros) na PUC-SP. Além disso, tem uma larga produção intelectual e atuação acadêmica internacional. Para uma biografia de Abdias do Nascimento, ver a dissertação de mestrado de Márcio Macedo, que faz uma importante reflexão da atuação deste importante militante nos principais
} 
As aspirações de Eduardo para a organização do evento eram vistas como inapropriado pela ASI da USP: “[...] o que é perigoso é que a coordenação esteja na mão do citado elemento, além de que algumas das pessoas indicadas para participar na 'quinzena', como exemplo, a antropóloga Joana Elbein dos Santos (Bahia), vem desenvolvendo atividades no campo do 'negro' numa perspectiva negativa." 388 Entre outros aspectos que "desabonariam" a pretensão de Eduardo, segundo a documentação, seria sua proximidade como os movimentos negros norte-americanos. O teor desta documentação demonstra que não só a mobilização anti-racista de cunho político estava sob a mira do DEOPS, mas também a própria produção intelectual de cientistas sociais sobre a presença negra no Brasil faziam parte das preocupações deste órgão. ${ }^{389}$

$\mathrm{O}$ redator do documento da ASI/USP apresentava ao DEOPS sugestões que explicitam essa questão, dividida em 2 fases:

"Fase 1.

1. Proceder ao levantamento de toda a bibliografia disponivel.

2. Catalogar todos os artigos em jornais, revistas, etc.

3. Catalogar todos os eventos.

4. Catalogar todos os especialistas ou pessoas (não especialistas) que trataram ou tratam do assunto, indicando os trabalhos.

5. Catalogar todos os institutos que tratam direta ou indiretamente do assunto.

6. Catalogar todas as referências no exterior: eventos, obras, imprensa, etc." "Fase 2

1. A estudar (a curto e a longo prazo)

2. Implantação de uma comissão nacional com vistas às comemorações do centenário da abolição da escravatura.

3. Como 'responder' aos ataques e à campanha (a exemplo do caso do índio) que agora se inicia no plano internacional." 390

Textos como Democracia Racial, de Thales de Azevedo, apresentam-se xerocado e anexado aos dossiês. A suspeição a respeito desses intelectuais por certo se deve a aproximação entre os conceitos de "raça" de "classe", conferindo um referencial marxista ao debate da questão racial brasileira. ${ }^{391}$

movimentos negros do século XX, investigando as construções do seu pensamento. MACEDO, M. Abdias do Nascimento. A trajetória de um negro revoltado (1914-1968). Dissertação de mestrado. São Paulo: FFLCH/USP, 2005.

${ }^{387}$ Dossiê 50-J-0- 5371. DEOPS/SP, DAESP.

${ }^{388}$ Dossiê 50-J-0 sem número. DEOPS/SP, DAESP.

${ }^{389}$ A documentação trás os participantes da Quinzena do Negro com os seus nomes riscados e fichados pelos policiais do DEOPS. Dossiê 50-J-0- 5364. DEOPS/SP, DAESP.

${ }^{390}$ Dossiê 50-J-0 sem número. DEOPS/SP, DAESP.

391 Texto dos Anais do Museu de Antropologia da UFSC, Florianópolis. Dossiê 50-J-0- sem número. DEOPS/SP, DAESP. 
A censura a pesquisas acadêmicas da temática racial não se dava apenas pela aproximação ao referencial teórico marxista, por exemplo, a pesquisa de Edward de Barros Verlinker, de nacionalidade indiana e que pesquisava na USP "o comportamento da classe média negra brasileira". Em aviso confidencial direcionado ao governador do estado, de 18 de março de 1977, solicitava-se providências a pedido da Secretaria Geral do Conselho de Segurança Nacional, afim de que limitasse a atuação do professor, uma vez que: " $a$ pesquisa não foi autorizada pelos órgãos competentes, segundo disposições dos Decretos n. 62.203, de 31 de janeiro de 1968, e 65.057, de 26 de agosto de 1969, e propõe a sua suspensão, 'por tratar de assunto polêmico, suscetível de criar tensões sociais indesejáveis e realmente inexistentes até então." 392

A proibição da pesquisa se deu por "debaixo dos panos", como apresenta documentação da Divisão de Informações do DEOPS que informava por meio dos esclarecimentos do orientador Fernando A. A. Mourão, do Centro de Estudos Africanos da USP, a modificação da temática da pesquisa de Verlinker e que a bolsa de estudos expiraria em um mês e não seria mais prorrogada. O delegado adjunto do DEOPS declarava: "opino V.Sa. remeter tão somente as informações às autoridades solicitantes, para dest'arte evitar possivel repercussão negativas, dentro e fora, do país, que possa advir de uma ação proibitiva mais direta." ${ }^{393}$ A preocupação da comunidade de informação e segurança não era apenas com o protesto dos movimentos negros, mas também com a discussão das referidas temáticas.

Anexo a documentação, encontra-se a cópia xerox do painel "O Negro no Brasil" produzido pela ASI/USP que se alinhava, ao menos em parte, a ideologia do regime militar: "O problema racial está reabrindo-se a partir, principalmente, da influência dos vários movimentos negros norte americanos, alguns dos quais com características revolucionárias e, ao que consta, infiltrados, entre outros, por elementos comunistas." 394 Criticava Thomas Skidmore por ser "extremamente perigoso" para o Brasil, por tornar a abordar "o problema do negro" em termos raciais. Além disso, citava o texto "Etnia" um

\footnotetext{
${ }^{392}$ Aviso SG n. 2117. Dossiê 50-J-0- 5363. DEOPS/SP, DAESP.

${ }^{393}$ Dossiê 50-J-0- 5362. DEOPS/SP, DAESP.

${ }^{394}$ Dossiê 50-J-0- sem número. DEOPS/SP, DAESP.
} 
fenômeno mundial" de N. Glazer ${ }^{395}$, que analisava a constituição do protesto negro brasileiro em decorrência da formação do grupo negro enquanto etnia, idéia considerada como perigosa ao Brasil, por "conturbar a ordem social”. Além disso, o documento classificava de forma pejorativa a ação de Abdias do Nascimento em colóquios como própria de quem faz parte da "intriga internacional", já que este criticava a postura dos governos militares. Abdias teria passado a "atacar sistematicamente o Brasil, fato amplamente conhecido pelas autoridades que, nesse sentido foram informadas a partir de Lagos, em caráter reservado." 396 "A par do surgimento do movimento 'Black' em São Paulo, surgem vários indícios. Assim consta que tem sido desenvolvido proselitismo junto a Associações Negras e Escolas de Samba, entre as quais a de Casa Verde." 397 Além disso, indicava ser necessário pensar as comemorações da abolição para que não fosse “apropriada por algum grupo contestatório", 398

Segundo Márcio Macedo a partir da obra Sortilégio, de Abdias do Nascimento, de 1951, houve uma proposta de valorização negro com incorporação e manipulação de elementos culturais visando uma possível "etnização". ${ }^{399}$ Desse modo, o pensamento de Abdias tornava-se um elemento de subversão que poderia provocar uma configuração de etnia dos afro-descendentes. Abdias do Nascimento, desde 1968, por um "auto-exílio", residindo nos EUA, possuía desde 1975 dificuldades para viajar, já que não conseguia expedir seu passaporte, mesmo não havendo nenhum processo contra ele no país. Dessa forma, para continuar viajando fora do Brasil Abdias possuía um passaporte especial da UNESCO. ${ }^{400}$

Pesquisas em Salvador sobre o negro também foram alvo de vigilância, como a da Sociedade de Estudos da Cultura Negra no Brasil, um projeto cooperativo entre historiadores, sociólogos e militantes negros. ${ }^{401}$ Também foi digno de nota pela polícia a divulgação de pesquisas relativas aos afro-descendentes no programa Fantástico da Rede

\footnotetext{
395 Texto presente na Revista Arquivos, publicação policial. GLAZER, Nathan. "Etnia, um fenômeno mundial" In Arquivos, vol. XXVIII. São Paulo: Polícia Civil de São Paulo, 1976, pp. 203-216.

${ }^{396}$ Dossiê 50-J-0- sem número. DEOPS/SP, DAESP.

${ }^{397}$ Dossiê 50-J-0- sem número. DEOPS/SP, DAESP.

${ }^{398}$ Dossiê 50-J-0- sem número. DEOPS/SP, DAESP.

399 MACEDO, M. Abdias do Nascimento. A trajetória de um negro revoltado (1914-1968). Dissertação de mestrado. São Paulo: FFLCH/USP, 2005, p. 240.

${ }^{400}$ Matéria "Nossos negros solitários", entrevista com Abdias do Nascimento na Revista Veja, n. 512, de 28/6/1978. Dossiê 50-Z-0- 14627. DEOPS/SP, DAESP.

${ }^{401}$ Dossiê 50-J-0- sem número. DEOPS/SP, DAESP.
} 
Globo, em 1976, em entrevista realizadas como um historiador afro-descendente da FGV do Rio de Janeiro. ${ }^{402}$

Todas essas informações provinham da ASI da USP, órgão de vigilância e informação interna estabelecidas nas instituições públicas no período do regime militar. Esse órgão visava controlar todas as atividades da Universidade, informando aos órgãos de repressão a relação de bolsistas, a produção acadêmica e a atuação de funcionários, entre outros dados. ${ }^{403}$

O jornal Árvore das Palavras ${ }^{404}$, ao comentar de forma crítica os festejos do 13 de maio de uma organização dos movimentos negros que havia convidado o presidente da República destacava que:

"Não concordamos com as razões alegadas pelos presidente para justificar sua não participação. Considera ele, segundo os noticiários, tal sociedade de 'homem de cor' de caráter racista e segregacionista. Será racista uma sociedade que congrege (sic), predominantemente, cidadãos de dada etnia? Interpretando de 'cor' como negro gostaríamos de saber encadas (sic) as Câmaras Inglesas de Cultura, os Nipon-clube, os Italo-brasileiros. Por que o mesmo presidende (sic) participou na semana seguinte das festas em comemoração do centenário da emigração italiana no sul? Dois pesos para uma medida: Não é preciso buscar 'razões históricas' para justificar as sociedades e as festas. A questão é saber se esse tipo de sociedade e de festas são permitidas ou não, mas que sejam todas encaradas de mesma forma." 405

Este relato demonstra que a repressão aos movimentos negros era vivida pelos afrodescendentes como segregacionista e questionava a classificação da atuação de racismo, pelo regime militar.

Por outro lado, na perspectiva de um "racismo às avessas", encontra-se o pedido de busca n. 2991/320, confidencial, Agência de São Paulo do SNI para o DOPS, com assunto: "Patrick Modiba - Membro do Congresso Nacional Africano sul-africano", no qual expunha os "dados conhecidos" no item 1:

"a .PATRICK MODIBA (SDQ), membro da organização negra racista "Congresso Nacional Africano Sul-Africano" (AS ANC - South African African National Congress),

\footnotetext{
${ }^{402}$ Dossiê 50-J-0- sem número. DEOPS/SP, DAESP.

${ }^{403}$ Exemplo dessa ação da ASI ver Encaminhamento confidencial de 22/02/1974, contendo relação de bolsistas daquele ano. Dossiê 50-K-104- 363. DEOPS/SP, DAESP.

${ }^{404} \mathrm{O}$ periódico Árvores das Palavras: "corriam de mão em mão sem que se soubesse quem eram os responsáveis, um jornal que veiculava notícias de revoluções africanas nas então colonias portuguesas e trazia uma mensagem de consciência política do negro brasileiro." In Cadernos Negros Apud SOUZA, F. Afro-descendência em Cadernos Negros e Jornal do MNU. Belo Horizonte: Autêntica, 2005, p. 82.

${ }^{405}$ Dossiê 50-Z-138- 806. DEOPS/SP, DAESP.
} 
embarcou clandestinamente, em fins de agosto/ princípios de setembro de 1979, com destino ao Brasil, procedente da África do Sul." 406

É perceptível que o temor dos conflitos raciais extrapolava as fronteiras geográficas do Brasil e a vigilância aos movimentos negros externos também se tornava questão de segurança interna. ${ }^{407} \mathrm{O}$ interesse dos órgãos de vigilância e repressão aos africanos que se dirigiam ao Brasil ocorreu pelo temor de que o discurso anti-racista brasileiro, que já era entendido como "racista", fosse ainda mais radicalizado. O debate, a troca de informações ou mesmo a presença física de militantes africanos, como a de Patrick Modiba, tornaram-se elementos de vigilância e preocupação para os órgãos de repressão. Essa questão foi uma característica particular do regime militar, uma vez que até a década de 1960, o DEOPS/SP, não havia registrado nenhuma referência direta aos debates dos movimentos negros brasileiros em relação ao exterior.

A "influência" dos movimentos negros norte-americanos preocupava a comunidade de informações e segurança, principalmente no que se refere à música: 'O movimento 'black' originou-se nos EEUU, com uma maior penetração na música negra 'soul', que através das Multinacionais da música, penetraram em todos os países com população negra jovem, que é o caso do BRASIL. Por intermédio da COMPANHIA BRASILEIRA DE DISCOS FONOGRAM (CBD), subsidiária do grupo PHILIPS (etiquetas PHILLIPS e POLYDOR), o grupo sentiu que poderia lançar o movimento 'black' no Brasil, através de um cantor negro que atingisse os seus objetivos, que eram garantir o mercado brasileiro para a música 'soul', estrangeira, e atingir setores nacionais ainda não definidos no gênero. Dentro desse esquema, a FONOGRAM produziu o cantor negro GERSON KING COMBO, que atualmente lidera o movimento "black", bem como apóia as equipes de som, principalmente no RIO E SÃO PAULO, incentivando-as com a finalidade de não deixar o Movimento esmorecer. Aparentemente, o Movimento visava lucros financeiros imediatos, quando na verdade, seu objetivo mostra-se outro, devido a sua propagação entre os jovens negros, que para seguirem a 'moda americana' usam jargões ultrapassados, mas que

\footnotetext{
${ }^{406}$ Pedido de busca n. 2991/320, confidencial, do SNI agência de São Paulo para o DOPS. Dossiê 20-C-434508. DEOPS/SP, DAESP.

${ }^{407}$ O documento Sumário Semanal de Informações n. 25 do CODIN/CONSEG, da Secretária de Estado da Segurança Pública de Minas Gerais, Coordenação Geral de Segurança e Coordenação de Informações, de 11 de setembro de 1981, confidencial expressa sobre o Movimento Negro Unificado Contra a Discriminação Racial (MNUCDR) como item de "Segurança Interna". Dossiê 50-H-84- 4696. DEOPS/SP, DAESP.
} 
consciente ou inconscientemente, pregam o preconceito racial, a discórdia e o desentendimento nocivo a comunidade brasileira." 408

O documento transmite a visão de uma "importação", enfatizada com a utilização do termo "estrangeiro" ao caracterizar a música "soul" como parte do movimento "black". Essa importação não foi classificada como conseqüência de interesses comerciais e financeiros, e sim, como parte da "conspiração subversiva" que, dentro dessa ótica, visava desestabilizar a sociedade brasileira. A explicitação da participação do jovem negro nesse movimento cultural deriva da idéia de que a rebeldia da juventude se alimentava de “estrangeirismos". Também esteve presente a relação entre o comunismo e a "desagregação moral", e que pela sua natureza contestatório teria maiores ligações com a juventude. ${ }^{409}$

No artigo "Etnia, um fenômeno mundial" da Revista da Polícia Civil de São Paulo, Arquivos, o "poder negro" ou "black power", entendido como articulação da valorização da cultural, política e social do afro-descendente, era apontado como uma conseqüência da exportação das idéias dos movimentos negros norte americanos. ${ }^{410}$

A documentação sobre o jornal Sinba transmite a preocupação com a questão do “antagonismo racial”, o que levaria essa publicação a ser caracterizada como contrária aos “interesses nacionais”: “Em Jul 77, foi lançado, principalmente na área de NITERÓI/RJ, a edição $n 1$ do jornal 'SINBA', órgão de divulgação da 'SOCIEDADE DE INTERCÂMBIO BRASIL-ÁFRICA'. A publicação foi vendida ou oferecida gratuitamente aos que se mostraram indiferentes ao assunto. Todas as matérias veiculadas no referido periódico apresentam tópicos que incentivam o antagonismo racial, razão pela qual tal publicação configura-se contrária aos interesses nacionais. [...]Esses movimentos revelam o incremento das tentativas subversivas de exploração de antagonismos raciais em nosso País, merecendo uma observação acurada das infiltrações no Movimento 'black', tendo em

\footnotetext{
${ }^{408}$ Encaminhamento confidencial n. 0386/08/78 da Central de Informações do Departamento de Policia Federal para difusão agencia SP SNI, II Ex, 4 COMAR, DOPS/SP com copia xerox do informe n. 318/01/78, de avaliação A1, expedido em 14 de agosto de 1978 com assunto "Movimento Nacional dos Blacks". Dossiê 50-E-33-2150/2155. DEOPS/SP, DAESP.

${ }^{409}$ Sumário de Informações, n. 3, março 1971, reservado da Agência Central do SNI, p. 1.6. Dossiê 20-C-432500. DEOPS/SP, DAESP.

${ }^{410}$ No item "2.4 Os movimentos negros dos Estados Unidos no debate policial" trataremos melhor dessa questão.
} 
vista que se por ventura houver incitação de ódio ou racismo entre o povo, caberá Lei de Segurança Nacional." 411 Os responsáveis pela sua edição também foram identificados. ${ }^{412}$ Preocupados com o "comunismo internacional", ou seja, com a "infiltração" estrangeira, os órgãos de informação e segurança estavam particularmente atentos aos movimentos negros dos EUA e a exportação do comportamento "black power", bem como ao intenso debate dos periódicos afro-descendentes que davam destaque à situação política da África. Ao reproduzir trechos dos periódicos Tição e Sinba, essas autoridades de polícia apresentaram um quadro que demonstra um claro desgosto e intenção de limitar a reunião, expressão e divulgação dos militantes ligados a um movimento de conscientização do negro brasileiro, denominado por essas autoridades como "movimento nacional dos blacks". Assim, a comunidade de informações e segurança classificava a atuação dos movimentos negros como incitadores do "ódio racial", o que incidiria contra a Lei de Segurança Nacional. $^{413}$

Sobre a reunião do MNUCDR, um investigador infiltrado relatava que esta "contou com a presença - de agitadores principais do 'black-power' nanico, que é o verdadeiro movimento, camuflado com o nome acima citado. O movimento racista negro, pretende 'botar prá quebrar' em todo o país." ${ }^{414}$ Ao descrever os líderes do movimento em São Paulo, identificava-os com as idéias marxistas e as do "black power" dos EUA. Além disso, classificava-os de forma pejorativa como "agitadores", "agressivos", "racistas" e “exaltados". ${ }^{415}$ Os tópicos abordados na reunião e destacados pelo "araponga" foram: a

\footnotetext{
411 Encaminhamento confidencial n. 0386/08/78 da Central de Informações do Departamento de Policia Federal para difusão agencia SP SNI, II Ex, 4 COMAR, DOPS/SP com cópia xerox do informe n. 318/01/78, de avaliação A1, expedido em 14 de agosto de 1978 com assunto "Movimento Nacional dos Blacks". Dossiê 50-E-33-2150/2155. DEOPS/SP, DAESP.

412 Anexo B "Diretoria das publicações "nanicas", Encaminhamento n. 0393/78 do Ministério da Marinha. Dossiê 50-Z-0- 14914. DEOPS/SP, DAESP.

${ }^{413}$ Outros periódicos afro-descendentes foram apreendidos pela comunidade de informações e segurança, por exemplo, os relacionado à vigilância no evento $34^{\mathrm{a}}$ Reunião Anual da SBPC, no período de 7 a 14 de julho de 1982, realizado na UNICAMP. Em relatório, no item 5 "Panfletagem e propaganda subversiva e contestatória", consta lista dos materiais recolhidos no evento: o livreto "Relações entre Israel e África do Sul (Liga dos Estados Árabes)", o jornal "Negô" que era boletim informativo do MNU n. 3 de Salvador de março de 1982, as revistas do MNU de março/abril e novembro de 1981. Dossiê 20-C-44- 28548. DEOPS/SP, DAESP.

${ }^{414}$ Informação da Divisão de Informações do DEOPS, 22/10/1979. Dossiê 20-C-44- 6306. DEOPS/SP, DAESP.

${ }^{415}$ Informação da Divisão de Informações do DEOPS, 22/10/1979. Dossiê 20-C-44- 6306. DEOPS/SP, DAESP.
} 
reação a violência policial, a falsa democracia racial, a inoperância da lei Afonso Arinos, Zumbi e o sistema capitalista.

Sobre a FRENAPO o DEOPS associava a entidade com a esquerda, ressaltando sua proximidade com MNU e ligações com a "Tendência Popular" no PMDB, o que era interpretado pela polícia como vinculações com o "esquerdismo mais radical", aventando a possibilidade de manipulação do $\mathrm{PC}$ do $\mathrm{B}^{416}$ :

“[...] nota-se palavras de ordem próprias do esquerdismo, o interesse das esquerdas em atuar paralelamente dentro dos partidos legais, bem como o esforço em acirrar o preconceito racial nas camadas populares, procurando a emergência de um 'poder negro' como instrumento de pressão política." 417

Em debate, Wilson Prudente afirmou que "Uma revolução popular negra ainda irá acabar com tudo isso." ${ }^{418}$ Desta forma, a polícia política via uma ameaça clara provinda da organização dos afro-descendentes. “[...] aqui no Brasil também vamos sair pras ruas e botar o capitalismo abaixo e implantar o socialismo, vamos acabar com essa discriminação que nos marginaliza. " 419 O discurso inflamado apresentava a perspectiva de “células" nos bairros não só para a conscientização dos negros como para levar adiante um "levante armado" às ruas, em 20 de novembro, em forma de ato público defronte ao Teatro Municipal. ${ }^{420}$

Quase ao mesmo tempo Hamilton Cardoso Bernardes ressaltava a luta contra o regime político em vigor: “[...] como se bota prá quebrar contra esse governo ditatorial e racista que está ai. Abaixo a ditadura, abaixo a $p^{*}$ da princesa Isabel, - que abandonou os pretos e deu terra aos imigrantes estrangeiros, abaixo o capitalismo, viva o socialismo e a raça negra." 421 Assim a crítica ao regime militar ampliava a suspeição em relação aos movimentos negros.

$\mathrm{Na}$ análise policial acerca do Centro de Estudos Brasil-África (CEBA), encontra-se o entendimento que essa associação: "visa também, conscientizar e congregar os negros em

\footnotetext{
416 Relatório confidencial sobre a FRENAPO, de 18/7/1980, fl. 3. Dossiê 50-Z-130- 3802. DEOPS/SP, DAESP.

${ }^{417}$ Relatório confidencial sobre a FRENAPO, de 18/7/1980. Dossiê 50-Z-130- 3802. DEOPS/SP, DAESP.

${ }^{418}$ Informação da Divisão de Informações do DEOPS, 22/10/1979, fl. 2. Dossiê 20-C-44- 6305. DEOPS/SP, DAESP.

${ }^{419}$ Informação da Divisão de Informações do DEOPS, 22/10/1979, fl. 2. Dossiê 20-C-44- 6305. DEOPS/SP, DAESP.

${ }^{420}$ Informação da Divisão de Informações do DEOPS, 22/10/1979, fl. 2. Dossiê 20-C-44- 6305. DEOPS/SP, DAESP.

${ }^{421}$ Informação da Divisão de Informações do DEOPS, 22/10/1979, fl. 3. Dossiê 20-C-44- 6304. DEOPS/SP, DAESP.
} 
torno de um programa de 'assumir seu lugar na sociedade pela libertação do preconceito racial. [...] Elementos ligados ao CEBA/RJ, recentemente fundado em SÃO GONÇALO, afirmam que o objetivo fundamental daquela agremiação seria o chamado 'PODER $N E G R O^{\prime}$." Este fato gerou a solicitação de investigação sobre nomes dos dirigentes, estatutos, locais de reuniões, contatos nacionais e internacionais, fontes de recursos, número de associado, apoio recebido. ${ }^{422}$ Vale lembrar que o artigo $11^{\circ}$ do $2^{\circ}$ capítulo da LSN de 1967 apontava como crime: "Redistribuir material ou fundos de propaganda de proveniência estrangeira, sob qualquer forma ou a qualquer título, para a infiltração de doutrinas ou idéias incompativeis com a Constituição." ${ }^{423}$ Desse modo, um dos principais itens investigados nos movimentos sociais era a proveniência dos seus recursos e os seus contatos externos.

O debate sobre o "poder negro" na formação da identidade dos movimentos negros constituiu-se, na ótica do regime militar, em "subversão". Os movimentos negros procuravam articular uma identidade étnica, em que: "A identidade racial e cultural é nossa herança, construída pelos nossos irmãos negros, numa historia de lutas. Em cada gota de suor, de sangue, há uma afirmação: Viver é preciso, como povo como cultura." ${ }^{424}$ Assim, a idéia de que um negro é sempre um negro onde quer que esteja, impulsionava o debate sobre a situação racial não apenas, no Brasil, mas em outras regiões do mundo, em particular nos EUA e na África.

Enquanto isso, a polícia civil preocupava-se em estudar a questão da etnia, nos termos apresentados no artigo Etnia, um fenômeno mundial do sociólogo norte-americano Glazer. Na Revista Arquivos $^{425}$, este autor defendia que os conflitos sociais baseados na etnia, combinando elementos culturais e biológicos, eram ser uma tendência mundial daquele período. ${ }^{426}$ Diferenciando "raça" de "etnia", o autor afirmava que uma raça poderia não ser

\footnotetext{
${ }^{422}$ Pedido de Busca confidencial n. 418/76 - LS de origem do CIE para DOPS/SP sobre assunto "Centro de Estudos Brasil-África". Dossiê 50-J-0-4866. DEOPS/SP, DAESP.

${ }^{423}$ Lei de Segurança Nacional de 11 de março de 1967. Apud FICO, C. Além do golpe: a tomada do poder em 31 de março de 1964 e a ditadura militar. Rio de Janeiro: Record, 2004, p. 364.

${ }^{424}$ Manifesto do MNU sobre o Dia Nacional da Consciência Negra assinado pela Comissão Executiva Nacional do MNU. Dossiê 20-C-44-14605. DEOPS/SP, DAESP.

${ }^{425}$ Os textos presentes na Revista Arquivos são de autoria de delegados, juristas, militares, etc. Mas também contava com traduções de textos internacionais, de cientistas sociais, e de autoridades policiais, em particular, de autores norte-americanos.

${ }^{426}$ GLAZER, N. "Etnia, um fenômeno mundial” In Arquivos, vol. XXVIII. São Paulo: Polícia Civil de São Paulo, 1976, pp. 203-216.
} 
um grupo étnico, exemplificando: "os brasileiros de raça predominantemente negra não são classificados como um grupo étnico porque não estão particularmente cônscios de uma cultura comum diferente da dos outros brasileiros. Isso é também porque não têm uma auto-identificação conjunta como um grupo distinto, muito embora alguns, individualmente, percebam suas características físicas e que essas diferenças físicas tendem a ser associadas com algumas características comuns de grupo, como um nível de renda mais baixo ou determinadas ocupações. Recentes informações do Brasil parecem mostrar que os negros no Brasil começam a construir um grupo étnico. Isso estaria de acordo com um dos maiores temas do meu artigo, ou seja, que o grupo étnico está tendendo a se tornar, em muitos países, uma base mais significativa de organização social e de identificação individual." 427

Se o pensamento de um Brasil homogêneo e sem conflitos raciais já estava presente em 1976 (data do artigo), certamente com a mobilização maior dos movimentos negros com o MNCDR, em 1978, propondo a sua unificação, houve maior vigilância policial, para combater o "conflito étnico" e a constituição de uma organização social própria. "Há por certo uma tensão entre grupos étnicos e Estados. À medida que cada Estado tenta tornarse uma nação, ele procura reduzir a intensidade das reivindicações étnicas subordinadas. O problema é que tanto os grupos étnicos como os estados exigem lealdade total. E o Estado, inevitavelmente, entra em conflito com qualquer forma social que tem uma reivindicação de lealdade total." 428 Assim, para o autor, o Estado estava intimamente ligado à Nação, e um exame de que a heterogeneidade étnica seria um "problema", um entrave ao Estado, apesar de declarar que os esforços dos estados para atingirem uma "pureza racial” fosse também uma causa perdida. Analisando o crescimento dos conflitos étnicos entendia que se deve ao " apelo da identidade étnica toca mais as camadas emocionais da personalidade humana e social do que faz o apelo à identidade de classe. Ela toca em coisas fundamentais como a nossa língua e religião, às nossas primeiras experiências familiares, à nossa auto-imagem física. " 429

A leitura desse artigo pelos quadros policiais transmitiria a idéia do "perigo" eminente da questão étnica no Brasil. A solução proposta por Glazer foi que cada grupo social tivesse

\footnotetext{
427 GLAZER, N. Op. Cit., p. 205.

${ }^{428}$ GLAZER, N. Idem, p. 208.

${ }^{429}$ GLAZER, N. Ibdem, p. 215.
} 
seus direitos garantidos. Mas como é sabido, passando a "perigosos inimigos" os movimentos negros foram sistematicamente vigiados e controlados pelos órgãos de informação e segurança.

No entanto, observamos ainda no estudo da revista policial Arquivos que não havia, entre os anos de 1964 a 1983, um debate explicito sobre a questão racial brasileira. ${ }^{430}$ Entretanto, há alguns traços próprios de um pensamento conservador, pautado em postulados da Criminologia, evidentes ao considerar determinadas ações políticas como crime, da mesma forma que o "crime comum", o "crime político" era passível de ser analisado pelas idéias da Antropologia Criminal. Em artigo "Fatores Criminógenos", o crime era causado por fatores endógenos, isto é, biológicos e aos fatores exógenos, ligados ao meio social. ${ }^{431}$

Isso se torna bastante complexo, à medida que alguns crimes são construções históricas de um determinado período, como o do nosso estudo, do dito "crime político". O pensamento: que o crime relacionava-se a fatores biológicos e a "pré-disposição" à criminalidade $^{432}$, tornava o debate enfraquecido e sem sustentação. Elementos preconceituosos apresentavam-se na abordagem policial, em 1965, quando a raça era citada como fator causal da criminalidade: "Para poder distinguir as fontes de informações, o investigador tem de recorrer, em especial, à Psicologia, ciência que estuda o comportamento humano, mostrando que raça, idade, sexo, educação, estado de saúde, situações social e econômica, idéias políticas, profissão, sentimento religioso e outros fatores, influem nas atitudes dos seres humanos, fazendo-os sentir e agir de modos diversos, em situações idênticas." 433

Questionamos se o pequeno número de artigos relacionados diretamente à questão racial naquele momento, não seria decorrência do fato de já haver um pensamento sobre a

\footnotetext{
${ }^{430}$ Exceto por dois artigos que trataram de alguma forma a questão racial brasileira: GLAZER, N. Idem, Ibdem, pp. 203-216. e SILVA, J. "Artur Ramos e o Direito Penal (Escola Brasileira)” In Arquivos, vol. XXX. São Paulo: Polícia Civil de São Paulo, $2^{\circ}$ semestre 1977, pp. 101-109.

${ }^{431}$ FERREIRA, I. "Fatores Criminógenos" In Arquivos, vol. 32. São Paulo: Polícia Civil de São Paulo, $1^{\circ}$ semestre de 1979, pp. 65-71.

${ }^{432}$ A autora assume que não há fatalidade para alguém ser criminoso devido a seus caracteres biológicos, no entanto, ainda sustenta a idéia de uma predisposição genética para a criminalidade. Além disso, a autora afirma que raça não influiria nos fatores criminológicos. FERREIRA, I. "Fatores Criminógenos" In Arquivos, vol. 32. São Paulo: Polícia Civil de São Paulo, $1^{\circ}$ semestre de 1979, pp. 65-71, p. 66.

${ }^{433}$ NOGUEIRA, C. Manual de Investigação Policial. São Paulo: Escola de Polícia de São Paulo, 1965, pp. 42/43.
} 
questão racial brasileira consolidada no meio policial, carregada de preconceitos e estereótipos, ainda hoje, presentes na ação policial brasileira. Na pesquisa do jornalista Caco Barcellos sobre mortes cometidas pela polícia, ele conclui que a maioria era negra, embora fosse a minoria populacional da cidade. Além disso, mais da metade dos identificados nunca tinha sido processado criminalmente e nem era suspeita de crime violento quando faleceram. ${ }^{434}$ Há ainda, indicadores que "mostram que os negros tendem a ser mais perseguidos pela vigilância policial, enfrentam obstáculos maiores no acesso à justiça criminal e têm mais dificuldade de proteção e promoção de seus direitos constitucionais." ${ }^{435}$ Desse modo, os cientistas sociais constataram em suas pesquisas que negros "parecem mais vulneráveis à vigilância policial. Os rigores da detenção arbitrária, maiores perseguições e intimidação, um número maior de funcionários da polícia em comunidades onde a maioria das classes populares vivem, tudo isso contribui para o fato de que os negros sejam os alvos preferidos da repressão policial. "436

A carga de preconceitos faz-se presente na identificação de "desordem" e "caos" acerca da atuação desses movimentos, como consta de um relatório sobre manifestações na 34 SBPC, em 1982, no pátio interno da UNICAMP. Segundo a descrição: "aconteceram manifestações de toda ordem, não faltando a presença de vendedores de revistas, livros, vendas de assinatura de jornais, revistas e publicações diversas, além de apregoações políticas e coleta de assinaturas em prol dos diversos partidos políticos. Não bastasse todo esse mafuá, ocorreram diversos abaixos assinados em prol OLP, em apoio à questão racial e contra a discriminação [...] O Movimento Negro Unificado também se fez presente, ao lado do Movimento Feminista todos de cunho reivindicatório." ${ }^{437}$ Sobre os movimentos negros (assim como para outros movimentos reivindicatórios) incidiram um maior número de preconceitos pelo fato de serem manifestastes e por serem negros. $\mathrm{O}$ "poder, no discurso

\footnotetext{
${ }^{434}$ BARCELLOS, C. Rota 66: A História da Polícia que Mata. São Paulo: Globo, 1992.

${ }^{435}$ COOK, R. "Superando a discriminação: Introdução. In MÉNDEZ, J. , O’ DONNELL, G. E PINHEIRO, P. S. Democracia, Violência e Injustiça. O Não-Estado de Direito na América Latina. São Paulo: Paz e Terra, 2000 , p. 129.

${ }^{436}$ ADORNO, S. Discriminação Racial e Justiça Criminal em São Paulo. In Novos Estudos n. 45. São Paulo: Cebrap, 1995, p. 53.

${ }^{437}$ Referente a SBPC, fl 38, dossiê 20-C-44- 28567 até 28505. DEOPS/SP, DAESP.
} 
racista, é epistemologicamente exercido nas práticas duais de nomear e avaliar o outro. ${ }^{, 438}$

Também é necessário salientar que houve uma constante vigilância e repressão aos movimentos negros ao longo do funcionamento do DEOPS/SP entre 1924 a 1983, com particularidades próprias no regime militar. A noção de que os movimentos negros brasileiros introduziam conflitos raciais que a "democracia racial" brasileira desconhecia, esteve presente também na documentação policial do regime militar, porém, somada a novos valores e definições próprias da Doutrina de Segurança Nacional, como a de "antagonismo racial". Notamos que existiram mais continuidades do que dessemelhanças. De forma geral, permaneceu a mentalidade racista em nossa sociedade, que se reconfigurou ao longo do tempo, adaptando-se a diferentes conjunturas, mas mantendo as desigualdades, hierarquias e assimetrias entre brancos e negros.

A presença de um discurso racista próprio das estruturas repressivas do regime militar revela mais um dos limites sociais impostos à população afro-brasileira. Refiro-me a mais um limite, uma vez que o preconceito, a discriminação e o racismo incidem em diversos planos sobre a população afro-brasileira, ou seja, econômica, social e, sobretudo, politicamente. As reivindicações dos movimentos negros no período em questão foram criminalizadas e só fizeram ampliar a exclusão política dos afro-brasileiros.

\section{Denúncia do racismo}

Apesar de notarmos uma prática racista nos quadros policiais brasileiros, não se pode negar a existência de investigações sobre denúncias de racismo, como o caso do Clube de Regatas Tietê. ${ }^{439}$ Porém, ao mesmo tempo, encontramos uma forte preocupação com a ação dos movimentos negros, resultado das contradições do racismo à brasileira que também se fizeram presentes na polícia política, levando a questionar qual foi o real empenho dessas investigações, e quais as suas conclusões.

Ao analisar o prontuário do Clube de Regatas Tietê, sobre o inquérito que se refere a denúncia de um caso de racismo cometido por sua diretoria, o presidente do clube teria proibido 4 garotos negros de participarem de modalidade esportiva nas equipes infantis e

\footnotetext{
438 GUIBERNAU, M. Nacionalismos: o estado nacional e o nacionalismo no século XX. Rio de Janeiro: Jorge Zahar Ed., 1997, p. 97.

439 Prontuário n. 149176, Clube de Regatas Tietê. DEOPS/SP, DAESP. Também há a documentação do dossiê 50-Z-129- 17846 sobre denúncia de racismo.
} 
mirins. $\mathrm{O}$ treinador de vôlei depôs afirmando ter sido chamado por um funcionário, que o alertara que os garotos não poderiam treinar por ordem da diretoria, em "razão da cor", informação que não foi confirmada pelo funcionário e nem pelo presidente.

Em depoimento de 30/5/1978, Paulo Sergio Moreira Gomes, um dos atletas, disse que era barrado pelos porteiros do clube por não ser sócio, mas sempre que chamado o técnico ele conseguia entrar no clube e treinar vôlei. Contou que uma vez ele e seus colegas foram proibidos de treinar, sendo que o técnico João Crisostomos apresentou um abaixo assinado em que os técnicos e jogadores da equipe protestavam contra a situação e pediam a volta dos jogadores negros.

No relatório judicial, de 4/8/1978, do Promotor Público Messias Piva, propunha ao Juiz o arquivamento por: "Um argumento, pois, que nos parece fundamental, excluindo de vez a tipicidade da contravenção em foco, é o seguinte: vários e vários sócios, de cor preta, pertencem aos quadros do clube, freqüentando e participando de todas as modalidades esportivas, inclusive natação, conforme se vê de farta comprovação nos autos. " 440

No entanto, no depoimento de Walter dos Santos Junior, de 30/5/1978, consta que ele nunca viu nenhum negro freqüentar o clube como sócio. Também o depoente Elias do Sacramento Machado Filho, em 8/6/78, afirma que nunca viu nenhum sócio negro no clube. Nos depoimentos dos garotos envolvidos, todos afirmaram que queriam ser sócios militantes, ou seja, serem atletas do clube, mas a carteirinha nunca ficava pronta. Os técnicos depuseram e confirmaram que Waldemar Pontes Talarico foi comunicado da proibição do presidente de haverem negros no clube.

A conclusão judicial baseou-se, também, nos depoimentos de funcionários da portaria do clube que não puderam confirmar as denúncias e alegaram existirem sócios negros no clube. Dois funcionários ainda alegaram que havia negros, "inclusive" freqüentando a natação do clube. Os diretores, em depoimento, alegaram que foi comunicado aos técnicos que a quadra não poderia ser utilizada de fim de semana e que esta foi a única proibição. Esclareceram, também, que os técnicos foram demitidos por não estarem comparecendo aos jogos e que estavam treinando os jogadores fora do clube. Já no depoimento, em 3/7/78, o presidente Otavio Decio Mariotto disse ser absurda a acusação de discriminação racial no clube e, a fim de comprovar a inexistência de tal fato exibiu às autoridades fichas

${ }^{440}$ Prontuário n. 149176, Clube de Regatas Tietê. DEOPS/SP, DAESP. 
individuais de funcionários e de sócios negros do clube. Tomado depoimentos de alguns dos sócios negros às autoridades policiais, declaram que não tinham dificuldades de acesso ao clube ou restrições.

A legislação em vigor que punia a discriminação racial era a de 1951, a Lei Afonso Arinos. Mas só na Constituição de 1988 a prática racista ao invés de contravenção foi definida como crime. Ao mesmo tempo, lembremos que a Lei de Segurança, de 29/09/1969, considerava crime incitar o "ódio" ou à discriminação racial. ${ }^{441}$ O manual base da polícia enumerava como crimes contra a ordem política e social, definidos pela lei de $\mathrm{n}$. 1802, de 5 de janeiro de 1953: "Fazer publicamente propaganda [...] de ódio de raça, de religião ou de classe." 442 Segundo Ayrton Baffa, o SNI e a EsNI, em 1973, produziram documentação reservada referente a "movimentos revolucionários" que eram alimentados, pela ótica do SNI, por "insatisfações reais, fictícias ou incitadas de uma parte da população", entre as quais foi apontado os "preconceitos raciais". ${ }^{443}$ Ou seja, nesse quadro legislativo, a vítima de uma discriminação racial, se não comprovasse tal ação, poderia ser enquadrada em uma dessas leis por incitar o "ódio racial”.

Havia a visão no regime militar de que "A subversão tem por mira destruir os valores, a vontade e os sentimentos da coletividade, substituindo-os por outros, e a instilação do ódio aos antigos padrões de julgamento ou filosofia de vida. Para que ela tenha êxito, é necessário que existia um núcleo dirigente, apoiado por parcela significativa da população, e que a maioria da população esteja descontente com os padrões vigentes da sociedade." 444 Dessa forma, os movimentos negros tornavam-se "subversivos", uma vez considerados como "desagregadores" da sociedade brasileira.

Como parte da estratégia do escamotear do racismo no Brasil, o item cor não fez parte dos recenseamentos do IBGE durante 2 décadas uma vez que os governantes entendiam

\footnotetext{
${ }^{441}$ ALVES, M. H. Estado e Oposição no Brasil (1964-1984). Petrópolis: Vozes, 1985, pp. 158/159.

${ }^{442}$ APOLLONIO, L. Manual de polícia política e social. São Paulo: Escola de Polícia de São Paulo, 1963. (3 ${ }^{\mathrm{a}}$ Edição), p. 319.

${ }^{443}$ BAFFA, A. Nos porões do SNI. O retrato do monstro de cabeça oca. Rio de Janeiro: Editora Objetiva, 1989, p. 20.

${ }^{444}$ NASCIMENTO, F. "Contra-informação" In Arquivos, vol. XXXI. São Paulo: Polícia Civil de São Paulo, $1^{\mathrm{o}}$ e $2^{\circ}$ semestre de 1978 , pp. 57-62, p. 62.
} 
não haver racismo no Brasil ${ }^{445}$ "o brasileiro não tem cor, todos são iguais perante a lei e têm acesso a todas as oportunidades." 446

Da mesma forma, o IBGE não teria divulgado dados referentes a presença do racismo nas relações de trabalho, segundo matéria do jornal Folha de São Paulo, de 22/01/1982. A reportagem denunciou que o IBGE tinha conhecimento, desde 1980, sobre o racismo no mercado de trabalho com dificuldades na contratação e salários menores para os negros e pardos, mas essa pesquisa do Departamento de Estudos e Indicadores Sociais, foi mantida em sigilo. ${ }^{447}$ Essas medidas revelam a preocupação de sigilo que o regime militar manteve em relação aos movimentos negros, que por certo se tivessem conhecimento desses dados fortaleceriam os seus argumentos e a sua própria luta.

A existência da longa escravidão negra, por 3 séculos trouxe, sem dúvida, marcas profundas à sociedade brasileira. Dentre elas, uma série de estigmas e estereótipos sobre os afro-descendentes. Em séculos de relações hierarquizadas teve-se a formação de uma "brasilidade excludente" 448 que celebra a "democracia racial", selecionando representações culturais afro-brasileiras, mas excluindo os afro-descendentes de seus direitos sociais. “ $A$ história da escravidão, da abolição e pós-libertação foi uma luta contínua pela etnia dominante para evitar, em qualquer grau ou acordo, a reconciliação com as etnias subjugadas. " 449

\section{2) Os discursos sobre os movimentos de independência africanos}

\footnotetext{
445 Andrews comenta sobre o censo realizado em 1970 não ter incluído dados do quesito raça em sua pesquisa, escamoteando a situação dos afro-brasileiros na sociedade brasileira. ANDREWS, G. Negros e Brancos em São Paulo (1888-1988) Bauru: Editora do Sagrado Coração, 1998, p. 378.

${ }^{446}$ Periódico Manifestação, em edição n. 4 de janeiro de 1980. Pasta Movimento Negro. CEDIC/PUC-SP.

${ }^{447}$ Matéria "IBGE sabia do racismo no trabalho mas não divulga", Folha de S. Paulo, 22/1/1982, p. 30. OP 1079 Racismo vol. 2. DEOPS/SP, DAESP.

448 SAMET, H. "Construção da brasilidade excludente." In ARQUIVO PÚBLICO DO ESTADO. DOPS: $a$ lógica da desconfiança. Rio de Janeiro: Secretária de Estado de Justiça, 1996.

${ }^{449}$ MIR, L. Guerra Civil: estado e trauma. São Paulo: Geração Editorial, 2004, p. 39.
} 


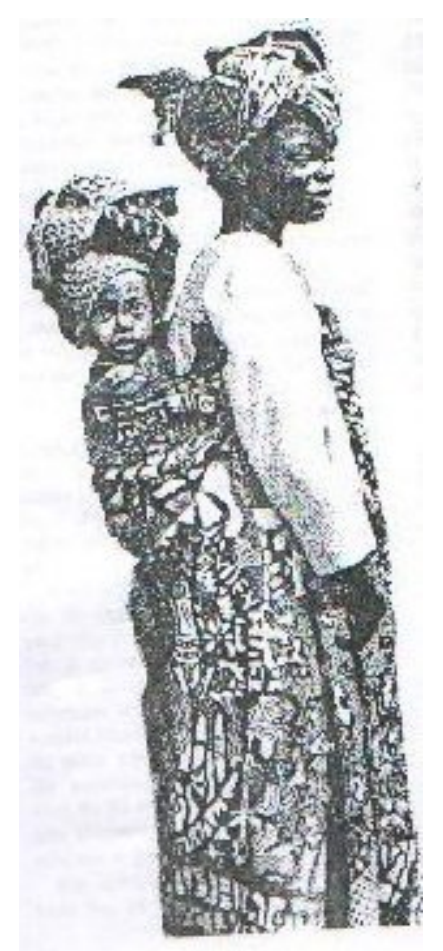

Imagem fotográfica de uma mulher e uma criança africanas constante em artigo da Mitary Review, em 1968.

Os debates sobre a situação política africana também eram classificados pelas autoridades policiais como ação "subversiva", sendo os diversos impressos, elementos da construção de uma "narração" policial que definia os movimentos negros como "perniciosos à ordem pública". Dessa forma, todo e qualquer material que discutisse tais questões eram apreendidos. Estes impressos foram apreendidos pela polícia política, em geral, em eventos vigiados por seus agentes que, muitas vezes, apresentavam-se à paisana $\mathrm{e}$ coletavam esse "material subversivo" para identificar e conhecer os "inimigos da ordem". Os debates de tais movimentos eram identificados como "perniciosos à ordem pública" ao divulgar as idéias presentes de linha "marxista".

\footnotetext{
${ }^{450}$ Imagem de mulher e criança africanas constante em artigo BROWN, N. "A guerra civil na Nigéria” In Military Review (Publicação Profissional do Exército dos EUA), vol. XLVIII, n. 10. Kansas: Escola de Comando e Estado-Maior do Exército dos Estados Unidos, outubro de 1968, pp. 20-31, p. 20.
} 
A preocupação em conhecer melhor a África e ampliar o debate anti-racista se fez presente no jornal Sinba, lançado em 1977, em Niterói pela Sociedade de Intercambio Brasil-África. Segundo a polícia, este jornal em particular, foi criado: "como veiculo de divulgação dos movimentos que lutam contra o racismo e o colonialismo, dando atenção ao noticiário sobre a realidade dos povos africanos que lutam na Rodésia, Namíbia e África do Sul, porém, até o momento, não se tem conhecimento de novas edições." ${ }^{451}$ Por atentar contra a lei de Segurança Nacional (LSN), a publicação foi classificada como nociva e passível de processo. Desse modo, notamos que o debate sobre a África tornavase, aos olhos da repressão, nociva, por seu potencial "subversivo", pois: "Todas as matérias veiculadas no referido periódico apresentam tópicos que incentivam o antagonismo racial, razão pela qual tal publicação configura-se contrária aos interesses nacionais". ${ }^{452}$

Tais documentos demonstram a vigilância realizada pelos aparatos repressivos do regime militar contra temas referentes a África no seio dos movimentos negros e nos meios estudantis e acadêmicos. A situação vivenciada pelos movimentos de independência em países africanos contra o jugo colonial, sobretudo os de colonização portuguesa, trouxe ao debate dos movimentos negros brasileiros novos elementos para a discussão sobre a violência e o racismo dos quais eram alvo os afro-descendentes, de forma geral, em todo mundo. O terror "anti-comunista" sustentado pelo governo militar acirrou ainda mais o controle, uma vez que os movimentos negros passaram a debater os modelos desenvolvimento africanos de tendência "marxista-leninista". Como a polícia e os militares avaliavam os movimentos negros de forma duplamente preconceituosa, como desinformados e manipuláveis, identificavam como "presas fáceis" dos "comunistas". Exemplo dessa conduta é a análise policial da Revista Tição, do Rio Grande do Sul que anunciava o lançamento do livro de poemas do angolano Agostinho Neto, tornando-se

\footnotetext{
${ }^{451}$ Encaminhamento confidencial n. 0386/08/78 da Central de Informações do Departamento de Policia Federal para difusão agencia SP SNI, II Ex, 4 COMAR, DOPS/SP com copia xerox do informe n. 318/01/78, de avaliação A1, expedido em 14 de agosto de 1978 com assunto "Movimento Nacional dos Blacks". Dossiê 50-E-33-2150/2155. DEOPS/SP, DAESP.

452 Informe n. 318 confidencial do Centro de Informações da Polícia Federal sobre o "Movimento Nacional dos Blacks", de 14/08/1978. Dossiê 50-E-33- 2153. DEOPS/SP, DAESP.
} 
altamente perigosa por exaltar a figura de um líder marxista e o Movimento Popular de Libertação de Angola (MPLA). ${ }^{453}$

A realização do III Congresso de Cultura Negra das Américas realizado na PUC/SP, em 1982 e presidido por Abdias do Nascimento, foi acompanhada de perto pelos agentes da polícia política. Em especial por este evento ter apresentado como pauta temas da situação das lutas de independência africanas, e a necessária a construção de uma solidariedade entre os negros de todo o mundo. Quanto a este debate acerca do racismo no mundo, incentivava os movimentos negros a refletirem sobre o racismo brasileiro, levando o III Congresso de Cultura Negra das Américas a denunciar a existência de uma discriminação oficializada no Brasil, um "racismo praticado pelo próprio governo". ${ }^{454}$ A África se tornava parâmetro comparativo à situação racial brasileira, como no panfleto "Dia Nacional de Denúncia contra o Racismo", em que entre outros dados apresenta-se que em "4 meses a polícia matou quase 150 pessoas, mais do que a racista polícia sul-africana mata por ano." 455 Estas idéias debatidas pelos movimentos negros levou a comunidade de informações e segurança a dispensar uma redobrada atenção, em particular, desde o momento em que passou a crescer o apoio ao fim do colonialismo nos países de língua oficial portuguesa e a construção de Estados independentes.

No contexto mundial bipolar, a África tornava-se um locus de vigilância, pelos movimentos de independência declaradamente anti-capitalistas e, muitas vezes, proclamada como marxista-leninista, tornando-se objeto de relatórios e estudos das instituições de vigilância e repressão do regime militar brasileiro.

No estudo Sumário de Informações, de caráter reservado, distribuído pela Agência Central do Serviço Nacional de Informação (SNI) aos órgãos repressivos, com o título "Comunismo Internacional”, havia um item reservado à África ${ }^{456}$ O Sumário de

\footnotetext{
${ }^{453}$ Encaminhamento confidencial n. 0386/08/78 da Central de Informações do Departamento de Policia Federal para difusão agencia SP SNI, II Ex, 4 COMAR, DOPS/SP com cópia xerox do informe n. 318/01/78, de avaliação A1, expedido em 14 de agosto de 1978 com assunto "Movimento Nacional dos Blacks". Dossiê 50-E-33-2150/2155. DEOPS/SP, DAESP.

${ }^{454}$ Recorte do Jornal Folha de São Paulo, 20/08/1982, p. 13. OP 0989 Movimento Negro vol 2. DEOPS/SP, DAESP.

${ }^{455}$ Panfleto do Grupo Negro da PUC, do Movimento Negro Unificado e da Comissão de Negros do Partido dos Trabalhadores. OP 0989 Movimento Negro vol 2. DEOPS/SP, DAESP.

${ }^{456}$ Esse item, em geral, apresentava em seus Sumários de Informações "Comunismo Internacional”. Dos números consultados até agora, 9, 7 desses apresentavam esse item, das 10 pastas consultadas até agora, referentes a troca de informações entre DEOPS/SP e SNI.
} 
Informações, de setembro de 1970, Com os seguintes sub-itens: "A Penetração Russa na África" e "Angola - organizações subversivas MPLA - FDLA - FLNA - Mud Juvenil”.

Sobre a situação política angolana, o Sumário de Informações fez um apanhado geral sobre as "organizações subversivas de libertação", indicando seus principais membros, como o MPLA (Movimento pela Libertação de Angola) em Angola, a FDLA (Frente Democrática de Libertação de Angola), o MNA (Movimento Nacional de Angola) composto por filhos de angolanos sediado no Congo e o MUD (Movimento de Unidade Democrática Juvenil), em Portugal com uma grande participação de membros do Partido Comunista Português. ${ }^{457}$

O relatório apresentado no Sumário informava que Moscou manteria relações regulares com 33 países africanos, mediante acordos econômicos com a maioria deles, o que resultaria, por exemplo, numa votação conjunta com a URSS na ONU.

Além disso, os aspectos econômicos foram pontos importantes desse estudo, que constatou o aumento do comércio da África com o Leste Europeu e o crédito russo a países africanos. A revista Mirovia Ekononomika Mezhdunav Ovie Otnoshenia, especializada em assuntos econômicos internacionais, serviu de fonte para o SNI compreender as táticas do Kremlin na África, que "não desprezando os textos ideológicos de Lenine, parece preferir uma forma de penetração mais prática, que consiste, sobretudo, na ajuda econômica e militar”. Concluía que as políticas soviéticas se consolidaram gradativamente na África enquanto "o Ocidente se limita a uma ajuda econômica, em pura perda". 458

Notamos que os interesses do governo militar brasileiro nesses estudos não se referiam apenas à "prevenção ao comunismo" presente em suas estratégias militares ${ }^{459}$, mas também nos interesses econômicos e comerciais que possuíam em relação aos países africanos, como mercados para a produção industrial brasileira. Estes estudos integravam o projeto de hegemonia no Cone e Atlântico Sul, para o qual seria estratégico para o Brasil ser o

\footnotetext{
457 "Comunismo Internacional" Sumário de Informações Reservado n.9 de setembro de 1970. Dossiê 20-C43-2489. DEOPS/SP, DAESP.

458 "Comunismo Internacional" Sumário de Informações Reservado n.9 de setembro de 1970. Dossiê 20-C43-2489. DEOPS/SP, DAESP.

${ }^{459}$ Parte da literatura militar brasileira entendia ser vital a segurança do Atlântico Sul para a conservação dos valores ocidentais e cristãos do Mundo, impedindo o alastramento do "comunismo". MIYAMOTO, S. $O$ Brasil e o Pacto do Atlântico Sul. Marília”: FEFCSD/ UNESP, 1987, pp. 6-7.
} 
primeiro país a reconhecer a independência de Angola, em janeiro de $1975 .{ }^{460}$ No intento de fazer o Brasil uma "grande potência mundial", os militares entendiam ser necessário desenvolver a hegemonia brasileira, em particular no chamado Cone Sul, cumprindo seu "destino de grandeza"461 , do "Brasil potência", capaz de um crescimento cada vez mais notório: "potencialmente existente para ocupar o lugar exato que lhe estava previamente atribuido no mapa mundo". 462

Percebemos que o código de classificação da documentação do Sumário de Informações, trata-se de dossiês do código "20" que significaria "política nacional”. Um código tanto surpreendente quando seu objeto principal é o "comunismo internacional"463

Os debates acerca do Cone e do Atlântico Sul já apareciam na década de 1960 e início da década de 1970 na literatura militar da Escola Superior de Guerra. ${ }^{464}$ Golbery Couto e Silva ${ }^{465}$ defendia que o Brasil tinha grande importância no confronto com o bloco “comunista", pois sua localização era privilegiada, tornando-o um país capaz de proteger o continente sul americano, o Atlântico Sul e a África Meridional. Nesse projeto, Golbery entendia que o Brasil deveria ser reconhecido pelos EUA como aliado preferencial como país hegemônico no pólo regional, ampliando as potencialidades geopolíticas brasileiras e servir como "guardião dos valores ocidentais" no continente. ${ }^{466}$ Como exemplo desse pensamento, a Revista Defesa Nacional, apresentava artigo que defendia que: "a luta pelo domínio do mundo pode ser decidida no continente sul-americano pois que, dessa região estratégica, é possivel isolar os E.U.A. e só esta parte da terra oferece, presentemente, condições para uma vantajosa oposição à União Soviética." 467

\footnotetext{
${ }^{460}$ Planos desenvolvidos pelos estudos da Escola Superior de Guerra, no seu exemplo maior com Golbery de Couto e Silva, desenvolvendo planos de estratégia geopolítica no Cone Sul e no Atlântico Sul. SILVA, G. Conjuntura Nacional - O Poder Executivo. Geopolitica do Brasil. Rio de Janeiro: José Olympio, 1981. E SILVA, G. Geopolítica do Brasil. Rio de Janeiro: José Olympio, 1967.

${ }^{461}$ MIYAMOTO, S. e GONÇALVES, W. A Política Externa Brasileira e o Regime Militar: 1964-1984. Campinas: IFCH/ UNICAMP, 1991.

462 GIRARDET, R. Mitos e Mitologias Políticas. São Paulo: Cia. Letras, 1987, p. 159.

${ }^{463}$ LEITÃO, A. "Estudo sobre os códigos da série Dossiês do Fundo DEOPS-SP" In Informativo Associação dos Arquivistas de São Paulo. São Paulo: Arquivo do Estado, junho de 2000, n. 2, p. 7.

${ }^{464}$ MIYAMOTO, S. O Brasil e o Pacto do Atlântico Sul. Marília”: FEFCSD/ UNESP, 1987., p. 13.

${ }_{465}$ Assessor político do presidente Figueiredo e chefe da Casa Civil a partir de 1974 (ainda no governo Geisel) até 1981. Foi o maior estrategista do regime militar e autor de obras como O Brasil e a Defesa do Ocidente, Geopolítica do Brasil e Conjuntura política nacional, o poder executivo. Geopolítica do Brasil.

466 SILVA, G. Conjuntura Nacional - O Poder Executivo. Geopolítica do Brasil. Rio de Janeiro: José Olympio, 1981. E SILVA, G. Geopolitica do Brasil. Rio de Janeiro: José Olympio, 1967.

467 TOSTA, O. "Problemas da América Latina. A segurança dos EUA está na América do Sul" In Defesa Nacional, Ano XLVII, n. 546. Rio de Janeiro: Ministério da Guerra, janeiro de 1960, pp. 151-158, p. 157.
} 
Nessa perspectiva, a África fez parte das preocupações defensivas do regime militar, desde a implantação de governos "comunistas" na costa ocidental da África que poderiam ameaçar os "valores ocidentais" defendidos pelo governo brasileiro, além do perigo de bloqueio do Atlântico Sul, impedindo navios de navegarem, sobretudo petroleiros. ${ }^{468}$

Segundo artigo da Revista Defesa Nacional: "o conceito de guerra de libertação nacional ocupava uma alta prioridade no esquema operacional comunista na década dos 60.” ${ }^{469}$ No entanto, na avaliação do autor, para a URSS os movimentos de libertação nacional africanos deixaram de ser prioritários. A revista militar A Defesa Nacional, preocupava-se em dar um panorama dos conflitos armados pelo Mundo e tratou dos conflitos da África também, destacando onde acontecia o conflito, a data, os envolvidos e a situação até aquele momento. ${ }^{470}$ Em especial, os países africanos de antiga colonização portuguesa, como Angola e Moçambique, interessavam por questões econômicas e estratégicas de defesa do Atlântico Sul. Além disso, a guerra de guerrilhas era outro fator de interesse para o estudo desses países, fornecendo subsídios para o combate das guerrilhas no Brasil.

\section{Military Review: uma visão sobre a África}

A análise da revista Military Review, publicação do exército dos Estados Unidos ${ }^{471}$, entre setembro de 1966 a março a 1974, também apresenta o interesse constante dos militares dos EUA pela situação político-militar da África, e a importância que o Brasil conferia a essa publicação ao traduzi-la e publica-la. ${ }^{472}$

O artigo de março de 1967, "As forças armadas africanas", assinalava o interesse soviético e chinês pelo continente africano. Todavia, ressaltava que os "oficiais da maioria destas pequenas forças [exércitos africanos], pelo decréscimo da atividade comunista nesta parte do mundo." 473 Apontava, demonstrando a disputa da África no contexto da Guerra

\footnotetext{
${ }^{468}$ MIYAMOTO, S. Op. Cit., p. 15.

${ }^{469}$ POZZOBON, Z. "Guerrilha Urbana” In A Defesa Nacional, Ano 59, n. 647. Rio de Janeiro: Ministério da Guerra, jan/fev 1973, p. 80.

${ }^{470}$ A Defesa Nacional, Ano 59, n. 647. Rio de Janeiro: Ministério da Guerra, jan/fev 1973, pp. 167-170.

${ }^{471}$ Os articulistas eram de origens diversas, mas na maior parte das vezes, tratam-se de pessoas pertencentes ao exército dos EUA ou então cientistas políticos de diferentes nacionalidades.

${ }^{472}$ Entre o período de setembro de 1966 a março de 1974, encontramos 9 artigos que tratam da política e dos militares na África, além de 2 artigos que tratam das relações raciais no exército dos EUA.

${ }^{473}$ STEVENSON, C. “As forças armadas africanas” In Military Review (Publicação Profissional do Exército dos EUA), vol. XLVII, n. 3. Kansas: Escola de Comando e Estado-Maior do Exército dos Estados Unidos, março de 1967, pp. 18-23, p. 23.
} 
Fria, a ajuda financeira dos EUA para exércitos de países africanos, além de assistência técnica, missões de instrução e formação, armas e equipamentos.

O artigo "O exército nos países afro-asiáticos", escrito por um colaborador do governo do Vietnã, de agosto de 1967, entendia que "os povos afro-asiáticos [...] rejeitam o comunismo que prega a revolução pelo completo divórcio das tradições nacionais e de todos os valores humanos do passado. " ${ }^{474}$ Desse modo, alimentava-se uma visão de que a atuação "comunista" na África era limitada, incentivando ações dos países capitalistas nessa região.

Em “Assistência Militar Soviética à África Tropical”, de julho de 1968, notamos que as preocupações com a presença da URSS aumentavam, mostrando uma preocupação maior com o "comunismo internacional". O autor ressaltava a África Tropical que ainda não era prioridade das duas potências como se fazia necessária. Em análise da influencia do comunismo na África ${ }^{475}$ foi avaliado que a fragilidade das instituições dos Estados recém independentes e a "identidade fragmentada" das Nações tornava necessária uma homogenização cultural e identitária. ${ }^{476}$ Dessa forma, entendia-se que "com a retirada do governo imperial e o relaxamento da humilhação racial, cedo apareceram divisões dentro da solidariedade do anticolonialismo. Um ressurgimento da identificação, com base em unidades étnicas menores, irrompeu em um país africano após o outro. Houve, de fato, o que já chamei de retribalização." ${ }^{477}$ Ressalta-se que incidiam sobre a análise da situação

\footnotetext{
${ }^{474}$ TRI, N. "O exército nos países afro-asiáticos" In Military Review (Publicação Profissional do Exército dos EUA), vol. XLVII, n. 8. Kansas: Escola de Comando e Estado-Maior do Exército dos Estados Unidos, agosto de 1967 , pp. $54-63$, p. 56.

${ }^{475}$ TRI, N. "O exército nos países afro-asiáticos" In Military Review (Publicação Profissional do Exército dos EUA), vol. XLVII, n. 8. Kansas: Escola de Comando e Estado-Maior do Exército dos Estados Unidos, agosto de 1967, pp. 54-63, p. 61. SADLER, J. "A África Ocidental: em busca da estabilidade" In Military Review (Publicação Profissional do Exército dos EUA), vol. XLIX, n. 11 Kansas: Escola de Comando e Estado-Maior do Exército dos Estados Unidos, novembro de 1969, pp. 28-38, p. 34. CLOTFELTER, J. "Os militares na África" In Military Review (Publicação Profissional do Exército dos EUA), vol. XLVIII, n. 5. Kansas: Escola de Comando e Estado-Maior do Exército dos Estados Unidos, maio de 1968, pp. 23-31, p. 30. WELCH JR., C. "Intervenção Militar na África Tropical" In Military Review (Publicação Profissional do Exército dos EUA), vol. L, n. 5. Kansas: Escola de Comando e Estado-Maior do Exército dos Estados Unidos, maio de 1970, pp. 25-38, p. 26.

${ }^{476}$ MAZRUI, A. “África na década de 70” In Military Review (Publicação Profissional do Exército dos EUA), vol. LII, n. 11. Kansas: Escola de Comando e Estado-Maior do Exército dos Estados Unidos, novembro de 1972, pp. 89-98, p. 89.

${ }^{477}$ MAZRUI, A. Op. Cit., p. 94.
} 
sócio-política na África, estigmas e estereótipos sobre as populações africanas, vistas como "tribalizadas" e "incivilizadas".

A análise desses artigos revela uma visão distorcida da referida revista ao analisar as estruturas sociais africanas. A Revista Military Review era uma publicação do exército dos EUA que possuía uma edição brasileira, em português, o que revela quais temáticas eram importantes para o exército e para o governo militar brasileiro e quais eram seus interlocutores privilegiados, influindo na própria avaliação que a comunidade de segurança e informações fez dos debates travados pelos movimentos negros sobre as lutas de independência no continente africano.

A "Libertação Nacional" era entendida pelos militares norte-americanos e também pelos brasileiros como um "jargão comunista", como pode-se observar em artigos da publicação Military Review. ${ }^{478}$ Desse modo, as ações de "libertação nacional" eram entendidas como distúrbios sociais apoiados pela URSS ou pela China, no intento de "comunização" do mundo. Por trás, encontra-se a visão de que todo conflito mundial do período fazia parte da guerra fria, em que a URSS exploraria "o descontentamento popular (real ou imaginário) e a inquietação em todas as áreas fora da esfera soviética onde haja possibilidade de solapar o poder e o prestígio dos Estados Unidos." ${ }^{479}$ Nesta análise o articulista destacava a África Sub-saariana como um dos principais pontos de "terrorismo". A preocupação do artigo era em torno do fato que os "Conflitos armados podem irromper em qualquer parte do mundo em desenvolvimento, causados por uma diversidade de razões, nem todas de inspiração comunista, e tendo como sua mais eficaz arma o terrorismo e a guerrilha. Estes movimentos podem facilmente ser explorados pelos comunistas." ${ }^{480}$ Lógica essa que se desenvolveu do mesmo modo no regime militar no Brasil, influindo na própria atuação das políticas internacionais brasileiras.

\section{Política externa brasileira para a África}

No governo de Castelo Branco (1964-1967) articulava-se a idéia de formar uma "comunidade luso-brasileira" que incluiria as colônias africanas sob o domínio português, uma vez que os militares optaram por uma aproximação com o regime salazarista, somando

\footnotetext{
478 KAUFFMAN, A. "Guerras de "Libertação Nacional"” In Military Review (Publicação Profissional do Exército dos EUA), vol. XLVIII, n. 10. Kansas: Escola de Comando e Estado-Maior do Exército dos Estados Unidos, outubro de 1968, pp. 32-44, p. 33.

${ }^{479}$ KAUFFMAN, A. Op. Cit., p. 35.

${ }^{480}$ KAUFFMAN, A. Idem, p. 43.
} 
esforços contra a instalação de regimes hostis ao "bloco capitalista" na África. Ao mesmo tempo, o governo tinha "o sério dilema de como evitar uma ruptura com Portugal, mantendo e desenvolvendo simultaneamente nosso relacionamento com a África." ${ }^{481}$, para que obtivesse sucesso nos seus interesses econômicos com a África. De toda forma, a aproximação econômica com os países africanos, não apenas os de colonização portuguesa, se desenvolvia desde setembro de 1964, quando ocorreu a visita ao Brasil de Léopold Senghor, presidente do Senegal. Castelo Branco e Senghor assinaram uma declaração conjunta e diversos acordos que procuravam estreitar os laços, principalmente os econômicos. $^{482}$

O apoio do regime militar brasileiro ao colonialismo luso na África e na Ásia, por certo influenciou negativamente os debates dos movimentos negros sobre a África. Garrido Torres, em artigo na Revista Segurança e Desenvolvimento da Associação dos Diplomados da ESG, condenava: “Em nosso país, porém, um grupelho afro-asiático, alienado ideologicamente, incorrigivelmente romântico, ou simplesmente ignorante, bate palmas à propaganda anti-portuguesa, para vergonha nossa." ${ }^{483}$ As estreitas relações políticas com Portugal levava à condenação dos que apoiavam a independência das suas colônias.

A preocupação ideológica se dava, em especial, em relação a Angola, com a política de linha marxista-leninista desenvolvida por Agostinho Neto vista como perigosa, uma vez que: “Angola está em linha reta frente ao território brasileiro, separado apenas pelo grande lago Atlântico. Por isso, o reconhecimento desse país foi visto com reticência pelos militares, quando o Ministério das Relações Exteriores, antecipando-se ao resto do mundo, reconheceu o MPLA sem que os combates houvessem sido encerrados. O Itamaraty vira no Movimento Popular de Libertação de Angola o legítimo representante de Angola [...] Esta ousadia da Chancelaria lhe custaria críticas violentas, não só no seio das Forças Armadas, que viam atemorizadas um país comunista do outro lado do oceano, não tão

\footnotetext{
${ }^{481}$ VIZENTINI, P. A política externa do regime militar brasileiro: multilateralização, desenvolvimento e a construção de uma potência média (1964-1985). Porto Alegre: Ed. da Universidade/ UFRGS, 1998, p. 179. ${ }^{482}$ VIZENTINI, P. Op. Cit., p. 65.

${ }^{483}$ TORRES, G. "Condicionamentos da Comunidade Lusíada" In Segurança e Desenvolvimento, Ano XVII, n. 131. Rio de Janeiro: Associação dos Diplomados da Escola Superior de Guerra, 1968, pp. 124-134, p. 126.
} 
distante assim, mas também pela imprensa como o Estado de S. Paulo que atacava, em constantes editoriais, a posição assumida por Azeredo da Silveira. " 484

Desse modo a política para África oscilava entre o interesse econômico e o receio político-ideológico:

"No conhecido discurso de julho de 1964, aos jovens diplomatas, Castello Branco ao dizer que 'a política externa não pode esquecer que fizemos uma opção básica que se traduz numa fidelidade cultural e política ao sistema democrático ocidental', ressaltava que 'dentro desse condicionante geral, a nossa independência se manifestará na aferição de cada problema especifico, estritamente em termos de interesse nacional, com margem de aproximação comercial técnica e financeira com países socialistas, desde que estes não procurem invalidar nossa opção básica. ", 485

No governo de Arthur da Costa e Silva (1967-1969) ampliaram-se os crescentes interesses econômicos pelo continente africano. Costa e Silva enfatizou o desenvolvimento do país por intermédio da ampliação dos mercados externos, no entanto, a política externa brasileira para a África manteve-se aliada a Portugal, com acordos de apoio à repressão sobre os movimentos de independência nas colônias, "a diplomacia brasileira deixava intocada a tese de que, nos territórios colonizados por Portugal o aspecto principal da guerra era a luta do mundo ocidental contra a expansão comunista. ", 486

Interesses econômicos, ideológicos e estratégicos aliaram-se num primeiro momento da política brasileira em relação à África. Pretenderam-se expandir os incipientes canais de comércio com os países da faixa tropical para mercado de exportação o que levou, em 1972, no governo Emílio Garrastazu Médici (1969-1974), o ministro das Relações Exteriores, Mário Gibson Barboza, empreender visitas a nove países africanos: Senegal, Costa do Marfim, Gana, Togo, Daomé, Nigéria, Camarões, Gabão e Zaire. Mario Gibson Barbosa, ao retornar de viagem à África auxiliou na criação do Museu Afro-brasileiro, em Salvador e o Programa de Cooperação Cultural com a África, que fazia concessões de bolsas de formação e especialização para estudantes e técnicos africanos. ${ }^{487}$ No entanto, estudantes africanos da USP permaneciam com seus dados devidamente arquivados no

\footnotetext{
${ }^{484}$ MIYAMOTO, S. O Brasil e o Pacto do Atlântico Sul. Marília": FEFCSD/ UNESP, 1987, pp. 16-17. Ver também MIYAMOTO, S. e GONÇALVES, W. Militares, Diplomatas e Política Externa no Brasil Pós-64. Campinas: IFCH/UNICAMP, 1991, p. 45.

${ }^{485}$ MiYAMOTO, S. e GONÇALVES, W. Militares, Diplomatas e Política Externa no Brasil Pós-64. Campinas: IFCH/UNICAMP, 1991, p. 26.

${ }^{486}$ MIYAMOTO, S. e GONÇALVES, W. A Política Externa Brasileira e o Regime Militar: 1964-1984. Campinas: IFCH/ UNICAMP, 1991, p. 32.

487 SANTOS, J. "Ações afirmativas e ditadura militar: imagens e propostas" In evento The Cultures of Dictatorship: Historical Reflections on the Brazilian Golpe of 1964, University of Maryand, 14-16 de outubro de 2004. (html/www.history.umd.edu/Historycenter/2004-05/conf/Brazil64/program), p. 181.
} 
DEOPS/SP, como outros estrangeiros, ampliando as informações da comunidade de segurança e informações. ${ }^{488}$

Até o governo Médici, as estratégias militares para a política externa para a África derivavam, principalmente, das concepções geopolíticas sobre o Atlântico Sul como vital para a segurança do Brasil. Para isso investiu-se nas relações diplomáticas com Portugal e África do Sul, "embora o primeiro já evidenciasse sinais de esgotamento, devido à sua total incapacidade de decidir a guerra colonial a seu favor, e o segundo se encontrasse estigmatizado pela comunidade internacional, em função da política de apartheid desenvolvida pela minoria branca dominante, predominava ainda entre os estrategistas brasileiros a idéia de que o eixo central do sistema internacional de poder era o conflito Leste-Oeste e que os movimentos de libertação nacional nas colônias portuguesas e o movimento anti-apartheid dos sul-africanos negros, na realidade, serviam como peões do expansionismo soviético." 489

A idéia de formação de uma unidade entre os países de língua oficial portuguesa ganhava força com a perspectiva de "uma cultura sob ameaça" nos anos seguintes. Utilizando-se do pensamento de Gilberto Freyre sobre o lusotropicalismo, entendia-se que o português criou "sociedades multirraciais" com "valores comuns". ${ }^{490}$ Assim, Portugal desempenharia uma "missão histórica" e uma "obra colonizadora" e fortaleceriam o Ocidente. ${ }^{491}$ Em apoio ao colonialismo português na África, o regime militar entendia que havia uma "relevância de uma geo-politica que, não só seja facilitada por meio de entendimento com Portugal, como por via de nossa mediação que as faça compreender a injustiça de sua atitude hostil e até irracional contra um povo e um país sem nenhum preconceito racial, que realiza pesados investimentos em suas Províncias para promover o desenvolvimento." 492 Obviamente que esse interesse de aproximação com nações de língua portuguesa passava também pelos interesses econômicos, como podemos ver pelo item

\footnotetext{
488 Por exemplo, ver o estudante Kazadi Wa Mukuna. Dossiê 50-K-104- 1364 A. DEOPS/SP, DAESP. Também os "bolsistas estrangeiros da USP em 1975". Dossiê 50-K-104- 2278 - 2273.

${ }^{489}$ MIYAMOTO, S. e GONÇALVES, W. A Política Externa Brasileira e o Regime Militar: 1964-1984. Campinas: IFCH/ UNICAMP, 1991, pp. 39-40.

490 TORRES, G. "Condicionamentos da Comunidade Lusíada” In Segurança e Desenvolvimento, Ano XVII, n. 131. Rio de Janeiro: Associação dos Diplomados da Escola Superior de Guerra, 1968, pp. 124-134, p. 124.

${ }^{491}$ TORRES, G. Op. Cit., pp. 125 e 127.

${ }^{492}$ TORRES, G. Idem, p. 127.
} 
"Condicionamento Econômico" em artigo da Revista Segurança e Desenvolvimento, na matéria "Condicionamentos da Comunidade Lusíada". 493

Conforme o depoimento do deputado inglês Biggs-Davidson à imprensa, o autor Garrido Torres, no mesmo artigo da Revista Segurança e Desenvolvimento, defendia o colonialismo português na África: "São inacreditáveis as acusações de racismo ouvidas contra Portugal nas Nações Unidas. Na Guiné, Angola e Moçambique, misturei me com gente de todos os credos e de todas as cores, nas igrejas, no cinema e nos clubes. Não há segregação racial nas escolas, nem nas piscinas. Nas forças armadas, todas as raças se misturam, nas casernas e nas messes. Vi brancos comandados por negros." 494 Desse modo, o articulista entendia que competia a Portugal e ao Brasil a "preservação do patrimônio lusíada no mundo." 495

Na década de 1970, com os movimentos de independência nos países de colonização portuguesa, com a instabilidade política portuguesa que culminou com a Revolução dos Cravos, em $1974^{496}$, e com os conseqüentes governos de transição para a negociação de independência de Angola, Cabo Verde, Guiné, Moçambique e São Tomé e Príncipe, iniciou-se uma nova política externa brasileira para a África. Aos poucos o Brasil foi se afastando do apoio dado a Portugal na questão das colônias africanas e na Assembléia da ONU, de 1973, absteve-se em pontos que até então votava tradicionalmente com Portugal. Em discurso da Assembléia Geral da ONU, de 1974, o chanceler brasileiro Azeredo, declarou que não havia mais motivo para o adiamento da descolonização. ${ }^{497}$

Houve diversos conflitos entre os militares até a consolidação dessa nova postura: "As divergências apresentadas pelo ex-chanceler Ramiro Saraiva Guerreiro, com ministérios econômicos e mesmo, discordâncias (mais veladas) com setores militares traz à cena uma dúvida levantada pelo jornalista Newton Carlos em debate realizado pela Folha de $S$.

\footnotetext{
${ }^{493}$ TORRES, G. Ibdem, p. 128.

494 TORRES, G. Idem, Ibdem, p. 133.

495 TORRES, G. Op. Cit., p. 133.

${ }^{496}$ A Revolução dos Cravos, de 25/04/1974, decorre do descontentamento dos portugueses ao fascismo e a longa guerra colonial contra os movimentos de independência africanos. A Revolução dos Cravos encerrou os 48 anos do regime salazarista, que sobrevivera até a própria morte de Salazar em 1970 e que era mantida pelo governo de Caetano. SECCO, L. A Revolução dos Cravos e a Crise do Império Colonial Português (19611975). São Paulo: Alameda, 2004.

${ }^{497}$ Ministério das Relações Exteriores. Resenha de Política Externa do Brasil, n. 2. Brasília: MRE, 1974 a 1985, p. 41. Apud VIZENTINI, P. A politica externa do regime militar brasileiro. Porto Alegre: Ed. da Universidade/UFRGS, 1998, p. 242.
} 
Paulo, em 1979: 'Quem faz a política externa do Brasil? É o Itamaraty ou é o Conselho de Segurança Nacional?' E ele mesmo respondia: 'Eu tenho informações muito segura de que o voto do Brasil na ONU, considerando o sionismo uma forma de racismo foi dado em desacordo com a opinião do Itamaraty'. E concluía afirmando que o Itamaraty preferia que o Brasil se abstivesse em questões dessa natureza." 498 As políticas externas brasileiras ao longo do regime militar estiveram intimamente ligadas a "segurança nacional", como declarou o próprio chanceler Saraiva Guerreiro, por isso as divergências foram constante no que dizia respeito aos movimentos de independência africanos. ${ }^{499}$

A política externa brasileira para a África de colonização portuguesa, até 1974 com o governo Emílio Garrastazu Médici (1969-1974), procurou apoiar as ações repressivas portuguesas nas colônias. Desta forma, mantinha contatos com os órgãos polícias repressivos portugueses, trocando informações sobre os movimentos de independência africanos. O SNI remeteu ao DEOPS/SP informação, de 26 de maio de 1973, obtida por meio dos Órgãos de Segurança portugueses que interceptaram e enviaram às autoridades brasileiras cartas enviadas do Centro de Informação e Documentação Anti-Colonial (CIDAC) para o Centro de Estudos Afro-Asiáticos (CEAA) e para José Maria Nunes Pereira da Conceição. ${ }^{500}$ Nestas cartas continha manifesto em apoio ao MPLA contra o imperialismo e o neo-colonialismo. A carta, em francês, encontra-se em anexo e enfatiza: "a luta continua". ${ }^{501}$ Constam também em anexo ao dossiê, trechos de conferência do comandante do MPLA, Neto Alves, de 8 de maio de 1975.

José Maria Nunes Pereira da Conceição, teria feito parte de um inquérito policial militar contra angolanos por ações "subversivas" no Brasil. Segundo reportagem de O Estado de S. Paulo, de 23 de setembro de 1964, foram "qualificados doze oficiais" em que o referido nome aparece citado no item "IPM diz que grupo angolano é comunista": " $A$ Procuradoria Geral da Justiça da Guanabara encaminhou à Corregedoria, para distribuição a uma das Varas Criminais, o inquérito policial-militar incumbido de apurar

\footnotetext{
${ }^{498}$ MIYAMOto, S. e GONÇAlveS, W. Militares, Diplomatas e Política Externa no Brasil Pós-64. Campinas: IFCH/UNICAMP, 1991, p. 34.

${ }^{499}$ MIYAMOTO, S. e GONÇALVES, W. Op. Cit., p. 34.

${ }^{500}$ Segundo documentação ele era casado com uma angolana, viveu grande parte da sua vida em Portugal e em alguns países de colonização portuguesa, esteve preso pela PIDE - polícia política portuguesa e voltou ao Brasil em 1962. Foi preso em 1964 no Rio de Janeiro por envolvimento com elementos da UNE. Em 1966 voltou a Lisboa. De 1967 a 1970 fez parte do Movimento de Libertação Nacional MOLINA. Foi indiciado em IPM n. 405 (angolanos/64) por atividades subversivas. Dossiê 50-E-29- s/n. DEOPS/SP, DAESP.

${ }^{501}$ Dossiê 50-E-29- s/n. DEOPS/SP, DAESP.
} 
as atividades do "grupo angolano", constituido de portugueses que se arregimentaram no Brasil com a finalidade de acelerar a independência das colonias portuguesas em terras da África. O IPM foi presidido pelo general Panasco Alvim que, em seu relatório, afirma que o grupo angolano é de tendência comunista, e aponta como seus chefes José Lima Azevedo, José Manuel Gonçalves Rosa, José Maria Nunes Pereira da Conceição e Antonio Lauro." 502 O jornal encontra-se todo grifado pela autoridade policial do Serviço Secreto responsável pela análise jornal, sobretudo onde havia tendências identificadas como “comunistas", além dos nomes citados na reportagem.

A matéria "Angolano é contrabandista", do jornal Diário Popular de 26 de setembro de 1964, anexa aos dossiês DEOPS, relatava que os documentos em poder de autoridades da Marinha provariam que o angolano José Lima de Azevedo ${ }^{503}$ era "agitador internacional", ligado ao Partido Comunista Chinês, além de apontá-lo como "contrabandista de armas". 504

O temor da aproximação de militantes e políticos com os movimentos de independência africanos aumentava com especulações, como as apresentadas nos itens de um pedido de busca do CIE:

"a. O Diretor do jornal angolano "A PROVINCIA DE ANGOLA" informou ao Chefe da Representação Diplomática Especial do BRASIL, em LUANDA/ANGOLA, que uma delegação política e econômica estaria no BRASIL com a finalidade de obter apoio político e financeiro, para a FRENTE NACIONAL DE LIBERTACAO DE ANGOLA/FNLA, dirigida por HOLDEN ROBERTO. $b$. O jornalista brasileiro FERNANDO LUIZ CAMARA CASCUDO, que trabalha para aquele jornal, estaria atualmente no BRASIL, acompanhando a delegação. c. CAMARA CASCUDO diz-se Diretor-Presidente das COMPANHIAS REUNIDAS DE COMUNICACOES, com sede na rua Siqueira Campos, n. 43, cobertura. RJ, sendo THEO DRUMOND, DiretorComercial. Ambos foram contratados por HOLDEN ROBERTO para trabalharem em ANGOLA, fazendo publicidade para FNLA, visando as futuras eleições. d. Caso a delegação se encontre no BRASIL, teria viajado sem conhecimento das autoridades diplomáticas em LUANDA. " 505

A partir desses dados foi solicitada a localização e a identificação dos membros da delegação, além dos possíveis resultados obtidos pela mesma nos campos político ou econômico, mais uma síntese da situação política em Angola.

\footnotetext{
${ }^{502}$ Dossiê 50-Z-9- 1346. DEOPS/SP, DAESP.

${ }^{503}$ Citado em documento anteriormente citado. Dossiê 50-Z-9- 1346. DEOPS/SP, DAESP.

${ }^{504}$ Dossiê 30-C-1- 16671. DEOPS/SP, DAESP.

${ }^{505}$ Pedido de busca confidencial n. 350/75-MC do CIE para DOI/CODI, IIEX, DOPS/SP e SNI/SP, assunto "Missão política e econômica de Angola no Brasil". Dossiê 50-Z-9- 41256. DEOPS/SP, DAESP.
} 
Em 1973, a preocupação com os movimentos de independência africanos parece ter sido intensa nos órgãos de segurança brasileira. O DEOPS/SP, ao analisar o periódico Notícias de Portugal, de Lisboa, de 8 de setembro de 1973, destacou à caneta a matéria “A África Austral sob a influência da Rússia ou da China significaria o fim da Europa”, a qual afirmava que os "partidos comunistas interessam-se por tudo o que possa enfraquecer o Ocidente”, relatando a guerra entre as Forças Armadas portuguesas contra os movimentos de guerrilhas nos "territórios portugueses" do continente africano.

A matéria "Brasil Africano" no Jornal do Brasil, de 9 de junho de 1974, expressava a política africana adotada pelo Brasil, discorrendo que a diplomacia brasileira defendia a "auto-determinação" 506 dos povos e buscava colaborar nas negociações na África portuguesa, procurando, ao mesmo tempo, manter boas relações com Portugal e com os países africanos. A “manifestação de crédito do Brasil na África não terá sido ignorada em Portugal. Ela foi sinal marcante da confiança na modificação havida em nossa política para os chamados territórios portugueses. A mudança de posição brasileira terá sido precipitada pelos acontecimentos politicos em Lisboa. [a Revolução dos Cravos] Hoje se revela apta para não decepcionar as expectativas africanas moderadas e responsáveis. „507

Da mesma forma, ganhou destaque a matéria sobre a "infiltração extremista" nos movimentos de independência de Angola, Moçambique e Guiné Bissau, além de uma suposta posição favorável do Brasil à independência desses territórios: "Queremos, portanto, nesse espírito de moderação, que prevalece nas capitais africanas, colaborar sem mediar - não tem cabimento qualquer mediação - para que se fortaleça a influência realista e pragmática dos Governos africanos constituidos sobre os movimentos de libertação. [...] Trata-se, antes de tudo, de construir nações viáveis na moldura geopolítica

\footnotetext{
${ }^{506}$ Segundo as formulações da Organização das Nações Unidas (ONU) em sua carta de criação assinada por 51 países, quando de sua fundação em 24 de outubro de 1945, suas missões principais seriam: "garantir a paz e a segurança internacionais, o progresso social coletivo e os direitos humanos, devendo respeitar o princípio da auto-determinação dos povos". In MARCONI, E. e BICUDO, F. "Os 60 anos da ONU” In http://www.historianet.com.br/conteudo/default.aspx?codigo=779. Em 14 de dezembro de 1966, foi aprovado pela ONU o Pacto sobre os Direitos Econômicos, Sociais e Culturais e o Pacto sobre os Direitos Civis e Políticos que apregoava que todos os povos teriam o direito à auto-determinação. A auto-determinação dos povos foi palavra-chave aos povos sem reconhecimento ou oprimidos, seja pela interpretação da ONU ou pela vertente leninista reforçada pelas resoluções da II Internacional Comunista. "Do ideário marxista destaca-se o princípio leninista da libertação dos povos oprimidos como um dos objetivos da estratégia revolucionária contra o imperialismo, o que permite reivindicar o direito das nações à auto-determinação como um dos objetivos da estratégia revolucionária." In HERNANDEZ, L. A África na sala de aula: visita à história contemporânea. São Paulo: Selo Negro, 2005, p. 164.

${ }^{507}$ Jornal do Brasil, Rio de Janeiro 9/06/1974. Dossiê 50-E-29-96. DEOPS/SP, DAESP.
} 
atlântica. ${ }^{\text {,508 }}$ Em síntese, uma vez mais, a política foi apresentada segundo os moldes da Doutrina de Segurança Nacional e dos estudos de geopolítica no Atlântico, da ESG.

A matéria no intento de exaltar as ligações históricas com a África, pautada no mito da democracia racial brasileira, ressaltava que esta colaboração coadunada com as idéias da geopolítica da ESG, de hegemonia no Atlântico Sul, visava: "a criação de nações multirraciais através de formas pacíficas, que possibilitem o destaque de um Brasil africano, pronto a ajudar economicamente e dar assistência às nações de nossa fronteira. ${ }^{, 509}$

Com o intuito de manter suas estruturas repressivas informadas sobre a "infiltração comunista" no contexto internacional, o Departamento de Polícia do Rio de Janeiro difundiu alguns dados colhidos no jornal Tempo, de 18 de setembro de 1975, sobre o MPLA. O informe classificava o movimento como "comunista" e identificava Agostinho Neto como um dos responsáveis. A União Nacional para a Independência Total de Angola (UNITA) foi categorizada como "socialista maoísta", tendo como principais líderes Jonas Malheiros Savimbi e Isaias Chitambi. Por sua vez, a FNLA entendida como ideologicamente "capitalista" seria apoiada pelo Zaire (antigo Congo Belga) que se presumia ter o apoio dos Estados Unidos, sendo liderada por Holden Robert, ao lado de José Manoel Graça (que possuiria ligações com brasileiros) e Daniel Cipenda. ${ }^{510}$ Tais dados discutidos pela historiografia sobre os movimentos de independência em Angola, foram obtidos na matéria "Esclarecer aos portugueses da honestidade da FNLA" do referido jornal. ${ }^{511}$

Além dos estudos dos movimentos de independência africanos, diversas investigações foram procedidas sobre cidadãos provenientes das colônias portuguesas que pudessem ter alguma ligação com esses movimentos africanos. Foi expedido um Pedido de Busca pelo Ministério do Exército, em 30 de julho de 1975, de portugueses suspeitos no Brasil. Entre estes figuravam os angolanos Saraiva de Oliveira e "Braz" que teriam colaborado com Lúcio Lara, do MPLA. Estes elementos teriam trabalhado para o "governo

\footnotetext{
508 Jornal do Brasil, Rio de Janeiro 9/06/1974. Dossiê 50-E-29-96. DEOPS/SP, DAESP.

509 Jornal do Brasil, Rio de Janeiro 9/06/1974. Dossiê 50-E-29-96. DEOPS/SP, DAESP.

${ }^{510}$ Dossiê 50-E-29- 126. DEOPS/SP, DAESP.

${ }^{511}$ Xérox do jornal "Tempo" de 18/09/1975. Dossiê 50-E-29-125. DEOPS/SP, DAESP.
} 
esquerdista de Portugal". ${ }^{512}$ Em resposta a esse Pedido de Busca foi apurado: "o nome de Lucio Rodrigo Barreto de Lara figura na relação de membros do MPLA 'Movimento Popular de Libertação de Angola' com sede em Angola. Conforme informação - do Serviço Nacional de Informações - Agência São Paulo [...] ", 513

Em informação confidencial do Serviço de Informação, de 5 de fevereiro de 1975, sobre uma carta escrita no Rio de Janeiro por um residente na África com data de 18 de janeiro de 1975, era apresentado um estudo sobre a Frente de Libertação de Moçambique (FRELIMO), da qual a autoridade policial destacou alguns temas como: "apoio logístico da Rússia a FRELIMO”; "as fases do processo revolucionário”; "as contradições”; "O racismo é explorado até as últimas conseqüências."; "Agitação no meio operário"; "Greves"; "Falta de artigos de primeira necessidade"; "todos os meios são usados como divulgadores da FRELIMO”; "As mensagens divulgam o valor do comunismo." 514 Esse conjunto de temas evidenciava o receio que a expansão do comunismo pelo mundo dominasse as relações brasileiras.

O serviço de informação da Aeronáutica considerava que o ativista afro-descendente Clovis Moura era elemento de ligação entre o MPLA e o PCB e segundo dados apresentados entre os asilados políticos brasileiros em Portugal, manteria contatos com um funcionário do consulado português em São Paulo. ${ }^{515} \mathrm{Em}$ outro informe, também da Aeronáutica, constava que Clovis trocava correspondências com o refugiado brasileiro Américo Orlando da Costa que transitava de Luanda (Angola) para Portugal. ${ }^{516}$ Esse documento mostra a atenção constante em relação aos contatos efetivos entre militantes das guerrilhas africanas e os movimentos negros brasileiros. O simples contato com os movimentos de independência da África já era razão para ser observado pelas estruturas repressivas, como ocorreu com João Belizário que esteve por 7 anos em Angola e teria participado da formação do governo marxista-leninista daquele país. ${ }^{517}$

Em relatório de 2 de fevereiro de 1976, da Divisão de Estrangeiros e Passaporte de Congonhas, o DEOPS era informado sobre as investigações efetivadas a partir da denúncia

\footnotetext{
${ }^{512}$ Dossiê 50-E-29-112. DEOPS/SP, DAESP.

${ }^{513}$ Informação Reservada de 5/08/1975. Dossiê s/n. DEOPS/SP, DAESP.

${ }^{514}$ Dossiê 50-E-29-103. DEOPS/SP, DAESP.

${ }^{515}$ Informação confidencial sobre Clovis Moura, fl. 2. Dossiê 50-Z-0- 14615. DEOPS/SP, DAESP.

${ }^{516}$ Informação confidencial sobre Clovis Moura, fl. 2. Dossiê 50-Z-0- 14615. DEOPS/SP, DAESP.

${ }^{517}$ Mensagem n. 2EM/PM-445/1, Sumário de Informações n. 072/4, de 20/11/1980. Dossiê 20-D-18- 2811. DEOPS/SP, DAESP.
} 
de que um português carregaria uma bomba no aeroporto. Este teria sido localizado, por uma descrição física, no momento de seu embarque para Portugal. Ele seria o português José Pereira e consigo não foi encontrada nenhuma bomba, mas documentos que chamaram atenção das autoridades policiais como uma carteira de identificação da UNITA $^{518}$ e uma carta dirigida a Holden Robert, presidente da FNLA. Interrogado, disse ser filiado da UNITA, por ter residido em Angola na região de domínio desse movimento, e que em Angola era obrigatório portar identificação produzida por um dos 3 movimentos de libertação. Afirmou não possuir nenhuma ideologia política ou ter preferência por qualquer desses movimentos. Fato que para o policial seria desmentido pelo conteúdo da carta a Holden Robert, na qual o investigado expressava o desejo de ver concretizado o "movimento de libertação" angolano para retornar a Angola, além de demonstrar o seu interesse na publicação no Brasil, das idéias em favor da liberdade de Angola. ${ }^{519}$ Estes aspectos tornavam, com clareza, "perigoso" à Nação Brasileira.

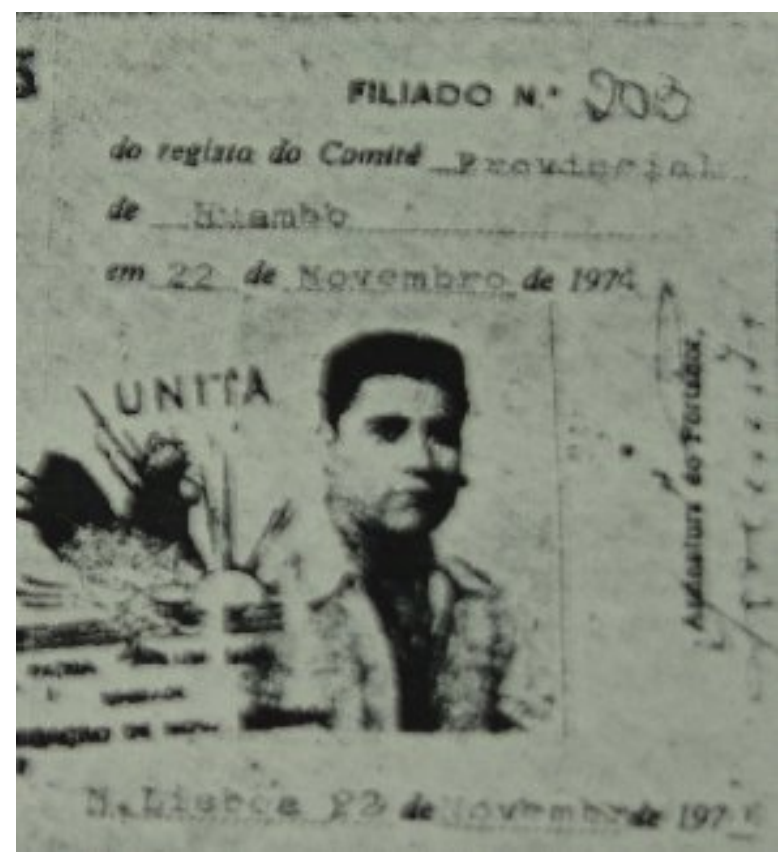

\section{Parte Interna do Passaporte de José Pereira, de 1974.}

\footnotetext{
${ }^{518}$ Anexa cópia no dossiê 50-E-29-154. DEOPS/SP, DAESP.

${ }^{519}$ Dossiê 50-E-29-155. DEOPS/SP, DAESP.

${ }^{520}$ Passaporte de José Pereira. 50-E-29-154. DEOPS/SP, DAESP.
} 


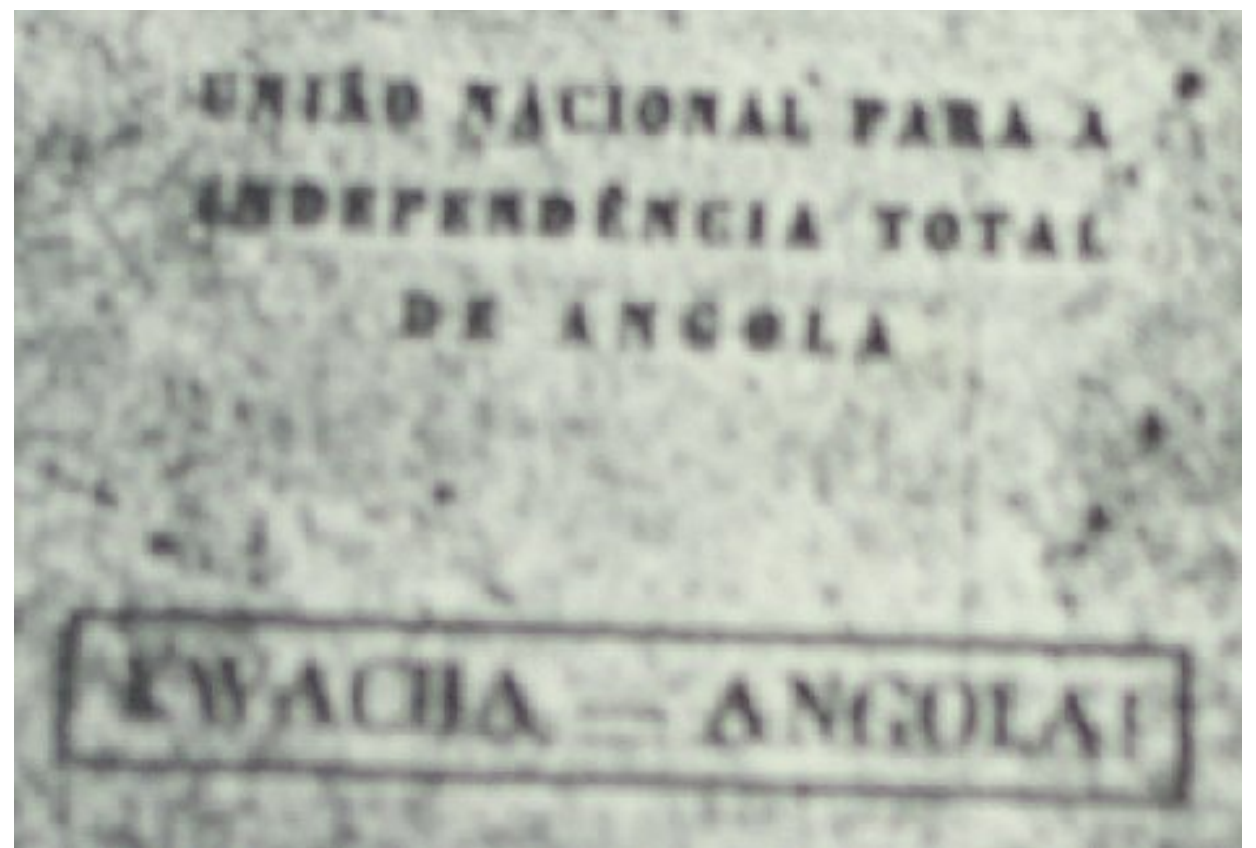

Parte frontal do Passaporte de José Pereira, em 1974.

Pode-se perceber, por esses exemplos de documentos presentes nas pastas dos dossiês do DEOPS/SP, a preocupação da comunidade de informações e segurança em relação aos movimentos de independência na África, sempre presente, em relação à questão ideológica que abrangia a formação dos novos Estados-Nação. Embora, "No final de 1974, o Brasil já estava engajado nas discussões sobre a descolonização de Angola. Diplomatas brasileiros discutiram com o MPLA, FNLA e Unita sobre as possibilidades de cooperação para a independência. Ítalo Zappa, chefe do Departamento da África, Ásia e Oceania encontrou em dezembro de 1974 Samora Machel, do Frelimo de Moçambique. [...] Em março de 1975, o Brasil foi o primeiro país a estabelecer relações com Angola." 522 Mais exatamente, em 11 de novembro de 1975, quando as tropas portuguesas se retiraram de Angola, o Brasil reconheceu o governo do MPLA, enquanto a maioria dos países africanos apoiavam um governo repartido entre o MPLA, a FNLA e a UNITA.

\footnotetext{
${ }^{521}$ Passaporte de José Pereira. 50-E-29-154. DEOPS/SP, DAESP.

${ }^{522}$ VIZENTINI, P. A politica externa do regime militar brasileiro: multilateralização, desenvolvimento e a construção de uma potência média (1964-1985). Porto Alegre: Ed. da Universidade/ UFRGS, 1998, p. 242.
} 
O reconhecimento de Angola como Estado independente, em 1975, pelo Brasil, não foi o primeiro caso na África, pois em 1974, mesmo antes de Portugal, o Brasil reconhecera a independência da Guiné-Bissau. Porém, foi o reconhecimento da conquista da soberania de Angola que gerou maior impacto político. Afinal, Angola encontrava-se com disputas internas pelo poder por parte dos três movimentos de "independência", separados por diferentes opções ideológicas que, com o Acordo de Alvor ${ }^{523}$, negociavam a independência angolana com Portugal. O governo militar brasileiro depositou suas apostas na vitória do MPLA, movimento alinhado com a URSS, enquanto a maior parte dos Estados africanos apoiou o governo misto de Angola e os EUA apoiaram a FNLA.

Com isso, o Brasil procurou dialogar com a luta anti-apartheid e os movimentos de independência africanos. Angola interessava ao Brasil economicamente, seja pelas possibilidades de um mercado consumidor crescente como pelo seu território rico em matérias-primas vegetais e minerais, em particular, o petróleo.

Sobre o reconhecimento da independência de Angola, Geisel afirmou:

"Quando eu fui reatar, logo no começo, as relações com Angola, do Brasil com Angola, a área militar ficou contra, foi contrária. Eu não atendi o ponto de vista militar. Argumentava que Angola era, em primeiro lugar, uma nação, um país de formação portuguesa. Portanto, de certa forma, vinculado a nós. Por tradição, pelo idioma etc. Segundo, é a nossa fronteira marítima. Em terceiro lugar, nós tínhamos interesses em Angola, inclusive na produção de petróleo. Havia todas as razões. Embora houvesse lá um regime comunista, não tinha importância. Não tinha influência nenhuma sobre a vida no Brasil. Eu fiz os acordos. Embora eles se manifestassem contrariamente, eu fiz a abertura. Fiz restabelecer as relações." 524

Suas palavras ilustram os intensos debates entre os militares para que fosse traçada a política externa brasileira para África. Miyamoto e William Gonçalves defendem que existiam divergências entre diplomatas e militares quanto à política externa, ao menos, para a África Austral. ${ }^{525}$ Os autores concluíram que a política externa brasileira desde os anos 1970 foi dirigida por termos estratégicos militares mas, também, por fatores econômicos, pautados na Doutrina de Segurança e Desenvolvimento, estruturando as relações com

\footnotetext{
${ }^{523}$ O Acordo de Alvor firmado entre o governo português, o MPLA, a FNLA e a UNITA resultou em um governo de transição entre 1974 a 1975. Após o período de transição o MPLA, em 11 de novembro de 1975, depois de 14 anos de luta, proclamou a independência que foi reconhecida pelo governo português. In HERNANDEZ, L. A África na sala de aula: visita à história contemporânea. São Paulo: Selo Negro, 2005, p. 582.

${ }^{524}$ Memória Ernesto Geisel In COUTO, R. Memória viva do regime militar - Brasil: 1964-1985. Rio de Janeiro: Record, 1999, pp. 210-211.

${ }_{525}$ MIYAMOTO, S. e GONÇALVES, W. Militares, Diplomatas e Politica Externa no Brasil Pós-64. Campinas: IFCH/UNICAMP, 1991, p. 47.
} 
outros países por meio de relações de poder que possibilitassem ao Brasil se afirmasse como "potência" econômica.

Entretanto, no que se refere à questão do racismo e sua possível ligação com os novos Estados africanos, não era sequer mencionado. O Brasil também não participava da campanha anti-apartheid:

"Reiterando a postura brasileira de 'repulsa do povo brasileiro a todos as formas de discriminação racial como conseqüencia direta de sua formação', o Ministro Azeredo da Silveira assegurava o apoio 'moral', à campanha, com uma colaboração de U\$10.000 dólares; entretanto, não se comprometia a assinar a Convenção Internacional para a Supressão e Punição do crime do apartheid, e muito menos de participar do bloqueio econômico, político ou cultural a África do Sul." "526

Por aparente paradoxo, constata-se que as esferas de poder do regime militar sustentavam o mito da "democracia racial" brasileira, enaltecendo o Brasil como país mestiço e harmônico e condenando a segregação da África do Sul: "O povo brasileiro é completamente avesso ao racismo por sua própria formação e seus princípios morais. "527

Assim, não por acaso, a política brasileira em relação à África do Sul despertou polêmica e pressões de diferentes setores à "esquerda, o governo era criticado por não ter rompido relações com àquele país, enquanto à direita, havia pressão pela manutenção de laços comerciais, bem como de segurança." 528 Ao mesmo tempo, líderes africanos pressionavam a chancelaria brasileira a apoiar a campanha anti-apartheid ao lado dos movimentos negros brasileiros que se engajaram nesta luta organizando diversos atos públicos, manifestações e protestos. De todo modo, as relações oficiais entre o Brasil e a África do Sul eram boas. Esse aspecto apresenta-se por meio da troca de correspondência entre o DEOPS/SP e o consulado geral da África do Sul, no qual este último solicitava antecedentes políticos de pessoas. ${ }^{529}$

A África, principalmente de colonização portuguesa, junto com a América do Sul foi prioridade nas políticas externas adotadas pelos dois últimos governos do regime militar, em que cada vez mais a estratégia brasileira passara a voltar-se para um projeto de

\footnotetext{
526 SANTOS, J. "Ações afirmativas e ditadura militar: imagens e propostas" In evento The Cultures of Dictatorship: Historical Reflections on the Brazilian Golpe of 1964, University of Maryand, 14-16 de outubro de 2004. (html/www.history.umd.edu/Historycenter/2004-05/conf/Brazil64/program), p. 43.

${ }^{527}$ Discurso do chefe da Delegação do Brasil à XXX Sessão da Assembléia Geral das Nações Unidas, embaixador Sérgio Corrêa da Costa em 10/11/1975 sobre projetos de Resolução à questão da Palestina. Apud MIYAMOTO, S. e GONÇALVES, W. Op. Cit., p. 49.

${ }^{528}$ VIZENTINI, P. A política externa do regime militar brasileiro: multilateralização, desenvolvimento e a construção de uma potência média (1964-1985). Porto Alegre: Ed. da Universidade/ UFRGS, 1998, p. 329.

${ }^{529}$ Dossiê 50-Z-0- 15330. DEOPS/SP, DAESP.
} 
hegemonia brasileira no chamado "Cone Sul". Essa política de aproximação com a África levou à condenação do apartheid na África do Sul pelo Itamaraty e as suas ações invasoras na Namíbia, em Angola e em Moçambique. Nota-se que apenas "durante a visita do ministro dos Negócios Estrangeiros de Cabo Verde, Abílio Duarte, nos dias 13 e 14 de outubro de 1980, o Brasil afirmou seu apoio à independência do Zimbábue, à causa da SWAPO na Namíbia e condenou o Apartheid." 530

O governo brasileiro a partir do processo de abertura política, adequando a política externa às mudanças internacionais, com relações externas multilaterais ${ }^{531}$, deixou de lado aspectos ideológicos da doutrina de fronteiras ideológicas, o que significou uma abertura para a política de consolidação de uma hegemonia no Atlântico Sul e para expansão econômica do Brasil, independente da posição política-ideológica dos países "parceiros". Desse modo, ocorreu uma aproximação de alguns países do bloco "comunista", como os novos governos africanos de colonização portuguesa assentados em movimentos de independência de linha "marxista-leninista", como o caso de Angola e de Moçambique.

Essa política não foi aceita por todos os segmentos dos militares, envolvendo disputas internas entre linhas mais conservadoras e anti-comunistas versus as linhas que se preocupavam mais com o desenvolvimento econômico e a abertura do comércio internacional. Claro que essa aproximação se deu predominantemente por meio de interesses econômicos, mas trouxe debates internos nos quadros de poder em torno de questões ideológicas. Essa virada da política externa brasileira também fez parte do processo de diminuição das tensões entre os blocos antagônicos (blocos capitalista e comunista), contexto no qual, além do conflito Leste-Oeste havia o conflito Norte-Sul (países “desenvolvidos” versus países "subdesenvolvidos”).

Todavia, esse contexto de aproximações com a África também teve limites bem definidos para evitar propagação de idéias "indesejáveis" de países "comunistas": "Desde de 1981, havia regras rígidas para a aprovação de eventos culturais que, de algum modo, incluíssem os países comunistas, conforme estabelecia uma Exposição de Motivos

\footnotetext{
${ }^{530}$ VIZENTINI, P. Op. Cit., p. 331.

531 "Por multilateralização das relações exteriores entende-se a busca de novos espaços, regionais e institucionais, para além dos relacionamentos tradicionais (que não são interrompidos), de atuação política e econômica da diplomacia brasileira." VIZENTINI, P. Op. Cit., p. 10.
} 
aprovada pelo presidente da República em 6 de julho daquele ano." ${ }^{532} \mathrm{Se}$ as relações diplomáticas e os acordos econômicos com os países africanos de linha política "marxistaleninista" aconteciam, por outro lado, a ação vigilante dos órgãos repressores permanecia atenta às posições ideológicas.

Além das ações da URSS na África, Cuba também esteve na mira do governo militar brasileiro, preocupado com a atuação de Fidel Castro na desestabilização política do continente americano, mas também na sua atuação na África, em particular em Angola, onde sua presença militar era expressiva. Esta atenção aparece expressa no informe confidencial do Ministério da Aeronáutica, de 15 de fevereiro de 1978, sobre a partida de 820 estudantes angolanos para Cuba. Este documento circulava, em 1977, nos órgãos de poder e repressão brasileiros, por meio da Embaixada do Brasil em Luanda, que informava os órgãos de informação e segurança brasileiros por intermédio das notícias publicadas pelo Jornal de Angola. Comunicava acerca da cooperação entre Cuba, Angola e Moçambique, com um intercâmbio "cultural" que destinou 4 escolas para os moçambicanos e 2 escolas para os angolanos. ${ }^{533}$

Analisando a documentação do Fundo DEOPS/SP, apreende-se que, ao mesmo tempo em que havia uma política externa brasileira que reconhecia os movimentos de libertação de Angola e Moçambique, havia uma rede de informações atenta às posturas políticas desses movimentos e de seus adeptos, em particular dos presentes no Brasil. Isto poderia, sob a lógica da desconfiança da polícia política, trazer instabilidade política ao Brasil, com a circulação de idéias "marxistas" desses movimentos. Desta forma, cidadãos das excolônias portuguesas, tendo ou não relação com os movimentos de independência africanos, eram vigiados no Brasil pelos órgãos de repressão. ${ }^{534}$

Os governos militares ao longo do regime desenvolveram estratégias de defesa e aproximação econômica com os recém-independentes países africanos. Ao mesmo tempo, no plano interno, as estruturas de repressão permaneciam vigilantes aos movimentos de independência africanos e sua influência tanto na África quanto no Brasil. Em poucas

\footnotetext{
${ }^{532}$ FICO, C. Como eles agiam. Os subterrâneos da Ditadura Militar: espionagem e polícia política. Rio de Janeiro: Record, 2001, p. 191.

${ }^{533}$ Informe Confidencial n. 42/ A-2/ IV COMAR. Dossiê 50-Z-0- 14319. DEOPS/SP, DAESP.

534 Como exemplo, temos o caso dos estudantes Carlos Pacheco, de Angola e Maria Aurora Fernandes Martins, de Cabo Verde. Relatório da Delegacia Especializada de Estrangeiros de 1/04/1975. Dossiê 50-E-2995. DEOPS/SP, DAESP.
} 
palavras: "O tema do Atlântico Sul, aliás, se converteu em todos esses anos, em um dos pontos de discórdia maiores entre militares e diplomatas." 535

Necessário ressaltar que existia também o interesse pelas informações dos movimentos de independência africanos no sentido de estudar a "guerra revolucionária" e o possível desenvolvimento desta no Brasil. Assim, como afirma o militar Enio dos Santos Pinheiro: "fui procurar um português que lutou em Angola, um professor que escreveu um livro sobre guerra revolucionária. Descobrimos e estudamos todos os tipos de guerra revolucionária que estavam se desenvolvendo pelo mundo." ${ }^{536} \mathrm{Na}$ base desse pensamento estava a idéia de que o comunismo era internacional, como afirmou o militar José Luiz Coelho Netto, em suas memórias acerca da seção de comunismo internacional no SNI: "Porque o comunismo veio de fora para cá, não foi? Então tínhamos que estar de olho." 537

Afirmando que "Só os tolos desprezam a experiência alheia" 538 o artigo "Guerras Revolucionárias e Insurrecionais: Breve História”, da Revista Militar Brasileira, procurava traçar um perfil das guerrilhas no mundo e formulava uma estratégia de "contenção" desses movimentos. O articulista destacou como causas das guerras insurrecionais os antagonismos políticos e sociais, religiosos e econômicos. Desse modo, entendia como necessário "o desenvolvimento militar em consonância com os objetivos nacionais de nosso país, tendo sempre em vista os perigos e as investidas do inimigo oculto que poderá estar ao nosso lado." 539 Ao mesmo tempo, destacava que a "Pátria é antes de tudo, a paz social, a concórdia de todas as classes, a união total do Exército e da Nação." 540 Desse modo, o estudo sobre as guerrilhas no mundo visava contê-las na "pátria brasileira".

Também a preocupação com os movimentos de independência africanos derivava do pensamento da ESG de que a guerra revolucionária era um "conflito, normalmente interno, estimulado ou auxiliado do exterior, inspirado geralmente em uma ideologia, e

\footnotetext{
535 MiYamoto, S. e GONÇALVES, W. Militares, Diplomatas e Política Externa no Brasil Pós-64. Campinas: IFCH/UNICAMP, 1991, p. 40.

${ }_{536}$ Memória de Enio dos Santos Pinheiro In ARAÚJO, M. e SOARES, G. e CASTRO, C. Os anos de chumbo: a memória militar sobre a repressão. Rio de Janeiro: Relume - Dumará, 1994, p. 139.

${ }^{537}$ Memória de José Luiz Coelho Netto In ARAÚJO, M. e SOARES, G. e CASTRO, C. Op. Cit., p. 230.

538 SANCHES, A. "Guerras Revolucionárias e Insurrecionais Breve História” In In Revista Militar Brasileira, Ano LXIV, vol. CXII. Rio de Janeiro: Centro de Documentação do Exército, janeiro/março de 1978, pp. 8390, p. 83.

${ }^{539}$ SANCHES, A. Op. Cit., p. 89.

${ }^{540}$ SANCHES, A. Idem., p. 89.
} 
que visa à conquista do poder pelo controle progressivo da nação." 541 Ao analisar o Manual Básico da ESG, Maria Helena Moreira Alves destacou que o conceito de guerra revolucionária: "conflito, normalmente interno, estimulado ou auxiliado do exterior, inspirado geralmente em uma ideologia, e que visa à conquista do poder pelo controle progressivo da nação." ${ }^{542}$, abrangeria toda iniciativa de oposição organizada com força suficiente para desafiar as políticas de Estado, reafirmando "a idéia de um estado de guerra, também permanente, no País, de acordo com a hipótese de uma Guerra Total. "543

Era também repetidamente clara a preocupação de que a guerrilha na África fosse "exportada" para o Brasil, como coloca o pedido de busca, solicitando confirmação de dados passado em informe que destacava que: "a. Estudantes brasileiros estariam sendo treinados em ação subversiva e operações de guerrilhas, em acampamentos permanentes de treinamento em ANGOLA, por instrutores cubanos que fazem parte das forças cubanas ali estacionadas." ${ }^{544}$ A guerra experimentada por Portugal contra as guerrilhas em Angola, Moçambique e Guiné, também compuseram esse quadro de análise sobre os conflitos no contexto mundial. ${ }^{545}$

Reforçamos que, no âmbito dessa perspectiva, torna-se evidente o receio do regime militar, por meio de seus aparatos de informação e segurança, em relação aos debates e possíveis contatos dos movimentos negros brasileiros com os movimentos de independência africanos e também com os movimentos negros dos EUA, em especial os Panteras Negras. ${ }^{546}$ Os movimentos marxista-leninistas, como na Guiné Bissau, em Moçambique e em Angola eram inseridos, na visão militar, como elementos de uma conspiração do "Comunismo Internacional". Um constante estudo estratégico analisava a situação das guerrilhas, em especial nos países de colonização portuguesa, visando ampliar o conhecimento das estratégias guerrilheiras para contê-las no Brasil.

\footnotetext{
${ }^{541}$ ALVES, M. H. Estado e Oposição no Brasil (1964-1984). Petrópolis: Vozes, 1985, p. 37.

${ }^{542}$ ALVES, M. H. Op. Cit., p 37.

${ }^{543}$ ROCHA, M. A Evolução dos conceitos da doutrina da Escola Superior de Guerra nos anos 70. Dissertação de Mestrado. São Paulo: FFLH/USP, 1996, p. 154.

${ }_{544}$ Pedido de Busca confidencial n. 364/76- BG, de 30/9/1976 do SNI/AC para 11a Bda Inf Bld, 12a Bda Inf AD2, DOPS/SP, PMESP e IV COMAR, assunto "Treinamento de guerrilheiros brasileiros em Angola". Dossiê 50-Z-9- 41257. DEOPS/SP, DAESP.

${ }^{545}$ Memória de Octávio Costa In D' ARAÚJO, M. e SOARES, G. e CASTRO, C. (orgs). Os anos de chumbo: a memória militar sobre a repressão. Rio de Janeiro: Relume - Dumará, 1994, p. 78.

${ }^{546}$ Tema que será tratado no próximo item.
} 
Ao mesmo tempo, tinha-se temor em relação às lutas anti-racistas travadas no período, em que se associava o "comunismo". A denúncia do racismo apresentava-se como estratégia de arregimentação dos "comunistas" e, portanto, assim como os movimentos de independência africanos, os movimentos negros brasileiros poderiam se "influenciar" pelos "comunistas". Ayrton Baffa, ao analisar documentação do SNI, assinalou que o relatório do CIE, de 10 de maio de 1976, declarava que "os soviéticos ultimavam preparativos para a difusão em toda África negra de uma versão marxista do cristianismo, objetivando a exploração do ódio racial, já desenvolvida na América Latina." 547 Desse modo, nota-se uma preocupação com a propagação de "ódio racial" e o "potencial de conflito" (atribuições do discurso policial-militar) nas lutas anti-racistas.

A partir de 1975, o regime militar sustentou uma política externa de apoio à luta antiapartheid e aos Estados recém independentes de colonização portuguesa na África, apoiado no pressuposto da "democracia racial" brasileira. Desta forma, retirava-se o foco da "questão racial", que se encontrava em curso pelo "protesto negro", que lutava para superar as dificuldades sociais que geravam a marginalização social dos afro-brasileiros. Enquanto isso, os atos públicos dos movimentos negros e os debates acerca do apartheid na África do Sul chamavam a atenção dos investigadores do DEOPS que visavam apurar as ligações com o tema, os organizadores, as posturas adotadas, etc. Foi assim na apuração do ato público organizado pela FRENAPO, em frente ao consulado da África do Sul para protestar a condenação de 8 presos africanos. ${ }^{548}$

\section{3) Os discursos sobre os movimentos negros dos Estados Unidos}

\footnotetext{
${ }^{547}$ BAFFA, A. Nos porões do SNI. O retrato do monstro de cabeça oca. Rio de Janeiro: Editora Objetiva, 1989, p. 123.

${ }^{548}$ Relatório de investigações n. 501 . OS 1157 p. 218 C. DEOPS/SP, DAESP.
} 


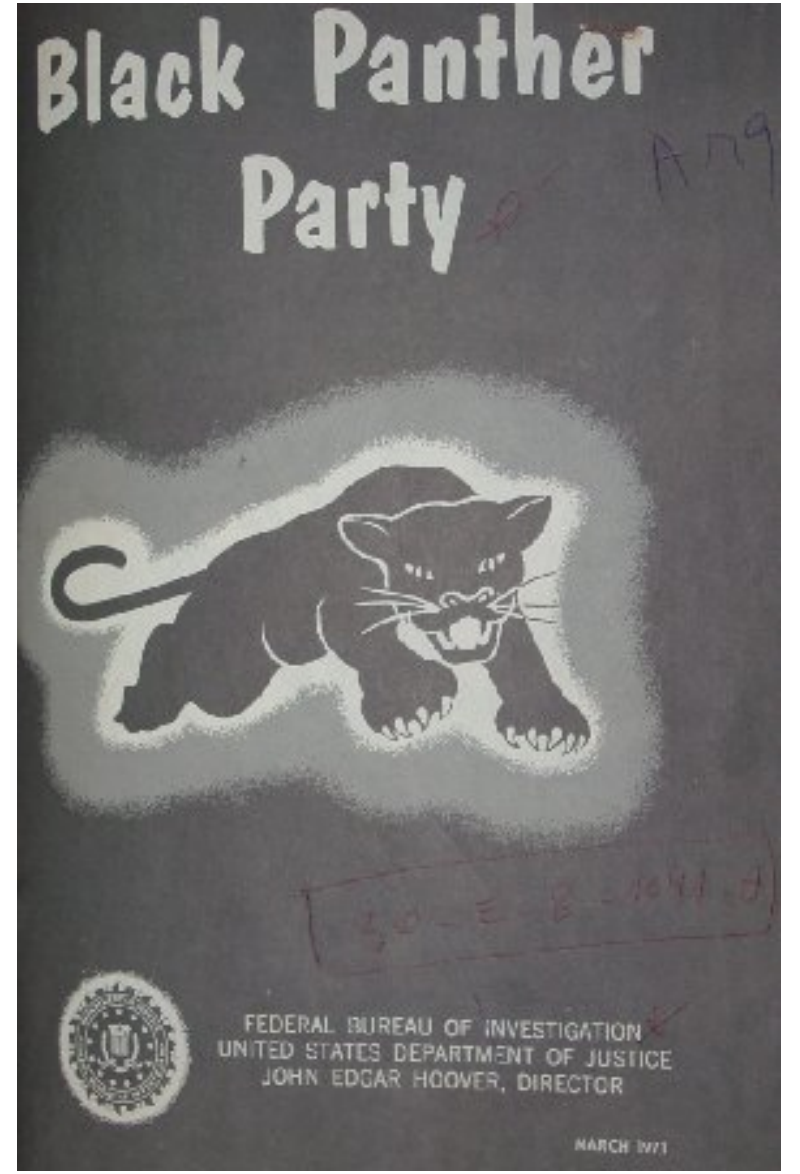

Capa de documento proveniente do FBI sobre os Panteras Negras (Black Panther Party), de 1971.

Os movimentos negros dos EUA causavam grandes preocupações ideológicas para o regime militar, em especial, por sua "penetração" nos debates dos movimentos negros brasileiros. Antônio Guimarães salienta que "os avanços da luta pelos direitos civis dos negros americanos foram decisivos para chamar a atenção dos brasileiros para a importância da mobilização em linhas raciais." ${ }^{550}$ A questão racial brasileira era assunto tabu que não interessava ao regime militar discutir. Na busca por traçar o "perfil doutrinário" de investigados do SNI, apresenta-se em sua documentação reservada,

\footnotetext{
${ }^{549}$ Capa documento sobre Black Panther Party do FBI dos EUA, março de 1971. Dossiê 50-E-1048A . DEOPS/SP, DAESP.

${ }^{550}$ GUIMARÃES, A. Classes, Raças e Democracia. São Paulo: Ed. 34, 2002, p. 98.
} 
segundo Ayrton Baffa, um quesito sobre o que estes achavam sobre "o problema racial nos EUA", e sobre a "auto-determinação". 551

Dessa forma, os movimentos negros dos EUA estiveram constantemente presentes nos estudos dos órgãos de informação e segurança. Ao discorrer sobre os "movimentos revolucionários" nos EUA, o SNI, por meio do artigo "Perspectivas sobre os Movimentos Revolucionários nos EUA", de Rosemary Ruether, com título publicado no Frères de Monde, n. 68, (revista mensal francesa "esquerdista") assinalava: "Nós vemos uma radicalização no movimento negro, no desenvolvimento histórico que vai dos 'direitos cívicos' ao 'poder negro' e ao socialismo revolucionário. A perspectiva do movimento passou de um âmbito nacional a um âmbito internacional, (...)existem os 'movimentos de liberdade' no interior dos grupos minoritários. Aqui os negros são a vanguarda. $O$ movimento de libertação negra partiu do reformismo para chegar ao separatismo e ao nacionalismo cultural. [...] Assim, vimos emergir uma nova fase, animada pelos 'Panteras Negras', que chamam pelo socialismo revolucionário e procuram através de uma união de todas as minorias oprimidas." $552 \mathrm{O}$ artigo entendia que grupos como os Panteras Negras representavam a "fase que vai do nacionalismo cultura ao socialismo revolucionário e interracial. ", 553

A aproximação dos Panteras Negras ${ }^{554}$ com o discurso marxista e uma prática "revolucionária" levou a um constante estudo do SNI sobre tudo que era publicado sobre o referido movimento. O primeiro movimento "revolucionário" apontado pela comunidade de

\footnotetext{
551 BAFFA, A. Nos porões do SNI. O retrato do monstro de cabeça oca. Rio de Janeiro: Editora Objetiva, 1989, pp. 28-29.

552 Sumário de Informações, n. 3, março 1971, reservado da Agência Central do SNI, Item "7. América do Norte”, subitem “a. EUA”, p. 2.4. Dossiê 20-C-43- 2500. DEOPS/SP, DAESP.

${ }^{553}$ Sumário de Informações, n. 3, março 1971, reservado da Agência Central do SNI, Item "7. América do Norte”, subitem “a. EUA”, p. 7.4. Dossiê 20-C-43- 2500. DEOPS/SP, DAESP.

554 "Os Panteras Negras foram um grupo de ativistas negros norte-americanos associados ao Partido dos Panteras Negras para Autodefesa, organização político-partidária originária de Oakland, Califórnia, no ano de 1966 e extinta em 1982 após intensa repressão política por parte do FBI (Federal Bureau of Investigation). Foi fundada por Huey Newton e Bobby Seale para a legítima defesa da população negra contra o racismo e a violência policial. Foi uma organização de esquerda de influência marxista que defendia uma agenda revolucionária contra o capitalismo e a escravidão. Os Panteras Negras se organizaram em 48 estados norte-americanos e chegaram a ter expressão na África, principalmente na África do Sul e em Moçambique." In SANTOS, G. "A luta contra o racismo na esquerda brasileira" In IANNI, O. [et. al.] $O$ negro e o socialismo. São Paulo: Fundação Perseu Abramo, 2005, p. 35. Essa denominação Panteras Negras deriva do significado desse animal: "Chamamo-nos 'Panteras', por que a Pantera vive na selva, como nós aqui na sociedade capitalista. Por que é um animal que não ataca a menos que seja ameaçado. E também por ser ele um animal que deve ser temido." In Sumário de Informações do SNI sobre Comunismo Internacional, p. 8.6. Dossiê 20-C-43- 2485. DEOPS/SP, DAESP.
} 
segurança e informações quando se tratava da situação política dos EUA, principalmente nos "Sumários de Informações" do SNI, eram os Panteras Negras. Isto revela as representações sobre os conflitos raciais para os Estados Unidos e para o mundo, ao mesmo tempo em que espalhou o receio de outros países sofrerem semelhantes conflitos baseados na guerrilha urbana, como o movimento dos Panteras Negras propunha. Os órgãos de informação e segurança brasileiros estavam a par da atuação desse movimento nos EUA, também por meio de comunicação e divulgação do FBI, que enviou um livreto que descrevia este movimento, valendo-se de material apreendido pela polícia norte-americana como: textos; charges; plataforma e programa; fotos de militantes, livros e armas entre outros. ${ }^{555}$

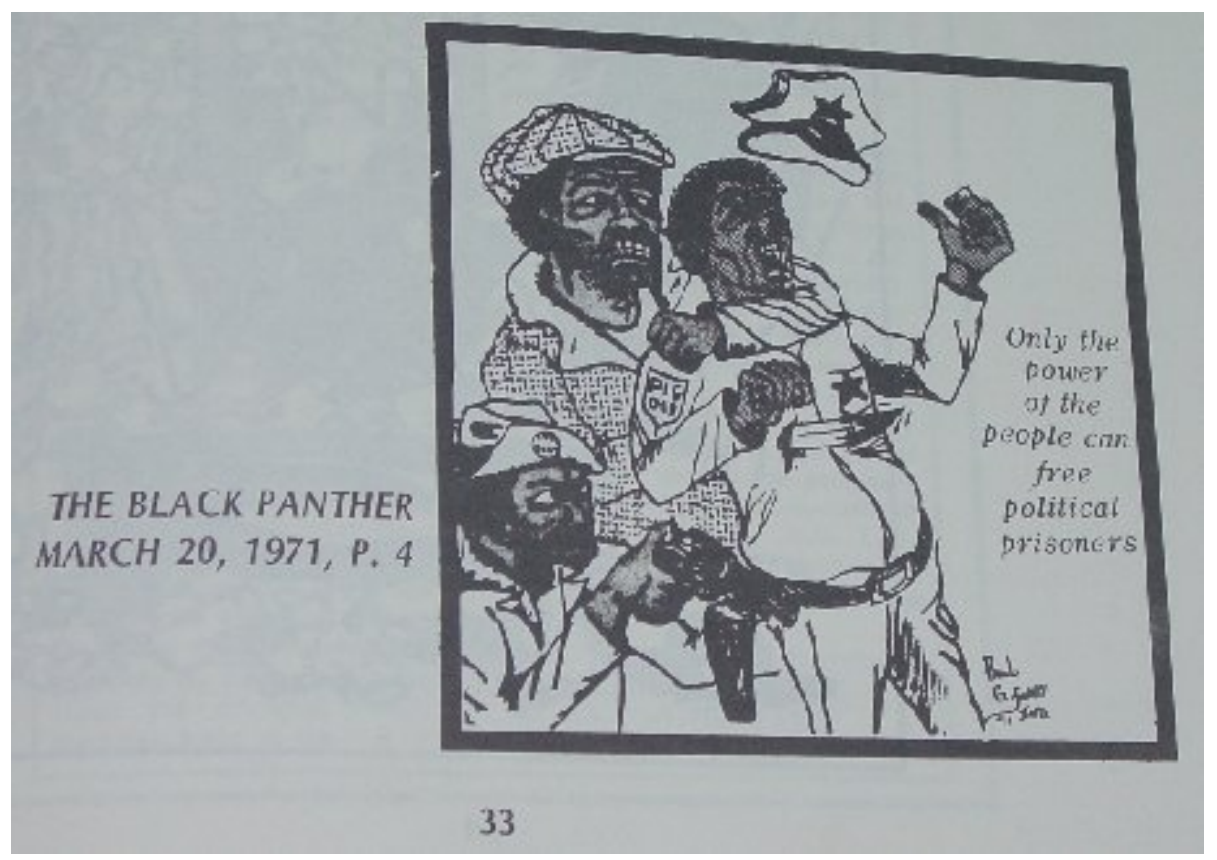

Charge atribuída aos Panteras Negras que afirmava ser apenas por meio do poder do povo que iria se libertar os prisioneiros políticos, no documento proveniente do FBI sobre os Panteras Negras (Black Panther Party), de 1971.

\footnotetext{
${ }^{555}$ Black Panther Party do FBI dos EUA, março de 1971. Dossiê 50-E-1048A . DEOPS/SP, DAESP.

${ }^{556}$ Black Panther Party do FBI dos EUA, março de 1971, p. 33. Dossiê 50-E-1048A. DEOPS/SP, DAESP.
} 


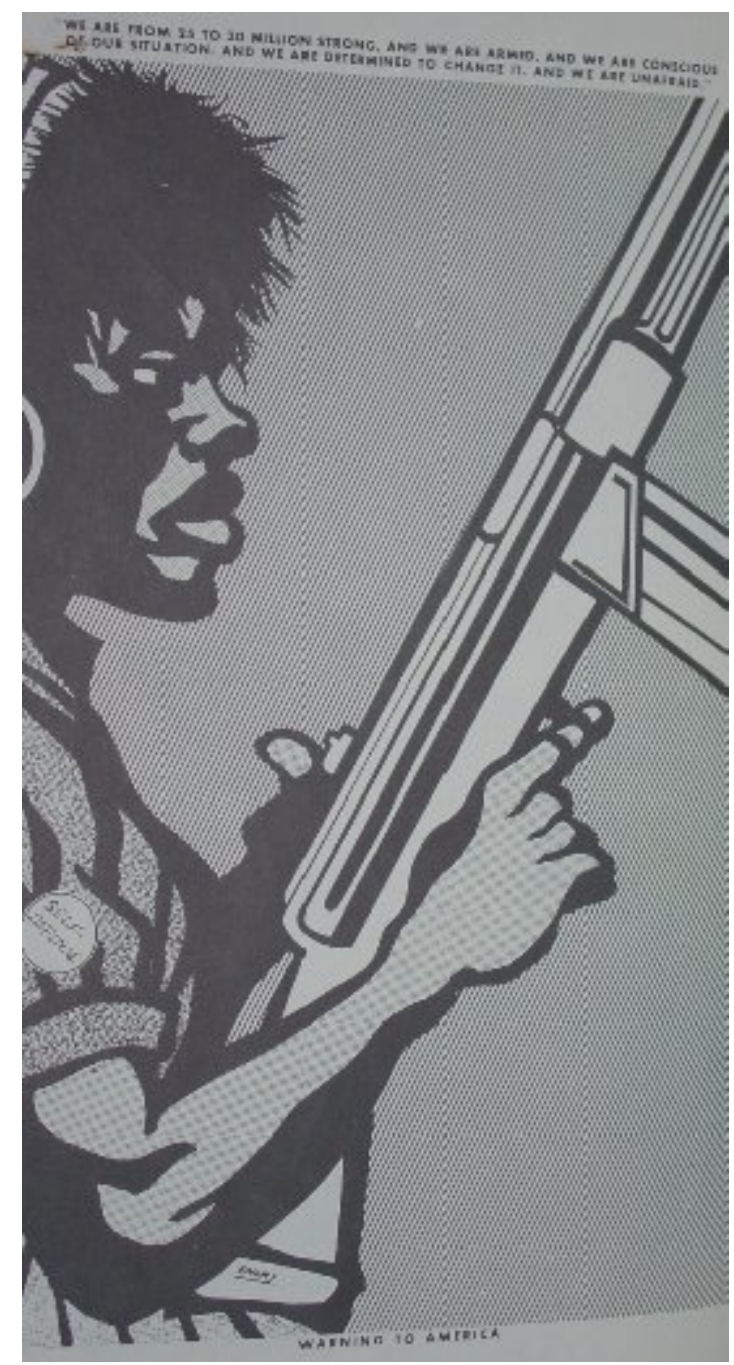

Charge atribuída aos Panteras Negras com uma ameaça de ação de guerrilha se não fossem ouvidos: "Nós somos 25 a 30 milhões fortes, e nós estamos armados, e nós estamos conscientes de nossa situação, e nós estamos determinados a mudar isto, e somos destemidos", documento proveniente do FBI sobre os Panteras Negras (Black Panther Party), de 1971.

557 Black Panther Party do FBI dos EUA, março de 1971. sem número de página Dossiê 50-E-1048A . DEOPS/SP, DAESP. 


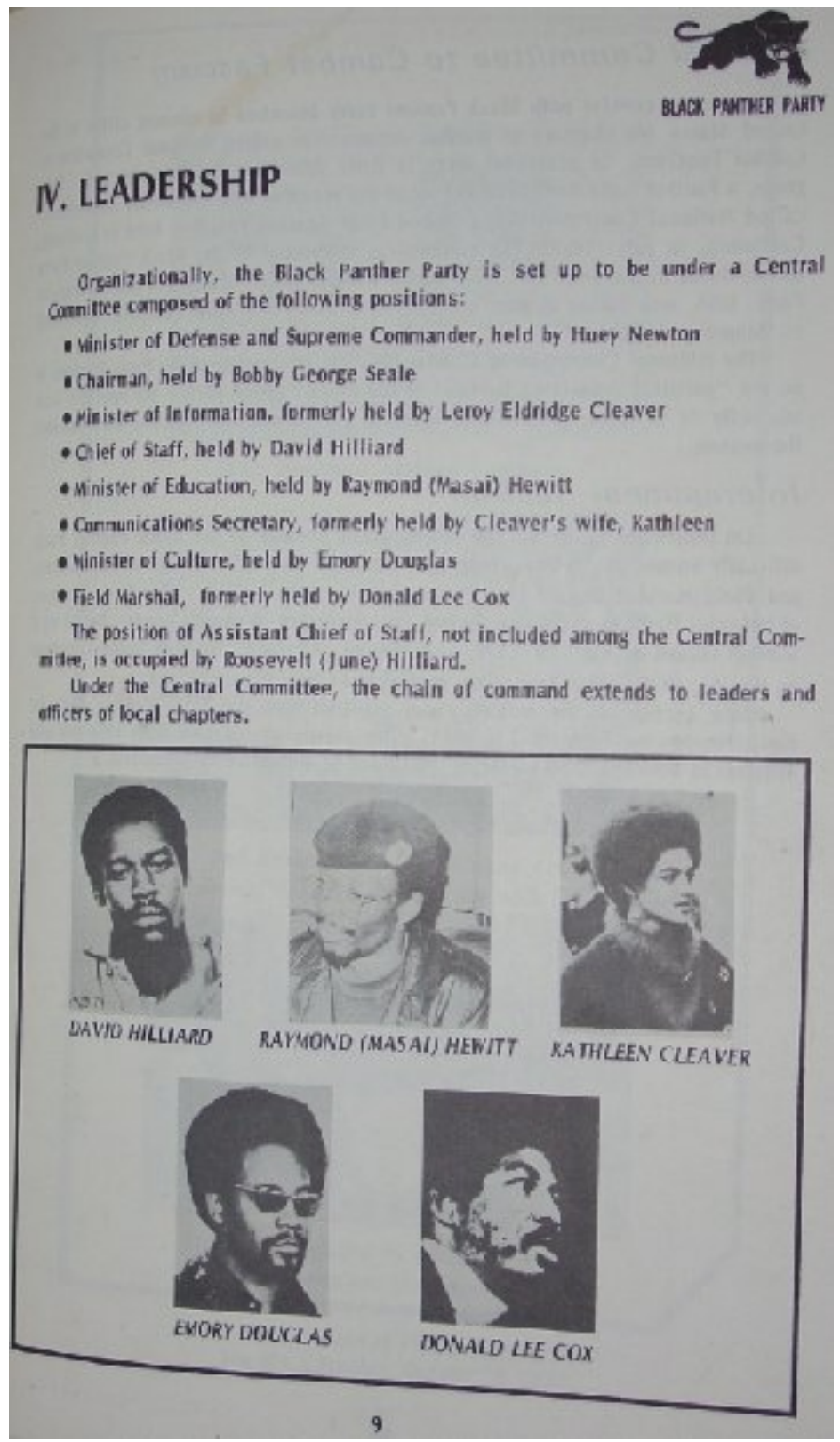

Fotografias dos líderes dos Panteras Negras, documento proveniente do FBI sobre os Panteras Negras (Black Panther Party), de 1971.

${ }^{558}$ Black Panther Party do FBI dos EUA, março de 1971, p. 9. Dossiê 50-E-1048A . DEOPS/SP, DAESP. 


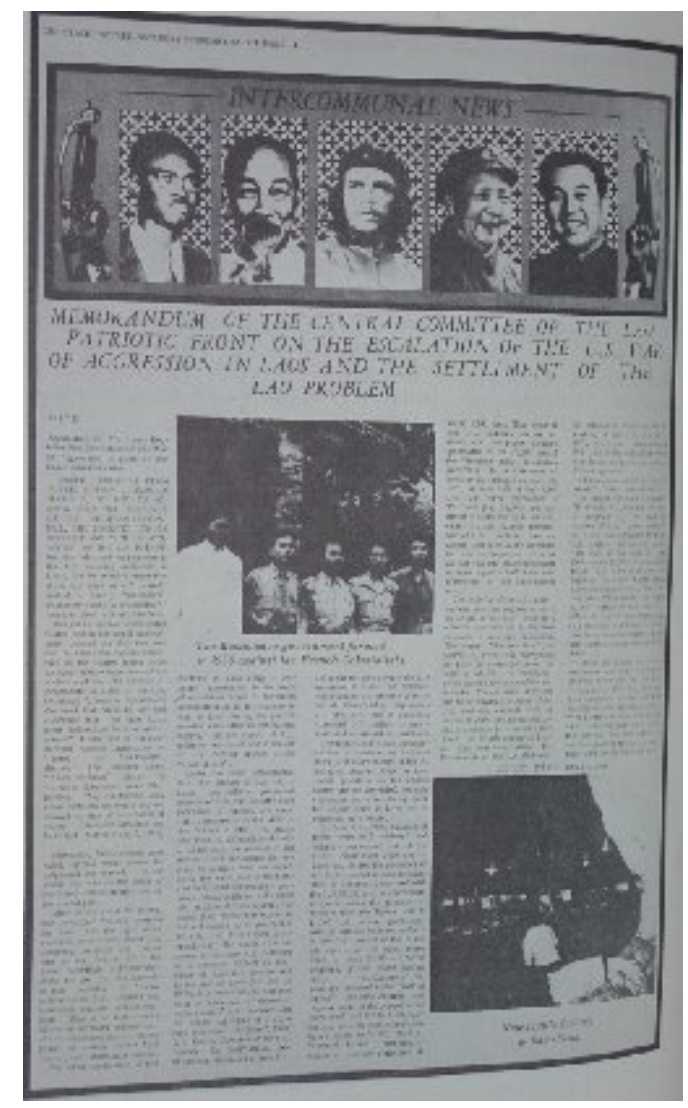

Imagem de diferentes personalidades internacionais associadas ao "comunismo", assim como os Panteras Negras foram identificados, documento proveniente do FBI sobre os Panteras Negras (Black Panther Party), de 1971.

Em artigo da revista militar A Defesa Nacional, sobre a guerrilha urbana, traduzido da revista americana Nato's, do tenente coronel Pozzobon, ao exemplificar um caso de guerrilha urbana, utilizou-se do caso dos Panteras Negras nos EUA como ponto de referência. ${ }^{560}$ Já o documento traduzido pelo Departamento Federal "O policial - Alvo principal das guerrilhas urbanas" trazia uma análise sobre a guerrilha urbana dos Panteras Negras, informando que o FBI realizou um seminário sobre guerrilhas urbanas e o seu

\footnotetext{
${ }_{559}$ Black Panther Party do FBI dos EUA, março de 1971, p. 35. Dossiê 50-E-1048A. DEOPS/SP, DAESP.

${ }^{560}$ POZZOBON, Z. "Guerrilha Urbana" In A Defesa Nacional, Ano 59, n. 647. Rio de Janeiro: Ministério da Guerra, jan/fev 1973, p. 82.
} 
combate no preparo de policiais, em 1971, em Washington. ${ }^{561}$ O documento apresentava ainda que o partido "Black Panther" (Pantera Negra) utilizava-se do jornal Eldridge Cleaver Panther como canal de divulgação; e que, em 1971, esse grupo teria se dividido em dois grupos, sendo que um destes realizava "propaganda e expropriações armadas", ou seja, guerrilha ${ }^{562}$, e o fornecedor de armas seria Stokely Carmichael, em "defesa do panafricanismo". 563 Concluía afirmando que os Panteras Negras eram uma "ameaça aos representantes da lei americana" e citava o líder pantera negra, Eldridge Cleaver, alertando que estes pretendiam: "o direito absoluto do povo afro-americano de pegar armas $e$ guerrear ... tomando a iniciativa e, de fato, atacando os 'tiras' armas." 564

Para a polícia dos Estados Unidos havia uma forte intersecção entre movimentos negros e "comunismo", mesmo para movimentos que não seguiam essa ideologia como, por exemplo, o movimento de Direitos Civis. Parte da mentalidade anti-comunista da época, qualquer dissensão era compreendida como ação "comunista", o que por certo influiu na formação da comunidade de informações e segurança brasileira, que mantinha contatos com polícia e com o exército dos EUA.

Em relatório da polícia brasileira torna-se evidente a preocupação das autoridades com a circulação das idéias dos Panteras Negras: “Citamos o jornal 'Versus', porta voz da Convergência Socialista que tem dedicado muitas páginas ao Movimento Afro Latino América com matérias de conhecidos esquerdistas como Clovis de Moura e Florestan Fernandes, entre outros que tentam agitar a questão com um movimento de emancipação de cunho socialista, inspirado nos 'Panteras Negras', grupo que nos Estados Unidos, tem se notabilizado pelas ações radicais e violentas." 565 Sob essa ótica os movimentos negros brasileiros sob a influência das idéias de esquerda e inspirados no modelo dos Panteras Negras, propunham uma ação revolucionária contra as instituições constituídas. Essa análise não contava com provas de propostas concretas de ações guerrilheiras pelos diversos setores dos movimentos negros, como ocorreu com os Panteras Negras.

As análises do SNI no Sumário de Informações sobre o Comunismo Internacional, sempre apontavam para a ação de guerrilha dos Panteras Negras nos EUA, o gerava

\footnotetext{
${ }^{561}$ Dossiê 50-Z-9- 30840. DEOPS/SP, DAESP.

${ }^{562}$ Dossiê 50-Z-9- 30838. DEOPS/SP, DAESP.

${ }^{563}$ Dossiê 50-Z-9- 30837. DEOPS/SP, DAESP.

${ }^{564}$ Dossiê 50-Z-9- 30837. DEOPS/SP, DAESP.

${ }^{565}$ Relatório Policial de 6 de julho de 1978. Dossiê 50-Z-0- 14623. DEOPS/SP, DAESP.
} 
desconfiança das estruturas repressivas, sobretudo com a tática "killing coops" (assassinar policiais) dos Panteras. ${ }^{566} \mathrm{O}$ método violento era justificado como reação ao método utilizado pela polícia. "Os 'Panteras' estão armados. Estão armados porque esta é a única linguagem que os 'porcos' e capitalistas compreendem. Malcolm X tinha denunciado a não-violência, mas para que? Porque, segundo os apóstolos da não violência, éramos nós que devíamos nos tornar não-violentos, enquanto os outros tornavam-se violentos. Nós dizemos como Malcolm X: nós queremos ser não-violentos, mas somente com os nãoviolentos. A não-violência deve ser pregada pelos 'Brancos', porém inicialmente para eles mesmos. Infelizmente é sempre do lado dos oprimidos que a não violência é reclamada. "567

As insurreições da "guerrilha urbana" experimentada nos EUA, em particular pelos Panteras Negras, eram alvo de estudo pelos militares para evitarem as ações de guerrilha no Brasil. ${ }^{568}$ Por isso mesmo, promoveram diversos cursos e articularam intercâmbios para a troca de experiências com o exterior. ${ }^{569}$ Cursos, artigos e debates sobre Segurança Nacional nos quadros militares e da polícia civil foram objeto de especial cuidado durante o século XX, como constatamos pela análise de impressos militares e policiais. ${ }^{570}$

O discurso dos Panteras Negras sobre a internacionalização do seu movimento apresentava-se no jornal francês Hebdo-TC Témoignage Chrétien, n. 1363, de 20 agosto de 1970, em reportagem "Nossa luta, está inscrita no combate mundial, combate contra a opressão da forma mais característica que é o imperialismo americano." 571 Essas idéias certamente circularam, sendo classificadas como "indesejáveis" ao regime militar no Brasil. A "internacionalização" dos movimentos negros certamente preocupava os aparatos de segurança. O II Festival das Artes Negras, realizado em 1978, na Nigéria visava a “[...]

\footnotetext{
${ }^{566}$ P. 8.2. Dossiê 20-C-43- 2486. DEOPS/SP, DAESP.

${ }^{567}$ Sumário de Informações do SNI sobre Comunismo Internacional. Dossiê 20-C-43- 2485. DEOPS/SP, DAESP.

${ }^{568}$ Em documento traduzido pelo Departamento Federal "O policial - Alvo principal das guerrilhas urbanas" do FBI, trazia uma análise sobre a guerrilha urbana dos Panteras Negras nos EUA. Dossiê 50-Z-9- 30840. DEOPS/SP, DAESP.

${ }^{569}$ Essas trocas de informações internacionais ocorreram em conferências, com artigos de publicações de exércitos estrangeiros (como, por exemplo, a edição brasileira da revista Military Review do exército EUA), ou mesmo, em artigos traduzidos na publicações militares e da polícia civil paulista, como artigo GLAZER, N. "Etnia, um fenômeno mundial”' In Arquivos, vol. XXVIII. São Paulo: Polícia Civil de São Paulo, 1976, pp. 203-216.

${ }^{570}$ Ver a relação dessas publicações consultas na parte "Fontes", p. 204.

${ }^{571}$ Sumário de Informações do SNI sobre Comunismo Internacional. Dossiê 20-C-43- 2485. DEOPS/SP, DAESP.
} 
busca de uma identidade negra mundial." 572 O relatório deste encontro concluía ainda: "A unidade do mundo negro é também uma necessidade histórica, geográfica e cultural." 573 Essa matéria fora enviada ao DEOPS pela ASI da USP, em um Painel "O negro no Brasil", junto com outros documentos, demonstrando a preocupação em relação a sua divulgação.

Aspecto importante do mito da conspiração é a idéia da dominação do mundo, a “inextinguivel vontade de poder e de retomar o sonho eterno da edificação de um Império em escala universal, da unificação do globo sob uma única e total autoridade. "574 Este desejo era imputado ao "inimigo da nação brasileira", o comunismo, a "guerra interna", à sua internacionalização. ${ }^{575}$

No artigo "Etnia um fenômeno mundial", da Revista Arquivos da Polícia Civil de São Paulo, têm-se uma análise do movimento do "Black Power", nos EUA: “Tornou-se lugar comum dizer que os pretos ensinaram através do seu exemplo outros grupos étnicos nos Estados Unidos a fazerem determinadas exigências, a usarem uma certa linguagem, a sentirem ressentimento pela exploração e subordinação em contextos que antes haviam aceito. Isso é obviamente verdadeiro. O que me impressiona é o quanto o movimento da militância negra afetou outros grupos em outros países." 576 Assim, o "poder negro" estaria se "alastrando" pelo mundo por meio da mídia internacional que divulgava suas idéias e slogans. Desse modo, as denominações dos movimentos negros norte-americanos, como o movimento dos direitos civis e os Panteras Negras, entre outros, foram utilizadas em outras regiões do mundo.

$\mathrm{Na}$ esteira desse pensamento os movimentos negros dos EUA eram apresentados como "exportadores" de conflitos étnicos, de tal modo, que o prognóstico do autor de que estavam se "internacionalizando", até porque os debates acerca desses conflitos repercutiam em outros movimentos sociais pelo mundo. ${ }^{577}$ Assim, a proposta dos movimentos negros norte-americanos era percebida pela polícia política como uma via

\footnotetext{
${ }^{572}$ Matéria “Os blacks se unem" In Folha de S. Paulo, 15/04/1979. Dossiê 50-J-0 - sem número. DEOPS/SP, DAESP.

${ }^{573}$ Matéria “Os blacks se unem” In Folha de S. Paulo, 15/04/1979. Dossiê 50-J-0 - sem número. DEOPS/SP, DAESP.

${ }^{574}$ GIRARDET, R. Mitos e Mitologias Políticas. São Paulo: Cia. Letras, 1987, p. 36.

575 SALMON, H. Idem, p. 78.

${ }^{576}$ GLAZER, N. "Etnia, um fenômeno mundial” In Arquivos, vol. XXVIII. São Paulo: Polícia Civil de São Paulo, 1976, pp. 203-216, p. 213.

${ }^{577}$ GLAZER, N. Op. Cit., p. 214.
} 
possível de ser seguida pelos movimentos negros brasileiros, o que certamente também influiu na ação repressiva brasileira.

As notícias dos EUA, seja por meio da análise da imprensa ou pela própria troca de informações entre o aparato de informações e segurança brasileiro e o FBI, trouxe o debate sobre a guerrilha urbana desenvolvida pelos Panteras Negras e a idéia de "Poder Negro", levando a uma apreciação negativa dos debates desenvolvidos pelos movimentos negros brasileiros. Tais idéias podem ser observadas na documentação do Fundo DEOPS/SP, ao tratarem do Centro de Estudos Brasil-África (CEBA) que segundo investigação do CIE, visava: "também, conscientizar e congregar os negros em torno de um programa de assumir seu lugar na sociedade pela libertação do preconceito racial. "578 Com a afirmação do "poder negro" por essa associação o CIE solicitou investigações sobre essa associação.

Desde a idéia de que "toda reunião de cidadãos com a finalidade de reivindicação, contém sementes potenciais de violência que germinam quando nutridas com propagandas e boatos. As autoridades responsáveis, em todos os níveis de governo, do governador ao prefeito, precisam saber que protestos, demonstrações e piquetes constituem sinais de perigo, indicativos de que se rompeu a comunicação entre os que governam e os governados." 579 A “agitação urbana” nos EUA, incluindo os movimentos negros, eram apresentados na revista norte-americana Military Review como elementos "subversivos": "Direitos civis, direitos estudantis, discriminação contra grupos minoritários, todas essas situações servem como temas eficientes de propaganda para os agitadores subversivos. "580

\footnotetext{
${ }^{578}$ Pedido de Busca confidencial n. 418/76 - LS de origem do CIE para DOPS/SP sobre assunto "Centro de Estudos Brasil-África". Dossiê 50-J-0-4866. DEOPS/SP, DAESP.

${ }^{579}$ NEY, V. (coronel reformado do Exército dos EUA) "Tática e Técnicas da Agitação Urbana" In Military Review (Publicação Profissional do Exército dos EUA), vol. L, n. 5. Kansas: Escola de Comando e EstadoMaior do Exército dos Estados Unidos, maio de 1970, pp. 67-74, p. 70.

${ }^{580}$ NEY, V. Op.Cit., p. 72.
} 


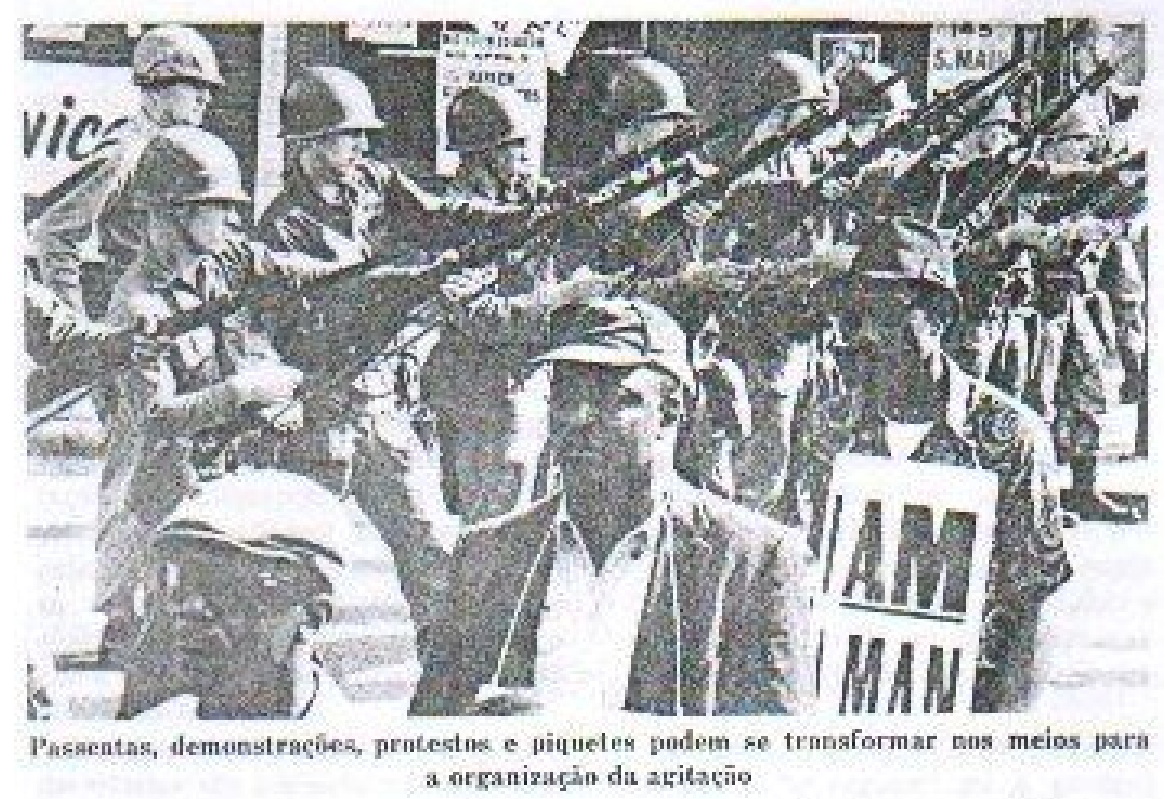

Fotografia de passeata dos movimentos negros dos EUA presente em artigo da revista Military Review, de 1970.

Desse modo, o foco de "agitação urbana" dos "grupos minoritários" encontrava-se presente na universidade (sempre vista como local de circulação de idéias "perigosas"), coadunada com a "nova esquerda" o que, segundo o autor, teria "transformado o campus pacífico em sangrentos campos de batalha da agitação."582 Além disso, os "guetos"583 apresentavam-se como locus de conflitos e eram considerados de alta "periculosidade". Os movimentos negros dos EUA, por meio de suas reivindicações, eram compreendidos como elementos "desestabilizadores" da nação norte-americana: "a agitação racial constitui um

581 NEY, Virgil. (coronel reformado do Exército dos EUA) "Tática e Técnicas da Agitação Urbana" In Military Review (Publicação Profissional do Exército dos EUA), vol. L, n. 5. Kansas: Escola de Comando e Estado-Maior do Exército dos Estados Unidos, maio de 1970, pp. 67-74, p. 71.

${ }^{582} \mathrm{NEY}, \mathrm{V}$. Idem, p. 73.

${ }^{583}$ Gueto: "Bairro, em qualquer cidade, onde são confinadas certas minorias por imposições econômicas elou raciais." In FERREIRA, A. Dicionário Aurélio Século XXI. Rio de Janeiro: Nova Fronteira; Lexikon, 1999. CD-ROM. 
dos mais sérios problemas que enfrenta a sociedade norte-americana." 584 o que, sem dúvida, notamos também no discurso dos aparatos repressivos no Brasil sobre a questão racial.

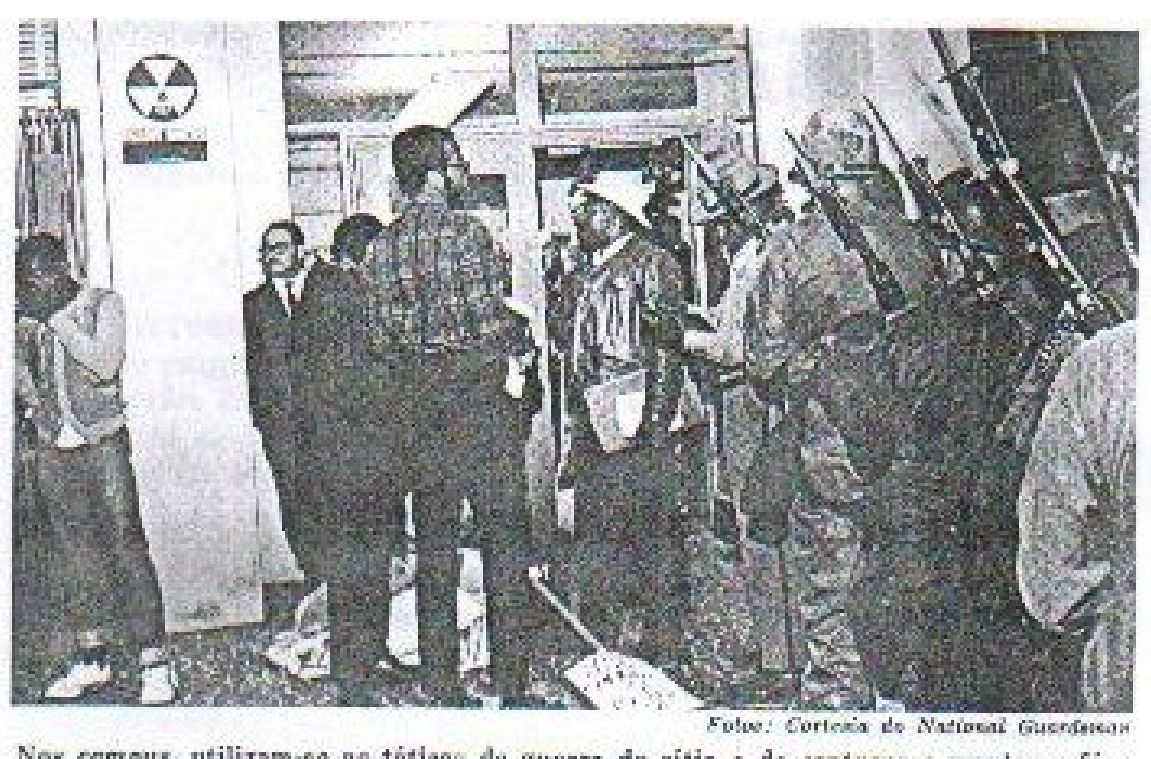

Nos campus, utilizam-se as thitieas de guerra de sitio e de eapturar e manter reféns

Fotografia dos campus universitários norte-americanos, envolvendo conflitos raciais no EUA, presente na Revista Military Review, em 1970.

Analisando a problemática da discriminação racial, o artigo "Relações Raciais no Exército" da Revista Military Review, de julho de 1970, revela a preocupação de manter a coesão dessa instituição abalada pela "divisão racial”, discutindo possíveis soluções para uma possível "harmonia racial". Nota-se uma preocupação de colocar esta questão não como uma prática disseminada e incentivada pelas cúpulas de poder do exército, mas sim como problemas pontuais de alguns indivíduos tidos como "racistas". Além disso, entendia ser um problema do próprio afro-americano: "Esta atitude passiva dos negros teve o

\footnotetext{
${ }^{584}$ WHITE, J. (tenente-coronel do Exército dos EUA) "Relações Raciais no Exército" In Military Review (Publicação Profissional do Exército dos EUA), vol. L, n. 7. Kansas: Escola de Comando e Estado-Maior do Exército dos Estados Unidos, julho de 1970, pp. 03-12, p. 5.

${ }^{585}$ NEY, Virgil. (coronel reformado do Exército dos EUA) "Tática e Técnicas da Agitação Urbana" In Military Review (Publicação Profissional do Exército dos EUA), vol. L, n. 5. Kansas: Escola de Comando e Estado-Maior do Exército dos Estados Unidos, maio de 1970, pp. 67-74, p. 73.
} 
desagradável efeito de encobrir ao comandante branco as realidades da experiência negra nos Estados Unidos." 586 O autor refere-se à desconfiança dos afro-americanos em relação ao Exército e a seus superiores (em sua maioria brancos) o que gerava o silêncio dos afroamericanos frente às atitudes discriminatórias e segregacionistas, classificando essa desconfiança como uma "passividade", revelando que este estereótipo atribuído ao negro fazia parte do pensamento do articulista norte-americano.

Em 1969, o chefe do Estado-Maior do Exército determinou que fosse realizado um estudo sobre os problemas potenciais nas relações raciais e a realização de programas para enfrentar esta questão. ${ }^{587} \mathrm{O}$ articulista concluía que esse problema provinha da sociedade civil, ou seja, "de fora para dentro": "o jovem e agressivo negro que traz para o Exército uma desconfiança e uma aversão inatas pela chamada 'instituição branca' e que acredita que a igualdade racial só pode ser obtida através da violência, punindo aqueles que cometem ações discriminatórias contra qualquer de seus 'irmãos espirituais'." 588 Essa afirmação retrata os efeitos dos movimentos negros nos EUA e os valores preconceituosos da sociedade norte-americana no pensamento dos órgãos de repressão dos EUA, que receavam o "separatismo negro". Desse modo, o "problema" racial no Exército só se tornou perceptível com o protesto do afro-americano. Mas, assim como no Brasil, combatia-se o protesto negro e não a causa deste, o racismo.

$\mathrm{O}$ autor entendia que as distâncias entre brancos e negros provinham também do distanciamento do negro: "O branco pode sentir-se alienado pela tendência dos pretos de se aglutinarem intimamente." ${ }^{589}$ Assim, o autor desconsiderava que essa distância foi criada a partir da segregação que os brancos implantaram e não pelos afro-americanos.

Além disso, percebemos que o autor buscou mascarar a situação racial nos EUA: "As relações raciais criaram poucos problemas nas unidades combatentes no Vietnã." 590 , justamente em relação à guerra que os conflitos raciais dos EUA apresentaram-se de forma mais latente. Esse aspecto se faz presente também no artigo "Seminário de Relações

\footnotetext{
${ }^{586}$ WHITE, J. Op. Cit., p. 4.

${ }^{587}$ Essa medida foi conseqüência de conflitos raciais no exército no ano de 1968. In GIBSON, J. (coronel do Exército dos EUA) "Seminário de Relações Raciais" In Military Review (Publicação Profissional do Exército dos EUA), vol. L, n. 7. Kansas: Escola de Comando e Estado-Maior do Exército dos Estados Unidos, julho de 1970, pp. 13-19, p. 13.

${ }^{588}$ WHITE, J. Idem, p. 6.

${ }^{589}$ WHITE, J. Ibdem, p. 8.

${ }^{590}$ WHITE, J. Idem, Ibdem, p. 9.
} 
Raciais": "O seminário baseou-se no fato de que, embora o racismo dentro de uma unidade seja frequentemente citado nas queixas feitas ao inspetor geral, a investigação revelou que, na maioria dos casos, não é ele o motivo principal. A causa mais comuns das queixas recebidas é a falta de compreensão, provocada pelo boato e pelo desvirtuamento da verdade." ${ }^{591}$ Esse tipo de argumento buscava minimizar os casos de discriminação racial, colocando-os como excepcionais ou ainda como inverdades, em uma ação similar a apresentada pelo regime militar brasileiro, como aprontamos no item "Os discursos policial e militar sobre o negro: estigmas e estereótipos", em que casos de discriminação eram apresentados como exceção.

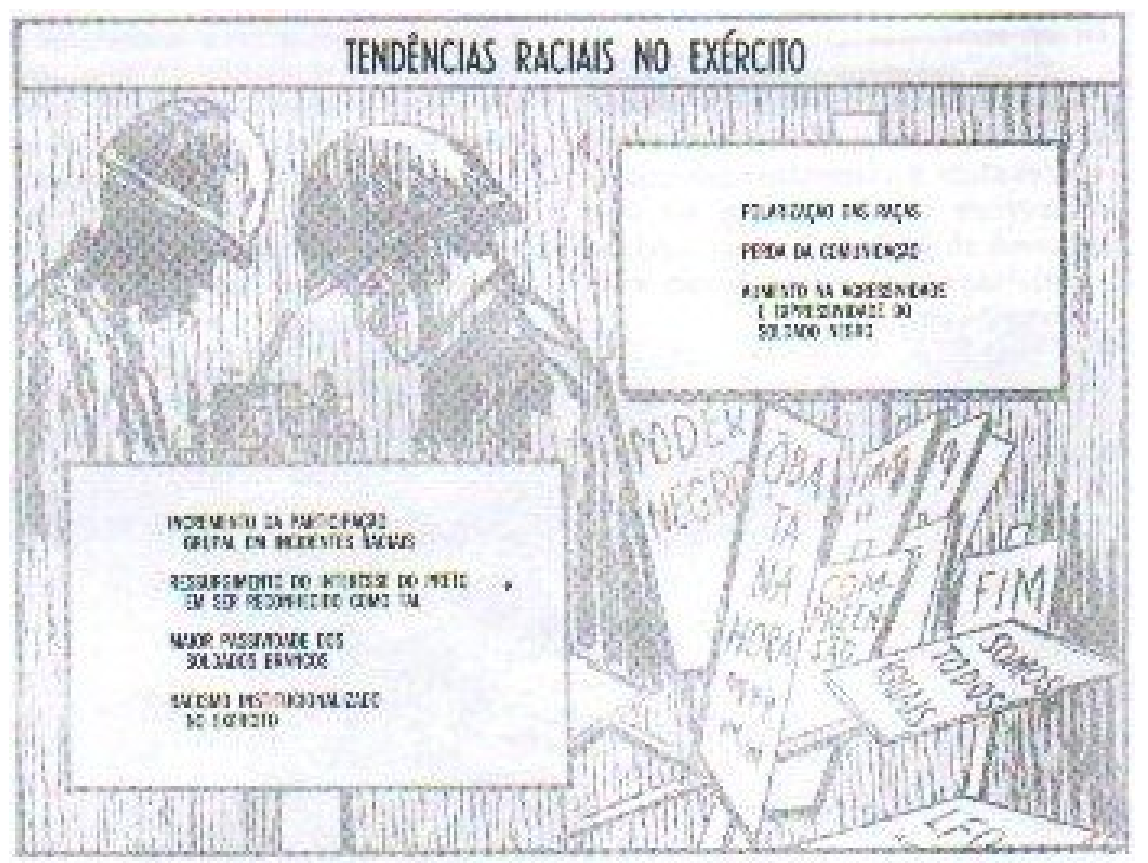

Quadro a direita e acima:

POLARIZAÇÃO DAS RAÇAS

PERDA DA COMUNICAÇÃO

AUMENTO NA AGRESSIVIDADE E EXPRESSIVIDADE DO SOLDADO NEGRO

591 GIBSON, J. (coronel do Exército dos EUA) "Seminário de Relações Raciais" In Military Review (Publicação Profissional do Exército dos EUA), vol. L, n. 7. Kansas: Escola de Comando e Estado-Maior do Exército dos Estados Unidos, julho de 1970, pp. 13-19, p. 15.

${ }^{592}$ WHITE, J. S. (tenente-coronel do Exército dos EUA) "Relações Raciais no Exército" In Military Review (Publicação Profissional do Exército dos EUA), vol. L, n. 7. Kansas: Escola de Comando e Estado-Maior do Exército dos Estados Unidos, julho de 1970, pp. 03-12, p. 7. 
Quadro a esquerda e abaixo:

INCREMENTO DA PARTICIPAÇÃO GRUPAL EM INCIDENTES RACIAIS

RESSURGIMENTO DO INTERESSE DO PRETO EM SER RECONHECIDO COMO TAL

MAIOR PASSIVIDADE DOS SOLDADOS BRANCOS

RACISMO INSTITUCIONALIZADO NO EXÉRCITO

Quadro ilustrativo da análise realizada pelo exército dos EUA sobre as relações raciais nesta instituição, em artigo da Revista Military Review, de 1970.

Da mesma forma, havia um entendimento de que os afro-americanos eram "hipersensíveis" a certos termos empregados pelos soldados brancos, como "black" ("preto") ou "colored" (“de cor"), que eram termos historicamente construídos pelos brancos de forma pejorativa. ${ }^{593}$ Ora, não se trata de uma "hipersensibilidade", mas sim o objetivo dos movimentos negros norte-americanos de construir uma imagem positiva sobre o "ser negro" e a busca por respeitabilidade da sua população, assim como os movimentos brasileiros, que em sua atuação almejavam uma identidade positiva do negro.

Foi realizada uma série de seminários sobre "igualdade de oportunidades" e "tensões raciais" no Exército dos EUA. ${ }^{594}$ Concluiu-se com esses seminários que as tensões raciais no Exército eram "inferiores" as existentes na sociedade civil, ao mesmo tempo em que os conflitos poderiam ser aumentados com os novos recrutas que carregariam os "preconceitos" criados com as "inquietações sociais" em suas comunidades, ou seja, com a maior mobilização das lutas anti-racistas norte-americanas. ${ }^{595}$ Assim, a preocupação do autor se dirigia aos movimentos do período que propunham medidas de combate à discriminação racial e que não descartavam o uso da violência para atingir seus objetivos. Dessa forma, eram cada vez mais classificados como "separatistas" e "desordeiros", ao

\footnotetext{
${ }^{593}$ GIBSON, J. Op. Cit., p. 17.

${ }^{594}$ WHITE, J. Op. Cit., p. 8.

${ }^{595}$ WHITE, J. Idem, p. 9.
} 
invés de haver um debate para combater o pensamento racista e excludente dos membros do exército norte-americano. A partir desses seminários foi proposto um curso de relações raciais nos centros de instrução e nas escolas militares visando conquistar a "harmonia racial". ${ }^{596}$ Enquanto isso, os militares brasileiros visavam salvaguardar o que entendiam já existir no Brasil.

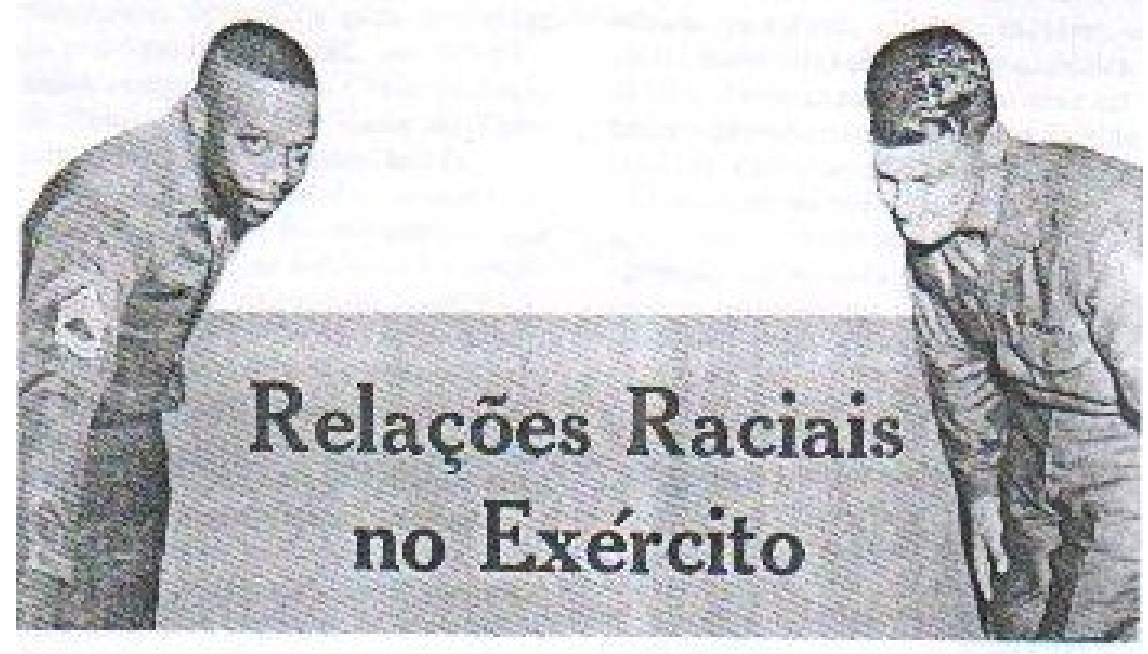

Fotografia e título de artigo presente na Revista Military Review, em 1970.

Divisões, sem dúvida, eram contrárias à perspectiva de unidade que o exército procura na formação de seus quadros, tornando-se o afro-descendente o "agitador": "não lhe deve ser permitido pregar a separação das raças ou atacar o regime com palavras que constituem insubordinação no sentido militar." ${ }^{598}$ Assim, notamos que esses artigos revelam o medo da postura "black power" que trouxe o "orgulho negro" e a consciência do poder político que a união entre os afro-descendentes poderia trazer. ${ }^{599}$

Esses conflitos apresentavam também preocupação para os militares brasileiros, que nos seus estudos a cerca do "comunismo internacional" assinalavam que "O conflito racial

\footnotetext{
${ }^{596}$ WHITE, J. Ibdem, p. 11.

${ }^{597}$ WHITE, J. Idem, Ibdem, p. 3.

598 GIBSON, J. (coronel do Exército dos EUA) "Seminário de Relações Raciais" In Military Review (Publicação Profissional do Exército dos EUA), vol. L, n. 7. Kansas: Escola de Comando e Estado-Maior do Exército dos Estados Unidos, julho de 1970, pp. 13-19, p. 19.

${ }^{599}$ GIBSON, J. Op. Cit., p. 18.
} 
atinge atualmente também as FF AA americanas. O tumor canceroso dos 'guettos' das grandes cidades contaminou os quartéis, até mesmo no Vietnã, e decompõem as FF AA. E não se vê salvação. Para muitos defensores norte-americanos, há muito que o inimigo não está no estrangeiro, e sim no país, ao lado, no quartel, e tem unicamente a pele de outra cor." 600

A Revista Military Review, uma publicação do exército dos EUA, trouxe debates ao pensamento militar brasileiro, uma vez que ganhou uma edição brasileira em português, editada entre a década de 1940 a 1970 . Na lógica de prevenção desenvolvida pela polícia e pelos militares brasileiros, o estudo dos movimentos negros norte-americanos se tornava de extrema importância na prevenção da atuação dos movimentos negros brasileiros. $\mathrm{O}$ material enviado pelo FBI ou os artigos da Military Review, tornavam-se matéria de estudo sobre a guerrilha urbana e seu combate, mas também, sobre os conceitos e tendências envolvidos nas lutas anti-racistas que circulavam entre os movimentos negros. Essas preocupações também foram expressas nos Sumários de Informações do SNI que traziam o debate do "comunismo internacional", reproduzindo diversas fontes com notícias da luta anti-racista nos EUA.

\section{Influência Black Power no Brasil}

O movimento black brasileiro se inspirava na cultura dos negros dos EUA, com seus penteados "black power", a música soul e a dança. ${ }^{601}$ Porém, esse movimento, segundo análise da ASI/USP apresentava-se como algo a ser combatido, pois o "o 'soul' funciona ao nível profundo - psicologia. O integrante, na sua maioria pertencendo a camadas sociais menos dotadas financeiramente, encontra no 'soul' um mecanismo de compensação, a exemplo do que ocorreu com o candomblé na sua origem (séc. XVIII e $X I X)$, mas enquanto este tinha raizes profundas e autênticas o 'soul' é importado - o que facilita seu combate. A título de hipótese, o combate ao 'soul' deverá partir de um projeto a ser elaborado por pessoas com prática (Assessoria de Relações Públicas da Presidência,

\footnotetext{
${ }^{600}$ Sumário de Informações do SNI sobre Comunismo Internacional. Dossiê 20-C-43- 2485. DEOPS/SP, DAESP.

${ }^{601}$ Matéria “Os blacks se unem” In Folha de S. Paulo, 15/04/1979. Dossiê 50-J-0 - sem número. DEOPS/SP, DAESP.
} 
por exemplo), levando em linha de conta que se trata de uma moda e de um movimento de massa." 602

Essa análise demonstra o quanto os movimentos negros eram vistos de forma pejorativa e a possibilidade de contato ou influência das idéias e práticas dos movimentos e cultura negra norte-americanos era visto como nocivo.

O periódico Sinba analisando o Black Rio relatava a influência da musicalidade norteamericana e a polêmica gerada em torno desta: "Alvo de críticas e debates em todos os veículos de comunicação..., e de nossa intelectualidade (como o escritor Gilberto Freire que fez uma denúncia leviana e facciosa, alertando a Nação para um pretensa influência de negros norte-americanos no movimento Black Rio, tentando fazer com que a música negra - principalmente o samba - se transforme em música de protesto) [...]", 603

O DEOPS constatou em suas investigações que os movimentos negros possuíam ligações com debates externos, que também estiveram na mira policial. Por exemplo, " $O$ MNU foi bastante influenciado pelas lutas dos negros na África e na diáspora, principalmente por movimentos negros americanos como o Black Power, que divulgou para toda a diáspora africana suas propostas de orgulho de ser negro, reversão de estereótipos, popularização de nomes, estilos de roupas e penteados de origem africana." ${ }^{604}$ A polícia política esteve atenta a circulação dessas idéias, em nome de evitar um possível choque racial no país.

\footnotetext{
${ }^{602}$ Dossiê 50-J-0 sem número. DEOPS/SP, DAESP.

${ }^{603}$ Sinba, Ano I, n. 1, Rio de Janeiro, julho de 1977, p. 6. Dossiê 50-Z-130- 5588. DEOPS/SP, DAESP.

${ }^{604}$ SOUZA, F. Afro-descendência em Cadernos Negros e Jornal do MNU. Belo Horizonte: Autêntica, 2005, p. 80 .
} 


\section{III - MOVIMENTOS NEGROS E SEUS PRINCIPAIS DEBATES}

"Queremos com isso despertar a sua consciência para que não aconteça com seu filho ou com você o que anda acontecendo" 605

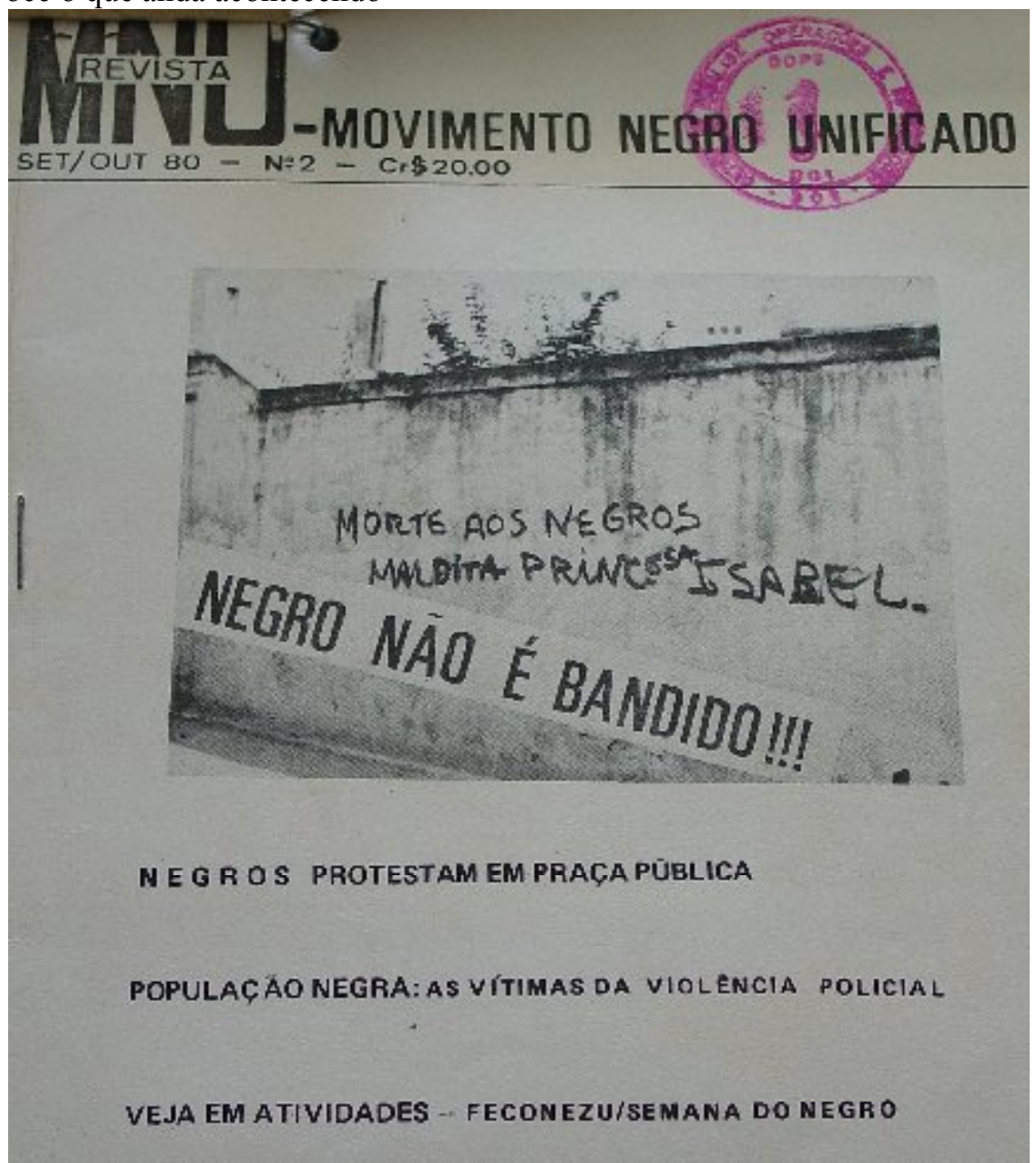

Capa Revista do $M N U$, em 1980.

No processo de construção de uma "conscientização" étnica os movimentos negros desenvolveram um intenso debate com algumas temáticas recorrentes, as quais buscamos identificar neste capítulo.

\footnotetext{
${ }^{605}$ OP 0989 Movimento Negro vol 2. DEOPS/SP, DAESP.

${ }^{606}$ Capa Revista do $M N U$, n. 2, setembro/outubro, 1980, na qual encontramos alguns dos principais debates dos movimentos negros. Ordem Política 1079, Racismo vol. 2. DEOPS/SP, DAESP.
} 
Constatamos, assim como Carlos Hasenbalg, que "Os temas do movimento negro estão centrados em torno de dois eixos. Um deles é a denúncia do racismo; temas como discriminação no mercado de trabalho, violência policial, exploração sexual e econômica da mulher negra, a questão do menor, a questão dos presidiários. Estas são as questões sobre as quais tem girado a denúncia do racismo. Por outro lado, o segundo grande eixo é o da cultura e da identidade. Os aspectos mais frisados são as denúncias do eurocentrismo cultural da sociedade brasileira e o "brancocentrismo" do sistema educacional. Há um persistente apelo à África, uma África mítica, outra histórica, bem como a contemporânea. Este apelo é usado para tentar construir uma nova identidade negra positiva, não estigmatizada." 607

Assim neste capítulo destacamos os temas, considerando dois eixos, mais recorrentes (porque eram consideradas pelos movimentos negros como prioritárias) na documentação analisada. O primeiro eixo, de denúncia do racismo, apresentava uma perspectiva do debate interna, focada no contexto brasileiro e ligada às práticas sociais dos afro-descendentes. Enquanto o segundo eixo se relacionava mais a uma perspectiva externa, como um argumento fundamental para a reflexão das questões da dimensão interna. Era constituída pelas idéias em circulação nos EUA, na África e na Europa que propunham a unidade e a solidariedade de todos negros no Mundo. $\mathrm{O}$ interesse de debater a situação do afrodescendente também na diáspora era para compreender as semelhanças e as peculiaridades do racismo em cada país e pensar as diferentes estratégias de luta anti-racista. Assim, "referências políticas e culturais internacionais eram tomadas como paradigmas da luta anti-racista no país." 608

O movimento pelos direitos civis e os Panteras Negras nos EUA; o pan-africanismo; o movimento da negritude, na vertente de língua francesa; ou os clássicos como Crummell, Du Bois, Blyden ou Garvey na vertente de língua inglesa; e as lutas pelas independências na África fizeram parte do repertório de debates, congressos, encontros e diferentes

\footnotetext{
${ }^{607}$ HASENBALG, C. "O movimento negro” In Anais do Seminário O Retorno do Ator. São Paulo: FE/USP, 1991, p. 129.

${ }^{608}$ CUNHA, O. “Depois da festa: movimentos negros e 'políticas de identidade' no Brasil” In ALVAREZ, S. e DAGNINO, E. e ESCOBAR, A. Cultura e política nos movimentos sociais latino-americanos: novas leituras. Belo Horizonte: Ed UFMG, 2000, p. 344.
} 
protestos. Florentina da Silva Souza, em seu estudo sobre as publicações Cadernos Negros e o Jornal do $M N U^{609}$ afirma que:

"A influência exercida pelos fatos políticos ocorridos na África e na diáspora nos movimentos negros no Brasil pode ser comprovada pelas freqüentes referências, na produção textual dos grupos negros da década de setenta, às lutas e aos heróis africanos, assim como pelo uso constante de epígrafes e citações de autoria de intelectuais e personalidades africanas, ou membros do movimento da Negritude, presentes em muitos números das publicações aqui estudadas." 610

A África tornava-se o locus privilegiado nesse debate, pois na concepção dos militantes desse período, olhar para África era "voltar-se às raízes". ${ }^{611}$ Os debates dos movimentos negros apresentaram a "interação entre o contexto local e um circuito transatlântico de idéias, categorias, hierarquias e objetos negros; o de que as culturas negras desenvolveram-se em todas as etapas da modernidade; o de que os brasileiros de ascendência africana, em diferentes etapas e por uma variedade de meios, criaram sua própria 'África'..." ${ }^{612}$ Nesse sentido, a África foi (re)criada no âmbito de um processo de valorização de uma identidade negra engajada na luta anti-racista.

Estes dois grandes eixos temáticos apresentaram-se mesclados nos debates como no $\mathrm{I}^{\mathrm{O}}$ Encontro da Raça Negra, de 23 de maio de 1981, quando foram debatidos: a violência policial, o desemprego, as reivindicações contra a violência e a injustiça social, a campanha de revisão da literatura negra nas escolas e nos livros didáticos, a maior participação do negro na política e a proposta contra a violência cultural e moral sofrida pelos afrodescendentes. ${ }^{613}$

\section{1) Afro-marxismo}

"Não adianta se libertar do sistema, se todos estão presos ao sistema." 614

A circulação das idéias marxistas também se fez presente nos movimentos negros, em especial com as análises de cientistas sociais sobre o contexto racial brasileiro, como

\footnotetext{
${ }^{609}$ No período que aqui tratamos o Jornal do $M N U$ denominava-se Nêgo, entre 1978 a 1981. Um exemplar desse jornal foi apreendido pelo DEOPS/SP numa reunião da SBPC em 1982. Dossiê 20-C-44- 28567. DEOPS/SP, DAESP.

${ }^{610}$ SOUZA, F. Afro-descendência em Cadernos Negros e Jornal do MNU. Belo Horizonte: Autêntica, 2005, pp. 39-40.

${ }^{611}$ Jornegro n. 12, Ano 4, 1981, p. 6. In Dossiês 20-C-44- 17284. DEOPS/SP, DAESP.

${ }^{612}$ SANSONE, L. Negritude sem Etnicidade. Rio de Janeiro: Pallas, 2004, p. 248.

${ }^{613}$ Relatório policial. Dossiê 20-C-44- 17293. DEOPS/SP, DAESP.

${ }^{614}$ SANTOS, Aparecido Tadeu dos. Como se fosse pecado. São Paulo: Edição do Autor, 1980, p. 17. Dossiê 20-C-44-17290. DEOPS/SP, DAESP. Coletado por ocasião do Io Encontro em Defesa da Raça Negra, realizado em 23/5/1981, na PUC-SP. Relatório diário n. 1505, entre 25 e 26/5/1981, da Divisão de Informações do DEOPS, fl. 2. Dossiê 21-Z-14-11366. DEOPS/SP, DAESP.
} 
Florestan Fernandes e Octavio Ianni. Foram análises que repercutiram na militância afrobrasileira, sobretudo na década de 1980, quando os movimentos negros centravam seu debate "em torno da denúncia do racismo e da condição de classe dos trabalhadores negros." ${ }^{615}$ Nessa linha de pensamento, mesclava-se a interferência do capitalismo e do racismo na exploração e na exclusão social dos afro-descendentes.

Dessa forma, "o MNU procurou se apoiar nas pesquisas da equipe de Roger Bastide e Florestan Fernandes e nos trabalhos da escola sociológica paulista. Com esse respaldo político-científico, o MNU ocupou o espaço politico e procurou fazer valer as suas posturas ideológicas, ao lado de outros movimentos sociais que entravam na agenda política da época." ${ }^{616}$ Autores como Fernandes, ao lado de Eldridge Cleaver e Franz Fanon $^{617}$, entre outros, introduziam a questão da luta de classes nos debates do MNU. ${ }^{618}$

O IBEA, em conjunto com o Centro de Intercâmbio de Pesquisas e Estudos Econômicos e Sociais (CIPES), organizou o seminário "O marxismo e a questão racial" com palestras de Florestan Fernandes, Celso Prudente, Jacob Gorender, Romeu Sabará e Clovis Moura. Este evento visava questionar a contribuição do pensamento marxista para a compreensão das questões relativas ao racismo. ${ }^{619}$

A leitura marxista fazia-se presente como no relatório policial de 7/08/1980, com observações o ciclo de debates "marginalização social do negro e a violência policial" e a atuação da editora Quilombo na venda de livros como: Democracia Soviética e Em marcha para o socialismo, ou ainda de periódico como o Trabalho e A Tribuna Operária. ${ }^{620}$

Existe uma percepção de alguns autores de que o diálogo entre os "comunistas" e os afro-descendentes teria apenas começado na década de 1970, quando a atuação dos movimentos negros aliado ao referencial teórico marxista, teria "desnudado" a questão

\footnotetext{
${ }^{615}$ SANTOS, G. "A luta contra o racismo na esquerda brasileira" In IANNI, O. [et. al.] $O$ negro e o socialismo. São Paulo: Fundação Perseu Abramo, 2005.

${ }^{616}$ FÉLIX, J. Chic Show e Zimbabwe e a construção da identidade nos bailes black paulistanos. Dissertação de Mestrado. São Paulo: FFLCH/USP, 2000, p. 21.

${ }^{617}$ Frantz Fanon participou da revolução argelina e publicou Peles negras, máscaras brancas e o livro Os condenados da terra. Em relatório da Divisão de Informações do DEOPS sobre ato público organizado pelo MNU, em 7/7/1980, Milton Barbosa importante militante do MNU citou Fanon para criticar o imperialismo. Dossiê 50-Z-130- 3773. DEOPS/SP, DAESP.

${ }^{618}$ FÉLIX, J. Op. Cit., p. 41.

${ }^{619}$ Panfleto de divulgação do Seminário “O marxismo e a questão racial”. Dossiê 50-Z-0- 15328. DEOPS/SP, DAESP.

${ }^{620}$ OP 1157 p. 218 C. DEOPS/SP, DAESP.
} 
racial para os partidos de esquerda. ${ }^{621}$ No entanto, esse "desnudar" foi iniciado na década de 1930, e nos anos de 1970 houve uma ampliação do debate racial. ${ }^{622}$ Mesmo na década de 1960, o Partido Comunista do Brasil (PCdoB) em seu manifesto-programa, de fevereiro de 1962, mencionava-se contrário a todas as formas de racismo ${ }^{623}$, revelando que essa questão não foi totalmente desconsiderada pelas esquerdas brasileiras antes de 1970 .

Nas declarações prestadas por Jarbas Teobaldo dos Santos, da Ala Vermelha do PC do $\mathrm{B}$, em 12/10/1969, há registro de que entre o material a ser distribuído pelo seu grupo encontrava-se documento sobre o movimento afro-americano. ${ }^{624} \mathrm{O}$ PCB buscava contatos com os movimentos negros, fosse para atuações conjuntas ${ }^{625}$ ou mesmo debatendo, em suas publicações, a "questão racial", como no periódico Voz da Unidade, onde era defendidos os movimentos que combatiam o preconceito de cor. ${ }^{626}$

A relação de militantes afro-descendentes com os movimentos de resistência gerou o debate interno dos movimentos negros sobre a relação entre as categorias "classe social" e "raça", mas também introduziu a "questão racial" no interior das esquerdas. "O período de inserção da luta contra o racismo na perspectiva de raça/ classe está intimamente ligado à experiência de várias lideranças negras dentro da esquerda, entre 1975 e 1978 e o surgimento do Núcleo Negro Socialista no interior da Convergência Socialista. " 627

Segundo o relatório do DEOPS, de 20/8/1978, na reunião plenária da $1^{\text {a }}$ Convenção Nacional da Convergência Socialista ${ }^{628}$, a mesa diretora era composta por um representante

\footnotetext{
621 SANTOS, G. "A luta contra o racismo na esquerda brasileira" In IANNI, O. [et. al.] $O$ negro e o socialismo. São Paulo: Fundação Perseu Abramo, 2005, p. 23.

${ }^{622} \mathrm{O}$ debate em torno da questão racial empreendido pelo PCB fez parte de minha iniciação científica Movimentos Negros: Identidade étnica, Identidade politica (1924-1983).

${ }^{623}$ SANTOS, G. Op. Cit., p. 24.

${ }^{624}$ Dossiê 50-D-26- 2243. DEOPS/SP, DAESP.

${ }^{625}$ Informe da II Seção do II Exército, de 2/7/1981. Dossiê 30-C-1- 24941. DEOPS/SP, DAESP.

${ }^{626}$ Compilação do jornal $A$ Voz da Unidade, n. 55, de 8 a 14/05/1981, do suplemento "teses para a legalidade do PCB”, fl. 2. Dossiê 30-C-1- sem número. DEOPS/SP, DAESP.

627 SANTOS, G. "A luta contra o racismo na esquerda brasileira" In IANNI, O. [et. al.] $O$ negro e o socialismo. São Paulo: Fundação Perseu Abramo, 2005, p. 26.

${ }^{628}$ Segundo informe confidencial n. 671/09 do Serviço de Informações da Polícia Federal, de 19 de setembro de 1980, sobre a Convergência Socialista: "depois de uma análise da situação internacional (Vietnam, África, Grécia, Espanha, América Latina, América Central e Brasil) 'se construiu e tem toda a sua trajetória intimamente ligada à luta feroz contra o governo, pelas liberdades democráticas, e ao lado das lutas dos trabalhadores e estudantes'. Em princípio de 1978, aproveitando o espaço aberto pelas mobilizações anteriores, foi lançada publicamente. No mesmo ano realizou duas reuniões nacionais, divulgadas abertamente, consolidando sua 'legalidade de fato', e concentrou sua atividade no ABC [...] $A$ CS 'se constrói nos marcos do internacionalismo proletário e apóia as posições politicas do COMITÊ PARITÁRIO e FRAÇÃO BOLCHEVIQUE. ’. DEOPS/SP, DAESP.
} 
(não identificado) do movimento negro ${ }^{629}$, revelando uma relação de militantes negros com a Convergência Socialista. A informação confidencial da 2a Seção do I Exército, de 17 de agosto de 1978, apresentava entre um dos temas da circular nacional n. 5, da Convergência Socialista, era a atuação do grupo Afro-Latino-América e o seu contato com o movimento negro de Salvador. ${ }^{630}$

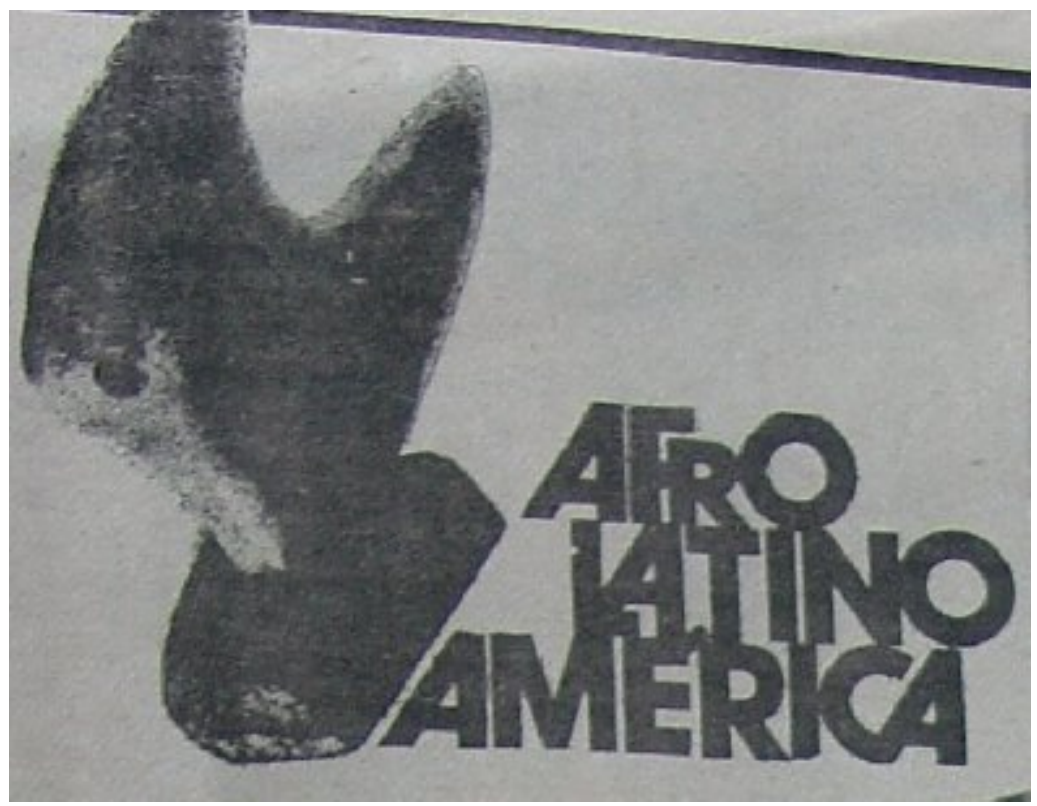

Símbolo da Coluna Afro-Latino-América no periódico Versus, de 1978.

$\mathrm{Na}$ documentação confidencial referente a Convergência Socialista, em uma das pastas de Ordem Social, há um item dedicado ao Grupo Afro-Latino-Americano e ao MUCDR. Conforme relatório de 20/3/1978, o grupo teria feito parte da reunião nacional da Convergência Socialista. Além disso, identificava, por meio do auto de qualificação e interrogatório de Arnaldo Shreiner, do jornal Versus, que o responsável pela coluna do grupo, no referido periódico, era Hamilton Bernardes. ${ }^{632}$

\footnotetext{
${ }^{629}$ Informação Confidencial sobre o Movimento Negro Unificado Contra a Discriminação Racial. OS 1157 p. 218 C. DEOPS/SP, DAESP.

${ }^{630}$ OS 1061. DEOPS/SP, DAESP.

${ }^{631}$ Símbolo da Coluna Afro-Latino-América In Versus, n. 23, de julho-agosto de 1978, p. 32. Dossiê 50-K-6280. DEOPS/SP, DAESP.

${ }^{632}$ Documento do Setor de Análise, Operações e Informações da Divisão de Ordem Social referente a carta convocatória para ato público contra o racismo. OS 1061. DEOPS/SP.
} 


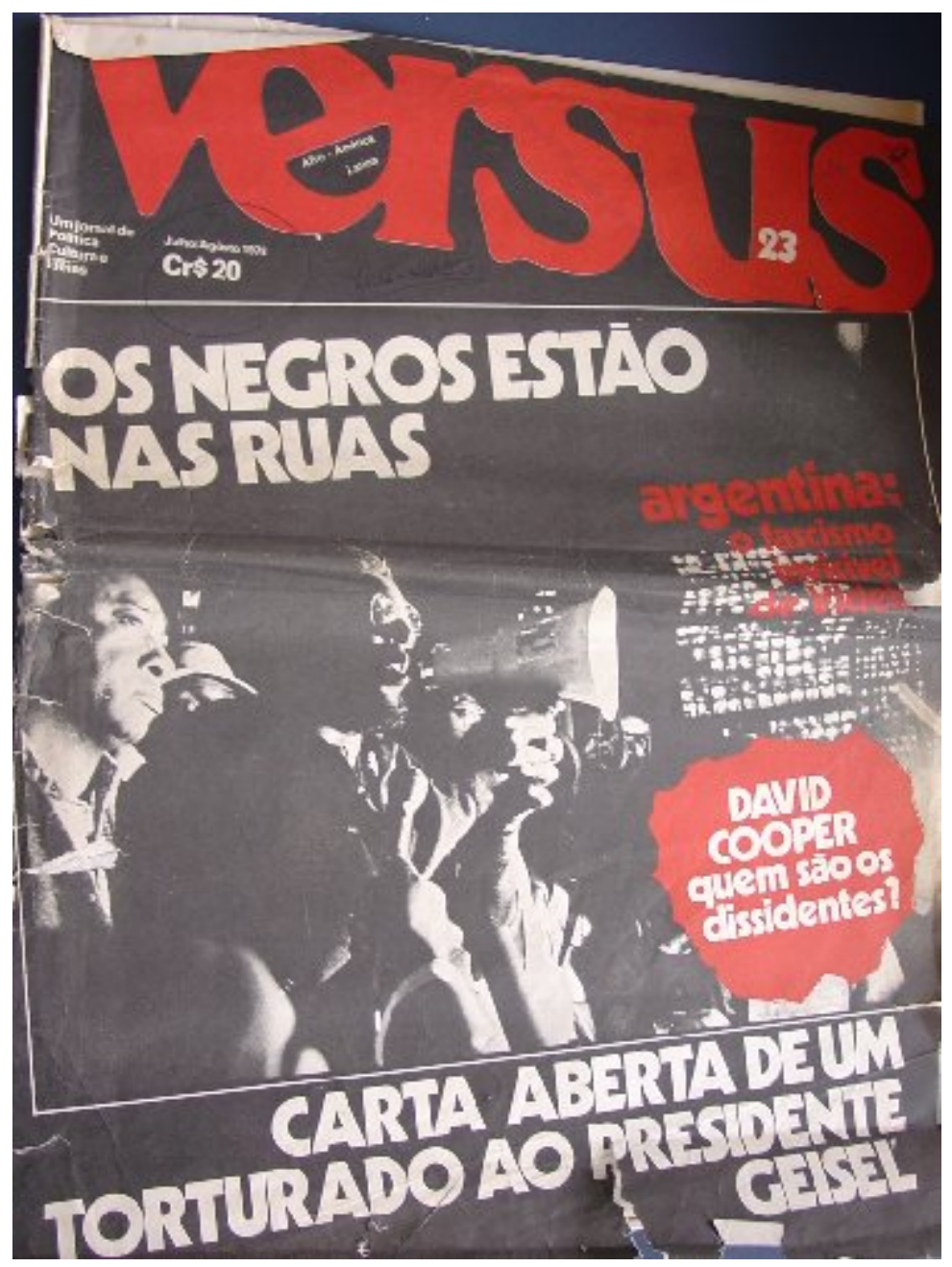

\section{Capa do periódico Versus, de 1978.}

Ao mesmo tempo, os militantes negros influíam no pensamento da Convergência Socialista, como na declaração de princípios do Partido Socialista, base da Convergência Socialista, apresentando o item "pela democracia racial - pelos direitos dos trabalhadores negros": "Contra toda prática discriminatória que prive os negros de igualdade de oportunidades no desempenho de suas atividades. Pelo comprimento efetivo da lei que estabelece o trabalho igual, salário igual. Pela participação obrigatória dos negros em

\footnotetext{
${ }^{633}$ Capa do periódico Versus, n. 23, de julho-agosto de 1978. Foto de Rosa Gauditano de ato público contra o racismo de 7/7/1978, no qual foi lançado ao público o MUCDR que posteriormente denominou-se MNU. Dossiê 50-K-6- sem número documento. DEOPS/SP, DAESP.
} 
todos os organismos sindicais em proporção à participação negra nos ramos de produção correspondentes, em todos os organismos governamentais e de representação popular. Pelo direito de livre organização e manifestação política, cultural e social dos negros." 634 Segundo documentação policial, o Partido Socialista estaria dividido em regionais com frentes de atuação e sendo uma delas a do movimento negro. Também constava, entre suas publicações, com o jornal Versus, do qual participava o grupo Afro-Latino-América. ${ }^{635}$

Essa relação dos movimentos negros com a Convergência Socialista foi intensificada com a organização do Núcleo Negro Socialista, experiência que unifica a atuação de universitários e jornalistas do periódico Versus. Estes articularam a formação do núcleo, com um projeto político que "foi criado estrategicamente pelas tendências trotskistas Liga Operária $^{636}$ e a Fração Bolchevique, que acabaram fundindo-se na Convergência Socialista. " ${ }^{637}$ É oportuno lembrar que a Liga Operária, a partir da experiência na década de 1950 e 1960, nos Estados Unidos, e na década de 1970, na África do Sul e na GuinéBissau, orientou a sua propaganda política para os negros. ${ }^{638}$ A polícia política destacava que "Ultimamente temos observado o nascimento da Convergência Socialista que propõe a fundação do Partido Socialista. Constatamos nesta Frente Socialista uma entidade que se propõe a lutar pela libertação e organização do negro no Brasil, denominada 'AFRO LATINO AMERICA', , 639

Dentre esses militantes, faz-se necessário destacar a atuação de Hamilton Bernardes Cardoso que teve uma atuação bastante engajada no núcleo, fazendo a relação entre movimentos negros e as esquerdas. "É inegável que a grande maioria dos pensadores/escritores do movimento negro ou dos estudos negros (black studies) têm ou tiveram sua formação política em partidos de esquerda, de orientação marxista. Isto marca

\footnotetext{
${ }^{634}$ Item V da Declaração de Princípios do Partido Socialista, fl. 12. OS 1157 p. $218 C$. DEOPS/SP, DAESP.

${ }^{635}$ Informação confidencial n. 878, de 30/08/1978, sobre o Partido Socialista dos Trabalhadores, fl. 2. OS 1157 p. $218 \mathrm{C}$. DEOPS/SP, DAESP.

${ }^{636}$ Linha trotskista segundo os órgãos de informação e segurança, que a partir de 1978 passou a denominar-se Partido Socialista dos Trabalhadores e subordinar-se-ia internacionalmente a tendência bolchevique. Informação confidencial n. 878, de 30/08/1978, sobre o Partido Socialista dos Trabalhadores. Dossiê OS 1157 p. $218 \mathrm{C}$. DEOPS/SP, DAESP.

637 SANTOS, G. "A luta contra o racismo na esquerda brasileira" In IANNI, O. [et. al.] O negro e o socialismo. São Paulo: Fundação Perseu Abramo, 2005, p. 26.

${ }^{638}$ SANTOS, G. Op. Cit., pp. 26-27.

${ }^{639}$ Dossiê 50-Z-0- 14623. DEOPS/SP, DAESP.
} 
decisivamente não somente o tom e o vocabulário dos seus discursos, mas também algumas das posições por eles assumidas e defendidas." 640

A postura socialista empregada pelo Núcleo Negro Socialista encontrou muita resistência diante dos outros movimentos negros ${ }^{641}$, em parte devido o próprio processo de repressão que divulgava que a direção do MNU era socialista, aspecto que dificultava a unificação desse movimento, levando à entidades negras do interior de São Paulo se retiraram do MNU. ${ }^{642}$

Para Hamilton Cardoso, a luta anti-racista desenvolvida pelo MNU teve influências do pensamento dos Panteras Negras, enquanto que o Núcleo Negro Socialista, refletia também sobre o apartheid na África do Sul, a guerra de guerrilhas na Guiné-Bissau e o trotskismo. ${ }^{643}$ Hamilton destacou que os Panteras Negras foram o modelo de atuação do MNU, mas pela documentação apreendida pelo DEOPS/SP constata-se que este movimento considerou diversas tendências.

A mobilização afro-descendente fora do Brasil, em particular quando apresentava tendências de esquerda, chamou a atenção de militantes brasileiros que debateram não só as idéias como as ações dos movimentos externos, levando em conta as como possíveis estratégias para os movimentos brasileiros. Hamilton Bernardes, em Ato Público contra o Racismo, organizado pelo MNCDR, em 1979, ressaltava que "o imperialismo é o sustentáculo principal do racismo. " 644 Portanto, o imperialismo incidira sobre a população negra na diáspora e interessava aos movimentos negros brasileiros discuti-lo para combater o racismo. O Programa de Ação do MNU anunciava que "O sistema capitalista marginaliza as camadas mais baixas da população do processo social e econômico, tendo como objetivo a permanência da exploração mantida pela minoria no poder." ${ }^{445}$ A crítica

\footnotetext{
${ }^{640}$ SOUZA, F. Afro-descendência em Cadernos Negros e Jornal do MNU. Belo Horizonte: Autêntica, 2005, p. 221.

${ }^{641}$ Conforme documento de uma Assembléia Nacional do MUCDR s/d. Apud SANTOS, G. "A luta contra o racismo na esquerda brasileira" In IANNI, O. [et. al.] O negro e o socialismo. São Paulo: Fundação Perseu Abramo, 2005, p. 32.

${ }^{642}$ O DEOPS acusava que a Convergência Socialista dirigia o MNU. Documento publicado pelo Núcleo Negro Socialista s/d. Apud SANTOS, G. Idem, p. 33.

${ }^{643}$ SANTOS, G. Ibdem, p. 35.

${ }^{644}$ Relatório de observação da Divisão de Informações do DEOPS, de 17/10/1979. Dossiê 21-Z-14- 7947. DEOPS/SP, DAESP.

${ }^{645}$ Dossiê 20-C-44- 17289. DEOPS/SP, DAESP.
} 
ao sistema apresentava-se na introdução à proposta da ação anti-racista, que buscava por fim à discriminação e à marginalização do negro.

Ao analisar a situação social do negro, enfrentando o desemprego e outras problemáticas sociais, Dalmir Francisco Costa do MNU de MG utilizava-se de uma base marxista, criticando o capitalismo: "[...] a atual crise de desemprego é fruto do sistema capitalista em decadência, e que os burgueses e empresários utilizam esta arma quando os lucros ameaçam os seus bolsos, despedindo os trabalhadores." 646

A coluna Afro-Latino-América, do jornal Versus, segundo a documentação policial, dedicava-se a "a conscientização e mobilização do negro na luta de classes, de caráter socialista, focalizando as lutas negras tanto na América Latina como em outras regiões do mundo." 647 Nesse sentido, refletir sobre a opressão sofrida pela população afrodescendente, seja no Brasil ou no exterior, obrigava os movimentos negros a pensarem nas desigualdades sociais como decorrentes do sistema capitalista.

A concepção marxista do MNU conduziu as estratégias de luta organizadas pela concepção leninista de "vanguarda revolucionária", que tinha como uma de suas tarefas conduzir a "massa" de negros à "libertação". ${ }^{648}$ A linguagem utilizada pelos movimentos negros era próxima daquela utilizada pelos movimentos de esquerda, levando os aparatos de segurança a entenderem estes como subversivos. Termos ligados ao marxismo, como "consciência", "mobilização", "classes", "libertação", "burguesia", "proletário", entre outros, eram utilizados nos discursos dos movimentos negros. Em documento do III Congresso do MNU apresentavam-se elementos de análise "marxista" como "exploração do homem pelo homem", "posição alienada", "burguesia nacional”, "imperialismo". 649

As referências marxistas estiveram presentes de forma constante, por exemplo, no $3^{\circ}$ Congresso de Cultura Negra das Américas, organizado IPEAFRO da PUC-SP, que utilizou um símbolo ligado as religiões afro-brasileiras que também apresentava relações com o universo marxista:

\footnotetext{
${ }^{646}$ Sumário Semanal n. 40, entre 18 a 28/12/1981, de 29/12/1981, do CODIN/CONSEG da Coordenação de Informação da Secretaria de Estado da Segurança Pública de MG, fl. 9. Dossiê 50-H-84- 5116. DEOPS/SP, DAESP.

${ }^{647}$ Informação de 27 de junho de 1978. Dossiê 50-E-33- 1735. DEOPS/SP, DAESP.

${ }^{648}$ JESUS, I. "O pensamento do MNU - Movimento Negro Unificado" In BARBOSA, L. e SILVA, P. $O$ pensamento negro em educação no Brasil. São Carlos: Editora da UFSCar, 1997, p. 45.

649 "Um balanço crítico de nossa atuação" In Sumário Semanal de Informações n. 15 da CODIN/COSEG, do período entre 9 a 15/4/1982, de 16/4/1982, fl. 10 e fl. 11, fl. 16. Dossiê 50-H-84- 5498. DEOPS/SP, DAESP.
} 


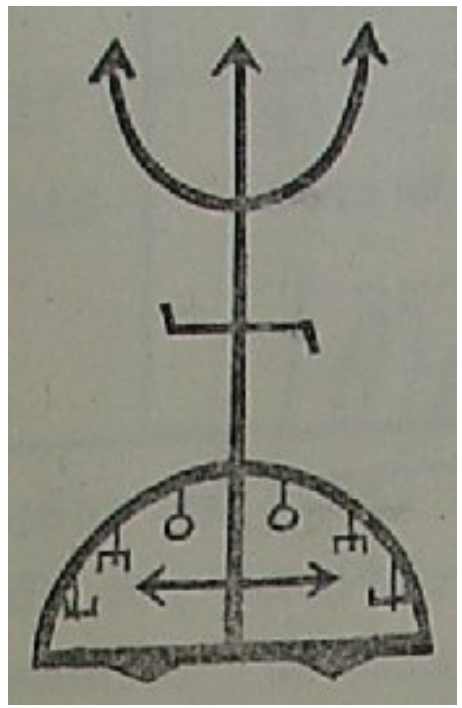

Símbolo presente na documentação do III Congresso de Cultura Negra das Américas.

Em nota sobre o símbolo destacava-se a simbologia do exu (presente no tridente do símbolo acima) de forma análoga, a idéia de dialética. Segundo a nota, o exu "incorpora os princípios da contradição e da dialética (já presentes na filosofia africana muito antes de Hegel e Marx)..." 651 Esse trecho demonstra a importância da circulação das idéias marxistas nos movimentos negros para a construção do seu pensamento anti-racista. Ao mesmo tempo, a parte inferior do símbolo representaria Ogum destacando "a luta africana e afro-americana pela justiça e libertação..." ${ }^{652}$, ou seja, ideais marxista-leninistas, próprios das lutas de libertação.

O argumento doutrinário da autodeterminação dos povos, proveniente das idéias de Lênin estiveram presentes nas discussões dos movimentos negros, principalmente em relação à situação política da África, elemento discursivo que também foi o mais difundido entre os africanos, indo de encontro ao anseio de liberdade de africanos e afrobrasileiros. $^{653}$

\footnotetext{
${ }^{650}$ OP 0989, Movimento Negro vol 2. DEOPS/SP, DAESP.

${ }^{651}$ OP 0989, Movimento Negro vol 2. DEOPS/SP, DAESP.

${ }^{652}$ OP 0989, Movimento Negro vol 2. DEOPS/SP, DAESP.

${ }^{653}$ HERNANDEZ, L. Os Filhos da Terra do Sol. São Paulo: Summus, 2002, p. 149.
} 
A categoria "libertação" fazia sentido nos debates dos movimentos negros brasileiros a partir da constatação que a Abolição não trouxera liberdade à população afro-brasileira. Como a iconografia abaixo simboliza os grilhões ainda tinham que ser rompidos:

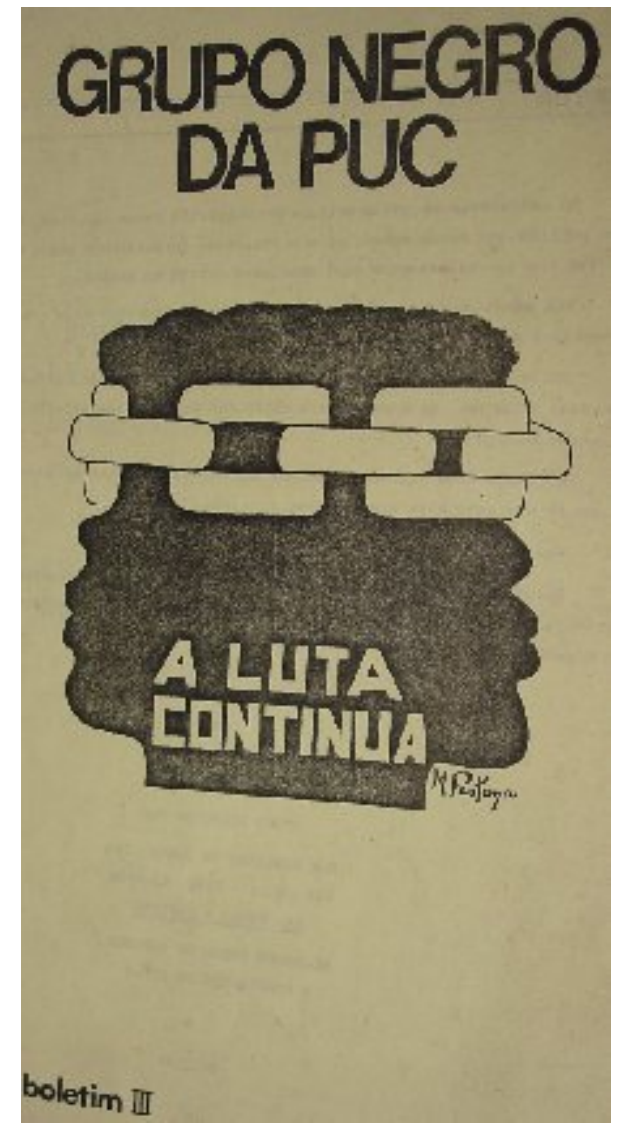

Panfleto do Grupo Negro da PUC-SP.

O panfleto de divulgação do I Encontro da Raça Negra apresentava uma interpretação da exploração capitalista pela perspectiva do "afro-marxismo", em debate no ano de 1981: “A situação opressiva em que vive o povo brasileiro, em especial nós negros, expressada através da expropriação de nossos valores, da exploração de nossas manifestações culturais, da discriminação individual que nos é imposta, tem como conseqüência a nossa perda de identidade, o subemprego, a alta do índice de criminalidade e a violência policial." ${ }^{655}$ No texto do Grupo Negro, da PUC-SP, apresentava-se a constatação acerca da

\footnotetext{
${ }^{654}$ Pasta Movimento Negro. CEDIC/PUC-SP.

${ }^{655}$ Dossiê 20-C-44- 17283. DEOPS/SP, DAESP.
} 
exploração geral do povo brasileiro, mas que sobre os negros incidiria uma exploração maior. Nesse sentido, a luta anti-racista não poderia se desvincular da própria luta anticapitalista e mesmo da luta contra o regime militar.

O MNU apresentava "a necessidade dos negros expressarem seus interesses no quadro geral da luta dos oprimidos contra a ditadura. " ${ }^{656}$ Sua luta se inseria no quadro de contestação do regime militar. Em Relatório do MNU de São Paulo sobre assembléia estadual realizada em Campinas, dia 21/9/1980, apresentava como um dos eixos de discussão a "combinação da questão racial com a luta de classes." 657 Ao discutir o imbricamento entre o aspecto racial e o aspecto de classe social, os movimentos negros tinham que enfrentar a resistência dos militantes "marxistas" que entendiam que a questão de classe já englobava as outras problemáticas sociais. Portanto, os ativistas negros defendiam a especificidade da exploração que os afro-descendentes enfrentavam na sociedade brasileira.

\section{2) Críticas às estruturas do regime militar}

"Há muito que falar/ Há muito que refletir:/ O tronco, o chicote,/ O cativeiro, a senzala, / A degradação, o desrespeito,/ A selvageria, a humilhação.../ Para cair no esquecimento./ Há muito que falar,/ Há muito que refletir:/ O medo, o desespero,/ A carência, a angústia,/ O domínio, o sofrimento,/ A tortura, a desfiguração.../ Que nos dias de hoje ainda sofremos. Há muito que falar,/ Há muito que refletir/ O cansaço, o esgotamento,/ As tramas, as rebeldias,/ As lutas, as fugas,/ O quilombo dos Palmares!/ Há muito que falar,/ Há muito que refletir/Com paciência vamos lutar/ Pouco a pouco vamos restituir/ A participação, o respeito.../ Centavo por centavo que esta negra nação/ Tem direito!" "658

"Por isso, hoje ele levanta e pões - com sua humildade de pobre e seu fanatismo de guerreiro - abaixo todas as leis, e ergue bandeiras desprezando vossas armas, deixa o sangue de seus ombros descer à terra, e ignorando vossa nefasta presença, ele sorri serenamente, amigo, serenamente como se fosse um sol, um universo, um negro Deus..." 659

\footnotetext{
${ }^{656}$ Dossiê 50-H-84- 5504. DEOPS/SP, DAESP.

${ }^{657}$ Dossiê 50-Z-32- 4601. DEOPS/SP, DAESP. Em outros documentos do MNU apresentam essa relação fundamental para o ideário do MNU, por exemplo, no relatório da reunião de avaliação de 20/9/1981 do MNU em MG, que expressava que o MNU: “[...] deixava bem claro que a sua proposta de discussão da questão racial combinando a questão de classe [...]" In Sumário Semanal de Informações n. 15 da CODIN/COSEG, do período entre 9 a 15/4/1982, de 16/4/1982, fl. 19. Dossiê 50-H-845498. DEOPS/SP, DAESP.

${ }^{658}$ SANTOS, Aparecido Tadeu dos. Como se fosse pecado. São Paulo: Edição do Autor, 1980, p. 12. Dossiê 20-C-44-17290. DEOPS/SP, DAESP. Coletado por ocasião do Io Encontro em Defesa da Raça Negra, realizado em 23/5/1981, na PUC-SP. Relatório diário n. 1505, entre 25 e 26/5/1981, da Divisão de Informações do DEOPS, fl. 2. Dossiê 21-Z-14-11366. DEOPS/SP, DAESP.

${ }^{659}$ Impresso "Negro", ano I, n. 1, de 1977, por Edivaldo Teixeira e Ivair Matias. Distribuído em Presidente Prudente no meio estudantil. Dossiê 50-C-0- 4130 e 50-C-22- 9704. DEOPS/SP, DAESP.
} 
O contexto histórico de repressão generalizada dos aparatos de segurança levou ao engajamento dos movimentos negros na luta contra o regime militar, em particular derivado do quadro sócio-político, repleto de violência policial e da carestia que atingia principalmente a população afro-descendente. "A luta contra o regime militar ganhava eco nas pressões pela defesa dos direitos humanos e pela liberdade de expressão, na qual os militantes negros detectavam um espaço de crítica do caráter autoritário das instituições de segurança que, em última análise, penalizavam com maior freqüência indivíduos duplamente excluidos: pela pobreza e pela cor da pele." 660

Benedito Cintra, vereador pelo PMDB, em ato público organizado pelo MNU, afirmou que "não se ganha essa batalha em reunião ou ato público, e sim sairmos em luta contra o regime; contra a repressão policial; por uma frente ampla e unida." 661 Sob essa perspectiva, os movimentos negros consideravam necessário um engajamento na luta antiregime militar.

Nos diversos impressos apresentam-se o envolvimento dos movimentos negros na luta pela democratização, sendo que o Jornal do MNU, discutia as “questões políticas nacionais, especificamente na luta pelas 'Diretas já' e pela inserção da questão racial na Assembléia Constituinte." 662 Temas como eleição, constituinte, partidos políticos e candidatos afro-descendentes, apareciam com freqüência neste periódico. $\mathrm{O}$ engajamento de parcela dos movimentos negros na luta pela democratização transparece nos escritos do Grupo Negro da PUC-SP: “...tem gente contra as diretas já mas, o importante é que A LUTA CONTINUA." ${ }^{663}$ No manifesto do MNU e da FRENAPO para a organização da campanha contra a violência policial, apresenta-se também uma argumentação em favor da abertura política "Como nação não exigimos somente a abertura ampla, irrestrita, exigimos, também, a segurança de manifestação de nossas idéias, o direito de reunir e

\footnotetext{
${ }^{660}$ CUNHA, O. "Depois da festa: movimentos negros e 'políticas de identidade' no Brasil” In ALVAREZ, S. e DAGNINO, E. e ESCOBAR, A. Cultura e política nos movimentos sociais latino-americanos: novas leituras. Belo Horizonte: Ed UFMG, 2000, p. 335.

${ }^{661}$ Relatório da Divisão de Informações do DEOPS. Dossiê 50-Z-130- 3773. DEOPS/SP, DAESP.

${ }^{662}$ SOUZA, F. Afro-descendência em Cadernos Negros e Jornal do MNU. Belo Horizonte: Autêntica, 2005, p. 81 .

663 “Ao leitor" In Boletim III do Grupo Negro da PUC-SP. Pasta Movimento Negro. CEDIC/PUC-SP.
} 
reivindicar." 664 Em panfleto, a FRENAPO revelando como preocupação central a democratização do país anunciava que teria sua ação voltada para uma mudança do regime político daquele período, lutando pela convocação de uma Assembléia Nacional Constituinte. Atrelada a estes objetivos salientava a importância da luta por uma real "libertação" do povo negro brasileiro e dos "irmãos negros" africanos. ${ }^{665}$

A crítica ao regime militar não se restringia apenas a sua ação anti-democrática, mas também ao próprio contexto econômico, que atingia sobretudo os afro-descendentes:

"todos aqueles que batalham por melhores condições de vida e trabalho no sentido de caminharmos para uma unidade de todos frente aqueles que insistem em manter de pé um regime militar que deu origem a um modelo econômico e político que trouxe o país a situação de falência dos dias atuais. "666

"Vivemos num regime ditatorial que enfaixa o poder nas mãos, decidindo pela maioria, sobre as questões nacionais. O desmantelamento da forma organizativa dos trabalhadores após 64 serviu como base para uma superexploração e concentração de renda, assim como para a entrega de nosso país as multinacionais." ${ }^{667}$

Esse contexto levou ao MNU a participar das lutas contra o regime militar, visando ampliar ou assegurar, na prática social, os direitos da população afro-descendente. Em ato público contra o racismo, em 13 de maio de 1981, a polícia política constatou que “ $A$ maioria dos discursos criticaram o atual governo e centraram-se principalmente no problema de desemprego." ${ }^{668}$ Da constatação de sua exclusão social e, em certa medida, da colaboração do regime militar para a manutenção das desigualdades raciais, parte dos movimentos negros rejeitavam o regime com veemência. Por exemplo, no ato público contra o racismo do MNCDR, com o enterro simbólico da Lei Afonso Arinos, os manifestantes se posicionaram contra o regime militar, como constou do discurso de um militante não identificado: "se a ditadura militar não aceita os negros, então abaixo a ditadura." 669

\footnotetext{
${ }^{664}$ Panfleto "Campanha Nacional Contra a Violência Policial". Dossiê 21-Z-14- 9873. DEOPS/SP, DAESP. Esse panfleto foi classificado como "subversão", segundo relatório diário n. 1364, entre 26 a 29/9/1980, da Divisão de Informações do DEOPS, fl. 4. Dossiê 21-Z-14- 9876. DEOPS/SP, DAESP.

${ }^{665}$ Relatório confidencial sobre a FRENAPO, de 18/7/1980. Dossiê 50-Z-130- 3803. DEOPS/SP, DAESP.

${ }^{666}$ Boletim III do Grupo Negro da PUC-SP, p. 18. Pasta Movimento Negro. CEDIC/PUC-SP.

${ }^{667}$ Programa de Ação do MNU, p. 12. Dossiê 20-C-44- 17289. DEOPS/SP, DAESP.

${ }^{668}$ Editorial da Revista do MNU, n. 4, julho e agosto de 1981, fl. 3. Sumário Semanal n. 27, entre 18 a 24/9/1981, de 25/9/1981, do CODIN/CONSEG da Coordenação de Informação da Secretaria de Estado da Segurança Pública de MG, fl. 12. Dossiê 50-H-84-4848. DEOPS/SP, DAESP.

${ }_{669}$ Relatório de observação da Divisão de Informações do DEOPS, de 17/10/1979. Dossiê 21-Z-14- 7947. DEOPS/SP, DAESP.
} 
O universo discursivo presente no regime militar, que visava congregar a população brasileira em torno de seu projeto político controlador, os afro-descendentes foram uma oposição constante. Em “Cartas da prisão", publicado no periódico Árvore das Palavras, edição n. 12, há traços críticos da ideologia do regime militar: "não devo nada pra 'sociedade', muito pelo contrário, ela é que me deve, pois meus antepassados e meus irmãos do Norte muito contribuíram para este 'Brasil Grande'.," ${ }^{670}$ Assim, a constatação da exclusão afro-descendente do "Brasil Grande" propagado pelos militares, levava a desnudar o discurso de harmonia racial presente no regime militar e as fortes desigualdades que incidiam sobre os afro-descendentes.

Assim, em meio aos debates das questões próprias da luta anti-racista, os militantes encontravam espaço para debater a situação política da época. Dalmir Francisco da Costa, líder do MNU em Minas Gerais, encerrou o evento de manifestação do Dia da Consciência Negra, em 1981, com um protesto que condenava o julgamento de Luís Inácio Lula da Silva e de outros militantes, salientando que o governo militar "tenta de todas as maneiras calar toda a ameaça que surge no meio trabalhista e, também, toda forma de organização do povo oprimido." 671

Dalmir, em suas propostas de ação para o MNU, se alinhava com uma postura fortemente combativa:

"Devemos enxergar nossos problemas como negro e lutar para acabar com essa falsa imagem de que somos classe inferior, submissa a essa política fascista que está nas mãos de uma minoria burguesa e desse sistema vigente, que não deixa o povo se conscientizar e lutar por seus direitos. Que democracia é esta que só aplica golpes e mais golpes, em cima do povo brasileiro, num desrespeito sem tamanho à suas próprias leis e decreto-leis?" ${ }^{672}$

Destacava que o posicionamento diante da estrutura política vigente era uma esfera da consciência negra uma razão pela qual os afro-descendentes deveriam estar lutando com o restante do povo brasileiro. ${ }^{673}$

\footnotetext{
${ }^{670}$ Dossiê 50-Z-130- 2270. DEOPS/SP, DAESP.

671 "Dia Nacional da Consciência Negra - Movimento Negro Unificado (MNU)" Sumário Semanal de Informações n. 36, entre 20/11 a 26/11/1981, de 27/11/1981, CODIN/CONSEG da Coordenação de Informações da Secretaria de Estado de Segurança Pública de MG, fl 39. Dossiê 50-H-84- 5045. DEOPS/SP, DAESP.

${ }_{672}$ Sumário Semanal de Informações n. 37, entre 27/11 a 3/12/1981, de 4/12/1981, fl 48, do CODIN/CONSEG da Coordenação de Informações da Secretaria do Estado de Segurança Pública de MG. Dossiê 50-H-84- 5068. DEOPS/SP, DAESP.

673 Sumário Semanal de Informações n. 37, entre 27/11 a 3/12/1981, de 4/12/1981, fl 49, do CODIN/CONSEG da Coordenação de Informações da Secretaria do Estado de Segurança Pública de MG. Dossiê 50-H-84- 5067. DEOPS/SP, DAESP.
} 
O MNUCDR de MG realizava constantes debate sobre a situação política brasileira, e assim o fez em relação ao pacote eleitoral, em 1981. Ora, tal debate era considerado subversivo, em especial pela posição político-ideológica dos seus líderes: "Sobre o 'Pacotão Eleitoral', Dalmir Francisco Costa opinou dizendo ser este o golpe mais audacioso aplicado pelo governo”. Afirmação crítica a política dos militares que se encontra grifada pela polícia política no relatório do investigador infiltrado. ${ }^{674}$

A crítica à repressão do regime militar aos movimentos negros também era apresentado em charges como a de Pestana, a qual demonstra que os temas de debate e as reivindicações dos movimentos negros eram tratados com repressão e violência:

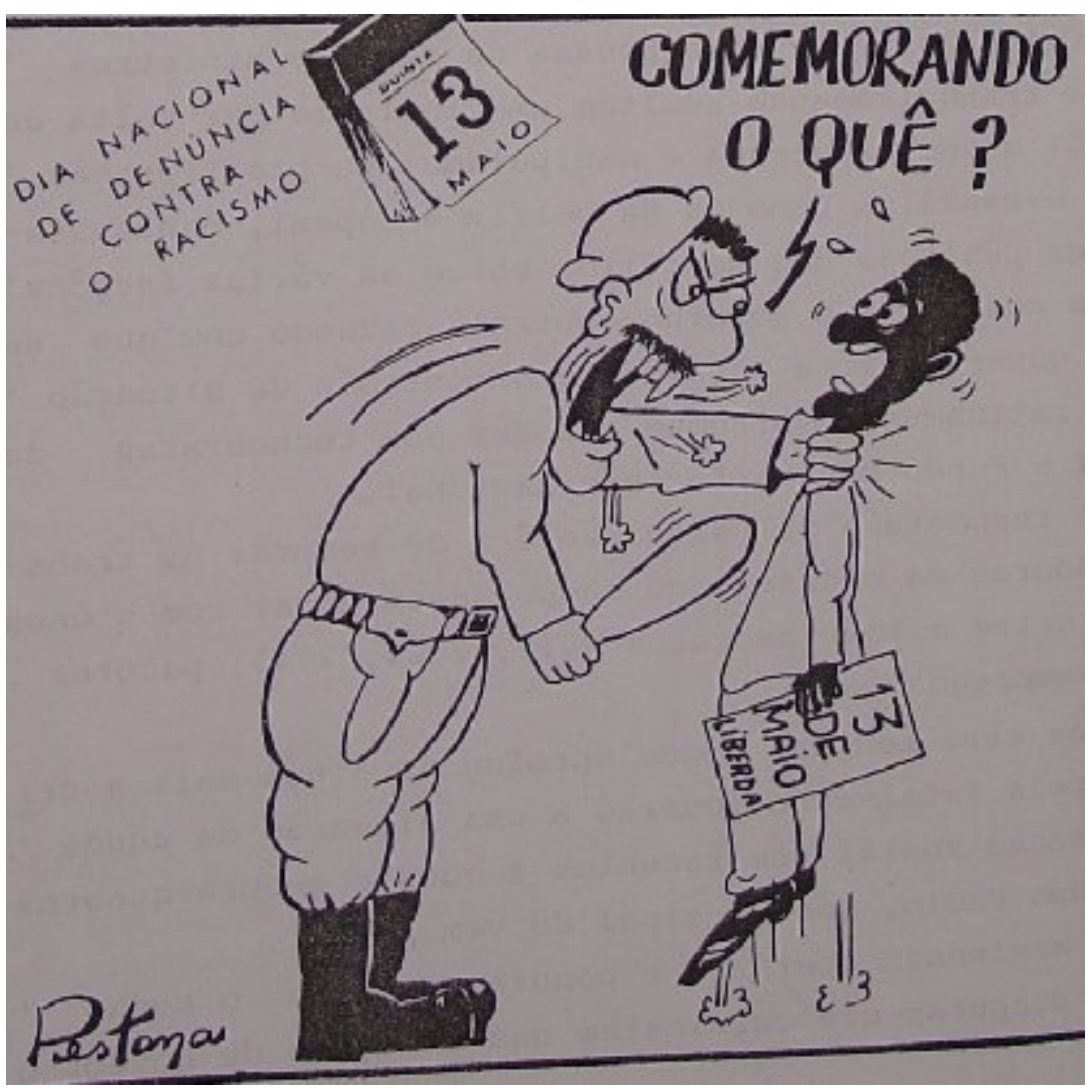

Charge de Pestana presente em boletim do Grupo Negro da PUC-SP.

\footnotetext{
${ }^{674}$ Sumário Semanal n. 39, entre 11 a 17/12/1981, de 18/12/1981, do CODIN/CONSEG da Coordenação de Informação da Secretaria de Estado da Segurança Pública de MG, fl. 7 e 8. Dossiê 50-H-84- 5104 e 50-H-845103. DEOPS/SP, DAESP.

${ }^{675}$ Boletim III do Grupo Negro da PUC-SP. Pasta Movimento Negro. CEDIC/PUC-SP.
} 
As charges de Pestana contemplavam os aspectos repressivos e anti-democráticos que assolavam a população brasileira. Pestana utilizava-se dos principais temas e de aspectos culturais do universo afro-brasileiro para criticar o regime militar, principalmente no que concerne a condição social dos afro-descendentes obtendo, assim, uma arte engajada.

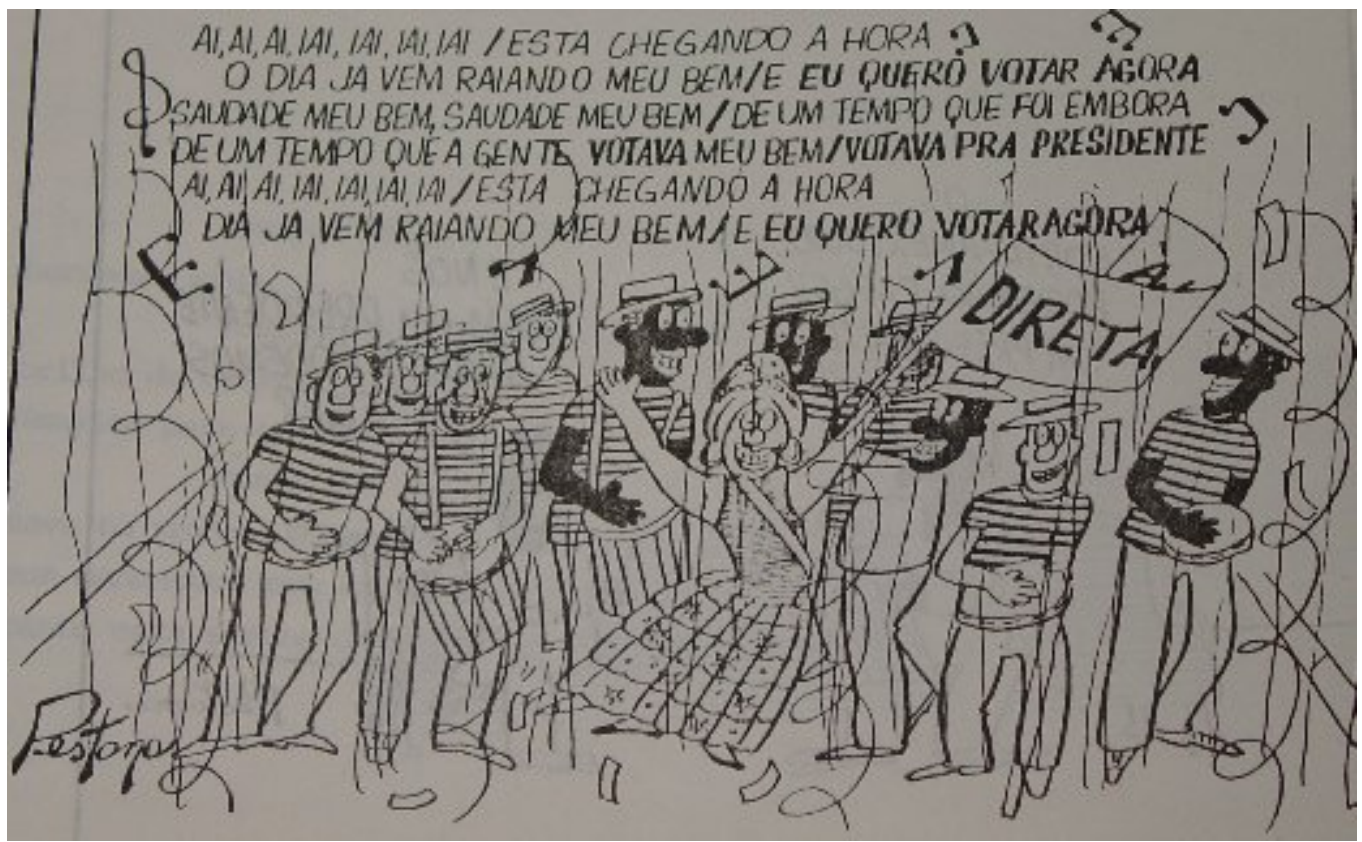

Charge de Pestana presente em boletim do Grupo Negro da PUC-SP.

Estes aspectos também estiveram presentes em charges da campanha pelas "diretas já" pelas eleições diretas, início de um restabelecimento das condições democráticas no país, o que se apresentava como condição prioritária para que os debates sobre as questões raciais se desenvolvessem. Assim, a crítica ao regime militar e a participação da luta pela democracia no Brasil faziam parte da agenda dos movimentos negros.

\footnotetext{
${ }^{676}$ Boletim III do Grupo Negro da PUC-SP. Pasta Movimento Negro. CEDIC/PUC-SP.
} 


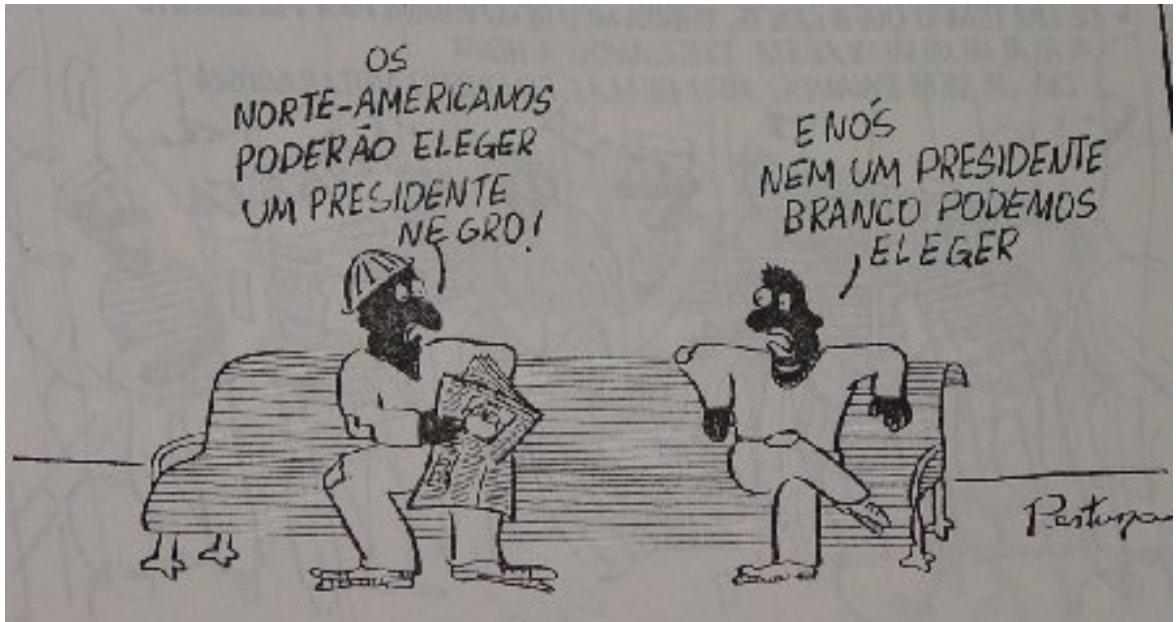

Charge de Pestana presente em boletim do Grupo Negro da PUC-SP.

Uma outra charge de Pestana, parte da campanha pela eleição direta para presidente da República para também fazer referência à necessidade de um Estado de Direito para se ter liberdade de expressão, podendo lutar contra a discriminação.

Em ato contrário ao apartheid da África do Sul, organizado pelos movimentos negros, o jornalista Nilson da Hora do Povo, criticou o regime militar classificando-o como o braço do imperialismo, causador de desigualdade, exploração e violência. ${ }^{678}$

Ao analisar o quadro político, o MNU o interpretava como um cenário de "forte onda de repressão a que estão submetidos os negros e os trabalhadores em virtude da recessão econômica internacional, provocando o desemprego massivo em todo mundo." 679

\section{Carestia $^{680}$ e Violência policial}

"Antes eramos escravos, agora somos desempregados, sub-empregados, mal remunerados, marginalizados e perseguidos pela policia." 681

"Que liberdade é essa? Continuamos sendo discriminados, sem emprego e perseguidos pela polícia." 682

\footnotetext{
${ }^{677}$ Boletim III do Grupo Negro da PUC-SP. Pasta Movimento Negro. CEDIC/PUC-SP.

${ }^{678}$ Dossiê 20-C-44-24720. DEOPS/SP, DAESP.

${ }^{679}$ Editorial da Revista do MNU, n. 4, julho e agosto de 1981, fl. 1. Sumário Semanal n. 27, entre 18 a 24/9/1981, de 25/9/1981, do CODIN/CONSEG da Coordenação de Informação da Secretaria de Estado da Segurança Pública de MG, fl. 10. Dossiê 50-H-84-4848. DEOPS/SP, DAESP.

${ }^{680}$ A carestia era um termo empregado como pobreza, carências propriamente dita até mesmo ao se referir ao desemprego. Ou seja, relaciona-se a questões próprias do encarecimento do custo de vida, preço elevado acima do valor real do período.

${ }^{681}$ Panfleto "13 de maio: dia nacional de denúncia contra o racismo". Dossiê 20-C-44- 23944. DEOPS/SP, DAESP.
} 


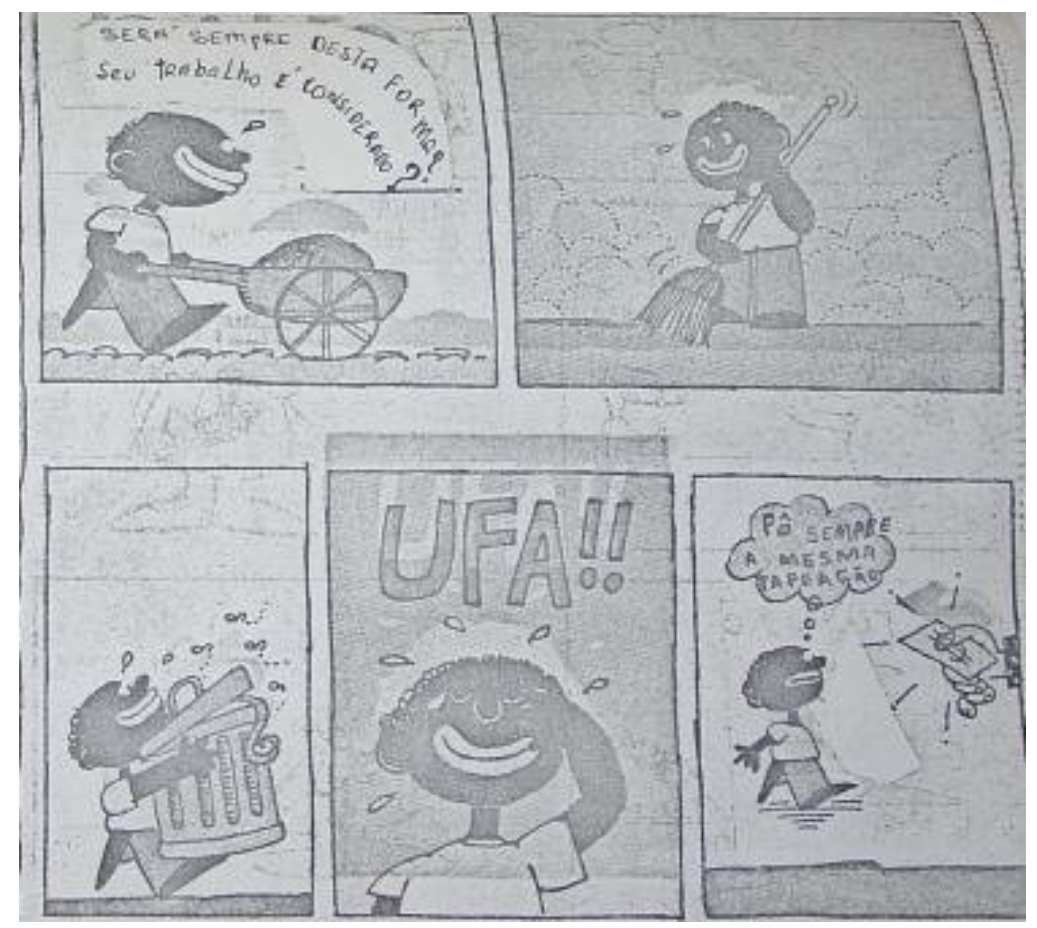

Charge no periódico Árvore das Palavras, 1974.

A constatação de que "o negro é quem mais sofre no Brasil com o desemprego, repressão e péssimas condições de vida da maioria da população brasileira, da qual somos o maior número" ${ }^{684}$ levava os temas da carestia e da violência policial apresentarem-se de forma central nos debates dos movimentos negros.

Esses dois temas possuíam ligação na própria organização de debates sobre a "marginalização social do negro e a violência policial" ${ }^{685}$ ou como no panfleto do $\mathrm{I}^{\mathrm{O}}$ Encontro Estadual em Defesa da Raça Negra, que apresentava como um dos itens de discussão "Contra o desemprego e a violência policial". Destacava-se que o trabalhador devido a crise econômica brasileira tornava-se desempregado e, se fosse negro e sem carteira de trabalho assinada, sofria os maiores preconceitos, sendo classificado pela polícia como "bandidos". 686

\footnotetext{
${ }^{682}$ Panfleto "Dia nacional de denúncia contra o racismo". Dossiê 20-C-44- 23945. DEOPS/SP, DAESP.

${ }^{683}$ Detalhe da charge no periódico Árvore das Palavras n. 6 de novembro de 1974. Dossiê 50-Z-129- 15426. DEOPS/SP, DAESP.

${ }^{684}$ Boletim III do Grupo Negro da PUC-SP, p. 18. Pasta Movimento Negro. CEDIC/PUC-SP.

${ }^{685}$ Relatório de investigação n. 501 de 7/08/1980. OS 1157 p. 218C. DEOPS/SP, DAESP.

${ }^{686}$ Dossiê 20-C-44- 17287. DEOPS/SP, DAESP.
} 
Dessa forma, o MNU, em seu I Congresso, traçou como prioridade da sua luta o combate ao desemprego e a violência policial, sendo que a segunda questão teve maior empenho da militância e gerou uma campanha nacional, em 1980. ${ }^{687}$ No ano seguinte, II Congresso Nacional do MNU, em Belo Horizonte foram reafirmados como principais temas o desemprego e a violência policial e, portanto, como lutas prioritárias. ${ }^{688}$

O MNU em seus impressos afirmava a pobreza e o desemprego que eram oriundos da política econômica brasileira que, em conjunto com os lucros dos patrões, levavam a população brasileira à miséria. ${ }^{689}$ Os militantes afro-descendentes encontravam-se "envolvidos na atmosfera político-cultural do período e procuraram definir uma posição política marcada pela compreensão das especificidades da discussão de raça/etnia para os afro-brasileiros." ${ }^{690}$ Portanto, os problemas sócio-econômicos do período fizeram parte do debate dos movimentos negros, especialmente com a crise econômica pós "milagre brasileiro" do final da década de 1970 que trouxe uma inflação monstruosa e um aumento violento do desemprego.

A situação de exploração do trabalho e a constatação das diferenças salariais que os afro-descendentes sofriam, eram sistematicamente discutidas. "Depois de muitos anos de arrocho salarial e da inexistência de liberdade de manifestação e organização, o trabalhador brasileiro (em sua maioria negro), ganha da crise econômica que se abate sobre o país mais um 'presente': o desemprego." ${ }^{691}$ Essas condições adversas para os afro-descendentes acabavam por agravar os preconceitos, pois desempregados, eles eram mais vezes confundidos com "bandidos", ficando à mercê de uma crescente violência policial.

\footnotetext{
${ }^{687}$ Relatório de avaliação de 20/9/1981 do MNU de MG. In Sumário Semanal de Informações n. 15 da CODIN/COSEG, do período entre 9 a 15/4/1982, de 16/4/1982, fl. 20. Dossiê 50-H-845498. DEOPS/SP, DAESP.

688 "Nos dias 18, 19 e 20 de abril o MNU, realizou o seu II $^{\circ}$ Congresso Nacional, na cidade de Belo Horizonte" In Revista do $M N U$, n. 4, julho e agosto de 1981, fl. 5. Sumário Semanal n. 27, entre 18 a 24/9/1981, de 25/9/1981, do CODIN/CONSEG da Coordenação de Informação da Secretaria de Estado da Segurança Pública de MG, fl. 14. Dossiê 50-H-84-4848. DEOPS/SP, DAESP.

${ }^{689}$ Editorial da Revista do MNU, n. 4, julho e agosto de 1981, fl. 1. Sumário Semanal n. 27, entre 18 a 24/9/1981, de 25/9/1981, do CODIN/CONSEG da Coordenação de Informação da Secretaria de Estado da Segurança Pública de MG, fl. 10. Dossiê 50-H-84-4848. DEOPS/SP, DAESP.

${ }^{690}$ SOUZA, F. Afro-descendência em Cadernos Negros e Jornal do MNU. Belo Horizonte: Autêntica, 2005, p. 41.

${ }^{691}$ Panfleto do Grupo Negro da PUC "I Encontro Estadual em Defesa da Raça Negra” In Dossiês 20-C-44 17287. DEOPS/SP, DAESP.
} 
Como os problemas sociais de carestia não eram enfrentados apenas pelos afrobrasileiros, os movimentos negros percebiam a necessidade de comunicação com outros movimentos sociais também temerosos desse contexto adverso. "Hoje vemos nossa situação de negros, afro-brasileiros, e nos levantamos para buscar o lugar que como homens temos direitos: 1)o direito ao emprego, as condições dignas de vida ; 2) o respeito a nossa dignidade." ${ }^{692}$ Nesse sentido, procuravam incentivar uma maior participação dos afro-descendentes nas instituições representantes dos trabalhadores. ${ }^{693}$ Por seu turno, os movimentos negros não passavam desapercebidos à polícia política, em especial por eles se solidarizarem "com qualquer luta de setores populares da sociedade brasileira que visa a real conquista de seus direitos políticos, econômicos e sociais. " 694

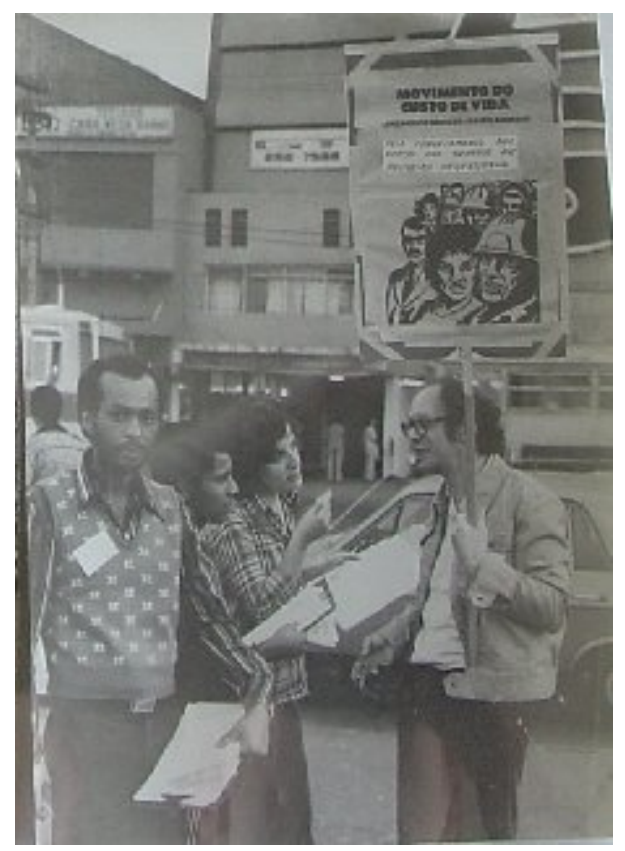

Imagem fotográfica de participantes do Movimento do Custo de Vida, dentre eles aparece um afro-descendente não identificado pela polícia.

${ }^{692}$ Panfleto sobre a "caminhada em memória a zumbi dos palmares em 20 de novembro, dia nacional da consciência negra" escrito pelo Grupo Negro da PUC. FRENAPO e o MNU. Dossiê 20-C-44- 14611. DEOPS/SP, DAESP.

${ }^{693}$ Panfleto do Grupo Negro da PUC "I Encontro Estadual em Defesa da Raça Negra” In Dossiês 20-C-44 17287. DEOPS/SP, DAESP.

${ }^{694}$ Informação Confidencial sobre o Movimento Negro Unificado Contra a Discriminação Racial. OS 1157 p. 218 C. DEOPS/SP, DAESP.

${ }^{695}$ Dossiê 50-Z-0- sem número documento. Pasta 77. DEOPS/SP, DAESP. 
Ainda em relação ao mercado de trabalho, apresentava-se permeado pelo racismo: " $A$ discriminação que os trabalhadores negros sofrem no processo de seleção de candidatos $e$ o fato das empresas reservarem para eles as piores funções, são manifestações evidentes de um racismo profundamente enraizado nas classes dominantes e, através delas, disseminado pelo conjunto da sociedade." 696

No Programa de Ação do MNU apresenta-se uma discussão sobre a falta de condições de vida ligadas ao "sub-emprego" que os afro-descendentes eram submetidos, levando o MNU a reivindicar melhores condições de vida, creches populares, assistência médica hospitalar, saneamento básico, melhores habitações e transportes. ${ }^{697}$ Este conjunto de reivindicações levou o MUCDR a apresentar uma carta aberta à população "Contra o Racismo", no ato público de 7/7/1978, em frente ao Teatro Municipal, denunciando as condições de vida dos afro-descendentes: "Campanha contra a discriminação racial, contra a opressão policial, contra o desemprego, o sub-emprego e a marginalização. Estamos nas ruas para denunciar as péssimas condições de vida da Comunidade Negra." 698

Mas essa temática não era consenso entre os militantes. No $3^{\circ}$ Congresso de Cultura Negra das Américas, em 1982, esse debate foi acalorado: a militante Teresa Santos defendia e expunha os problemas pontuais enfrentados pelos negros, como moradia, enquanto Ciro alegava que esse tema não tinha fundamentos concretos e objetivos para ser levado ao congresso. ${ }^{699}$ Diante da constatação dos problemas sociais dos afro-descendentes houve debates específicos para as mulheres, que eram afetadas de forma diferenciada pelo racismo. Assim, em 1981 o grupo de mulheres do MNU organizou um ciclo de debates sobre sua situação, com o programa: "partidos políticos", "educação e cultura", "sexualidade", "saúde" e "desemprego e movimento sindical". 700

\footnotetext{
${ }^{696}$ Proposta de ponto de luta da Comissão de negros do PT, 9/12/1981. Dossiê 50-H-84- 5505. DEOPS/SP, DAESP.

${ }^{697}$ Dossiê 20-C-44- 17289. DEOPS/SP, DAESP.

${ }^{698}$ Dossiê 50-Z-0- 14629. DEOPS/SP, DAESP.

${ }^{699}$ Relatório de observação do $3^{\circ}$ Congresso de Cultura Negra das Américas, 24/08/1982. DEOPS/SP, DAESP.

${ }^{700}$ Recorte de jornal da Folha de S. Paulo de 3/8/1981. OP 0989 Movimento Negro, vol 2. DEOPS/SP, DAESP.
} 
Com o mesmo intuito foi realizado o I Encontro Regional da Mulher Negra que discutiu a dupla discriminação sofrida pelas mulheres negras, especialmente no mercado de trabalho. ${ }^{701}$ A emancipação feminina, um dos temas centrais nas discussões das décadas de 1960 e 1970 foi apresentado no debate dos movimentos negros como tema do Boletim do Grupo Negro da PUC-SP “A mulher negra", "E a mulher negra com anda?”, debatendo as modificações sociais decorrentes da revolução sexual e a especificidade da condição da mulher negra. ${ }^{702} \mathrm{O}$ debate da exploração e marginalização das mulheres afro-descendentes foi centrado no mercado de trabalho, o que levou ao MNU discutir o machismo em seu programa de ação, constatando que "A discriminação da mulher se define pela sua marginalização sexual, política, econômica e social." 703

Segundo informação confidencial, de 28/7/1978, no panfleto do MUCDR "quem luta por nós" visava chamar atenção dos negros para juntar-se ao movimento, com o objetivo de "melhorar as condições nesta sociedade que os expulsa dos empregos, atira-os à favelas e cortiços,...” 704 Portanto, o MUCDR entendia que a discriminação racial era o elemento chave para a compreensão dos problemas sociais dos afro-descendentes, impedindo o "desenvolvimento do negro". ${ }^{705}$ A partir dessa constatação eram relacionados os principais problemas sociais a serem combatidos como o desemprego, o sub-emprego, a moradia precária e a perseguição e a violência policial. ${ }^{706}$

A ligação das temáticas da violência policial e da carestia não foi reunida aqui indiscriminadamente, sua relação se encontra nos debates e impressos dos movimentos negros, que elegeram como o principal foco de combate do racismo em sua estratégia de luta. "Devido a dificuldade de se discutir no FECONEZU todos os problemas que passa a população negra, resolvemos, a partir destas propostas mínimas: Violência Policial e Desemprego, chamar toda a comunidade negra à discutir e se organizar através de

\footnotetext{
${ }^{701}$ Recorte de jornal da Folha de S. Paulo de 17/11/1981. OP 0989 Movimento Negro, vol 2. DEOPS/SP, DAESP.

${ }^{702}$ Boletim III do Grupo Negro da PUC-SP. Pasta Movimento Negro. CEDIC/PUC-SP.

${ }^{703}$ Programa de Ação do MNU, p. 9. Dossiê 20-C-44- 17289. DEOPS/SP, DAESP.

${ }^{704}$ OS 1061. DEOPS/SP, DAESP.

${ }^{705}$ Carta convocatória para o ato público contra o racismo do MUCDR. OS 1061. DEOPS/SP, DAESP.

${ }^{706}$ Carta convocatória para o ato público contra o racismo do MUCDR. OS 1061. DEOPS/SP, DAESP. Segundo observação policial feita de forma manuscrita no panfleto, teria sido distribuído cerca de 20 mil cópias desta carta convocatória.
} 
entidades..." 707 Trabalho e violência policial, sem dúvida, foram as temáticas mais recorrentes nos diversos materiais impressos dos movimentos negros.

\section{Violência Policial}

"A violência policial é uma das formas mais comuns assumidas pelo racismo no Brasil."

A temática da violência policial foi presença constante em debates, atos públicos, palavras de ordem, panfletos e cartas abertas, entre outras estratégias de discussão dos movimentos negros. Em ato público de 13 de maio de 1981, a violência policial estava estampada em faixas, palavras de ordem, ${ }^{709}$ ou no ato intitulado "violência" que fora organizado pelo MNU e pela FRENAPO. Manifestavam-se contra a violência policial e lançavam uma campanha para combatê-la. ${ }^{710}$ Também eram recorrentes os debates sobre "Marginalização Social do Negro e a Violência Policial”. 711

Contra a violência policial do final da década de 1970 ao início da década de 1980, que era questão central para os seus líderes, esta temática foi uma das principais bandeiras de luta do MNU. ${ }^{712}$ Entre outros panfletos e reuniões dos movimentos negros que tocam nesta temática, destacam-se os debates ocorridos no III Congresso Nacional do Movimento Negro Unificado, no qual os Grupos de Trabalho em cada estado trataram sobre denúncias de violência policial sofrida pelos afro-descendentes. Da mesma forma, o I Encontro Estadual em Defesa da Raça Negra, colocava como um dos tópicos de luta combater a violência policial. A constatação de que a violência contra a população afro-descendente era uma herança da escravidão, fez com que o periódico Jornegro criticasse por meio de charge a violência policial brasileira, comparando o policial ao feitor "antes e depois de 13 de maio de 1888":

\footnotetext{
${ }^{707}$ Panfleto Io Encontro Estadual em Defesa da Raça Negra. Pasta Movimento Negro. CEDIC/PUC-SP.

${ }^{708}$ Proposta de ponto de luta da Comissão de negros do PT, 9/12/1981. Dossiê 50-H-84- 5505. DEOPS/SP, DAESP.

${ }^{709}$ Por exemplo, em ato público de 13 de maio de 1981 a violência policial estava estampado em faixas, palavras de ordem, etc. Mensagem sobre Sumário de Informações n. 035/4 sobre Ato Público do MNU, de 13 de maio de 1981. Dossiê 50-D-18- 2850. DEOPS/SP, DAESP.

${ }^{710}$ Relatório de observação n. 3435 da Divisão de Informações do DEOPS, de 28/9/1980. Dossiê 40-Z-101326 ou 21-Z-14- 9872. DEOPS/SP, DAESP.

${ }^{711}$ Relatório n. 507 de investigador estagiário da Divisão de Ordem Política, ao delegado titular, de 8/8/1980. Dossiê 40-Z-10-1225. DEOPS/SP, DAESP.

${ }^{712}$ Informe n. 89/Conseg/82 de Belo Horizonte de 19/04/1982, fl. 2. Ordem Social 1157 pasta $218 C$. DEOPS/SP, DAESP.
} 


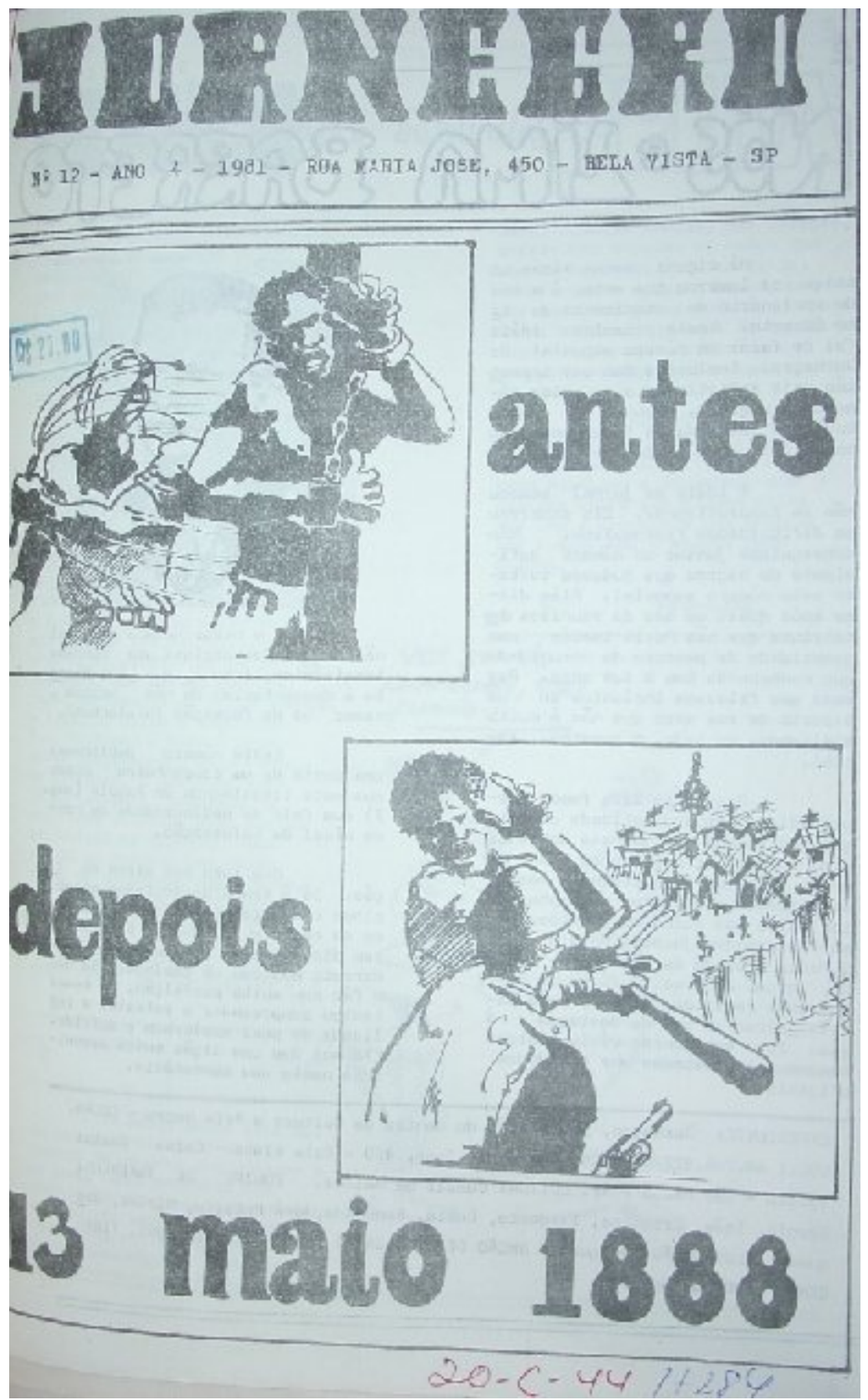

Capa do Jornegro, de 1981.

713 Jornegro, n. 12, Ano 4, 1981. Dossiê 20-C-44- 17284. DEOPS/SP, DAESP. Coletado por ocasião do Io Encontro em Defesa da Raça Negra, realizado em 23/5/1981, na PUC-SP. Relatório diário n. 1505, entre 25 e 26/5/1981, da Divisão de Informações do DEOPS, fl. 2. Dossiê 21-Z-14-11366. DEOPS/SP, DAESP. 
O sistema repressivo próprio do regime político dos militares levava a uma crítica das formas repressivas da atuação policial. Assim, os movimentos negros atuaram em diversos atos públicos que protestavam contra a violência policial como, por exemplo, no ato na Praça Ramos que contou com diversos segmentos sociais e com a presença do MNU, e com a distribuição de diversos panfletos contrários à ação da polícia na região contra prostitutas, travestis, homossexuais e negros. ${ }^{714}$ Segundo Carta Aberta à População, o delegado José Wilson Richetti apoiado pelos comerciantes, realizava uma "limpeza" dos "marginais" na cidade, prendendo que não tivesse carteira de trabalho assinada. ${ }^{715}$

A ação violenta da polícia no processo de ocupação do espaço público, por diversas vezes, associou-se a projetos de afastamento dos afro-descendentes de determinadas regiões da cidade, sobretudo da região central. Na década de 1940 houve a tentativa de proibição do trânsito e da permanência dos afro-descendentes na Rua Direita, medida tomada em virtude de uma representação do Sindicato dos Lojistas junto à Secretaria de Segurança Pública. ${ }^{716}$

Os estereótipos presentes no imaginário auxiliaram na fundamentação de políticas segregacionistas, seja no âmbito legal ou no simbólico, colocando cada qual em um lugar social pré-determinado. A polícia, junto aos seus diversos departamentos e enquanto uma instituição responsável pela manutenção da ordem pública, assumiu a tarefa de regular a manutenção da ordem racial.

Um recorte de jornal sem identificação apresentava matéria de atos públicos no $92^{\circ}$ Aniversário da Abolição, de 14 de maio de 1980, que apresentava documento do MNU criticando a ação violenta da polícia: "Essa violência tem como função manter a população sob rigoroso controle, para impedir a reação à exploração econômica, social e política. A exigência da Carteira Profissional é um dos meios de pressionar os negros a ocuparem os piores trabalhos como mão de obra barata. O governo não pode exigir, através da polícia, que tenhamos emprego, quando todos sabemos a grande quantidade de desempregados que existem em São Paulo e em todo País." 717

\footnotetext{
${ }^{714}$ Relatório de investigações n. 356, 13/06/1980. OP 0654 Atos Públicos. DEOPS/SP, DAESP.

${ }^{715}$ OP 0654 Atos Públicos. DEOPS/SP, DAESP.

${ }^{716}$ KÖSSLING, Karin Sant' Anna. "O discurso policial sobre o afro-descendente: estigmas e estereótipos" In Revista Histórica, edição n. 15. São Paulo: Arquivo do Estado de São Paulo, julho/agosto/setembro de 2004.

${ }^{717}$ OP 0654 Atos Públicos. DEOPS/SP, DAESP.
} 
O MNU destacava que: "a repressão policial que se abate principalmente sobre a população negra, tem como objetivo mantê-la desorganizada, bloqueando qualquer iniciativa política que ela possa fazer, visando melhores condições de vida e uma participação igualitária na sociedade. Impedindo o negro de andar livremente nas ruas, obrigando-o à apresentar Carteira de Trabalho assinada, matando menores, invadindo casas e entidades negras, o regime policial procura amedrontar e desestimular o Negro de lutar contra o racismo existente na sociedade brasileira." Perante esse quadro, o MNU propunha uma luta com as forças democráticas por uma campanha nacional contra a violência policial. Faziam parte dessa campanha debates, mobilizações de protesto, atos públicos, reuniões e abaixo-assinados. ${ }^{718}$

Especificamente diante da violência policial, foi organizada uma campanha nacional com abaixo-assinados e constantes referências a este problema social enfrentado, sobretudo, pelos afro-descendentes. ${ }^{719}$ Esta temática por certo, desagradava os aparelhos repressores, uma vez que essas discussões eram classificadas como uma forma de incitar a população contra a polícia. ${ }^{720}$

No ato público de 7 de julho de 1978, constava como um dos itens do protesto pela morte de Robson Silveira Luz, no $44^{\circ}$ Distrito Policial. Mas, para a polícia esta campanha dos movimentos negros era uma mobilização que tinha por fim "desmoralizar as autoridades constituídas, principalmente as Policiais." ${ }^{721}$

No periódico Árvore das Palavras, edição n. 12, a matéria "Cartas da prisão", retrata a relação com a polícia e com o sistema penitenciário: "e não ia deixar que ninguém viesse me desrespeitar (falei a respeito dos 'Direitos Humanos'), aí ficaram abismados como que aquele 'negrão' sabia disto. Aqui na cela forte fui jogado depois de quase uma hora eles me provocando tentando uma deicha (sic) pra me pegar de pau mais (sic) eu não marquei [...] Depois de vez em quando mandavam um funcionário me provocar, os quais eu repelia com 'respostas inteligentes' e eles iam embora sem entender [...] Ouço os gemidos

\footnotetext{
${ }^{718}$ Revista do MNU. OS 1157 p. 218 C. DEOPS/SP, DAESP. Também Panfleto do Io Encontro em Defesa da Raça Negra, p. 2. Dossiê 20-C-44- 17287. DEOPS/SP, DAESP. Coletado por ocasião do Io Encontro em Defesa da Raça Negra, realizado em 23/5/1981, na PUC-SP. Relatório diário n. 1505, entre 25 e 26/5/1981, da Divisão de Informações do DEOPS, fl. 2. Dossiê 21-Z-14-11366. DEOPS/SP, DAESP.

${ }^{719}$ Panfleto do Grupo Negro da PUC "I Encontro Estadual em Defesa da Raça Negra" In Dossiês 20-C-44 17287. DEOPS/SP, DAESP.

${ }^{720}$ Boletim de Ocorrência da Polícia Civil de São Paulo em 10/01/1982. OP 0989 Movimento Negro vol 2. DEOPS/SP, DAESP.

${ }^{721}$ Relatório Policial de 6 de julho de 1978. Dossiê 50-Z-0- 14623. DEOPS/SP, DAESP.
} 
de alguns companheiros do lado, eles tentaram uma fuga (pular o muro) quase os matam de pau.", 722

A tortura nas penitenciárias, por razões políticas ou não, era um problema enfrentado, em constância, pelos afro-descendentes. Para combater a violência e a arbitrariedade foi fundado, em 1978, o MNUCDR protestando contra a tortura e a morte de Robson Silveira Luz. Do mesmo modo, o programa de ação do MNU permanecia protestando contra a violência policial incluindo a exercida nas prisões e nos cárceres; contra os esquadrões da morte; contra os órgãos repressivos; contra a tortura; e contra a opressão diária da polícia. 723

O periódico Árvore das Palavras ressaltava a falta de segurança dos afro-descendentes: “É a polícia que nos causa esta preocupação agindo discriminatoriamente. Prender negrão é a ordem. Em nome da lei? Mas que ação da lei é esta que nos persegue. Isto é racismo declarado. " 724

A ação violenta em relação ao afro-descendente iniciava-se na abordagem na rua, por meio das "batidas policiais" e pelas prisões arbitrárias e completava-se nas torturas. Discriminações, batidas policiais e violências e eram sofridas de forma cotidiana pelos afro-descendentes, as quais se acrescentava a atuação dos Esquadrões da Morte nos centros urbanos. Os esquadrões da morte eram formações ilegais que reuniam policiais e expoliciais, visando acabar fisicamente com a criminalidade, não raro associada com o racismo, dando origem a assassinatos de afro-descendentes ${ }^{725}$, como apresenta a imagem a seguir, representando uma batida policial no Recife, numa operação da Secretaria de Segurança, do Estado de Pernambuco. ${ }^{726}$

\footnotetext{
${ }^{722}$ Dossiê 50-Z-130- 2270. DEOPS/SP, DAESP.

${ }^{723}$ Dossiê 20-C-44- 17289. DEOPS/SP, DAESP.

${ }^{724}$ Dossiê 50-Z-138- 806. DEOPS/SP, DAESP.

${ }^{725}$ Revista MNU, p. 7 . OS 1157 p. 218 C. DEOPS/SP, DAESP.

${ }^{726}$ Dossiê 50-Z-138- 806. DEOPS/SP, DAESP.
} 


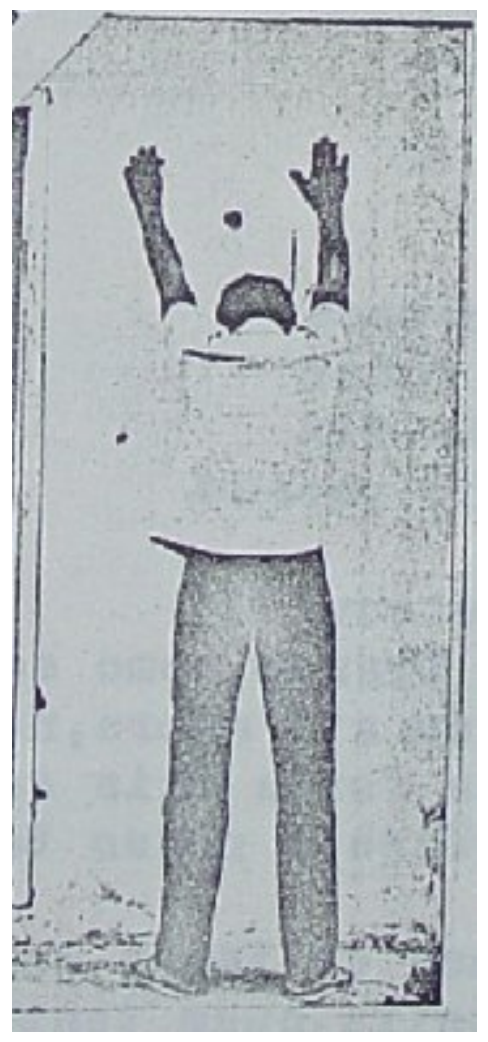

Fotografia de uma batida policial presente na revista do MNU.

A violência policial aparecia como a face mais visível do racismo, pois " $a$ discriminação racial é dissimulada oficialmente mas é muito objetiva nos órgãos de segurança corporificados nas 'tático móvel, rotas etc.", 727

Em 1981, o militante Marcos Antônio Pereira Cardoso, em uma Manifestação do Dia da Consciência Negra, em Minas Gerais, destacava que a abordagem policial em relação aos negros era diferenciada: “[...] quer onde estejam, eles são procurados para provarem sua ocupação, e caso não o consigam, são logo presos e espancados, sofrendo toda sorte de humilhações, [...]", 728

Em ato público contra o racismo pelo MNUCDR, em 1979, dois militantes acusaram a polícia de tratamento diferenciado em relação aos afro-descendente:

\footnotetext{
${ }^{727}$ Boletim III do Grupo Negro da PUC-SP, p. 11. Pasta Movimento Negro. CEDIC/PUC-SP.

728 "Dia Nacional da Consciência Negra - Movimento Negro Unificado (MNU)" Sumário Semanal de Informações n. 36, entre 20/11 a 26/11/1981, de 27/11/1981, CODIN/CONSEG da Coordenação de Informações da Secretaria de Estado de Segurança Pública de MG, fl 37. Dossiê 50-H-84- 5047. DEOPS/SP, DAESP.
} 
"fomos presos a toa, porque somos negros, fomos presos por meganhas, prosseguiram, a advogada Nair Silveira, também foi desacatada como pessoa, porque é negra, quizeram (sic) obrigá-la a subir pela entrada de serviço de um edifício. Nós negros somos vistos como serviçais, como favelados; isso precisa acabar." 729

Em Carta Aberta à População "Por Igualdade ... Racial", os movimentos negros apresentavam uma relação direta entre a violência policial e a carestia, salientando a contradição das estruturas governamentais, em um país que não oferecia empregos para todos, ao mesmo tempo os órgãos de segurança exigiam carteira de trabalho assinada para simples transeuntes. ${ }^{730}$ Dalmir Francisco Costa, presidente do MNUCDR em MG, discorrendo sobre a temática da violência policial, destacava que “[...] a Polícia está a serviço da 'ditadura' e das classes dominantes pois, além de marginalizar as camadas mais baixas da população, subjugam-nas através da repressão e da violência." 731 Portanto, a temática da violência policial, assim como da carestia, apresentava-se como elemento de um outro debate: a crítica ao regime militar.

Em discurso no ato contra o racismo, em função do 13 de maio de 1981, Milton Barbosa expôs a problemática da violência policial: "nós somos esmagados psicologicamente; esta é a tarefa da polícia: destruir as nossas mentes para melhor nos dominar [...]" 732 A ação da polícia e sua constante suspeição para com os afrodescendentes apresentava-se como elemento desagregador dos afro-descendentes: "Sobre $o$ Negro a polícia exerce uma função extraordinária, a de quebrá-lo psicoligico (sic) $e$ organizativamente. Para a polícia todo negro é um criminoso em potencial. Ela o persegue em qualquer lugar e a todo momento. Isto faz com como que o individuo negro sinta vergonha da sua raça e se isole do seu grupo." ${ }^{733}$ Uma vez mais, o MNU ressaltava a relação que a polícia mantinha com os afro-descendentes: "O Poder de Polícia tem o

\footnotetext{
${ }^{729}$ Relatório sobre ato público em protesto à Lei Afonso Arinos, de 17/10/1979. Dossiê 21-Z-14- 7946. DEOPS/SP, DAESP.

${ }^{730}$ Dossiê 21-Z-14- 7945. DEOPS/SP, DAESP.

731 Sumário Semanal n. 5, entre 24/01 a 4/02/1982, de 5/2/1982, do CODIN/CONSEG da Coordenação de Informação da Secretaria de Estado da Segurança Pública de MG, fl. 6. Dossiê 50-H-84- 5138. DEOPS/SP, DAESP.

732 “Os negros queriam continuar protestando" In Revista do MNU, n. 4, julho e agosto de 1981, fl. 3. Sumário Semanal n. 27, entre 18 a 24/9/1981, de 25/9/1981, do CODIN/CONSEG da Coordenação de Informação da Secretaria de Estado da Segurança Pública de MG, fl. 12. Dossiê 50-H-84-4848. DEOPS/SP, DAESP.

${ }^{733}$ Tese "O papel do aparato policial do Estado no processo de dominação do Negro e a Anistia" por ocasião do I Congresso Nacional da Anistia, de 5/11/1978, em São Paulo. Dossiê 50-Z-130- 5174. DEOPS/SP, DAESP.
} 
objetivo de garantir uma dominação, uma ordem de exclusão." 734 Nesse sentido, destacava que o preso "comum" era também um preso "político", a partir da ampliação do conceito de política, pois esses “criminosos" também contestavam de alguma maneira a ordem política estabelecida, a qual o excluía de condições sociais mínimas.

No jornal O Estado de S. Paulo, de 21 de fevereiro de 1982, arquivado pelo DEOPS, em pasta sobre a temática "violência policial", a matéria "Na justiça, a violência policial: 2533 casos" ressaltava um crescimento na justiça militar de processos de envolvimento de PMs em ocorrências policiais. Os processos sob sigilo, movidos contra policiais que se supunha que tinham envolvimento com casos de violência, resultavam em condenação ou absolvição. A reportagem ainda questionou os representantes da Justiça sobre as críticas dos policiais militares serem julgados por oficiais da própria corporação ${ }^{735}$, tendo Nasser Bussamra, juiz da Justiça Militar do Estado, afirmado serem estas críticas uma campanha para denegrir a imagem do órgão que representava uma vez que a PM paulista era exemplar. É provável que a censura aos resultados dos processos procurasse não fomentar essas "campanhas" citadas por Nasser. ${ }^{736}$

O general Arnaldo Braga, comandante da PM paulista, em entrevista ao Estado de S. Paulo sobre a violência policial, afirmava que o número de processos contra os soldados era praticamente "inexpressivo". Em defesa da atuação policial declarava: "Não desejamos a morte do marginal - assegura. Vamos combatê-lo e nos responsabilizamos por isso. Dizem que já matamos muitos e que isso não resolveu nada. Você já imaginou se todos eles ainda estivessem vivos?" 737 Além de não apresentar o menor respeito ao direito à vida, o general apresentava a priori todos os abordados pela polícia como marginais, não esclarecendo quais os critérios para identificá-los desta forma.

Em Carta Aberta à População contra a Violência Policial, assinada pelo Departamento Jurídico do Centro Acadêmico XI de Agosto, Comissão Justiça e Paz São Paulo, MNU, Grupo Negro da PUC-SP e Negros da UMES foram denuncidos os abusos cometidos nas

\footnotetext{
${ }^{734}$ Relatório de avaliação de 20/9/1981 do MNU de MG. In Sumário Semanal de Informações n. 15 da CODIN/COSEG, do período entre 9 a 15/4/1982, de 16/4/1982, fl. 19. Dossiê 50-H-845498. DEOPS/SP, DAESP.

${ }^{735}$ Críticas feitas, por exemplo, do promotor João Benedito de Azevedo Marques na matéria "Promotor fala de aberração" In Folha de S. Paulo, 21/02/1982, p. 18. OP 1184 Violência Policial. DEOPS/SP, DAESP.

736 "Na justiça, a violência policial: 2533 casos" In Folha de S. Paulo, 21/02/1982, p. 18. OP 1184 Violência Policial. DEOPS/SP, DAESP.

737 "Nossa PM é uma das melhores do mundo" In Folha de S. Paulo, 21/02/1982, p. 18. OP 1184 Violência Policial. DEOPS/SP, DAESP.
} 
batidas policiais, contrariando a função policial de "assegurar a convivência harmoniosa entre os cidadãos." ${ }^{738}$ Ressaltava que o cidadão, diferente do que asseguram as leis, é considerado culpado pela polícia, até que se prove o contrário. A Carta, por meio de uma argumentação jurídica fundada na Constituição Brasileira, buscava comprovar que diversos direitos estavam sendo desrespeitados pela polícia, em especial pela Rota, exatamente a corporação mais elogiada pelas altas autoridades da polícia na referida reportagem do $O$ Estado de S. Paulo. A Carta orientava que quem tivesse seus direitos violados procurasse o MNU, o Departamento Jurídico Centro Acadêmico XI de agosto ou o Centro Santo Dias de Defesa dos Direitos Humanos. ${ }^{739}$

Em “Arbitrariedade e morte, um problema nacional" publicado no jornal Folha de $S$. Paulo, de 26 de maio de 1981, demonstra-se que havia se disseminado no país todo, uma cultura de arbitrariedade em meio a ação policial. "Em todo o país os fatos e os dados disponíveis mostram que a polícia virtualmente se considera dentro de uma 'guerra diária', esquecendo-se de que sua função principal é garantir a segurança do cidadão e da coletividade." 740 A reportagem fornecia exemplos de mortes decorrentes da violência policial, além de números de mortos, brancos e negros (maioria), segundo dados do Grupo Negro da PUC.

Paulo Sérgio Pinheiro analisando a tortura no país, em editorial da Folha de S. Paulo, de 5/11/1980, afirmou:

"A polícia brasileira vive dominada pelo fetichismo da confissão: é preciso obter a todo custo que os suspeitos confessem. Outra motivação, além da confissão, é a mania de reunir informações que sempre surgem nas sessões de pancadaria, choques, paus-de-arara. É a mesma compulsão que movia os órgãos de segurança: é preciso saber cada vez mais e mais rapidamente. E mais barato do que empregar métodos de raciocínios e técnicos para deslindar crimes. Não importa que se mandem às favas as garantias do cidadão e as leis vigentes no Pais." " 741

As notícias e campanhas contra a violência policial incomodaram as autoridades, mas nem por isso foram objeto de investigação, como demonstram a pasta arquivada com tal

\footnotetext{
${ }^{738}$ I Carta aberta à população contra a violência policial. OP 1184 Violência Policial. DEOPS/SP, DAESP.

739 Boletim de Ocorrência n. 76/82de 10/01/1982 e encaminhamento da Delegacia de Barueri ao Delegado Seccional de Osasco, de 10/01/1982. Oficio n. 55/82 ao Delegado Regional provinda da Delegacia Seccional de Osasco, 14/01/1982. Despacho 0055/82 da Delegacia Geral de Polícia ao DEOPS, 27/01/1982. OP 1184 Violência Policial. DEOPS/SP, DAESP.

740 “Arbitrariedade e morte, um problema nacional” In Folha de S. Paulo, 26/05/1981, p. 19. OP 1184 Violência Policial. DEOPS/SP, DAESP.

${ }^{741}$ PINHEIRO, S. "A tortura continua" In Folha de S. Paulo, 5/11/1980, p. 3. OP 1184 Violência Policial. DEOPS/SP, DAESP.
} 
temática no DEOPS/SP, e denunciam as matérias da Folha de S. Paulo "Secretários não querem notícias contra a polícia" e do Jornal da Tarde, "Um controle sobre as notícias de violência policial?". ${ }^{742}$ Álias, a atuação da imprensa levou o Ministério da Justiça formas de controle dos jornais, TVs e rádios, no que se refere a notícias sobre a criminalidade e violência de policiais, apoiados pelos secretários de Segurança Pública dos estados. ${ }^{743}$

A discussão acerca da violência policial tomava conta da sociedade civil como um todo, como registra editorial de Hélio Bicudo, no jornal O São Paulo, de 20/09/1978, no qual: “As ocorrências noticiadas pelos jornais das últimas semanas, revelam que a violência policial não parece ceder a passo e reflete, sem dúvida, o caráter arbitrário do sistema político...". ${ }^{744}$ Assim, os setores comprometidos com os direitos humanos combatiam a arbitrariedade e a violência policial.

No entanto, as denúncias não encontravam respaldo nas estruturas de poder. O Secretário de Segurança Pública de São Paulo, Otávio Gonzaga Júnior, diante das denúncias da imprensa sobre a violência policial afirmou que: "A violência é inerente a função policial.", 745

\section{3) Negritude e Pan-africanismo}

"Minha negritude não é uma pedra, surdez que é lançada contra o clamor do dia, não é uma catarata de água morta sobre o olho morto da terra minha negritude não é nem torre nem catedral ela mergulha na carne rubra da terra ela mergulha na ardente carne do céu ela perfura o opaco desanimo com sua precisa paciência" 746

O termo negritude trata da maneira do negro se exprimir, do mundo ou civilização negra. ${ }^{747}$ "A negritude, como movimento e como teoria, teve precursores nas duas bandas

\footnotetext{
742 "Um controle sobre as notícias de violência policial?" In Jornal da Tarde, 26/10/1979, p. 2. OP 1184 Violência Policial. DEOPS/SP, DAESP.

743 "Secretários não querem notícias contra a polícia" In Folha de S. Paulo, 26/10/1979. OP 1184 Violência Policial. DEOPS/SP, DAESP. "Um controle sobre as notícias de violência policial?" In Jornal da Tarde, 26/10/1979, p. 2. OP 1184 Violência Policial. DEOPS/SP, DAESP.

${ }^{744}$ OP 1184 Violência Policial. DEOPS/SP, DAESP.

745 “A polícia não pode dar beijinhos” In Folha de S. Paulo, 10/09/1979, p. 10. OP 1184 Violência Policial. DEOPS/SP, DAESP.

${ }^{746}$ Poesia de Senghor In ALVES, H. L. Dialogo da Negritude. Lorena: Centro de Estudo Históricos "Gustavo Barroso", s/ d., p. 9. Pasta Movimento Negro. CEDIC/PUC-SP.
} 
do Atlântico. Na sua gênese, entronca nas diásporas negras da América e de Paris, passando pelo renascimento haitiano." 748

Dessa forma, a circulação das idéias sobre a negritude tanto na América, na Europa e na África, ressoou no Brasil, auxiliando a construção do pensamento afro-brasileiro sobre o "ser negro" no Brasil e no mundo. Negritude foi um dos termos recorrentes na militância afro-brasileira, que buscou (re)compor valores da "civilização do mundo negro" e valorizar o afro-descendente, desenvolvendo-lhe o orgulho de ser negro. ${ }^{749}$ A negritude relaciona-se, ainda, com a "tomada de consciência de uma situação de dominação e de discriminação, $e$ a conseqüente reação pela busca de uma identidade negra.", 750

As idéias próprias da negritude, de reivindicação de direitos sociais e emancipação, calaram fundo nas aspirações afro-brasileiras e fizeram parte de seu repertório de análise social. Assim, a negritude tornou-se um movimento político e ideológico que lutou contra o racismo brasileiro. Houve, portanto, "usos" da negritude na escolha de estratégias de luta, por parte da militância negra brasileira, visando resgatar elementos que afirmassem a ascendência africana e negra e, acima de tudo, (re)conquistar a auto-estima e (re)afirmar sua humanidade. ${ }^{751}$ Assim:

"a negritude consiste na adoção e ressignificação do ser negro - um trabalho de revalorização dos múltiplos aspectos da cultura africana, recalcada como primitiva e fetichista, e a construção de um discurso identitário que transcende os estreitos limites da cor da pele e define-se pelo desejo de compor uma tradição de resistência e auto-estima."

O desejo de construir uma identidade alinhada com a ascendência africana e não somente pelas características físicas apresentava-se na poesia dos militantes:

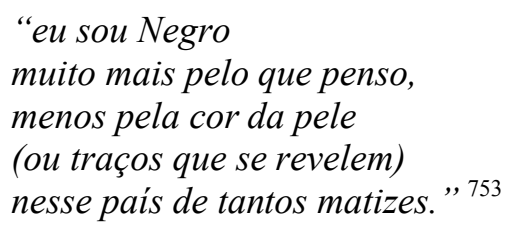

\footnotetext{
${ }^{747}$ SANTOS, E. A negritude e a luta pelas independências na África Portuguesa. Lisboa: Minerva, 1975, p. 7.

${ }^{749}$ MUNANGA, K. "Negritude afro-brasileira: perspectivas e dificuldades” In Revista de Antropologia, vol. 33. São Paulo: Departamento de Antropologia da FFLCH/USP, 1990, pp. 109-117, p. 109 e 111.

${ }^{750}$ BERND, Z. O que é negritude. São Paulo: Brasiliense, 1988, p. 20.

${ }^{751}$ SANSONE, L. Negritude sem etnicidade. Salvador: Edufba; Pallas, 2003, p. 285.

752 SOUZA, F. Afro-descendência em Cadernos Negros e Jornal do MNU. Belo Horizonte: Autêntica, 2005, p. 137.

${ }^{753}$ Cadernos Negros, n. 19, p. 110. Apud SOUZA, F. Afro-descendência em Cadernos Negros e Jornal do $M N U$. Belo Horizonte: Autêntica, 2005, p. 137.
} 
Essa apologia de um "pensamento negro" levou a aproximações com o movimento pan-africano e com o movimento de negritude, multiplicando as formas de pensar dos militantes, como descreve um trecho de poema do afro-brasileiro Oubi Inaê Kibuko:

"trajando realidade sigo Zumbi Agostinho Neto, Luther King, Mandela... imortais guerreiros do meu povo" 754

Ressaltando laços entre os negros da diáspora africana, apresenta algumas das alusões heróicas de lutas anti-racistas que compõe um repertório de resistência e de valorização do negro. Esta perspectiva de valorização do afro-descendente era absolutamente compatível com o programa de ação do MNU, o qual propunha uma luta pela transformação dos conteúdos presentes no sistema educacional brasileiro, buscando valorizar o negro e sua história, além de incluir história da África nos currículos escolares. "A identidade cultural do negro e do índio não chega a se organizar completamente, pois desde criança sofrem a imposição de uma cultura branca que distorce todos os dados e manifestações de suas culturas." 755 Desta forma, inspirado pela negritude e pelo pan-africanismo o MNU buscava (re)contruir uma cultura especificamente negra.

Aliás, o pan-africanismo era ressaltado como exemplo de luta para os afro-brasileiros. Segundo Abdias do Nascimento:

"O negro brasileiro precisa informar-se sobre a luta pan-africana, pois, quando tive acesso a representatividade e ao poder, este país será uma grande nação e significará a descolonização cultural total do homem brasileiro. O caminho para isso é retomar a inspiração africana e ver a nossa experiência histórica e cultural, dando a elas a dimensão das exigências contemporâneas." 756

Aspectos da cultura afro-brasileira também eram sinais da construção de uma identidade positiva, ligada à valorização do "ser negro". Isto ocorreu, por exemplo, na valorização da capoeira pelo grupo de teatro e academia de capoeira Capitães D’Areia, que tinha como lema em sua pesquisa artística: "aprender capoeira, não é competir mas, lutando, aprender a história de um povo que se expressou em movimentos físicos, pela necessidade de liberdade, a liberdade de ser gente." 757 Dessa forma, resgatava-se a história afro-brasileira: "enfim todos juntos, unidos e fortes, para contar a nossa própria história, através da Capoeira, que foi a história de gente igual a nós, lutando por

\footnotetext{
${ }^{754}$ Cadernos Negros, n 13, p. 71 Apud SOUZA, F. Op. Cit., p. 187.

${ }^{755}$ Dossiê 20-C-44- 17289. DEOPS/SP, DAESP.

${ }^{756}$ Matéria "Nossos negros solitários", entrevista de Abdias do Nascimento a Revista Veja, n. 512, de 28/06/1978. Dossiê 50-Z-0- 145627. DEOPS/SP, DAESP.

${ }^{757}$ Dossiê 20-C-44- 26003. DEOPS/SP, DAESP.
} 
liberdade, e que a partir dela nos expressamos, e nos manifestamos, numa maneira de ser e de existir [...]" ${ }^{758}$ A capoeira apresentava-se como símbolo de origem, mas também como representação dos anseios por liberdade pelos movimentos negros.

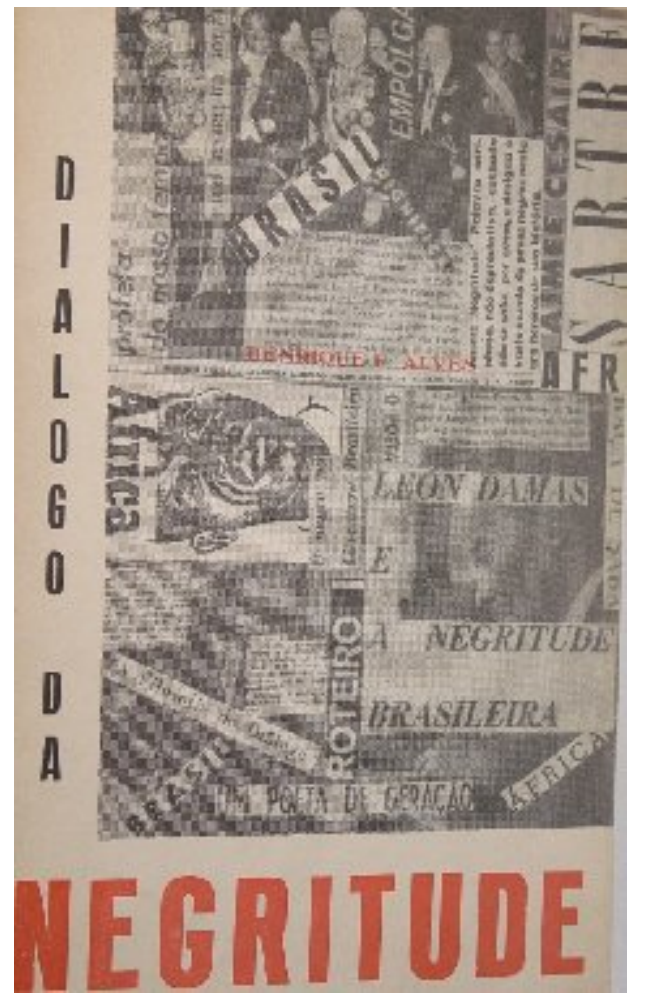

\section{Capa do livro Dialogo da Negritude.}

A obra de Henrique Alves é um exemplo do diálogo com a negritude, apresentando as idéias de Senghor, Aimé Cesaire e Damas. O referido autor teria inclusive dialogado com dois desses autores, por meio da Associação Cultural do Negro de São Paulo, e na própria ocasião da visita de Senghor ao Brasil. ${ }^{760}$ A circulação de idéias apresentou-se de forma importante:

\footnotetext{
${ }^{758}$ Dossiê 20-C-44- 26003. DEOPS/SP, DAESP.

${ }^{759}$ Livro Dialogo da Negritude de Henrique L. Alves editado pelo Centro de Estudo Históricos "Gustavo Barroso da cidade de Lorena. Esse livro foi resultado de uma conferência dentro do curso de extensão universitária "Formação étnica do Brasil" ao encerramento da Semana de Estudos Africanos na Faculdade Saeleciana de Filosofia de Lorena. Pasta Movimento Negro. CEDIC/PUC-SP.

${ }^{760}$ ALVES, H. L. Dialogo da Negritude. Lorena: Centro de Estudo Históricos “Gustavo Barroso”, 1965, p. 9. Pasta Movimento Negro. CEDIC/PUC-SP, p. 9.
} 
"É marcante a influência que os escritores negros no Brasil receberam das literaturas africanas escritas em língua portuguesa que chegavam ao Brasil por meio de jornais, revistas e livros, ou ainda a influência das traduções de Fanon e de textos de Garvey e Du Bois que circulavam no movimento negro no Brasil desde a década de trinta."

Além do aspecto político-social, poetas como Solano Trindade, Oswaldo de Camargo, Carlos de Assumpção, Eduardo de Oliveira e Madalena de Souza inspiraram-se na negritude e produziram uma literatura ligada as idéias deste movimento. ${ }^{762}$ Por isso, a poesia apresentava-se como expressão de uma arte engajada na luta anti-racista: "Minha arte não é racista, nem discriminatória. É apenas o manifesto artístico das aspirações de uma raça que viveu e ainda vive na subexistência" 763

A produção de um discurso, seja poético ou político, sobre a valorização do "ser negro" traz ao debate essas questões e contempla o protagonismo afro-descendente, por meio de um discurso que ressalta a diferença. ${ }^{764}$ Em decorrência os impressos, de forma geral, divulgavam as idéias de "ser negro" que os movimentos negros construíam naquele período. Desse modo:

"As revistas e os jornais tiveram um papel importante na afirmação coletiva do espírito de conscientização para a libertação e a liberdade da Negritude literária, enquanto componente cultural percutida profundamente pelo Pan-africanismo, parte integrante do movimento doutrinário e cívico de libertação da África e do mundo." 765

Nesse sentido, militantes dos movimentos negros apropriaram-se da denominação negritude tanto em seus discursos quanto em suas produções literárias que não seguiam necessariamente as formas apresentadas nos movimentos externos. A negritude brasileira visava a (re)leitura das heranças culturais de origem africana e as qualificações sóciopolíticas positivas de se assumir enquanto negro.

O periódico Árvore das Palavras ${ }^{766}$ apresentava a negritude como um sinônimo de identificação da ascendência africana e o orgulho de ser negro e era assim que sugeria que

\footnotetext{
${ }^{761}$ SOUZA, F. Afro-descendência em Cadernos Negros e Jornal do MNU. Belo Horizonte: Autêntica, 2005, p. 162.

${ }_{762}$ ALVES, H. L. Dialogo da Negritude. Lorena: Centro de Estudo Históricos “Gustavo Barroso", 1965, p. 9. Pasta Movimento Negro. CEDIC/PUC-SP, p. 16.

${ }^{763}$ SANTOS, Aparecido Tadeu dos. Como se fosse pecado. São Paulo: Edição do Autor, 1980, p. 22. Dossiê 20-C-44- 17290. DEOPS/SP, DAESP. Coletado por ocasião do Io Encontro em Defesa da Raça Negra, realizado em 23/5/1981, na PUC-SP. Relatório diário n. 1505, entre 25 e 26/5/1981, da Divisão de Informações do DEOPS, fl. 2. Dossiê 21-Z-14-11366. DEOPS/SP, DAESP.

${ }_{764}$ LARANJEIRA, P. A negritude Africana de lingua portuguesa. Porto: Afrontamento, 1995, p. 17.

${ }^{765}$ LARANJEIRA, P. Op. Cit., p. 71.

${ }^{766}$ O periódico Árvores das Palavras: "corriam de mão em mão sem que se soubesse quem eram os responsáveis, um jornal que veiculava notícias de revoluções africanas nas então colônias portuguesas e trazia uma mensagem de consciência política do negro brasileiro." In Cadernos Negros Apud SOUZA, F. Afro-descendência em Cadernos Negros e Jornal do MNU. Belo Horizonte: Autêntica, 2005, p. 82.
} 
fizesse parte da educação dos filhos afro-descendentes. ${ }^{767}$ O Grupo Negro da PUC-SP observava que a consciência racial se dava por meio da consciência dos valores de sua negritude, além dos seus direitos sociais. ${ }^{768}$ Desta forma, a negritude se apresentava como instrumento primordial de mobilização para os movimentos negros.

Nesta perspectiva, valorizavam-se não só as entidades político-sociais dos movimentos negros, mas também as mobilizações culturais que pudessem auxiliar na identificação da negritude em uma renovação cultural ligada à estética e cultura africanas, como bailes, blocos, escolas de samba, capoeira e candomblé, entre outras manifestações. Mas para tal, avaliavam como necessária a contestação da situação sócio-política do negro no Brasil. ${ }^{769}$

Na construção da cultura afro-brasileira valorizava-se a contribuição cultural da África, dos negros dos EUA e das Antilhas. ${ }^{770}$ Mas buscava-se a particularidade cultural do negro no Brasil e a sua valorização, uma vez que "Na sociedade brasileira o negro enquanto um elemento cultural distinto tem sido negado sob todos os aspectos sociais." 771 Portanto, rejeitava-se o lugar social destinado ao afro-descendente, propondo uma luta anti-racista que rompesse com essa estrutura social e com qualquer estratégia "assimilacionista" ou "integracionista".

A frase de James Baldwin: "A palavra 'independência' na África e a palavra 'integração' na América são ambas quase igualmente inexpressivas.”, expressa a estratégia preponderante dos anos de 1960 e 1970 nos movimentos negros (tanto afro-americanos e afro-brasileiros), isto é, a romper com a estratégia de integração do negro nas sociedades norte-americana e na brasileira.

A tomada de consciência do racismo e o voltar-se "às raízes" da cultura e da identidade afro-brasileira era um ponto estratégico para muitos militantes.

"A explosão dessa negritude ativada pela população negra brasileira se não é hoje um dado de revolução cultural, é porque os meios de comunicação omitem sua difusão, e só o utiliza de forma isolada e com fins lucrativos." 772

Os movimentos negros no Brasil inspiravam-se também no pensamento de Carmichael: "Uma de nossas maiores batalhas é, portanto, fazer o expurgo dos corruptos valores

\footnotetext{
${ }^{767}$ Dossiê 50-Z-138- 806. DEOPS/SP, DAESP.

${ }^{768}$ Boletim III do Grupo Negro da PUC-SP, p. 19. Pasta Movimento Negro. CEDIC/PUC-SP.

${ }^{769}$ Boletim III do Grupo Negro da PUC-SP, p. 25. Pasta Movimento Negro. CEDIC/PUC-SP.

${ }^{770}$ Boletim III do Grupo Negro da PUC-SP, p. 24. Pasta Movimento Negro. CEDIC/PUC-SP.

${ }^{771}$ Boletim III do Grupo Negro da PUC-SP, p. 33. Pasta Movimento Negro. CEDIC/PUC-SP.

772 Boletim III do Grupo Negro da PUC-SP, p. 33. Pasta Movimento Negro. CEDIC/PUC-SP.
} 
ocidentais e nossa resistência não pode prevalecer sem que nossa integridade cultural seja restabelecida e mantida. É através das histórias de nossos povos que chegaremos à conclusão de que a nossa luta é a mesma." ${ }^{773}$ Nesse sentido, a África é (re)inventada pelos movimentos negros, visando (re)construir uma cultura própria afro-brasileira, por meio da negritude e do pan-africanismo.

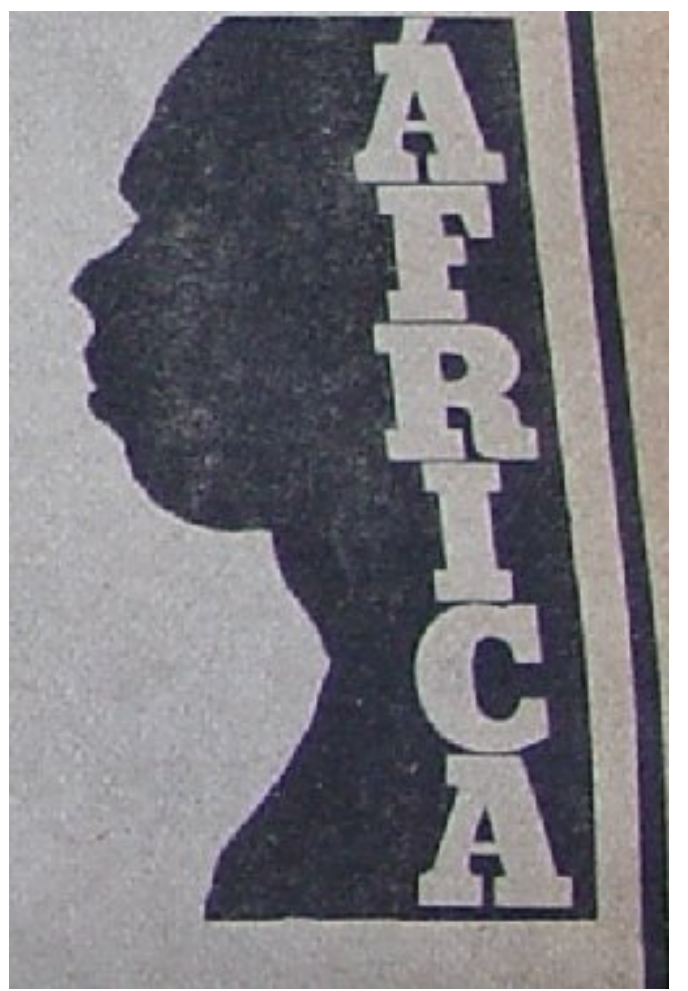

Detalhe imagem representando a África no periódico Versus, de 1978.

Além disso, a negritude construída pelos movimentos negros, além de definir o que era "ser negro", traçando elementos de identidade afro-descendente, orientava os comportamentos da sua militância, contribuindo para a coesão interna do grupo.

A construção da identidade afro-brasileira empreendida nesse período passou pela "invenção" de marcos e tradições dessa ancestralidade africana no Brasil, ou seja, a reminiscência de uma tradição que se acreditava provinda da África reforçava a identidade

\footnotetext{
${ }^{773}$ Programa do Oficina, Poder Negro. Pasta Movimento Negro. CEDIC/PUC-SP.

${ }^{774}$ Matéria "A legião da morte" de Marcos Faerman na Coluna Afro-Latino-América do periódico Versus, . 22, junho e julho de 1978, p. 40. DEOPS/SP, DAESP.
} 
afro-brasileira. A África emergia como marco simbólico de origem ${ }^{775}$, com representações positivas do continente e dos afro-descendentes. É possível considerar que desde a década de 1960 essa identidade afro-brasileira foi "inventada" com a construção de heróis, datas significativas, celebrações públicas, costumes e tradições que remetessem à condição de afro-descendente. Por meio de uma revisão do passado histórico, fossem construídos valores como "consciência étnica" e "solidariedade étnica". Há de se destacar que os próprios termos de identidade se formam a partir da "invenção das tradições", construindo termos como "afro-descendente" ou "afro-brasileiro", demarcando uma conexão entre a África e a sua diáspora. ${ }^{776}$

Também nesse sentido, a negritude foi um importante instrumento para o processo de elaboração de representações e identidades fundadas na ancestralidade africana. Na construção da identidade afro-brasileira daquele período os militantes buscavam inventar tradições e estabelecer vínculos, entre os africanos e a chamada diáspora negra. Assim, os militantes buscavam "nos contatos com as culturas de origem africana motivações para a criação de suas bases culturais e de seus perfis identitários de auto-afirmação." 777 A negritude visava, então, estimular os negros e mestiços brasileiros a construírem uma identidade a partir de uma ruptura com os estereótipos e estigmas produzidos pelo racismo.

Importante ressaltar que 'Esse olhar para 'as raizes culturais brasileiras' de matrizes africanas se fez presente, sobretudo, nos ambientes de formação e sociabilidade de uma pequena camada de não-brancos, em grande parte universitários, que emergiu no cenário político-cultural contemporâneo ao que muitos chamaram de 'renascimento do movimento negro." 778 Portanto, o contexto de emergência dos movimentos negros na década de 1970 esteve envolto no debate acerca dos principais fatos históricos na África e na diáspora africana.

\footnotetext{
${ }^{775}$ SOUZA, F. Afro-descendência em Cadernos Negros e Jornal do MNU. Belo Horizonte: Autêntica, 2005, p. 106.

776 "Por 'tradição inventada' entende-se um conjunto de práticas, normalmente reguladas por regras tácitas ou abertamente aceitas; tais práticas, de natureza ritual ou simbólica, visam incultar certos valores e normas de comportamento através da repetição, o que implica, automaticamente; uma continuidade em relação ao passado. Aliás, sempre que possivel, tenta-se estabelecer continuidade com um passado histórico apropriado." In HOBSBAWM, E. e RANGER, T. (org) A invenção das tradições. Rio de Janeiro: Paz e Terra, 1997, p. 9.

${ }^{777}$ SOUZA, F. Op. Cit., p. 24.

${ }^{778}$ CUNHA, O. "Depois da festa: movimentos negros e 'políticas de identidade' no Brasil" In ALVAREZ, S. e DAGNINO, E. e ESCOBAR, A. Cultura e politica nos movimentos sociais latino-americanos: novas leituras. Belo Horizonte: Ed UFMG, 2000, p. 335.
} 


\section{4) África: o colonialismo e o racismo}

“Mais um tijolo na construção do nosso futuro: sem miséria, sem opressão, sem racismo.”

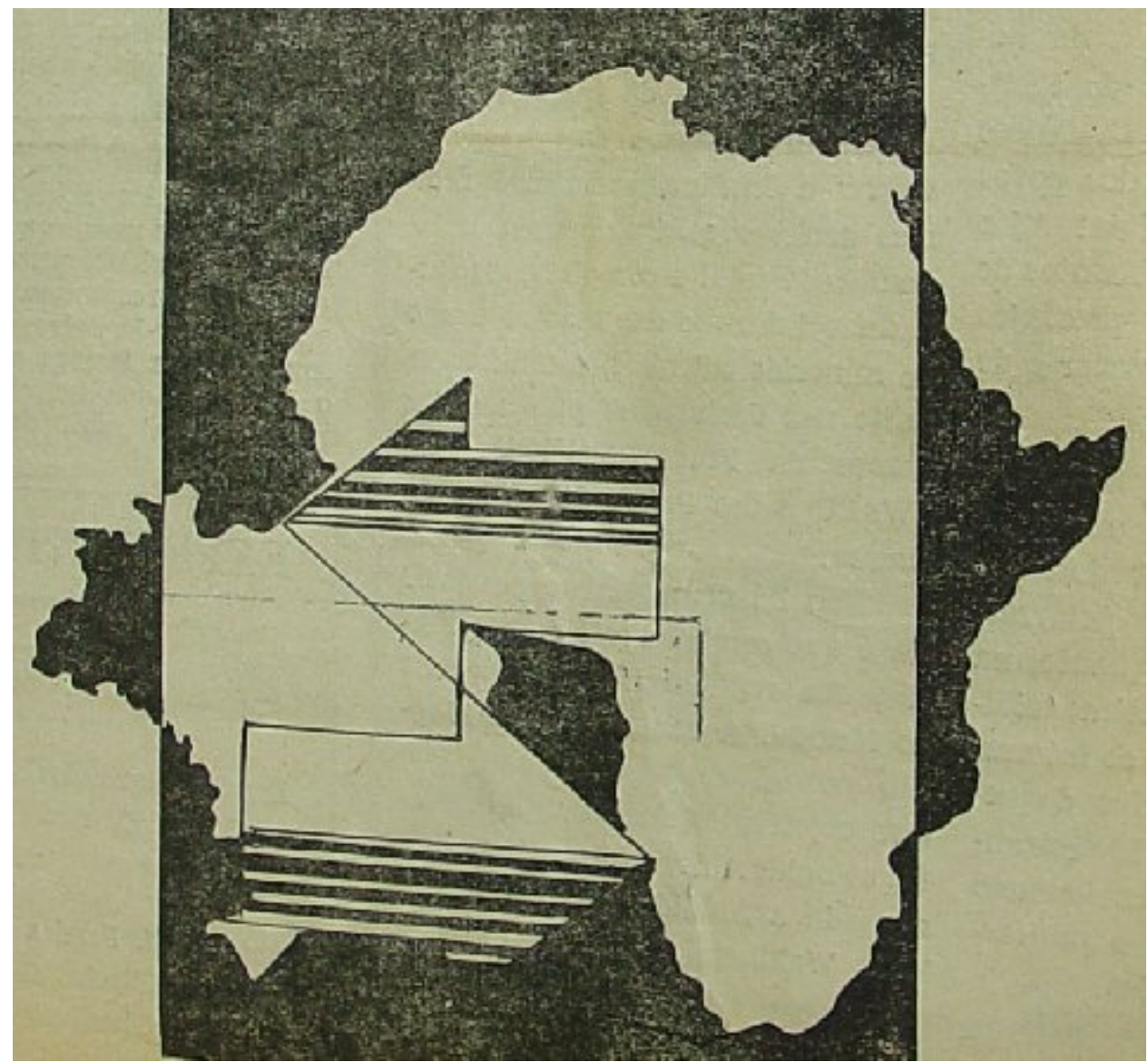

Imagem representando os contatos entre Brasil e África na capa do periódico Sinba, em 1977.

Os movimentos negros brasileiros na construção da sua luta anti-racista procuraram resgatar a raiz africana na formulação de sua identidade e voltaram-se para a África, locus primordial da negritude, e para a situação do afro-descendente no Mundo. "Implícita à

\footnotetext{
${ }^{779}$ Panfleto do Io Encontro Estadual em Defesa da Raça Negra. Dossiê 20-C-44- 17287. DEOPS/SP, DAESP. ${ }^{780}$ Imagem representando os contatos entre Brasil e África, na capa do periódico Sinba, Ano 1, n. 1, Rio de Janeiro, julho de 1977. Dossiê 50-Z-130- 5588. DEOPS/SP, DAESP.
} 
afirmação da estética de origem africana estava a questão da matriz identitária enquanto suporte de realização humana no plano individual e coletivo. A identidade elaborada de forma positiva permitiria a criação de condições necessárias ao exercício da agência humana e histórica por parte do povo afro-descendente." ${ }^{781}$ Este aspecto esteve presente na poesia "Nascença" de Carlos Gabriel e foi publicada no periódico paulista Jornegro:

"Meus pés pisam o chão da América.

Minhas mãos fazem o pão da América.

Meus ouvidos ouvem o som da América.

Minha boca fala a língua da América.

Meus olhos enxergam as cores da América.

Minhas narinas respiram o ar da América.

Mas, pelas minhas artérias transita incessante o sangue do coração da África." 782

A África representou o "norte" desses movimentos, ou seja, a raiz a ser buscada. As interpretações dos traços tidos como africanos, foram uma (re)criação do universo cultural afro-descendente, por meio dos movimentos que buscaram intensificar o intercâmbio transatlântico. Voltavam o seu olhar para o que acontecia no continente africano $\mathrm{e}$ reconhecendo aspectos culturais dessa origem que se aproximassem do Brasil, construíam uma imagem e os ativistas incorporavam atributos africanos. ${ }^{783}$

Voltar o olhar para África não significou necessariamente um estabelecimento de laços com a "Mãe-África" por meio da adoção de comportamentos ou valores africanos, embora houvesse militantes que buscassem essa maneira de aproximação. Mas esses laços muitas vezes se realizaram com o debate da situação política e social desse continente, visando compreender suas possíveis heranças no Brasil que constituiriam a identidade afrobrasileira. ${ }^{784}$

O debate sobre a África nos movimentos negros brasileiros, apresentava-se por meio de panfletos, congressos ${ }^{785}$, reuniões, etc. que foram realizados por movimentos como o MNU, o Grupo Negro da PUC, a FRENAPO, entre outras associações de afro-

\footnotetext{
${ }^{781}$ NASCIMENTO, E. O Sortilégio da Cor. Identidade Afro-descendente no Brasil. Tese Doutorado. São Paulo: USP/IP, 2000, p.271

${ }^{782}$ Jornegro n. 12 Ano IV, 1981, p. 6. Dossiê 20-C-44-17284. DEOPS/SP, DAESP. Coletado por ocasião do Io Encontro em Defesa da Raça Negra, realizado em 23/5/1981, na PUC-SP. Relatório diário n. 1505, entre 25 e 26/5/1981, da Divisão de Informações do DEOPS, fl. 2. Dossiê 21-Z-14-11366. DEOPS/SP, DAESP.

${ }^{783}$ SANSONE, L. Negritude sem etnicidade. Salvador: Edufba; Pallas, 2003, p. 118.

${ }^{784}$ SOUZA, F. Afro-descendência em Cadernos Negros e Jornal do MNU. Belo Horizonte: Autêntica, 2005, p. 157.

${ }_{785}$ Por exemplo, o congresso "África, Ontem e Hoje" realizado em 11/6/1977 no na Faculdade de Direito da USP promovido pelo Centro Acadêmico XI Agosto e o Centro de Estudos Africanos da USP. Dossiê 21-Z14-2649. DEOPS/SP, DAESP.
} 
descendentes. No seu conjunto, traziam na pauta de mobilização o apoio aos movimentos de independência africanos. Por exemplo, o Jornal Árvore das Palavras ${ }^{786}$ publicou, no ano de 1975, a matéria "Guerra de Libertação" que discutia a situação em Guiné-Bissau, Moçambique e Angola. A matéria anunciava que a África estava se libertando. ${ }^{787}$ Além disso, os movimentos solidarizavam-se com aqueles que sofriam com sistemas segregacionistas, como a África do Sul sob o regime do apartheid. Exemplo desse apoio apresenta-se no panfleto "Fora ao Regime Racista da África do Sul. ${ }^{788}$

O livreto "Angola", recolhido durante a SPBC, visava divulgar as poesias angolanas Agostinho Neto, Costa Andrade, David Mestre e seus organizadores explicavam que a escolha por Angola se devia ao fato que "seus negros fizeram o Brasil. Deixaram suas marcas: o samba, a capoeira, Iemanjá, tanto mais. Angola, terra de língua portuguesa, como a nossa. Mas não sabemos de Angola: de seus caminhos, suas angústias, horizontes. Não conhecemos sua arte, sua cultura, seu meio de vida. Divulguemos Angola!" 789 Desse modo, o debate sobre a África exprimia, em primeiro lugar, uma busca dos afrodescendentes por si mesmos, resgatando sua ancestralidade africana. A poesia angolana esteve intimamente ligada à contestação do colonialismo português e a luta de libertação no âmbito do marxismo-leninismo, o que fez o DEOPS apreendê-lo.

Os debates acadêmicos também voltavam seu olhar para a África. Por exemplo, o debate "África, Ontem e Hoje" realizado em 1977, na Faculdade de Direito da USP, promovido pelo Centro Acadêmico XI de Agosto e o Centro de Estudos Africanos da USP, discutiram o colonialismo, os movimentos de independência, os regimes políticos e o movimento da negritude, entre outros temas, como a presença de interlocutores africanos. 790 Do mesmo modo, o Curso "África e sua herança no Brasil”" contendo temas como a “independência dos países africanos" e a "África Moderna”, apresentado pelo Centro Afro-

\footnotetext{
${ }^{786}$ O periódico Árvores das Palavras: "corriam de mão em mão sem que se soubesse quem eram os responsáveis, um jornal que veiculava notícias de revoluções africanas nas então colônias portuguesas e trazia uma mensagem de consciência política do negro brasileiro." In Cadernos Negros Apud SOUZA, F. Afro-descendência em Cadernos Negros e Jornal do MNU. Belo Horizonte: Autêntica, 2005, p. 82.

787 Jornal Árvore das Palavras n. 12, sem data. Dossiê 50-Z-130-2270. DEOPS/SP, DAESP.

${ }^{788}$ Dossiê 40-Z-10-1881. DEOPS/SP, DAESP.

${ }^{789}$ Livreto Angola. Dossiê 50-L-1-11. DEOPS/SP, DAESP.

${ }^{790}$ Folheto de divulgação do Debate "África, Ontem e Hoje" com a programação do evento. Dossiê 21-Z-142649. DEOPS/SP, DAESP.
} 
brasileiro de Cultura Religiosa e deveria ser realizado em 1981, mas teve seu programa apreendido. ${ }^{791}$

Em boletim da ABRASSO, o artigo "O Poder Popular" tratava do processo de independência em Moçambique apoiando a via da luta armada pela FRELIMO. ${ }^{792}$ Além disso, divulgava os resultados de um Ato na Câmara Municipal de São Paulo, de 3 de setembro, realizado por um conjunto de movimentos, em especial a FRENAPO, tratou da luta anti-colonial na África, pela passagem do $11^{\circ}$ aniversário da morte de Agostinho Neto, do MPLA e $1^{\circ}$ Presidente da República Popular de Angola. ${ }^{793}$ O jornal Árvore das Palavras $^{794}$ divulgava o poema "Onde te encontrar?" de Samora Machel, primeiro presidente de Moçambique. Era dedicado à sua mulher, falecida, e ressaltava a luta e a revolução em Moçambique. O referido jornal divulgava também a "guerra de libertação" na Guiné Bissau sob liderança de Amílcar Cabral e em Moçambique, com Samora Machel. ${ }^{795}$

Esse olhar para a África não se deu somente por meio de debates acadêmicos ou impressos dos movimentos negros, mas também por meio de expressões culturais, como o grupo Ilê-Aiyê, bloco de carnaval baiano, que desde 1974 apresentava como tema os diversos países da África, visando resgatar a história dos negros. ${ }^{796}$

Necessário ressaltar que a visão dos militantes sobre a África apresentava-se de forma idealizada: "Nós tínhamos cultura, pensamentos, comportamento e formas de vida bem mais coletivas e diferentes da atual, através da escravidão e do colonialismo isso foi roubado, mas nós podemos retoma-las." 797 Nessa perspectiva a África apresentava-se de forma harmônica e coesa, sendo destruída pela presença do colonialismo. A África, no discurso dos movimentos negros era a "mãe",798, o epicentro da diáspora do povo negro e, portanto para onde deveria estar voltado o olhar dos afro-descendentes.

\footnotetext{
${ }^{791}$ Dossiê 20-C-44-17282. DEOPS/SP, DAESP.

792 Boletim da ABRASSO, p. 3. Dossiê 20-C-44-24720. DEOPS/SP, DAESP.

${ }^{793}$ Boletim da ABRASSO, p. 15. Dossiê 20-C-44-24720. DEOPS/SP, DAESP.

${ }^{794}$ O periódico Árvores das Palavras: "corriam de mão em mão sem que se soubesse quem eram os responsáveis, um jornal que veiculava notícias de revoluções africanas nas então colônias portuguesas e trazia uma mensagem de consciência política do negro brasileiro." In Cadernos Negros Apud SOUZA, F. Afro-descendência em Cadernos Negros e Jornal do MNU. Belo Horizonte: Autêntica, 2005, p. 82.

${ }^{795}$ Dossiê 50-Z-130- 2270. DEOPS/SP, DAESP.

${ }^{796}$ Boletim III do Grupo Negro da PUC-SP, p. 39. Pasta Movimento Negro. CEDIC/PUC-SP.

${ }^{797}$ Periódico Árvore das Palavras, s/n. e s/d. Dossiê 50-Z-138- 806. DEOPS/SP, DAESP.

${ }^{798}$ Exemplo do "Mãe África" no Boletim III do Grupo Negro da PUC-SP, p. 35. Pasta Movimento Negro. CEDIC/PUC-SP.
} 
Essa África mítica apresentou-se de diversas formas no Brasil: “A África nos poemas brasileiros, incluindo os do Modernismo, não sugere quase nada da África real, de ontem ou de hoje. É eleita como símbolo ou ícone uma África ausente (imaginária e fantasiosa quando ultrapassa a mera nomeação) e o negro, porque mais próximo, encarna a representação que do continente imaginam os que nenhum conhecimento dele têm." 799 Nessa (re)construção da África, visava-se construir um "orgulho negro" com a absorção de "diversos símbolos associados a um grande 'passado africano'." ${ }^{800}$ Assim, "A cultura afro-brasileira tradicional inspirou-se no contexto local [...] e numa África imaginária ou sentimental..." 801 Ou seja, numa dinâmica de dialogo entre interno e externo. A "África passou a significar cultura e tradição dentro da cultura negra. 'Afro' é um termo que representa um estilo de vida, que incorpora elementos da 'África' ou da cultura africana na formação da identidade negra e na vida cotidiana - o acréscimo de um toque africano à experiência da modernidade." 802

$\mathrm{Na}$ África buscava-se o resgate das "autênticas" raízes afro-brasileiras: “[...] em cada oportunidade temos que atentar bem para o valor das nossas autênticas raízes culturais." $\mathrm{O}$ resgate das origens africanas apresentava-se como estratégia de valorização do negro, de suas origens, de sua história e de sua cultura. Mas, como o periódico Sinba, reivindicava também um conhecimento sobre a África atual, com o objetivo de romper estereótipos de identificação do negro apenas com a África ancestral, dos tempos do tráfico de escravos, ou mesmo anterior.

$\mathrm{Na}$ busca pela renovação dos contatos culturais com a África, Abdias do Nascimento considerava: "[...] inspiração da autodeterminação africana, do respeito africano por todas as coisas da África, o esforço que o continente está fazendo para se levantar dessa grande queda de 500 anos de colonialismo, essa reaproximação nos vai reforçar, enquanto nós estaremos reforçando nosso continente original. " 803

\section{O apartheid na África do Sul}

\footnotetext{
${ }^{799}$ LARANJEIRA, P. A negritude Africana de língua portuguesa. Porto: Afrontamento, 1995, p. 40.

${ }^{800}$ SANSONE, L. Negritude sem Etnicidade. Rio de Janeiro: Pallas, 2004, p. 99.

${ }^{801}$ SANSONE, L. Op. Cit., p. 130.

${ }^{802}$ SANSONE, L. Idem, p. 134.

${ }^{803}$ Matéria "Nossos negros solitários", entrevista de Abdias do Nascimento a Revista Veja, n. 512, de 28/06/1978. Dossiê 50-Z-0- 145627. DEOPS/SP, DAESP.
} 
O apartheid na África do Sul foi um dos pontos de intenso debate nos movimentos afro-brasileiros, que se engajaram na luta contra a segregação racial. Nesta perspectiva, formou-se uma Comissão Pró-Comitê Brasileiro Anti-apartheid que exigia do governo brasileiro a condenação de regimes de apartheid na África (como África do Sul, Namíbia, Quênia, Zimbábue), a ruptura das relações diplomáticas com a África do Sul, o reconhecimento das representações nos territórios africanos, a libertação dos presos políticos da África do Sul, como Nelson Mandela, e a condenação do racismo. Conclamavam a todas as entidades negras para a formação do comitê brasileiro antiapartheid. $^{804}$

Segundo documentação do MNU o II Congresso das Culturas das Américas propôs a criação de comitês anti-apartheids em todos os países onde houvesse negros nas Américas ${ }^{805}$, demonstrando a importância dessa temática aos movimentos negros brasileiros, num sentido de solidariedade entre os negros na diáspora.

Em relatório da assembléia estadual, do MNU de São Paulo, realizada em Campinas em 21/9/1980, apresentam-se contatos desenvolvidos com Angola, visando preparar uma documentação da campanha anti-apartheid, com a qual pretendia pressionar o Itamarati para que o Brasil rompesse com a África do Sul. Além disso, buscava auxiliar Angola na construção da nova nação, fornecendo trabalhadores que pudessem ir para lá construir o "socialismo". 806

No final da década de 1970 e início da década de 1980 a diplomacia e a política externa brasileira condenou o apartheid e toda e qualquer forma de discriminação racial. ${ }^{807}$ Porém, como já registrado nesta dissertação esse processo foi complexo e tenso, especialmente porque a postura do regime militar contrária ao apartheid demorou só acontecendo, pelas pressões dos movimentos brasileiros em diversas esferas de poder e por diversas formas, como atos e debates na câmaras. Por exemplo:

"Ato na Câmara Municipal de São Paulo, de condenação ao apartheid (SIC), onde se somou à decisão tomada em plenário de solicitação de ruptura das relações diplomáticas do governo brasileiro com aquele regime racista. Setembro foi marcado pela realização de

\footnotetext{
${ }^{804}$ Panfleto da Comissão Pró-Comitê Brasileiro Anti-apartheid. Ordem Política 1079, Racismo volume 2. DEOPS/SP, DAESP.

${ }^{805}$ Revista do MNU. OS 1157 p. 218 C. DEOPS/SP, DAESP.

${ }^{806}$ Dossiê 50-Z-32- 4599. DEOPS/SP, DAESP.

${ }^{807}$ VIZENTINI, P. A politica externa do regime militar brasileiro. Porto Alegre: Ed. da Universidade/ UFRGS, 1998, 332.
} 
debates sobre a luta anti-colonial, na África pela passagem do 11 o aniversario da morte de Agostinho Neto, lo presidente do MPLA - Partido do Trabalho e lo Presidente da Republica Popular de Angola. Este ate, realizado em conjunto com a FRENAPO - Frente Negra para a Ação Política de Oposição, contou com a presença dos professores Carlos Serrano - de Angola - e de Kabengele Mununga - do Zaire." ${ }^{808}$

O debate sobre o apartheid na África do Sul era fomentado por textos como "minoria branca x maioria negra na África do Sul" apreendido pelo DEOPS. ${ }^{809}$ Neste texto há uma descrição de como funcionava o sistema segregacionista na África do Sul e seus mecanismos de controle da população, além de ressaltar a resposta dos negros em mobilizações anti-apartheid.

O periódico Sinbá era o órgão de divulgação da Sociedade de Intercâmbio BrasilÁfrica. ${ }^{810} \mathrm{O}$ depoimento de um líder estudantil de Soweto afirmava que "A população negra sul-africana é constantemente submetida a uma repressão tão grande, que bastam poucas iniciativas para que se alcance certa prática política, passando à luta organizada, ideologia política seguida pelos negros é na verdade traçada pelas atrocidades a que os brancos nos submeteram." 811 Sob essa perspectiva, a luta contra o apartheid tornava-se exemplo de luta política para os movimentos negros, construindo discursos similares.

Essa reivindicação dos movimentos brasileiros era constantemente vigiada pela comunidade de segurança. Na pasta Ordem Política, com a temática de "Movimento Negro vol. 2" encontramos diversos recortes de jornais referentes à atuação dos movimentos negros brasileiros. Dentre suas ações encontramos algumas diretamente relacionadas à África como, por exemplo, o recorte "Negros contra segregação" publicado na Folha de S. Paulo, de 27 de agosto de 1982. A reportagem relatava um protesto com 70 pessoas no consulado da África do Sul e organizado por diversas entidades dos movimentos negros que reivindicavam o rompimento das relações diplomáticas com a África do Sul e o reconhecimento formal do Congresso Nacional Africano e da Organização do Povo do Sudoeste Africano (SWAPO) como representantes do povo da Namíbia. ${ }^{812}$

\footnotetext{
${ }^{808}$ Boletim da ABRASSO, pg. 15. Dossiê 20-C-44-24720. DEOPS/SP, DAESP.

${ }^{809}$ Informação Confidencial sobre o Movimento Negro Unificado Contra a Discriminação Racial. OS 1157 p. 218 C. DEOPS/SP, DAESP.

${ }^{810}$ Sinba, Ano I, n. 1, Rio de Janeiro, julho de 1977. Dossiê 50-Z-130- 5588. DEOPS/SP, DAESP.

${ }^{811}$ Sinba, Ano I, n. 1, Rio de Janeiro, julho de 1977, p. 1. Dossiê 50-Z-130- 5588. DEOPS/SP, DAESP.

${ }^{812}$ OP 0989 Movimento Negro vol 2. DEOPS/SP, DAESP.
} 
Essa manifestação foi acompanhada de perto por uma equipe de investigações da Divisão de Ordem Política do DEOPS/SP, dando origem ao relatório de 26 de agosto de 1982, no qual consta que:

"o assunto em pauta versou contra o regime racista de Apartheid e contra todas as formas de racismos a nivel mundial. Entre os discursantes, o mais agressivo foi justamente o presidente da comunidade negra [...] dizendo entre outras coisas que é necessário o rompimento total das relações entre o governo Brasileiro com a África do Sul, bem como fazendo críticas a ação policial, alegando que a maioria dos crimes praticados pro policiais são cometidos contra negros. Os demais oradores se limitaram a criticar o racismo e a politica de Apartheid."

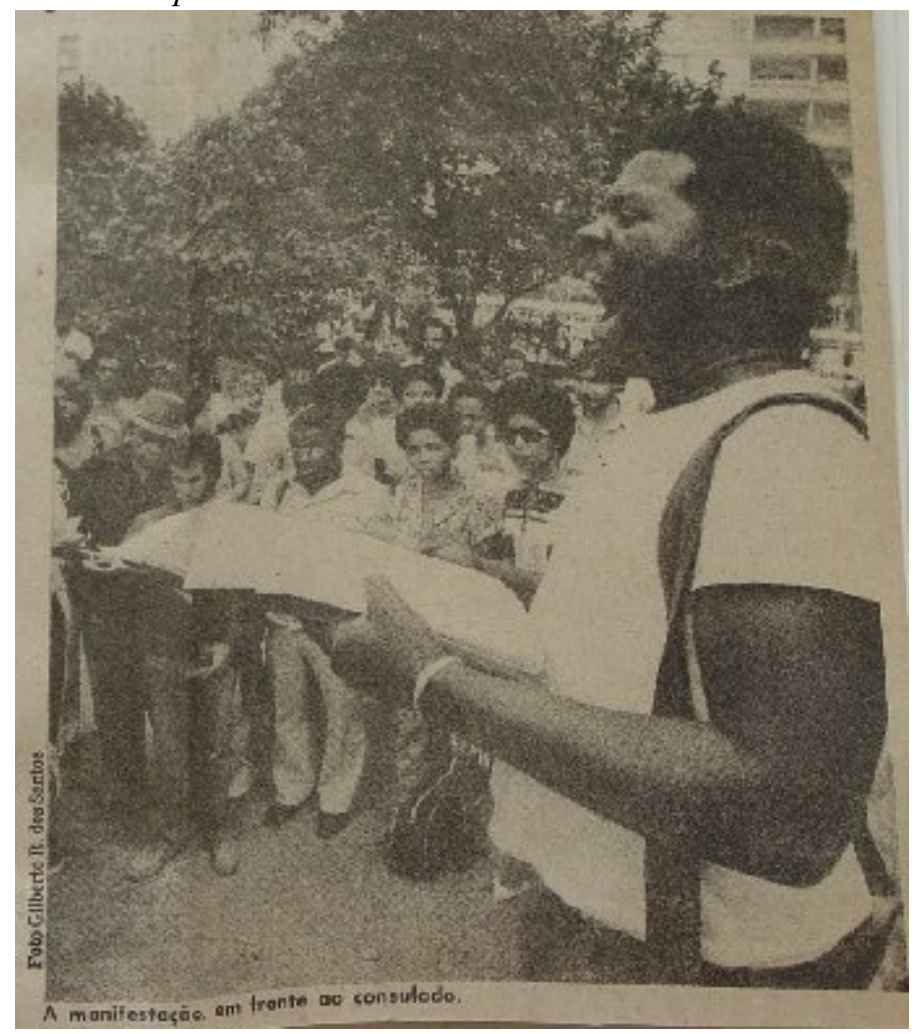

Fotografia de uma manifestação em frente ao Consulado da África do Sul, em 1982, no periódico Folha de S. Paulo.

Em manifesto à população brasileira sobre a $1^{\text {a }}$ Convenção do Movimento Negro, envolvendo a coordenação estadual das entidades negras de São Paulo, a Associação

813 OP 0989 Movimento Negro vol 2. DEOPS/SP, DAESP.

${ }^{814}$ Recorte Folha de S. Paulo matéria "Negros contra segregação", 27/8/1982. OP 0989 Movimento Negro vol 2. DEOPS/SP, DAESP. 
Brasileira de Solidariedade ao povo Moçambicano e o Instituto de Pesquisa e Estudos Afrobrasileiros, se posicionaram contrários ao regime do apartheid na África do Sul, a ocupação na Namíbia, os atentados ao povo moçambicano, a reclusão de Nelson Mandela, entre outras questões africanas. ${ }^{815}$

No I Encontro Estadual em Defesa da Raça Negra, realizado na PUC-SP, em 1981, apresentou-se um debate acerca da atuação das relações internacionais brasileiras diante do África do Sul e exigiam rompimento total das relações com este país. ${ }^{816}$

No III Congresso de Cultura Negra das Américas realizado na PUC/SP, em 1982 e presidido por Abdias do Nascimento, foi criado o Comitê Brasileiro Anti-Apartheid e organizadas passeatas e protestos. A luta anti-apartheid internacional foi destaque no $3^{\circ}$ Congresso de Cultura Negra das Américas, além das denúncias de racismo no Brasil.

Na Informação confidencial n. 940B/82, de 17 de junho de 1982, sobre o "Ato de solidariedade ao povo de Angola e a Nelson Mandela" com difusão para a comunidade de informações , trazia em anexo cópia de relatório do DOPS sobre o ato realizado em 16/6 na PUC-SP, coordenado por Clovis Moura. Nessa ocasião foram distribuídos o Caderno n. 2, ano II, de maio de 1982, intitulado "O Poder Popular", da Associação Brasileira de Solidariedade ao Povo Moçambicano (ABRASSO) e uma Carta Protesto denunciando o governo racista.

Em cartaz divulgando o ato era apresentada a situação da África do Sul, visando posicionamentos contrários ao apartheid por parte do governo brasileiro:

"As tropas sul africanas que em 16.6 .74 promoveram o massacre dos estudantes de SOWETO, formam hoje a força de ocupação da Namíbia e de constantes agressões a Angola e Moçambique. Em agosto de 1962 os racistas sul africanos prenderam Nelson Madela, o mais importante líder histórico e atual do povo de Azania.

Pelo reaparecimento de Nelson Mandela,

Pelo fim das invasões a Angola e Moçambique,

Pelo fim das relações do Brasil com a África do Sul,

contra o silêncio da imprensa sobre atos de guerra com a África do Sul. ${ }^{1817}$

No Ato, o militante Augusto, o presidente da ABRASSO teria criticado o "regime imperialista" responsável pelos conflitos no mundo e teria afirmado:

\footnotetext{
${ }^{815}$ OP 0989 Movimento Negro vol 2. DEOPS/SP, DAESP.

816 "I Encontro Estadual em Defesa da Raça Negra" In Revista do MNU, n. 4, julho e agosto de 1981, fl. 9. Sumário Semanal n. 27, entre 18 a 24/9/1981, de 25/9/1981, do CODIN/CONSEG da Coordenação de Informação da Secretaria de Estado da Segurança Pública de MG, fl. 18. Dossiê 50-H-84-4848. DEOPS/SP, DAESP.

${ }^{817}$ Cartaz "Ato de Solidariedade ao povo de angola e a Nelson Mandela"
} 
"que os negros no Brasil são desunidos, e que, atualmente, para ocupar espaço político, estão se vinculando a partidos políticos, mas não terão seus problemas resolvidos. Informou que a política externa do Brasil, em relação a solidariedade a outros povos, não e' clara e ninguém se da conta em cobra-la, nem o Congresso Nacional o fez, assim temos que exigir do nosso governo uma posição digna e clara, principalmente aos povos oprimidos. O governo brasileiro não faz por ser um braço do imperialismo."

A Comissão de negros do PT, em 1981, posicionava-se a favor de um rompimento das relações entre o governo brasileiro e a África do Sul, participando do debate anti-apartheid. 818 "Os trabalhadores do mundo inteiro estão diretamente interessados na libertação de todos os oprimidos e a derrubada do regime racista na África do Sul. Isto é uma etapa crucial do combate pela libertação dos povos africanos da opressão colonial e imperialista." ${ }^{819}$ A luta contra o apartheid apresentava-se como mais uma esfera da luta anti-racista, mobilizando diversos setores sociais em torno da condenação desse regime segregacionista.

\section{5) Os conflitos raciais nos Estados Unidos}

"Um dia.../ Quando perguntarem ao meu filho:/ Crioulo, quem foi seu pai?/ Hã?/ Quem ${ }_{820}$ fou pai crioulo???/ Eu quero que com orgulho ele responda:/ Meu pai foi Black (...)"

A campanha pelos direitos civis nos EUA, as idéias de "black power" foram debatidas nos movimentos negros brasileiros, auxiliando-os a construir suas próprias estratégias de luta. Temáticas similares aproximavam os seus discursos como, por exemplo, a violência policial. Ao discutí-la posicionavam-se diante da situação norte-americana exigindo a "aprovação de uma moção de repudio aos assassinatos de crianças negras em Atlanta, Estados Unidos. Essa moção mostrará que a violência contra o negro não ocorre só no Brasil, ocorre em todos os lugares onde existem explorados e exploradores, sobre as mais variadas justificativas." 821

\footnotetext{
${ }^{818}$ Proposta de ponto de luta da Comissão de negros do PT, 9/12/1981. Dossiê 50-H-84- 5505. DEOPS/SP, DAESP.

${ }_{819}$ Proposta de ponto de luta da Comissão de negros do PT, 9/12/1981. Dossiê 50-H-84- 5505. DEOPS/SP, DAESP.

${ }_{820}$ SANTOS, Aparecido Tadeu dos. Como se fosse pecado. São Paulo: Edição do Autor, 1980, p. 4. Dossiê 20-C-44-17290. DEOPS/SP, DAESP. Coletado por ocasião do Io Encontro em Defesa da Raça Negra, realizado em 23/5/1981, na PUC-SP. Relatório diário n. 1505, entre 25 e 26/5/1981, da Divisão de Informações do DEOPS, fl. 2. Dossiê 21-Z-14-11366. DEOPS/SP, DAESP.

${ }^{821}$ Panfleto do Grupo Negro da PUC "I Encontro Estadual em Defesa da Raça Negra” In Dossiês 20-C-44 17287. DEOPS/SP, DAESP.
} 
O periódico Árvore das Palavras ${ }^{822}$, edição n. 12 de 1975, divulgou a prisão do líder dos Panteras Negras, Eldridge Cleaver, nos EUA, pelo FBI, ao mesmo tempo que ressaltava à importância da luta pela liberdade, revelando o interesse dos movimentos negros brasileiros em relação aos movimentos nos EUA. ${ }^{823}$

A polícia política imputou aos movimentos negros brasileiros uma grande influência do pensamento dos Panteras Negras, o que certamente correspondia ao intenso debate que houve entre os militantes brasileiros.

O livreto da peça Poder Negro encenado por Ítala Nandi, Antonio Pitanga, José Batista, Sebastião Arruda e Sebastião Guilherme no Teatro Oficina ${ }^{824}$, de autoria do militante Le Roi Jones, líder do movimento norte-americano Black Power, em certo momento apresenta um trecho de Carmichael: “' 'Poder Negro' não é um slogan. É uma atitude diante de nossos problemas e o começo de suas soluções." 825

Assim o "black power" apresentava-se no debate "porque estamos sem poder que estamos oprimidos, e é somente pelo poder que teremos a possibilidade de tomar as decisões que orientem a vida das nossas comunidades. Aqueles que tem o poder tem tudo. Aqueles que não tem o poder não tem nada. Sem poder nós estamos reduzidos a mendigar aquilo que é nosso por direito." ${ }^{826}$ Em torno da idéia de poder negro concentrava-se a possibilidade de união dos afro-descendentes na luta pelo poder político e pelo atendimento de reivindicações sociais. Poder Negro, "não quer dizer anti-branquismo, violência, separatismo, nem nenhuma das outras tendencias racistas que a imprensa quer a ele atribuir." 827

Outro militante negro, Malcom X frisava que "Quando nós nos exprimimos assim, isso não quer dizer que somos contra os brancos, mas que nós somos contra a exploração, contra a degradação, contra a opressão." 828 “Eu não sou racista e nem subscrevo nenhum

\footnotetext{
${ }^{822}$ O periódico Árvores das Palavras: "corriam de mão em mão sem que se soubesse quem eram os responsáveis, um jornal que veiculava notícias de revoluções africanas nas então colônias portuguesas e trazia uma mensagem de consciência política do negro brasileiro." In Cadernos Negros Apud SOUZA, F. Afro-descendência em Cadernos Negros e Jornal do MNU. Belo Horizonte: Autêntica, 2005, p. 82.

${ }^{823}$ Dossiê 50-Z-130- 2270. DEOPS/SP, DAESP.

${ }^{824} \mathrm{O}$ MNU obteve contatos com o Teatro Oficina a ponto de ter realizado um ato público neste teatro, em 7/7/1980, ato classificado segundo relatório diário n. 1310 da Divisão de Informações do DEOPS como “subversão". Dossiê 50-Z-130- 3773 e 21-Z-14- 9362. DEOPS/SP, DAESP.

${ }^{825}$ Programa do Oficina, Poder Negro. Pasta Movimento Negro. CEDIC/PUC-SP.

${ }^{826}$ Programa do Oficina, Poder Negro. Pasta Movimento Negro. CEDIC/PUC-SP.

${ }^{827}$ Programa do Oficina, Poder Negro. Pasta Movimento Negro. CEDIC/PUC-SP.

${ }^{828}$ Programa do Oficina, Poder Negro. Pasta Movimento Negro. CEDIC/PUC-SP.
} 
dos dogmas do racismo. Com toda a honestidade e com toda sinceridade, não quero outra coisa senão a liberdade, a justiça e a igualdade: a vida, a liberdade, e a busca da felicidade para todo mundo." ${ }^{829}$ Mesmo assim, o ideal de conquista de poder político pelos afro-descendentes era considerado "racismo negro", não apenas no Brasil, mas também nos EUA.

As diferentes estratégias de luta empregadas nos EUA foram assuntos que inspiraram as lideranças de afro-brasileiros na organização de suas próprias estratégias de luta. Assim, a política de não violência pelos Direitos Civis, da década de 1950, principalmente representado por Martin Luther King, era contestada por sua não eficiência, em termos de resultados. Cada vez mais a tendência seguida era a de rompimento social, inspirada, em particular, nos discursos dos Panteras Negras e do Black Power, que buscavam alcançar o poder político.

Apesar das estratégias mais revolucionárias terem sido preponderantes nos debates dos movimentos negros brasileiros, destacava-se a atuação dos militantes afro-brasileiros de forma legal e não violenta. O "terrorismo" ou ações de guerrilha não foram utilizadas pelos movimentos negros para uma tomada de poder pela força. Ao mesmo tempo, imagens dos conflitos raciais nos EUA foram apresentados nos debates dos movimentos negros e em setores intelectuais engajados com ideais de igualdade social, como no teatro Oficina:

${ }^{829}$ Programa do Oficina, Poder Negro. Pasta Movimento Negro. CEDIC/PUC-SP. 


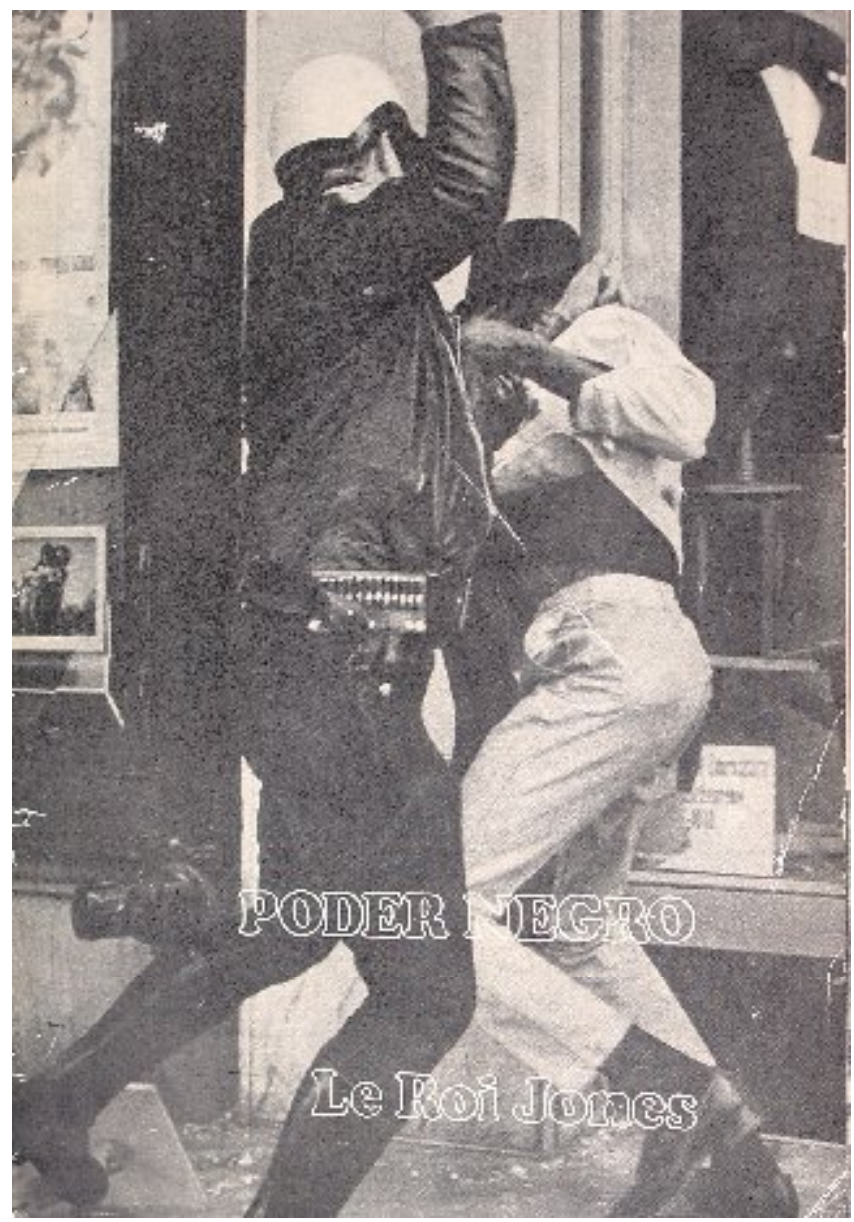

Programa do teatro Oficina, Poder Negro.

A transcrição da palestra do reverendo James F. Breeden, "Direitos Civis: a busca do negro pela igualdade", mostra uma síntese da situação dos afro-americanos nos EUA, com dados como renda, desemprego e pobreza, além de aspectos históricos para analisar a desigualdade racial norte-americana. ${ }^{831}$ Destacava que o racismo aliado as prioridades das políticas econômicas geravam o crescimento da exclusão e da marginalização dos afrodescendentes. Por isso, no I Encontro Estadual em Defesa da Raça Negra foi apresentada a proposta de:

"aprovação de uma moção de repudio aos assassinatos de crianças negras em Atlanta, Estados Unidos. Essa moção mostrará que a violência contra o negro não ocorre só no

\footnotetext{
${ }^{830}$ Pasta Movimento Negro. CEDIC/PUC-SP.

${ }^{831}$ Transcrição da palestra do reverendo James F. Breeden "Direitos Civis: a busca do negro pela igualdade" Pasta Movimento Negro. CEDIC/PUC-SP.
} 
Brasil, ocorre em todos os lugares onde existem explorados e exploradores, sobre as mais variadas justificativas. " 832

Demonstrava-se, assim, o interesse dos movimentos negros brasileiros em participarem ativamente das questões relativas à diáspora negra, opinando e apoiando as questões afroamericanas. Nesse sentido, Hamilton Cardoso concluía que o racismo não era apenas um problema circunscrito aos EUA, ou a região sul deste país, antes era um problema internacional. E destacava a necessidade de reação, ressaltando o referido assassinato de negros em Atlanta, EUA: “Aos negros e outros oprimidos restam destinos como o das 26 vítimas de Atlanta, ou então a revolta. " 833

O interesse sobre a história afro-americana também apresentava por meio dos intelectuais dos movimentos negros, com exposição de livros, documentos, filmes e músicas, no Museu de Arte de São Paulo Assis Chateaubriand (MASP), em evento organizado por Eduardo Oliveira e Oliveira ${ }^{834}$, entre 21/08 a 8/9 de 1976. ${ }^{835}$ A construção de um visual dos ativistas afro-descendentes "black power" inspirava-se no que estava em voga nos EUA. Procurava-se construir uma identidade negra afirmativa, influenciando a mobilização e a organização afro-brasileira. ${ }^{836}$ Assim, a divulgação e a internacionalização de uma cultura jovem e negra provinda do estilo "black power", do "soul" e do "hip hop" norte-americano tornavam-se elementos de debate e de admiração por parte dos movimentos brasileiros.

Um dos mais importantes aspectos da situação "racial" norte-americana que influenciou - e ainda influencia - os debates dos movimentos negros brasileiros é a divisão binária entre brancos e negros dos EUA, onde há uma prevalência da "origem", ou seja, da descendência. Como Oracy Nogueira apontou esse sistema de classificação difere do sistema brasileiro, que organiza as relações "raciais" por meio da "marca", ou seja, da "aparência" do sujeito, compondo relações de padrões diferentes quando comparados os

\footnotetext{
${ }^{832}$ Panfleto Io Encontro Estadual em Defesa da Raça Negra, fl.2. Dossiê 20-C-44- 17287. DEOPS/SP, DAESP.

${ }^{833}$ CARDOSO, H. “Atlanta: Um problema local?" Revista do MNU, n. 4, julho e agosto de 1981, fl. 27. Sumário Semanal n. 27, entre 18 a 24/9/1981, de 25/9/1981, do CODIN/CONSEG da Coordenação de Informação da Secretaria de Estado da Segurança Pública de MG, fl. 36. Dossiê 50-H-84-4848. DEOPS/SP, DAESP.

${ }^{834}$ Eduardo de Oliveira e Oliveira se suicidou em 1980 por discriminação nos meios acadêmicos, era sociólogo e teatrólogo, fundou o Centro de Cultura e Arte Negra e o Centro de Estudos Afro-Brasileiro em São Carlos.

${ }^{835}$ Programação do Evento anexada Dossiê 50-J-0 - sem número. DEOPS/SP, DAESP.

${ }^{836}$ SANSONE, L. Negritude sem Etnicidade. Rio de Janeiro: Pallas, 2004, p. 121.
} 
racismos brasileiro e o norte-americano. ${ }^{837}$ Os discursos de parte da militância afrobrasileira apresentavam o sistema norte-americano para compreensão da realidade brasileira, com o objetivo de desmascarar as desigualdades brasileiras e arregimentar os afro-descendentes por meio da descendência e não da aparência. A polarização também visava demonstrar que o racismo incidiria igualmente nos negros e nos mestiços. ${ }^{838}$

Esse aspecto não foi (e nem é) unanimidade entre os militantes e ainda gera muita polêmica, se relaciona diretamente com a representação que os movimentos negros possuem (ou não) dos afro-brasileiros.

Um panfleto de grupo de capoeira apresentava um diálogo com as idéias de afroamericanos, com uma frase de Marcus Garvey, ressaltando a busca histórica que os movimentos negros brasileiros empreenderam na sua própria luta: "Um povo que não tem conhecimento do seu passado histórico do seu passado histórico da sua origem e da sua cultura é igual uma árvore que não tem raízes." 839

\section{6) Construção do herói: Zumbi e o Dia da Consciência Negra}

"Meu verso fala de negro Meu verso fala do grito que os brancos não escutaram porque fecharam os ouvidos Meu verso fala do ódio encolhido Do nosso olhar espremido E lança zagaias ao som de batuques de noite que não vivi mas vivem em mim no meu sangue aos comandos de Zumbi que fala bem alto aos irmãos e sorri...

Sorri...

Sorri." 840

"Eu sou descendente de Zumbi Zumbi é meu pai, é meu guia

\footnotetext{
${ }^{837}$ NOGUEIRA, O. Tanto preto quanto branco: estudo de relações raciais. São Paulo: T.A. Queiroz, 1985.

${ }^{838}$ Como, por exemplo, o pensamento do militante e intelectual Eduardo de Oliveira e Oliveira, em 1974. Ver em CUNHA, O. "Depois da festa: movimentos negros e 'políticas de identidade' no Brasil” In ALVAREZ, S. e DAGNINO, E. e ESCOBAR, A. Cultura e política nos movimentos sociais latino-americanos: novas leituras. Belo Horizonte: Ed UFMG, 2000, p. 342.

${ }^{839}$ Dossiê 20-C-44- 26009. DEOPS/SP, DAESP.

${ }^{840}$ CUTI Cadernos Negros, n. 1, p. 47 Apud SOUZA, F. Afro-descendência em Cadernos Negros e Jornal do $M N U$. Belo Horizonte: Autêntica, 2005, p. 132.
} 
Eu trago quilombos e vozes bravias dentro de mim

Eu trago os duros punhos cerrados

Cerrados como rochas

Floridos como jardins. " 841

"Salve o Rei Negro Zumbi" ${ }^{842}$

As frases selecionadas como epígrafes apresentavam a relevância da figura de Zumbi nos diversos segmentos dos movimentos negros, fossem eles de expressão cultural ou política. O desejo de construir uma identidade afro-brasileira positiva, ativa e orgulhosa levou aos militantes buscarem na histórica brasileira personagens que contribuíssem para essa imagem, visando romper com estereótipos como o de negro "passivo", inclusive na escravidão. Desse modo, Zumbi apresentava uma imagem de resistência que alcançava esses propósitos, levando o a ser eleito como principal herói negro a ser louvado pelos movimentos negros. "A presença freqüente de Zumbi nos textos dos periódicos torna evidente o desejo de construção de um perfil heróico para o componente do panteão afrobrasileiro." 843

Zumbi fazia parte do discurso recorrente dos militantes em suas reuniões, atos, manifestos, palavras de ordem e impressos. Em reunião do MNUCDR, em 1979, Zumbi foi assim lembrado: “Wilson Prudente disse que 'Zumbi' foi o maior de todos os negros e é apontado pela história como marginal." ${ }^{844}$ Em outro ato público do MNU, em 13 de maio de 1981, Wilson voltou a enaltecer Zumbi em seu discurso, assim como "Osvaldão" da Guerrilha do Araguaia. ${ }^{845}$ Wilson se referindo a estas personalidades afro-descendentes destacava a resistência que buscava implementar nos movimentos negros. Palavra de ordem de ato e passeata do MNU, em 20 de novembro de 1980, ressaltava: "vamos lutar para

\footnotetext{
${ }^{841}$ Carlos Assumpção em Cadernos Negros, n. 9, p. 129 Apud SOUZA, F. Afro-descendência em Cadernos Negros e Jornal do MNU. Belo Horizonte: Autêntica, 2005, p. 148.

${ }^{842}$ Programa do espetáculo "Capoeira Roda Festa Manifestação de um Povo" do Grupo Capitães D' Areia. Dossiê 20-C-44- 26003. DEOPS/SP, DAESP.

${ }^{843}$ SOUZA, F. Afro-descendência em Cadernos Negros e Jornal do MNU. Belo Horizonte: Autêntica, 2005, p. 149.

${ }^{844}$ Informação da Divisão de Informações do DEOPS, 22/10/1979, fl. 2. Dossiê 20-C-44- 6305. DEOPS/SP, DAESP.

${ }^{845}$ Mensagem sobre Sumário de Informações n. 035/4 sobre Ato Público do MNU, de 13 de maio de 1981. Dossiê 50-D-18- 2850. DEOPS/SP, DAESP.
} 
Palmares levantar" 846 Zumbi foi uma constante nos discursos da militância afrodescendente.

A partir dessa construção em torno de Zumbi, o Dia da Consciência Negra em 20 de novembro visava (e ainda visa) marcar uma data de protesto e reflexão afro-descendente homenageando a data de morte de Zumbi, 20/11/1694. A escolha desta data é uma “invenção de tradições”, segundo a noção de Hobsbawm em $A$ invenção das tradições. ${ }^{847}$

Segundo consta, a origem do Dia da Consciência Negra, remonta ao "grupo gaúcho Palmares, com base em pesquisas na historiografia, que iniciou, em 1971, a comemoração do dia 20 de novembro como marco da história do negro no Brasil, promovendo recitais, palestras e debates. A partir de 1978, o MNU propõe a data como Dia Nacional da Consciência Negra, e o movimento negro no Brasil passa a festejá-la." ${ }^{848} \mathrm{Na}$ III Assembléia Nacional do MNU, de 4/11/1978, fora aprovada a data de 20 de novembro como o Dia Nacional da Consciência Negra, em função do aniversario da morte de Zumbi. 849

O MNU via no dia da consciência negra a celebração de: "Palmares, terra de homens livres, que não aceitou o julgo da escravidão, resistiu cerca de um século, às investidas de Portugueses e holandeses, que objetivavam destrui-lo. A 20 de Novembro Zumbi morre lutando em defesa do mais alto ideal pelo qual a toda humanidade sempre lutou - A liberdade." ${ }^{850}$ Dessa forma, Zumbi e Palmares representavam ao MNU a resistência e o ideal de liberdade: "Hoje, relembramos em Zumbi, a luta de libertação do povo negro do Brasil, das Américas e da África." 851

Segundo documentação do SNI acerca da Teoria de Contra-Rebelião: “... a guerrilha já foi empregada em diversos movimentos populares ... Nos Quilombos ..., na Cabanagem, no Pará, em Canudos na Bahia e no contestado nos limites de PARANÁ e SANTA

\footnotetext{
${ }^{846}$ Mensagem n. 2EM/PM-445/1, Sumário de Informações n. 072/4, de 20/11/1980. Dossiê 20-D-18- 2811. DEOPS/SP, DAESP.

${ }^{847}$ HOBSBAWM, E. e RANGER, T. (org) A invenção das tradições. Rio de Janeiro: Paz e Terra, 1997.

${ }^{848}$ SOUZA, F. Afro-descendência em Cadernos Negros e Jornal do MNU. Belo Horizonte: Autêntica, 2005, p. 206.

${ }^{849}$ Informação n. 350 confidencial, da $2^{\text {a }}$ Seção da Aeronáutica, de 15/12/1978. Dossiê 50-D-26- 5923. DEOPS/SP, DAESP.

${ }^{850}$ Revista MNU, p. 19. OS 1157 p. 218 C. DEOPS/SP, DAESP.

${ }^{851}$ Manifesto Nacional Dia Nacional da Consciência Negra do MNU. Dossiê 20-C-44- 14605. DEOPS/SP, DAESP.
} 
CATARINA, entre outras, as, táticas de luta tinham muita guerra de guerrilhas. " 852 Dessa forma, Palmares apresentava-se como uma expressão de guerrilha, da luta mais expressiva do povo negro, ressaltando a resistência dos afro-descendentes. ${ }^{853}$

Os militantes do MNU apresentavam-se como orgulhosos descendentes de Zumbi na luta "pela libertação integral do povo negro" ${ }^{854}$ Zumbi simbolizava a identidade de lutas com que os movimentos negros queriam (e ainda querem) tomar para si, representante dos ideais de justiça e igualdade, "ZUMBI o grande símbolo de nossa luta e nossas aspirações, como negros, como oprimidos. " 855

O Panfleto "Dia Nacional da Consciência Negra" ressaltava que esse seria o dia em que "a comunidade negra se manifesta contra a discriminação política, social e econômica a que vem sendo submetida há longos anos." ${ }^{856} 20$ de novembro, dia da morte de Zumbi, representava o auge da luta do negro contra a opressão, o que tornava da mais contundente crítica às violências institucionais e simbólicas características do regime militar. Dentro dessa representação mítica da história afro-brasileira, Palmares era a "república negra que durou quase um século e foi o exemplo de vida de um povo, reunindo brancos, índios e negros sem discriminação, sem desemprego e sem violência." Por meio da mitificação do passado criticava-se o presente, ressaltando o quadro de pobreza, dificuldades econômicas e violência policial enfrentado pelo afro-descendente.

Porém a "presença" de Zumbi na simbologia e imaginário dos movimentos negros não se deu apenas no "Dia da Consciência Negra", mas também, Festival Comunitário Negro Zumbi, o FECONEZU, que era realizado de forma continua no estado de São Paulo. ${ }^{857}$ Buscava formar uma cultura de resistência frente aos padrões hegemônicos da cultura branca. Nesse sentido, Zumbi apresentava-se como elemento central para a produção de um símbolo heróico de resistência. O Festival Comunitário Negro Zumbi era realizado todos os

\footnotetext{
${ }^{852}$ Prontuário n. 42098, Teoria e Prática da Contra-Rebelião. DEOPS/SP, DAESP.

${ }^{853}$ Panfleto "20 de novembro - Dia da Consciência Negra" In Sumário Semanal n. 34, entre 6 a 12/11/1981, de 12/12/1981, do CODIN/CONSEG da Coordenação de Informação da Secretaria de Estado da Segurança Pública de MG, fl. 11. Dossiê 50-H-84- 5033. DEOPS/SP, DAESP.

${ }^{854}$ Manifesto Nacional Dia Nacional da Consciência Negra do MNU. Dossiê 20-C-44- 14605. DEOPS/SP, DAESP.

${ }^{855}$ Manifesto Nacional Dia Nacional da Consciência Negra do MNU. Dossiê 20-C-44- 14605. DEOPS/SP, DAESP.

${ }^{856}$ Panfleto do MNU, Comissão de Negros do PT, Grupo Negro da PUC-SP, CEABAR, Departamento Negro da UMES, Comissão de Direitos Humanos do Departamento Jurídico do XI de Agosto, SACHAC. OP 1079. DEOPS/SP, DAESP.

${ }^{857}$ Boletim III do Grupo Negro da PUC-SP, p. 24. Pasta Movimento Negro. CEDIC/PUC-SP.
} 
anos, em diversas cidades do interior de São Paulo. Era organizado por diversas entidades dos movimentos negros para comemorar e manifestar a cultura afro-brasileira em uma diversidade de eventos. ${ }^{858}$

O militante mineiro Dalmir Francisco da Costa, em discurso no Dia da Consciência Negra, em 1981, ressaltava que Zumbi era um líder que: “ [...] morreu lutando por uma causa justa, a liberdade e a dignidade da raça negra, pontos em que também se inspira o MNUCDR no combate à discriminação e opressão dos negros." ${ }^{859}$ Sob essa perspectiva, Zumbi era apresentado como mártir e herói a ser seguido, ainda que suas causas e os contextos sociais estivessem muito distantes da realidade enfrentada pelos militantes negros durante o regime militar. Portanto, havia uma idealização por parte dos militantes negros, no qual Zumbi era o exemplo a ser seguido, uma vez consideradas as contingências com que os militantes se depararam. Como apresentou, Vicente Gonçalves em seu discurso, os afro-descendentes deveriam: "[...] lutarem como lutou 'Zumbi', 'que morreu lutando por condições humanas de trabalho e pela liberdade de vida e organização." 860

Ao mesmo tempo em que se construía um marco histórico em torno de Zumbi, refutava-se a data comemorativa do 13 de maio, da abolição da escravatura, por nesta estar inscrita uma "liberdade consentida" por meio do ato da princesa Isabel. Exemplo dessa rejeição ao 13 de maio foi apresentada nas manifestações de 1982, em missa na Igreja N.S. do Rosário, em que o padre fez em seu sermão comentários sobre o 13 de maio, ressaltando que "esse dia não é o dia da libertação dos escravos, e sim, o dia 20 de novembro, que é o dia da revolta de Quilombo de Palmares." 861

Como na poesia "Instru/abnega/cão", de Aparecido Tadeu, a abolição era apresentada de forma consentida: "Na escola me ensinaram/ Que meus ancestrais foram escravos/E

\footnotetext{
${ }^{858}$ Revista MNU, p. 19. OS 1157 p. 218 C. DEOPS/SP, DAESP.

859 "Dia Nacional da Consciência Negra - Movimento Negro Unificado (MNU)" Sumário Semanal de Informações n. 36, entre 20/11 a 26/11/1981, de 27/11/1981, CODIN/CONSEG da Coordenação de Informações da Secretaria de Estado de Segurança Pública de MG, fl 37. Dossiê 50-H-84- 5047. DEOPS/SP, DAESP.

860 "Dia Nacional da Consciência Negra - Movimento Negro Unificado (MNU)" Sumário Semanal de Informações n. 36, entre 20/11 a 26/11/1981, de 27/11/1981, CODIN/CONSEG da Coordenação de Informações da Secretaria de Estado de Segurança Pública de MG, fl 39. Dossiê 50-H-84- 5045. DEOPS/SP, DAESP.

${ }^{861}$ Relatório da Divisão de Informações do DEOPS, de 13/05/1982. Dossiê 21-Z-14- 13558. DEOPS/SP, DAESP.
} 
que uma princesa bondosa os libertou?/ No trabalho aprendi/ Que eles foram, q' eu também ainda sou.", 862

Este sentido foi apresentado muitas vezes, como no Panfleto " 20 de novembro - Dia da Consciência Negra": "Entre os líderes de Palmares, ZUMBI foi o mais fiel na defesa das aspirações do povo negro em luta constante pela justiça e igualdade. ZUMBI é o grande símbolo de nossa luta e nossas aspirações, como negros, como oprimidos. ", 863

O projeto Zumbi da década de 1980, sem dúvida, auxiliou a construção e a valorização de Zumbi como o grande herói afro-brasileiro. Esse projeto, desenvolvido pela Universidade Federal de Alagoas, pela Fundação Nacional Pró-Memória e pelos movimentos negros estavam voltados para criar um parque-monumento homenageando Palmares. ${ }^{864}$

Um outro periódico, Árvore das Palavras ${ }^{865}$, n. 6, de novembro de 1974, apresentava uma crítica ao dia comemorativo da Mãe Negra, identificando-o como o dia do Racismo, representado pela exploração e submissão das mães negras escravas que amamentavam os filhos dos senhores. Incitando um debate acerca da situação precária dos afro-descendentes, especialmente das mulheres, exaltava a figura de Zumbi como simbologia de resistência e crítica a escravidão e suas conseqüências até aquele momento. ${ }^{866}$

Na construção da consciência negra, o jornal Árvore das Palavras ressaltava que "Se você pensa em negro como minoria, está errado, por tempos, sempre que falavam de nós, diziam: minorias negras, insistiam na palavra minoria. Por que? Talvez tendo exata consciência do número que somos o pessoal sentiria a foça (sic) que temos. O censo atual

\footnotetext{
${ }^{862}$ SANTOS, Aparecido Tadeu dos. Como se fosse pecado. São Paulo: Edição do Autor, 1980, p. 9. Dossiê 20-C-44-17290. DEOPS/SP, DAESP. Coletado por ocasião do Io Encontro em Defesa da Raça Negra, realizado em 23/5/1981, na PUC-SP. Relatório diário n. 1505, entre 25 e 26/5/1981, da Divisão de Informações do DEOPS, fl. 2. Dossiê 21-Z-14-11366. DEOPS/SP, DAESP.

${ }^{863}$ Panfleto "20 de novembro - Dia da Consciência Negra" In Sumário Semanal n. 34, entre 6 a 12/11/1981, de 12/12/1981, do CODIN/CONSEG da Coordenação de Informação da Secretaria de Estado da Segurança Pública de MG, fl. 11. Dossiê 50-H-84- 5033. DEOPS/SP, DAESP.

${ }^{864}$ Segundo relatório do MNU de São Paulo, sobre uma assembléia estadual, realizada em Campinas em 21/9/1980, 3 ativistas do MNU participavam das discussões sobre o Parque Histórico Nacional Zumbi. Dossiê 50-Z-32- 4601, fl. 280. DEOPS/SP, DAESP.

${ }^{865}$ Em documentação policial o periódico Árvore das Palavras era apontado como uma produção dos "homens de côr" possivelmente impresso numa tipografia particular de São Carlos e que estava sendo distribuído em Campinas por Antonio Carlos Santos Silva. Dossiê 21-Z-14- 440. DEOPS/SP, DAESP. O periódico foi categorizado pela polícia de Campinas como "movimento racista", conforme informe de 23/9/1975. Dossiê 50-Z-138- 807. DEOPS/SP, DAESP. Outro exemplar fora apreendido em pose de João da Silva Filho, Orlando Silva Gouveia e Mariano Alves de Oliveira que foram detidos em São Paulo em 10/12/1974. Dossiê 50-Z-129- 15427. DEOPS/SP, DAESP.

${ }^{866}$ Dossiê 50-Z-129- 15426. DEOPS/SP, DAESP.
} 
não divide mais em números de habitantes por raça e esconde sob o dado de 90 milhões de brasileiros, a grande verdade milhões e milhões de negros." ${ }^{867}$ Desta forma, a luta pela consciência de que havia uma maioria de afro-descendentes no Brasil passava pela própria identificação destes, seja pelas estruturas do Estado ou seja pela própria identificação individual, resgatando a auto-estima e a beleza negra. A exaltação e a mitificação de personagens históricos afro-brasileiros apresentaram-se como parte da luta por uma identidade negra positiva.

Na edição n. 12 de 1975, do Árvore das Palavras, apresenta-se matéria sobre Quilombos, divulgando a história de resistência escrava. A partir dessa luta de independência do passado, o jornal pensava em seu presente de forma provocativa: "E hoje em dia, como é que são as coisas? Será que eles mudaram? O nosso pessoal metia bronca; e a gente hoje? Falar em Quilombo, é até certo ponto muito fácil, mas encarar essa barra de independência é que não é mole." ${ }^{868}$ Assim (re)visitar um passado de resistência tornava-o exemplar para um presente de repressão social que exigia igualmente uma formação de resistência negra.

Na construção de um dia comemorativo que ressaltasse o protagonismo afro-brasileiro, por meio do Dia da Consciência Negra centrado em Zumbi, houve o combate aos festejos do 13 de maio, o qual não teria dado uma real liberdade aos afro-descendentes. Assim, o Grupo Negro da PUC-SP, o MNU e a Comissão de Negros do PT, propunham que o 13 de maio fosse o dia de denúncia contra o racismo, questionando a liberdade provinda da abolição, uma vez que a discriminação racial impediria os afro-descendentes do acesso à cidadania. ${ }^{869}$ Resistindo a uma data imposta, os movimentos negros buscavam decidir quais datas lhes eram significativas e como lhes dar significados.

O periódico Árvore das Palavras criticava setores dos movimentos negros que comemoravam o 13 de maio, com a Lei Áurea, voltando a torná-lo feriado nacional e cultivá-lo com as autoridades constituídas. "Esses 'homens de cor' devem aprender ainda que nós não temos nada a ver com o 13 de maio. A lei Áurea, na verdade, defendia os interesses dos senhores brancos e não dos escravos." 870 Revelavam-se os dissensos

\footnotetext{
${ }^{867}$ Dossiê 50-Z-129- 15426. DEOPS/SP, DAESP.

${ }^{868}$ Dossiê 50-Z-130- 2271. DEOPS/SP, DAESP.

${ }^{869}$ Panfleto s/d. OP 0989 Movimento Negro vol 2. DEOPS/SP, DAESP.

${ }^{870}$ Dossiê 50-Z-138- 806. DEOPS/SP, DAESP.
} 
internos sobre as datas comemorativas significativas para os afro-descendentes, sobretudo com a crescente crítica ao 13 de maio, que não valorizaria a resistência escrava, como queriam fazer os setores dos movimentos negros mais progressistas e esquerdistas. A luta pelo 20 de novembro e a representação de Zumbi contemplava esta perspectiva de resistência que esses setores dos movimentos negros queriam empreender. O 13 de maio era revisto pelos movimentos negros como o dia nacional de denúncia do racismo e não o dia da libertação dos escravos. Dessa forma a data comemorativa ganha um novo significado.

Em entrevista ao Estado de S. Paulo sobre ato público do MNU em 1980, Eduardo de Oliveira, coordenador nacional do MNU, afirmou sobre a abolição da escravidão: "não houve nenhuma libertação; apenas passamos de mão-de-obra escrava para mão-de-obra desqualificada." ${ }^{871}$ Eduardo ainda ressaltava que a população afro-descendente teve com herança da abolição o desemprego, o sub-emprego, as marginalidades, a discriminação racial e a violência policial. Por isso, os movimentos negros re-significavam essa data comemorativa como o dia nacional de denúncia contra o racismo.

O 13 de maio era marcado por atos públicos em protesto ao racismo, como por exemplo, o ato do "Dia Nacional de Denúncia Contra o Racismo", organizado pelo Grupo Negro da PUC, o MNU e a Comissão de Negros do PT. ${ }^{872}$

Em panfleto, distribuído em tal ato, intitulado "13 de maio: dia nacional de denúncia contra o racismo" apresenta-se um repúdio desta data, para resgatar o caráter de resistência dos escravos e de sua importância no processo de abolição, além de analisar tal fato por um viés marxista: "Através dos aparelhos ideológicos da classe dominante tentam incutir-nos a idéia de que a abolição da escravatura se fez por motivos humanitários; quando na verdade sabemos que ela ocorreu por uma necessidade histórica do momento; a emergência do sistema capitalista. [...] Esta abolição se constituiu numa mudança de ordem social em que apenas a elite branca estabeleceu os interesses econômicos, políticos e sociais, a seu favor, deixando o negro a mercê de sua sorte." 873

\footnotetext{
871 "Negros fazem ato público" In Estado de S. Paulo, 14/05/1980, p. 13. OP 0654 Atos Públicos. DEOPS/SP, DAESP.

${ }^{872}$ Informação Confidencial n. 705B/82, 14/05/1982. DEOPS/SP, DAESP.

${ }^{873}$ Dossiê 20-C-44- 23944. DEOPS/SP, DAESP.
} 


\section{IV -CARACTERÍSTICAS DOS MOVIMENTOS NEGROS BRASILEIROS}

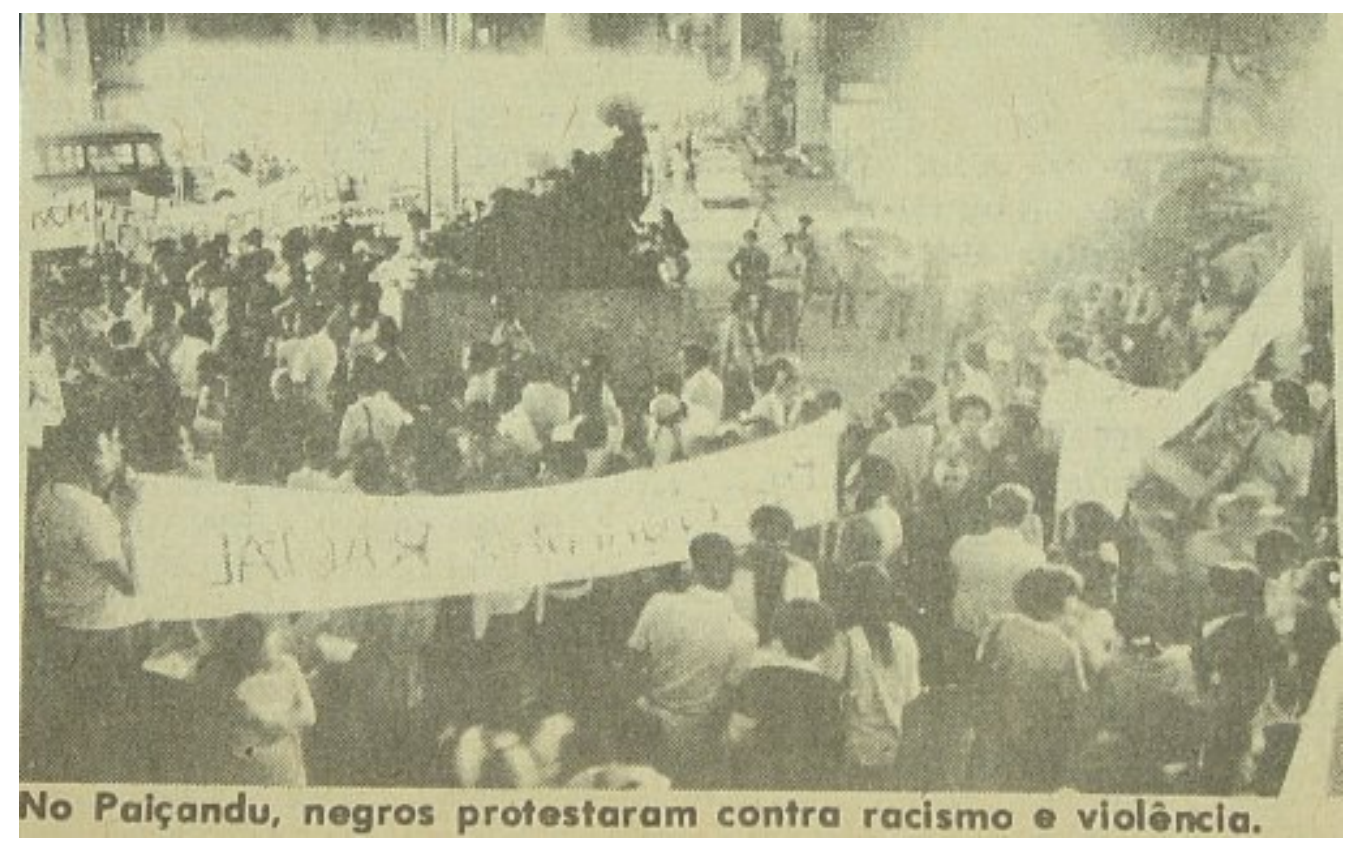

Foto de Rosa Gauditano do ato público contra o racismo no periódico Versus, de 1978.

"Mostro os dentes.

Dou risada.

Sou o cara engraçado.

Estou sempre: Sim Senhor; não senhor.

Enquanto levo na brincadeira.

Sou o preto simpático

o moreno educado.

Mas ao menor protesto, me chamam de negro atrevido." 875

Os movimentos negros representavam "o conjunto de iniciativas de resistência e de produção cultural e de ação política explícita de combate ao racismo que se manifesta por via de uma multiplicidade de organização em diferentes instâncias de atuação, com diferentes linguagens, por via de uma multiplicidade de organização espalhadas pelo

\footnotetext{
${ }^{874}$ Versus, n. 23, de julho-agosto de 1978, p. 32. Dossiê 50-K-6- 280. DEOPS/SP, DAESP.

${ }^{875}$ Periódico Árvore das Palavras, n. 6 novembro de 1974. Dossiê 50-Z-129- 15426. DEOPS/SP, DAESP.
} 
país." 876 Neste capítulo vamos apresentar 2 importantes aspectos presentes nos movimentos negros daquele período que trouxeram embates e decisões importantes para a estruturação dos movimentos negros. O primeiro trata-se da questão do diálogo com outros movimentos, aspecto que foi muitas vezes incentivado pelos ativistas, visando ampliar a sua mobilização e fazer circular os seus debates por outros setores sociais. $\mathrm{O}$ outro aspecto é a questão da união entre os movimentos negros, especialmente pelo MNU que visava organizar as diversas entidades sob uma diretriz unificada.

Além disso, apresentamos algumas questões relativas a MNUCDR e MNU, uma vez que esse movimento teve grande importância e repercussão no período, especialmente porque foi esse movimento quem liderou a idéia de unificação.

\section{1) Diálogo com outros movimentos}

"[...] o Movimento Negro não é algo isolado do conjunto de manifestações de massas. Dele se alimenta, alimentando-o, participa de suas derrotas e de suas vitórias." 877

Partindo da percepção da riqueza que o contato com outros movimentos sociais levava como apresenta a epígrafe acima - atentando para o que acontecia no Brasil e no Mundo, os movimentos negros buscavam ampliar esse diálogo. "Convidamos aos setores democráticos da sociedade que nos apóiem, criando as condições necessárias para criar uma verdadeira democracia racial." ${ }^{878}$ Estava presente a preocupação de ampliação do movimento negro para além de debates internos e levar sua mensagem a toda a sociedade brasileira. Como estratégia para isso, os setores democráticos foram eleitos como interlocutor principal, dado a identificação que tinham com estes setores e seus projetos.

O MNUCDR encontrava-se em formação e precisava atingir um público maior para possibilitar que suas reivindicações fossem ouvidas. Com o intuito de sensibilizar a população em prol de sua causa, o MNUCDR convocava “[...] todos os setores democráticos, que lutam contra as injustiças e o desrespeito aos direitos humanos, a engrossarem as fileiras com a Comunidade Afro-brasileira, nesse ato contra o racismo."

\footnotetext{
${ }^{876}$ Documento do Io Encontro Nacional de Entidades Negras no Jornal do MNU, n. 18, p. 6. Apud SOUZA, F. Afro-descendência em Cadernos Negros e Jornal do MNU. Belo Horizonte: Autêntica, 2005, p. 14.

${ }^{877}$ CARDOSO, H. "Alguns pontinhos..." In Versus, n. 22, junho e julho de 1978, p. 38. Dossiê 20-K-135424. DEOPS/SP, DAESP.

878 "Carta Aberta à População - Contra o Racismo" do MNUCDR In Dossiê 21-Z-14 - s/n. DEOPS/SP, DAESP.
} 
${ }^{879}$ Desde a sua fundação o MUCDR buscava associação com outros setores sociais, como nesta convocação para ato público, em 7/7/1978, que lançou publicamente o movimento.

Num primeiro plano procurou arregimentar os afro-descendentes. Nesse sentido, buscavam aproximar-se da comunidade afro-brasileira aonde quer que estivessem, chegando a propor um "movimento volante" que percorresse diversos lugares. ${ }^{880}$ Num segundo plano, participava dos debates democráticos, por exemplo, como a luta pela anistia $^{881}$, visando ampliar a discussão do racismo e conquistar simpatizantes para sua causa.

Em material de divulgação da Anistia fomentava-se na organização do movimento pró Anistia o debate de outros movimentos, entre eles, os negros. ${ }^{882}$ Representantes dos movimentos negros participaram do I Congresso Nacional pela Anistia. ${ }^{883}$ Segundo informação policial o representante do MNUCDR nos movimentos pró-anistia fora Eduardo de Oliveira, em novembro de 1978. ${ }^{884}$ O MNUCDR por essa ocasião apresentara seu ponto de vista, por meio da feitura da tese "O papel do aparato policial do Estado no processo de dominação do Negro e a Anistia". ${ }^{885}$ Panfleto de julho de 1979 do MNU apresentava a postura deste movimento diante da campanha pela anistia, na luta contra a discriminação racial, a luta pela anistia, ampla, geral e irrestrita apresentava-se como primordial para o avanço das lutas específicas dos movimentos negros, levando ao apoio para tal campanha. ${ }^{886}$

Os debates se davam constantemente, como consta da Plenária Democrática de São Paulo, fundada em setembro de 1980, visando a conquista da democracia, a participação da

\footnotetext{
${ }^{879}$ Carta convocatória para o ato público contra o racismo, 29/06/1978. Dossiê 50-Z-0- 14620. DEOPS/SP, DAESP.

${ }^{880}$ Panfleto do Grupo Negro da PUC “I Encontro Estadual em Defesa da Raça Negra” In Dossiês 20-C-44 17287. DEOPS/SP, DAESP.

${ }^{881} \mathrm{O}$ MNU participava de manifestações pela anistia com cartazes, panfletos e palavras de ordem contra o regime militar. Panfleto "Movimento Unificado contra a ditadura assassina" assinado pelo movimento negro. Palavra de ordem do movimento negro: "pelo desmonte de todo aparelho repressivo" In Informação da Divisão de Informações do DEOPS, 8/8/1979, fl. 1. Dossiê 50-Z-130- 2675. DEOPS/SP, DAESP.

${ }^{882}$ Anexo G do Encaminhamento do Ministério da Marinha n. 0393/78. Dossiê 50-Z-0- sem número. DEOPS/SP, DAESP.

${ }^{883}$ Manifesto a Nação, de 5/11/1978, anexo F do Encaminhamento do Ministério da Marinha n. 0393/78. Dossiê 50-Z-0- sem número. DEOPS/SP, DAESP.

${ }^{884}$ Informação do MNUCDR. Dossiê 52-Z-0- 28559. DEOPS/SP, DAESP.

${ }^{885}$ Dossiê 50-Z-130- 5174. DEOPS/SP, DAESP.

${ }^{886}$ Informação do MNUCDR. Dossiê 52-Z-0- 28559. DEOPS/SP, DAESP.
} 
FRENAPO e do MNU. ${ }^{887}$ Essa participação apresenta-se no debate de questões como a violência policial e a discriminação racial nos pontos do protocolo de intenções. ${ }^{888} \mathrm{Em}$ relatório do MNU de São Paulo sobre assembléia estadual, realizada em Campinas em 21/9/1980, apresentava-se a necessidade de "agilizar e atuar efetivamente nas lutas democráticas da sociedade como um todo." ${ }^{889}$ Ampliando os contatos com os "movimentos democráticos" foi realizado um ciclo de debates denominado "A esquerda e o movimento negro" no ano de 1983, organizado pelo periódico Em Tempo. ${ }^{890}$

Na visão do Grupo Negro da PUC-SP o diálogo com outros movimentos sociais se fazia de suma importância para o enfrentamento do contexto sócio-político do país. E criticava os movimentos negros por um "isolamento" desses perante a situação do país que gerava um problema estratégico de uma falta de organismos capazes de expressar as reivindicações dos afro-descendentes. ${ }^{891}$ Isso decorre da visão de que as questões que eram pertinentes a comunidade afro-descendente passavam em primeiro lugar pela crítica do regime militar.

Visando atingir uma maior atuação política o Grupo Negro da PUC-SP incentivava a atuação dos militantes a participarem ativamente nos sindicatos, associações de bairro, partidos políticos e as mais diversas formas de organização social que lutassem pela defesa de direitos sociais. Obviamente que essa aproximação deveria manter a autonomia dos movimentos negros para que não houvesse exploração dos movimentos por interesses alheios. ${ }^{892}$

As temáticas que envolviam os movimentos negros levavam a busca destes para unir esforços com outros setores sociais visando ampliar a luta e ter conquistas na luta perante as estruturas de poder. Por exemplo, na luta contra os efeitos da crise econômica brasileira os movimentos negros no I Encontro Estadual em Defesa da Raça Negra também propunham: "nossa unificação com todas as entidades, associações, sindicatos, partidos e setores, que incluam essa luta em suas reivindicações." 893 Incentivando que os

\footnotetext{
${ }^{887}$ Plenária realizada em 10/12/1980. Dossiê 20-C-44- 14995 A e 20-C-44- 14987. DEOPS/SP, DAESP.

${ }^{888}$ Pontos "defesa dos direitos do povo contra a violência policial" e "luta contra a discriminação racial" In Plenária Democrática de São Paulo, fl 2. Dossiê 20-C-44- sem número. DEOPS/SP, DAESP.

${ }^{889}$ Dossiê 50-Z-32- 4601. DEOPS/SP, DAESP.

${ }^{890}$ Relatório da Divisão de Informações do DEOPS. Dossiê 21-Z-14- 15182. DEOPS/SP, DAESP.

${ }^{891}$ Boletim III do Grupo Negro da PUC-SP, p. 18. Pasta Movimento Negro. CEDIC/PUC-SP.

${ }^{892}$ Boletim III do Grupo Negro da PUC-SP, p. 19. Pasta Movimento Negro. CEDIC/PUC-SP.

${ }^{893}$ Dossiê 20-C-44- 17287. DEOPS/SP, DAESP.
} 
trabalhadores negros tivessem uma atuação nas entidades representativas, levando até elas o debate dos movimentos negros e auxiliassem a conquista da democracia no país.

O MNU buscava ampliar a sua atuação apoiando a abertura do debate do racismo no Brasil entre entidades representativas de categorias trabalhistas: "Em todo o país surgem novos grupos e entidades em defesa das reivindicações da população negra, e já começam a surgir grupos organizados de negros em categorias importantes como bancários, metalúrgicos e no funcionalismo público." 894 A participação dos movimentos negros em eventos de outras organizações também facilitava o diálogo e levava os debates próprios dos afro-descendentes a circular em outros movimentos. Por exemplo, presença de Wilson Prudente do MNU no ato público de 21 de maio de 1981, da unidade sindical. ${ }^{895}$

$\mathrm{Na}$ luta contra o regime militar, os militantes negros entendiam que era por meio da organização e conscientização junto com outros movimentos populares, associações e sindicatos que seria possível um posicionamento de resistência a política autoritária dos militares. ${ }^{896} \mathrm{O}$ ato contra o racismo no 13 de maio de 1981 fora apoiado por outras entidades civis, “[...] contou com o apoio de várias outras entidades democráticas da sociedade brasileira, como Movimento Custo de Vida, União Municipal dos Estudantes Secundaristas, Associação das Empregadas Domésticas de São Paulo." 897 A partir da atuação do MNU seus militantes realizaram debates sobre os problemas sociais que afetavam os afro-descendentes e começaram a exigir posicionamento e propostas das organizações político-partidárias a cerca de suas reivindicações e problemas sociais: “[...] todas as organizações políticas do país, hoje, tem que ter um posicionamento sobre a questão racial." 898

\footnotetext{
${ }^{894}$ Revista do $M N U$, n. 4, julho e agosto de 1981, fl. 13. Sumário Semanal n. 27, entre 18 a 24/9/1981, de 25/9/1981, do CODIN/CONSEG da Coordenação de Informação da Secretaria de Estado da Segurança Pública de MG, fl. 22. Dossiê 50-H-84-4848. DEOPS/SP, DAESP.

${ }^{895}$ Mensagem 462 do Sumário de Informações n. 036-4, de 21/05/1981. Dossiê 50-D-18- 2852. DEOPS/SP, DAESP.

${ }^{896}$ Sumário Semanal n. 39, entre 11 a 17/12/1981, de 18/12/1981, do CODIN/CONSEG da Coordenação de Informação da Secretaria de Estado da Segurança Pública de MG, fl. 9. Dossiê 50-H-84- 5102. DEOPS/SP, DAESP.

${ }^{897}$ Matéria "Os negros queriam continuar protestando" In Revista do MNU, n. 4, julho e agosto de 1981, fl. 3. Sumário Semanal n. 27, entre 18 a 24/9/1981, de 25/9/1981, do CODIN/CONSEG da Coordenação de Informação da Secretaria de Estado da Segurança Pública de MG, fl. 12. Dossiê 50-H-84-4848. DEOPS/SP, DAESP.

${ }^{898}$ Revista do MNU, n. 4, julho e agosto de 1981, fl. 13. Sumário Semanal n. 27, entre 18 a 24/9/1981, de 25/9/1981, do CODIN/CONSEG da Coordenação de Informação da Secretaria de Estado da Segurança Pública de MG, fl. 22. Dossiê 50-H-84-4848. DEOPS/SP, DAESP.
} 
Segundo documentação policial, militante representado o MNU esteve presente na $1^{\text {a }}$ Convenção Nacional da Convergência Socialista. ${ }^{899}$ Assim, os representantes dos movimentos negros buscavam ter voz e atuação em outros setores sociais para ampliar o debate das questões que lhes afligiam. "Solidarizam-se com qualquer luta de setores populares da sociedade brasileira que visa a real conquista de seus direitos políticos, econômicos e sociais. " ${ }^{900}$ Estratégia que visava abrir espaços na sociedade brasileira, obter reconhecimento da necessidade de suas reivindicações e aumentar o número de seus militantes e simpatizantes. O MNU de Minas Gerais propunha que "Os militantes devem se engajar nos movimentos que já existem, levando lá a questão racial." 901

\section{Mulheres}

A mobilização das mulheres dos movimentos negros trouxe naturalmente um diálogo com o movimento feminista, como exemplo a coluna para as mulheres negras no jornal Mulherio do Rio de Janeiro, que discutia a situação de exploração extrema a que as mulheres negras sofriam (e ainda sofrem) na sociedade brasileira. ${ }^{902}$

\footnotetext{
${ }^{899}$ Juntada de informações sobre o MNUCDR. Dossiê 52-Z-0- 26882. DEOPS/SP, DAESP.

${ }^{900}$ Informação n. 352 da IV COMAR, de 15/12/1978. In Juntada de Informações da Divisão de Informações do DEOPS, fl 2. Dossiê 52-Z-0- 26882. DEOPS/SP, DAESP.

${ }^{901}$ Sumário Semanal de Informações n. 35 do CODIN/COSEG, entre 27/8 a 2/9/19782, de 3/9/1982, fl. 25. Dossiê 50-H-84- sem número. DEOPS/SP, DAESP.

902 Segundo observação de agente infiltrado no III Congresso Nacional do MNU, quando a militante do Rio de Janeiro Lélia descrevia as atividades em sua cidade. Informe confidencial n. 89 da CONSEG/MG, de 19/04/1982, fl.3. OS 1157 p. 218 C. DEOPS/SP. DAESP.
} 


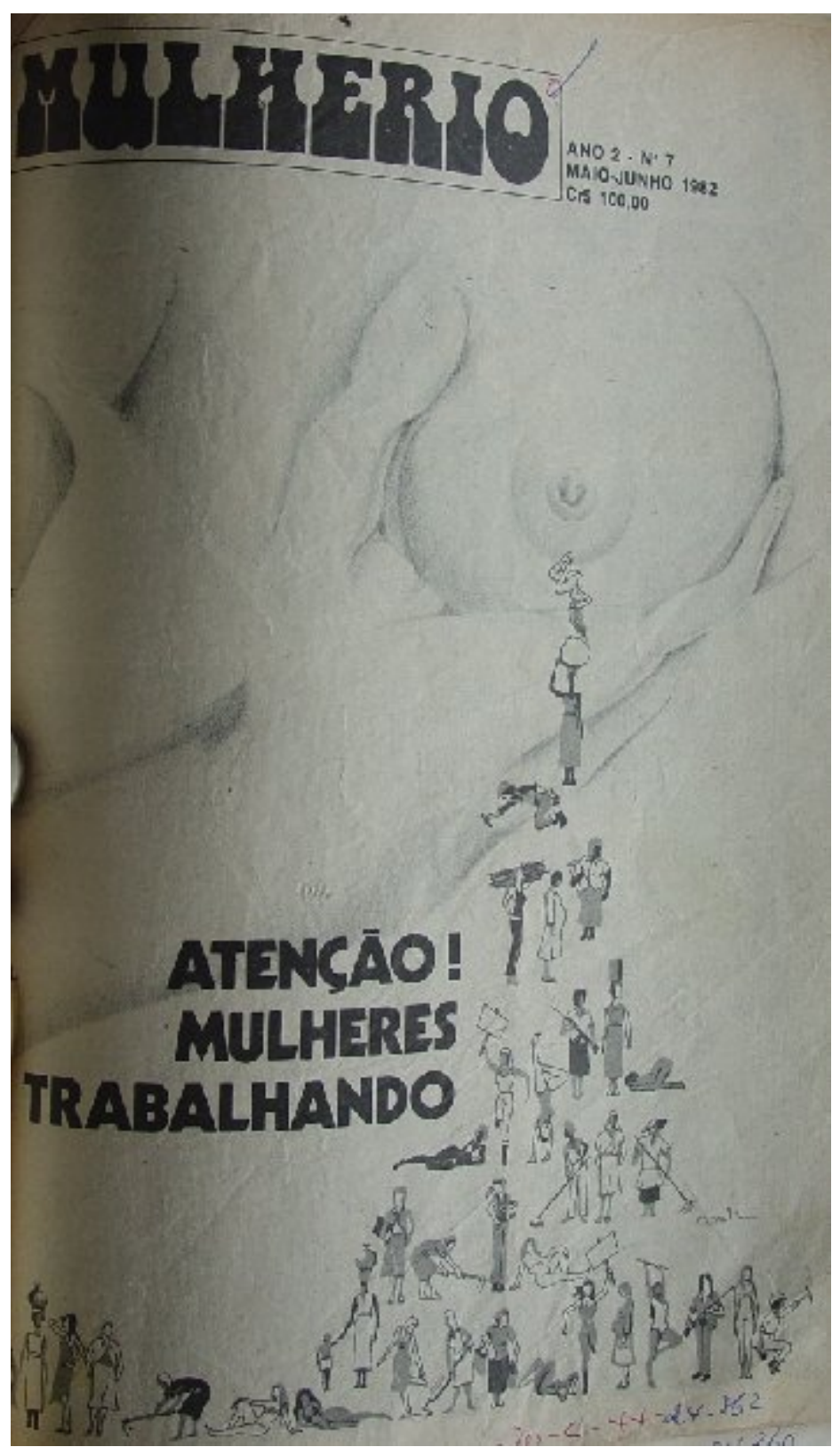

Capa periódico Mulherio, de 1982, com representações de vários tipos de mulheres.

${ }^{903}$ Capa periódico Mulherio, Ano II, n. 7, maio-junho de 1982. Dossiê 20-C-44- 24362. DEOPS/SP, DAESP. 
Neste periódico apresentava-se a matéria "E a trabalhadora negra, cumé que fica?" da importante militante negra Lélia Gonzalez. ${ }^{904}$ Nesta matéria Lélia apresentava a questão do trabalho sob o viés racial e de gênero, ressaltando o quanto a mulher negra sofria dificuldades maiores em relação a esse setor, ganhando menos e trabalhando mais. Obtendo a mulher negra uma tríplice discriminação: social, racial e sexual.

A charge de Henfil presente no periódico apresenta síntese das permanências do período escravagista nas relações de trabalho:

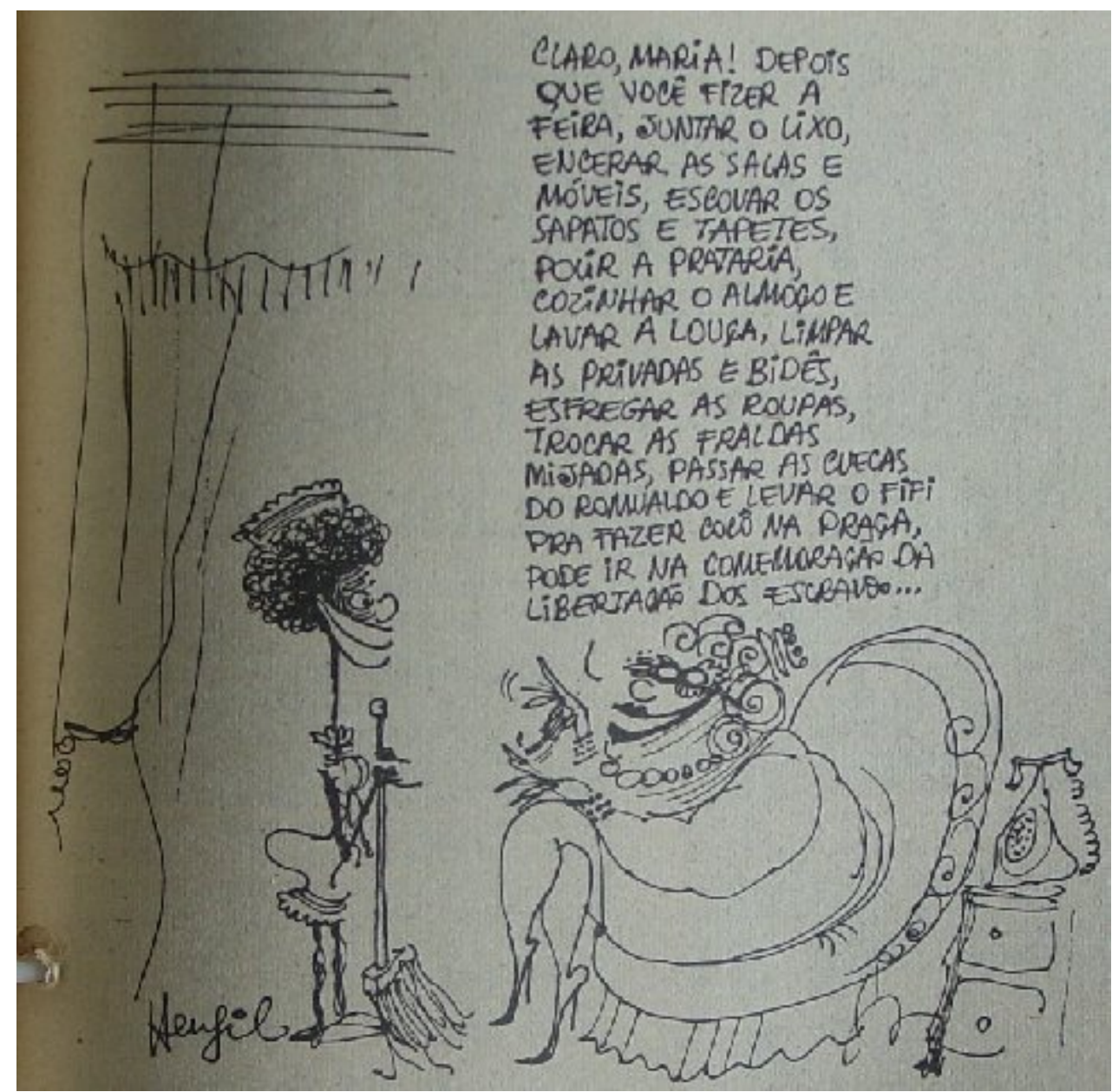

Charge de Henfil no periódico Mulherio, de 1982.

${ }_{904}$ Mulherio, Ano II, n. 7, maio-junho de 1982, p. 9. Dossiê 20-C-44- 24362. DEOPS/SP, DAESP.

${ }^{905}$ Mulherio, Ano II, n. 7, maio-junho de 1982, p. 9. Dossiê 20-C-44- 24362. DEOPS/SP, DAESP. 
Por sua vez o periódico Sinba apresentava reflexão e provocação do papel da mulher nos movimentos negros daquele período, década de 1970, chamando a participar deste e organizar suas reivindicações. ${ }^{906}$ Como destacava o Io Encontro de Mulheres Negras em Belo Horizonte, com seu material de divulgação, “Ser negra e mulher no Brasil é ser objeto de uma tríplice discriminação, uma vez que os estereótipos gerados pelo racismo e pelo sexismo a colocam no mais baixo nível da opressão." 907

\section{Movimento Estudantil}

O movimento estudantil foi interlocutor mais profícuo dos movimentos negros seja no nascedouro de associações de militantes afro-descendentes estudantes, ou mesmo no debate da questão racial brasileira realizada por diversas entidades estudantis. Comprovado, por exemplo, pelo Grupo Negro da PUC-SP, ou pelo Movimento Negro Universitário que organizavam nas faculdades e universidades os estudantes afro-descendentes. Ou mesmo nos debates nos locus estudantis que apresentavam a temática afro-descendente ou africana, por exemplo, o ciclo de debate contra a repressão ao negro e a violência policial. ${ }^{908}$. A própria divulgação dos eventos dos movimentos negros, como atos, reuniões e debates aconteciam nos meios estudantis. Os estudantes se faziam presente também em atos públicos contra o racismo promovido pelos movimentos negros: "Foi notada a presença de diversos estudantes da USP que participam da Convergência Socialista, revela a maioria do Curso de Ciências Sociais, ECA e um da FEA.", 909

A documentação policial a que se refere aos movimentos negros, em grande parte, encontra-se anexada aos dossiês classificados pelo código alfa-numérico do DEOPS que se destinava ao movimento estudantil. Revelando que os aparatos de informação e segurança notavam essas relações, especialmente pelo acompanhamento diário das atividades estudantis, conforme notamos pelo relatório de investigadores que monitoravam o que acontecia nas diversas faculdades da USP, desde cartazes afixados, aulas, reuniões de centros acadêmicos, etc. Tudo era devidamente vigiado e relatado.

\footnotetext{
906 “A omissão da mulher negra”, Sinba, Ano I, n. 1, Rio de Janeiro, julho de 1977, p. 3. Dossiê 50-Z-1305588. DEOPS/SP, DAESP.

907 "A discriminação da mulher negra" do Io Encontro de Mulheres Negras em Belo Horizonte. In Sumário de Informações n. 7 do CODIN/CONSEG, entre 12 a 18/2/1982, em 19/2/1982, fl. 35. Dossiê 50-H-84- sem número. DEOPS/SP, DAESP.

908 Relatório n. 506 de observação junto ao campus da USP no período matutino da Divisão de Ordem Política, de 8/8/1980. Dossiê 40-Z-10 - sem número. DEOPS/SP, DAESP.

${ }^{909}$ Relatório sobre Ato Público contra o Racismo, da Divisão de Informações do DEOPS, de 7/7/1978, fl. 2. Dossiê 50-Z-0- 14632A . DEOPS/SP, DAESP.
} 
A SBPC (Sociedade Brasileira Para o Progresso da Ciência) em suas atividades do ano de 1981 de debate acadêmico reunindo estudantes apresentou um dos tópicos sobre a situação do negro. ${ }^{910}$ Mostrando também o intenso debate científico sobre a questão racial brasileira, que também foi objeto de vigilância pelos aparatos de informação e segurança.

Esse diálogo se fez presente também nos periódicos dos estudantes. O jornal estudantil Manifestação, em edição n. 4 de janeiro de 1980, participara da denúncia do racismo na sociedade brasileira e apoiava o MNUCDR e conclamava por uma verdadeira "democracia racial". ${ }^{911}$ Os estudantes seguiam a lógica de que a melhor estratégia de luta contra o regime militar era unir todos os setores oprimidos da sociedade, principalmente através de pautas como anistia, liberdade partidária e melhores condições de vida e trabalho; os quais interessavam a diversos setores sociais. ${ }^{912}$

O periódico estudantil do Largo São Francisco Idéia apresentava reflexão sobre a situação afro-descendente por meio da matéria "Além da Segunda Abolição". ${ }^{913}$ Utilizando de uma análise marxista, especialmente a partir do estudo de Florestan Fernandes do ingresso do negro numa nova ordem econômica pós-abolição, destacava as permanências do sistema escravista brasileiro nas relações raciais. A charge do mesmo periódico revelava os meandros do racismo à brasileira, com estereótipos e estigmas no tratamento aos afrodescendentes. Nesse sentido, a participação ativa de estudantes afro-descendentes no meio estudantil traçava caminhos para diálogos com um público maior sobre as relações raciais no Brasil.

\footnotetext{
${ }^{910}$ Revista do MNU, n. 4, julho e agosto de 1981, fl. 13. Sumário Semanal n. 27, entre 18 a 24/9/1981, de 25/9/1981, do CODIN/CONSEG da Coordenação de Informação da Secretaria de Estado da Segurança Pública de MG, fl. 22. Dossiê 50-H-84-4848. DEOPS/SP, DAESP.

${ }^{911}$ Pasta Movimento Negro. CEDIC/PUC-SP.

912 Periódico Manifestação, em edição n. 4 de janeiro de 1980. Pasta Movimento Negro. CEDIC/PUC-SP.

913 "Além da Segunda Abolição" In Idéia, n. 2, Ano 1, 08/1977, p. 13. Dossiê 50-Z-13-876. DEOPS/SP, DAESP.
} 


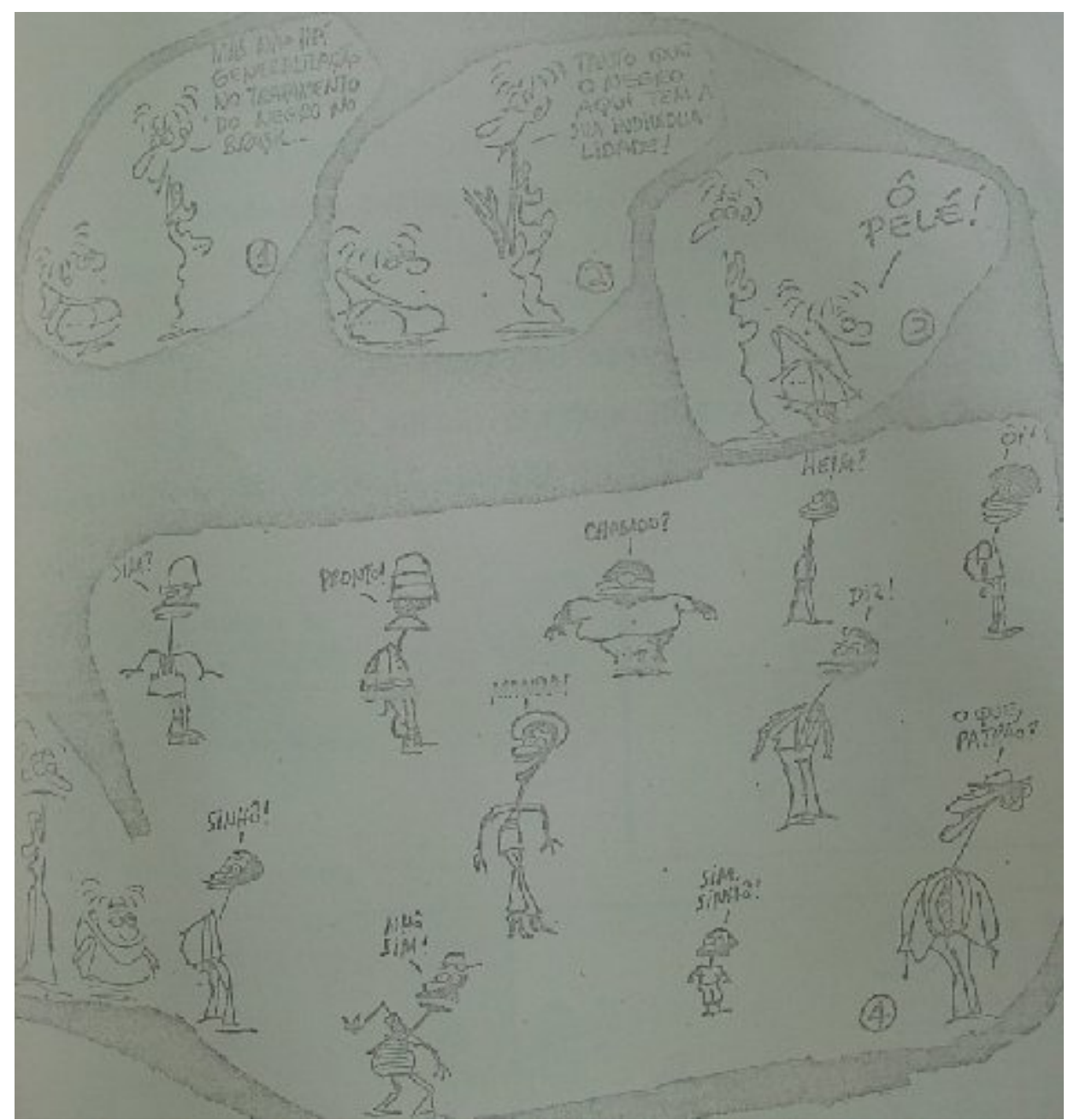

Charge representando as formas estereotipadas de denominar os afro-descendentes, no periódico Idéia, de 1977.

\section{2) A visão do MUCDR e MNU}

"É preciso se unir, se organizar e lutar" 915

"A consciência negra não é só enxergar como negro. É lutar pela causa negra." 916 (Dalmir Francisco Costa)

914 “Além da Segunda Abolição" In Idéia, n. 2, Ano 1, 08/1977, p. 16. Dossiê 50-Z-13-876. DEOPS/SP, DAESP.

${ }^{915}$ Panfleto "Dia Nacional de Denúncia Contra o Racismo" do Grupo Negro da PUC-SP, MNU e Comissão de Negros do PT. OP 0989. DEOPS/SP, DAESP. 


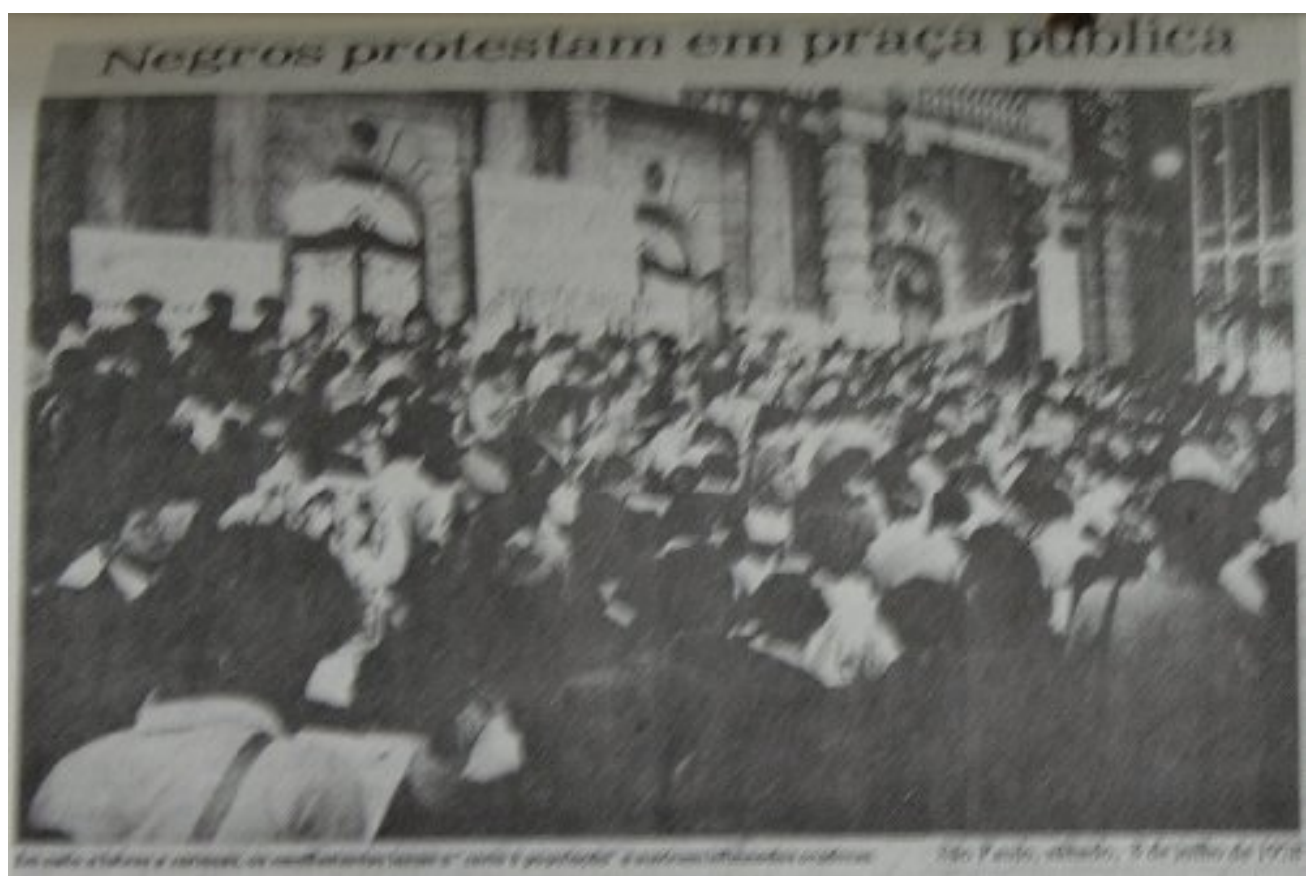

Foto da manifestação que fundou o MNUCDR, em 1978 em frente ao Teatro Municipal, publicado em jornal não identificado.

Ainda na década de 1970 os afro-descendentes tinham que reafirmar e reivindicar seus direitos de cidadãos: “O Movimento Contra a Discriminação Racial foi criado para que os direitos dos homens negros, também, sejam respeitados." ${ }^{918}$ Seu primeiro evento foi o ato público, em 7 de julho de 1978, em São Paulo, registrado na fotografia acima. Organizou-se o ato para protestar contra os casos de discriminação racial, que levou a morte de Robson Silveira Luz em decorrência de torturas numa delegacia de polícia de Guaianazes e o caso do clube de Regatas Tietê, que teria proibido o treino de alguns garotos negros no clube. Sobre o ato que lançou publicamente o MUCDR, Hamilton Bernardes Cardoso relatou:

"Havia medo, ironias e preocupações, nas entidades, nas redações de jornais brancos. E a repressão? Se a polícia atuasse seria um golpe mortal para o movimento negro, um golpe

\footnotetext{
916 Sumário Semanal de Informações n. 37, entre 27/11 a 3/12/1981, de 4/12/1981, fl 48, do CODIN/CONSEG da Coordenação de Informações da Secretaria do Estado de Segurança Pública de MG. Dossiê 50-H-84- 5068. DEOPS/SP, DAESP.

${ }^{917}$ OS 1157 p. 218 C. DEOPS/SP, DAESP.

${ }^{918}$ Carta convocatória para o ato público contra o racismo, 29/06/1978. Dossiê 50-Z-0- 14620. DEOPS/SP, DAESP.
} 
mortal para a democracia racial. Reprimir uma manifestação antiracista não seria aconselhável para um país mestiço; por outro lado o medo poderia ser instalado na Comunidade Negra. Uma faca de dois gumes. [...] o negro, hoje, pode sair para as ruas e ali discutir junto à massa negra desempregada; as lutas negras internacionais, a crise do capitalismo, o futuro que a Africa representa para o Brasil, aliado ao próprio racismo a necessidade de mostrar aos Africanos que aqui existem negros livres [...]" 919

Utilizando se de ironia, Hamilton ressaltava o receio de que a repressão impedisse a atuação do MUCDR e ao mesmo tempo, analisava as interpretações do regime militar sobre as relações raciais no Brasil que eram sustentadas inclusive na política externa brasileira. Esses aspectos tratos no capítulo anterior desta dissertação eram de alguma maneira percebido por Hamilton.

A presença dos investigadores do DEOPS em meio as manifestações do ato público contra o racismo organizado pelo MUCDR foi notada por alguns militantes negros, revelando que a ação da comunidade de informações e segurança nem sempre atingia êxito no seu disfarce. Pelas próprias características repressivas da época os movimentos sociais "aprendiam" a lidar com as técnicas empreendidas pelo DEOPS:

"O 7 de julho prosseguia. E as pessoas chegavam, cada vez em maior quantidade, cada vez mais atentas. Os policiais do Deops, à paisana, misturavam-se entre os presentes. Quietos. Havia negros que ao conhecê-los (qual negro não conhece um policial?) diziam para o companheiro: 'Até que enfim eles, aqui, são obrigados a calar, a ficar quietos e não agredir...,", 920

Os movimentos negros visavam unir esforços no sentido de combater o racismo por meio do viés político, diferentemente da estratégia predominante até então dos movimentos negros que priorizavam a sociabilidade entre afro-descendentes e resistiam a politização do debate. 921 "O MUCDR foi um projeto pensado inicialmente por negros que se autodenominavam trotskistas e que militavam na Liga Operária - depois transformada em Convergência Socialista -, organização que editava o jornal Versus." 922 O MNU investia "além do resgate da história e da tradição de afro-descendência, necessárias para a construção da identidade negra, os militantes devem também empenhar-se na disputa por espaços nas várias instâncias de poder." ${ }^{923}$ Isso se deve especialmente a base ideológica

\footnotetext{
${ }^{919}$ Versus, n. 23, de julho-agosto de 1978, p. 33. Dossiê 50-K-6- 280. DEOPS/SP, DAESP.

${ }^{920}$ Versus, n. 23, de julho-agosto de 1978, p. 33. Dossiê 50-K-6- 280. DEOPS/SP, DAESP.

${ }^{921}$ CUNHA, O. "Depois da festa: movimentos negros e 'políticas de identidade' no Brasil" In ALVAREZ, S. e DAGNINO, E. e ESCOBAR, A. Cultura e política nos movimentos sociais latino-americanos: novas leituras. Belo Horizonte: Ed UFMG, 2000, p. 336.

922 FÉLIX, J. Chic Show e Zimbabwe e a construção da identidade nos bailes black paulistanos. Dissertação de Mestrado. São Paulo: FFLCH/USP, 2000, p. 40.

${ }_{923}$ SOUZA, F. Afro-descendência em Cadernos Negros e Jornal do MNU. Belo Horizonte: Autêntica, 2005, p. 80 .
} 
do MNU ligada a própria filiação dos militantes aos partidos de esquerda. Elementos que os aproximava dos movimentos "subversivos" e, na ótica do DEOPS, tornavam-os também subversivos.

Embora, o MNUCDR apresentava em sua carta de princípios alguns de seus objetivos gerais, que não tratava de idéias de rompimento social, ao contrário traziam uma perspectiva de inclusão na sociedade brasileira e assegurar os direitos sociais:

"o combate ao racismo onde se faça presente; a luta constante contra a discriminação e preconceito racial e toda forma de opressão existente na sociedade brasileira; bem como a mobilização e organização da comunidade negra na luta de emancipação política, econômica, social e cultural." 924

Na Carta Princípios do MNU havia destaque para o seu objetivo central:

“[...] defesa do povo negro em todos os aspectos: político, economico, social e cultural, através de maiores oportunidades de emprego, melhor assistência à saúde, à educação e à habitação, reavaliação do papel do negro na História do Brasil, valorização da cultura negra e combate sistemático à sua comercialização, folclorização e distorção; extinção de todas as formas de perseguição, exploração, repressão e violência; e liberdade de organização e de expressão do povo negro [...]", 925

Dentro de uma perspectiva de integração social, o MNU encontrava-se aberto a participação de outros segmentos da sociedade brasileira, como apresentava em seu discurso Dalmir Francisco Costa:

"O MNU é um movimento aberto a todos, sem distinção de credo, raça, ideais politicos, etc.... O nome unificado não quer dizer união da raça negra, mas sim união de várias idéias que têm o mesmo objetivo, ou seja: abraçar a luta do povo oprimido, marginalizado, discriminado e explorado, que somos nós brasileiros, e especificamente, a luta do negro, que é discriminado como raça e como brasileiro." ${ }^{26}$

O que contrariava a visão policial de separatismo imputado pelos aparatos de informações e segurança aos movimentos negros, em especial ao MNU, embora estes utilizassem de um discurso marxista. Como na concepção de "vanguarda", alguns dos militantes do MNU entendiam que uma "vanguarda revolucionária" do movimento deveria conscientizar os afro-descendentes da sua condição e levá-los ao movimento. Por exemplo, na fala de Jorge Posadas em reunião do MNU em Minas Gerais, em 28/11/1981: “ [...] nós devemos não só traze-los ao MNU e conscientiza-los do problema da discriminação racial

\footnotetext{
${ }^{924}$ Carta do MNUCDR, p. 3 Apud SOUZA, F. Op. Cit., p. 202.

925 SANTOS, G. "A luta contra o racismo na esquerda brasileira" In IANNI, O. [et. al.] O negro e o socialismo. São Paulo: Fundação Perseu Abramo, 2005, pp. 34-35.

926 Sumário Semanal de Informações n. 37, entre 27/11 a 3/12/1981, de 4/12/1981, fl 48, do CODIN/CONSEG da Coordenação de Informações da Secretaria do Estado de Segurança Pública de MG. Dossiê 50-H-84- 5068. DEOPS/SP, DAESP.
} 
que sofrem, mas nós militantes temos de ir a eles." 927 Nesse sentido, entendia ser necessário expandir o movimento, não só a população brasileira como um todo, mas principalmente em meio aos afro-brasileiros que ainda não estavam mobilizados nas lutas anti-racistas.

Os movimentos negros, de forma geral, tinham uma intenção didática em seus impressos visando formar o pensamento dos afro-brasileiros. Dessa forma, "fazem uso de termos como conscientizar, reflexão, mobilizar, organizar, resgatar, lutar, combater, palavras de ordem que se repetem em artigos do Jornal do Mnu e em poemas e contos do CN." 928

Em auto-avaliação da sua mobilização apresentava-se como um tópico importante para seus militantes a necessidade de união: "passamos hoje por uma fase desarticulação que tem levado a um esvaziamento quase que total de nossas entidades. [...] o movimento negro ressente-se da falta de uma estrutura organizativa e política que aglutine de fato, todas as formas de luta" ${ }^{929}$ Visando avançar a luta contra a discriminação buscava-se um ação em conjunto das diversas entidades dos movimentos negros. Nesse sentido, o Grupo Negro da PUC-SP colocava que o MNU foi uma importante conquista para a organização, mas que na década de 1980 já não conseguia mais cumprir a função aglutinadora.

O representante do MNUCDR, em São Paulo, Reginaldo Bispo Pereira ${ }^{930}$ avaliando a atuação desse movimento afirmou: "existem várias correntes políticas, devendo o Movimento, por ser autônomo, acolhera todas elas." 931 O MNU em seu relatório das atividades realizadas em São Paulo, por meio de uma assembléia estadual, realizada em Campinas em 21/9/1980, apontava para uma atuação política, no entanto esta deveria ser

927 Sumário Semanal de Informações n. 37, entre 27/11 a 3/12/1981, de 4/12/1981, fl 47, do CODIN/CONSEG da Coordenação de Informações da Secretaria do Estado de Segurança Pública de MG. Dossiê 50-H-84- 5069. DEOPS/SP, DAESP.

${ }^{928}$ SOUZA, F. Afro-descendência em Cadernos Negros e Jornal do MNU. Belo Horizonte: Autêntica, 2005, p. 64.

${ }_{929}$ Boletim III do Grupo Negro da PUC-SP, p. 16. Pasta Movimento Negro. CEDIC/PUC-SP.

${ }^{930}$ Reginaldo Bispo Pereira era $1^{\circ}$ secretário da Associação de Servidores da UNICAMP, membro da Comissão Executiva do MNU. Revista do MNU, n. 4, julho e agosto de 1981, fl. 18. Sumário Semanal n. 27 , entre 18 a 24/9/1981, de 25/9/1981, do CODIN/CONSEG da Coordenação de Informação da Secretaria de Estado da Segurança Pública de MG, fl. 27. Dossiê 50-H-84-4848. DEOPS/SP, DAESP.

${ }^{931}$ Sumário Semanal de Informações n. 27, entre 18 a 24/9/1981, de 25/9/1981, fl. 8. CODIN/CONSEG da Coordenação de Informação da Secretaria de Estado da Segurança Pública de MG, fl. 7. Dossiê 50-H-844849. DEOPS/SP, DAESP. 
autônoma e sem influências partidárias. ${ }^{932}$ Da mesma forma na III Congresso Nacional do MNU, em Minas Gerais, o militante Anilson da Bahia afirmava que "O MNU não é um partido político, ele é muito mais do que isso, portanto, não deve apoiar militantes candidatos de partidos políticos, quer seja da situação ou oposição, uma vez que vai contra seus principios básicos." 933

Embora o MNU não se comprometesse com um partido político de forma direta, obviamente que sua postura apresentava-se alinhada aos pensamentos de esquerda e, como documentação do MNU que abordava a postura político-partidária, o MNU indicava a seus militantes a recomendação de que votassem e participassem dos partidos que fossem comprometidos com as causas dos oprimidos. ${ }^{934}$

Apresentava-se uma problemática de representação no meio afro-brasileiro: "MNU reivindica para si, desde o seu surgimento no cenário político brasileiro, a condição de principal catalisador dos anseios da população negra brasileira (...)" ${ }^{935}$ Nesse sentido, buscava ser protagonista principal das decisões da população afro-descendente, mas não conseguia ampliar suas discussões para a população afro-brasileira como um "todo".

Havia uma auto-crítica de alguns militantes que entendiam que "Somos hoje um movimento sem bases políticas, isso é, sem penetração junto aqueles a quem dizemos representar." 936 Corroborando a essa visão e refletindo o porque disso, João Batista de Jesus Félix, ex-militante do MNU entre o período de 1982 a 1991 e intelectual das ciências sociais, em sua dissertação de mestrado demonstrou que o MNU encontrava-se distanciado justamente por sustentar elementos culturais e simbólicos que seus próprios militantes não participavam, visando construir uma identidade negra que reafirmasse a ascendência africana. $^{937}$

\footnotetext{
${ }_{932}$ Dossiê 50-Z-32- 4601. DEOPS/SP, DAESP.

${ }_{933}$ Informação n. 89, confidencial, do CODIN/COSEG, de 12/4/1982, fl. 11. Dossiê 50-H-84- 5507. DEOPS/SP, DAESP.

${ }_{934}$ Relatório de avaliação de 20/9/1981 do MNU de MG. In Sumário Semanal de Informações n. 15 da CODIN/COSEG, do período entre 9 a 15/4/1982, de 16/4/1982, fl. 43. Dossiê 50-H-84- 5497. DEOPS/SP, DAESP.

${ }^{935}$ FÉLIX, J. Chic Show e Zimbabwe e a construção da identidade nos bailes black paulistanos. Dissertação de Mestrado. São Paulo: FFLCH/USP, 2000, p. 15.

${ }^{936}$ Boletim III do Grupo Negro da PUC-SP, p. 17. Pasta Movimento Negro. CEDIC/PUC-SP.

${ }^{937}$ FÉLIX, J. Chic Show e Zimbabwe e a construção da identidade nos bailes black paulistanos. Dissertação de Mestrado. São Paulo: FFLCH/USP, 2000, p. 15.
} 


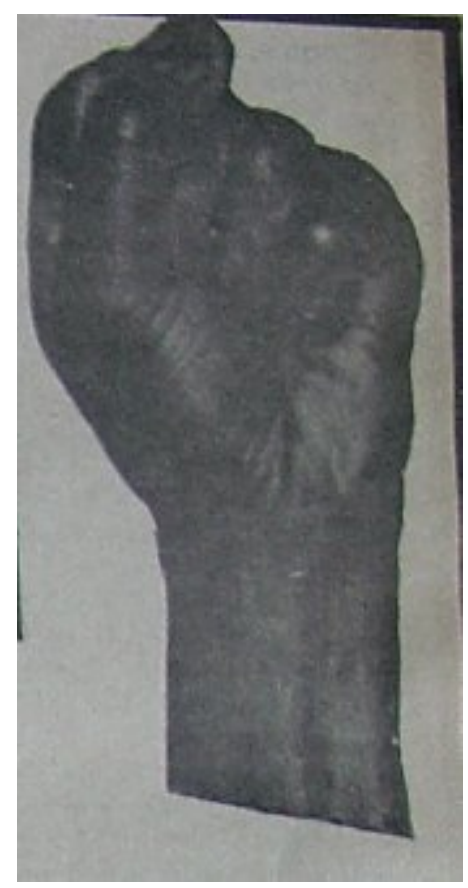

Fotografia ressaltando um punho erguido, representando a luta afro-descendente no combate ao racismo e exclusão social, em ato público contra o racismo. Fotografia de Rosa Gauditano no jornal Versus.

\section{3) Divergências e Unidade}

As posições políticas foi o ponto central nas divergências estratégicas e ideológicas das diversas expressões dos movimentos negros. Certamente as divergências entre os movimentos e os militantes a cerca de como deveria ser a sua atuação influíram na relativa liberdade que a repressão manteve a este, apenas os vigiando e não proibindo suas reuniões e encontros. "Durante as 2,5hs de discussão não houve consenso sobre qualquer meta a ser atingida ou os meios a serem empregados para definição de uma proposta razoavelmente positiva." 939

\footnotetext{
${ }^{938}$ Versus, n. 23, de julho-agosto de 1978, p. 32. Dossiê 50-K-6- 280. DEOPS/SP, DAESP.

939 Relatório de observação do $3^{\circ}$ Congresso de Cultura Negra das Américas, 24/08/1982. OP 0989, Movimento Negro vol 2. DEOPS/SP, DAESP.
} 
As dificuldades de unificação eram detectadas pelos próprios militantes que em sua organização viam seus esforços lograrem: "Não nos parece mais possível que se fale em unificação do Movimento Negro pois as convocações politicas não foram atendidas pelas entidades e nem mesmo aquelas que se propuseram a organizar o II encontro compareceram." 940

A própria formação do MUCDR já iniciou sem o comprometimento de todas as entidades dos movimentos negros. A carta convocatória ao Ato Público de 1978 contra tratamento discriminatório no Clube Tietê e a violência policial que levou a morte de Robson Silveira da Luz " foi assinada por apenas seis das 13 organizações negras que estavam articuladas nesse processo." 941

O Grupo Negro da PUC-SP avaliando a Coordenação Estadual de Entidades Negras do Estado de São Paulo procurou levantar as razões para a desarticulação entre as entidades participantes: "Uma delas é a divergência interna das entidades. [...] diferentes opções partidárias também serviram para acirrar as divergências dentro das entidades. "942 A questão partidária e política parece ter sido o grande entrave a qualquer iniciativa de unificação.

A questão político partidária foi extremamente importante para o MNU, levando até a Comissão Executiva Nacional obter como função assessorar sobre os assuntos políticospartidários. ${ }^{943}$ A política torna-se importante, especialmente, pela constatação dos militantes de que o racismo é um fato político. ${ }^{944}$ Ao mesmo tempo, notamos que esse era o ponto de fragilidade do MNU em relação a sua unidade, já que diversas tendências político-partidárias se faziam presente, tornando objetivos e estratégias dissensos. ${ }^{945}$

Em sua auto-crítica, avaliando os suas atividades até 1981, o MNU de MG colocava que "O Movimento Negro Unificado foi balançado por um esvaziamento crescente $e$

\footnotetext{
${ }^{940}$ Carta Convocatória do II Encontro Estadual em Defesa da Raça Negra. OS 1157 p. 218C. DEOPS/SP, DAESP.

${ }^{941}$ SANTOS, G. "A luta contra o racismo na esquerda brasileira" In IANNI, O. [et. al.] $O$ negro e $o$ socialismo. São Paulo: Fundação Perseu Abramo, 2005, p. 29.

${ }_{942}$ Boletim III do Grupo Negro da PUC-SP, p. 22. Pasta Movimento Negro. CEDIC/PUC-SP.

${ }^{943}$ Sumário Semanal de Informações do CODIN/COSEG, n. 16, entre 3 a 9/7/1981, de 10/7/1981, fl. 12. Dossiê 50-H-84- 4421. DEOPS/SP, DAESP.

944 Sumário Semanal de Informações n. 35 do CODIN/COSEG, entre 27/8 a 2/9/19782, de 3/9/1982, fl. 25. Dossiê 50-H-84- sem número. DEOPS/SP, DAESP.

${ }^{945}$ Em MG investigador apresentava 2 correntes políticas de dissenso: PT e PMDB. Sumário Semanal de Informações n. 35 do CODIN/COSEG, entre 27/8 a 2/9/19782, de 3/9/1982, fl. 23. Dossiê 50-H-84- 5913. DEOPS/SP, DAESP.
} 
também Por correntes políticas brigando o tempo todo pela direção do movimento." ${ }^{946} \mathrm{Na}$ busca por unidade as comissões organizadoras de cada estado comunicavam-se constantemente por meio de informes e buscavam se reunir regularmente, visando obter uma pauta, uma linguagem, um ideário comum e uno. ${ }^{947}$

As divergências eram frutos do combate de uma leitura da questão racial pela matriz de esquerda e voltada para a atuação política e uma outra leitura que valorizava o combate do racismo por meio da cultura. Assim, o Núcleo Negro Socialista obteve oposição de militantes do Centro de Cultura e Arte Negra (Cecan), fundado em 1970. ${ }^{948}$

União apresentava-se como questão central nos diversos discursos dos militantes negros, uma vez que entendiam ser a união vital para o avanço de sua luta. Por exemplo, na fala dos diversos militantes mineiros na manifestação pelo Dia da Consciência Negra em 1981 organizada pelo MNUCDR, todos os oradores citaram a importância da união. ${ }^{949} \mathrm{Da}$ mesma forma, o poema Reali/uni/dade apresenta a busca por unificação dos movimentos:
"Precisamos juntos lutar
Mas você fica com medo, parado
Carecemos a verdade falar
Porém vocêfica passivo, calado
Os dias vão entrando
E lentos passos conseguimos dar
Os meses vão terminando
E poucas barreiras conseguimos quebrar!
Você ganhou uma posição
Mas não conquistou um prato cheio
Você comprou um filão
Mas lhe embrulharam somente meio.
Você é mais um irmão
Que não larga e nem mete
Você é mais vilão
Neste show de marionetes!" 950

\footnotetext{
${ }^{946}$ Relatório de avaliação de 20/9/1981 do MNU de MG. In Sumário Semanal de Informações n. 15 da CODIN/COSEG, do período entre 9 a 15/4/1982, de 16/4/1982, fl. 23. Dossiê 50-H-845- 498. DEOPS/SP, DAESP.

${ }^{947}$ Relatório de avaliação de 20/9/1981 do MNU de MG pode-se observar a troca de informação entre os estados, principalmente MG, SP, RJ e BA. In Sumário Semanal de Informações n. 15 da CODIN/COSEG, do período entre 9 a 15/4/1982, de 16/4/1982. Dossiê 50-H-845498. DEOPS/SP, DAESP.

948 SANTOS, G. "A luta contra o racismo na esquerda brasileira" In IANNI, O. [et. al.] $O$ negro e o socialismo. São Paulo: Fundação Perseu Abramo, 2005, p. 28.

949 "Dia Nacional da Consciência Negra - Movimento Negro Unificado (MNU)" Sumário Semanal de Informações n. 36, entre 20/11 a 26/11/1981, de 27/11/1981, CODIN/CONSEG da Coordenação de Informações da Secretaria de Estado de Segurança Pública de MG, fl 37. 50-H-84- 5047. DEOPS/SP, DAESP.

${ }^{950}$ SANTOS, Aparecido Tadeu dos. Como se fosse pecado. São Paulo: Edição do Autor, 1980, p. 17. Dossiê 20-C-44-17290. DEOPS/SP, DAESP. Coletado por ocasião do Io Encontro em Defesa da Raça Negra,
} 
A percepção dos conflitos internos e das divergências políticas apresentava-se na produção impressa do MNU que buscava mobilizar os afro-descendentes para a luta: "Como produção textual de protesto e de luta, a linguagem utilizada é predominantemente de apelo e persuasão, uma vez que interessa mobilizar o leitor para reagir às situações de discriminação e racismo que continuam a acontecer." 951

No Primeiro Encontro Estadual em Defesa da Raça Negra apresenta-se a problemática da unidade não alcançada presente nos discursos dos movimentos negros:

"Em que pese a desorganização na preparação do ENCONTRO, um número de entidades que poderiam ser bem maior, ele pode representar um marco importante no avanço de nossa organização, em busca de uma resposta unitária frente a situação de opressão, de péssimas condições de vidas trabalho (sic) a que somos submetidos, e a constante expropriação de nossos valores e exploração de nossas manifestações culturais. " 952

Essa falta de unidade apresenta-se até mesmo na presença das entidades nos encontros. $\mathrm{O}$ redator do panfleto destacava que havia divisões entre os movimentos negros e que a unidade deveria ser preocupação constante. O Encontro, dirigido pelo Grupo Negro da PUC-SP, visava reunir as diversas entidades negras, seja culturais, recreativas ou políticas, visando ampliar as suas atividades. ${ }^{953}$

Mesmo tendo o MNU intenção de aglutinar os esforços, logrou seu intento ao não superar as diferenças. O discurso do MNU buscava a construção dos laços de solidariedade e união do grupo por intermédio do referencial afro, o que certamente apagava a diversidade das experiências e identidades dos afro-descendentes. Uma das principais críticas a atuação do MNU era deste movimento não conseguir atingir a maioria da população afro-descendente: "As atuais organizações, como as suas congêneres do passado, não conseguiram elaborar em conjunto uma visão do negro em relação ao meio que o cerca e nunca procuraram entender, na sua forma concreta, os problemas da massa negra no seu dia-a-dia. " 954

Um outro aspecto importante a se levar em conta nas dificuldades de união é a questão regional. O MNU visava atingir o país como um todo, no entanto sua atuação foi

realizado em 23/5/1981, na PUC-SP. Relatório diário n. 1505, entre 25 e 26/5/1981, da Divisão de Informações do DEOPS, fl. 2. Dossiê 21-Z-14-11366. DEOPS/SP, DAESP.

${ }^{951}$ SOUZA, F. Afro-descendência em Cadernos Negros e Jornal do MNU. Belo Horizonte: Autêntica, 2005, p. 104.

952 Panfleto Io Encontro Estadual em Defesa da Raça Negra, p. 1. Dossiê 20-C-44- 17287. DEOPS/SP, DAESP.

${ }_{953}$ Panfleto Io Encontro Estadual em Defesa da Raça Negra. Dossiê 20-C-44- 17287. DEOPS/SP, DAESP.

${ }^{954}$ Sinba, Ano I, n. 1, Rio de Janeiro, julho de 1977, p. 5. Dossiê 50-Z-130- 5588. DEOPS/SP, DAESP. 
diversificada nos estados. São Paulo e Rio de Janeiro ganhavam destaque nas decisões dos dirigentes do movimento, por estarem mais estruturadas. Enquanto os representantes dos outros estados não se viam contente com esse rumo. ${ }^{955}$

Com todas essas dificuldades de consenso, havia quem optasse por não se vincular totalmente aos movimentos negros e buscar uma atuação independente. Segundo relatório policial, alguns ativistas do MNU mantinham uma militância independente desse movimento, apesar de participarem deste, por discordarem das posturas de alguns membros. ${ }^{956}$

\section{4) Os partidos políticos e as "comissões de negros"}

Havia uma desconfiança de setores dos movimentos negros em relação às ações de políticos voltados para a comunidade negra, como apresentado no Jornegro sobre o projeto de uma lei que fizesse uma substituição da ineficaz lei anti-racista Afonso Arinos: "Evidentemente, esta proposta tem um objetivo político, principalmente porque no próximo ano, ao que tudo indica, teremos eleições. Foi também às vésperas de uma eleição que, por proposta do parlamentar de mesmo nome, surgiu a Lei Afonso Arinos. "957 Apesar dessa desconfiança houve algumas parcerias com determinados partidos políticos com as chamadas Comissões de Negros integrantes destes partidos.

As comissões de negros nos partidos políticos fazem parte também do "campo de ação das lutas democratizantes se estende para abranger não só o sistema politico, mas também o futuro do 'desenvolvimento' e a erradicação de desigualdades sociais tais como as de raça e gênero, profundamente moldadas por práticas culturais e sociais." 958 Os movimentos negros, assim como outros movimentos sociais, trouxeram demandas sociais que foram apreendidas por alguns partidos políticos que buscavam construir um discurso assentado na democracia. A proximidade dos movimentos negros, em especial o MNU, com partidos e tendências políticas de esquerda foi intensa, gerando influências mútuas. Os militantes participantes dos movimentos negros possuem outras identificações que

\footnotetext{
${ }^{955}$ Informação n. 350 confidencial, da $2^{\text {a }}$ Seção da Aeronáutica, de 15/12/1978, fl. 2. Dossiê 50-D-26- 5922. DEOPS/SP, DAESP.

${ }^{956}$ Relatório da Divisão de Informações do DEOPS. Dossiê 21-Z-14- 15182. DEOPS/SP, DAESP.

957 Jornegro n. 12, Ano 4, 1981, p. 5. In Dossiês 20-C-44- 17284. DEOPS/SP, DAESP.

958 ALVAREZ, S. e DAGNINO, E. e ESCOBAR, A. Cultura e politica nos movimentos sociais latinoamericanos: novas leituras. Belo Horizonte: Ed UFMG, 2000, p. 16.
} 
influíram em aproximações com outros segmentos sociais com outros movimentos, entre eles partidos políticos.

Com as manifestações do MNU a partir de 1978, os partidos reagiram e inseriram a temática do racismo em seus programas. ${ }^{959}$ Importante ressaltar também a atuação dos políticos afro-descendentes que realizavam uma ligação entre os movimentos negros e os partidos, como Benedito Cintra que se fazia presente nos atos públicos e debates promovidos pelos movimentos negros, ao mesmo tempo em que atuava como vereador do PMDB. ${ }^{960}$ Representantes dos movimentos negros, como Lélia Gonzales, participaram da Convenção Nacional do Partido dos Trabalhadores (PT), em 1981, o que certamente propiciou a constituição da Comissão de Negros nesse partido. ${ }^{961}$

Segundo a polícia, “Os programas preconizados pelo Partido Democrático Trabalhista (PDT) e pelo Partido dos Trabalhadores (PT), exemplificam em parte a introdução de um novo alinhamento no que tange ao relacionamento com as bases." ${ }^{962}$ Assim, esse partidos dialogavam com os movimentos daquele período, visando fortalecer laços com as bases.

Em contrapartida, a ação por meio das Comissões de Negros, os afro-descendentes buscavam uma atuação política com ingresso de políticos que lutassem pelas causas dos afro-descendentes: "Entendemos que nosso papel na luta parlamentar é basicamente impulsionar a organização do conjunto dos oprimidos, onde o negro é maioria. " 963

A participação efetiva em partidos políticos relacionava-se com a necessidade dos ativistas negros em participar das decisões do sistema político, ao mesmo tempo que sensibilizaria a sociedade brasileira para a situação social desigual dos afro-descendentes.

\footnotetext{
959 Relatório de avaliação de 20/9/1981 do MNU de MG. In Sumário Semanal de Informações n. 15 da CODIN/COSEG, do período entre 9 a 15/4/1982, de 16/4/1982, fl. 19. Dossiê 50-H-845498. DEOPS/SP, DAESP.

${ }^{960}$ Mensagem sobre Sumário de Informações n. 035/4 sobre Ato Público do MNU, de 13 de maio de 1981. Dossiê 50-D-18- 2850. DEOPS/SP, DAESP. Ou em Mensagem n. 2EM/PM - 445/1, Sumário de Informações n. 072/4, de 20/11/1980. Dossiê 20-D-18- 2811. DEOPS/SP, DAESP. Ou no Io Encontro em Defesa da Raça Negra na PUC-SP, em 23/05/1981. Relatório da Divisão de Informações, de 24/05/1981. Dossiê 21-Z-1411364. DEOPS/SP, DAESP.

${ }^{961}$ Sumário Semanal de Informações n. 27, entre 18 a 24/9/1981, de 25/9/1981, fl. 8. CODIN/CONSEG da Coordenação de Informação da Secretaria de Estado da Segurança Pública de MG, fl. 7. Dossiê 50-H-844849. DEOPS/SP, DAESP.

962 Sumário Semanal de Informações n. 30, entre 9 a 15/10/1981, CODIN/CONSEG da Coordenação de Informações da Secretaria de Estado da Segurança Pública de MG, 16/10/1981, fl. 17. Dossiê 50-H-84- 4958. DEOPS/SP, DAESP.

${ }^{963}$ Dossiê 50-H-84- 5504. DEOPS/SP, DAESP.
} 


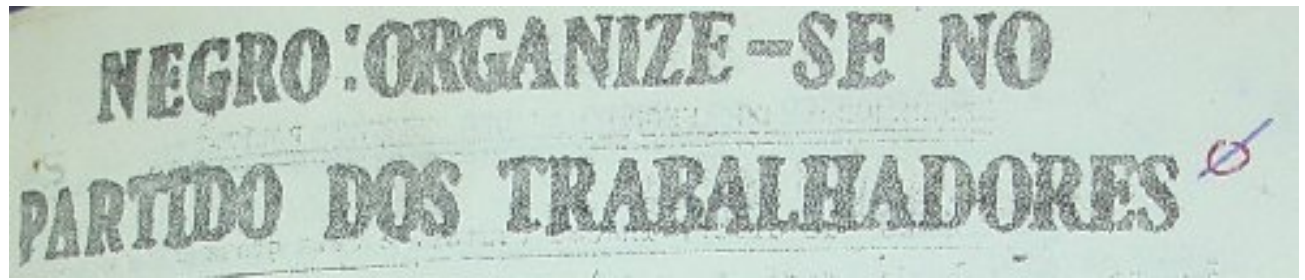

Destaque de parte do panfleto que convocava os negros a participarem do PT, panfleto da Comissão de Negros do PT, em 1981.

$\mathrm{Na}$ "Proposta de pontos de luta sobre a questão do negro", a Comissão de negros do PT ressaltava que a discriminação racial é um dos meios de manutenção do poder da "burguesia branca" e fazia a crítica à "democracia racial” identificando-a como uma forma de mascarar a opressão racial. ${ }^{965}$

Em proposta de definição dos pontos de luta sobre a questão do negro, de 9/12/1981, a Comissão de Negros do PT, analisando os mecanismos de manutenção dos privilégios da classe dominante do país, apontava a discriminação racial como um desses mecanismos que separariam brancos e negros, impossibilitando a união contra o "inimigo em comum". Destacava também a ideologia da "democracia racial" como forma de mascarar a opressão racial decorrente das discriminações. E para a Comissão, seria justamente a ideologia da "democracia racial" que impediria setores das esquerdas de perceberem a importância da questão racial brasileira. ${ }^{966}$

Para compreendermos o interesse desse partido pelos afro-descendentes, faz-se necessário retomar a formação do PT, que buscava contemplar os diversos segmentos espoliados da sociedade brasileira, entre eles os afro-descendentes:

"A idéia do Partido dos Trabalhadores surgiu com o avanço e o fortalecimento desse novo e amplo movimento social que, hoje, se estende das fábricas aos bairros, dos sindicatos às Comunidades Eclesiais de Base, dos movimentos contra a carestia às associações de moradores, do movimento estudantil e de intelectuais às associações profissionais; do

\footnotetext{
${ }_{964}$ Parte do panfleto da Comissão de Negros do PT, 9/12/1981. Dossiê 20-C-44- 23972. DEOPS/SP, DAESP.

${ }^{965}$ Dossiê 50-H-84- 5505. DEOPS/SP, DAESP.

${ }^{966}$ Dossiê 20-C-44- 23972. DEOPS/SP, DAESP.
} 
movimento dos negros ao movimento das mulheres e ainda outros como os que lutam pelos direitos das populações indígenas." 967

Dessa forma, o PT nascia das lutas populares e buscava dialogar constantemente com estes movimentos de cujos participantes auxiliaram a fundar o partido. Em seu plano de ação o PT destacava entre suas prioridades o item 7: “apoio aos movimentos de defesa dos direitos das mulheres, negros e índios. " 968

Segundo a resolução política da $1^{\mathrm{a}}$ reunião ampliada da comissão de negros do $\mathrm{PT}$, de 1/10/1981 destacava-se:

"A existência de uma opressão particular que atinge os trabalhadores negros, o racismo, coloca para o PT, a necessidade de organização desses trabalhadores para a luta contra essa opressão e determina que o Partido responda essa questão, organizando e armando politicamente o conjunto de seus militantes, em particular os negros, para a luta contra toda discriminação, econômica, social, política, e racial." 969

A constatação do racismo permeando as relações de trabalho levou ao PT formular o seu combate como estratégia para desenvolver a organização da classe trabalhadora contra as formas de opressão do capitalismo. ${ }^{970}$

O desemprego que assolava o país, em especial os afro-descendentes, apresentava-se como temática explorada pela Comissão de Negros do PT. Os dados do IBGE de 1976 foram posteriormente utilizados pela Comissão para demonstrar que os afro-descendentes ocupavam empregos menos valorizados e possuíam menores remunerações, evidenciando a marginalização dos negros no mercado de trabalho. Dessa forma, a principal bandeira da comissão era o combate do racismo presente na admissão dos empregos. ${ }^{971}$

Temáticas dos movimentos negros também se fizeram presentes no discurso da Comissão dos Negros no PT, como a temática central da violência policial, o " $\underline{\text { Partido dos }}$ Trabalhadores deve colocar a luta contra a violência policial no centro de suas preocupações (...)" 972

A Comissão de Negros do PT, contemplava essa temática em seu material de divulgação, como na charge que mostra uma relação intrínseca entre a violência policial e o

\footnotetext{
967 BERBEL, M. Partido dos Trabalhadores: tradição e ruptura na esquerda brasileira (1978-1980). Dissertação de mestrado. São Paulo: FFLCH/USP, 1991, p. 12.

${ }^{968}$ BERBEL, M. Op. Cit., p. 130.

${ }^{969}$ Dossiê 50-H-84- 5505. DEOPS/SP, DAESP.

${ }^{970}$ Dossiê 50-H-84- 5505. DEOPS/SP, DAESP.

${ }^{971}$ Panfleto Comissão de Negros do PT, 9/12/1981, p. 2. Dossiê 20-C-44- 23972. DEOPS/SP, DAESP.

${ }^{972}$ Dossiê 50-H-84- 5505. DEOPS/SP, DAESP.
} 
racismo evidente em toda e qualquer manifestação afro-descendente, de caráter político, cultural ou social.

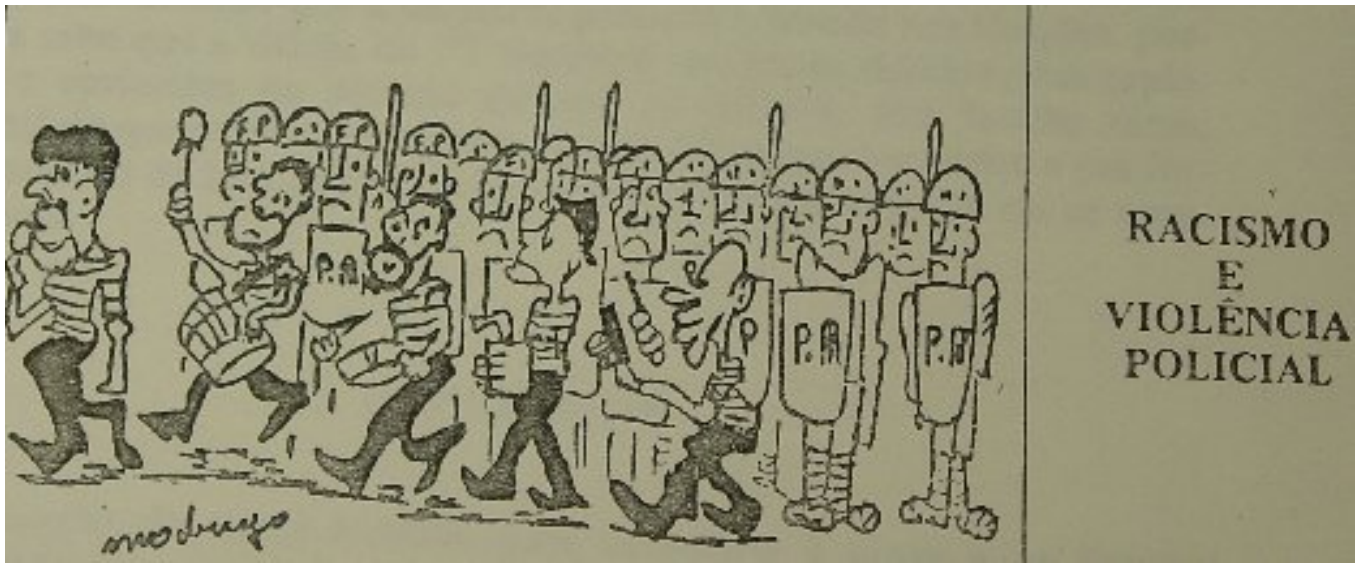

Charge ressaltando a violência policial contra os afro-descendentes presente em documentação da Comissão de Negros do PT, em 1982.

A Comissão de Negros do PT constatava que "A violência policial tem suas raízes nas formas de repressão utilizadas pelas classes dominantes do País a fim de desbaratar todo tipo de organização popular contra a exploração, desde a repressão aos escravos fugidos até a utilização constante de prisões arbitrárias, torturas e mortes." 974

A atuação de esquadrões da morte, face ilegal e mais exacerbada da violência policial, era vista pela Comissão como: “o meio da (sic) que a burguesia se utiliza para controlar a explosividade da situação marginal em que se encontra o povo negro, desde a abolição da escravatura, e que os governos militares só fizeram acentuar." $975 \mathrm{Ou}$ seja, a Comissão compreendia que essa violência era para impedir a organização dos afro-descendentes a lutarem contra a opressão.

A mulher também obteve espaço nos debates da Comissão de Negros do PT salientando que o trabalho doméstico, composto em sua maioria por mulheres negras, era uma forma de

973 “O negro e o PT" Livreto da Comissão de Negros do PT, setembro de 1982. Pasta Movimento Negro. CEDIC/PUC-SP.

${ }_{974}$ Panfleto Comissão de Negros do PT, 9/12/1981, p. 2. Dossiê 20-C-44- 23972. DEOPS/SP, DAESP.

${ }^{975}$ Panfleto Comissão de Negros do PT, 9/12/1981, p. 3. Dossiê 20-C-44- 23972. DEOPS/SP, DAESP. 
subemprego, sem garantia dos direitos trabalhistas. ${ }^{976}$ Em charge no seu material de divulgação a Comissão do PT apontava que a mulher negra tinha de enfrentar um duplo estigma, por ser mulher e por ser negra.

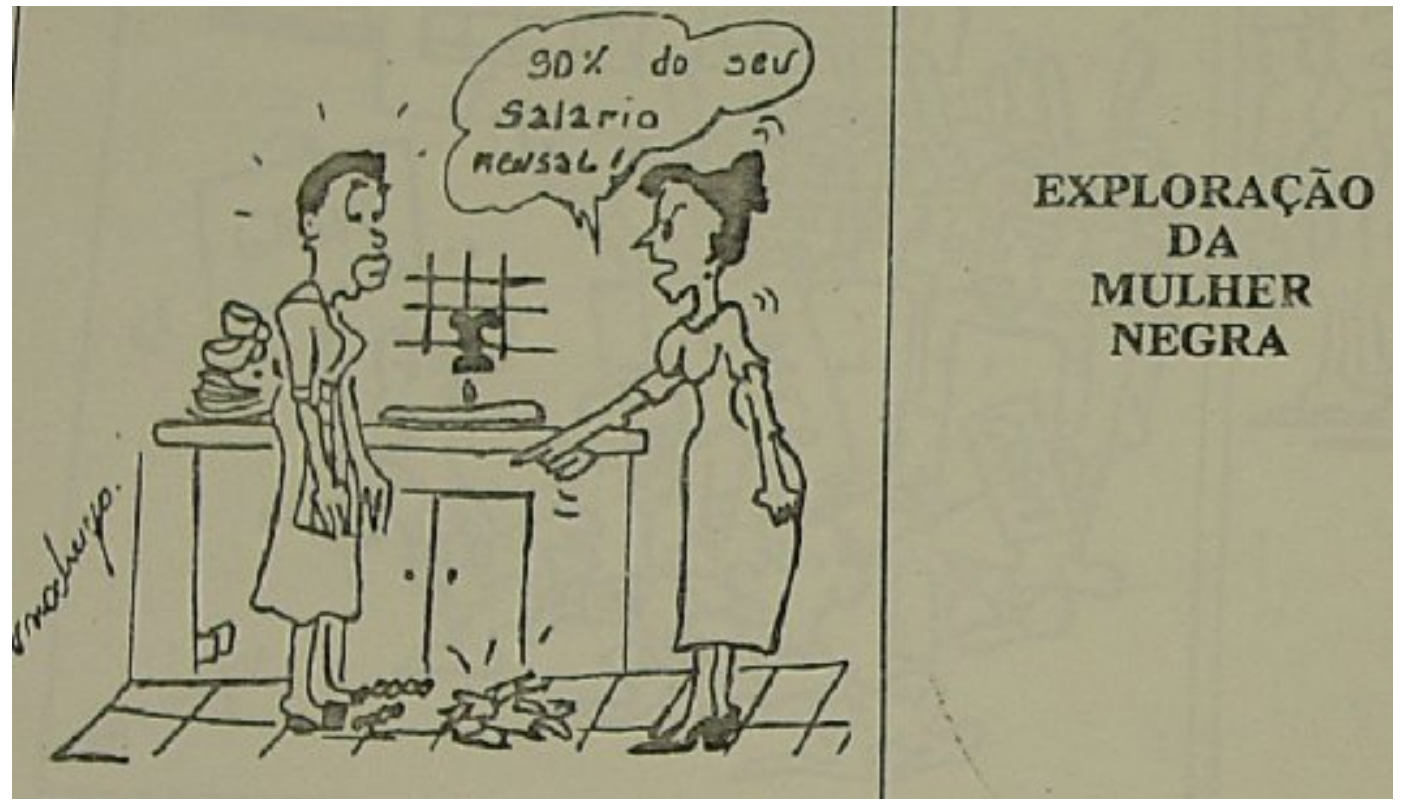

Charge ressaltando a exploração do trabalho da mulher negra no Brasil na documentação da Comissão de Negros do PT, em 1982.

A Comissão de Negros do PT defendia, já na década de 1980, a incorporação da História da África nos currículos escolares, ansiando pela valorização do afro-descendente, sua origem, cultura e história. A importância da incorporação dessa temática no sistema de ensino brasileiro se dava no sentido de conceber a educação como um instrumento de "libertação" e não de "alienação". Além disso, na luta contra o imperialismo a Comissão de Negros do PT defendia as lutas dos oprimidos do mundo todo, especialmente os da África.

\footnotetext{
${ }^{976}$ Dossiê 50-H-84- 5505. DEOPS/SP, DAESP.

977 “O negro e o PT" Livreto da Comissão de Negros do PT, setembro de 1982. Pasta Movimento Negro. CEDIC/PUC-SP.
} 
978 Além disso, a Comissão se engajava na luta anti-apartheid, a favor do rompimento de relações com a África do Sul. ${ }^{979}$

Exatamente por ser um partido dos trabalhadores, a principal temática da Comissão de Negros do PT foi a questão do trabalho. Assim a incidência do racismo no mundo do trabalho apresentava-se como o principal foco de debates, denunciando inclusive o racismo que incidia sobre os afro-descendentes. "Além do atraso social, econômico, cultural e político, conseqüencia do processo de escravidão, o negro sofre ainda as malezas do racismo, ideologia herdada do regime escravocrata, que a Abolição da Escravatura vestiu com nova roupagem." 980 Nesse sentido, a Comissão constatava que o desemprego, atingia mais os afro-descendentes, que também tinham menor renda, eram mais vulneráveis à violência policial e viviam em péssimas condições de vida.

No que concerne ao tema do trabalho vale reproduzir a charge a seguir que trata do eufemismo da "boa aparência" na seleção de empregados, questão permanentemente denunciada pelos movimentos negros:

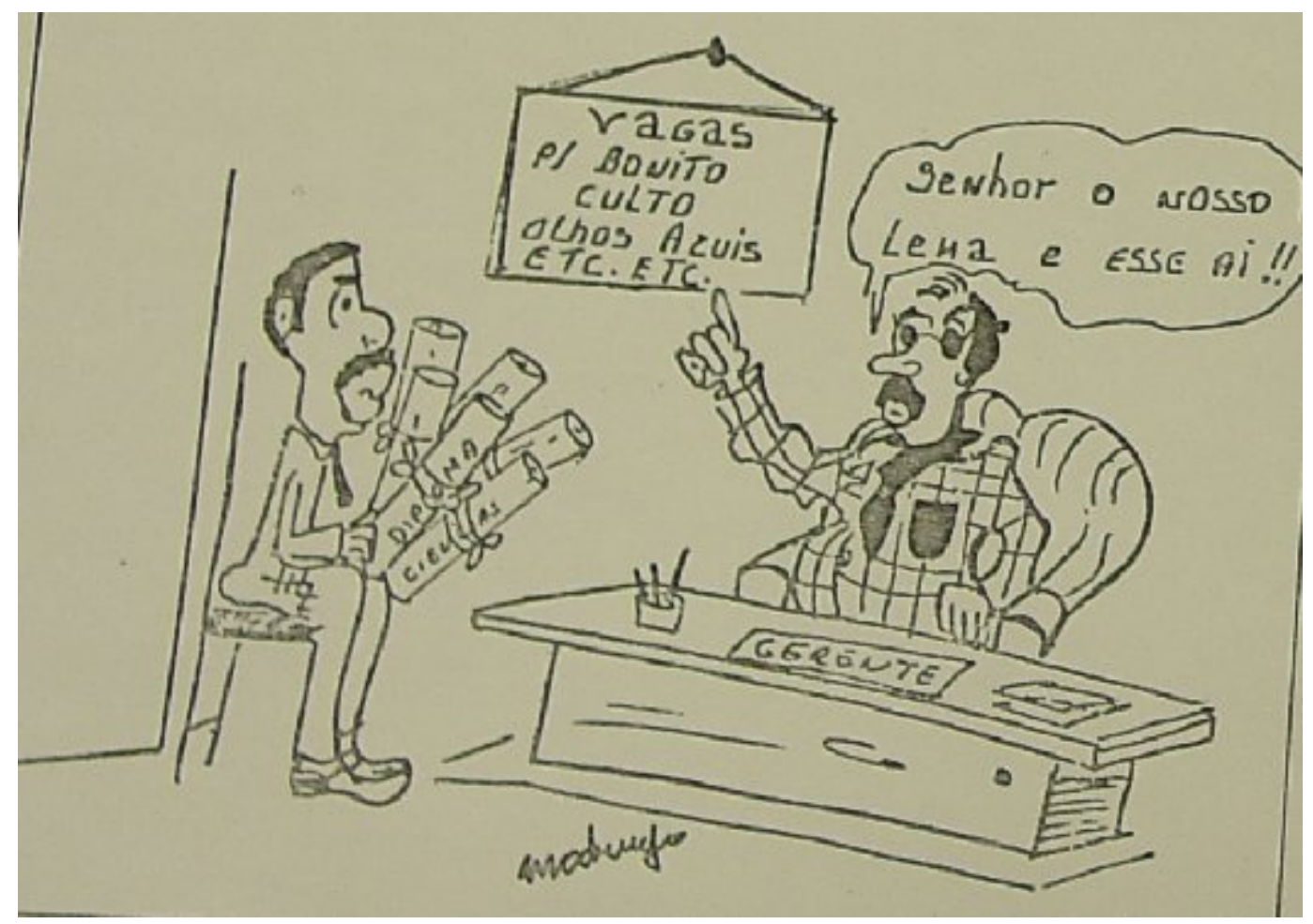

978 “O negro e o PT" Livreto da Comissão de Negros do PT, setembro de 1982. Pasta Movimento Negro. CEDIC/PUC-SP.

${ }_{979}$ Panfleto Comissão de Negros do PT, 9/12/1981, p. 4. Dossiê 20-C-44- 23972. DEOPS/SP, DAESP.

980 "O negro e o PT" Livreto da Comissão de Negros do PT, setembro de 1982, p. 5. Pasta Movimento Negro. CEDIC/PUC-SP. 
Charge que questiona o quesito "boa aparência" dos anúncios de emprego, ressaltando a exclusão dos afro-descendentes do mercado de trabalho independente de sua formação, em material da Comissão de Negros do PT, em 1982.

Apesar de uma análise centrada na luta de classes, a Comissão atribuía importância ao aspecto racial para a compreensão das desigualdades sociais e buscava contemplar as diversas reivindicações dos movimentos negros.

No panfleto "O MNU e o jogo eleitoral de 82" 982 ressaltava que "A partir de 78, com a emergência do movimento dos trabalhadores por um caminho próprio para poder construído democraticamente a partir de setores que sofrem a opressão de forma direta, a comunidade negra começou a entender que seus interesses são os mesmos das classes oprimidas. " ${ }^{983}$ Este panfleto refletia a preocupação do MNU em ter parlamentares negros que representassem os interesses da sua população. Também revelava uma preocupação com as Comissões de Negros: "No atual jogo eleitoral, alguns partidos políticos, ao se aperceberem da limitada consciência política e racial a que está submetida a maioria da população negra, tentam utiliza-la, incentivando o surgimento de um 'Movimento Negro' segundo a orientação ideológica e política dos próprios partidos." ${ }^{984} \mathrm{Nessa}$ iniciativa o MNU considerava a utilização dos afro-descendentes como massa de manobra ou mesmo como cabos-eleitorais de partidos políticos. Aliás, o MNU tinha uma relação tensa em relação aos candidatos de 1982, principalmente porque na eleição anterior, de 1978, não obteve retorno dos políticos que apoiou. Além disso, as divergências político-partidárias no seio do MNU apresentavam dificuldades no relacionamento com os partidos políticos,

\footnotetext{
981 “O negro e o PT” Livreto da Comissão de Negros do PT, setembro de 1982, p. 5. Pasta Movimento Negro. CEDIC/PUC-SP.

${ }^{982}$ Esse documento foi citado na observação de agente infiltrado no III Congresso do MNU. Informe confidencial n. 89 da CONSEG/MG, de 19/04/1982, fl.9. OS 1157 p. 218 C. DEOPS/SP. DAESP.

${ }_{983}$ Dossiê 50-H-84- 5504. DEOPS/SP, DAESP.

${ }^{984}$ Dossiê 50-H-84- 5504. DEOPS/SP, DAESP.
} 
levando à busca de uma postura "neutra", o que parece não ter sido alcançado. ${ }^{985}$ A própria proximidade com o PT foi alvo de divergência entre os seus militantes: " $O$ documento sobre a 'linha politica do MNU', elaborado por REGINALDO BISPO PEREIRA, assumiu claramente as bandeiras do PARTIDO DOS TRABALHADORES (PT), o que veio a causar polêmica entre os diversos grupos... "986

Apesar do MNU se apresentar como apartidário este movimento buscava participar ativamente da vida política nacional, além de estabeleceu ligações estreitas com as esquerdas. A fala de Anilson da Bahia demonstra as tensões provocadas pelas divergências partidárias: "O MNU não é um partido político, ele é muito mais que isso, portanto, não deve apoiar militantes candidatos de partidos políticos, quer seja da situação ou oposição, uma vez que vai contra seus princípios básicos. " 987 Mais uma vez os movimentos negros, assim como na década de 1930 com a Frente Negra Brasileira, sofriam com as divergências e polêmicas em torno de sua atuação política.

Visando acentuar a independência da mobilização afro-descendente a FRENAPO, em panfleto, afirmava que congregava "militantes dos diversos partidos de oposição existentes no país." 988 Ao mesmo tempo, acentuava a participação no processo de democratização do país por meio dos partidos políticos. Mas, sobretudo, a FRENAPO alertava para os políticos oportunistas que se aproveitavam da temática afro-descendente para obterem votos. ${ }^{989}$ Faziam parte da FRENAPO os vereadores Milton Santos e Benedito Cintra, ambos do PMDB e o Genésio Arruda vereador de Carapicuíba. Assim, a FRENAPO estaria se constituindo principalmente por parlamentares negros. ${ }^{990}$

Nos debates dos movimentos negros apresentaram-se propostas de criação de um novo partido que arregimentasse a população afro-descendente. Há registro neste sentido referente ao ciclo de debates sobre a marginalização social do negro e a violência policial, em que os irmãos escritores Celso e Wilson Prudente discutiram com os membros da mesa e participantes do debate para a criação de um partido de unidade que envolvesse os negros

\footnotetext{
985 Informe confidencial n. 89 da CONSEG/MG, de 19/04/1982, fl.8 e 9. OS 1157 p. 218 C. DEOPS/SP. DAESP.

${ }_{986}$ Informe confidencial n. 89 da CONSEG/MG, de 19/04/1982, fl.3. OS 1157 p. 218 C. DEOPS/SP. DAESP.

${ }^{987}$ Informe confidencial n. 89 da CONSEG/MG, de 19/04/1982, fl.11. OS 1157 p. 218 C. DEOPS/SP. DAESP.

${ }_{988}$ Relatório confidencial sobre a FRENAPO, de 18/7/1980. Dossiê 50-Z-130- 3803. DEOPS/SP, DAESP.

${ }^{989}$ Relatório confidencial sobre a FRENAPO, de 18/7/1980. Dossiê 50-Z-130- 3803. DEOPS/SP, DAESP.

${ }^{990}$ Relatório confidencial sobre a FRENAPO, de 18/7/1980. Dossiê 50-Z-130- 3802. DEOPS/SP, DAESP.
} 
e as "demais classes operárias". A proposta partidária não agradou boa parte dos presentes, levando os irmãos aserem expulsos do debate. ${ }^{991}$

"A consciência de que a luta racial não se esgota em si mesma mas que cabe a todos os setores explorados, unidos por uma concepção de sociedade independente das classes dominantes, é uma das condições fundamentais para que nos identifiquemos com candidatos negros ou brancos." 992 Dessa forma, o que importava ao MNU em suas declarações oficiais sobre o processo eleitoral era o comprometimento com a causa da sua luta, ou seja, combater a discriminação racial. Além disso, o MNU buscava manter a autonomia política no processo eleitoral e visava ampliar seu campo de influência nas decisões políticas.

Por sua vez, avaliando o processo eleitoral de 1982, o Grupo Negro da PUC-SP, indicava que pouquíssimos candidatos negros foram eleitos. Num contexto de crise econômica do país, ainda assim, o discurso dos candidatos negros não conseguiu atingir o eleitorado. ${ }^{993}$ Nas "eleições houve um número grande de negros vinculados ao movimento que se candidataram a cargos eletivos de todos os níveis e nenhum deles se elegeu." 994 Por certo um dos aspectos que deve ser levado em conta para compreender essa questão é a falta de penetração das idéias dos movimentos negros na "massa negra", em especial, pela incidência de um conjunto de identidades políticas que não convergiam para os movimentos negros.

A atuação das Comissões de Negros nos partidos políticos era acompanhada pela comunidade de informações e segurança que enviava investigadores para observá-los, como aponta a informação n. 715B/82, de 17 de maio de 1982, sobre a sessão solene comemorativa da Lei Áurea na Assembléia Legislativa. Nesta reunião foi distribuída uma convocatória para as reuniões da Comissão de Negros do PT, de 9/12/1981. ${ }^{995}$ Mas a aproximação dos movimentos negros com os partidos políticos era mais um elemento de "subversão" que não escapava do olhar vigilante do DEOPS.

\footnotetext{
${ }^{991}$ Relatório de investigações n. 501 . OS 1157 p. 218 C. DEOPS/SP, DAESP.

${ }^{992}$ Dossiê 50-H-84- 5504. DEOPS/SP, DAESP.

${ }_{993}$ Boletim III do Grupo Negro da PUC-SP, p. 17. Pasta Movimento Negro. CEDIC/PUC-SP.

${ }^{994}$ HASENBALG, C. "O movimento negro" In Anais do Seminário O Retorno do Ator. São Paulo: FE/USP, 1991, p. 130.

${ }^{995}$ Dossiê 20-C-44- 23974. DEOPS/SP, DAESP.
} 


\section{Considerações finais}

Buscamos detectar quais as identificações político-ideológicas dos movimentos negros vigiados e, em que medida, correspondiam à classificação da polícia. Nesta busca, observamos que alguns segmentos dos movimentos negros possuíam uma identificação com o instrumental teórico "marxista". Porém, essa não era uma postura unânime, a divergência política-partidária fora uma constante entre os diversos movimentos e mesmo dentro das entidades como, por exemplo, o MNU. Mas, para as estruturas repressivas, todos os movimentos eram caracterizados como "subversivos" e, muitas vezes, taxados de “comunistas", independente de suas diferentes idéias e estratégias de ação.

A ascensão dos movimentos negros no final da década de 1970 esteve ligada ao período conhecido por "abertura política", "lenta e gradual", conduzido pelos militares como resposta às lutas de resistência. Por sua vez, ao analisar a documentação do DEOPS é justamente no final da década de 1970 e início da década de 1980 que observamos uma intensa vigilância aos movimentos negros.

Notamos que as preocupações que envolviam a comunidade de segurança e informações nessa vigilância em pleno processo de abertura se dava não apenas pelos conceitos "marxistas" que circulavam nos movimentos negros, mas também se fundamentavam na perspectiva de preservação da "democracia racial" brasileira, evitando a introdução de "antagonismo racial" pelos movimentos negros. Visando evitar conflitos dessa ordem e salvaguardar a "harmonia racial" esses movimentos eram identificados como "subversivos", aspecto presente na atuação do DEOPS desde a década de 1930. Historicamente, o regime militar apenas introduziu novos conceitos para idéias já existentes no meio policial. ${ }^{996}$

Além disso, os diálogos com outros movimentos considerados "subversivos" ampliavam a suspeição dos órgãos repressores. Os debates de mobilizações da diáspora negra e da África também levavam ao receio da influência internacional nos movimentos negros brasileiros, em especial pelo envolvimento com ações de guerrilha por parte desses movimentos internacionais, o que leva a comunidade de informações e segurança a classificá-los como "perniciosos" à ordem pública brasileira. Além disso, a análise da

\footnotetext{
${ }^{996}$ Conceitos novos como antagonismo, pressão, objetivos nacionais, entre outros que compunham o ideário da Doutrina de Segurança e Desenvolvimento que norteou o regime militar.
} 
mobilização afro-descendente no Brasil, nos EUA ou na África pelas estruturas de repressão, estava ligada ao combate ao "comunismo internacional". Assim qualquer proximidade com idéias "marxistas", ou assim classificadas, levava à vigilância e à repressão.

Os governos militares, na busca por homogeneidade social, desconsideravam a possibilidade da afirmação de uma identidade afro-brasileira. Ao contrário, o "protesto negro" nesse contexto político-social trazia à tona a desigualdade racial, pondo em xeque a massificação presente nos projetos políticos dos órgãos governamentais. Assim, a denúncia do racismo, a articulação de gestos, músicas, visuais, comportamentos, religiosidades, enfim, o cultivo de formas de representações próprias ligadas à ascendência africana, levou a formulação de uma cultura de resistência fundada em signos e símbolos identitários afrobrasileiros que ganhou ares subversivos para as autoridades policiais e militares.

O discurso militar autoritário que legitimava a ação policial discricionária e desmedida desenvolveu-se por meio do nacionalismo, que buscava apagar as divisões sociais ou, para ir mais longe, tentava apagar o espaço público, na medida em que negava a possibilidade de atuação crítica dos movimentos negros. Portanto, a ação de denúncia do racismo trazia à tona as desigualdades e assimetrias existentes na sociedade brasileira, o que o projeto homogenizador do regime militar buscava escamotear. Apoiado num projeto político de Segurança Nacional, os militares empreenderam o terror para calar as vozes dissonantes por meio de uma rede de estrutura complexa que vigiava e reprimia os movimentos sociais. A construção de uma política autoritária dos militares trazia como legitimação um sistema policial coercivo que utilizava a idéia de "crise social" e apelava para um sentimento patriótico exacerbado e uma pretensa necessidade de vigilância e punição dos transgressores da ordem estabelecida, visando eliminar o conflito, a diversidade e a crítica. 


\section{FONTES}

- Fundo DEOPS/SP. DAESP.

- Livros Biblioteca Academia de Polícia de São Paulo:

ALONSO, Annibal Martins. Poder de Polícia, 1954.

APOLlONIO, Luiz. Manual de polícia política e social. São Paulo: Escola de Polícia de São Paulo, 1954. ( $1^{\text {a }}$ Edição)

APOLlONIO, Luiz. Manual de polícia política e social. São Paulo: Escola de Polícia de São Paulo, 1958. (2 ${ }^{\text {a }}$ Edição)

APOLlONIO, Luiz. Manual de polícia política e social. São Paulo: Escola de Polícia de São Paulo, 1963. ( $3^{\text {a Edição) }}$

NOGUEIRA, Cobra. Manual de Investigação Policial. São Paulo: Escola de Polícia de São Paulo, 1965.

NOGUEIRA, Olyntho. Polícia Técnica. Base para a criação da Escola Brasileira de Detetives. Rio de Janeiro: Renascença, 1934.

PEStANA, José César. Manual de Organização Policial do Estado de São Paulo. (2ª edição). São Paulo: Escola de Polícia de São Paulo, 1957.

TERRA, Sylvio e CORD, Pedro. Polícia, Lei e Cultura. Rio de Janeiro: Gráfica Guarany, 1939.

WILSON, O. Administracion de la policia. México: Ed. Limusa - Wiley, 1963.

- Revistas Policiais

Arquivos:

(consultado os números entre vol. I, n. 1, $1^{\circ}$ semestre de 1941 até vol. XLII, n. 42, $2^{\circ}$ semestre de 1984)

ALVES, Lindolpho. "Poder de polícia” In Arquivos, vol. XXVI. São Paulo: Polícia Civil de São Paulo, $2^{\circ}$ semestre 1975, pp. 171-178. 
DIAS, Benedito Nunes. "O dia da polícia" In Arquivos, vol. XXIX. São Paulo: Polícia Civil de São Paulo, $1^{\circ}$ semestre de 1977, pp. 7-12.

FERNANDES, Walter. "A inquirição científica do interrogado" In Arquivos, vol. XXX. São Paulo: Polícia Civil de São Paulo, 2º semestre de 1977.

FERREIRA, Haroldo. "Do Exame Criminológico na Fase Policial” In Arquivos, vol. XXV. São Paulo: Polícia Civil de São Paulo, $1^{\text {o }}$ semestre 1975, pp. 58-72.

FERREIRA, Ivette Senise. "Fatores Criminógenos" In Arquivos, vol. 32. São Paulo: Polícia Civil de São Paulo, $1^{\circ}$ semestre de 1979, pp. 65-71.

GLAZER, Nathan. "Etnia, um fenômeno mundial” In Arquivos, vol. XXVIII. São Paulo: Polícia Civil de São Paulo, 1976, pp. 203-216.

MEIRELLES, Hely Lopes. "O poder de polícia, o desenvolvimento e a segurança nacional" In Arquivos, vol. XXVII. São Paulo: Polícia Civil de São Paulo, $1^{\circ}$ semestre 1976, pp. 27-37.

MENDES, Nelson Pizzotti. "Prevenção do Delito e Proposições sobre a Política de Defesa Social no Plano de Desenvolvimento do Brasil.” In Arquivos, vol. XXVI. São Paulo: Polícia Civil de São Paulo, $2^{\circ}$ semestre 1975, pp. 217-229.

MORAES, Bismael B. "Apontamentos sobre a autoridade policial" In Arquivos, vol. 41. São Paulo: Polícia Civil de São Paulo, $2^{\circ}$ semestre 1983, pp. 5-33.

NASCIMENTO, Francisco Guimarães do. "Contra-informação" In Arquivos, vol. XXXI. São Paulo: Polícia Civil de São Paulo, $1^{\circ}$ e $2^{\circ}$ semestre de 1978, pp. 5762.

NOVAES, Joaquim Humberto de Moraes. "Modernização" In Arquivos, vol. XXVII. São Paulo: Polícia Civil de São Paulo, $1^{\circ}$ semestre 1976, pp. 5-6.

PEStANA, J. "Poder de Polícia" In Revista de Criminologia, Ano I, n. 1. São Paulo: Centro Oficial do Centro Acadêmico de Criminologia, 1954.

SALMON, Henry. "O fascismo de hoje, o comunismo de ontem” In Arquivos, vol. XXVIII. São Paulo: Polícia Civil de São Paulo, 1976, pp. 69-83. 
SILVA, Jorge Medeiros da. "Artur Ramos e o Direito Penal (Escola Brasileira)" In Arquivos, vol. XXX. São Paulo: Polícia Civil de São Paulo, $2^{\circ}$ semestre 1977, pp. 101-109.

SILVA, Oswaldo. "Poder de Polícia" In Arquivos, vol. 42. São Paulo: Polícia Civil de São Paulo, $2^{\circ}$ semestre de 1984, pp. 41-43.

VARGAS, Heber Soares. "Reflexões Epistemológicas em Criminologia" In Arquivos, vol. XXVI. São Paulo: Polícia Civil de São Paulo, $2^{\circ}$ semestre 1975, pp. 49-54.

- Revista militar

Defesa Nacional - publicado desde 10/10/1913

(consultados os números 260, 261, 264 ,265, 271 do ano de 1936; 272, 273, $274,275,276,277,278,279,281,282,283$ do ano de 1937; 349, 350, 351, $352,353,361$ de 1943; 357, 362 do ano de 1944; 647 do ano de 1973)

TOSTA, Octávio. "Problemas da América Latina. A segurança dos EUA está na América do Sul" In Defesa Nacional, Ano XLVII, n. 546. Rio de Janeiro: Ministério da Guerra, janeiro de 1960, pp. 151-158.

CARVALHO, Ferdinando. "Por que devemos lutar contra o comunismo" In $A$ Defesa Nacional, Ano 59, n. 647. Rio de Janeiro: Ministério da Guerra, jan/fev 1973, pp. 39-51.

POZZOBON, Zola. "Guerrilha Urbana” In A Defesa Nacional, Ano 59, n. 647. Rio de Janeiro: Ministério da Guerra, jan/fev 1973, pp. 79-87.

Segurança e Desenvolvimento:

(consultados os números 130 e 131 do ano de 1968; 144 do ano de 1971; 182 e 183 do ano de 1980) 
MORAES FILHO, Benjamin de. "Elementos básicos da nacionalidade as instituições" In Segurança e Desenvolvimento, Ano XVII, n. 130. Rio de Janeiro: Associação dos Diplomados da Escola Superior de Guerra, 1968, pp. 50-60.

MOTTA FILHO, Cândido. "Elementos básicos da nacionalidade - o homem” In Segurança e Desenvolvimento, Ano XVII, n. 130. Rio de Janeiro: Associação dos Diplomados da Escola Superior de Guerra, 1968, pp. 61-78.

SENGHOR, Henri Pierre Arphang. "A África: Atualidade e Perspectivas" In Segurança e Desenvolvimento, Ano XVII, n. 131. Rio de Janeiro: Associação dos Diplomados da Escola Superior de Guerra, 1968, pp. 64-81.

TORRES, Garrido. "Condicionamentos da Comunidade Lusíada" In Segurança e Desenvolvimento, Ano XVII, n. 131. Rio de Janeiro: Associação dos Diplomados da Escola Superior de Guerra, 1968, pp. 124-134.

\section{Revista Militar Brasileira}

(consultados os números entre janeiro/junho de 1975 a julho/dezembro de 1981)

BASTOS, Lígia Lessa. "Congresso Nacional Homenageia Memória das vítimas da Intentona Comunista de 1935" In Revista Militar Brasileira, Ano 66, vol. 117, n. 1,2 e 3. Rio de Janeiro: Centro de Documentação do Exército, 1980, pp. 135138.

SANCHES, Antonio Estanislau. "Guerras Revolucionárias e Insurrecionais - Breve História" In Revista Militar Brasileira, Ano LXIV, vol. CXII. Rio de Janeiro: Centro de Documentação do Exército, janeiro/março de 1978, pp. 83-90.

VEADO, Wilson. "Homenagem às vítimas de 35" In Revista Militar Brasileira, vol. 118, n. 1. Rio de Janeiro: Centro de Documentação do Exército, julho/dezembro de 1981, pp. 101-105. 
Military Review - edição brasileira publicado entre abril de 1945 a março de 1974 (consultados entre os anos de 1964 a 1974):

BAKER, Ross K. “Assistência Militar Soviética à África Tropical” In Military Review (Publicação Profissional do Exército dos EUA), vol. XLVIII, n. 7. Kansas: Escola de Comando e Estado-Maior do Exército dos Estados Unidos, julho de 1968, pp. 76-81.

BROWN, Neville. "A guerra civil na Nigéria” In Military Review (Publicação Profissional do Exército dos EUA), vol. XLVIII, n. 10. Kansas: Escola de Comando e Estado-Maior do Exército dos Estados Unidos, outubro de 1968, pp. 20-31.

CLOTFELTER, James. “Os militares na África” In Military Review (Publicação Profissional do Exército dos EUA), vol. XLVIII, n. 5. Kansas: Escola de Comando e Estado-Maior do Exército dos Estados Unidos, maio de 1968, pp. 23-31.

GANN, Lewis H. "Perspectiva militar: África Meridional" In Military Review (Publicação Profissional do Exército dos EUA), vol. LII, n. 7. Kansas: Escola de Comando e Estado-Maior do Exército dos Estados Unidos, julho de 1972, pp. $59-72$.

GIBSON, James M. (coronel do Exército dos EUA) "Seminário de Relações Raciais" In Military Review (Publicação Profissional do Exército dos EUA), vol. L, n. 7. Kansas: Escola de Comando e Estado-Maior do Exército dos Estados Unidos, julho de 1970, pp. 13-19.

KAUFFMAN, Andrew J. "Guerras de 'Libertação Nacional”" In Military Review (Publicação Profissional do Exército dos EUA), vol. XLVIII, n. 10. Kansas: Escola de Comando e Estado-Maior do Exército dos Estados Unidos, outubro de 1968, pp. 32-44.

MAZRUI, Ali A. “África na década de 70” In Military Review (Publicação Profissional do Exército dos EUA), vol. LII, n. 11. Kansas: Escola de Comando e Estado-Maior do Exército dos Estados Unidos, novembro de 1972, pp. 89-98. 
NEY, Virgil. (coronel reformado do Exército dos EUA) "Tática e Técnicas da Agitação Urbana" In Military Review (Publicação Profissional do Exército dos EUA), vol. L, n. 5. Kansas: Escola de Comando e Estado-Maior do Exército dos Estados Unidos, maio de 1970, pp. 67-74.

SADLER, Jack R. (tenente-coronel exército dos EUA) "A África Ocidental: em busca da estabilidade" In Military Review (Publicação Profissional do Exército dos EUA), vol. XLIX, n. 11 Kansas: Escola de Comando e Estado-Maior do Exército dos Estados Unidos, novembro de 1969, pp. 28-38.

STEVENSON, Charles S. "As forças armadas africanas" In Military Review (Publicação Profissional do Exército dos EUA), vol. XLVII, n. 3. Kansas: Escola de Comando e Estado-Maior do Exército dos Estados Unidos, março de 1967, pp. 18-23.

TRI, Nguyen Bao. "O exército nos países afro-asiáticos" In Military Review (Publicação Profissional do Exército dos EUA), vol. XLVII, n. 8. Kansas: Escola de Comando e Estado-Maior do Exército dos Estados Unidos, agosto de 1967, pp. 54-63.

WELCH JR., Claude E. “Intervenção Militar na África Tropical” In Military Review (Publicação Profissional do Exército dos EUA), vol. L, n. 5. Kansas: Escola de Comando e Estado-Maior do Exército dos Estados Unidos, maio de 1970, pp. 25-38.

WHITE, James S. (tenente-coronel do Exército dos EUA) "Relações Raciais no Exército" In Military Review (Publicação Profissional do Exército dos EUA), vol. L, n. 7. Kansas: Escola de Comando e Estado-Maior do Exército dos Estados Unidos, julho de 1970, pp. 03-12. 


\section{BIBLIOGRAFIA}

ADORNO, Sérgio. "Violência urbana, justiça criminal e organização social do crime" In Revista Crítica de Ciências Sociais, n. 33, outubro 1991, pp. 145150.

- "Crime, justiça penal e desigualdade jurídica: as mortes que se contam no tribunal do júri” In Revista Crítica de Ciências Sociais, n. 33, outubro 1991, pp. 132-151.

. Discriminação Racial e Justiça Criminal em São Paulo. In Novos Estudos n. 45. São Paulo: Cebrap, 1995.

ALVAREZ, Sonia. e DAGNINO, Evelina. e ESCOBAR, Arturo. Cultura e politica nos movimentos sociais latino-americanos: novas leituras. Belo Horizonte: Ed UFMG, 2000.

ALVES, Maria Helena Moreira. Estado e Oposição no Brasil (1964-1984). Petrópolis: Vozes, 1985.

ANDERSON, Benedict. Nação e Consciência Nacional. São Paulo: Ática, 1989.

. Comunidades Imaginadas. Reflexiones sobre el origen y la difusión del nacionalismo. México: Fondo de Cultura Económica, 1993.

ANDREWS, George Reid. Negros e Brancos em São Paulo (1888-1988). Bauru, São Paulo: Editora do Sagrado Coração, 1998.

APPELBAUM, Nancy ; MACPHERSON, Anne e ROSEMBLATT, Karin. Race \& Nation in Modern Latin America. North Carolina: The University of North Carolina Press.

AQUINO, Maria Aparecida. Censura, Imprensa, Estado Autoritário (1968-1978): o exercício cotidiano da dominação e da resistência: O Estado de São Paulo e Movimento. Bauru: EDUSC, 1999.

e MATTOS, M. e SWENSSON JR., W. (orgs); ARAÚJO, L. e NETO, O . (co-orgs). No coração das trevas: o DEOPS/SP visto por dentro. São Paulo: Arquivo do Estado, 2001. 
e MORAES, M. e MATTOS, M. e SWENSSON JR., W. (orgs). $A$ constância do olhar vigilante: a preocupação com o crime político. São Paulo: Arquivo do Estado, 2002.

e MORAES, M. e MATTOS, M. e SWENSSON JR., W. (orgs). O Dissecar da estrutura administrativa do DEOPS/SP - o Anticomunismo: Doença do aparato repressivo brasileiro. São Paulo: Arquivo do Estado, 2002.

e LONGHI, C. e MATTOS, M. e SWENSSON JR., W. (orgs). O DEOPS/SP Em busca do crime político. São Paulo: Arquivo do Estado, 2002.

e LESITER FILHO, A. e MATTOS, M. e SWENSSON JR., W. (orgs). $A$ Alimentação do Leviatã nos planos regional e nacional: mudanças no DEOPS/SP no pós-1964. São Paulo: Arquivo do Estado, 2002.

"História e Autoritarismo". Entrevista In Informe: edição especial 19992001. São Paulo: SDI/FFLCH/USP, 2002, pp. 105-107.

. Mudanças e permanências: ambigüidades do Estado Autoritário brasileiro pós-64.

ARENDT, Hannah. Entre o Passado e o Futuro. São Paulo: Editora Perspectiva, 1954.

ARQUIVO PÚBLICO DO ESTADO. DOPS: a lógica da desconfiança. Rio de Janeiro: Secretária de Estado de Justiça, 1996.

BACZKO, Branislaw. "Imaginação Social” In ROMANO, Ruggiero (org.) Enciclopédia Einaudi, vol 5: Anthropos - Homem. Lisboa: Imprensa Nacional e Casa da Moeda, 1985, pp. 297-332.

BAFFA, A. Nos porões do SNI. O retrato do monstro de cabeça oca. Rio de Janeiro: Editora Objetiva, 1989.

BARBOSA, Lucia e SILVA, Petrolina e SILVÉRIO, Valter. (orgs.) De preto a Afro-Descendente: trajetos de pesquisa sobre o negro, cultura negra e relações étnico-raciais no Brasil. São Carlos: EdUFSCar, 2003.

e SILVA, Petrolina. O pensamento negro em educação no Brasil. São Carlos: Editora da UFSCar, 1997. 
BARCEllos, C. Rota 66: A História da Polícia que Mata. São Paulo: Globo, 1992.

BASTIDE, Roger e FERNANDES, Florestan. Raça e Ciência I e II. São Paulo: Perspectiva/UNESCO, 1950.

BAYLEY, David. Padrões de Policiamento: Uma Análise Internacional Comparativa. São Paulo: Editora da Universidade de São Paulo, 2001.

BERBEL, Márcia Regina. Partido dos Trabalhadores: tradição e ruptura na esquerda brasileira (1978-1980). Dissertação de mestrado. São Paulo: FFLCH/USP, 1991.

BERNARDINO, Joaze. “Ação Afirmativa e a Rediscussão do Mito da Democracia Racial no Brasil" In Estudo Afro-asiático, v. 24, n. 2. Rio de Janeiro: Centro de Estudos afro-asiático, 2002, pp. 247-273. In World Wide Web:<http://www.scielo.br/scielo.php?script=sci_arttext\&pid=S0101546X200 2000200002\&lng=pt\&nrm=iso $>$. ISSN 0101-546X.

BERND, Zilá. O que é negritude. São Paulo: Brasiliense, 1988.

BITTENCOURT, M. Dois jornais às armas - trajectórias da contestação angolana. São Paulo: Veja e autor, 1999.

BOBBIO, Norberto. O conceito de sociedade civil. Rio de Janeiro: Edições Graal, 1982. . A Era dos Direitos. Rio de Janeiro: Campus, 1992. . e MATTEUCCI,N. e PASQUINO, G. Dicionário de Política. Brasília: UnB, 1999.

BRITO, Fabio Bezerra. "A ditadura militar no Brasil - livros recentes" In Estudios Interdisciplinares de America Latina y el Caribe. Tel Aviv: EIAL, vol. 12 n. 1, enero - junio 2001, pp. 157 - 165.

CAMARGO, Ana Maria de Almeida e BELLOTTO, Heloísa Liberalli. (orgs.) Dicionário de terminologia arquivística. São Paulo: Associação dos 
Arquivistas Brasileiros - Núcleo Regional de São Paulo: Secretaria de Estado da Cultura, 1996.

CANCELLI, Elizabeth. O Mundo da Violência: A polícia da Era Vargas. Brasília: EUNB, 1993.

CANCLINI, Néstor García. Culturas Hibridas: Estratégias para Entrar e Sair da Modernidade. São Paulo: EDUSP, 1997.

CARDOSO, Flamarion e MALERBA, Jurandir. (org) Representações. Contribuições a um debate transdisciplinar. Campinas: Papirus, 2000.

CARNEIRO, Maria Luiza Tucci. O Racismo na História do Brasil - Mito e Realidade. São Paulo: Ática, 1994.

. "O discurso da Intolerância - fontes para o estudo do racismo" In Fontes Históricas: Abordagens e Métodos. Assis/ SP: Faculdade de Ciências e Letras UNESP, 1996.

"Força, Medo, Liberdade: algumas coisas não combinam entre si..." in Cidadania, Verso e Reverso (vários autores). São Paulo: Imprensa Oficial, 1997/1998.

. "Os arquivos da Polícia Política Brasileira- uma alternativa para os estudos de História do Brasil Contemporâneo" Comunicação apresentada no II Congresso Internacional Historia a Debate. Santiago de Compostella, Espanha, julho de 1999.

. (org) Minorias Silenciadas. São Paulo: Edusp/Imprensa Oficial do Estado/ Fapesp, 2002.

CASTORIADIS, Cornelius. A Instituição imaginária da sociedade. Rio de Janeiro: Paz e Terra, 1982.

CERQUEIRA, Daniel e LOBÃO, Waldir. "Determinantes da criminalidade: arcabouços teóricos e resultados empíricos” In Revista Dados, v. 47, n. 2. Rio de Janeiro: IUPERJ, 2004, pp. 247 - 273.

CERTEAU, Michel. A Escrita da História. Rio de Janeiro: Forense Universitária, 1982. 
CHARTIER, Roger. A História Cultural. Entre práticas e representações. Lisboa: Difel, 1990.

CHÂTELET, François, DUHAMEL, Olivier e PISIER-KOUCHNER, Evelyne. História das Idéias Políticas. Rio de Janeiro: Jorge Zahar Editor, 1982.

CHAUÍ, Marilena. Ideologia e mobilização popular. Rio de Janeiro: Paz e Terra: Cedec, 1978.

COGGIOLA, Osvaldo. (org.) Segunda Guerra Mundial: um balanço histórico. São Paulo: Xamã e FFLCH/USP, 1995.

COSTA, Florência. "Foi ele quem prendeu José Dirceu” In Revista Isto é. São Paulo: Editora Três, 26 de janeiro de 2005.

COUTO, Ronaldo Costa. Memória viva do regime militar - Brasil: 1964-1985. Rio de Janeiro: Record, 1999.

CUNHA, Antônio Geraldo da. Dicionário etimológico Nova Fronteira da língua portuguesa. Rio de Janeiro: Nova Fronteira, 1982. (2ª edição, 1986)

DAMATTA, Roberto. Relativizando: Uma Introdução à Antropologia Social. Rio de Janeiro: Rocco, 2000.

D’ ARAÚJO, Maria Celina e SOARES, Gláucio Ary Dillon e CASTRO, Celso. (orgs). Visões do golpe: a memória militar sobre 1964. Rio de Janeiro: Relume - Dumará, 1994.

e SOARES, Gláucio Ary Dillon e CASTRO, Celso. (orgs) Os anos de chumbo: a memória militar sobre a repressão. Rio de Janeiro: Relume Dumará, 1994.

e SOARES, Gláucio Ary Dillon e CASTRO, Celso. (orgs) A volta aos quartéis: a memória militar sobre a abertura. Rio de Janeiro: Relume Dumará, 1995. e CASTRO, C. (orgs) Ernesto Geisel. Rio de Janeiro: Editora FGV, 1997.

FÉLIX, João Batista de Jesus. Chic Show e Zimbabwe e a construção da identidade nos bailes black paulistanos. Dissertação de Mestrado. São Paulo: FFLCH/USP, 2000. 
FERNANDES, Florestan. A integração do Negro na sociedade de classes. Vol. $23^{\mathrm{a}}$ ed. São Paulo: Ática, 1978.

. O negro no mundo dos brancos. São Paulo: Difusão Européia do Livro, 1972.

FERREIRA, Aurélio Buarque de Holanda. Dicionário Aurélio Século XXI. Rio de Janeiro: Nova Fronteira; Lexikon, 1999. CD-ROM.

FERREIRA, Marieta de Moraes e AMADO, Janaína. (coords.) Usos e abusos da história oral. Rio de Janeiro: Fundação Getulio Vargas, 1996.

. As reformas de base - Governo versus Congresso. In http://www.cpdoc.fgv.br/nav_jgoulart/htm/6Na_presidencia_republica/As_refo rmas_de_base.asp, sem data.

FERREIRA, Ricardo Franklin. Afro-descendente: Identidade em Construção. São Paulo: EDUC, Rio de Janeiro: Pallas, 2000.

FICO, Carlos. Reinventando o otimismo. Ditadura, propaganda e imaginário social no Brasil. Rio de Janeiro: Editora Fundação Getulio Vargas, 1997.

. Como eles agiam. Os subterrâneos da Ditadura Militar: espionagem e polícia política. Rio de Janeiro: Record, 2001.

. Além do golpe: a tomada do poder em 31 de março de 1964 e a ditadura militar. Rio de Janeiro: Record, 2004.

FOUCAULT, Michel. Vigiar e punir. Petrópolis: Vozes, 1977. . A Ordem do discurso. São Paulo: Edições Loyola, 1996.

FREYRE, Gilberto. Casa Grande e Senzala: formação da família brasileira sob o regime da economia patriarcal. Rio de Janeiro: Record, 1933.

O Mundo que o Português criou: aspectos das relações sociais e de cultura do Brasil com Portugal e as colonias portuguesas. Rio de Janeiro: José Olympio, 1940. 
FRY, Peter. "O que a cinderela negra tem a dizer sobre a 'política racial' no Brasil" In Revista USP. São Paulo: Coordenadoria de Comunicação Social USP, 1989, pp. 122-135.

FUNDAÇÃO GETÚLIO VARGAS. Dicionário Histórico-Biográfico Brasileiro. Rio de Janeiro: CPDOC, 1984. CD-ROM.

GASPARI, E., HOLLANDA, H. e VENTURA, Z. 70/80 Cultura em Trânsito. Da Repressão à Abertura. Rio de Janeiro: Aeroplano, 2000. . A Ditadura Escancarada. São Paulo: Cia das Letras, 2002. . A ditadura derrotada. O sacerdote e o feiticeiro. São Paulo: Companhia das Letras, 2003.

GINZBURG, C. Mitos, Emblemas, Sinais. São Paulo: Cia das Letras, 1989.

GOFFMAN, Erving. Estigma: notas sobre a manipulação da identidade deteriorada. Rio de Janeiro: Guanabara Koogan, 1988.

GOMES, Flávio. Negros e política (1888-1937). Rio de Janeiro: Jorge Zahar, 2005.

GRUZINSKI, Serge. O pensamento mestiço. São Paulo: Cia das Letras, 2002.

GUIBERNAU, Montserrat. Nacionalismos: o estado nacional e o nacionalismo no século XX. Rio de Janeiro: Jorge Zahar, 1997.

GUIMARÃES, Antônio Sérgio Alfredo. Racismo e Anti-Racismo no Brasil. São Paulo: Editora 34, 1999.

. "O insulto racial: as ofensas verbais registradas em queixas de discriminação" In Estudos afro-asiáticos, n. 38. Rio de Janeiro: Centro de Estudos afro-asiáticos, dezembro de 2000, pp. 31- 48. In World Wide Web: $<$ http://www.scielo.br/scielo.php?script=sci_arttext\&pid=S0101546X20000002 00002\&lng $=$ pt\&nrm=iso $>$. ISSN 0101-546X

. "O problema do racismo à brasileira". Entrevista In Informe: edição especial 1999-2001. São Paulo: SDI/FFLCH/USP, 2002, pp. 147-151.

. Classes, Raças e Democracia. São Paulo: Ed. 34, 2002. 
. "Preconceito de cor e racismo no Brasil" In Revista Antropologia, v. 47, n. 1. São Paulo: Departamento de Antropologia da FFLCH/USP, 2004, pp. 943. In World Wide Web: $<$ http://www.scielo.br/scielo.php?script=sci_arttext\&pid=S0034701200400010 0001\&lng=pt\&nrm=iso $>$. ISSN 0034-7701.

HAAG, Carlos. "Duro de matar. Autoritarismo ainda rege serviço de informação brasileiro" In Revista Pesquisa Fapesp, n. 113. São Paulo: FAPESP, julho, 2005, pp. 80-83.

HALL, Stuart. Da diáspora: Identidade e Mediações Culturais. Belo Horizonte: Editora UFMG, 2003.

HANCHARD, Michael. Orfeu e o poder: Movimento Negro no Rio de Janeiro e São Paulo (1945-1988). Rio de Janeiro: EdUERJ/UCAM - Centro de Estudos Afro-Asiáticos, 2001.

HASENBALG, Carlos Discriminação e desigualdades raciais no Brasil. Rio de Janeiro: Graal, 1979. - e GONZALEZ, Lélia. Lugar de Negro. Rio de Janeiro: Editora Marco Zero, 1982.

- Estrutura social, mobilidade e raça. Rio de Janeiro: Instituto Universitário de Pesquisas do Rio de Janeiro, 1988.

. "O movimento negro" In Anais do Seminário O Retorno do Ator. São Paulo: FE/USP, 1991.

. e SILVA, Nelson do Vale. Relações raciais no Brasil contemporâneo. Rio de Janeiro: Rio Fundo, 1992.

HERNANDEZ, Leila Maria Gonçalves Leite. Os Filhos da Terra do Sol: A formação do Estado-nação em Cabo Verde. São Paulo: Summus, 2002. . A África na sala de aula: visita à história contemporânea. São Paulo: Selo Negro, 2005. 
HOBSBAWM, Eric J. Rebeldes Primitivos. Estudos sobre Formas Arcaicas de Movimentos Sociais nos Séculos XIX e XX. Rio de Janeiro: Zahar, 1970. . Nações e Nacionalismo desde 1780. Rio de Janeiro: Paz e Terra, 1990. . A Era dos Extremos 1914-1991. São Paulo: Cia. das Letras, 1993. e RANGER, T. (org) A invenção das tradições. Rio de Janeiro: Paz e Terra, 1997.

HOFBAUER, Andreas. Uma história de branqueamento ou $O$ negro em questão. Tese de Doutorado. São Paulo: FFLCH/USP, 1999.

HOUAISS, A. Dicionário Houaiss de Língua Portuguesa. Rio de Janeiro, Objetiva, 2001. (versão eletrônica)

HUGGINS, Martha. Polícia e Política: Relações EUA/ América Latina. São Paulo: Cortez, 1998.

IANNI, Octavio. Raças e Classes Sociais no Brasil. 2a ed. Rio de Janeiro: Civilização Brasileira, 1972.

- [et. al.] O negro e o socialismo. São Paulo: Fundação Perseu Abramo, 2005.

JAPIASSU, Hilton. e MARCONDES, Danilo. Dicionário Básico de Filosofia. Rio de Janeiro: Jorge Zahar Editor, 1989.

JONES, James M. Racismo e Preconceito. São Paulo: Editora da Universidade de São Paulo, 1973.

KÖSSLING, Karin Sant' Anna. "O discurso policial sobre o afro-descendente: estigmas e estereótipos" In Revista Histórica, edição n. 15. São Paulo: Arquivo do Estado de São Paulo, julho/agosto/setembro de 2004.

KONH, Hans. A Era do Nacionalismo. Rio de Janeiro, Fundo de Cultura, 1963.

LARANJEIRA, Pires. A negritude Africana de língua portuguesa. Porto: Afrontamento, 1995.

LE GOFF, Jacques. História e Memória. São Paulo: Editora da Unicamp, 2003. 
LEITÃO, Alfredo Moreno. "Estudo sobre os códigos da série Dossiês do Fundo DEOPS-SP” In Informativo Associação dos Arquivistas de São Paulo. São Paulo: Arquivo do Estado, junho de 2000, n. 2.

LEITE, Rogerio Proença de Sousa. A dupla face do nacionalismo no Brasil: Kubitschek e Médici. Dissertação de Mestrado. Recife: CFCH/UFPE, 1992.

LONGHI, Carla Reis. Idéias e práticas do aparato repressivo: um olhar sobre o acervo do DEOPS/SP - a produção do SNI em comunicação com o DEOPS/SP (1964-1983). Tese de Doutorado. São Paulo: FFLCH/USP, 2005.

MACEDO, Márcio José de. Abdias do Nascimento. A trajetória de um negro revoltado (1914-1968). Dissertação de mestrado. São Paulo: FFLCH/USP, 2005.

MAGALHÃES, Marionilde Dias Brepohl de. "A lógica da suspeição: sobre os aparelhos repressivos à época da ditadura militar no Brasil." In Revista Brasileira de História. São Paulo: ANPUH/Humanitas, vol. 17, n. 34, 1997.

MARCONI, Elisa. e BICUDO, Francisco. "Os 60 anos da ONU" In http://www.historianet.com.br/conteudo/default.aspx?codigo $=779$.

MARTINS, Roberto R. Segurança Nacional. São Paulo: Brasiliense, 1986.

MATTOS, Marco Aurélio Vannucchi Leme de. Em nome da segurança nacional: os processos da Justiça Militar contra a Ação Libertadora Nacional (ALN), 19691979. Dissertação de Mestrado. São Paulo: FFLCH/USP, 2002.

MÉNDEZ, Juan E., O’ DONNELL, Guillermo e PINHEIRO, Paulo Sérgio. Democracia, Violência e Injustiça. O Não-Estado de Direito na América Latina. São Paulo: Paz e Terra, 2000.

MENDONÇA, Luciana F. M. Movimento Negro: da marca da inferioridade racial a construção da identidade étnica. Dissertação de Mestrado. São Paulo: FFLCH/USP, 1996.

MESQUITA, Érika. "Clóvis Moura e a sociologia da práxis" In Estudos AfroAsiátiacos, v. 25, n. 3. Rio de Janeiro:Centro de Estudos Afro-asiático Universidade Candido Mendes, $2003 . \quad$ In 
http://www.scielo.br/scielo.php?pid=S0101-

546X2003000300007\&script=sci_arttext

MIR, Luís. Guerra Civil: estado e trauma. São Paulo: Geração Editorial, 2004.

MIYAMOTO, Shiguenoli. O Brasil e o Pacto do Atlântico Sul. Marília": FEFCSD/ UNESP, 1987.

e GONÇALVES, Williams. A Politica Externa Brasileira e o Regime Militar: 1964-1984. Campinas: IFCH/ UNICAMP, 1991. - Militares, Diplomatas e Política Externa no Brasil Pós-64. Campinas: IFCH/UNICAMP, 1991.

MOTTA, Rodrigo Patto Sá. Em guarda contra o perigo vermelho. O anticomunismo no Brasil (1917-1964). São Paulo: Editora Perspectiva, 2002.

MOURA, Clóvis. História do Negro Brasileiro. São Paulo: Ática, 1989. . Brasil: as raízes do Protesto Negro. São Paulo: Global Ed., 1983. . Organizações negras. São Paulo: o povo em movimento. Petrópolis: Vozes/ CEBRAP, 1980. . Dialética radical do Brasil Negro. São Paulo: Ed. Anita, 1994. . O negro, de bom escravo a mau cidadão? Rio de Janeiro: Conquista, 1977. . Sociologia do negro brasileiro. São Paulo: Ática, 1988.

MUNANGA, Kabengele. Preconceito de Cor: Diversas Formas, Um Mesmo Objetivo. In Revista de Antropologia vol. 21. São Paulo: Departamento de Antropologia FFLCH/USP, 1978.

. Negritude: Usos e Sentidos. São Paulo: Ática, 1986. . Racismo da desigualdade à intolerância. São Paulo: Revista São Paulo em Perspectiva, vol.4 número 2, abril/junho de 1990, pp. 51-54. . "Negritude afro-brasileira: perspectivas e dificuldades" In Revista de Antropologia, vol. 33. São Paulo: Departamento de Antropologia da FFLCH/USP, 1990, pp. 109-117. 
- Rediscutindo a mestiçagem no Brasil: identidade nacional versus identidade negra. Belo Horizonte: Autêntica, 2004.

NASCIMENTO, Abdias. O Negro Revoltado. Congresso do Negro Brasileiro, 1968. . O genocídio do negro brasileiro. Rio de Janeiro: Paz e Terra, 1978. . Sortilégio II. Rio de Janeiro: Paz e Terra, 1979. . Quilombismo. Petropólis: Vozes, 1980. . O Brasil na mira do pan-africanismo. Salvador: EDUFBA/CEAO, 2002.

NASCIMENTO, Elizabeth Larkin. O Sortilégio da Cor. Identidade Afrodescendente no Brasil. Tese Doutorado. São Paulo: USP/IP, 2000.

NASCIMENTO, Maria Ercília. A estratégia da desigualdade. O Movimento Negro dos anos 70. Dissertação de Mestrado. São Paulo: PUC-SP, 1989.

NEIBURG, Federico. [et al]e WAIZBORT, Leopoldo. (org) Dossiê Nobert Elias. São Paulo: Editora da Universidade de São Paulo, 1999.

NEVES, Paulo Sérgio da Costa. (org) Polícia e Democracia: desafios à educação em direitos humanos. Recife: Edições Bagaço, 2002.

NOGUEIRA, Oracy. Tanto preto quanto branco: estudo de relações raciais. São Paulo: T.A. Queiroz, 1985.

OLIVEIRA, Dijaci David. [et.al.] (orgs) A cor do medo: homicídios e relações raciais no Brasil. Brasília: Editora UnB e UFG, 1998.

OLIVEIRA, Eduardo. Quem é quem na negritude brasileira. São Paulo: Congresso Nacional Afro-Brasileiro, 1998.

OLIVEIRA, Iolanda. (org.) Relações raciais e educação: alguns determinantes. Niterói: Intertexto, 1999. . (org.) Relações Raciais e Educação: A produção de saberes e práticas pedagógicas. Niterói: EdUFF, 2001.

. (org.) Relações raciais e educação: temas contemporâneos. Niterói: EdUFF, 2002.

OLIVEIRA, Roberto Cardoso de. Identidade, Etnia e Estrutura Social. São Paulo: Pioneira, 1976. 
ORTIZ, Renato. Cultura Brasileira \& Identidade Nacional. São Paulo: Brasiliense, 2003.

PINSKY, Carla Bassanezi. (org.) Fontes Históricas. São Paulo: Contexto, 2005.

PINTO, Regina Pahim. Movimento Negro em São Paulo: luta e identidade. Tese Doutorado. São Paulo, FFLCH/USP, 1993.

RAMPINELLI, Waldir José. As duas faces da moeda: as contribuições de JKe Gilberto Freyre ao colonialismo português. Florianópolis: Editora da UFSC, 2004.

REGINALDO, Lucilene. A História que não foi contada: Identidade negra e experiência religiosa na prática do Grupo União e Consciência Negra (19791988). Dissertação de Mestrado. São Paulo: PUC-SP, 1995.

REIS FILHO, DANIEL Aarão.(org) Intelectuais, História e Politica (século XIX e $X X)$ Rio de Janeiro: 7Letras, 2000.

REIS, José Carlos. As identidades do Brasil: de Varnhagen a FHC. Rio de Janeiro: Editora Fundação Getulio Vargas, 1999.

RÉMOND, René (org). Por uma história política. Rio de Janeiro: Editora FGV, 2003. ( $2^{\mathrm{a}}$ edição)

REZENDE, Maria José de. A ditadura militar no Brasil: repressão e pretensão de legitimidade (1964-1984). Tese de Doutorado. São Paulo: FFLCH/USP, 1996.

REZNIK, Luís. Democracia e Segurança Nacional. A Polícia Política no pósguerra. Rio de Janeiro: Editora FGV, 2004.

ROCHA, Maria Selma de Moraes. A Evolução dos conceitos da doutrina da Escola Superior de Guerra nos anos 70. Dissertação de Mestrado. São Paulo: FFLH/USP, 1996.

SANSONE, Livio. Negritude sem etnicidade. Salvador: Edufba; Pallas, 2003.

SANTOS, Eduardo dos. A negritude e a luta pelas independências na África Portuguesa. Lisboa: Minerva, 1975. 
SANTOS, Gevanilda Gomes dos. Partidos políticos e etnia negra. Dissertação de Mestrado. São Paulo: Departamento Ciências Sociais/ PUC, 1992.

SANTOS, Gislene Aparecida dos. A invenção do "ser negro": um percurso das idéias que naturalizaram a inferioridade dos negros. São Paulo: Educ/ Fapesp; Rio de Janeiro: Pallas, 2002.

SANTOS, Jocélio Teles dos. "Ações afirmativas e ditadura militar: imagens e propostas" In evento The Cultures of Dictatorship: Historical Reflections on the Brazilian Golpe of 1964, University of Maryand, 14-16 de outubro de 2004.(html/www.history.umd.edu/Historycenter/200405/conf/Brazil64/program )

SARTRE, Jean Paul. Reflexões sobre o Racismo. São Paulo: Difusão Européia do Livro, 1960.

SCHWARCZ, Lilia e REIS, Letícia (orgs). Negras Imagens. São Paulo: EDUSP e Estação Ciência, 1996.

SECCO, Lincoln. A Revolução dos Cravos e a Crise do Império Colonial Português (1961-1975). São Paulo: Alameda, 2004.

SILVA, Golbery do Couto e. Geopolítica do Brasil. Rio de Janeiro: José Olympio, 1967.

Conjuntura Nacional - O Poder Executivo. Geopolítica do Brasil. Rio de Janeiro: José Olympio, 1981.

SILVA, Nelson Fernando Inocêncio da. Consciência Negra em cartaz. Brasília: Editora Universidade de Brasília, 2001.

SILVA, René Marc da Costa. A cidadania em Revista: Intelectualidade política e a questão racial na Revista Civilização Brasileira. Dissertação de Mestrado. Brasília: UNB, 1993.

SKIDMORE, Thomas. Brasil: de Castelo a Tancredo (1965-1985). Rio de Janeiro: Paz e Terra, 1989.

SOARES, Gláucio Ary Dillon e D' ARAÚJO, Maria Celina. 21 anos de regime militar: balanços e perspectivas. Rio de Janeiro: Editora da Fundação Getulio Vargas, 1994. 
SORJ, Bernardo e ALMEIDA, Maria Hermínia Tavares de. (orgs) Sociedade e política no Brasil pós-64. São Paulo: Brasiliense, 1984.

SOUZA, Florentina da Silva. Afro-descendência em Cadernos Negros e Jornal do MNU. Belo Horizonte: Autêntica, 2005.

TELES, Janaína. (org) Mortos de desaparecidos políticos: reparação ou impunidade? São Paulo: Humanitas/ FFLCH-USP, 2001.

TELLES JÚNIOR, Goffredo. "Meditações sobre a desordem" In Revista Imaginário. $\quad$ SãoPaulo: 2002. (http://www.imaginario.com.br/artigo/a0031_a0060/a0049.shtml)

THOMAZ, Omar Ribeiro. "Um viajante tropicalista pelas terras d'além mar" In Folha de S.Paulo http://www1.folha.uol.com.br/fol/brasil500/zumbi_34.htm, sem data.

VECCHIO, Ângelo Del. Impasses do Regime Militar Brasileiro: Construção de Potência, Institucionalização e Estabilização Política (1964-1979). Tese de doutorado. São Paulo: FFLCH/USP, 1998.

VISENTINI, Carlos Alberto. A teia do fato: uma proposta de estudo sobre a memória histórica. São Paulo: Hucitec, 1997.

VIZENTINI, Paulo Fagundes. A política externa do regime militar brasileiro: multilateralização, desenvolvimento e a construção de uma potência média (19641985). Porto Alegre: Ed. da Universidade/ UFRGS, 1998.

VOVELLE, Michel. Ideologias e Mentalidades. São Paulo: Brasiliense, 1987.

WARREN, Ilse e KRISCHKE, Paulo. Uma Revolução no Cotidiano? Os novos movimentos sociais na América do Sul. São Paulo: Brasiliense, 1987.

WEBER, Max. Economia e Sociedade: fundamentos da sociologia compreensiva. Brasília: UNB, 1991.

WEFFORT, Francisco. Qual Democracia? São Paulo: Companhia das Letras, 1992. 
VIII. ANEXOS 


\section{Anexo I \\ Aspectos da construção da Informação}

Todo o sistema de organização da informação visava esclarecer os dados "sobre qualquer questão considerada relevante pela lógica do sistema. Toda uma rotina extremamente normatizada regulava a produção das informações. Primeiramente, o agente de informações devia recolher um 'informe', espécie de dado bruto inicial, base para elaborar-se a 'informação'." 997 Faz-se necessário aqui atentar para a diferença entre um informe de uma informação: o informe era aquilo que não havia sido processado, não foi investigado e não obteve confirmação, mas era arquivado para, mais tarde, com outros informes semelhantes para serem averiguados. O trabalho do analista de informações era o de cotejar esses informes em quantidade imensurável, posteriormente, classificá-los, juntálos e analisá-los quanto ao seu grau de probabilidade de veracidade. ${ }^{998}$

Segundo o Manual de Informações consultado pelo historiador Carlos Fico, uma informação era "o conhecimento de um fato ou situação, resultante do processamento inteligente de todos os informes disponíveis, relacionados com o referido fato ou situação. Uma informação deve sempre atender a uma necessidade de planejamento, execução elou de acompanhamento de atos decisórios. " 999 A construção de uma informação originava-se pelo "pedido de busca", muitas vezes fundado em um primeiro informe, que orientava a produção da informação por meio de um planejamento da missão, reunião dos conhecimentos pertinentes, processamento dos dados e difusão da informação aos demais órgãos do sistema. ${ }^{1000}$ Lançavam-se informações no intuito de colher mais informações sobre o assunto em questão: "na mesma hora que tomávamos conhecimento de uma informação, comunicávamos aos demais. Apenas alguns informes que não eram caracterizados e portanto não permitiam a certeza absoluta, não se passava adiante." 1001

Os informes e informações eram classificados em escalas entre "A" a "F" e "1" a "6" em que quanto menor a classificação era maior a idoneidade e validade dos dados

\footnotetext{
${ }^{997}$ FICO, C. Como eles agiam. Os subterrâneos da Ditadura Militar: espionagem e polícia politica. Rio de Janeiro: Record, 2001, p. 95.

998 ARAÚJO, M. e SOARES, G. e CASTRO, C. Os anos de chumbo: a memória militar sobre a repressão. Rio de Janeiro: Relume - Dumará, 1994, p. 47.

${ }^{999}$ Manual de Informações fls. 17-18 Apud FICO, C. Op. Cit., p. 95.

${ }^{1000}$ FICO, C. Idem, p. 97.

${ }^{1001}$ Memória de João Paulo Moreira Burnier In ARAÚJO, M. e SOARES, G. e CASTRO, C. Op. Cit., pp. 199-200.
} 
constantes na documentação. As letras de "A" a "F" classificavam a fonte da informação, enquanto que a veracidade do conteúdo recebia classificação de "1" a "6". 1002 Assim o analista de informações junta todos esses informes e quando lhe pedem informações a respeito de um fato ou de uma pessoa ele analisa tudo que tem e elabora uma informação. ${ }^{1003}$ Por conseguinte, "A informação não tem geração espontânea. A busca de informe é uma operação. "1004

Cabia ao Sistema de Informações, o SISNI ${ }^{1005}$ determinar a forma de execução da informação normatizando, supervisionando e fiscalizando os órgãos. O regime militar voltou-se para centralizar, ampliar e fornecer diretrizes para a coordenação do aparato de informações e segurança. Nesse sentido, também foi elaborada uma "Diretriz para a Política de Segurança Interna” para a consolidação, em 1969, do sistema de segurança , o SISSEGIN, mais tarde reformulado, originando o "Planejamento de Segurança Interna". 1006 Percebe-se que havia uma preocupação em regular o trabalho da informação como algo "técnico": "As ligações entre as várias agências caracterizam o canal técnico de informações, e são feitas dentro de normas e limites perfeitamente definidos, pressupondo conhecimento prévio e autorização dos respectivos comandantes. Ou seja, uma $2^{a}$ Seção de Exército presta contas ao seu general e, depois, informa ao CIE. O CIE, por sua vez, informa ao ministro e, dentro das normas, ao SNI. Isso é uma cadeia técnica de informações." 1007 Esses órgãos seguiam um planejamento provindo das instâncias superiores como o Conselho de Segurança Nacional.

A intensa comunicação entre a comunidade de informações e segurança, visava ampliar o conjunto de dados de seus arquivos para a "manutenção da ordem pública". Notório que informação e segurança estivessem absolutamente correlacionados no

\footnotetext{
${ }^{1002}$ FICO, C. Como eles agiam. Os subterrâneos da Ditadura Militar: espionagem e polícia política. Rio de Janeiro: Record, 2001, p. 95.

${ }^{1003}$ ARAÚJO, M. e SOARES, G. e CASTRO, C. Os anos de chumbo: a memória militar sobre a repressão. Rio de Janeiro: Relume - Dumará, 1994, p. 47.

${ }^{1004}$ Memória de Gustavo Moraes Rego Reis In ARAÚJO, M. e SOARES, G. e CASTRO, C. Op. Cit., p. 151.

${ }^{1005}$ Sigla para o Sistema de Informações, que era formado pelo SNI, Sistemas Setoriais de Informação dos Ministérios Civis, Sistemas Setoriais de Informações Ministérios Militares, Sub-sistema de Informações Estratégicas Militares e por outros órgãos setoriais. In FICO, C. Op. Cit., p. 81.

${ }^{1006}$ FICO, C. Idem, pp. 118/119.

1007 Memória de Cyro Guedes Etchegoyen In ARAÚJO, M. e SOARES, G. e CASTRO, C. Os anos de chumbo: a memória militar sobre a repressão. Rio de Janeiro: Relume - Dumará, 1994, p. 110.
} 
raciocínio do regime militar, ainda que fossem normatizados, coordenados e executados em esferas próprias. ${ }^{1008}$

A informação, nesse sistema, era tida como essencial, o que para alguns, demandava sua centralização. ${ }^{1009}$ Dessa forma, havia "um Sistema de Informações. Você apanha uma informação e transmite. Todo elemento de informação pertence a um sistema ou a um subsistema." ${ }^{1010}$ Assim, a rede de informações na comunidade de informações e segurança possuíam um padrão de comunicação interna: primeiro com a identificação dos órgãos de origem e de difusão do documento, seguindo padrões de fichamento, especificando a tipologia do documento (Atestado, Pedido de Busca, Informe, etc.) e, a partir desta tipologia o documento seguia a um perfil de preenchimento. ${ }^{1011}$

${ }^{1008}$ FICO, C. Como eles agiam. Os subterrâneos da Ditadura Militar: espionagem e polícia política. Rio de Janeiro: Record, 2001, pp. 27-28.

1009 Memória de Enio dos Santos Pinheiro In ARAÚJO, M. e SOARES, G. e CASTRO, C. Os anos de chumbo: a memória militar sobre a repressão. Rio de Janeiro: Relume - Dumará, 1994, p. 142.

${ }^{1010}$ Memória de Carlos de Meira Mattos In ARAÚJO, M. e SOARES, G. e CASTRO, C. Op. Cit., p. 104.

1011 AQUINO, M. e LONGHI, C. e MATTOS, M. e SWENSSON JR., W. (orgs). O DEOPS/SP Em busca do crime político. São Paulo: Arquivo do Estado, 2002, p. 78. 


\section{Anexo II}

\section{Controle preventivo do Estado}

Com a perspectiva de que a vigilância poderia prevenir um eminente "golpe" que assombrava a estabilidade do país com a ação dos "comunistas", discurso que sustentou uma constante vigilância sobre a sociedade. Dividiu-se a atuação policial em duas esferas: uma de caráter preventivo, também denominado polícia administrativa e a outra, a repressiva, também nomeada como polícia judiciária. ${ }^{1012}$ À segunda esfera caberia investigar os crimes que não puderam ser prevenidos além de proceder o inquérito e o processo penal.

A ação dos diversos órgãos de repressão seguia uma concepção de "repressão preventiva", visando identificar o "criminoso político" antes de acontecer propriamente o “crime”. O DEOPS/SP possuía uma lógica de investigação que, "prioritariamente, não buscava o criminoso a partir do crime, mas o crime a partir do (potencialmente) criminoso." 1013 Os mecanismos de informação fizeram parte do pensamento de repressão preventiva, "que consistia na vigilância e controle cotidiano sobre a sociedade, prática consolidada pela criação do que foi denominado comunidade de informações." 1014 Prevenção significou, em nome da "segurança nacional", vigiar e reprimir qualquer atividade considerada potencialmente perturbadora da ordem, segundo a idéia de que era necessário "prevenir o delito em função de uma sociedade sã ." ${ }^{1015}$ Importante atentar que existia e ainda existe uma relação umbilical entre prevenção e coibição na ação policial.

Esta idéia de prevenção saneadora também esteve presente no pensamento militar " $A$ atitude preventiva visa a enfrentar os tipos de ação adversa caracterizados como

\footnotetext{
${ }^{1012}$ Entre as obras que tratam desse tema encontramos: NOGUEIRA, C. Manual de Investigação Policial. São Paulo: Escola de Polícia de São Paulo, 1965. Também ALONSO, A. Poder de Polícia, 1954, p. 8. Também PESTANA, J. Manual de Organização Policial do Estado de São Paulo. (2 ${ }^{\mathrm{a}}$ edição). São Paulo: Escola de Polícia de São Paulo, 1957, pp. 28-31. Também ALVES, L. "Poder de polícia" In Arquivos, vol. XXVI. São Paulo: Polícia Civil de São Paulo, $2^{\circ}$ semestre 1975, pp. 171-178.

1013 AQUINO, M. e MORAES, M. e MATTOS, M. e SWENSSON JR., W. (orgs). A constância do olhar vigilante: a preocupação com o crime político. São Paulo: Arquivo do Estado, 2002, p. 45.

${ }^{1014}$ MAGALHÃES, M. "A lógica da suspeição: sobre os aparelhos repressivos à época da ditadura militar no Brasil.” In Revista Brasileira de História. São Paulo: ANPUH/Humanitas, vol. 17, n. 34, 1997, p. 204.

${ }^{1015}$ MENDES, N. "Prevenção do Delito e Proposições sobre a Política de Defesa Social no Plano de Desenvolvimento do Brasil.” In Arquivos, vol. XXVI. São Paulo: Polícia Civil de São Paulo, $2^{\circ}$ semestre 1975, pp. 217-229, p. 217.
} 
perturbação de ordem." 1016 Sob essa ótica, no manual da ESG a noção de segurança interna vinha atrelada à prevenção, com "um sentido característico de prevenção antes que de punição. Assim, ela procura pôr em execução um elenco de medidas preventivas, destinadas a neutralizar as causas que possam favorecer os antagonismos cuja ação ameaça a conquista e salvaguarda dos Objetivos Nacionais.” 1017

O sentido de prevenção no pensamento policial e militar envolvia a identificação do “criminoso em potencial”, por meio de uma lógica de suspeição apoiada em noções de suspeitos "preferenciais". Assim, determinados espaços e grupo sociais eram tidos como mais "perigosos" à incidência de idéias contestatórias como, por exemplo, o meio estudantil. ${ }^{1018}$ Nesse sentido, a política de prevenção adotada pelo regime militar tornou-se uma repressão a priori.

Estudos sociológicos descreveram que num processo judiciário se fazem presentes critérios burocráticos ligados às legislações penais, articulados a critérios subjetivos relativos à figura do criminoso, ao invés do crime. ${ }^{1019} \mathrm{O}$ desfecho processual utilizava-se de "fatores que não apenas a comprovação da autoria e da materialidade do crime. Tratava-se de conhecer a atuação social de réus e vítimas e, consequentemente, sua adequação a modelos de comportamento previstos para homens e mulheres." 1020 Vale dizer que os fatores subjetivos não podem ser excluídos da análise do trabalho policial e o judiciário, mesmo com o esforço da polícia em fornecer um suporte de pensamento científico para a sua atuação, como se depreende das leituras das publicações da polícia civil, desde o início do século XX. ${ }^{1021}$ Esse aspecto era frequentemente tratados pelos

\footnotetext{
${ }^{1016}$ Manual ESG, "Seção II - Segurança Interna", "3- Resposta ao processo subversivo" Apud ROCHA, M. A Evolução dos conceitos da doutrina da Escola Superior de Guerra nos anos 70. Dissertação de Mestrado. São Paulo: FFLH/USP, 1996. ANEXO 22, p. 249.

1017 Manual ESG, "Seção II - Segurança Interna", "7- Conclusão" Apud ROCHA, M. A Evolução dos conceitos da doutrina da Escola Superior de Guerra nos anos 70. Dissertação de Mestrado. São Paulo: FFLH/USP, 1996. ANEXO 22, p. 255.

${ }^{1018}$ Desse modo, encontramos diversos relatórios diários da ação vigilante dos investigadores do DEOPS/SP nos Campus da USP e da PUC-SP nos diversos dossiês. Exemplos pastas 142 e 143, 144 do dossiê 21-Z-14 e a pasta 480 do dossiê $52-Z-0$.

${ }^{1019}$ Em especial o trabalho de Sérgio Adorno. ADORNO, S. "Violência urbana, justiça criminal e organização social do crime" In Revista Crítica de Ciências Sociais, n. 33, outubro 1991, pp. 145-150. e "Crime, justiça penal e desigualdade jurídica: as mortes que se contam no tribunal do júri” In Op. Cit., pp. 132-151.

1020 MATTOS, M. Em nome da segurança nacional: os processos da Justiça Militar contra a Ação Libertadora Nacional (ALN), 1969-1979. Dissertação de Mestrado. São Paulo: FFLCH/USP, 2002, p. 50.

${ }^{1021} \mathrm{Na}$ biblioteca da Academia de polícia civil de São Paulo realizamos uma pesquisa sistemática com duas importantes revistas produzidas pela instituição ao longo do século XX: a Arquivos, produzida pela Polícia Civil e a Investigações, produzida pelo Departamento de Investigações da Polícia Civil. Além disso,
} 
artigos das revistas produzidas pela polícia civil de São Paulo, o pensamento policial sobre a prevenção produziu um debate sobre o ajustamento comportamental dos "criminosos".

Por definir "prevenção" de forma instrumental no âmbito do governo militar o Departamento de Investigações da Polícia Civil justificava que "A ação da Polícia, no sentido preventivo, evita crimes que poderiam causar prejuizos avultados, não só ao Estado, como à população. No tocante à Polícia Política, ela, com seus setores especializados, age num sentido mais preventivo, que é tachado, muitas vezes, de arbitrário." 1022 No entanto, a subjetividade dos critérios de "prevenção" deram margem à afirmação da arbitrariedade envolvida no trabalho policial.

Ao investigar a mentalidade policial-militar acerca da vigilância e repressão às lutas anti-racistas no Fundo DEOPS/SP, tornou-se clara a importância de consultar textos teóricos do pensamento policial e militar sobre suas atividades, presente em livros e em revistas, sobretudo editados pela Escola de Polícia de São Paulo. ${ }^{1023}$

pesquisamos obras de referência sobre teoria policial, principalmente aquelas que trataram de algum modo sobre o "crime político" ou o DEOPS, no intento de auxiliar-nos a compreender a mentalidade policial.

${ }^{1022}$ APOLlONIO, L. Manual de polícia politica e social. São Paulo: Escola de Polícia de São Paulo, 1954. ( $1^{\text {a }}$ Edição), p. 154.

${ }^{1023}$ A Escola de Polícia de São Paulo foi fundada em 1934, visando ministrar um ensino técnico e científico aos policiais. In PESTANA, J. Manual de Organização Policial do Estado de São Paulo. (2a edição). São Paulo: Escola de Polícia de São Paulo, 1957, p. 33. 


\section{Anexo III}

\section{Prontuários de afro-descendentes}

Na pesquisa de iniciação científica Movimentos Negros: Identidade étnica, Identidade política (1924-1954) foi realizado um mapeamento dos afro-descendentes na Série Prontuários, construindo um banco de dados referente aos prontuariados que possuíssem o dado cor identificado pela polícia política. Dessa forma, dos 150000 números de prontuários foram encontrados 3168 afro-descendentes ${ }^{1024}$. Esse número reduzido se deve a uma grande parte dos prontuários do acervo que não possuía a indicação da cor, 63314 prontuários não constam o dado "cor" e 8357 são prontuários institucionais ou temáticos. Portanto, pudemos investigar 78329 dos prontuários pessoais com a possibilidade de identificar a cor do indivíduo. Nesta tabela em anexo destacamos os prontuariados afrodescendentes do período de 1964 a 1983.

\begin{tabular}{|l|l|l|l|l|l|}
\hline Prontuário & \multicolumn{1}{|c|}{ Nome } & Data & Nacionalidade & Motivo Identificação & \multicolumn{1}{|c|}{ Cor } \\
\hline 44142 & $\begin{array}{l}\text { Crisogone Valetim } \\
\text { da Silva }\end{array}$ & 1972 & Brasileira & $\begin{array}{l}\text { Artigo 305 do } \\
\text { Código Penal }\end{array}$ & $\begin{array}{l}\text { parda } \\
\text { escura }\end{array}$ \\
\hline 44207 & $\begin{array}{l}\text { Isildo Soares da } \\
\text { Silva } 1980\end{array}$ & Brasileira & Assalto & $\begin{array}{l}\text { parda } \\
\text { clara }\end{array}$ \\
\hline 44426 & $\begin{array}{l}\text { João Christomo } \\
\text { Torquato }\end{array}$ & 1968 & Brasileira & Legitimação & parda \\
\hline 42968 & $\begin{array}{l}\text { Maria Doris } \\
\text { Yucatan }\end{array}$ & 1960 & Brasileira & Não consta & parda \\
\hline 42997 & $\begin{array}{l}\text { Domingos Barboza } \\
\text { Miranda }\end{array}$ & 1971 & Brasileira & Legitimação & parda \\
\hline 43011 & $\begin{array}{l}\text { José Cavalcanti } \\
\text { Ribeiro }\end{array}$ & 1965 & Brasileira & Inquilinato & $\begin{array}{l}\text { parda } \\
\text { escura }\end{array}$ \\
\hline
\end{tabular}

1024 Afro-descendente foi a uma categoria utilizada nesta tabela com um asteristico para assinalar os prontuários identificados por meio de fotografia ou outro elemento que não a classificação policial. Além disso, necessário destacar que incluímos todos os prontuários que tivessem classificações diversas que remetessem aos afro-descendentes como pardo, negro, preto, moreno, etc. Essas diferentes classificações incidem mais de uma vez para um mesmo indivíduo em alguns prontuários, uma vez que a documentação utilizava diversas categorias, como: "preto", "pardo", "moreno", "mestiço" e "mulato". A escolha do termo "afro-descendente" responde melhor ao anseio de incluir os "pardos" ou "mestiços" no debate. Além de abarcar um universo mais amplo, é um termo que foi "construído" ao longo do processo de militância negra tendo o termo "afro-brasileiro" o seu uso iniciado a partir da década de 1940. A incidência do "afro" no discurso adotado pelos movimentos negros favoreceu a compreensão da questão racial e sensibilizou as lideranças para além do aspecto "cor", remetendo a ancestralidade africana. Além disso, as múltiplas categorias encontradas na documentação, revelam uma relativização das classificações de cor proveniente do "racismo à brasileira", que se utiliza de eufemismos de cor. ("Racismo à Brasileira", Expressão cunhada por Da Matta e utilizado sobretudo no capítulo "Digressão: A Fábula das Três Raças, ou o Problema do Racismo à Brasileira", em que o autor explica "o racismo à brasileira" como uma construção cultural ímpar e específica. In DAMATTA, R. Relativizando: Uma Introdução à Antropologia Social. Rio de Janeiro: Rocco, 2000.). 


\begin{tabular}{|c|c|c|c|c|c|}
\hline 43040 & Nivaldo Laurindo & 1982 & Brasileira & $\begin{array}{l}\text { Artigo } 155 \text { Código } \\
\text { Penal }\end{array}$ & $\begin{array}{l}\text { parda } \\
\text { clara }\end{array}$ \\
\hline 43125 & $\begin{array}{ll}\text { Adalberto } & \text { Ribeiro } \\
\text { das Neves } & \end{array}$ & 1982 & Brasileira & Assalto a banco & parda \\
\hline 43203 & Carlos Elias Sauma & 1982 & Brasileira & Não consta & parda \\
\hline 43386 & $\begin{array}{ll}\text { Juraci } & \text { Laercio } \\
\text { Guimarães }\end{array}$ & 1982 & Brasileira & Contravenção & parda \\
\hline 43418 & $\begin{array}{l}\text { Flavio de } \\
\text { Pereira }\end{array}$ & 1982 & Brasileira & Furto & parda \\
\hline 43908 & $\begin{array}{l}\text { João de Oliveira } \\
\text { Mendes }\end{array}$ & 1965 & Brasileira & Depoimento & preta \\
\hline 45587 & $\begin{array}{l}\text { Francisco Barbosa } \\
\text { de Mendonça }\end{array}$ & 1981 & Brasileira & Roubo & parda \\
\hline 1611 & $\begin{array}{l}\text { Curlee Washington } \\
\text { Jr. }\end{array}$ & 1974 & $\begin{array}{l}\text { Norte- } \\
\text { americana }\end{array}$ & Legitimação & preta \\
\hline 1652 & $\begin{array}{ll}\text { Moacir } & \text { Julio } \\
\text { Barbosa } & \end{array}$ & 1974 & Brasileira & Legitimação & Parda \\
\hline 1744 & $\begin{array}{ll}\text { José } & \text { Maria } \\
\text { Cordeiro } & \end{array}$ & 1974 & Brasileira & Legitimação & Preta \\
\hline 1758 & $\begin{array}{l}\text { José Angelo Cezar } \\
\text { dos Santos }\end{array}$ & 1974 & Brasileira & Legitimação & Parda \\
\hline 1785 & $\begin{array}{ll}\text { Geraldo } & \text { Siqueira } \\
\text { Almeida } & \\
\end{array}$ & 1974 & Brasileira & $\begin{array}{l}\text { Artigo } 304 \text { Código } \\
\text { Penal }\end{array}$ & Parda \\
\hline 2376 & Antonio Silva & 1974 & Brasileira & $\begin{array}{l}\text { Fins civis - atestado } \\
\text { de antecedentes }\end{array}$ & Parda \\
\hline 46571 & Ivo da Silva & 1973 & Brasileira & Averiguações & Parda \\
\hline 47021 & $\begin{array}{l}\text { Wanderley de } \\
\text { Freitas }\end{array}$ & 1970 & Brasileira & $\begin{array}{l}\text { Artigo } 46 \text { Lei de } \\
\text { Segurança Nacional }\end{array}$ & Preta \\
\hline 47121 & Gregorio Mendonça & 1971 & Brasileira & $\begin{array}{l}\text { Infração a Lei de } \\
\text { Segurança Nacional }\end{array}$ & Parda \\
\hline 49390 & $\begin{array}{l}\text { Geraldo Vieira do } \\
\text { Nascimento }\end{array}$ & 1971 & Brasileira & Legitimação & Parda \\
\hline 51039 & José Barbosa Junior & 1981 & Brasileira & $\begin{array}{l}\text { Artigo } 171 \text { Código } \\
\text { Penal - estelionato }\end{array}$ & Preta \\
\hline 52402 & $\begin{array}{l}\text { José Pessoa de } \\
\text { Albuquerque }\end{array}$ & 1971 & Brasileira & Legitimação & Preta \\
\hline 53020 & $\begin{array}{l}\text { Paulo } \quad \text { Barbosa } \\
\text { Santos }\end{array}$ & 1973 & Brasileira & Averiguações & Parda \\
\hline 54432 & Eunir Leite Ribeiro & 1970 & Brasileira & Segurança Nacional & Parda \\
\hline 54598 & $\begin{array}{l}\text { Ednald Ferreira da } \\
\text { Silva }\end{array}$ & 1973 & Brasileira & Legitimação & Preta \\
\hline 54639 & Geralda de Freitas & 1974 & Brasileira & Legitimação & Parda \\
\hline 54679 & $\begin{array}{ll}\text { Azor } & \text { Orlando } \\
\text { Lemes } & \\
\end{array}$ & 1982 & Brasileira & $\begin{array}{l}\text { Entorpecentes } \\
\text { porte arma }\end{array}$ & $\begin{array}{l}\text { Parda } \\
\text { clara }\end{array}$ \\
\hline $\begin{array}{l}54679 \\
\text { (citado no }\end{array}$ & José Roque & 1982 & Brasileira & $\begin{array}{l}\text { Entorpecentes } \\
\text { porte arma }\end{array}$ & Preta \\
\hline
\end{tabular}




\begin{tabular}{|c|c|c|c|c|c|}
\hline $\begin{array}{l}\text { prontuário } \\
\text { de Azor) }\end{array}$ & & & & & \\
\hline 55244 & $\begin{array}{l}\text { Marcos Pereira de } \\
\text { Castro }\end{array}$ & 1981 & Brasileira & Roubo a banco & $\begin{array}{l}\text { Parda } \\
\text { escura }\end{array}$ \\
\hline 55348 & José Carlos Santos & 1969 & Brasileira & Legitimacão & Parda \\
\hline 56974 & $\begin{array}{l}\text { Salvador Manoel da } \\
\text { Rocha }\end{array}$ & 1972 & Brasileira & Legitimação & Parda \\
\hline 58116 & $\begin{array}{ll}\text { Washington } & \\
\text { Danielo } & \text { Salas } \\
\text { Fernandez } & \end{array}$ & 1975 & Uruguaia & Legitimação & Parda \\
\hline 58272 & Oswaldo Luiza & 1972 & Brasileira & Legitimação & Preta \\
\hline 58527 & Erivaldo de Souza & 1982 & Brasileira & Assalto a banco & $\begin{array}{ll}\text { Preta ou } \\
\text { parda }\end{array}$ \\
\hline 59828 & $\begin{array}{l}\text { Antonio Theodoro } \\
\text { dos Santos }\end{array}$ & 1982 & Brasileira & Legitimação & $\begin{array}{l}\text { Parda } \\
\text { clara }\end{array}$ \\
\hline 60500 & $\begin{array}{l}\text { Luiz Pinheiro de } \\
\text { Oliveira }\end{array}$ & 1968 & Brasileira & $\begin{array}{l}\text { Legitimação por } \\
\text { agitação }\end{array}$ & $\begin{array}{ll}\text { Parda } & \text { ou } \\
\text { preta }\end{array}$ \\
\hline 60943 & $\begin{array}{l}\text { Maria Madalena } \\
\text { Prata Soares }\end{array}$ & 1974 & Brasileira & $\begin{array}{l}\text { Lei de segurança } \\
\text { nacional }\end{array}$ & Parda \\
\hline 61141 & $\begin{array}{l}\text { Sebastião Palmeiras } \\
\text { dos Santos }\end{array}$ & 1972 & Brasileira & Sonegação fiscal & $\begin{array}{l}\text { Parda } \\
\text { clara }\end{array}$ \\
\hline 61150 & $\begin{array}{l}\text { Aldo Moreira dos } \\
\text { Santos }\end{array}$ & 1973 & Brasileira & Legitimação & Parda \\
\hline 61891 & $\begin{array}{l}\text { Rui Luiz Lopes de } \\
\text { Oliveira }\end{array}$ & 1971 & Brasileira & Legitimação & Preta \\
\hline 62477 & $\begin{array}{lll}\text { Mario } & \text { Paulino da } \\
\text { Silva } & & \end{array}$ & 1969 & Brasileira & Legitimação & Parda \\
\hline 62844 & $\begin{array}{ll}\text { José } & \text { Antonio } \\
\text { Antunes } & \end{array}$ & 1971 & Brasileira & Legitimação & Parda \\
\hline 63109 & Nelson dos Santos & 1968 & Brasileira & Legitimação & Preta \\
\hline 63992 & João Pedro da Silva & 1974 & Brasileira & Documentação falsa & Parda \\
\hline 64006 & $\begin{array}{l}\text { Sinval Augusto de } \\
\text { Araújo }\end{array}$ & 1970 & Brasileira & Averiguações & Parda \\
\hline 64105 & $\begin{array}{ll}\text { Ricardo } & \text { Prata } \\
\text { Soares } & \\
\end{array}$ & 1971 & Brasileira & Legitimação & $\begin{array}{ll}\text { Parda ou } \\
\text { branca }\end{array}$ \\
\hline 64135 & José Benedito & 1970 & Brasileira & Legitimação & Parda \\
\hline 64208 & $\begin{array}{l}\text { Antonio de Araujo } \\
\text { Freire }\end{array}$ & 1968 & Brasileira & Legitimação & Parda \\
\hline 65056 & Natanael Medeiros & 1972 & Brasileira & Legitimação & Parda \\
\hline 66507 & $\begin{array}{ll}\text { Gerson } & \text { Simplicio } \\
\text { da Silva } & \\
\end{array}$ & 1971 & Brasileira & Legitimação & Parda \\
\hline 67229 & $\begin{array}{ll}\text { Carlos } & \text { Roberto } \\
\text { Klefenz } & \end{array}$ & 1975 & Brasileira & $\begin{array}{l}\text { Falsificação } \\
\text { documento }\end{array}$ & Parda \\
\hline 67530 & $\begin{array}{l}\text { Carlos Alberto de } \\
\text { Souza Lara }\end{array}$ & 1970 & Brasileira & Não consta & Parda \\
\hline 68424 & Helcio Alves de & 1973 & Brasileira & Legitimação & Parda \\
\hline
\end{tabular}




\begin{tabular}{|c|c|c|c|c|c|}
\hline & Oliveira & & & & \\
\hline 3220 & $\begin{array}{ll}\text { Natanael Gomes } \\
\text { Sobral }\end{array}$ & 1975 & Brasileira & $\begin{array}{l}\text { Roubo e extorsão } \\
\text { mediante seqüestro }\end{array}$ & $\begin{array}{ll}\text { Preta } & \text { ou } \\
\text { parda } & \end{array}$ \\
\hline 3330 & $\begin{array}{lr}\text { Julio } & \text { Cesar } \\
\text { Aristimune Mendez }\end{array}$ & 1972 & Uruguaia & $\begin{array}{l}\text { Legitimação } \\
\text { (decreto 11285) }\end{array}$ & Parda \\
\hline 8011 & $\begin{array}{l}\text { Maria Bernarda } \\
\text { Ferreira Silva }\end{array}$ & 1971 & Brasileira & $\begin{array}{l}\text { Legitimação } \\
\text { (decreto 11285) }\end{array}$ & Parda \\
\hline 9690 & José Carlos Avelino & 1972 & Brasileira & $\begin{array}{l}\text { Legitimação } \\
\text { (decreto 11285) }\end{array}$ & $\begin{array}{l}\text { Parda ou } \\
\text { preta }\end{array}$ \\
\hline 10208 & $\begin{array}{l}\text { Arlindo Alves de } \\
\text { Oliveira }\end{array}$ & 1970 & Brasileira & $\begin{array}{lr}\text { Lei de Segurança } \\
\text { Nacional por Ordem } \\
\text { Social (co-autoria), } \\
\text { artigor } 11285 . \\
\text { Inquéritor sobre } \\
\text { morte de "Zé Dico" }\end{array}$ & $\begin{array}{ll}\text { Parda } & \\
\text { clara } & \text { ou } \\
\text { branca } & \text { ou } \\
\text { parda } & \end{array}$ \\
\hline 10401 & Ageu Aguiar & 1968 & Brasileira & $\begin{array}{lr}\begin{array}{l}\text { Prisão } \\
\text { por }\end{array} & \text { preventiva } \\
\text { judicial } & \text { mandado } \\
\end{array}$ & Preta \\
\hline 10956 & Jorge da Silva & 1972 & Brasileira & $\begin{array}{l}\text { Legitimação } \\
\text { (decreto 11285) }\end{array}$ & Parda \\
\hline 12270 & Jerônimo Alves & 1972 & Brasileira & $\begin{array}{l}\text { LSN - Ação Popular } \\
\text { Marxista Leninista }\end{array}$ & Preta \\
\hline $12842-$ & $\begin{array}{lrr}\begin{array}{l}\text { Arnaldo da } \\
\text { Ramos } \\
\text { prontuário }\end{array} & \begin{array}{r}\text { Silva } \\
\text { (no }\end{array} \\
\begin{array}{l}\text { Fernando } \\
\text { outros) }\end{array} & & \\
\end{array}$ & 1969 & Brasileira & $\begin{array}{l}\text { Sindicância policiais } \\
\text { pertencentes ao } \\
\text { "ccc" (comando de } \\
\text { caça aos comunistas) }\end{array}$ & Parda \\
\hline 16020 & $\begin{array}{l}\text { Oswaldo Francelino } \\
\text { Cerqueira }\end{array}$ & 1970 & Brasileira & Legitimação & Parda \\
\hline 16834 & José Cyres da Silva & 1973 & Brasileira & Legitimação & Parda \\
\hline 18432 & Gerônimo Alves & 1971 & Brasileira & Averiguações & Preta \\
\hline 18579 & $\begin{array}{ll}\text { Etemilton Ferreira } \\
\text { Silva }\end{array}$ & 1971 & Brasileira & Legitimação & Preta \\
\hline 19169 & Alberto Ribeiro & 1972 & Brasileira & Legitimação & Parda \\
\hline 19341 & Gil Brás de Lima & 1974 & Brasileira & Legitimação & Preta \\
\hline 23079 & Jurandir Rosa & 1971 & Brasileira & Legitimação & Preta \\
\hline 69503 & $\begin{array}{ll}\text { Raimundo Dias } \\
\text { Borges }\end{array}$ & 1973 & Brasileira & $\begin{array}{l}\text { Falsificação } \\
\text { diplomas }\end{array}$ & Parda \\
\hline 69845 & $\begin{array}{l}\text { Alberto Moura do } \\
\text { Nascimento }\end{array}$ & 1982 & Brasileira & Roubo & $\begin{array}{l}\text { Parda } \\
\text { clara }\end{array}$ \\
\hline 69886 & $\begin{array}{lll}\text { José } & \text { Angelo Del } \\
\text { Nero } & & \\
\end{array}$ & 1982 & Brasileira & Sonegação fiscal & Parda \\
\hline 69891 & $\begin{array}{l}\text { José Francisco da } \\
\text { Silva }\end{array}$ & 1982 & Brasileira & Legitimação & Parda \\
\hline 71081 & $\begin{array}{lr}\text { José } & \text { Dias } \\
\text { ou } & \text { Rubens } \\
\end{array}$ & 1970 & Brasileira & Legitimação & Preta \\
\hline
\end{tabular}




\begin{tabular}{|c|c|c|c|c|c|}
\hline & Saturnino & & & & \\
\hline 71758 & $\begin{array}{l}\text { Leonel Alves de } \\
\text { Oliveira }\end{array}$ & 1973 & Brasileira & Averiguações & Parda \\
\hline 72357 & $\begin{array}{ll}\text { Antonio Fernandes } \\
\text { da Silva }\end{array}$ & 1971 & Brasileira & Legitimação & Parda \\
\hline 73770 & $\begin{array}{l}\text { Elmigio Magno } \\
\text { Gaynn }\end{array}$ & 1975 & Paraguaia & Legitimação & Parda \\
\hline 73812 & $\begin{array}{l}\text { Marco Antonio de } \\
\text { Oliveira }\end{array}$ & 1982 & Brasileira & Roubo & $\begin{array}{l}\text { Parda } \\
\text { escura }\end{array}$ \\
\hline 74117 & $\begin{array}{l}\text { Galdino dos Anjos } \\
\text { Ribeiro }\end{array}$ & 1970 & Brasileira & Legitimação & $\begin{array}{l}\text { Parda ou } \\
\text { morena }\end{array}$ \\
\hline 74222 & $\begin{array}{l}\text { Virgilio Pedro da } \\
\text { Silva }\end{array}$ & 1970 & Brasileira & Legitimação & $\begin{array}{l}\text { Parda } \\
\text { clara }\end{array}$ \\
\hline 74682 & $\begin{array}{l}\text { Eduardo Isaac } \\
\text { Michetti Coitino }\end{array}$ & 1972 & Uruguaia & Legitimação & Parda \\
\hline 75071 & $\begin{array}{l}\text { Oswaldo Alves } \\
\text { Tavares }\end{array}$ & 1972 & Brasileira & Legitimação & Preta \\
\hline 75363 & $\begin{array}{l}\text { Grover Raul Pinto } \\
\text { Santa Cruz }\end{array}$ & 1974 & Boliviana & Legitimação & Parda \\
\hline 75725 & $\begin{array}{ll}\text { José } & \text { Fernandes } \\
\text { Oliveira } & \end{array}$ & 1970 & Brasileira & Legitimação & $\begin{array}{l}\text { Parda ou } \\
\text { branca }\end{array}$ \\
\hline 75766 & $\begin{array}{l}\text { Maria Magdalena } \\
\text { Chagas }\end{array}$ & 1973 & Brasileira & Legitimação & Parda \\
\hline 76013 & $\begin{array}{lll}\text { Helio da Rocha } \\
\text { Pitta }\end{array}$ & 1971 & Brasileira & $\begin{array}{l}\text { Legitimação e e } \\
\text { falsidade ideológica }\end{array}$ & Parda \\
\hline 76503 & $\begin{array}{l}\text { José Carlos dos } \\
\text { Santos }\end{array}$ & 1974 & Brasileira & Roubo & Parda \\
\hline 76505 & José Policarpo & 1974 & Brasileira & Averiguações & Negra \\
\hline 76545 & Marcelino Vicente & 1974 & Brasileira & Legitimação & Preta \\
\hline 76546 & $\begin{array}{l}\text { Maria Angelica dos } \\
\text { Santos }\end{array}$ & 1974 & Brasileira & Legitimação & Parda \\
\hline 77271 & $\begin{array}{l}\text { Lupercio da Silva } \\
\text { Bueno }\end{array}$ & 1981 & Brasileira & Legitimação & $\begin{array}{l}\text { Parda } \\
\text { clara }\end{array}$ \\
\hline 78252 & $\begin{array}{l}\text { Florisval Pereira da } \\
\text { Silva }\end{array}$ & 1972 & Brasileira & Legitimação & Parda \\
\hline 78657 & $\begin{array}{l}\text { Luciano da Silva } \\
\text { Machado }\end{array}$ & 1970 & Brasileira & Legitimação & Preta \\
\hline 79495 & Ariston dos Santos & 1971 & Brasileira & Legitimação & Parda \\
\hline 81155 & $\begin{array}{l}\text { Dário Artigas } \\
\text { Correia Jariel }\end{array}$ & 1970 & Uruguaia & Legitimação & Parda \\
\hline 81696 & $\begin{array}{l}\text { Antonio Carlos da } \\
\text { Silva }\end{array}$ & 1981 & Brasileira & Extorsão & Parda \\
\hline 82717 & $\begin{array}{l}\text { Almerio } \\
\text { Melchiades } \\
\text { Araújo }\end{array}$ & 1972 & Brasileira & $\begin{array}{l}\text { Legitimação } \\
\text { (participação do } \\
\text { Partido Operário } \\
\text { Revolucionário }\end{array}$ & Parda \\
\hline
\end{tabular}




\begin{tabular}{|c|c|c|c|c|c|}
\hline & & & & Trotskista) & \\
\hline 83362 & $\begin{array}{l}\text { João Galdino de } \\
\text { Souza Filho }\end{array}$ & 1981 & Brasileira & Roubo a banco & Preta \\
\hline 83520 & $\begin{array}{l}\text { José Herminio de } \\
\text { Souza }\end{array}$ & 1970 & Brasileira & Legitimação & Parda \\
\hline 83620 & $\begin{array}{l}\text { José Rubens } \\
\text { Grande Filho }\end{array}$ & 1982 & Brasileira & Averiguações & $\begin{array}{l}\text { Parda } \\
\text { clara }\end{array}$ \\
\hline 84354 & $\begin{array}{l}\text { Francisco Lucrecio } \\
\text { Junior }\end{array}$ & 1969 & Brasileira & Legitimação & Preta \\
\hline 84800 & $\begin{array}{l}\text { Marcos Pereira de } \\
\text { Castro }\end{array}$ & 1981 & Brasileira & Roubo a banco & Preta \\
\hline 85217 & $\begin{array}{l}\text { Vidal Correia de } \\
\text { Moraes }\end{array}$ & 1971 & Brasileira & Legitimação & Parda \\
\hline 85316 & $\begin{array}{l}\text { Jair de Paula } \\
\text { Martins }\end{array}$ & 1981 & Brasileira & Legitimação & $\begin{array}{l}\text { Parda } \\
\text { clara }\end{array}$ \\
\hline 85399 & José Rosa Vieira & 1973 & Brasileira & Legitimação & Parda \\
\hline 85705 & $\begin{array}{l}\text { Manoel Mariano } \\
\text { Feitosa }\end{array}$ & 1973 & Brasileira & Legitimação & Parda \\
\hline 85925 & $\begin{array}{l}\text { José Roberto de } \\
\text { Souza }\end{array}$ & 1981 & Brasileira & Porte arma e disparo & Preta \\
\hline 86043 & $\begin{array}{ll}\text { Alcides } & \text { Francisco } \\
\text { Dourado } & \end{array}$ & 1965 & Brasileira & Não consta & Parda \\
\hline 86193 & $\begin{array}{ll}\text { Graciano } & \text { Alves } \\
\text { Oliveira } & \end{array}$ & 1970 & Brasileira & Legitimação & $\begin{array}{l}\text { Parda ou } \\
\text { morena }\end{array}$ \\
\hline 86928 & $\begin{array}{l}\text { Gilson Theodoro de } \\
\text { Oliveira }\end{array}$ & 1970 & Brasileira & Legitimação & Parda \\
\hline 87460 & $\begin{array}{l}\text { Euclides Marinho } \\
\text { Amaral }\end{array}$ & 1970 & Brasileira & Legitimação & Preta \\
\hline 88104 & $\begin{array}{lll}\text { Adair } & \text { Luiz } & \text { de } \\
\text { Souza } & & \end{array}$ & 1970 & Brasileira & Legitimação & $\begin{array}{l}\text { Parda } \\
\text { clara }\end{array}$ \\
\hline 89134 & José Maria da Silva & 1969 & Brasileira & Legitimação & Preta \\
\hline 89430 & $\begin{array}{lll}\text { Antão } & \text { Alves } & \text { da } \\
\text { Silva } & & \\
\end{array}$ & 1971 & Brasileira & Tentativa extorsão & Parda \\
\hline 89976 & $\begin{array}{l}\text { Honorino Gomes } \\
\text { Ribeiro }\end{array}$ & 1970 & Brasileira & Legitimação & $\begin{array}{l}\text { Parda } \\
\text { clara }\end{array}$ \\
\hline 90453 & José Honorio Filho & 1973 & Brasileira & Legitimação & Parda \\
\hline 91386 & $\begin{array}{l}\text { Laurindo } \\
\text { Guimarães }\end{array}$ & 1964 & Brasileira & Comunismo & Parda \\
\hline 93469 & $\begin{array}{l}\text { Miguel Batista da } \\
\text { Silva }\end{array}$ & 1974 & Brasileira & Legitimação & Parda \\
\hline 93700 & $\begin{array}{ll}\text { José Anselmo da } \\
\text { Silva }\end{array}$ & 1969 & Brasileira & Legitimação & Parda \\
\hline 94308 & João Francisco & 1974 & Brasileira & Legitimação & Parda \\
\hline 94333 & $\begin{array}{l}\text { Ageu Mariano de } \\
\text { Campos }\end{array}$ & 1974 & Brasileira & Legitimação & Preta \\
\hline 94564 & Adjanei $\quad$ Ferreira & 1971 & Brasileira & Legitimação e fuga & Preta \\
\hline
\end{tabular}




\begin{tabular}{|c|c|c|c|c|c|}
\hline & Ignácio & & & & \\
\hline 94622 & $\begin{array}{l}\text { José Carlos da Silva } \\
\text { Filho }\end{array}$ & 1970 & Brasileira & Legitimação & Preta \\
\hline 94697 & Walter Adriano & 1976 & Brasileira & Resistência & $\begin{array}{l}\text { Parda } \\
\text { clara }\end{array}$ \\
\hline 94802 & Edson Dias & 1975 & Brasileira & Legitimação & Preta \\
\hline 94907 & $\begin{array}{l}\text { José Alcides de } \\
\text { Oliveira }\end{array}$ & 1967 & Brasileira & Comunismo & $\begin{array}{l}\text { Parda } \\
\text { clara }\end{array}$ \\
\hline 94951 & $\begin{array}{l}\text { Valdivina } \\
\text { Rodrigues de Souza }\end{array}$ & 1974 & Brasileira & Legitimação & Parda \\
\hline 94960 & $\begin{array}{l}\text { Gasparino Alfredo } \\
\text { Ruas }\end{array}$ & 1974 & Brasileira & Legitimação & Preta \\
\hline 94967 & $\begin{array}{l}\text { Isaias Mariano de } \\
\text { Campos }\end{array}$ & 1974 & Brasileira & Legitimação & Preta \\
\hline 95309 & $\begin{array}{l}\text { Manuel Cardozo de } \\
\text { Andrade }\end{array}$ & 1975 & Brasileira & $\begin{array}{l}\text { Legitimação por } \\
\text { assalto }\end{array}$ & Parda \\
\hline 95317 & $\begin{array}{l}\text { Victor Eugene } \\
\text { Buchman Junior }\end{array}$ & 1969 & $\begin{array}{l}\text { Norte- } \\
\text { americana }\end{array}$ & $\begin{array}{l}\text { Situação irregular no } \\
\text { país }\end{array}$ & Preta \\
\hline 95344 & $\begin{array}{l}\text { Edwaldo Alves da } \\
\text { Silva }\end{array}$ & 1975 & Brasileira & Comunismo & Parda \\
\hline 95649 & $\begin{array}{l}\text { Benedita Aparecida } \\
\text { Chagas }\end{array}$ & 1973 & Brasileira & Legitimação & $\begin{array}{l}\text { Parda ou } \\
\text { branca }\end{array}$ \\
\hline 97082 & $\begin{array}{l}\text { Altair } \quad \text { Campos } \\
\text { Thiago }\end{array}$ & 1970 & Brasileira & Legitimação & Parda \\
\hline 97384 & Roberto Rocha & 1975 & Brasileira & $\begin{array}{l}\text { Legitimação } \\
\text { falsa identidade }\end{array}$ & $\begin{array}{l}\text { Parda } \\
\text { clara }\end{array}$ \\
\hline 97481 & Rubens dos Santos & 1975 & Brasileira & $\begin{array}{l}\text { Legitimação por } \\
\text { assaltos }\end{array}$ & Preta \\
\hline 97486 & $\begin{array}{l}\text { Pio Mariano de } \\
\text { Campos }\end{array}$ & 1974 & Brasileira & Legitimação & Preta \\
\hline 97489 & $\begin{array}{l}\text { Manoel Pereira } \\
\text { Juvenal }\end{array}$ & 1975 & Brasileira & Comunismo & $\begin{array}{l}\text { Parda ou } \\
\text { branca }\end{array}$ \\
\hline 97573 & $\begin{array}{l}\text { Djalma Mendes da } \\
\text { Silva }\end{array}$ & 1975 & Brasileira & Legitimação & $\begin{array}{l}\text { Parda ou } \\
\text { branca }\end{array}$ \\
\hline 97704 & $\begin{array}{l}\text { Gonçalo Pereira da } \\
\text { Silva }\end{array}$ & 1975 & Brasileira & Furto & Preta \\
\hline 97730 & $\begin{array}{l}\text { Genilda Souza } \\
\text { Costa }\end{array}$ & 1974 & Brasileira & Legitimação & $\begin{array}{l}\text { Parda } \\
\text { clara }\end{array}$ \\
\hline 97752 & $\begin{array}{lll}\text { Jose } & \text { Alberto } & \text { da } \\
\text { Silva } & & \end{array}$ & 1975 & Brasileira & Falsa identidade & $\begin{array}{l}\text { Parda } \\
\text { escura }\end{array}$ \\
\hline 97831 & Erdir Pena Oliveira & 1975 & Brasileira & Comunismo & $\begin{array}{l}\text { Parda } \\
\text { escura }\end{array}$ \\
\hline 97901 & $\begin{array}{l}\text { Domingos } \\
\text { Pergentino da Silva }\end{array}$ & 1975 & Brasileira & Falsificação & $\begin{array}{l}\text { Parda } \\
\text { clara }\end{array}$ \\
\hline 98171 & Waltemiro da Costa & 1975 & Brasileira & Legitimação & Preta \\
\hline 98310 & Reynolds $\quad$ Frank & 1975 & guianes & Legitimação & Preta \\
\hline
\end{tabular}




\begin{tabular}{|c|c|c|c|c|c|}
\hline & Culpepper & & $\begin{array}{l}\text { (Guiana } \\
\text { Inglesa) }\end{array}$ & expulsão do país & \\
\hline 98712 & Paulo Nieira e Silva & 1971 & Brasileira & Legitimação & Parda \\
\hline 98791 & $\begin{array}{ll}\text { Orlando } & \text { Silva } \\
\text { Gouveia } & \end{array}$ & 1974 & Brasileira & Comunismo & Preta \\
\hline 98812 & $\begin{array}{l}\text { Peterson Petronilho } \\
\text { de Souza }\end{array}$ & 1975 & Brasileira & Legitimação & Parda \\
\hline 98813 & $\begin{array}{l}\text { Otto Inacio da } \\
\text { Rocha }\end{array}$ & 1975 & Brasileira & Averiguações & Preta \\
\hline 99076 & $\begin{array}{l}\text { Gonçalo Pereira da } \\
\text { Silva }\end{array}$ & 1975 & Brasileira & $\begin{array}{l}\text { Legitimação por } \\
\text { assalto }\end{array}$ & Preta \\
\hline 99547 & Esmeraldo Lemos & 1975 & Brasileira & Falsificação & Preta \\
\hline 99590 & $\begin{array}{ll}\text { Sebastião } & \text { Dionisio } \\
\text { Lourenço } & \\
\end{array}$ & 1970 & Brasileira & Legitimação & Preta \\
\hline 99613 & $\begin{array}{ll}\text { Mariano Alves de } \\
\text { Oliveira }\end{array}$ & 1974 & Brasileira & Legitimação & Parda \\
\hline 99899 & Santo Cardoso & 1969 & Brasileira & Legitimação & Parda \\
\hline 100133 & $\begin{array}{l}\text { Francisca } \\
\text { Veneranda da Silva }\end{array}$ & 1975 & Brasileira & Legitimação & Parda \\
\hline 100136 & João da Silva Filho & 1974 & Brasileira & Legitimação & Preta \\
\hline 100174 & $\begin{array}{l}\text { José Manuel Paiva } \\
\text { Olivas }\end{array}$ & 1974 & Peruana & Legitimação & Parda \\
\hline 100225 & $\begin{array}{lr}\text { Antonio } & \text { Carlos } \\
\text { Clemente de Araújo }\end{array}$ & 1976 & Brasileira & Assalto a banco & Preta \\
\hline 100311 & $\begin{array}{l}\text { Gelson Dantas } \\
\text { Souza }\end{array}$ & 1975 & Brasileira & Legitimação & $\begin{array}{l}\text { Morena } \\
\text { ou parda }\end{array}$ \\
\hline 6539 & Maria Julia Oliveira & 1970 & Brasileira & Legitimação & $\begin{array}{l}\text { Parda ou } \\
\text { morena } \\
\text { clara ou } \\
\text { parda } \\
\text { clara }\end{array}$ \\
\hline 100317 & Oswaldo Costa & 1976 & Brasileira & Assalto a banco & Parda \\
\hline 100319 & $\begin{array}{l}\text { Antonio } \quad \text { Heitor } \\
\text { Lopes }\end{array}$ & 1976 & Brasileira & $\begin{array}{ll}\text { Falsificação } & \text { de } \\
\text { documentos }\end{array}$ & Parda \\
\hline 100406 & $\begin{array}{l}\text { Antonio Alves de } \\
\text { Souza }\end{array}$ & 1974 & Brasileira & Legitimação & Parda \\
\hline 100619 & $\begin{array}{l}\text { Carmen Wanda } \\
\text { Ramos Costa }\end{array}$ & 1975 & Brasileira & Legitimação & $\begin{array}{l}\text { Preta ou } \\
\text { branca }\end{array}$ \\
\hline 100648 & José Pires & 1975 & Brasileira & Comunismo & Preta \\
\hline 100988 & $\begin{array}{ll}\text { Laudelino } & \text { de } \\
\text { Carvalho } & \end{array}$ & 1973 & Brasileira & Crime fazendário & $\begin{array}{l}\text { Parda } \\
\text { escura }\end{array}$ \\
\hline 100996 & $\begin{array}{ll}\text { Clemente } & \text { Perez } \\
\text { Choque }\end{array}$ & 1974 & Boliviano & $\begin{array}{l}\text { Documentos } \\
\text { irregulares }\end{array}$ & $\begin{array}{ll}\text { Parda ou } \\
\text { branca }\end{array}$ \\
\hline 101362 & Servilio Hipólito & 1970 & Brasileira & Legitimação & Parda \\
\hline 101582 & $\begin{array}{lll}\text { Júlio } & \text { Cardoso da } \\
\text { Silva } & & \end{array}$ & 1968 & Brasileira & Legitimação & Preta \\
\hline
\end{tabular}




\begin{tabular}{|c|c|c|c|c|c|}
\hline 101908 & $\begin{array}{l}\text { Paulo Evaristo dos } \\
\text { Santos }\end{array}$ & 1975 & Brasileira & Comunismo & Preta \\
\hline 102005 & $\begin{array}{l}\text { Carlos } \\
\text { Corrêa }\end{array}$ & 1982 & Brasileira & Não consta & $\begin{array}{l}\text { Parda } \\
\text { clara }\end{array}$ \\
\hline 102154 & $\begin{array}{l}\text { Agostinho Eduardo } \\
\text { Silva }\end{array}$ & 1971 & Brasileira & Legitimação & $\begin{array}{ll}\text { Preta ou } \\
\text { parda }\end{array}$ \\
\hline 103317 & $\begin{array}{l}\text { Manoel Marques da } \\
\text { Silva }\end{array}$ & 1970 & Brasileira & Legitimação & Parda \\
\hline 103346 & $\begin{array}{l}\text { Manoel Joaquim da } \\
\text { Silva }\end{array}$ & 1971 & Brasileira & Não consta & Parda \\
\hline 103451 & $\begin{array}{l}\text { Raimundo Moreira } \\
\text { de Oliveira }\end{array}$ & 1971 & Brasileira & Legitimação & $\begin{array}{l}\text { Morena } \\
\text { ou parda } \\
\text { escura }\end{array}$ \\
\hline 103633 & $\begin{array}{l}\text { Luzia Trindade de } \\
\text { Rezende }\end{array}$ & 1971 & Brasileira & Legitimação & $\begin{array}{l}\text { Parda } \\
\text { clara }\end{array}$ \\
\hline 103866 & $\begin{array}{l}\text { Cassiano Nerys dos } \\
\text { Santos }\end{array}$ & 1973 & Brasileira & Legitimação & Parda \\
\hline 103888 & $\begin{array}{ll}\text { José Alves dos } \\
\text { Santos }\end{array}$ & 1973 & Brasileira & Legitimação & Parda \\
\hline 103920 & $\begin{array}{lll}\text { Elpidio José } & \text { da } \\
\text { Silva } & & \\
\end{array}$ & 1973 & Brasileira & Legitimação & $\begin{array}{ll}\text { Preta ou } \\
\text { parda }\end{array}$ \\
\hline 103948 & $\begin{array}{ll}\text { Claudimiro } & \mathrm{da} \\
\text { Conceição } & \end{array}$ & 1973 & Brasileira & $\begin{array}{l}\text { Legitimação (dupla } \\
\text { identidade) }\end{array}$ & Parda \\
\hline 104327 & $\begin{array}{l}\text { Nelson Alves de } \\
\text { Oliveira }\end{array}$ & 1973 & Brasileira & Legitimação & Parda \\
\hline 104330 & Newton Mamede & 1973 & Brasileira & Não consta & $\begin{array}{l}\text { Branca ou } \\
\text { parda }\end{array}$ \\
\hline 104337 & $\begin{array}{l}\text { Clementino Ribeiro } \\
\text { Cruz }\end{array}$ & 1972 & Brasileira & $\begin{array}{l}\text { Falsificação } \\
\text { documento }\end{array}$ & $\begin{array}{l}\text { Parda ou } \\
\text { mulata }\end{array}$ \\
\hline 104360 & $\begin{array}{lll}\text { Sergio } & \text { Luiz } & \text { dos } \\
\text { Santos } & & \\
\end{array}$ & 1973 & Brasileira & Legitimação & $\begin{array}{ll}\begin{array}{l}\text { Preta ou } \\
\text { negra }\end{array} & \\
\end{array}$ \\
\hline 104465 & $\begin{array}{l}\text { Ubirajara Carlos da } \\
\text { Silva }\end{array}$ & 1973 & Brasileira & Legitimação & $\begin{array}{ll}\begin{array}{l}\text { Preta } \\
\text { negra }\end{array} & \\
\end{array}$ \\
\hline 104493 & $\begin{array}{ll}\text { Irani } & \text { Martins } \\
\text { Ramos } & \end{array}$ & 1973 & Brasileira & Legitimação & $\begin{array}{ll}\text { Preta } & \text { ou } \\
\text { parda }\end{array}$ \\
\hline 104654 & $\begin{array}{l}\text { Carlos Roberto da } \\
\text { Silva }\end{array}$ & 1972 & Brasileira & Legitimação & Preta \\
\hline 104665 & José Pereira & 1974 & Brasileira & $\begin{array}{l}\text { Legitimação } \\
\text { (expulso } \\
\text { Argentina) }\end{array}$ & $\begin{array}{l}\text { Parda ou } \\
\text { morena }\end{array}$ \\
\hline 104677 & $\begin{array}{l}\text { Henrique Banegas } \\
\text { Callan }\end{array}$ & 1973 & Boliviana & $\begin{array}{l}\text { Permanência ilegal } \\
\text { país }\end{array}$ & $\begin{array}{l}\text { Morena } \\
\text { ou parda }\end{array}$ \\
\hline 104682 & $\begin{array}{l}\text { Odilon Antonio dos } \\
\text { Santos }\end{array}$ & 1973 & Brasileira & $\begin{array}{l}\text { Assalto comum e } \\
\text { suspeita roubo banco }\end{array}$ & Parda \\
\hline 104710 & Walter Cantovitz & 1981 & Brasileira & Não consta & $\begin{array}{l}\text { Parda } \\
\text { clara }\end{array}$ \\
\hline
\end{tabular}




\begin{tabular}{|c|c|c|c|c|c|}
\hline 104726 & $\begin{array}{l}\text { Joel Rufino dos } \\
\text { Santos }\end{array}$ & 1973 & Brasileira & $\begin{array}{l}\text { Legitimação } \\
\text { subversâo }\end{array}$ & Preta \\
\hline 104742 & $\begin{array}{l}\text { Antonio } \\
\text { Leite }\end{array}$ & 1973 & Brasileira & $\begin{array}{l}\text { Artigo } 304 \text { Código } \\
\text { Penal }\end{array}$ & Preta \\
\hline 104810 & $\begin{array}{l}\text { João Cardoso dos } \\
\text { Santos }\end{array}$ & 1973 & Brasileira & Legitimação & $\begin{array}{l}\text { Parda ou } \\
\text { preta }\end{array}$ \\
\hline 104820 & José Martins & 1973 & Brasileira & Homicídio & $\begin{array}{l}\text { Parda } \\
\text { escura }\end{array}$ \\
\hline 104822 & $\begin{array}{ll}\text { Roberto } & \text { Salazar } \\
\text { Serna } & \end{array}$ & 1973 & Colombiana & Roubo & Parda \\
\hline 104823 & $\begin{array}{ll}\text { Victor } & \text { Hugo } \\
\text { Llamozas } & \end{array}$ & 1973 & Paraguaia & Deportação país & Parda \\
\hline 104888 & Adão da Cruz Dias & 1973 & Brasileira & Averiguação & Parda \\
\hline 104904 & Benedito Pedroso & 1973 & Brasileira & Legitimação & $\begin{array}{ll}\text { Parda ou } \\
\text { preta }\end{array}$ \\
\hline 104906 & $\begin{array}{l}\text { Carlos Antonio } \\
\text { Oliveira da Silva }\end{array}$ & 1973 & Brasileira & Averiguações & Parda \\
\hline 104994 & $\begin{array}{l}\text { Maria } \\
\text { Jesuncisca de } \\
\text { Silva }\end{array}$ & 1973 & Brasileira & Legitimação & $\begin{array}{l}\text { Parda } \\
\text { clara ou } \\
\text { morena }\end{array}$ \\
\hline 105005 & $\begin{array}{l}\text { Pedro Martins dos } \\
\text { Santos }\end{array}$ & 1973 & Brasileira & $\begin{array}{lr}\text { Legitimação } & \text { pela } \\
\text { Delegacia } & \text { de } \\
\text { Explosivos } & \\
\end{array}$ & Preta \\
\hline 105006 & $\begin{array}{l}\text { Pedro Almeida } \\
\text { Gomes }\end{array}$ & 1973 & Brasileira & $\begin{array}{lr}\text { Legitimação } & \text { pela } \\
\text { Delegacia } & \text { de } \\
\text { Explosivos } & \end{array}$ & $\begin{array}{l}\text { Parda ou } \\
\text { branca }\end{array}$ \\
\hline 105007 & $\begin{array}{l}\text { Orlando } \quad \text { Vieira } \\
\text { Gomes }\end{array}$ & 1973 & Brasileira & $\begin{array}{lr}\text { Legitimação } & \text { pela } \\
\text { Delegacia } & \text { de } \\
\text { Explosivos } & \\
\end{array}$ & Parda \\
\hline 105012 & Miguel Moreira & 1973 & Brasileira & $\begin{array}{lr}\text { Legitimação } & \text { pela } \\
\text { Delegacia } & \text { de } \\
\text { Explosivos } & \\
\end{array}$ & Parda \\
\hline 105111 & $\begin{array}{l}\text { Baylon Pereira da } \\
\text { Silva }\end{array}$ & 1973 & Brasileira & $\begin{array}{l}\text { Averiguações por } \\
\text { estelionato }\end{array}$ & $\begin{array}{l}\text { Parda ou } \\
\text { morena }\end{array}$ \\
\hline 105123 & Leonildo Floriano & 1973 & Brasileira & Legitimação & $\begin{array}{ll}\text { Preta } & \text { ou } \\
\text { negra }\end{array}$ \\
\hline 105128 & $\begin{array}{l}\text { Neuza Corrêa de } \\
\text { Souza }\end{array}$ & 1973 & Brasileira & Legitimação & $\begin{array}{ll}\text { Parda ou } \\
\text { negra }\end{array}$ \\
\hline 105385 & $\begin{array}{l}\text { José Lopes Leitão } \\
\text { Filho }\end{array}$ & 1975 & Brasileira & Assalto a banco & Parda \\
\hline 105388 & $\begin{array}{ll}\text { Jovino } & \text { Lopes } \\
\text { Leitão } & \\
\end{array}$ & 1975 & Brasileira & Assalto a banco & Parda \\
\hline 105506 & $\begin{array}{l}\text { Edomicio Góes } \\
\text { Xavier }\end{array}$ & 1971 & Brasileira & Legitimação & $\begin{array}{l}\text { Parda ou } \\
\text { branca }\end{array}$ \\
\hline 106010 & $\begin{array}{lll}\text { Sinval } & \text { Soares } & \text { da } \\
\text { Silva } & & \\
\end{array}$ & 1974 & Brasileira & Greve & Preta \\
\hline
\end{tabular}




\begin{tabular}{|c|c|c|c|c|c|}
\hline 106013 & José Ronaldo & 1974 & Brasileira & Greve & Parda \\
\hline 106014 & $\begin{array}{ll}\text { José } & \text { Benedito } \\
\text { Muniz } & \end{array}$ & 1974 & Brasileira & Greve & Preta \\
\hline 106521 & Isaac de Jesus & 1976 & Brasileira & Extorsão & $\begin{array}{l}\text { Parda } \\
\text { escura ou } \\
\text { preta }\end{array}$ \\
\hline 106591 & $\begin{array}{l}\text { José Claudio de } \\
\text { Almeida }\end{array}$ & 1975 & Brasileira & Legitimação & Parda \\
\hline 107121 & $\begin{array}{l}\text { Eduardo Alves de } \\
\text { Moura }\end{array}$ & 1973 & Brasileira & $\begin{array}{l}\text { Legitimação por } \\
\text { estelionato }\end{array}$ & $\begin{array}{ll}\text { Parda ou } \\
\text { negra }\end{array}$ \\
\hline 107629 & $\begin{array}{ll}\text { Sueli } & \text { Aparecida } \\
\text { Lisboa } & \\
\end{array}$ & 1973 & Brasileira & Legitimação & Parda \\
\hline 107694 & $\begin{array}{ll}\text { Rufino } & \text { Rojas } \\
\text { Bustamante } & \\
\end{array}$ & 1973 & Boliviana & Comunismo & $\begin{array}{l}\text { Parda ou } \\
\text { morena }\end{array}$ \\
\hline 107696 & Antonio Custodio & 1970 & Brasileira & Legitimação & $\begin{array}{l}\text { Parda } \\
\text { escura }\end{array}$ \\
\hline 107781 & $\begin{array}{l}\text { José Jorley do } \\
\text { Amaral }\end{array}$ & 1971 & Brasileira & Averiguações & Parda \\
\hline 108128 & $\begin{array}{l}\text { Agemiro Francisco } \\
\text { Pereira }\end{array}$ & 1972 & Brasileira & Sonegação fiscal & $\begin{array}{l}\text { Parda ou } \\
\text { branca }\end{array}$ \\
\hline 108185 & $\begin{array}{ll}\text { Rolando } & \text { David } \\
\text { Pardo Loza } & \end{array}$ & 1971 & Peruana & Legitimação & $\begin{array}{l}\text { Parda ou } \\
\text { morena } \\
\text { clara }\end{array}$ \\
\hline 108759 & $\begin{array}{l}\text { Cyleia Rodrigues } \\
\text { Costa Pregnolatto }\end{array}$ & 1970 & Brasileira & $\begin{array}{l}\text { Legitimação por } \\
\text { subversão }\end{array}$ & $\begin{array}{l}\text { Preta ou } \\
\text { negra }\end{array}$ \\
\hline 108779 & $\begin{array}{l}\text { Antonio Mizael da } \\
\text { Silva }\end{array}$ & 1972 & Brasileira & Legitimação & Preta \\
\hline 109630 & Aton Fon Filho & 1970 & Brasileira & $\begin{array}{l}\text { Legitimação (por } \\
\text { meio da operação } \\
\text { bandeirante) }\end{array}$ & Parda \\
\hline 110051 & $\begin{array}{ll}\text { João Pereira do } \\
\text { Carmo }\end{array}$ & 1975 & Brasileira & Legitimação & $\begin{array}{l}\text { Parda } \\
\text { clara }\end{array}$ \\
\hline 110052 & $\begin{array}{l}\text { Francelino Lopes } \\
\text { Leitão }\end{array}$ & 1975 & Brasileira & Legitimação & $\begin{array}{l}\text { Parda } \\
\text { escura }\end{array}$ \\
\hline 110043 & $\begin{array}{ll}\text { Ivan Pereira do } \\
\text { Carmo }\end{array}$ & 1975 & Brasileira & Legitimação & $\begin{array}{l}\text { Parda ou } \\
\text { branca }\end{array}$ \\
\hline 110215 & $\begin{array}{lll}\text { Eloy } & \text { Martins } & \text { da } \\
\text { Silva } & & \\
\end{array}$ & 1971 & Brasileira & Falsa identidade & $\begin{array}{l}\text { Parda } \\
\text { clara }\end{array}$ \\
\hline 110766 & Bento Batista Neto & 1968 & Brasileira & Legitimação & Parda \\
\hline 110862 & $\begin{array}{l}\text { José Reinaldo Paes } \\
\text { Leme }\end{array}$ & 1971 & Brasileira & $\begin{array}{l}\text { Legitimação } \\
\text { participação } \\
\text { movimento } \\
\text { subversivo }\end{array}$ & $\begin{array}{l}\text { Parda } \\
\text { clara }\end{array}$ \\
\hline 111084 & Valter Dias & 1971 & Brasileira & Legitimação & $\begin{array}{l}\text { Parda ou } \\
\text { branca }\end{array}$ \\
\hline 111801 & Fred B. Brown & 1973 & Norte- & Legitimação & Preta \\
\hline
\end{tabular}




\begin{tabular}{|c|c|c|c|c|c|}
\hline & & & americana & (passaporte) & \\
\hline 111832 & Rivaldo Giraud & 1976 & Brasileira & Legitimação & $\begin{array}{l}\text { Branca ou } \\
\text { parda } \\
\text { escura }\end{array}$ \\
\hline 111834 & $\begin{array}{l}\text { Silvio da Rocha } \\
\text { Lira }\end{array}$ & 1976 & Brasileira & Legitimação & $\begin{array}{l}\text { Branca ou } \\
\text { parda } \\
\text { clara }\end{array}$ \\
\hline 112969 & Armando de Souza & 1975 & Brasileira & $\begin{array}{l}\text { Fins civis atestado } \\
\text { antecedentes }\end{array}$ & $\begin{array}{l}\text { Afro- } \\
\text { descenden } \\
\text { te* }\end{array}$ \\
\hline 112999 & $\begin{array}{l}\text { Daniel Aguillar } \\
\text { Goyenich }\end{array}$ & 1971 & Peruana & $\begin{array}{l}\text { Expulsão país } \\
\text { (antecedentes furto) }\end{array}$ & Preta \\
\hline 113041 & Gand de Souza & 1975 & Brasileira & Legitimação & $\begin{array}{l}\text { Parda } \\
\text { escura }\end{array}$ \\
\hline 113044 & $\begin{array}{l}\text { Rose Mary Ramos } \\
\text { de Araújo }\end{array}$ & 1975 & Brasileira & Legitimação & Preta \\
\hline 113059 & $\begin{array}{ll}\text { Francisco } & \text { Dantas } \\
\text { Ribeiro } & \\
\end{array}$ & 1976 & Brasileira & Legitimação & $\begin{array}{l}\text { Parda } \\
\text { clara }\end{array}$ \\
\hline 113556 & $\begin{array}{l}\text { Lindozino } \\
\text { Rodrigues } \\
\text { Medeiros }\end{array}$ & 1969 & Brasileira & $\begin{array}{l}\text { Falsificação } \\
\text { documentos }\end{array}$ & $\begin{array}{l}\text { Parda } \\
\text { escura }\end{array}$ \\
\hline 113687 & Aluizio Silveira & 1971 & Brasileira & Legitimação & Parda \\
\hline 113992 & Moises Eugenio & 1970 & Brasileira & Legitimação & Preta \\
\hline 114003 & $\begin{array}{l}\text { Pedro da Costa } \\
\text { Lima }\end{array}$ & 1975 & Brasileira & Legitimação & Preta \\
\hline 114045 & Moacyr Guimarães & 1975 & Brasileira & Crime fazendário & $\begin{array}{l}\text { Parda } \\
\text { escura }\end{array}$ \\
\hline 114249 & $\begin{array}{ll}\text { Oscar } & \text { Alberto } \\
\text { Luduena } & \end{array}$ & 1975 & Argentina & $\begin{array}{l}\text { Situação irregular no } \\
\text { país }\end{array}$ & $\begin{array}{l}\text { Branca ou } \\
\text { parda }\end{array}$ \\
\hline 114266 & $\begin{array}{l}\text { Mario Correia de } \\
\text { Araújo }\end{array}$ & 1975 & Brasileira & Falso policial & $\begin{array}{l}\text { Parda } \\
\text { escura ou } \\
\text { preta }\end{array}$ \\
\hline 114269 & $\begin{array}{ll}\text { Honorino } & \text { Soriano } \\
\text { de Souza } & \end{array}$ & 1975 & Brasileira & $\begin{array}{l}\text { Artigo } 351 \text { Código } \\
\text { Penal }\end{array}$ & $\begin{array}{l}\text { Preta ou } \\
\text { parda } \\
\text { clara }\end{array}$ \\
\hline 114337 & $\begin{array}{l}\text { Benedito Antonio } \\
\text { Ferraz }\end{array}$ & 1970 & Brasileira & $\begin{array}{l}\text { Averiguações (por } \\
\text { meio da operação } \\
\text { bandeirante, } \\
\text { participação da Var } \\
\text { Palmares) }\end{array}$ & $\begin{array}{l}\text { Parda ou } \\
\text { branca }\end{array}$ \\
\hline 114423 & $\begin{array}{l}\text { Natalicio Vieira dos } \\
\text { Santos }\end{array}$ & 1972 & Brasileira & Legitimação & $\begin{array}{ll}\text { Parda ou } \\
\text { branca }\end{array}$ \\
\hline 114612 & Rubens dos Santos & 1971 & Brasileira & $\begin{array}{ll}\text { Artigo } 304 & \text { do } \\
\text { Código Penal } & \end{array}$ & $\begin{array}{l}\text { Parda } \\
\text { clara }\end{array}$ \\
\hline 115218 & $\begin{array}{l}\text { Emanuel de } \\
\text { Oliveira Marques }\end{array}$ & 1975 & Brasileira & $\begin{array}{l}\text { Extorsão mediante } \\
\text { seqüestro }\end{array}$ & Parda \\
\hline
\end{tabular}




\begin{tabular}{|c|c|c|c|c|c|}
\hline 115344 & $\begin{array}{l}\text { Ladislau Crispim } \\
\text { de Oliveira }\end{array}$ & 1973 & Brasileira & $\begin{array}{l}\text { Impressos } \\
\text { subversivos da ALN }\end{array}$ & Parda \\
\hline 115589 & José Eleno dos Reis & 1969 & Brasileira & Legitimação & Preta \\
\hline 115897 & $\begin{array}{lll}\text { Aluizio José } & \text { dos } \\
\text { Santos } & & \end{array}$ & 1969 & Brasileira & Legitimação & Preta \\
\hline 116050 & $\begin{array}{l}\text { Waldomiro de } \\
\text { Souza Dias }\end{array}$ & 1972 & Brasileira & Legitimação & Preta \\
\hline 116735 & Celso Silva Alves & 1970 & Brasileira & $\begin{array}{l}\text { Morto em combate } \\
\text { com a polícia }\end{array}$ & Parda \\
\hline 117135 & $\begin{array}{l}\text { Severino Alves de } \\
\text { Souza }\end{array}$ & 1975 & Brasileira & $\begin{array}{ll}\text { Extorsão } & \text { com } \\
\text { seqüestro }\end{array}$ & Parda \\
\hline 117363 & Sebastião da Silva & 1970 & Brasileira & Legitimação & $\begin{array}{l}\text { Preta ou } \\
\text { parda } \\
\text { escura }\end{array}$ \\
\hline 117607 & $\begin{array}{l}\text { Domingos } \\
\text { Pergentino da Silva }\end{array}$ & 1975 & Brasileira & $\begin{array}{ll}\begin{array}{l}\text { Falsificação } \\
\text { documentos }\end{array} & \text { de } \\
\end{array}$ & Parda \\
\hline 117667 & $\begin{array}{ll}\text { Venancio } & \text { Dias } \\
\text { Costa Filho } & \\
\end{array}$ & 1974 & Brasileira & Legitimação & $\begin{array}{l}\text { Parda ou } \\
\text { branca }\end{array}$ \\
\hline 118209 & $\begin{array}{l}\text { Oscar das Neves de } \\
\text { Souza }\end{array}$ & 1971 & Brasileira & Legitimação & Parda \\
\hline 118259 & $\begin{array}{l}\text { José Patrício de } \\
\text { Souza }\end{array}$ & 1971 & Brasileira & Legitimação & $\begin{array}{ll}\text { Preta ou } \\
\text { parda } \\
\text { escura }\end{array}$ \\
\hline 118619 & $\begin{array}{l}\text { José Roberto } \\
\text { Evangelista }\end{array}$ & 1973 & Brasileira & Legitimação & Preta \\
\hline 119149 & $\begin{array}{l}\text { Sebastião } \\
\text { Rodrigues Neto }\end{array}$ & 1969 & Brasileira & Roubo a banco & Parda \\
\hline 119787 & $\begin{array}{l}\text { Augusto Rodrigues } \\
\text { da Silva }\end{array}$ & 1964 & Brasileira & Comunismo & Preta \\
\hline 119823 & $\begin{array}{l}\text { Marco Antonio da } \\
\text { Silva }\end{array}$ & 1971 & Brasileira & $\begin{array}{l}\text { Uso indevido do } \\
\text { uniforme marinha }\end{array}$ & Parda \\
\hline 120129 & Luiz Artur Toríbio & 1972 & Brasileira & Legitimação & $\begin{array}{l}\text { Parda ou } \\
\text { branca }\end{array}$ \\
\hline 120981 & $\begin{array}{l}\text { Eronildo Jose dos } \\
\text { Santos }\end{array}$ & 1975 & Brasileira & Legitimação & Parda \\
\hline 121321 & $\begin{array}{l}\text { Enrique Banegas } \\
\text { Callau }\end{array}$ & 1973 & Boliviana & Legitimação & Parda \\
\hline 122491 & $\begin{array}{l}\text { Anisio Alberto da } \\
\text { Silva }\end{array}$ & 1973 & Brasileira & $\begin{array}{l}\text { Legitimação por } \\
\text { assaltos, roubos e } \\
\text { furtos }\end{array}$ & $\begin{array}{l}\text { Parda } \\
\text { clara }\end{array}$ \\
\hline 122813 & $\begin{array}{lll}\text { Mario } & \text { Nunes } & \text { da } \\
\text { Silva } & & \\
\end{array}$ & 1971 & Brasileira & Legitimação & Parda \\
\hline 123452 & $\begin{array}{l}\text { Daniel Figueiredo } \\
\text { Martinho }\end{array}$ & 1971 & Brasileira & Legitimação & Parda \\
\hline 123980 & $\begin{array}{l}\text { José Ferreira do } \\
\text { Nascimento }\end{array}$ & 1981 & Brasileira & $\begin{array}{l}\text { Legitimação (Ordem } \\
\text { Social) }\end{array}$ & $\begin{array}{l}\text { Parda } \\
\text { clara }\end{array}$ \\
\hline
\end{tabular}




\begin{tabular}{|c|c|c|c|c|c|}
\hline 124121 & $\begin{array}{l}\text { Neusa Maria da } \\
\text { Conceição }\end{array}$ & 1973 & Brasileira & Legitimação & Parda \\
\hline 124193 & Valdomiro Lopes & 1973 & Brasileira & Averiguação & Preta \\
\hline 124859 & Onofre Pinto & 1969 & Brasileira & $\begin{array}{l}\text { Lei Segurança } \\
\text { Nacional } \\
\text { (participação na } \\
\text { VRP) }\end{array}$ & $\begin{array}{l}\text { Parda } \\
\text { clara }\end{array}$ \\
\hline 125557 & Fausto Reis & 1973 & Brasileira & Legitimação & Parda \\
\hline 125720 & Nilza Maria Lopes & 1970 & Brasileira & Legitimação & $\begin{array}{ll}\text { Parda } & \text { ou } \\
\text { preta }\end{array}$ \\
\hline 126497 & Amadeu de Souza & 1970 & Brasileira & Crime fazendário & Parda \\
\hline 126628 & Décio Cardoso & 1974 & Brasileira & Legitimação & Parda \\
\hline 126943 & $\begin{array}{ll}\text { Jorge } & \text { Roberto } \\
\text { Honorato } & \\
\end{array}$ & 1973 & Brasileira & Legitimação & Preta \\
\hline 127211 & $\begin{array}{l}\text { Gilson de Moura } \\
\text { Modesto }\end{array}$ & 1970 & Brasileira & $\begin{array}{ll}\text { Lei } & \text { Segurança } \\
\text { Nacional } & \\
\end{array}$ & $\begin{array}{l}\text { Parda ou } \\
\text { branca }\end{array}$ \\
\hline 127544 & Julio Montano & 1973 & Boliviana & $\begin{array}{l}\text { Para documentação } \\
\text { estrangeiro }\end{array}$ & Parda \\
\hline 127782 & $\begin{array}{l}\text { Gomes Gonçalo } \\
\text { Filho }\end{array}$ & 1971 & Brasileira & $\begin{array}{lrr}\text { Artigo } & 132 & \text { Código } \\
\text { Penal } & - & \text { Lei } \\
\text { Segurança } & \text { Nacional }\end{array}$ & $\begin{array}{l}\text { Parda } \\
\text { escura }\end{array}$ \\
\hline 128158 & Airton Fortunato & 1970 & Brasileira & $\begin{array}{l}\text { Falsificação de } \\
\text { documento público }\end{array}$ & Preta \\
\hline 128359 & $\begin{array}{ll}\text { José } & \text { Nonato } \\
\text { Mendes } & \end{array}$ & 1969 & Brasileira & $\begin{array}{l}\text { Legitimação (Ordem } \\
\text { Social) }\end{array}$ & $\begin{array}{l}\text { Parda } \\
\text { escura ou } \\
\text { morena ou } \\
\text { branca }\end{array}$ \\
\hline 128568 & $\begin{array}{l}\text { Jeronimo Alves } \\
\text { Santos }\end{array}$ & 1971 & Brasileira & Legitimação & Parda \\
\hline 128894 & $\begin{array}{l}\text { Judite dos Reis } \\
\text { Salomão }\end{array}$ & 1965 & Brasileira & $\begin{array}{l}\text { Declarações sobre } \\
\text { seqüestro de sua } \\
\text { filha }\end{array}$ & Parda \\
\hline 129229 & $\begin{array}{ll}\text { Geraldo } & \text { Delmiro } \\
\text { Pereira } & \\
\end{array}$ & 1972 & Brasileira & Sonegação fiscal & $\begin{array}{l}\text { Parda ou } \\
\text { branca }\end{array}$ \\
\hline 129919 & $\begin{array}{l}\text { Valdemar } \\
\text { Marcolino da Silva }\end{array}$ & 1971 & Brasileira & Legitimação & $\begin{array}{l}\text { Branca ou } \\
\text { parda } \\
\text { clara }\end{array}$ \\
\hline 129924 & $\begin{array}{l}\text { Zildo Felix de } \\
\text { Oliveira }\end{array}$ & 1964 & Brasileira & Greve & Parda \\
\hline 130064 & $\begin{array}{l}\text { José } \\
\text { Sobrinho }\end{array}$ & 1964 & Brasileira & $\begin{array}{l}\text { Economia popular - } \\
\text { inquilinato }\end{array}$ & Parda \\
\hline 130065 & Luiz Carlos Santos & 1971 & Brasileira & $\begin{array}{l}\text { Legitimação } \\
\text { (panfleto } \\
\text { subversivo) }\end{array}$ & $\begin{array}{ll}\text { Parda } & \\
\text { clara ou } \\
\text { branca }\end{array}$ \\
\hline 130784 & Geraldo Santana & 1970 & Brasileira & $\begin{array}{l}\text { Legitimação (Ordem } \\
\text { Social) }\end{array}$ & $\begin{array}{l}\text { Parda ou } \\
\text { branca }\end{array}$ \\
\hline
\end{tabular}




\begin{tabular}{|c|c|c|c|c|c|}
\hline 130927 & $\begin{array}{l}\text { Pedro Barbosa dos } \\
\text { Santos }\end{array}$ & 1972 & Brasileira & Legitimação & Parda \\
\hline 131775 & $\begin{array}{l}\text { Eustaquio } \quad \text { Vital } \\
\text { Nolasco }\end{array}$ & 1974 & Brasileira & $\begin{array}{l}\text { Lei de Segurança } \\
\text { Nacional - APML }\end{array}$ & $\begin{array}{l}\text { Parda } \\
\text { clara }\end{array}$ \\
\hline 132448 & $\begin{array}{l}\text { Abinael } \\
\text { Nascimento de } \\
\text { Souza }\end{array}$ & 1972 & Brasileira & Legitimação & $\begin{array}{l}\text { Parda } \\
\text { clara }\end{array}$ \\
\hline 136406 & $\begin{array}{l}\text { Januario Soares dos } \\
\text { Santos }\end{array}$ & 1970 & Brasileira & $\begin{array}{l}\text { Legitimação } \\
\text { (incitação } \\
\text { violência) }\end{array}$ & Parda \\
\hline 136773 & $\begin{array}{l}\text { José Geraldo da } \\
\text { Silva }\end{array}$ & 1972 & Brasileira & $\begin{array}{l}\text { Greve na } \\
\text { Ferro }\end{array}$ & Parda \\
\hline 138215 & $\begin{array}{l}\text { Edmur Pericles de } \\
\text { Camargo }\end{array}$ & 1970 & Brasileira & $\begin{array}{l}\text { Lei de } \text { Segurança } \\
\text { Nacional por } \\
\text { participar da ALN } \\
\text { ou "terrorismo" }\end{array}$ & $\begin{array}{ll}\text { Preta } & \text { ou } \\
\text { parda } & \text { ou } \\
\text { negra } & \end{array}$ \\
\hline 138247 & $\begin{array}{l}\text { Alcides Lopes de } \\
\text { Oliveira }\end{array}$ & 1964 & Brasileira & $\begin{array}{l}\text { Economia popular - } \\
\text { inquilinato }\end{array}$ & Preta \\
\hline 138632 & $\begin{array}{l}\text { Agostinho } \\
\text { Rodrigues } \\
\text { Macedo }\end{array}$ & 1970 & Brasileira & Peculato & Parda \\
\hline 138634 & $\begin{array}{l}\text { José Mendonça de } \\
\text { Oliveira Filho }\end{array}$ & 1972 & Brasileira & Legitimação & Parda \\
\hline 138686 & Olavo Ribeiro & 1972 & Brasileira & Peculato & $\begin{array}{l}\text { Parda ou } \\
\text { branca }\end{array}$ \\
\hline 139235 & Julia Bento Ribeiro & 1964 & Brasileira & Economia popular & Parda \\
\hline 139303 & $\begin{array}{ll}\text { Waldir } & \text { Nestor } \\
\text { Rezende } & \end{array}$ & 1974 & Brasileira & Legitimação & Preta \\
\hline 139317 & João Moreira & 1964 & Brasileira & Desacato & Parda \\
\hline 139366 & $\begin{array}{ll}\text { Maria } & \text { Aleixo } \\
\text { Ribeiro } & \\
\end{array}$ & 1964 & Brasileira & Incêndio & Preta \\
\hline 139385 & $\begin{array}{l}\text { Maria Augusta da } \\
\text { Silva Vilela }\end{array}$ & 1964 & Brasileira & Economia popular & Parda \\
\hline 139435 & $\begin{array}{l}\text { Francisco da Silva } \\
\text { Franco }\end{array}$ & 1964 & Brasileira & $\begin{array}{l}\text { Economia popular - } \\
\text { inquilinato }\end{array}$ & Parda \\
\hline 139440 & $\begin{array}{l}\text { Ivo Rodrigues da } \\
\text { Silva }\end{array}$ & 1965 & Brasileira & $\begin{array}{l}\text { Lei de Segurança } \\
\text { Nacional }\end{array}$ & Parda \\
\hline 139445 & $\begin{array}{ll}\text { Lazaro } & \text { Gabriel } \\
\text { Filho } & \\
\end{array}$ & 1964 & Brasileira & $\begin{array}{ll}\begin{array}{l}\text { Disposição } \\
\text { justiça }\end{array} & \text { da } \\
\end{array}$ & Preta \\
\hline 139459 & $\begin{array}{ll}\text { Francisco } & \text { Martins } \\
\text { Viana } & \end{array}$ & 1964 & Brasileira & $\begin{array}{l}\text { Legitimação (Ordem } \\
\text { Política) }\end{array}$ & Parda \\
\hline 139554 & $\begin{array}{lll}\text { José } & \text { de } & \text { Arruda } \\
\text { Lima } & & \end{array}$ & 1964 & Brasileira & $\begin{array}{l}\text { Malversação } \\
\text { fundos sindicais }\end{array}$ & Parda \\
\hline 139587 & $\begin{array}{l}\text { Olimpio de Souza } \\
\text { Mendes }\end{array}$ & 1964 & Brasileira & $\begin{array}{l}\text { Economia popular - } \\
\text { tabelamento }\end{array}$ & Parda \\
\hline 139633 & Helzofam & 1964 & Brasileira & Incêndio & Parda \\
\hline
\end{tabular}




\begin{tabular}{|c|c|c|c|c|c|}
\hline & Guimarães & & & & \\
\hline 139666 & $\begin{array}{l}\text { Orestes Borges de } \\
\text { Oliveira }\end{array}$ & 1964 & Brasileira & $\begin{array}{l}\text { Mandato cassado e } \\
\text { desaparecido }\end{array}$ & Parda \\
\hline 139749 & Godfrey John & 1964 & Inglesa & $\begin{array}{l}\text { Legitimação } \\
\text { (Delegacia } \\
\text { Estrangeiros) }\end{array}$ & Preta \\
\hline 139792 & $\begin{array}{l}\text { Emiliano Vieira } \\
\text { Pinto }\end{array}$ & 1964 & Brasileira & $\begin{array}{l}\text { Economia popular - } \\
\text { inquilinato }\end{array}$ & Preta \\
\hline 139804 & $\begin{array}{l}\text { Manoel Rogério de } \\
\text { Almeida }\end{array}$ & 1964 & Brasileira & Legitimação & Preta \\
\hline 139822 & $\begin{array}{l}\text { Luiz Rodrigues dos } \\
\text { Santos }\end{array}$ & 1964 & Brasileira & Greve & Parda \\
\hline 139832 & $\begin{array}{l}\text { Luiz Antonio dos } \\
\text { Santos }\end{array}$ & 1964 & Brasileira & $\begin{array}{ll}\text { Malversação } & \text { de } \\
\text { fundos sindicais } & \\
\end{array}$ & Parda \\
\hline 139841 & $\begin{array}{l}\text { João Gomes de } \\
\text { Macedo }\end{array}$ & 1964 & Brasileira & Comunismo & Parda \\
\hline 139876 & $\begin{array}{l}\text { José Cubertino de } \\
\text { Novais }\end{array}$ & 1964 & Brasileira & Comunismo & $\begin{array}{l}\text { Parda ou } \\
\text { morena }\end{array}$ \\
\hline 139895 & Elza Alves Siqueira & 1964 & Brasileira & $\begin{array}{l}\text { Economia popular - } \\
\text { inquilinato }\end{array}$ & Parda \\
\hline 139964 & $\begin{array}{l}\text { Cezar Tiburcio da } \\
\text { Silva }\end{array}$ & 1964 & Brasileira & Economia popular & Preta \\
\hline 140068 & Walter Modesto & 1964 & Brasileira & Greve & Parda \\
\hline 140098 & Noé dos Santos & 1964 & Brasileira & $\begin{array}{ll}\text { Malversação } & \text { de } \\
\text { fundos sindicais } & \\
\end{array}$ & Parda \\
\hline 140183 & $\begin{array}{l}\text { Benedito Pereira de } \\
\text { Lima }\end{array}$ & 1964 & Brasileira & $\begin{array}{ll}\text { Malversação } & \text { de } \\
\text { fundos sindicais } & \\
\end{array}$ & $\begin{array}{l}\text { Parda ou } \\
\text { morena }\end{array}$ \\
\hline 140196 & Devalmiro Rita & 1964 & Brasileira & $\begin{array}{l}\text { Economia popular - } \\
\text { inquilinato }\end{array}$ & Preta \\
\hline 140248 & $\begin{array}{l}\text { José Carmo dos } \\
\text { Santos }\end{array}$ & 1964 & Brasileira & $\begin{array}{ll}\text { Malversação } & \text { de } \\
\text { fundos sindicais } & \\
\end{array}$ & $\begin{array}{ll}\text { Preta ou } \\
\text { escura }\end{array}$ \\
\hline 140253 & $\begin{array}{l}\text { Waldemar Luiz } \\
\text { Barbosa }\end{array}$ & 1964 & Brasileira & $\begin{array}{ll}\text { Malversação } & \text { de } \\
\text { fundos sindicais } & \\
\end{array}$ & Parda \\
\hline 140255 & $\begin{array}{l}\text { Walter Vieira de } \\
\text { Amorim }\end{array}$ & 1964 & Brasileira & Economia popular & Parda \\
\hline 140290 & $\begin{array}{l}\text { Manoel Rodrigues } \\
\text { Dias }\end{array}$ & 1964 & Brasileira & $\begin{array}{lll}\text { Artigo } 121 & \text { Código } \\
\text { Penal } & & \\
\end{array}$ & Parda \\
\hline 140315 & $\begin{array}{ll}\text { Julia } & \text { Gonçalves } \\
\text { Sanches } & \\
\end{array}$ & 1964 & Brasileira & $\begin{array}{l}\text { Economia popular - } \\
\text { inquilinato }\end{array}$ & Parda \\
\hline 140323 & Nice Fernandes & 1964 & Brasileira & $\begin{array}{l}\text { Economia popular - } \\
\text { inquilinato }\end{array}$ & Parda \\
\hline 140383 & $\begin{array}{l}\text { Benedito Vitorino } \\
\text { Ferreira }\end{array}$ & 1964 & Brasileira & Incêndio & Preta \\
\hline 140409 & $\begin{array}{l}\text { Evaristo Gonzaga } \\
\text { da Cruz }\end{array}$ & 1964 & Brasileira & Incêndio em barraco & Preta \\
\hline 140416 & Gabriel & 1964 & Brasileira & Malversação & Preta \\
\hline
\end{tabular}




\begin{tabular}{|c|c|c|c|c|c|}
\hline & Viana & & & fundos sindicais & \\
\hline 140452 & $\begin{array}{l}\text { José Leonel de } \\
\text { Souza Dias }\end{array}$ & 1964 & Brasileira & Artigo 552 CLT & Parda \\
\hline 140485 & $\begin{array}{ll}\text { Osano José } & \text { de } \\
\text { Almeida } & \end{array}$ & 1964 & Brasileira & Economia popular & Parda \\
\hline 140487 & $\begin{array}{l}\text { Osorio de Oliveira } \\
\text { Campos Filho }\end{array}$ & 1964 & Brasileira & $\begin{array}{l}\text { Malversação de } \\
\text { fundos sindicais }\end{array}$ & Parda \\
\hline 140490 & $\begin{array}{ll}\text { Otaviano } & \text { Pereira } \\
\text { dos Santos } & \\
\end{array}$ & 1964 & Brasileira & Artigo 552 CLT & Parda \\
\hline 140615 & João dos Santos & 1964 & Brasileira & $\begin{array}{l}\text { Artigo } 129 \text { e } 200 \\
\text { Código Penal }\end{array}$ & Preta \\
\hline 140668 & $\begin{array}{l}\text { Nelson dos Santos } \\
\text { Batista }\end{array}$ & 1964 & Brasileira & Legitimação & $\begin{array}{l}\text { Parda ou } \\
\text { preta }\end{array}$ \\
\hline 140778 & $\begin{array}{l}\text { Hildebrando Alves } \\
\text { de Almeida }\end{array}$ & 1965 & Brasileira & Economia popular & Parda \\
\hline 140782 & $\begin{array}{l}\text { Chefez Gladys } \\
\text { Amandra Ghieler }\end{array}$ & 1965 & Peruana & Legitimação & Parda \\
\hline 140831 & $\begin{array}{l}\text { Hermegildo } \\
\text { Eufrásio }\end{array}$ & 1965 & Brasileira & Requisição judicial & Preta \\
\hline 140887 & $\begin{array}{l}\text { Maximo Montoya } \\
\text { Valdiva ou Romero }\end{array}$ & 1965 & Peruana & Averiguações & Parda \\
\hline 140899 & $\begin{array}{l}\text { Manoel Justino } \\
\text { Camilo }\end{array}$ & 1965 & Brasileira & Economia popular & Parda \\
\hline 140902 & $\begin{array}{ll}\text { Luiz } & \text { Antonio } \\
\text { Nonato } & \\
\end{array}$ & 1965 & Brasileira & $\begin{array}{l}\text { Legitimação (Ordem } \\
\text { Social) }\end{array}$ & Preta \\
\hline 140919 & $\begin{array}{lr}\text { José } & \text { Antonio } \\
\text { Timotheo } & \text { de } \\
\text { Oliveira } & \end{array}$ & 1965 & Brasileira & $\begin{array}{l}\text { Suspeita de } \\
\text { terrorismo (granadas } \\
\text { da Revolução de } \\
\text { 1932) }\end{array}$ & Preta \\
\hline 140923 & $\begin{array}{l}\text { Walter de Carvalho } \\
\text { Lima }\end{array}$ & 1965 & Brasileira & Requisição judicial & Preta \\
\hline 140997 & $\begin{array}{l}\text { Agenor Soares de } \\
\text { Lima }\end{array}$ & 1965 & Brasileira & Artigo 552 CLT & Parda \\
\hline 141018 & José Ferreira Alves & 1965 & Brasileira & $\begin{array}{l}\text { Economia popular - } \\
\text { inquilinato }\end{array}$ & Preta \\
\hline 141034 & $\begin{array}{l}\text { João Santana } \\
\text { Sacramento }\end{array}$ & 1965 & Brasileira & $\begin{array}{l}\text { Economia popular - } \\
\text { nota fiscal }\end{array}$ & Parda \\
\hline 141035 & $\begin{array}{lll}\text { João } & \text { Ribeiro } & \text { da } \\
\text { Silva } & & \\
\end{array}$ & 1965 & Brasileira & $\begin{array}{l}\text { Economia popular - } \\
\text { nota fiscal }\end{array}$ & $\begin{array}{l}\text { Parda ou } \\
\text { preta }\end{array}$ \\
\hline 141075 & Lazaro de Oliveira & 1965 & Brasileira & Artigo 552 CLT & Parda \\
\hline 141214 & $\begin{array}{l}\text { Guilhermino } \\
\text { Francisco da Silva }\end{array}$ & 1964 & Brasileira & Comunismo & Preta \\
\hline 141263 & $\begin{array}{l}\text { João Guilherme do } \\
\text { Nascimento }\end{array}$ & 1965 & Brasileira & $\begin{array}{l}\text { Atentado morteiro } \\
\text { em quartel }\end{array}$ & Parda \\
\hline 141329 & $\begin{array}{l}\text { Albino } \\
\text { Araújo }\end{array}$ & 1965 & Brasileira & $\begin{array}{lll}\text { Artigo } & 2 & \text { Lei } \\
1521 / 51 & & \\
\end{array}$ & Parda \\
\hline
\end{tabular}




\begin{tabular}{|c|c|c|c|c|c|}
\hline 141336 & $\begin{array}{l}\text { Antonio Francisco } \\
\text { de Barros }\end{array}$ & 1965 & Brasileira & $\begin{array}{lll}\text { Artigo } & 2 & \text { Lei } \\
1521 / 51 & & \\
\end{array}$ & Preta \\
\hline 141372 & $\begin{array}{l}\text { Maria Aparecida } \\
\text { Ferraz }\end{array}$ & 1965 & Brasileira & $\begin{array}{lll}\text { Artigo } & 2 & \text { Lei } \\
1521 / 51 & & \end{array}$ & Parda \\
\hline 141384 & $\begin{array}{lll}\text { Julio } & \text { Soares } & \mathrm{da} \\
\text { Silva } & & \end{array}$ & 1965 & Brasileira & $\begin{array}{lll}\text { Artigo } & 2 & \text { Lei } \\
1521 / 51 & & \end{array}$ & Parda \\
\hline 141389 & $\begin{array}{ll}\text { Jose } & \text { Leonel } \\
\text { Ferreira } & \end{array}$ & 1965 & Brasileira & Crime eleitoral & Parda \\
\hline 141391 & José Dias & 1965 & Brasileira & Sindicato & Parda \\
\hline 141451 & $\begin{array}{l}\text { Domingos Quintin } \\
\text { dos Santos }\end{array}$ & 1971 & Brasileira & $\begin{array}{l}\text { Legitimação } \\
\text { terrorismo }\end{array}$ & $\begin{array}{l}\text { Parda ou } \\
\text { morena }\end{array}$ \\
\hline 141459 & $\begin{array}{ll}\text { João } & \text { Benedito } \\
\text { Mendes } & \end{array}$ & 1965 & Brasileira & Legitimação & Preta \\
\hline 141468 & José Ribeiro & 1965 & Brasileira & $\begin{array}{l}\text { Legitimação (Ordem } \\
\text { Social) }\end{array}$ & Preta \\
\hline 141504 & $\begin{array}{l}\text { Daniel } \\
\text { Soares }\end{array}$ & 1965 & Brasileira & $\begin{array}{ll}\text { Distribuição } & \text { de } \\
\text { panfletos } & \\
\text { subversivos } & \end{array}$ & Preta \\
\hline 141530 & Geraldo Soares & 1965 & Brasileira & $\begin{array}{l}\text { Incêndio com } \\
\text { explosão botijão }\end{array}$ & Parda \\
\hline 141559 & $\begin{array}{l}\text { Raimundo } \\
\text { Francisco da Silva }\end{array}$ & 1965 & Brasileira & Ilegível & Parda \\
\hline 141571 & Neide da Silva & 1970 & Brasileira & $\begin{array}{l}\text { Legitimação (Ordem } \\
\text { Social) }\end{array}$ & $\begin{array}{l}\text { Parda } \\
\text { clara }\end{array}$ \\
\hline 141593 & Januário Bispo & 1965 & Brasileira & $\begin{array}{lll}\text { Artigo } & 2 & \text { Lei } \\
1521 / 51 & & \\
\end{array}$ & Parda \\
\hline 141654 & $\begin{array}{l}\text { Manoel Gaspar de } \\
\text { Souza }\end{array}$ & 1965 & Brasileira & Incêndio & Parda \\
\hline 141828 & Avelino dos Santos & 1965 & Brasileira & $\begin{array}{lll}\text { Artigo } & 2 & \text { Lei } \\
1521 / 51 & & \\
\end{array}$ & Preta \\
\hline 141926 & Palmiel Silva & 1965 & Brasileira & Documentos & Parda \\
\hline 141928 & $\begin{array}{l}\text { Sebastião } \\
\text { Raimundo de } \\
\text { Moura }\end{array}$ & 1965 & Brasileira & $\begin{array}{l}\text { Economia popular - } \\
\text { inquilinato }\end{array}$ & Preta \\
\hline 141965 & $\begin{array}{ll}\text { José } & \text { Paulino } \\
\text { Rodrigues } & \\
\end{array}$ & 1965 & Brasileira & Incêndio & Preta \\
\hline 141978 & $\begin{array}{lll}\text { Augusto Silva de } \\
\text { Souza }\end{array}$ & 1965 & Brasileira & Sabotagem & Preta \\
\hline 142019 & $\begin{array}{lll}\text { Paulo } & \text { Corrêa } & \text { da } \\
\text { Silva } & & \end{array}$ & 1965 & Brasileira & Incêndio & Parda \\
\hline 142041 & Alevino dos Santos & 1965 & Brasileira & Economia popular & Preta \\
\hline 142079 & $\begin{array}{l}\text { Miguel } \\
\text { Alvarenga }\end{array}$ & 1965 & Brasileira & $\begin{array}{l}\text { Fins civis - atestado } \\
\text { de antecedentes }\end{array}$ & Preta \\
\hline 142093 & $\begin{array}{l}\text { Hozelina } \\
\text { Santos Silva }\end{array}$ & 1965 & Brasileira & $\begin{array}{l}\text { Economia popular - } \\
\text { venda de lotes }\end{array}$ & Parda \\
\hline 142294 & Luiza Maria Rocha & 1970 & Brasileira & Legitimação (Ordem & Parda \\
\hline
\end{tabular}




\begin{tabular}{|c|c|c|c|c|c|}
\hline & & & & Social) & \\
\hline 142469 & $\begin{array}{ll}\text { Lourival } & \text { José } \\
\text { Gonçalves }\end{array}$ & 1965 & Brasileira & Legitimação & Parda \\
\hline 142470 & José Carlos da Silva & 1965 & Brasileira & Legitimação & Preta \\
\hline 142511 & $\begin{array}{ll}\text { João } & \text { Batista } \\
\text { Floriano } & \end{array}$ & 1965 & Brasileira & Incêndio & Preta \\
\hline 142517 & $\begin{array}{ll}\text { Alcides } & \text { do } \\
\text { Nascimento } & \\
\end{array}$ & 1966 & Brasileira & $\begin{array}{ll}\begin{array}{l}\text { Disposição } \\
\text { justiça }\end{array} & \text { da } \\
\end{array}$ & Preta \\
\hline 142592 & $\begin{array}{l}\text { Mauricio } \\
\text { Marques }\end{array}$ & 1972 & Brasileira & Legitimação & Parda \\
\hline 142656 & João Dias & 1965 & Brasileira & Incêndio em mata & Parda \\
\hline 142663 & Eddie V. Naidoo & 1966 & Sul-africana & $\begin{array}{l}\text { Legitimação } \\
\text { (Delegacia } \\
\text { Estrangeiros) }\end{array}$ & Preta \\
\hline 142789 & $\begin{array}{l}\text { Manuel Pereira do } \\
\text { Nascimento }\end{array}$ & 1966 & Brasileira & Incêndio & Parda \\
\hline 142834 & $\begin{array}{l}\text { José Aparecido } \\
\text { Belchior }\end{array}$ & 1966 & Brasileira & Averiguação & Preta \\
\hline 142835 & $\begin{array}{l}\text { Claudio } \quad \text { Jorge } \\
\text { Travers dos Santos }\end{array}$ & 1966 & Brasileira & Averiguação & Preta \\
\hline 142841 & $\begin{array}{l}\text { Antonia Marcondes } \\
\text { Salgado }\end{array}$ & 1964 & Brasileira & $\begin{array}{l}\text { Economia popular - } \\
\text { inquilinato }\end{array}$ & Preta \\
\hline 142906 & Sebastião Ramos & 1966 & Brasileira & Incêndio & Preta \\
\hline 142940 & $\begin{array}{lll}\text { Onofre } & \text { Elias dos } \\
\text { Santos } & & \\
\end{array}$ & 1964 & Brasileira & Incêndio & Preta \\
\hline 142978 & Luiz Faustino & 1966 & Brasileira & $\begin{array}{ll}\text { Crime } & \text { contra } \\
\text { fazenda }\end{array}$ & Preta \\
\hline 142995 & $\begin{array}{l}\text { João Baptista de } \\
\text { Lima Freitas }\end{array}$ & 1966 & Brasileira & $\begin{array}{l}\text { Artigo } 317 \text { Código } \\
\text { Penal }\end{array}$ & Parda \\
\hline 142997 & $\begin{array}{l}\text { Paulo Roberto dos } \\
\text { Santos }\end{array}$ & 1966 & Brasileira & $\begin{array}{l}\text { Artigo } 250 \text { Código } \\
\text { Penal }\end{array}$ & Preta \\
\hline 143076 & Oscar Daniel & 1966 & Brasileira & $\begin{array}{l}\text { Legitimação (Ordem } \\
\text { Social) }\end{array}$ & Parda \\
\hline 143079 & $\begin{array}{l}\text { Luiz Sabino de } \\
\text { Sant' Anna }\end{array}$ & 1968 & Brasileira & $\begin{array}{l}\text { Legitimação (Ordem } \\
\text { Social) }\end{array}$ & Parda \\
\hline 143314 & $\begin{array}{lll}\text { Maria } & \text { Neris } & \text { da } \\
\text { Silva } & & \\
\end{array}$ & 1966 & Brasileira & $\begin{array}{l}\text { Incêndio com } \\
\text { botijão gás }\end{array}$ & Parda \\
\hline 143345 & $\begin{array}{ll}\text { Jose } & \text { Carlos } \\
\text { Romualdo } & \end{array}$ & 1966 & Brasileira & Não consta & Preta \\
\hline 143585 & $\begin{array}{l}\text { Sebastião de Souza } \\
\text { Nogueira }\end{array}$ & 1966 & Brasileira & $\begin{array}{l}\text { Economia popular - } \\
\text { inquilinato }\end{array}$ & Parda \\
\hline 143662 & $\begin{array}{l}\text { José Balbino de } \\
\text { Moraes }\end{array}$ & 1969 & Brasileira & $\begin{array}{l}\text { Legitimação (Ordem } \\
\text { Social) }\end{array}$ & Parda \\
\hline 143673 & $\begin{array}{l}\text { Efigênia dos Santos } \\
\text { Gabriel }\end{array}$ & 1966 & Brasileira & $\begin{array}{l}\text { Incêndio em sua } \\
\text { residência }\end{array}$ & Preta \\
\hline 143707 & José Moreira dos & 1966 & Brasileira & Subversão & Preta \\
\hline
\end{tabular}




\begin{tabular}{|c|c|c|c|c|c|}
\hline & Santos & & & & \\
\hline 143727 & $\begin{array}{l}\text { Marcos Antonio da } \\
\text { Silva Lima }\end{array}$ & 1967 & Brasileira & $\begin{array}{l}\text { Disposição justiça } \\
\text { militar }\end{array}$ & Parda \\
\hline 143757 & $\begin{array}{ll}\text { Lailton } & \text { Marques } \\
\text { Soares } & \\
\end{array}$ & 1965 & Brasileira & $\begin{array}{l}\text { Economia popular - } \\
\text { inquilinato }\end{array}$ & Preta \\
\hline 143758 & Francisco Moraes & 1966 & Brasileira & $\begin{array}{l}\text { Denúncia } \\
\text { irregularidade } \\
\text { administração } \\
\text { municipal }\end{array}$ & Preta \\
\hline 143768 & $\begin{array}{l}\text { Calixto de Oliveira } \\
\text { Pinto }\end{array}$ & 1967 & Brasileira & $\begin{array}{l}\text { "Imperador } \\
\text { constitucional" e } \\
\text { defensor "Império } \\
\text { Brasil"" }\end{array}$ & $\begin{array}{l}\text { Branca ou } \\
\text { afro- } \\
\text { descenden } \\
\text { te* }\end{array}$ \\
\hline 143857 & José Carlos Pereira & 1967 & Brasileira & Sabotagem & Preta \\
\hline 143907 & $\begin{array}{l}\text { Satyri Feliciano dos } \\
\text { Santos }\end{array}$ & 1966 & Brasileira & Incêndio residência & Preta \\
\hline 143936 & $\begin{array}{l}\text { João Bonifácio dos } \\
\text { Santos }\end{array}$ & 1967 & Brasileira & $\begin{array}{l}\text { Economia popular - } \\
\text { inquilinato }\end{array}$ & Preta \\
\hline 144079 & $\begin{array}{l}\text { Joaquim Marques } \\
\text { da Silva }\end{array}$ & 1967 & Brasileira & $\begin{array}{l}\text { Desobediência de } \\
\text { intimação }\end{array}$ & Preta \\
\hline 144176 & $\begin{array}{l}\text { Maria José Alves } \\
\text { Ribeiro }\end{array}$ & 1966 & Brasileira & Queixosa & Preta \\
\hline 144200 & $\begin{array}{l}\text { Durvalina Conrado } \\
\text { Mariano }\end{array}$ & 1967 & Brasileira & $\begin{array}{l}\text { Economia popular - } \\
\text { inquilinato }\end{array}$ & Preta \\
\hline 144232 & $\begin{array}{l}\text { Gabriel Dias } \\
\text { Toledo }\end{array}$ & 1966 & Brasileira & $\begin{array}{l}\text { Economia popular - } \\
\text { inquilinato }\end{array}$ & Preta \\
\hline 144332 & $\begin{array}{l}\text { Evaristo Gomes de } \\
\text { Souza }\end{array}$ & 1967 & Brasileira & $\begin{array}{l}\text { Economia popular - } \\
\text { inquilinato }\end{array}$ & Parda \\
\hline 144363 & $\begin{array}{ll}\text { José Luiz de } \\
\text { Oliveira }\end{array}$ & 1967 & Brasileira & $\begin{array}{l}\text { Economia popular - } \\
\text { inquilinato }\end{array}$ & Preta \\
\hline 144441 & José Vieira Filho & 1967 & Brasileira & $\begin{array}{l}\text { Economia popular - } \\
\text { inquilinato }\end{array}$ & Parda \\
\hline 144454 & $\begin{array}{l}\text { Daniel Emilio } \\
\text { Aguilar Ozendre }\end{array}$ & 1967 & Peruana & $\begin{array}{l}\text { Legitimação } \\
\text { (Delegacia } \\
\text { Estrangeiros) }\end{array}$ & Preta \\
\hline 144460 & $\begin{array}{ll}\text { Assufio } & \text { Mendes } \\
\text { Ferreira } & \end{array}$ & 1967 & Brasileira & $\begin{array}{l}\text { Usurpação de função } \\
\text { pública }\end{array}$ & Preta \\
\hline 144483 & $\begin{array}{l}\text { José Augusto dos } \\
\text { Santos }\end{array}$ & 1967 & Brasileira & Tentativa de suicídio & Parda \\
\hline 144506 & $\begin{array}{ll}\text { Jesus } & \text { Romão } \\
\text { Ângelo } & \end{array}$ & 1967 & Brasileira & $\begin{array}{l}\text { Legitimação (Ordem } \\
\text { Social) }\end{array}$ & Preta \\
\hline 144515 & Francisco Lucrecio & 1967 & Brasileira & Legitimação & Preta \\
\hline 144526 & $\begin{array}{l}\text { Severino José de } \\
\text { Castro }\end{array}$ & 1967 & Brasileira & Ofensas & Parda \\
\hline 144606 & $\begin{array}{l}\text { Juvenal } \\
\text { Ribeiro }\end{array}$ & 1968 & Brasileira & $\begin{array}{l}\text { Legitimação (Ordem } \\
\text { Social) }\end{array}$ & Parda \\
\hline
\end{tabular}




\begin{tabular}{|c|c|c|c|c|c|}
\hline 144609 & Elcio dos Santos & 1968 & Brasileira & $\begin{array}{l}\text { Legitimação (Ordem } \\
\text { Social) }\end{array}$ & Preta \\
\hline 144630 & $\begin{array}{l}\text { Joanico } \quad \text { Manoel } \\
\text { Teixeira }\end{array}$ & 1968 & Brasileira & $\begin{array}{l}\text { Legitimação (Ordem } \\
\text { Social) }\end{array}$ & Parda \\
\hline 144643 & $\begin{array}{l}\text { Francisco Lucio } \\
\text { Filho }\end{array}$ & 1968 & Brasileira & Depredação de carro & Preta \\
\hline 144699 & Norival de Paula & 1968 & Brasileira & $\begin{array}{l}\text { Legitimação (Ordem } \\
\text { Social) }\end{array}$ & Preta \\
\hline 144712 & $\begin{array}{ll}\text { Juraci } & \text { Arcanjo } \\
\text { Santos } & \\
\end{array}$ & 1968 & Brasileira & Legitimação & Preta \\
\hline 144750 & Adalto Ferreira & 1968 & Brasileira & $\begin{array}{lll}\text { Greve } & \text { ilegal } & \text { em } \\
\text { Osasco } & & \\
\end{array}$ & Parda \\
\hline 144794 & $\begin{array}{l}\text { Atalgibson } \\
\text { Marques } \\
\text { Almeida }\end{array}$ & 1968 & Brasileira & $\begin{array}{l}\text { Legitimação (Ordem } \\
\text { Política) }\end{array}$ & Preta \\
\hline 144871 & $\begin{array}{ll}\text { Valmir } & \text { Souza } \\
\text { Novaes } & \end{array}$ & 1968 & Brasileira & Legitimação & parda \\
\hline 144929 & $\begin{array}{l}\text { Martha Maria H. da } \\
\text { Silva }\end{array}$ & 1968 & Brasileira & $\begin{array}{l}\text { Legitimação } \\
\text { (Reunião estudantil } \\
\text { em Ibiúna) }\end{array}$ & $\begin{array}{l}\text { Parda } \\
\text { clara }\end{array}$ \\
\hline 144982 & $\begin{array}{ll}\text { Fernando } & \text { de } \\
\text { Oliveira } & \end{array}$ & 1968 & Brasileira & $\begin{array}{l}\text { Legitimação } \\
\text { (Reunião estudantil } \\
\text { em Ibiúna) }\end{array}$ & $\begin{array}{l}\text { Parda } \\
\text { clara }\end{array}$ \\
\hline 145001 & $\begin{array}{l}\text { Carmen Maria da } \\
\text { Conceição }\end{array}$ & 1968 & Brasileira & $\begin{array}{l}\text { Legitimação } \\
\text { (Reunião estudantil } \\
\text { em Ibiúna) }\end{array}$ & $\begin{array}{l}\text { Parda ou } \\
\text { branca }\end{array}$ \\
\hline 145029 & $\begin{array}{l}\text { Elze Maria dos } \\
\text { Santos }\end{array}$ & 1968 & Brasileira & $\begin{array}{l}\text { Legitimação } \\
\text { (Reunião estudantil } \\
\text { em Ibiúna) }\end{array}$ & $\begin{array}{l}\text { Parda } \\
\text { clara }\end{array}$ \\
\hline 145084 & $\begin{array}{l}\text { Wellington Dantas } \\
\text { Magueira Marques }\end{array}$ & 1968 & Brasileira & $\begin{array}{l}\text { Legitimação } \\
\text { (Reunião estudantil } \\
\text { em Ibiúna) }\end{array}$ & $\begin{array}{l}\text { Parda } \\
\text { clara }\end{array}$ \\
\hline 145085 & $\begin{array}{l}\text { Helenira Rezende } \\
\text { de Souza Nazaré }\end{array}$ & 1968 & Brasileira & $\begin{array}{l}\text { Legitimação } \\
\text { (Reunião estudantil } \\
\text { em Ibiúna) }\end{array}$ & $\begin{array}{l}\text { Parda } \\
\text { clara ou } \\
\text { morena }\end{array}$ \\
\hline 145136 & $\begin{array}{ll}\text { Alcides } & \text { Medeiros } \\
\text { da Costa } & \end{array}$ & 1968 & Brasileira & $\begin{array}{l}\text { Legitimação } \\
\text { (Reunião estudantil } \\
\text { em Ibiúna) }\end{array}$ & $\begin{array}{l}\text { Parda ou } \\
\text { branca }\end{array}$ \\
\hline 145151 & $\begin{array}{l}\text { Mario Ferreira de } \\
\text { Aguiar Filho }\end{array}$ & 1968 & Brasileira & $\begin{array}{l}\text { Legitimação } \\
\text { (Reunião estudantil } \\
\text { em Ibiúna) }\end{array}$ & $\begin{array}{l}\text { Parda } \\
\text { clara }\end{array}$ \\
\hline 145289 & $\begin{array}{ll}\text { João } & \text { Bosco } \\
\text { Rolemberg Cortes }\end{array}$ & 1968 & Brasileira & $\begin{array}{l}\text { Legitimação } \\
\text { (Reunião estudantil } \\
\text { em Ibiúna) }\end{array}$ & $\begin{array}{l}\text { Parda } \\
\text { clara }\end{array}$ \\
\hline 145340 & $\begin{array}{l}\text { Miramar da Costa } \\
\text { Correia }\end{array}$ & 1968 & Brasileira & $\begin{array}{l}\text { Legitimação } \\
\text { (Reunião estudantil }\end{array}$ & $\begin{array}{l}\text { Parda } \\
\text { clara }\end{array}$ \\
\hline
\end{tabular}




\begin{tabular}{|c|c|c|c|c|c|}
\hline & & & & em Ibiúna) & \\
\hline 145352 & $\begin{array}{l}\text { Paulo Roberto de } \\
\text { Magalhães }\end{array}$ & 1968 & Brasileira & $\begin{array}{l}\text { Legitimação } \\
\text { (Reunião estudantil } \\
\text { em Ibiúna) }\end{array}$ & $\begin{array}{l}\text { Parda } \\
\text { clara }\end{array}$ \\
\hline 145428 & $\begin{array}{l}\text { Raimunda de } \\
\text { Oliveira Almeida }\end{array}$ & 1968 & Brasileira & $\begin{array}{l}\text { Legitimação } \\
\text { (Reunião estudantil } \\
\text { em Ibiúna) }\end{array}$ & $\begin{array}{l}\text { Parda } \\
\text { clara }\end{array}$ \\
\hline 145450 & $\begin{array}{l}\text { Jose Carlos Dias de } \\
\text { Oliveira }\end{array}$ & 1968 & Brasileira & $\begin{array}{l}\text { Legitimação } \\
\text { (Reunião estudantil } \\
\text { em Ibiúna) }\end{array}$ & $\begin{array}{l}\text { Parda } \\
\text { clara }\end{array}$ \\
\hline 145588 & José Genoino Neto & 1968 & Brasileira & $\begin{array}{l}\text { Legitimação } \\
\text { (Reunião estudantil } \\
\text { em Ibiúna) }\end{array}$ & $\begin{array}{l}\text { Parda ou } \\
\text { branca }\end{array}$ \\
\hline 145722 & $\begin{array}{ll}\text { José } & \text { Roberto } \\
\text { Domingos } & \\
\end{array}$ & 1968 & Brasileira & $\begin{array}{l}\text { Divulgação de } \\
\text { panfletos judaicos }\end{array}$ & Preta \\
\hline 145727 & José Carlos Nicolau & 1968 & Brasileira & $\begin{array}{l}\text { Divulgação de } \\
\text { panfletos judaicos }\end{array}$ & Preta \\
\hline 145872 & Odivino de Souza & 1969 & Brasileira & $\begin{array}{l}\text { Lei de Segurança } \\
\text { Nacional }\end{array}$ & Parda \\
\hline 145872 & $\begin{array}{l}\text { Fidelcino Santiago } \\
\text { dos Santos }\end{array}$ & 1969 & Brasileira & $\begin{array}{l}\text { Lei de Segurança } \\
\text { Nacional }\end{array}$ & Parda \\
\hline 145902 & $\begin{array}{ll}\text { Wilson } & \text { Anastácio } \\
\text { da Silva } & \\
\end{array}$ & 1969 & Brasileira & $\begin{array}{lll}\text { Artigo } 171 & \text { do } \\
\text { Código Penal } & \\
\end{array}$ & Preta \\
\hline 145903 & Ruth Nogueira & 1969 & Brasileira & $\begin{array}{lll}\text { Artigo } 171 & \text { do } \\
\text { Código Penal } & \end{array}$ & $\begin{array}{l}\text { Parda } \\
\text { clara ou } \\
\text { morena }\end{array}$ \\
\hline 145917 & José de Campos & 1969 & Brasileira & $\begin{array}{llr}\text { Artigo } 171 & \text { do } \\
\text { Código Penal } & \text { - } \\
\text { falsificação } \\
\text { imposto }\end{array}$ & $\begin{array}{l}\text { Parda ou } \\
\text { preta }\end{array}$ \\
\hline 145921 & $\begin{array}{ll}\text { Daniel } & \text { Anastácio } \\
\text { da Silva } & \end{array}$ & 1969 & Brasileira & $\begin{array}{llr}\text { Artigo } & 171 & \text { do } \\
\text { Código } & \text { Penal } \\
\text { falsificação } & \text { guia } \\
\text { imposto } & & \end{array}$ & Preta \\
\hline 145944 & $\begin{array}{ll}\text { Constantino } & \text { de } \\
\text { Oliveira Filho } & \\
\end{array}$ & 1969 & Brasileira & $\begin{array}{l}\text { Legitimação (Ordem } \\
\text { Social) }\end{array}$ & Preta \\
\hline 146129 & $\begin{array}{l}\text { Juan Carlos Barrica } \\
\text { Silva }\end{array}$ & 1969 & Uruguaia & $\begin{array}{l}\text { Legitimação } \\
\text { (Delegacia } \\
\text { Estrangeiros) } \\
\end{array}$ & Parda \\
\hline 146132 & José Aleixo Filho & 1969 & Brasileira & $\begin{array}{l}\text { Legitimação (Ordem } \\
\text { Social) }\end{array}$ & Preta \\
\hline 146171 & $\begin{array}{ll}\text { Caetana } & \text { Maria } \\
\text { Damasceno } & \end{array}$ & 1969 & Brasileira & $\begin{array}{l}\text { Incidentes USP em } \\
1968 \text { Lei de } \\
\text { Segurança Nacional }\end{array}$ & Parda \\
\hline 146178 & $\begin{array}{l}\text { Paulo Roberto de } \\
\text { Oliveira }\end{array}$ & 1969 & Brasileira & $\begin{array}{lcc}\text { Incidentes USP } & \text { em } \\
1968 \quad \text { Lei } & \text { de }\end{array}$ & $\begin{array}{l}\text { Parda } \\
\text { escura }\end{array}$ \\
\hline
\end{tabular}




\begin{tabular}{|c|c|c|c|c|c|}
\hline & & & & Segurança Nacional & \\
\hline 146279 & $\begin{array}{l}\text { Maginho Agostinho } \\
\text { Pinto }\end{array}$ & 1969 & Brasileira & $\begin{array}{l}\text { Lei de Segurança } \\
\text { Nacional }\end{array}$ & Parda \\
\hline 146304 & $\begin{array}{ll}\text { João } & \text { Estevão } \\
\text { Martins } & \\
\end{array}$ & 1969 & Brasileira & $\begin{array}{l}\text { Lei de Segurança } \\
\text { Nacional }\end{array}$ & Preta \\
\hline 146307 & $\begin{array}{ll}\text { João } & \text { Carlos } \\
\text { Ferreira } & \\
\end{array}$ & 1969 & Brasileira & $\begin{array}{l}\text { Lei de Segurança } \\
\text { Nacional }\end{array}$ & Preta \\
\hline 146322 & $\begin{array}{l}\text { Amaro Antonio da } \\
\text { Silva }\end{array}$ & 1969 & Brasileira & $\begin{array}{l}\text { Lei de Segurança } \\
\text { Nacional }\end{array}$ & Parda \\
\hline 146407 & $\begin{array}{l}\text { Francisco Borja de } \\
\text { Lana }\end{array}$ & 1969 & Brasileira & $\begin{array}{l}\text { Lei de Segurança } \\
\text { Nacional }\end{array}$ & $\begin{array}{l}\text { Parda } \\
\text { clara ou } \\
\text { morena }\end{array}$ \\
\hline 146436 & $\begin{array}{ll}\text { Antonio } & \text { Carlos } \\
\text { Mariano } & \\
\end{array}$ & 1969 & Brasileira & $\begin{array}{l}\text { Legitimação (Ordem } \\
\text { Política) }\end{array}$ & Parda \\
\hline 146438 & Clovis de Castro & 1969 & Brasileira & $\begin{array}{l}\text { Legitimação (Ordem } \\
\text { Social) }\end{array}$ & $\begin{array}{ll}\text { Parda } & \\
\text { clara ou } \\
\text { branca }\end{array}$ \\
\hline 146439 & $\begin{array}{l}\text { Edgard de Souza } \\
\text { Aranha Junior }\end{array}$ & 1969 & Brasileira & $\begin{array}{l}\text { Legitimação (Ordem } \\
\text { Política) }\end{array}$ & Parda \\
\hline 146440 & $\begin{array}{l}\text { Francisco Bispo de } \\
\text { Carvalho Filho }\end{array}$ & 1969 & Brasileira & $\begin{array}{l}\text { Legitimação (Ordem } \\
\text { Social) }\end{array}$ & $\begin{array}{l}\text { Preta ou } \\
\text { branca }\end{array}$ \\
\hline 146453 & $\begin{array}{l}\text { Valdervino } \\
\text { Raimundo da Silva }\end{array}$ & 1970 & Brasileira & $\begin{array}{l}\text { Legitimação } \\
\text { terrorismo }\end{array}$ & $\begin{array}{l}\text { Parda } \\
\text { clara }\end{array}$ \\
\hline 146458 & Octavio Angelo & 1970 & Brasileira & $\begin{array}{l}\text { Seqüestro do cônsul } \\
\text { do Japão } \\
\text { terrorismo banido do } \\
\text { país }\end{array}$ & $\begin{array}{l}\text { Parda } \\
\text { escura ou } \\
\text { morena }\end{array}$ \\
\hline 146464 & Lorival Ferraz & 1970 & Brasileira & $\begin{array}{l}\text { Legitimação (Ordem } \\
\text { Social) }\end{array}$ & Parda \\
\hline 146470 & $\begin{array}{ll}\text { Amaro } & \text { Luiz } \\
\text { Carvalho } & \\
\end{array}$ & 1970 & Brasileira & $\begin{array}{l}\text { Legitimação (Ordem } \\
\text { Social) }\end{array}$ & $\begin{array}{l}\text { Parda ou } \\
\text { branca }\end{array}$ \\
\hline 146477 & $\begin{array}{l}\text { Antonio Pedro de } \\
\text { Andrade }\end{array}$ & 1970 & Brasileira & $\begin{array}{l}\text { Legitimação (Ordem } \\
\text { Social) }\end{array}$ & Parda \\
\hline 146522 & $\begin{array}{l}\text { Manoel Candido do } \\
\text { Nascimento }\end{array}$ & 1970 & Brasileira & Mandado de prisão & Parda \\
\hline 146526 & $\begin{array}{ll}\text { Damaris } & \mathrm{de} \\
\text { Oliveira Lucena } & \end{array}$ & 1970 & Brasileira & $\begin{array}{l}\text { Seqüestro do cônsul } \\
\text { do Japão } \\
\text { terrorismo banida do } \\
\text { país }\end{array}$ & $\begin{array}{l}\text { Parda } \\
\text { clara }\end{array}$ \\
\hline 146548 & $\begin{array}{lll}\text { Alvaro } & \text { José } & \text { de } \\
\text { Oliveira } & & \end{array}$ & 1970 & Brasileira & $\begin{array}{l}\text { Legitimação } \\
\text { terrorismo e } \\
\text { subversão (por meio } \\
\text { da operação } \\
\text { bandeirante) }\end{array}$ & $\begin{array}{l}\text { Parda } \\
\text { clara }\end{array}$ \\
\hline 146550 & $\begin{array}{l}\text { Afonso Bezerra da } \\
\text { Silva }\end{array}$ & 1970 & Brasileira & $\begin{array}{ll}\text { Subversão } & \text { (por meio } \\
\text { da } & \text { operação }\end{array}$ & $\begin{array}{l}\text { Parda } \\
\text { escura }\end{array}$ \\
\hline
\end{tabular}




\begin{tabular}{|c|c|c|c|c|c|}
\hline & & & & bandeirante) & \\
\hline 146586 & $\begin{array}{ll}\text { Celia } & \text { Maria } \\
\text { Francisco } & \\
\end{array}$ & 1970 & Brasileira & Legitimação & $\begin{array}{ll}\begin{array}{l}\text { Preta } \\
\text { negra }\end{array} & \end{array}$ \\
\hline 146587 & $\begin{array}{l}\text { Boaventura José de } \\
\text { Araújo }\end{array}$ & 1970 & Brasileira & Legitimação & $\begin{array}{ll}\text { Parda ou } \\
\text { branca ou } \\
\text { morena }\end{array}$ \\
\hline 146623 & $\begin{array}{l}\text { Herminio } \\
\text { Apolinário }\end{array}$ & 1970 & Brasileira & Peculato & Preta \\
\hline 146684 & $\begin{array}{l}\text { Ana Maria } \\
\text { Rodrigues Ramos }\end{array}$ & 1973 & Brasileira & $\begin{array}{l}\text { Legitimação por } \\
\text { subversão (por meio } \\
\text { da operação } \\
\text { bandeirante) }\end{array}$ & $\begin{array}{l}\text { Branca ou } \\
\text { parda }\end{array}$ \\
\hline 146687 & $\begin{array}{l}\text { Wilson Conceição } \\
\text { Pinto }\end{array}$ & 1971 & Brasileira & $\begin{array}{l}\text { Legitimação } \\
\text { subversão (por meio } \\
\text { da operação } \\
\text { bandeirante) }\end{array}$ & $\begin{array}{ll}\text { Parda } & \\
\text { clara ou } \\
\text { escura }\end{array}$ \\
\hline 146749 & Natal Barbosa & 1970 & Brasileira & Legitimação & Preta \\
\hline 146819 & $\begin{array}{ll}\text { Leonardo Messias } \\
\text { Silva }\end{array}$ & 1970 & Brasileira & Legitimação & Parda \\
\hline 146821 & Getulio José Souza & 1970 & Brasileira & Legitimação & Parda \\
\hline 146824 & $\begin{array}{l}\text { Augusto Rocha } \\
\text { Pinto }\end{array}$ & 1970 & Brasileira & Legitimação & Parda \\
\hline 146825 & Aparecido da Silva & 1970 & Brasileira & $\begin{array}{l}\text { Legitimação por } \\
\text { porte de livro sobre } \\
\text { a URSS }\end{array}$ & Preta \\
\hline 146826 & $\begin{array}{l}\text { Aparecido Rocha } \\
\text { Pinto }\end{array}$ & 1970 & Brasileira & Legitimação & Parda \\
\hline 146840 & $\begin{array}{l}\text { Wanderley Ferreira } \\
\text { Santos }\end{array}$ & 1970 & Brasileira & $\begin{array}{lr}\text { Legitimação } & \text { por } \\
\text { panfletagem } & \text { e } \\
\text { subversivos } & \end{array}$ & Parda \\
\hline 146841 & $\begin{array}{l}\text { Waldemar Leme } \\
\text { Silva }\end{array}$ & 1970 & Brasileira & Legitimação & $\begin{array}{ll}\text { Parda } & \text { ou } \\
\text { preta }\end{array}$ \\
\hline 146859 & $\begin{array}{l}\text { Josefina } \quad \text { Nicacia } \\
\text { Santos }\end{array}$ & 1970 & Brasileira & Legitimação & Parda \\
\hline 146865 & $\begin{array}{l}\text { José Alberto da } \\
\text { Cruz }\end{array}$ & 1970 & Brasileira & $\begin{array}{l}\text { Legitimação (Ordem } \\
\text { Social) }\end{array}$ & Parda \\
\hline 146869 & $\begin{array}{l}\text { Jezomar Alves } \\
\text { Lobo }\end{array}$ & 1970 & Brasileira & $\begin{array}{l}\text { Legitimação (Ordem } \\
\text { Social) }\end{array}$ & Parda \\
\hline 146879 & Ivo Eugenio & 1970 & Brasileira & Legitimação & Preta \\
\hline 146889 & $\begin{array}{l}\text { Helena Maria } \\
\text { Ferreira Silva }\end{array}$ & 1970 & Brasileira & Legitimação & $\begin{array}{l}\text { Parda } \\
\text { clara }\end{array}$ \\
\hline 146895 & $\begin{array}{l}\text { Gerosina } \quad \text { Silva } \\
\text { Pereira }\end{array}$ & 1970 & Brasileira & Legitimação & $\begin{array}{l}\text { Parda ou } \\
\text { branca }\end{array}$ \\
\hline 146907 & $\begin{array}{l}\text { Benedito } \quad \text { Vitor } \\
\text { Silva }\end{array}$ & 1970 & Brasileira & $\begin{array}{l}\text { Legitimação (Ordem } \\
\text { Social) }\end{array}$ & $\begin{array}{l}\text { Parda ou } \\
\text { branca }\end{array}$ \\
\hline 146925 & Dorival & 1970 & Brasileira & Crime eleitoral & Preta \\
\hline
\end{tabular}




\begin{tabular}{|c|c|c|c|c|c|}
\hline & Oliveira & & & & \\
\hline 146956 & $\begin{array}{l}\text { Manoel Agostinho } \\
\text { de Souza Farias }\end{array}$ & 1970 & Brasileira & $\begin{array}{l}\text { Lei de Segurança } \\
\text { Nacional }\end{array}$ & Preta \\
\hline 146972 & $\begin{array}{l}\text { Alaor Resende de } \\
\text { Moura }\end{array}$ & 1971 & Brasileira & $\begin{array}{l}\text { Legitimação (Ordem } \\
\text { Social) }\end{array}$ & Parda \\
\hline 146977 & $\begin{array}{l}\text { José } \quad \text { Lourenço } \\
\text { Machado }\end{array}$ & 1971 & Brasileira & Legitimação & Preta \\
\hline 147014 & $\begin{array}{l}\text { Gelson Braga de } \\
\text { Souza }\end{array}$ & 1970 & Brasileira & Não consta & $\begin{array}{l}\text { Parda } \\
\text { clara }\end{array}$ \\
\hline 147018 & $\begin{array}{l}\text { Aristides Alves da } \\
\text { Silva Junior }\end{array}$ & 1970 & Brasileira & Legitimação & Parda \\
\hline 147059 & $\begin{array}{l}\text { Evelyn Lisle Costa } \\
\text { Clarke }\end{array}$ & 1971 & Inglesa & $\begin{array}{l}\text { Legitimação (Ordem } \\
\text { Social) }\end{array}$ & Preta \\
\hline 147065 & $\begin{array}{l}\text { Deusdedit } \\
\text { Fernandes }\end{array}$ & 1971 & Brasileira & Legitimação & $\begin{array}{l}\text { Parda ou } \\
\text { preta }\end{array}$ \\
\hline 147077 & $\begin{array}{l}\text { Carmem Conceição } \\
\text { da Silva }\end{array}$ & 1971 & Brasileira & Legitimação & Preta \\
\hline 147117 & $\begin{array}{ll}\text { Antonio } & \text { Nestor } \\
\text { Fortunato } & \end{array}$ & 1974 & Brasileira & Legitimação & $\begin{array}{l}\text { Parda } \\
\text { escura }\end{array}$ \\
\hline 147136 & Jordão Santos & 1971 & Brasileira & $\begin{array}{l}\text { Legitimação por } \\
\text { suspeita de roubo }\end{array}$ & Parda \\
\hline 147152 & Moisés Jacó Silva & 1971 & Brasileira & Legitimação & $\begin{array}{l}\text { Parda } \\
\text { escura }\end{array}$ \\
\hline 147153 & $\begin{array}{l}\text { Nestor José } \\
\text { Fortunato Filho }\end{array}$ & 1971 & Brasileira & Legitimação & $\begin{array}{l}\text { Parda } \\
\text { escura ou } \\
\text { preta }\end{array}$ \\
\hline 147211 & Joaquim Alexandre & 1971 & Brasileira & Falsidade ideológica & Preta \\
\hline 147231 & $\begin{array}{l}\text { Edson Baia do } \\
\text { Nascimento }\end{array}$ & 1971 & Brasileira & Averiguações & Preta \\
\hline 147232 & Egidio dos Santos & 1971 & Brasileira & Legitimação & Parda \\
\hline 147246 & Eneas da Silva & 1972 & Brasileira & $\begin{array}{l}\text { Legitimação por } \\
\text { tentativa de roubo }\end{array}$ & Parda \\
\hline 147254 & $\begin{array}{l}\text { Moacir Honorato } \\
\text { dos Santos }\end{array}$ & 1972 & Brasileira & Legitimação & Parda \\
\hline 147265 & $\begin{array}{l}\text { Severino Felix da } \\
\text { Silva }\end{array}$ & 1972 & Brasileira & $\begin{array}{l}\text { Legitimação (Ordem } \\
\text { Social) }\end{array}$ & Parda \\
\hline 147361 & $\begin{array}{l}\text { Hermes Candido de } \\
\text { Santana }\end{array}$ & 1972 & Brasileira & $\begin{array}{ll}\text { Artigo } 305 & \text { do } \\
\text { Código Penal } & \end{array}$ & $\begin{array}{l}\text { Parda } \\
\text { clara }\end{array}$ \\
\hline 147370 & $\begin{array}{l}\text { José Edmundo da } \\
\text { Silva }\end{array}$ & 1972 & Brasileira & $\begin{array}{l}\text { Legitimação (Ordem } \\
\text { Social) }\end{array}$ & Parda \\
\hline 147377 & $\begin{array}{ll}\text { Luiz } & \text { Claudio } \\
\text { Venâncio } & \end{array}$ & 1972 & Brasileira & Legitimação & $\begin{array}{l}\text { Parda ou } \\
\text { branca ou } \\
\text { morena }\end{array}$ \\
\hline 147388 & $\begin{array}{l}\text { Oswaldo Cardoso } \\
\text { dos Santos }\end{array}$ & 1972 & Brasileira & Legitimação & Preta \\
\hline 147467 & Francisco & 1972 & Brasileira & Artigo & Parda \\
\hline
\end{tabular}




\begin{tabular}{|c|c|c|c|c|c|}
\hline & Santana Carneiro & & & Código Penal & $\begin{array}{ll}\text { clara } & \text { ou } \\
\text { branca } & \end{array}$ \\
\hline 147473 & Iguatemi de Godoy & 1972 & Brasileira & $\begin{array}{ll}\text { Artigo } 304 & \text { do } \\
\text { Código Penal } & \end{array}$ & $\begin{array}{l}\text { Parda } \\
\text { escura }\end{array}$ \\
\hline 147475 & $\begin{array}{ll}\text { José } & \text { Araujo } \\
\text { Montalvão } & \\
\end{array}$ & 1972 & Brasileira & Terrorismo ALN & Parda \\
\hline 147542 & $\begin{array}{l}\text { Lamartine Caetano } \\
\text { Batista }\end{array}$ & 1972 & Brasileira & Legitimação & $\begin{array}{ll}\text { Parda ou } \\
\text { branca }\end{array}$ \\
\hline 147623 & $\begin{array}{l}\text { José Germano dos } \\
\text { Santos }\end{array}$ & 1972 & Brasileira & $\begin{array}{ll}\begin{array}{l}\text { Falsificação } \\
\text { documentos }\end{array} & \mathrm{de} \\
\end{array}$ & Preta \\
\hline 147638 & $\begin{array}{ll}\text { Moacyr de Souza } \\
\text { Araújo }\end{array}$ & 1972 & Brasileira & $\begin{array}{ll}\begin{array}{l}\text { Falsificação } \\
\text { documentos }\end{array} & \text { de } \\
\end{array}$ & Preta \\
\hline 147639 & $\begin{array}{l}\text { Miguel Archanjo da } \\
\text { Rocha Filho }\end{array}$ & 1972 & Brasileira & $\begin{array}{l}\text { Artigos } 297 \text { e } 304 \text { do } \\
\text { Código Penal }\end{array}$ & $\begin{array}{ll}\text { Preta ou } \\
\text { parda } \\
\text { escura }\end{array}$ \\
\hline 147663 & $\begin{array}{l}\text { Benedito Mariano } \\
\text { Neto }\end{array}$ & 1972 & Brasileira & Legitimação & Parda \\
\hline 147687 & $\begin{array}{l}\text { Corinto Antonio da } \\
\text { Silva }\end{array}$ & 1972 & Brasileira & $\begin{array}{l}\text { Falsificação de } \\
\text { documento público }\end{array}$ & Parda \\
\hline 147712 & Jorge Gonzaga & 1972 & Brasileira & Legitimação & Preta \\
\hline 147733 & $\begin{array}{ll}\text { Deocleciano de } \\
\text { Souza Dias }\end{array}$ & 1972 & Brasileira & Legitimação & $\begin{array}{l}\text { Parda ou } \\
\text { preta }\end{array}$ \\
\hline 147810 & $\begin{array}{ll}\text { Aparecido } & \text { de } \\
\text { Freitas Barboza } & \\
\end{array}$ & 1973 & Brasileira & $\begin{array}{lll}\text { Artigo } 299 & \text { do } \\
\text { Código eleitoral } & \\
\end{array}$ & $\begin{array}{l}\text { Parda } \\
\text { clara }\end{array}$ \\
\hline 147825 & $\begin{array}{l}\text { Geraldo Pereira do } \\
\text { Nascimento }\end{array}$ & 1973 & Brasileira & Legitimação & Parda \\
\hline 147959 & David de Lima & 1975 & Brasileira & Legitimação & Parda \\
\hline 147968 & $\begin{array}{lll}\text { João } & \text { Ferreira } & \text { da } \\
\text { Silva } & & \\
\end{array}$ & 1975 & Brasileira & Legitimação & $\begin{array}{l}\text { Parda ou } \\
\text { morena }\end{array}$ \\
\hline 147986 & $\begin{array}{ll}\text { Luzinaldo do } \\
\text { Nascimento }\end{array}$ & 1975 & Brasileira & Legitimação & Parda \\
\hline 147989 & Leo Gillitio & 1975 & Brasileira & Legitimação & Preta \\
\hline 148016 & $\begin{array}{ll}\text { José } & \text { Ribamar } \\
\text { Firmino } & \end{array}$ & 1975 & Brasileira & $\begin{array}{l}\text { Legitimação (Ordem } \\
\text { Social) }\end{array}$ & $\begin{array}{l}\text { Parda } \\
\text { escura ou } \\
\text { negra }\end{array}$ \\
\hline 148043 & $\begin{array}{l}\text { José } \\
\text { Gomes }\end{array}$ & 1976 & Brasileira & $\begin{array}{l}\text { Tentativa de assalto } \\
\text { a banco - Lei de } \\
\text { Segurança Nacional }\end{array}$ & $\begin{array}{l}\text { Parda } \\
\text { escura }\end{array}$ \\
\hline 148056 & $\begin{array}{l}\text { Enivaldo } \\
\text { Guimarães }\end{array}$ & 1975 & Brasileira & Legitimação & $\begin{array}{l}\text { Parda ou } \\
\text { branca }\end{array}$ \\
\hline 148062 & $\begin{array}{ll}\text { Cícero } & \text { Roberto } \\
\text { Ferreira } & \\
\end{array}$ & 1974 & Brasileira & $\begin{array}{l}\text { Legitimação por } \\
\text { assalto }\end{array}$ & Preta \\
\hline 148063 & $\begin{array}{l}\text { José } \\
\text { Campos } \\
\end{array}$ & 1975 & Brasileira & $\begin{array}{l}\text { Legitimação (Ordem } \\
\text { Social) }\end{array}$ & Preta \\
\hline 148083 & $\begin{array}{ll}\text { Alziro } & \text { Teixeira } \\
\text { Magalhães } & \\
\end{array}$ & 1976 & Brasileira & $\begin{array}{lrr}\text { Artigo } 317 & \text { do } \\
\text { Código Penal } & \\
\end{array}$ & $\begin{array}{l}\text { Parda } \\
\text { clara }\end{array}$ \\
\hline
\end{tabular}




\begin{tabular}{|c|c|c|c|c|c|}
\hline 148119 & Nayde Silva & 1974 & Brasileira & $\begin{array}{l}\text { Artigo } 171 \text { do } \\
\text { Código Penal }\end{array}$ & $\begin{array}{l}\text { Parda } \\
\text { clara }\end{array}$ \\
\hline 148121 & Tarcisio Ferreira & 1976 & Brasileira & $\begin{array}{l}\text { Artigo } 305 \text { do } \\
\text { Código Penal }\end{array}$ & Preta \\
\hline 148122 & $\begin{array}{ll}\text { Walmir } & \text { Ferreira } \\
\text { dos Santos } & \end{array}$ & 1976 & Brasileira & $\begin{array}{l}\text { Legitimação (Ordem } \\
\text { Social) }\end{array}$ & $\begin{array}{ll}\text { Parda } & \text { ou } \\
\text { negra }\end{array}$ \\
\hline 148124 & $\begin{array}{l}\text { Raimundo Conrado } \\
\text { de Souza Filho }\end{array}$ & 1976 & Brasileira & $\begin{array}{l}\text { Legitimação (Ordem } \\
\text { Social) }\end{array}$ & Parda \\
\hline 148132 & $\begin{array}{lll}\text { Joécio } & \text { Sales } & \text { do } \\
\text { Amaral } & & \end{array}$ & 1976 & Brasileira & Estelionato & $\begin{array}{l}\text { Parda } \\
\text { escura }\end{array}$ \\
\hline 148137 & $\begin{array}{ll}\text { Jorge } & \text { Alberto } \\
\text { Boedo } & \end{array}$ & 1976 & Argentina & $\begin{array}{l}\text { Legitimação por } \\
\text { situação irregular no } \\
\text { país }\end{array}$ & $\begin{array}{l}\text { Parda ou } \\
\text { branca }\end{array}$ \\
\hline 148140 & $\begin{array}{l}\text { Carlos Otávio } \\
\text { Zapata Cardona }\end{array}$ & 1975 & Colombiana & $\begin{array}{l}\text { Legitimação por } \\
\text { situação irregular no } \\
\text { país }\end{array}$ & Parda \\
\hline 148141 & $\begin{array}{lll}\text { Dolores Alves de } \\
\text { Souza }\end{array}$ & 1976 & Brasileira & $\begin{array}{lrr}\text { Artigo } 299 & \text { do } \\
\text { Código Penal } & \end{array}$ & $\begin{array}{l}\text { Parda } \\
\text { escura }\end{array}$ \\
\hline 148182 & $\begin{array}{l}\text { Morici Pereira da } \\
\text { Silva }\end{array}$ & 1976 & Brasileira & $\begin{array}{l}\text { Assalto a banco - } \\
\text { Lei de Segurança } \\
\text { Nacional }\end{array}$ & $\begin{array}{l}\text { Parda } \\
\text { escura }\end{array}$ \\
\hline 148242 & Haroldo Pires & 1976 & Brasileira & $\begin{array}{llr}\text { Artigo } & 313 & \text { do } \\
\text { Código } & \text { Penal } & \text { - } \\
\text { subversão } & & \end{array}$ & $\begin{array}{l}\text { Parda ou } \\
\text { branca }\end{array}$ \\
\hline 148290 & $\begin{array}{ll}\text { Luiz } & \text { Otavio } \\
\text { Macário } & \end{array}$ & 1976 & Brasileira & $\begin{array}{l}\text { Artigo } 333 \text { do } \\
\text { Código Penal }\end{array}$ & Preta \\
\hline 148298 & $\begin{array}{l}\text { Nelson } \text { Machado } \\
\text { Ribeiro }\end{array}$ & 1966 & Brasileira & $\begin{array}{l}\text { Artigo } 157 \\
\text { Código Penal }\end{array}$ & $\begin{array}{l}\text { Parda } \\
\text { escura }\end{array}$ \\
\hline 148306 & $\begin{array}{ll}\text { Iederte } & \text { Benedito } \\
\text { Faustino } & \end{array}$ & 1976 & Brasileira & $\begin{array}{l}\text { Artigo } 333 \\
\text { Código Penal }\end{array}$ & $\begin{array}{l}\text { Parda } \\
\text { escura }\end{array}$ \\
\hline 148310 & $\begin{array}{l}\text { Wilson Balsanufo } \\
\text { Bento }\end{array}$ & 1976 & Brasileira & $\begin{array}{l}\text { Artigo } 333 \\
\text { Código Penal }\end{array}$ & $\begin{array}{l}\text { Parda } \\
\text { escura }\end{array}$ \\
\hline 148311 & José Gilson Alves & 1976 & Brasileira & $\begin{array}{l}\text { Artigo } 333 \\
\text { Código Penal }\end{array}$ & Preta \\
\hline 148312 & $\begin{array}{l}\text { Nelson } \quad \text { Machado } \\
\text { Ribeiro }\end{array}$ & 1976 & Brasileira & $\begin{array}{l}\text { Artigo } 155 \text { do } \\
\text { Código Penal }\end{array}$ & $\begin{array}{l}\text { Parda } \\
\text { escura }\end{array}$ \\
\hline 148334 & Edgar Mussendijk & 1976 & Suriname & $\begin{array}{l}\text { Legitimação por } \\
\text { situação irregular no } \\
\text { país }\end{array}$ & $\begin{array}{l}\text { Parda ou } \\
\text { preta }\end{array}$ \\
\hline 148342 & $\begin{array}{ll}\text { José Bento de } \\
\text { Moraes }\end{array}$ & 1976 & Brasileira & $\begin{array}{lrr}\text { Artigo } 333 & \text { do } \\
\text { Código Penal } & \\
\end{array}$ & $\begin{array}{l}\text { Parda } \\
\text { clara }\end{array}$ \\
\hline 148347 & $\begin{array}{ll}\begin{array}{l}\text { Ariovaldo } \\
\text { Toledo }\end{array} & \text { Dias } \\
\end{array}$ & 1976 & Brasileira & $\begin{array}{lr}\text { Artigo } 155 \\
\text { Código Penal }\end{array}$ & Preta \\
\hline 148436 & $\begin{array}{l}\text { José Roberto de } \\
\text { Santana Oliveira }\end{array}$ & 1976 & Brasileira & $\begin{array}{l}\text { Artigo } 168 \\
\text { Código Penal }\end{array}$ & $\begin{array}{l}\text { Parda } \\
\text { clara }\end{array}$ \\
\hline 148443 & Noel Fernando da & 1976 & Brasileira & Artigo 155 & Parda \\
\hline
\end{tabular}




\begin{tabular}{|c|c|c|c|c|c|}
\hline & Costa & & & Código Penal & $\begin{array}{l}\text { escura ou } \\
\text { preta }\end{array}$ \\
\hline 148445 & $\begin{array}{ll}\text { Sebastião } & \text { Manoel } \\
\text { dos Anjos }\end{array}$ & 1966 & Brasileira & Não consta & Preta \\
\hline 148509 & $\begin{array}{l}\text { João Batista Luiz } \\
\text { Antonio }\end{array}$ & 1976 & Brasileira & $\begin{array}{lc}\text { Artigo } 299 & \text { e } 288 \text { do } \\
\text { Código } & \text { Penal - } \\
\text { Crime } & \text { contra } \\
\text { Fazenda } & \end{array}$ & Preta \\
\hline 148511 & Isaias Ferreira & 1976 & Brasileira & \begin{tabular}{lrr} 
Artigo & 298 & do \\
Código & Penal & - \\
crime & \multicolumn{2}{c}{ contra } \\
Fazenda & &
\end{tabular} & $\begin{array}{l}\text { Parda } \\
\text { clara }\end{array}$ \\
\hline 148518 & $\begin{array}{ll}\text { Ronald } & \text { Vascope } \\
\text { Pedriel } & \\
\end{array}$ & 1976 & Boliviana & Legitimação & Parda \\
\hline 148603 & $\begin{array}{ll}\text { Jonilson } & \text { Gomes } \\
\text { Oliveira } & \end{array}$ & 1977 & Brasileira & Assalto & $\begin{array}{ll}\text { Preta ou } \\
\text { parda } \\
\text { escura }\end{array}$ \\
\hline 148623 & $\begin{array}{lll}\text { Sergio } & \text { Tomaz } & \text { da } \\
\text { Silva } & & \end{array}$ & 1977 & Brasileira & $\begin{array}{lc}\text { Artigo } & 171 \text { e } 288 \text { do } \\
\text { Código } & \text { Penal - } \\
\text { Crime } & \text { contra } \\
\text { Fazenda } & \end{array}$ & Preta \\
\hline 148640 & $\begin{array}{l}\text { Manoel Porfirio de } \\
\text { Souza }\end{array}$ & 1977 & Brasileira & $\begin{array}{l}\text { Lei de Segurança } \\
\text { Nacional }\end{array}$ & $\begin{array}{l}\text { Parda } \\
\text { clara }\end{array}$ \\
\hline 148643 & $\begin{array}{lll}\text { José } & \text { Ribamar de } \\
\text { Brito } & & \\
\end{array}$ & 1977 & Brasileira & Falsidade ideológica & $\begin{array}{l}\text { Parda } \\
\text { clara }\end{array}$ \\
\hline 148777 & $\begin{array}{l}\text { Nivaldo Oliveira } \\
\text { Evangelista }\end{array}$ & 1977 & Brasileira & Furto & $\begin{array}{l}\text { Parda } \\
\text { escura }\end{array}$ \\
\hline 148793 & José de Lima Felix & 1977 & Brasileira & $\begin{array}{l}\text { Assalto a banco - } \\
\text { Lei de Segurança } \\
\text { Nacional }\end{array}$ & $\begin{array}{l}\text { Parda } \\
\text { escura }\end{array}$ \\
\hline 148799 & $\begin{array}{ll}\text { José } & \text { Renato } \\
\text { Oliveira } & \\
\end{array}$ & 1977 & Brasileira & $\begin{array}{lll}\text { Artigo } 155 & \text { do } \\
\text { Código Penal } & \\
\end{array}$ & Preta \\
\hline 148831 & $\begin{array}{lll}\text { João Carlos } & \text { de } \\
\text { Souza } & \text { Dias }\end{array}$ & 1977 & Brasileira & $\begin{array}{l}\text { Tentativa de } \\
\text { extorsão e ameaças }\end{array}$ & Preta \\
\hline 148856 & Irineu de Paiva & 1977 & Brasileira & $\begin{array}{lll}\text { Artigo } 328 & \text { do } \\
\text { Código Penal } & \\
\end{array}$ & $\begin{array}{l}\text { Parda } \\
\text { clara }\end{array}$ \\
\hline 148991 & $\begin{array}{ll}\text { Denir } & \text { Ferreira } \\
\text { Martins } & \\
\end{array}$ & 1977 & Brasileira & $\begin{array}{lll}\text { Artigo } 171 & \text { do } \\
\text { Código Penal } & \\
\end{array}$ & $\begin{array}{l}\text { Parda } \\
\text { escura }\end{array}$ \\
\hline 149002 & $\begin{array}{l}\text { Jesse Correia de } \\
\text { Oliveira }\end{array}$ & 1977 & Brasileira & $\begin{array}{ll}\text { Crime } & \text { contra } \\
\text { Fazenda } & \\
\end{array}$ & $\begin{array}{l}\text { Parda } \\
\text { clara }\end{array}$ \\
\hline 149017 & $\begin{array}{ll}\text { José } & \text { Ferreira } \\
\text { Caetano } & \\
\end{array}$ & 1977 & Brasileira & $\begin{array}{lrr}\text { Artigo } 386 & \text { do } \\
\text { Código Penal } & \\
\end{array}$ & Parda \\
\hline 149021 & $\begin{array}{lll}\text { Joel da } & \text { Silva } \\
\text { Franco } & & \\
\end{array}$ & 1977 & Brasileira & $\begin{array}{l}\text { Desvio numerário } \\
\text { em sindicato }\end{array}$ & Preta \\
\hline 149024 & $\begin{array}{llll}\text { João de Deus da } \\
\text { Silva }\end{array}$ & 1977 & Brasileira & $\begin{array}{ll}\text { Crime } & \text { contra } \\
\text { Fazenda } & \\
\end{array}$ & $\begin{array}{l}\text { Parda } \\
\text { clara }\end{array}$ \\
\hline
\end{tabular}




\begin{tabular}{|c|c|c|c|c|c|}
\hline 149041 & $\begin{array}{ll}\text { Raimundo } & \text { Jose } \\
\text { Barbosa } & \\
\end{array}$ & 1971 & Brasileira & Depoimento & Parda \\
\hline 149074 & $\begin{array}{l}\text { Guinimel Mendes } \\
\text { dos Santos }\end{array}$ & 1977 & Brasileira & $\begin{array}{lll}\text { Artigo } 312 & \text { do } \\
\text { Código Penal } & \end{array}$ & $\begin{array}{l}\text { Parda } \\
\text { clara ou } \\
\text { branca }\end{array}$ \\
\hline 149075 & $\begin{array}{l}\text { Edgard Euclydes de } \\
\text { Oliveira }\end{array}$ & 1977 & Brasileira & $\begin{array}{ll}\text { Artigo } 307 & \text { do } \\
\text { Código Penal } & \end{array}$ & Preta \\
\hline 149078 & $\begin{array}{l}\text { Antonio Sebastião } \\
\text { de Freitas }\end{array}$ & 1978 & Brasileira & $\begin{array}{l}\text { Falsificação } \\
\text { ideológica } \\
\text { estelionato }\end{array}$ & $\begin{array}{l}\text { Parda } \\
\text { clara }\end{array}$ \\
\hline 149094 & $\begin{array}{l}\text { Adilson Ferreira da } \\
\text { Silva }\end{array}$ & 1978 & Brasileira & $\begin{array}{ll}\text { Artigo } 157 & \text { do } \\
\text { Código Penal } & \end{array}$ & $\begin{array}{l}\text { Parda } \\
\text { escura }\end{array}$ \\
\hline 149100 & $\begin{array}{l}\text { Luiz Seraphim do } \\
\text { Espirito Santo }\end{array}$ & 1978 & Brasileira & Depoimento & Parda \\
\hline 149101 & José Vital Costa & 1978 & Brasileira & $\begin{array}{lll}\text { Queixa vítima } & \text { de } \\
\text { agressão } & & \\
\end{array}$ & Parda \\
\hline 149131 & $\begin{array}{l}\text { José Teixeira de } \\
\text { Morais }\end{array}$ & 1978 & Brasileira & $\begin{array}{l}\text { Artigo } 37 \text { - Lei de } \\
\text { Segurança Nacional }\end{array}$ & $\begin{array}{l}\text { Parda } \\
\text { clara }\end{array}$ \\
\hline 149140 & $\begin{array}{l}\text { Luiz Clementino } \\
\text { José }\end{array}$ & 1978 & Brasileira & $\begin{array}{l}\text { Artigo } 299 \text { e } 314 \text { do } \\
\text { Código Penal }\end{array}$ & Preta \\
\hline 149155 & Paulo Silva & 1978 & Brasileira & Furto qualificado & Preta \\
\hline 149174 & $\begin{array}{ll}\text { José } & \text { Joaquim } \\
\text { Jardim } & \\
\end{array}$ & 1978 & Brasileira & $\begin{array}{l}\text { Artigo } 27 \text { - Lei de } \\
\text { Segurança Nacional }\end{array}$ & $\begin{array}{l}\text { Parda } \\
\text { clara }\end{array}$ \\
\hline 149187 & $\begin{array}{l}\text { Sebastião Paulo da } \\
\text { Silva }\end{array}$ & 1978 & Brasileira & $\begin{array}{l}\text { Artigo } 29925 \text { e } 304 \\
\text { do Código Penal }\end{array}$ & $\begin{array}{l}\text { Parda } \\
\text { escura }\end{array}$ \\
\hline 149194 & $\begin{array}{l}\text { Salvador } \\
\text { Barbosa }\end{array}$ & 1978 & Brasileira & $\begin{array}{l}\text { Artigo } 171 \\
\text { Código Penal }\end{array}$ & $\begin{array}{l}\text { Morena } \\
\text { ou parda } \\
\text { clara }\end{array}$ \\
\hline 149217 & $\begin{array}{l}\text { Amaro Marques de } \\
\text { Carvalho }\end{array}$ & 1975 & Brasileira & Comunismo & $\begin{array}{l}\text { Parda } \\
\text { clara }\end{array}$ \\
\hline 149218 & $\begin{array}{ll}\text { Gumercindo } & \text { das } \\
\text { Dores Oliveira } & \\
\end{array}$ & 1978 & Brasileira & Receptação & $\begin{array}{l}\text { Parda } \\
\text { clara }\end{array}$ \\
\hline 149226 & $\begin{array}{ll}\begin{array}{l}\text { Benedito } \\
\text { de Moura }\end{array} & \text { Santana } \\
\end{array}$ & 1976 & Brasileira & Não consta & $\begin{array}{l}\text { Parda } \\
\text { clara }\end{array}$ \\
\hline 149269 & $\begin{array}{ll}\text { Joel } & \text { Fernandes } \\
\text { Lisboa } & \\
\end{array}$ & 1978 & Brasileira & $\begin{array}{lr}\text { Artigo } 157 \\
\text { Código Penal }\end{array}$ & $\begin{array}{l}\text { Parda } \\
\text { clara }\end{array}$ \\
\hline 149341 & $\begin{array}{ll}\text { Josué } & \text { Fernades } \\
\text { Lisboa } & \\
\end{array}$ & 1978 & Brasileira & $\begin{array}{lll}\text { Artigo } 157 & \text { do } \\
\text { Código Penal } & \\
\end{array}$ & $\begin{array}{l}\text { Parda } \\
\text { clara }\end{array}$ \\
\hline 149352 & $\begin{array}{l}\text { Jonas Marques da } \\
\text { Silva }\end{array}$ & 1976 & Brasileira & $\begin{array}{l}\text { Depredações } \\
\text { estabelecimento de } \\
\text { ensino }\end{array}$ & Preta \\
\hline 149359 & $\begin{array}{l}\text { Benedita Lima dos } \\
\text { Santos }\end{array}$ & 1978 & Brasileira & $\begin{array}{lll}\text { Crime contra } & \text { a } \\
\text { Fazenda } & & \end{array}$ & $\begin{array}{l}\text { Parda } \\
\text { escura }\end{array}$ \\
\hline 149376 & $\begin{array}{ll}\text { Francisco } & \text { das } \\
\text { Chagas Brito } & \end{array}$ & 1978 & Brasileira & Depoimento & Parda \\
\hline 149381 & Raimundo Elias & 1976 & Brasileira & Lei de Segurança & Parda \\
\hline
\end{tabular}




\begin{tabular}{|c|c|c|c|c|c|}
\hline & & & & $\begin{array}{l}\text { Nacional } \\
\text { (sindicalismo da } \\
\text { Pastoral Operária) }\end{array}$ & clara \\
\hline 149396 & $\begin{array}{ll}\text { José } & \text { Augusto } \\
\text { Nogueira } & \\
\end{array}$ & 1978 & Brasileira & $\begin{array}{ll}\text { Crime } & \text { contra } \\
\text { Fazenda } & \\
\end{array}$ & Preta \\
\hline 149403 & $\begin{array}{l}\text { Wilson } \\
\text { Coutinho }\end{array}$ & 1979 & Brasileira & Roubo a banco & $\begin{array}{l}\text { Parda } \\
\text { clara }\end{array}$ \\
\hline 149408 & Paulo Rosa da Silva & 1976 & Brasileira & Sociedade em favela & Parda \\
\hline 149415 & $\begin{array}{ll}\text { Jair da } & \text { Cunha } \\
\text { Severino } & \\
\end{array}$ & 1979 & Brasileira & $\begin{array}{lrl}\text { Artigo } 319 & \text { do } \\
\text { Código Penal } & \end{array}$ & $\begin{array}{l}\text { Parda } \\
\text { escura }\end{array}$ \\
\hline 149418 & José Minga & 1979 & Brasileira & $\begin{array}{l}\text { Artigo } 171 \text { e } 298 \text { do } \\
\text { Código Penal }\end{array}$ & $\begin{array}{l}\text { Parda } \\
\text { clara }\end{array}$ \\
\hline 149420 & Mario Américo & 1978 & Brasileira & $\begin{array}{lll}\text { Artigo } 282 & \text { do } \\
\text { Código Penal } & \\
\end{array}$ & Preta \\
\hline 149442 & $\begin{array}{l}\text { Issac Severino Jose } \\
\text { da Silva }\end{array}$ & 1982 & Brasileira & $\begin{array}{lrr}\text { Artigo } 157 & \text { do } \\
\text { Código Penal } & \\
\end{array}$ & $\begin{array}{l}\text { Parda } \\
\text { clara }\end{array}$ \\
\hline 149460 & $\begin{array}{ll}\text { Enes } & \text { Antonio } \\
\text { Ribeiro } & \\
\end{array}$ & 1979 & Brasileira & $\begin{array}{lll}\text { Artigo } \quad 180 & \text { do } \\
\text { Código Penal } & \\
\end{array}$ & Preta \\
\hline 149463 & $\begin{array}{lll}\text { José } & \text { Pereira } & \text { da } \\
\text { Silva } & & \\
\end{array}$ & 1979 & Brasileira & Averiguação & $\begin{array}{l}\text { Parda } \\
\text { clara }\end{array}$ \\
\hline 149498 & Luiz Carlos Pires & 1979 & Brasileira & \begin{tabular}{llr} 
Artigo & 171 & do \\
Código & Penal & - \\
crime & \multicolumn{2}{c}{ contra } \\
Fazenda & &
\end{tabular} & Preta \\
\hline 149531 & $\begin{array}{lr}\text { Marco } & \text { Aurélio } \\
\text { Ferreira de Oliveira }\end{array}$ & 1979 & Brasileira & $\begin{array}{lrr}\text { Artigo } 297 & \text { do } \\
\text { Código Penal } & \\
\end{array}$ & Preta \\
\hline 149532 & Brasileira & 1979 & Brasileira & \begin{tabular}{llr} 
Artigo & 171 & do \\
Código & Penal & - \\
crime & \multicolumn{2}{c}{ contra } \\
Fazenda & &
\end{tabular} & Preta \\
\hline 149547 & $\begin{array}{l}\text { Odilon Pereira da } \\
\text { Paixão }\end{array}$ & 1979 & Brasileira & $\begin{array}{l}\text { Legitimação por } \\
\text { estelionato }\end{array}$ & Preta \\
\hline 149553 & $\begin{array}{l}\text { José Pedro de } \\
\text { Freitas }\end{array}$ & 1979 & Brasileira & $\begin{array}{ll}\text { Artigo } 157 & \text { do } \\
\text { Código Penal } & \end{array}$ & $\begin{array}{l}\text { Parda } \\
\text { escura }\end{array}$ \\
\hline 149554 & Paulo Paiva Cajano & 1979 & Brasileira & $\begin{array}{lll}\text { Artigo } 157 & \text { do } \\
\text { Código Penal } & \end{array}$ & $\begin{array}{l}\text { Parda } \\
\text { clara }\end{array}$ \\
\hline 149571 & $\begin{array}{l}\text { Adilson de Souza } \\
\text { Medrado }\end{array}$ & 1979 & Brasileira & Depoimento & $\begin{array}{l}\text { Parda } \\
\text { clara }\end{array}$ \\
\hline 149655 & $\begin{array}{l}\text { Arnaldo de Paula } \\
\text { Correa }\end{array}$ & 1980 & Brasileira & $\begin{array}{lrr}\text { Artigo } 299 & \text { do } \\
\text { Código Penal } & \end{array}$ & $\begin{array}{l}\text { Parda } \\
\text { clara }\end{array}$ \\
\hline 149659 & $\begin{array}{l}\text { Joanito da Silva } \\
\text { Genestra }\end{array}$ & 1980 & Brasileira & $\begin{array}{l}\text { Artigo } 171 \text { do } \\
\text { Código Penal crime } \\
\text { contra Fazenda }\end{array}$ & $\begin{array}{l}\text { Parda } \\
\text { clara }\end{array}$ \\
\hline 149670 & $\begin{array}{l}\text { Carlos Eustáquio } \\
\text { Ferreira Mafra }\end{array}$ & 1980 & Brasileira & $\begin{array}{lrr}\text { Artigo } 157 & \text { do } \\
\text { Código Penal } & \\
\end{array}$ & $\begin{array}{l}\text { Parda } \\
\text { clara }\end{array}$ \\
\hline 149671 & José Luiz Juvêncio & 1980 & Brasileira & Artigo & Preta \\
\hline
\end{tabular}




\begin{tabular}{|c|c|c|c|c|c|}
\hline & & & & Código Penal & \\
\hline 149685 & $\begin{array}{l}\text { Dimas de Jesus dos } \\
\text { Santos }\end{array}$ & 1980 & Brasileira & $\begin{array}{lll}\text { Artigo } 157 & \text { do } \\
\text { Código Penal } & \end{array}$ & $\begin{array}{l}\text { Parda } \\
\text { clara ou } \\
\text { branca }\end{array}$ \\
\hline 149694 & $\begin{array}{l}\text { Antonio Carlos de } \\
\text { Campos }\end{array}$ & 1980 & Brasileira & Greve & Preta \\
\hline 149700 & Luis Alves & 1980 & Brasileira & Sindicato & Parda \\
\hline 149707 & José Luiz Coelho & 1980 & Brasileira & Não consta & Parda \\
\hline 149714 & Rubens Coelho & 1980 & Brasileira & Não consta & Parda \\
\hline 149725 & $\begin{array}{ll}\text { Rutemberg } & \text { Santos } \\
\text { Simões } & \end{array}$ & 1980 & Brasileira & Extorsão & $\begin{array}{l}\text { Parda } \\
\text { clara }\end{array}$ \\
\hline 149751 & $\begin{array}{l}\text { Haroldo Tadeu da } \\
\text { Silva }\end{array}$ & 1980 & Brasileira & $\begin{array}{ll}\text { Artigo } 157 & \text { do } \\
\text { Código Penal } & \end{array}$ & $\begin{array}{l}\text { Parda } \\
\text { clara }\end{array}$ \\
\hline 149768 & $\begin{array}{l}\text { Paulo Moisés de } \\
\text { Almeida Vidal }\end{array}$ & 1980 & Brasileira & $\begin{array}{lll}\text { Artigo } 157 & \text { do } \\
\text { Código Penal } & \end{array}$ & $\begin{array}{l}\text { Parda } \\
\text { clara }\end{array}$ \\
\hline 149780 & $\begin{array}{l}\text { Lauro Fortunato da } \\
\text { Silva }\end{array}$ & 1980 & Brasileira & $\begin{array}{lll}\text { Artigo } 157 & \text { do } \\
\text { Código Penal } & \end{array}$ & Preta \\
\hline 149785 & $\begin{array}{l}\text { Diogenes Rene } \\
\text { Tadeu de Oliveira }\end{array}$ & 1980 & Brasileira & $\begin{array}{lll}\text { Artigo } 317 & \text { do } \\
\text { Código Penal } & \end{array}$ & Preta \\
\hline 149795 & $\begin{array}{l}\text { Adgusmar Luiz } \\
\text { Ferreira }\end{array}$ & 1980 & Brasileira & Extorsão & $\begin{array}{l}\text { Parda } \\
\text { clara }\end{array}$ \\
\hline 149797 & João dos Santos & 1980 & Brasileira & Roubo & Preta \\
\hline 149803 & $\begin{array}{l}\text { Sebastião de Souza } \\
\text { Ramos }\end{array}$ & 1980 & Brasileira & $\begin{array}{lll}\text { Artigo } 157 & \text { do } \\
\text { Código Penal } & \end{array}$ & $\begin{array}{l}\text { Parda } \\
\text { clara }\end{array}$ \\
\hline 149808 & $\begin{array}{l}\text { Adauto Simões de } \\
\text { Almeida Filho }\end{array}$ & 1980 & Brasileira & $\begin{array}{ll}\text { Artigo } 288 & \text { do } \\
\text { Código Penal } & \end{array}$ & Parda \\
\hline 149817 & $\begin{array}{lll}\text { José Jurandir } & \text { da } \\
\text { Silva } & & \end{array}$ & 1980 & Brasileira & $\begin{array}{l}\text { Greve (atentado } \\
\text { contra liberdade do } \\
\text { trabalho) }\end{array}$ & Parda \\
\hline 149820 & $\begin{array}{l}\text { Antonio Wagner de } \\
\text { Souza }\end{array}$ & 1980 & Brasileira & $\begin{array}{lll}\text { Artigo } 171 & \text { do } \\
\text { Código Penal } & \\
\end{array}$ & Preta \\
\hline 149825 & $\begin{array}{l}\text { Arlindo Ferreira da } \\
\text { Silva }\end{array}$ & 1980 & Brasileira & $\begin{array}{lrr}\text { Artigo } 157 & \text { do } \\
\text { Código Penal } & \\
\end{array}$ & $\begin{array}{l}\text { Parda } \\
\text { clara }\end{array}$ \\
\hline 149826 & $\begin{array}{l}\text { José Evanir da } \\
\text { Rocha }\end{array}$ & 1980 & Brasileira & \begin{tabular}{llr} 
Artigo & 171 & do \\
Código & Penal & - \\
crime & \multicolumn{2}{c}{ contra } \\
Fazenda & & \\
\end{tabular} & Preta \\
\hline 149831 & $\begin{array}{ll}\text { Marco } & \text { Antonio } \\
\text { Siqueira } & \end{array}$ & 1980 & Brasileira & $\begin{array}{ll}\text { Artigo } 157 & \text { do } \\
\text { Código Penal } & \end{array}$ & $\begin{array}{l}\text { Parda } \\
\text { escura }\end{array}$ \\
\hline 149853 & José Silva Marques & 1981 & Brasileira & $\begin{array}{l}\text { Artigo } 12 \text { do Código } \\
\text { Penal }\end{array}$ & $\begin{array}{l}\text { Parda } \\
\text { clara }\end{array}$ \\
\hline 149857 & $\begin{array}{l}\text { Aguinaldo } \\
\text { Timotheo Pereira }\end{array}$ & 1981 & Brasileira & $\begin{array}{lr}\text { Lei de } & \text { Segurança } \\
\text { Nacional } & - \\
\text { declarações } & \text { contra } \\
\text { autoridades } & \text { em } \\
\text { programa de TV } & \end{array}$ & $\begin{array}{l}\text { Parda } \\
\text { escura }\end{array}$ \\
\hline
\end{tabular}




\begin{tabular}{|c|c|c|c|c|c|}
\hline 149858 & $\begin{array}{l}\text { Ajuricaba de Souza } \\
\text { Menezes }\end{array}$ & 1981 & Brasileira & $\begin{array}{ll}\text { Artigo } 159 & \text { do } \\
\text { Código Penal } & \\
\end{array}$ & $\begin{array}{l}\text { Parda } \\
\text { clara }\end{array}$ \\
\hline 149884 & $\begin{array}{l}\text { Célio Alves } \\
\text { Mello }\end{array}$ & 1981 & Brasileira & $\begin{array}{lll}\text { Artigo } 250 & \text { do } \\
\text { Código Penal } & \end{array}$ & $\begin{array}{l}\text { Parda } \\
\text { clara ou } \\
\text { morena } \\
\end{array}$ \\
\hline 147472 & $\begin{array}{l}\text { Heloisa da Silva } \\
\text { Bernardes }\end{array}$ & 1972 & Brasileira & $\begin{array}{l}\text { Legitimação por dar } \\
\text { guarda a subversivos }\end{array}$ & $\begin{array}{l}\text { Parda } \\
\text { clara ou } \\
\text { morena ou } \\
\text { branca }\end{array}$ \\
\hline 147473 & Iguatemi de Godoy & 1971 & Brasileira & $\begin{array}{lrr}\text { Artigo } 304 & \text { do } \\
\text { Código Penal } & \\
\end{array}$ & $\begin{array}{l}\text { Parda } \\
\text { escura }\end{array}$ \\
\hline 147475 & $\begin{array}{ll}\text { José } & \text { Araujo } \\
\text { Montalvão } & \\
\end{array}$ & 1972 & Brasileira & $\begin{array}{l}\text { Legitimação por } \\
\text { terrorismo na ALN }\end{array}$ & Parda \\
\hline 12040 & $\begin{array}{l}\text { Manoel Vilar de } \\
\text { Carvalho }\end{array}$ & 1966 & Brasileira & Incêndio & Preta \\
\hline 13109 & $\begin{array}{ll}\text { José } & \text { Monteiro } \\
\text { Sobral } & \\
\end{array}$ & 1972 & Brasileira & Legitimação & $\begin{array}{ll}\text { Preta } & \text { ou } \\
\text { parda } & \\
\end{array}$ \\
\hline 14520 & Geni de Barros & 1972 & Brasileira & $\begin{array}{l}\text { Lei de Segurança } \\
\text { Nacional }\end{array}$ & $\begin{array}{l}\text { Parda } \\
\text { escura ou } \\
\text { clara }\end{array}$ \\
\hline 14587 & Ari Pinto Nogueira & 1973 & Brasileira & $\begin{array}{l}\text { Artigo } 297 \text { e } 25 \text { do } \\
\text { Código Penal }\end{array}$ & $\begin{array}{l}\text { Branca ou } \\
\text { preta }\end{array}$ \\
\hline 17107 & $\begin{array}{l}\text { Jair Aparecido da } \\
\text { Silva }\end{array}$ & 1972 & Brasileira & $\begin{array}{l}\text { Legitimação } \\
\text { subversão }\end{array}$ & Preta \\
\hline 17118 & $\begin{array}{l}\text { Hasiel da Silva } \\
\text { Pereira Filho }\end{array}$ & 1972 & Brasileira & $\begin{array}{l}\text { Legitimação } \\
\text { subversão }\end{array}$ & $\begin{array}{ll}\text { Parda } & \\
\text { clara } & \text { ou } \\
\text { preta } & \text { ou } \\
\text { branca } & \\
\end{array}$ \\
\hline 18132 & Romeu da Silva & 1964 & Brasileira & Explosão & Parda \\
\hline 21305 & José Rodrigues & 1970 & Brasileira & Roubo & $\begin{array}{ll}\text { Preta } & \text { ou } \\
\text { parda } & \end{array}$ \\
\hline 22688 & Gentil Nascimento & 1971 & Brasileira & $\begin{array}{lr}\begin{array}{l}\text { Legitimação } \\
\text { crime }\end{array} & \text { por } \\
\text { Fazenda } & \\
\end{array}$ & Parda \\
\hline 23044 & Luzia Flora Leme & 1970 & Brasileira & $\begin{array}{l}\text { Legitimação (Ordem } \\
\text { Social) }\end{array}$ & Preta \\
\hline 24668 & $\begin{array}{l}\text { Fidelsino Santiago } \\
\text { dos Santos }\end{array}$ & 1969 & Brasileira & $\begin{array}{l}\text { Artigo } 39 \text { Lei de } \\
\text { Segurança Nacional }\end{array}$ & Parda \\
\hline 24995 & $\begin{array}{l}\text { Maria Duarte de } \\
\text { Oliveira }\end{array}$ & 1970 & Brasileira & $\begin{array}{lcr}\text { Crime } & \text { eleitoral } & \text { e } \\
\text { artigo } & 299 & \text { do } \\
\text { Código } & \text { Penal } & \\
\end{array}$ & $\begin{array}{l}\text { Parda } \\
\text { clara }\end{array}$ \\
\hline 25003 & Brasileira & 1973 & Brasileira & $\begin{array}{l}\text { Pedido de atestado } \\
\text { de antecedentes }\end{array}$ & Parda \\
\hline 26647 & $\begin{array}{ll}\text { Marinaldo } & \text { Santos } \\
\text { Gonçalves } & \end{array}$ & 1971 & Brasileira & $\begin{array}{ll}\text { Legitimação por Lei } \\
\text { de } & \text { Segurança } \\
\text { Nacional } & \\
\end{array}$ & $\begin{array}{ll}\text { Parda } & \\
\text { clara ou } \\
\text { preta }\end{array}$ \\
\hline
\end{tabular}




\begin{tabular}{|c|c|c|c|c|c|}
\hline 27251 & Pedro Sabino & 1970 & Brasileira & $\begin{array}{l}\text { Legitimação por Lei } \\
\text { de Segurança } \\
\text { Nacional } \\
\text { Maringuela) }\end{array}$ & Preta \\
\hline 28842 & Gilberto de Souza & 1982 & Brasileira & Roubo a banco & Preta \\
\hline 29355 & $\begin{array}{l}\text { Bernardino Manoel } \\
\text { Filho }\end{array}$ & 1968 & Brasileira & $\begin{array}{l}\text { Falsas denúncias e } \\
\text { uso irregular da } \\
\text { bandeira nacional }\end{array}$ & Parda \\
\hline 29676 & $\begin{array}{ll}\text { José } & \text { Arduino } \\
\text { Nóbrega } & \end{array}$ & 1972 & Brasileira & Subversão & Parda \\
\hline 30173 & $\begin{array}{l}\text { Francisco Nilson } \\
\text { Modesto }\end{array}$ & 1970 & Brasileira & $\begin{array}{l}\text { Lei de Segurança } \\
\text { Nacional }\end{array}$ & $\begin{array}{l}\text { Parda ou } \\
\text { branca }\end{array}$ \\
\hline 30692 & Wilson Nogueira & 1970 & Brasileira & $\begin{array}{l}\text { Lei de Segurança } \\
\text { Nacional }\end{array}$ & $\begin{array}{ll}\text { Preta ou } \\
\text { parda } \\
\text { escura }\end{array}$ \\
\hline 31403 & José Cardoso & 1975 & Brasileira & $\begin{array}{l}\text { Testemunha de } \\
\text { escolta de presos } \\
\text { com homicídio }\end{array}$ & Parda \\
\hline 31454 & $\begin{array}{l}\text { Josino Martins dos } \\
\text { Santos }\end{array}$ & 1969 & Brasileira & $\begin{array}{l}\text { Legitimação (Ordem } \\
\text { Política) }\end{array}$ & $\begin{array}{l}\text { Parda ou } \\
\text { preta }\end{array}$ \\
\hline 32453 & $\begin{array}{ll}\begin{array}{l}\text { Demetrio José de } \\
\text { Souza }\end{array} \\
\end{array}$ & 1972 & Brasileira & Legitimação & Parda \\
\hline 33143 & $\begin{array}{l}\text { Ignácio Antonio da } \\
\text { Silva }\end{array}$ & 1970 & Brasileira & $\begin{array}{l}\text { Legitimação (Ordem } \\
\text { Social) Lei de } \\
\text { Segurança Nacional }\end{array}$ & $\begin{array}{l}\text { Parda } \\
\text { clara ou } \\
\text { preta }\end{array}$ \\
\hline 33190 & Rubens de Oliveira & 1968 & Brasileira & 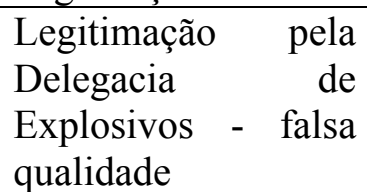 & Preta \\
\hline 33444 & $\begin{array}{l}\text { Jacinto Fernandes } \\
\text { da Silva }\end{array}$ & 1970 & Brasileira & Incitação à violência & Parda \\
\hline 34072 & $\begin{array}{l}\text { Juraci Maria de } \\
\text { Jesus Campos }\end{array}$ & 1970 & Brasileira & $\begin{array}{l}\text { Legitimação (Ordem } \\
\text { Social) }\end{array}$ & $\begin{array}{l}\text { Parda ou } \\
\text { morena }\end{array}$ \\
\hline 34375 & $\begin{array}{ll}\text { Mylene } & \text { Quin } \\
\text { Moore } & \end{array}$ & 1970 & Brasileira & $\begin{array}{l}\text { Legitimação } \\
\text { (Serviço de } \\
\text { Informação) }\end{array}$ & Preta \\
\hline 35612 & $\begin{array}{l}\text { Benedito Sergio de } \\
\text { Matos }\end{array}$ & 1982 & Brasileira & Furto qualificado & Preta \\
\hline 35734 & Jair da Cruz & 1981 & Brasileira & $\begin{array}{l}\text { Seqüestro, } \\
\text { prisão evasão, } \\
\text { corporais }\end{array}$ & $\begin{array}{l}\text { Parda } \\
\text { clara }\end{array}$ \\
\hline 36466 & Aldo Leite da Silva & 1981 & Brasileira & $\begin{array}{ll}\text { Artigo } 199 & \text { do } \\
\text { Código Penal } & \end{array}$ & $\begin{array}{l}\text { Parda } \\
\text { clara }\end{array}$ \\
\hline 36504 & Gésio Aparecido & 1981 & Brasileira & $\begin{array}{l}\text { Depoimento } \\
\text { denúncia preso de } \\
\text { roubo objetos deste }\end{array}$ & Preta \\
\hline
\end{tabular}




\begin{tabular}{|c|c|c|c|c|c|}
\hline 37868 & $\begin{array}{ll}\text { Ademar } & \text { Feitosa } \\
\text { Xavier } & \end{array}$ & 1971 & Brasileira & $\begin{array}{l}\text { Legitimação (Ordem } \\
\text { Social) }\end{array}$ & Parda \\
\hline 39259 & $\begin{array}{l}\text { Charlain Galvão da } \\
\text { Silva }\end{array}$ & 1981 & Brasileira & $\begin{array}{l}\text { Falsificação de } \\
\text { documentos } \\
\text { públicos }\end{array}$ & preta \\
\hline 39383 & $\begin{array}{l}\text { Luiz Carlos dos } \\
\text { Santos }\end{array}$ & 1982 & Brasileira & Estelionato & $\begin{array}{l}\text { Afro- } \\
\text { descenden } \\
\text { te* }\end{array}$ \\
\hline 41830 & $\begin{array}{ll}\text { Odandino } & \text { Ferreira } \\
\text { de Freitas } & \end{array}$ & 1970 & Brasileira & Legitimação & $\begin{array}{ll}\text { Parda ou } \\
\text { preta }\end{array}$ \\
\hline 41947 & $\begin{array}{l}\text { Wilson Roberto } \\
\text { Carlos }\end{array}$ & 1981 & Brasileira & Assalto a banco & Preta \\
\hline 42229 & $\begin{array}{l}\text { Jose Carlos Vieira } \\
\text { ou Helio Alves de } \\
\text { Almeida }\end{array}$ & 1982 & Brasileira & Assalto a banco & $\begin{array}{l}\text { Parda } \\
\text { clara }\end{array}$ \\
\hline 42232 & $\begin{array}{l}\text { Sinesio Alexandre } \\
\text { da Silva }\end{array}$ & 1970 & Brasileira & $\begin{array}{l}\text { Legitimação por Lei } \\
\text { de } \quad \text { Segurança } \\
\text { Nacional }\end{array}$ & Preta \\
\hline 42313 & $\begin{array}{l}\text { Duguai Barbosa } \\
\text { dos Santos }\end{array}$ & 1982 & Brasileira & $\begin{array}{ll}\text { Artigo } 155 & \text { do } \\
\text { Código Penal } & \end{array}$ & $\begin{array}{l}\text { Parda } \\
\text { clara }\end{array}$ \\
\hline 42331 & $\begin{array}{l}\text { Juarez Silva Mota } \\
\text { ou Monteiro }\end{array}$ & 1972 & Brasileira & Assalto a banco & $\begin{array}{l}\text { Parda } \\
\text { escura ou } \\
\text { preta }\end{array}$ \\
\hline
\end{tabular}

